Effects of Highways on Wildlife and Fish with Special Reference to Montana:

A ProCite Literature Collection

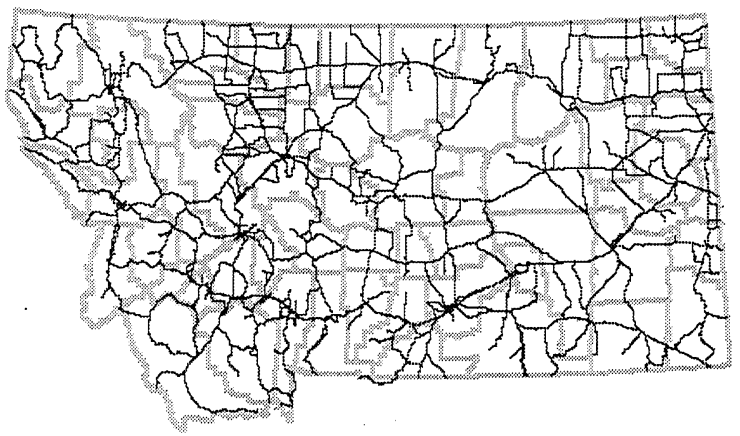

Submitted by:

Lynn R. Irby

Kevin M. Podruzny

Fish and Wildlife Management Program

Department of Ecology

Montana State University

Bozeman, MT 59717

Submitted to:

MONTANA DEPARTMENT OF TRANSPORTATION

RESEARCH MANAGEMENT UNIT

2701 PROSPECT AVENUE

HELENA, MT 59620

(February 2001) 


\title{
CONTENTS
}

Background Summary

Objectives

\author{
Benefits
}

Research Plan and Implementation

Literature Cited

Acknowledgements

Standard Database Entry Format

Instructions for Using ProCite

ProCite Literature Collection 


\section{Background Summary}

Road construction and the human activities associated with roads have the potential to produce negative impacts on aquatic and terrestrial wildlife populations (Oxley et al. 1974, Leedy et al. 1975, Ward et al. 1976, Adams and Geis 1980, Van der Zande et al. 1980, Mader 1984, McLellen and Shackleton 1988, Brown and Jones 1989, Mech 1989, Andrews 1990, Mace et al. 1996, Evink et al. 1996, 1998). Montana citizens are heavily committed to the freedom of movement and convenience of delivery of services that comes with a public road system. If public roads and healthy wildlife populations are to coexist, a better information base on the extent, type, and conditions that create impacts on wildlife is essential. If the population of Montana continues to grow, dependence on private passenger vehicles remains high, and costs of road construction and maintenance continue to escalate, finite resources will dictate compromises between the socially and environmentally desirable goal of minimizing impacts of roads on wildlife and the equally desirable goal of creating a safe, efficient, convenient personal transportation system within reasonable fiscal constraints.

Although studies of impacts of roads on wild vertebrates are common (Whitney and Bailey 1959; Leedy et al. 1975; Sidhu and Case 1977; Leedy 1979, Little and Mayer 1993 Evink et al. 1996, 1998), and studies of mitigation projects to decrease impacts and accidents are becoming more common (Foster and Humphrey 1992, Broekhuizen, S. and H. Derckx 1996, Forman and Hersperger 1996), the literature is widely dispersed and may or may nor be relevant to problems in Montana. Data relevant to interactions between transportation and wildlife and fisheries populations in Montana are also available from a wide array of studies that were not specifically designed to address transportation impacts (theses, agency reports, GAP project data, etc.). Efficiency in resolving problems could be greatly increased if information on impacts and location of information sources, especially for data relevant to Montana, were identified in an easily accessible database. This report provides a ProCite bibliographic database.

\section{Objectives}

1) Locate published and unpublished data on transportation system impacts on wildlife and fisheries that are relevant to problems likely to be encountered in Montana.

2) Identify sources of data that are collected on a routine basis (or could be collected on a routine basis) and would facilitate resolution of problems between wild vertebrate populations and transportation systems in Montana.

3) Create an easily accessible database that can be updated efficiently and distributed easily to managers and researchers with information relevant to transportation wildlife interactions in Montana. 


\section{Benefits}

A readily accessible database with information on relationships among highways, terrestrial ecosystems, and aquatic ecosystems specifically oriented towards Montana will enable highway planners, construction engineers, and maintenance personnel to identify potential problems on existing transportation corridors, to plan new highways and highway upgrades to address problems in a cost-effective manner, and to outline solutions to problems that are feasible given conditions in Montana. The database will also be invaluable to researchers attempting to resolve problems for which "standard fixes" do not exist or to assess the desirability of alternative resolutions to problems. Identification of sources that collect data on problems ranging from road kills to insurance claims to habitat fragmentation will facilitate monitoring efforts directed at ascertaining the extent of problems and the efficacy of solutions to problems implemented by MDT.

\section{Research Plan and Implementation}

The project was implemented in three phases:

1) Published data were identified via literature searches, internet searches, and examination of bibliographies. Sources included those directly related to transportation - wildlife issues as well as those related to effects of other linear developments such as railroads, pipelines, and transmission lines. This search also included publications and databases including information on terrestrial and aquatic species distribution, population status, life histories, movement patterns, and limiting factors that were not produced directly in response to transportation issues but had relevance to issues due either to location of the study, the species being studied, or information on populations that served as baseline data for changes associated with highways. Depending on the original source of the data, keywords and/or abstracts were often provided. Primary reference sources included: Clevenger 1998; CTE Information Services 2000; Danielson and Hubbard 1998; Jalkotzy et al. 1997; and Singleton and Lemkuhl 1998. Contents of these literature collections were supplemented with: relevant published sources available from the MT Department of Fish, Wildlife and Parks research library Bozeman; relevant published sources available from the MT Chapter of The Wildlife Society bibliographic database for the Effects of Recreation on Rocky Mountain Wildlife: A Review for Montana; and published records from a number of ProCite Internet searches from Z39.50 compliant libraries.

2) Unpublished data sources, reports, and theses at MSU, UM, and state agency offices were evaluated through visits to agency and university offices and libraries. These site visits were also used to identify contact personnel, routine data collection relevant to highway-wildlife impacts, and potential data that could be systematically collected with minimal impacts on agency operations. Data incorporated into the final 
literature list included: theses and dissertations from the fish and wildlife programs at the University of Montana and Montana State University; reports available from the MT Department of Fish, Wildlife and Parks research library - Bozeman; and reports available from the MT Chapter of The Wildlife Society bibliographic database for the Effects of Recreation on Rocky Mountain Wildlife: A Review for Montana.

3) Published and unpublished data, information contacts, and ongoing data collection efforts with proven or potential relevance to highway-wildlife interactions was assembled in a commercial database organization system (ProCite version 5). Encyclopedic versions of the assemblage were recorded on CD's for distribution to interested parties. A system for continual updating was developed.

Data collected in this report will be useful across all divisions of MDT. The database will be accessible through spatial, community, species, problem, and mitigation approach searches. Planners will be able to identify potential problems with rare species, critical habitat, or wildlife-highway related safety issues before highway designs are completed. Construction personnel will be able to access mitigation designs used in other areas and determine their utility for Montana early in the construction process. Environmental personnel will be able to assess the potential need for mitigation or research on individual road segments.

\section{Literature Cited}

Adams, L. W. and A. D. Geis. 1980. Effects of highways on wildlife. Urban Wildlife Research Center, Columbia, MD 152pp.

Andrews, A. 1990. Fragmentation of habitat by roads and utility corridors, a review. Australian Zoologist 26:130-141.

Broekhuizen, S. and H. Derckx. 1996. Passages for badgers and their efficacy. Zeitschrift fur Jagdwissenschaft 42:134-142.

Brown, L. and R. Jones. 1989. An annotated bibliography on the interrelationships of elk and roads. Bureau of Land Management, Idaho State Office, Tech Bull 892, Boise, $21 \mathrm{pp}$.

Clevenger, Anthony P. 1998. Effects of highways and other linear developments on wildlife populations: a literature collection. Parks Canada Banff National Park. $52 p$.

CTE Information Services. 2000. Design of wildlife crossings: a literature review. Prepared by The Center for Transportation and the Environment. North Carolina State University. 18pp. 
Danielson, B J. and M W. Hubbard. 1998. A literature review for assessing the status of current methods of reducing deer-vehicle collisions. Prepared for The Task Force on Animal Vehicle Collisions, lowa Department of Transportation, and lowa Department of Natural Resources. 26 pp.

Evink, G. L., P. Garrett, D. Zeigler, and J. Berry, eds. 1996. Trends in addressing transportation related wildlife mortality. Florida Department of Transportation, FL-ER-58-96, Tallahassee.

Evink, G. L., P. Garrett, D. Zeigler, and J. Berry, eds. 1998. Proceedings of the international conference on wildlife ecology and transportation. Florida Department of Transportation, FL-ER-69-98, Tallahassee

Forman, R. T. And A. M. Hersperger. 1996. Road ecology and road density in different landscapes, with international planning and mitigation solutions in Evink, G. L., P. Garrett, D. Zeigler, and J. Berry, eds. Trends in addressing transportation related wildlife mortality. Florida Department of Transportation, FL-ER-58-96, Tallahassee.

Foster, M. and S. R. Humphrey. 1992. Effectiveness of wildlife crossings in reducing animal-auto collisions on Interstate 75, Big Cypress swamp, Florida. Florida Department of Transportation, FL-ER-50-92.

Jalkotzy, M.G., P.I. Ross, and M.D. Nasserden. 1997. The effects of linear developments on wildlife: a review of selected scientific literature. Prepared for Canadian Association of Petroleum Producers. Arc Wildlife Services Ltd., Calgary. 352pp.

Leedy, D. H. 1979. An annotated bibliography on planning and management for urbansuburban wildlife. U. S. Fish and Wildlife Service, FWS/OBS-79/25. 265pp.

Leedy, D. H., T. M. Franklin, and C. E. Hekimian. 1975. Highway - wildlife relationships. Vol 2. An annotated bibliography. Federal Highway Administration, Off. Res. Devel., FHWA-RD-76-5, Washington, D.C., 417pp.

Little, J. D., and J. J. Mayer. 1 993. Road and bridge construction. Pages 221226 in C. F. Bryan and D. A. Rutherford, editors. Impact on warmwater streams: Guidelines for evaluation. Southern Division, American Fisheries Society, Little Rock, Arkansas.

Mace, R. D., J., S. Waller, T. L. Manley, L. J. Lyon, and H. Zuuring. 1996. Relationships among grizzly bears, roads, and habitat in the Swan Mountains, Montana. Journal of Applied Ecology 33:1395-1404.

Mader, H. J. 1984. Animal habitat isolation by roads and agricultural fields. Biological Conservation 29:81-96. 
Mech, L. D. 1989. Wolf population survival in an area of high road density. American Midlands Naturalist. 121:387-389.

Montana Chapter of the Wildlife Society. 1999. Effects of recreation on Montana wildlife. Montana Chapter of the Wildlife Society, Helena (available online: http://montanatws.org/pages/page4.html).

Oxley, D. J., M. B. Fenton, and G. R. Carmody. 1974. The effects of roads on populations of small mammals. Journal of Applied Ecology 11:51-59

Sidhu, S. S. and A. B. Case. 1977. A bibliography on the environmental impact of forest roads: a list. Newfoundland Forest Research Center, St. Johns, Info. Rep. N$\mathrm{X}-149.28 \mathrm{pp}$.

Singleton, P H. and J.F Lemkuhl. 1998. Wildlife-roadway interactions: a bibliography and review of roadway and wildlife interactions. Washington Departemnt of Transportaion. $161 \mathrm{pp}$.

Van der Zande, A. N., W. J. ter Keurs, and W. J. Van der Weyden. 1980. The impact of roads on the densities of four bird species - evidence of a long distance effect. Biological Conservation 18:299-321.

Ward, A. L., J. J. Cupal, G. A. Goodwin, and H. D. Morris. 1976. Effects of highway construction and use on big game populations. Federal Highway Administration Rep No. FHWA-RD-76, Washington, D.C. 92pp..,

Whitney, A. N., and J. E. Bailey. 1959. Detrimental effects of highway construction on a Montana stream. Transactions of the American Fisheries Society 88:72-73.

\section{Acknowledgements}

We thank the following individuals and organizations for providing data for the literature collection: Margaret Morelli, Ryan Rauscher, and Jim Williams with Montana Department of Fish, Wildlife and Parks, Amy Waller with the Montana Chapter of the Wildlife Society, Jeanne Franz with the Wildlife Biology Program, University of Montana, and Kristi Cocchiarella FitzGerald with the Department of Ecology, Montana State University. 


\section{Standard Database Entry Format}

We obtained electronic copies of several extensive documents and databases including literature reviews and bibliographies. Although some of the data were provided in standardized bibliographic format, most had an existing structure that was entered and compiled in a manner inconsistent with ProCite (e.g., MS Word, PDF, TXT). Because most literature reviews were not available in formats easily imported into bibliographic software, we standardized the format structure of all databases to accommodate importation into ProCite in a simplified format

Final standardized format for citation entries for MDT is in the form:

Author(s) (01)

Title (04)

Source/Citation (10)

Date of Publication (20)

Abstract (43)

MDT File Number (44)

Keywords (45)

While this format is not as detailed as ProCite can accommodate, it still allows for simple searches and queries by author, keyword, or any other term included within the title, source, or abstract. Additionally, MDT personnel have the option of entering additional descriptions, keywords, or internal file identification numbers. 


\section{Instructions for Using ProCite}

\section{Copy ProCite files from CD to local hard drive:}

Place data files "montana department of transportation.pdt" and "montana department of transportation.pdt" into a directory dedicated to the bibliography Place Workform file "MDT.pwf" into Procite subdirectory named "Forms" Place Output Style file "mdt.pos" into Procite subdirectory named "Styles"

\section{How to enter the program and open database:}

On DESKTOP click START and move curser to PROGRAMS and then ProCite 5 Click on FILE tab and then OPEN

Open file "montana department of transportation.pdt" in appropriate directory

\section{How to search and display results of search:}

Click SEARCH tab

Under "Search for:", enter any combination of terms (e.g., keywords, authors, year, etc.) Enter entire word (e.g., roads); portion of word (e.g., road*); or multiple words (e.g., roads AND elk)

Click SEARCH

This will list all records containing search terms

Highlighted records will be displayed in preview window

\section{How to print results of search:}

In SEARCH window, click MARK LIST

Click FILE then "Print bibliography"

Click OUTPUT STYLE tab and Choose "mdt" from list

Click CONFIGURE to change displayed fields

\section{Listing keywords:}

Click TERMS tab

Under "Show:" choose "Keywords"

Highlighting a keyword will display all Citations containing that keyword in the preview pane to the right of the screen.

Keywords can be added to records by double clicking a highlighted entry. Keyword list will be automatically updated.

How to enter new records:

Click DATABASE then "new Record"

Click WORKFORM tab and Choose "MDT" from list

Enter appropriate data in displayed fields 
How to edit existing records:

Double Click record to edit

Confirm WORKFORM tab is set to "MDT"

Edit appropriate data in displayed fields

For more detailed instructions, consult ProCite manual or Online Help 
ProCite Literature Collection 
1. Anonymous. 1988. CONSULTANT REPORT ON SMALL SCALE IRRIGATION FACILITIES, FISH PONDS, AND FEEDER ROADS. FAO, SETHEPUTRA, SACHA.

2. Anonymous. 1974? CORRIDOR WLDLIFE MAP SERIES / CANADIAN ARCTIC GAS PIPELINE LIMITED.

3. Anonymous. 1978. DEMPSTER HIGHWAY MANAGEMENT PLAN. DEPT. OF INDIAN AND NORTHERN AFFAIRS, NORTHERN ROADS AND AIRSTRIPS DIVISION, OTTAWA, ONTARIO.

4. Anonymous. 1991. EASTERN TRANSPORTATION CORRIDOR ENVIRONMENTAL IMPACT REPORT. TRANSPORTATION CORRIDOR AGENCIES, COSTA MESA, CALIFORNIA. 521PP.

5. Anonymous. 1972. FISHLINE IS FOULING OUR FLYWAYS. MINN. VOL.; 35(205):62-63

6. Anonymous. 1951. GLACIER NATIONAL PARK TOURIST SURVEY. MONTANA ST. HWY. COMM., US DEPT. OF COMMERCE, BUREAU OF PUBLIC ROADS, USDI, NATIONAL PARK SERV., 23 PP.

7. Anonymous. 1987. HABITATS, TRAILS, AND CAMPGROUND SITUATIONS ASSOCIATED WITH GRIZZLY-HUMAN CONFRONTATIONS IN GLACIER NATIONAL PARK, MONTANA. M.S. THESIS. 91PP.

8. Anonymous. 1952. INVESTIGATIONS OF METHODS OF APPRAISING THE ABUNDANCE OF MOURNING DOVES. --. SPECIAL SCIENTIFIC REPORT--WILDLIFE NO. 17. UNITED STATES DEPT. OF THE INTERIOR, FISH AND WILDLIFE SERVICE, WASHINGTON, D.C.

9. Anonymous. 1979. MITIGATION SYMPOSIUM A NATIONAL WORKSHOP ON MITIGATING LOSSES OF FISH AND WILDLIFE HABITATS, JULY 16-20, 1979, COLORADO STATE UNIVERSITY, FORT COLLINS, COLORADO. GENERAL TECHNICAL REPORT RM 65. U. S. DEPT. OF AGRICULTURE, FOREST SERVICE, ROCKY MOUNTAIN FOREST AND RANGE EXPERIMENT STATION, FORT COLLINS, COLORADO.

10. Anonymous. 1976. PROCEEDINGS OF THE ELK, LOGGING, ROADS SYMPOSIUM, MOSCOW, IDAHO, DECEMBER 16-17, 1975. FOREST, WILDLIFE AND RANGE EXPERIMENT STATION, UNIVESITY OF IDAHO, MOSCOW, IDAHO.

11. Anonymous. 1970. ROAD SALT AS A POLLUTING ELEMENT. U.S. FISH AND WILDLIFE SERVICE, WISCONSIN.

12. Anonymous. 1975. TASK FORCE REPORT ON THE EFFECTS OF ROAD CONSTRUCTION ON WETLAND WILDLIFE HABITAT. U.S. DEPARTMENT OF THE INTERIOR, FISH AND WILDLIFE SERVICE, TWIN CITIES, MINNESOTA.

13. Anonymous. 1999. TRANSPORTATION CONSTRUCTION AND MAINTENANCE AND THE PROTECTION OF FISH HABITAT. SYNTHESIS OF PRACTICE. TRANSPORTATION ASSOCIATION OF CANADA, OTTAWA, ONTARIO.

14. Anonymous. 1982? THE TRANSPORTATION CORRIDOR IN THE STATE OF CALIFORNIA, COUNTY OF MENDOCINO, ON ROUTE 101, PM 30.8 TO 36.1, FROM 0.2 MILE NORTH OF ROUTE 20 TO 4.3 MILES NORTH OF FORSYTHE CREEK, A DISTANCE OF 5.3 MILES STAGE 1, GRADE AND STRUCTURE : STAGE 2, BASE AND SURFACE : FINAL ENVIRONMENTAL IMPACT STATEMENT. S.N, EUREKA, CALIFORNIA.

15. Anonymous. UPPER YAZOO BASIN FISH AND WLDLIFE MITIGATION STUDY. DRAFT FEASIBILITY REPORT AND ENVIRONMENTAL IMPACT STATEMENT.

16. Anonymous. 1973. WESTERN COAL: DOES THE DEBATE FOLLOW IRREVERSIBLE COMMITMENT?. SCIENCE. 182

17. Anonymous. 1975. WETLAND LOSSES ASSOCIATED WTH HIGHWAY CONSTRUCTION IN WESTERN MINNESOTA. U.S. FISH AND WILDLIFE SERVICE, WASHINGTON, D.C.

18. Anonymous. 1982. WLDLIFE MORTALITY IN TRANSPORTATION CORRIDORS IN CANADA'S NATIONAL PARKS. NATURAL RESOURCE BULLETIN [VOL. UNKNOWN]:

19. AARISSORENSON, J. 1995. ROAD-KILLS OF BADGERS (MELES MELES) IN DENMARK. ANNALES ZOOLOGICI FENNICI 32(1):31-36. 
20. AASHEIM, R. 1980. SNOWMOBILE IMPACTS ON THE NATURAL ENVIRONMENT. PAGES 191-200 IN R. N. L. ANDREWS AND P. F. NOWAK, EDITORS. OFF-ROAD VEHICLE USE: A MANAGEMENT CHALLENGE. U.S. DEPARTMENT OF AGRICULTURE, OFFICE OF ENVIRONMENTAL QUALITY, WASHINGTON D.C.

21. ABBOTT, R. S. 1989. SEASONAL AND SUCCESSIONAL EFFECTS IN RECOVERY OF A VEHICLE-IMPACTED HYPERSALINE SALT MARSH IN SOUTH TEXAS. J. MINN. ACAD. SCI. 54:14.

22. ABDULLAH, A. S., D. M. MOONAFIZAD, A. OSMAN and I. DAHLAN. 1993. A COMPARISON OF LEAD LEVELS IN WATER, GRASS AND MILK IN DAIRY FARMS NEAR TO AND AWAY FROM THE HIGHWAY. JOURNAL VETERINARY MALAYSIA 5 (1):19-22.

23. ABELL, R. A. and WORLD WLDLIFE FUND (U.S.). 2000. FRESHWATER ECOREGIONS OF NORTH AMERICA A CONSERVATION ASSESSMENT. ISLAND PRESS, WASHINGTON, D.C.

24. ABENSPERG, T. M. 1991. A STUDY OF HOME-RANGE, MOVEMENTS AND SHELTER USE IN ADULT AND JUVENILE ECHIDNAS, TACHYGLOSSUS ACULEATUS (MONOTREMATA: TACHYGLOSSIDAE), IN WESTERN AUSTRALIAN WHEAT BELT RESERVES. AUSTRALIAN MAMMALOGY 14 (1-2):13-22.

25. ABERG, J., G. JANSSON, J. E. SWENSON and P. ANGELSTAM. 1995. THE EFFECT OF MATRIX. ON THE OCCURRENCE OF HAZEL GROUSE (BONASA BONASIA) IN ISOLATED HABITAT FRAGMENTS. OECOLOGIA (BERLIN) 103 (3):265-9.

26. ABERG, L. 1981. THE HUMAN FACTOR IN GAME-VEHICLE ACCIDENTS: A STUDY OF DRIVER'S INFORMATION ACQUISITION. PH.D. THESIS, DEPARTMENT OF PSYCHOLOGY, UPPSALA UNIVERSITY, UPPSALA, SWEDEN.

27. ABERG, L. 1981. THE HUMAN FACTOR IN GAME-VEHICLE ACCIDENTS A STUDY OF DRIVERS' INFORMATION ACQUISITION. ACTA UNIVERSITATIS UPSALIENSIS. STUDIA PSYCHOLOGICA UPSALIENSIA: ACTA UNIVERSITATIS UPSALIENSIS 6. DISTRIBUTOR, ALMQUIST \& WIKSELL, STOCKHOLM, SWEDEN.

28. ACOUSTICAL SOCIETY OF AMERICA. 1980. REPORT BY ACOUSTICAL SOCIETY OF AMERICA FOR ALASKA ESKIMO WHALING COMMISSION. SAN DIEGO WORKSHOP ON THE INTERACTION BETWEEN MAN-MADE NOISE AND VIBRATION AND ARCTIC MARINE WLDLIFE, 25-29 FEBRUARY 1980.

29. ACRES AMERICAN INCORPORATED. 1982. FISH AND WILDLIFE MITIGATION POLICY. REV. SUSITNA HYDROELECTRIC PROJECT. ALASKA POWER AUTHORITY, ANCHORAGE, ALASKA.

30. ADAM, M. D. and M. J. LACKI. 1993. FACTORS AFFECTING AMPHIBIAN USE OF ROAD-RUT PONDS IN DANIEL BOONE NATIONAL FOREST. TRANSACTIONS OF THE KENTUCKY ACADEMY OF SCIENCE 54 (1-2):13-6.

31. ADAM, M. D., M. J. LACKI and T. G. BARNES. 1994. FORAGING AREAS AND HABITAT USE OF THE VIRGINIA BIG-EARED BAT IN KENTUCKY. J. WILDL. MANAGE. 58 (3):462-9.

32. ADAMIC, M. 1992. EVALUATION OF POSSIBILITIES FOR NATURAL SPREADING OF BROWN BEAR (URSUS ARCTOS L.) TOWARDS THE ALPS, DIRECTIONS OF MAIN MIGRATION CORRIDORS AND DISTURBANCES IN THEIR FUNCTIONING. IN: RJAVI MEDVED V DEZELAH ALPE-ADRIA ZBORNIK POSVETOVANJA; LJUBLJANA. 29-30 JUNE, 1992. MINISTRSTVO ZA KMETIJSTVO IN GOZDARSTVO, REPUBLIKE SLOVENIJE, GOZDARSKI INSTITUT SLOVENIJE

33. ADAMS, A. W. 1982. MIGRATION (CHAPTER 7). P 301-21. IN: THOMAS, J.W., TOWEILL, D.E., (EDITORS). ELK OF NORTH AMERICA: ECOLOGY AND MANAGEMENT. HARRISBURG, PA: STACKPOLE BOOKS.

34. ADAMS, E. S. 1974. UPTAKE BY BROOK TROUT OF LEAD AND HYDROCARBONS FROM SNOWMOBILE EXHAUST. UNIVERSITY MICROFILMS ORDER NO 74-21088. UNIVERSITY OF NEW HAMPSHIRE, DEPT. OF ZOOLOGY, DURHAM, NEW HAMPSHIRE.

35. ADAMS, J. A., A. S. ENDO, L. H. STOLZY, P. G. ROWLANDS and H. B. JOHNSON. 1982. CONTROLLED EXPERIMENTS ON SOIL COMPACTION PRODUCED BY OFF-ROAD VEHICLES ON THE MOJAVE DESERT, CALIFORNIA. JOURNAL OF APPLIED ECOLOGY 19:167-176.

36. ADAMS, J. A., L. H. STOLZY, A. S. ENDO, P. G. ROWLANDS and H. B. JOHNSON. 1982. DESERT SOIL COMPACTION REDUCES ANNUAL PLANT COVER. CALIFORNIA AGRICULTURE 36:6-7. 
37. ADAMS, K. A. 1956. MULTIPLE USE ON PRIVATE LANDS. AMER. FOR. 62:14-15, 58-9.

38. ADAMS, L. W. 1984. SMALL MAMMAL USE OF AN INTERSTATE HIGHWAY MEDIAN STRIP. JOURNAL OF APPLIED ECOLOGY 21:175-178.

39. ADAMS, L. W. and L. E. DOVE. 1989. WLDLIFE RESERVES AND CORRIDORS IN THE URBAN ENVIRONMENT: A GUIDE TO ECOLOGICAL LANDSCAPE PLANNING AND RESOURCE CONSERVATION. NATIONAL INSTITUTE FOR URBAN WILDLIFE, COLUMBIA, MD.

40. ADAMS, L. W. and A. D. GEIS. 1981. EFFECTS OF HIGHWAYS ON WLDLIFE. U.S. DEPT. TRANSPORTATION, FEDERAL HIGHWAY ADMINISTRATION. REPORT NO. FHWA-RD-81-67.149 PP.

41. ADAMS, L. W. and A. D. GEIS. 1981. EFFECTS OF HIGHWAYS ON WLDLIFE. FHWA/RD-81/067. U.S. DEPARTMENT OF TRANSPORTATION, FEDERAL HIGHWAY ADMINISTRATION, WASHINGTON, DC.

42. ADAMS, L. W. and A. D. GEIS. 1978. EFFECTS OF HIGHWAYS ON WLDLIFE POPULATIONS AND HABITATS: SELECTION AND EVALUATION OF PROCEDURES. FHWA-RD-78-92. U.S. DEPARTMENT OF TRANSPORTATION, FEDERAL HIGHWAY ADMINISTRATION, WASHINGTON, DC.

43. ADAMS, L. W. and A. D. GEIS. 1984. EFFECTS OF ROADS ON BREEDING BIRDS. PAGES 562-569 IN CRABTREE,A.F., EDITOR. PROCEEDINGS OF THE THIRD INTERNATIONAL SYMPOSIUM ON ENVIRONMENTAL CONCERNS IN RIGHTS-OF-WAY MANAGEMENT; 1982 FEBRUARY 15-18; SAN DIEGO, CA. MISSISSIPPI STATE COLLEGE, [LOCATIONS OF PUBLISHER UNKNOWN].

44. ADAMS, L. W. and A. D. GEIS. 1983. EFFECTS OF ROADS ON SMALL MAMMALS. JOURNAL OF APPLIED ECOLOGY 20:403-416.

45. ADAMS, L. and A. D. GEIS. 1978. EFFECTS OF HIGHWAYS ON WILDLIFE POPULATIONS AND HABITATS PHASE 1 , SELECTION AND EVALUATION OF PROCEDURES. REPORT - FEDERAL HIGHWAY ADMINISTRATION ; NO. FHWA-RD-78-92. DEPT. OF TRANSPORTATION, FEDERAL HIGHWAY ADMINISTRATION, OFFICES OF RESEARCH \& DEVELOPMENT. FOR SALE BY THE NATIONAL TECHNICAL INFORMATION SERVICE, WASHINGTON, D.C.

46. ADAMS, L. W. 1978. EFFECTS OF HIGHWAYS ON WLDLIFE POPULATIONS AND HABITATS PHASE 1, SELECTION AND EVALUATION OF PROCEDURES. MICROFORM. PATUXENT WILDLIFE RESEARCH CENTER. UNITED STATES FEDERAL HIGHWAY ADMINISTRATION, OFFICES OF RESEARCH AND DEVELOPMENT AVAILABLE FROM NATIONAL TECHNICAL INFORMATION SERVICE, SPRINGFIELD, VIRGINIA.

47. ADAMS, L. W. and A. D. GEIS. 1980. EFFECTS OF HIGHWAYS ON WILDLIFE. U.S. DEPARTMENT OF TRANSPORTATION, FEDERAL HIGHWAY ADMINISTRATION; OFFICE OF RESEARCH AND DEVELOPMENT. WASHINGTON, D.C. INTERIM REPORT PHASE I NO. FHWA-RD-78-92. 179PP.

48. ADAMS, L. W. and A. D. GEIS. 1978. EFFECTS OF HIGHWAYS ON WILLIFE POPULATIONS AND HABITATS: SELECTION AND EVALUATION OF PROCEDURES. URBAN WILDLIFE RESEARCH CENTER. COLUMBIA, MARYLAND. 152PP.

49. ADAMS, L. W. and A. D. GEIS. 1978. EFFECTS OF HIGHWAYS ON WLDLIFE POPULATIONS AND HABITATS PHASE 1, SELECTION AND EVALUATION OF PROCEDURES : INTERIM REPORT. U.S. FEDERAL HIGHWAY ADMINISTRATION. AVAILABLE THROUGH NATIONAL TECHNICAL INFORMATION SERVICE, WASHINGTON, D.C.

50. ADAMS, L. W. and A. D. GEIS. 1978. EFFECTS OF HIGHWAYS ON WLDLIFE POPULATIONS AND HABITATS PHASE 1, SELECTION AND EVALUATION OF PROCEDURES. REPORT - FEDERAL HIGHWAY ADMINISTRATION ; NO. FHWA-RD-78-92: REPORT (UNITED STATES. FEDERAL HIGHWAY ADMINISTRATION) NO. FHWA-RD-78-92. DEPT. OF TRANSPORTATION, FEDERAL HIGHWAY ADMINISTRATION, OFFICES OF RESEARCH \& DEVELOPMENT. FOR SALE BY THE NATIONAL TECHNICAL INFORMATION SERVICE, WASHINGTON, D.C.

51. ADAMS, L. W. and A. D. GEIS. 1978. EFFECTS OF HIGHWAYS ON WLDLIFE POPULATIONS AND HABITATS PHASE I SELECTION AND EVALUATION OF PROCEDURES. U.S. FISH AND WLDLIFE SERVICE ; SPRINGFIELD, VA. NTIS DISTRIBUTOR, LAUREL, MARYLAND.

52. ADAMS, L. W. and A. D. GEIS. 1981. ROADS AND ROADSIDE HABITAT IN RELATION TO SMALL MAMMAL DISTRIBUTION AND ABUNDANCE. PAGES 1-54 IN R. E. TILLMAN, EDITOR. PROCEEDINGS OF SECOND SYMPOSIUM ON ENVIRONMENTAL CONCERNS IN RIGHTS-OF-WAY MANAGEMENT; 1979 OCTOBER 16-18; ANN ARBOR, MICHIGAN UNIVERSITY OF MICHIGAN, ANN ARBOR. 
53. ADDIS, M. C., I. G. SIMMONS and P. L. SMART. 1984. THE ENVIRONMENTAL IMPACT OF AN OPENCAST OPERATION IN THE FOREST OF DEAN, ENGLAND. JOURNAL OF ENVIRONMENTAL MANAGEMENT 19:79-95.

54. ADELMAN, E. B. 1979. A SURVEY OF THE NON-GAME MAMMALS IN THE UPPER RATTLESNAKE CREEK DRAINAGE OF WESTERN MONTANA. M.S. THESIS, UNIVERSITY OF MONTANA, MISSOULA, MT. 129 PP.

55. ADERHOLD, M. W. 1972. HISTORY, WINTER RANGE, AND CURRENT STATUS OF THE ROCK CREEK, MONTANA, BIGHORN SHEEP HERD. M.S. THESIS, UNIVERSITY OF MONTANA, MISSOULA, MT. 104 PP.

56. ADKINS, C. A. and P. STOTT. 1998. HOME RANGES, MOVEMENTS AND HABITAT ASSOCIATIONS OF RED FOXES VULPES VULPES IN SUBURBAN TORONTO, ONTARIO, CANADA. JOURNAL OF ZOOLOGY (LONDON) 244:335-346.

57. ADKINS, R. J. 1991. AN ANALYSIS OF GAME DAMAGE AND GAME DAMAGE COMPLAINTS IN MONTANA. M.S. THESIS, MONTANA STATE UNIVERSITY, BOZEMAN, MT. 90 PP.

58. ADKINSON, M. D. 1989. SPATIAL PATTERN IN THE INFLUENCE OF SULFUR DIOXIDE EMISSIONS FROM ARIZONA AND MEXICO COPPER SMELTERS. M.S. THESIS, MONTANA STATE UNIVERSITY, BOZEMAN, MT. 62 PP.

59. AEY, W. 1990. HISTORICAL AND ECOLOGICAL STUDIES OF THE URBAN ECOTOPES OF LUEBECK (GERMANY): FLORISTIC, PHYTOSOCIOLOGICAL, AND PEDOLOGICAL STUDIES OF URBAN AREAS OF VARIOUS AGES. MITTEILUNGEN DER ARBEITSGEMEINSCHAFT GEOBOTANIK IN SCHLESWIG HOLSTEIN UND HAMBURG 41:1-229.

60. AFIK, D. and B. PINSHOW. 1993. TEMPERATURE REGULATION AND WATER ECONOMY IN DESERT WOLVES. JOURNAL OF ARID ENVIRONMENTS 24 (2):197-209.

61. AGER, A. and M. HITCHCOCK. 1994. HEICALC - ELK HABITAT-EFFECTIVENESS INDEX SOFTWARE. WLDLIFE SOCIETY BULLETIN 22(1):126-128.

62. AHERN, J. 1991. PLANNING FOR AN EXTENSIVE OPEN SPACE SYSTEM: LINKING LANDSCAPE STRUCTURE AND FUNCTION. LANDSCAPE AND URBAN PLANNING 21(1-2):131-45.

63. AHLSTRAND, G. M. and C. H. RACINE. 1993. RESPONSE OF AN ALASKA, U.S.A., SHRUB-TUSSOCK COMMUNITY TO SELECTED ALL-TERRAIN-VEHICLE USE. ARCTIC ALPINE RES. 25:142-149.

64. AIROLA, D. A. 1986. BROWN-HEADED COWBIRD PARASITISM AND HABITAT DISTURBANCE IN THE SIERRA NEVADA. J. WILDL. MANAGE. 50 (4):571-5.

65. AITCHISON, S. W., S. W. CAROTHERS and R. R. JOHNSON. 1977. SOME ECOLOGICAL CONSIDERATIONS ASSOCIATED WITH RIVER RECREATION MANAGEMENT. PAGES 222-225 IN PROCEEDINGS: RIVER RECREATION MANAGEMENT AND RESEARCH SYMPOSIUM. VOLUME GENERAL TECHNICAL REPORT NC-28. USDA FOREST SERVICE, NORTH-CENTRAL FOREST EXPERIMENT STATION, ST. PAUL, MINNESOTA.

66. ALASKA, DEPT. OF FISH AND GAME and HABITAT DIVISION. 1986. ALASKA HABITAT MANAGEMENT GUIDE IMPACTS OF LAND AND WATER USE ON FISH AND THEIR HABITAT. ALASKA DEPT. OF FISH AND GAME, DIVISION OF HABITAT, JUNEAU, ALASKA

67. ALASKA, DEPT. OF FISH AND GAME and HABITAT DIVISION. 1986. ALASKA HABITAT MANAGEMENT GUIDE IMPACTS OF LAND AND WATER USE ON WILDLIFE AND THEIR HABITAT AND ON HUMAN USE OF FISH AND WILDIFE. ALASKA DEPT. OF FISH AND GAME, DIVISION OF HABITAT, JUNEAU, ALASKA.

68. ALASKA HIGHWAY GAS PIPELINE PROJECT. 1977. ENVIRONMENTAL CONCERNS AND RECOMMENDATIONS OF THE YUKON WILDLIFE BRANCH. GOVERNMENT OF YUKON, YUKON WLDLIFE BRANCH, WHITEHORSE, YUKON.

69. ALASKA POWER AUTHORITY and SUSITNA HYDROELECTRIC PROJECT. 1984. CANDIDATE LANDS FOR WILDLIFE HABITAT MITIGATION, SUSITNA HYDROELECTRIC PROJECT. ALASKA.

70. ALBANESE, P. and J. MIDDLETON. 1990. WOODY VEGETATION IN A POWER RIGHT-OF-WAY IN SHORT HILLS PROVINCIAL PARK, ONTARIO (CANADA). NATURALISTE CANADIEN (QUEBEC) 117 (1):9-12. 
71. ALBASEL, N. and A. COTTENIE. 1985: HEAWY METAL CONTAMINATION NEAR MAJOR HIGHWAYS, INDUSTRIAL AND URBAN AREAS IN BELGIAN GRASSLAND. WATER, AIR, SOIL POLLUTION 24:103-109.

72. ALBERT, D. M. and R. T. BOWYER. 1991. FACTORS RELATED TO GRIZZLY BEAR-HUMAN INTERACTIONS IN DENALI NATIONAL PARK. WILDLIFE SOCIETY BULLETIN 19:339-349.

73. ALBERT, S. W. 1981. MORPHOLOGICAL VARIATION IN BOBCATS IN NORTHWESTERN AMERICA. M.S. THESIS, UNIVERSITY OF MONTANA, MISSOULA, MT. 143 PP.

74. ALBERTA, ALBERTA ENERGY AND NATURAL RESOURCES, ALBERTA and FISH AND WLDLIFE DIVISION. 1982. FISHERIES HABITAT PROTECTION GUIDELINES. ALBERTA ENERGY AND NATURAL RESOURCES, FISH AND WILDLIFE DIVISION, EDMONTON, ALBERTA

75. ALBERTA, ALBERTA ENVIRONMENT, ALBERTA and ALBERTA FORESTRY, LANDS AND WLDLIFE. 1972-1992. WATER INFORMATION PAMPHLETS.

76. ALBERTA, ALBERTA ENVIRONMENT, ALBERTA, ENVIRONMENTAL ASSESSMENT AND STRATEGY DIVISION, LUSCAR LTD and ALBERTA ENERGY AND UTILITIES BOARD. 1999. GREGG RIVER MINE WEST EXTENSION. LUSCAR LTD., HINTON, ALBERTA.

77. ALBERTA, ALBERTA ENVIRONMENTAL PROTECTION, ALBERTA, ALBERTA AGRICULTURE, FOOD AND RURAL DEVELOPMENT and BOW CORRIDOR ECOSYSTEM ADVISORY GROUP. 1998. WILDLIFE CORRIDOR AND HABITAT PATCH GUIDELINES FOR THE BOW VALLEY. PUB. NO: PUBLICATION (ALBERTA. ALBERTA ENVIRONMENTAL PROTECTION) NO. T/411. ALBERTA ENVIRONMENTAL PROTECTION, EDMONTON, ALBERTA.

78. ALBERTA, ALBERTA ENVIRONMENTAL PROTECTION, ALBERTA, ALBERTA FORESTRY, LANDS AND WILDLIFE, ALBERTA, ALBERTA ENERGY AND NATURAL RESOURCES, ALBERTA and ALBERTA RECREATION, PARKS AND WILDLIFE. 1975. WIDLIFE MANAGEMENT INFORMATION PAMPHLETS.

79. ALBERTA and ALBERTA FORESTRY, LANDS AND WILDLIFE. 1992. BOW CORRIDOR LOCAL INTEGRATED RESOURCE PLAN. PUB: ENR REPORT I:301. ALBERTA FORESTRY, LANDS AND WILDLIFE, EDMONTON, ALBERTA.

80. ALBERTA and ALBERTA FORESTRY, LANDS AND WLDLIFE. 1991. CROWSNEST CORRIDOR, LOCAL INTEGRATED RESOURCE PLAN. [ENR] PUB: ENR REPORT I:287. ALBERTA FORESTRY, LANDS AND WILDLIFE, EDMONTON, ALBERTA.

81. ALBERTA and ALBERTA FORESTRY, LANDS AND WILDIFE. 1992. DAVID THOMPSON CORRIDOR LOCAL INTEGRATED RESOURCE PLAN. PUB. NO. T/189: PUBLICATION (ALBERTA. ALBERTA FORESTRY, LANDS AND WLDLIFE) NO. T:189. ALBERTA FORESTRY, LANDS AND WILDLIFE, EDMONTON, ALBERTA.

82. ALBERTA, ALBERTA FORESTRY, LANDS AND WILDLIFE, ALBERTA, EASTERN SLOPES REGION RESOURCE MANAGEMENT COMMITTEE, ALBERTA, ALBERTA ENERGY, ALBERTA and ALBERTA ENVIRONMENTAL PROTECTION. 1991-1995. EASTERN SLOPES REGION INTEGRATED RESOURCE PLANS. ALBERTA ENERGY FORESTRY, LANDS AND WILDLIFE, EDMONTON, ALBERTA.

83. ALBERTA, ALBERTA FORESTRY, LANDS AND WILDLIFE, ALBERTA and PUBLIC LANDS DIVISION. 1986. STATUS REPORT OF ALBERTA'S NATURAL AREAS. ALBERTA FORESTRY, LANDS AND WILDLIFE, PUBLIC LANDS DIVISION, NATURAL AREAS PROGRAM, EDMONTON, ALBERTA.

84. ALBERTA, ALBERTA FORESTRY, LANDS AND WILDLIFE and RESOURCE PLANNING BRANCH. 1986. ATHABASCA OIL SANDS MULTIPLE USE CORRIDOR STUDY CORRIDOR SELECTION PROCESS. ENR TECHNICAL REPORT NO. T 7-NO. 105. ALBERTA FORESTRY, LANDS \& WILDLIFE, RESOURCE EVALUATION AND PLANNING DIV, EDMONTON, ALBERTA.

85. ALBERTA, ALBERTA FORESTRY, LANDS AND WILDLIFE and SWEETGRASS CONSULTANTS LTD. 1989. ENVIRONMENTALLY SIGNIFICANT AREAS IN THE DAVID THOMPSON CORRIDOR. THE CONSULTANTS, CALGARY, ALBERTA.

86. ALBERTA and ALBERTA PUBLIC WORKS, SUPPLY AND SERVICES. 1998. OLDMAN RIVER DAM WLDLIFE HABITAT MITIGATION PROGRAM, PINCHER CREEK, ALBERTA FINAL REPORT : SUMMARY OF THE IMPLEMENTATION PHASE (1987-1993). ALBERTA PUBLIC WORKS, SUPPLY AND SERVICES, EDMONTON, ALBERTA. 
87. ALBERTA, ALBERTA PUBLIC WORKS, SUPPLY AND SERVICES, ALBERTA, DEPT. OF THE ENVIRONMENT, PLANNING DIVISION, ALBERTA and FISH AND WILDLIFE DIVISION. 1988-1990. A STRATEGY FOR FISHERIES MITIGATION IN THE OLDMAN RIVER BASIN. ALBERTA. SESSIONAL PAPER 317/88. ALBERTA ENVIRONMENT PLANNING DIVISION, EDMONTON, ALBERTA.

88. ALBERTA, ALBERTA RECREATION, PARKS AND WLDLIFE, ALBERTA and PARKS DIVISION. 1977. ENVIRONMENTAL GUIDELINES FOR ROAD DEVELOPMENT IN PROVINCIAL PARKS RESOURCE ASSESSMENT \& MANAGEMENT SECTION. THE DEPARTMENT, EDMONTON, ALBERTA.

89. ALBERTA, ALBERTA TRANSPORTATION AND UTILITIES, ALBERTA, ALBERTA FORESTRY, LANDS AND WILDLIFE, ALBERTA and ALBERTA ENERGY AND NATURAL RESOURCES. 1992. FISH HABITAT PROTECTION GUIDELINES FOR STREAM CROSSINGS. REV. ED. THE DEPTS, EDMONTON, ALBERTA.

90. ALBERTA, ALBERTA TRANSPORTATION AND UTILITIES, ALBERTA, ALBERTA FORESTRY, LANDS AND WILDLIFE, ALBERTA and ALBERTA ENERGY AND NATURAL RESOURCES. 1987. FISH HABITAT PROTECTION GUIDELINES FOR STREAM CROSSINGS. THE DEPTS, EDMONTON, ALBERTA.

91. ALBERTA, DEPT. OF THE ENVIRONMENT and PLANNING DIVISION. 1985. BADGER RESERVOIR ENVIRONMENTAL EFFECTS AND MITIGATION. THE DEPT, EDMONTON, ALBERTA.

92. ALBERTA, DEPT. OF THE ENVIRONMENT, PLANNING DIVISION and R L \& L ENVIRONMENTAL SERVICES. 1986 . PRELIMINARY ASSESSMENT OF FISHERIES MITIGATION OPTIONS AND RESERVOIR FISH POPULATIONS OLDMAN RIVER DAM. ALBERTA ENVIRONMENT PLANNING DIVISION, EDMONTON, ALBERTA.

93. ALBERTA and FISH AND WILDIFE DIVISION. 1987. HABITAT DEVELOPMENT FACT SHEET. ENR REPORT: ENR REPORT I:121. ALBERTA ENERGY AND NATURAL RESOURCES, FISH AND WILDLIFE DIVISION, EDMONTON, ALBERTA.

94. ALBERTA, FISH AND WILDLIFE DIVISION, ALBERTA, ALBERTA ENERGY AND NATURAL RESOURCES, ALBERTA and ALBERTA FORESTRY, LANDS AND WILDLIFE. 1979. ZOOLOGY INFORMATION PAMPHLETS.

95. ALBERTA, RECREATION DEVELOPMENT DIVISION, ALBERTA and ALBERTA RECREATION GOVERNMENT RECREATION COMMITTEE. 1978. THE RECREATION CORRIDOR CONCEPT A PROPOSAL FOR THE DEVELOPMENT OF AN ALBERTA TRAILS SYSTEM. ALBERTA RECREATION PARKS AND WILDLIFE, RECREATION DEVELOPMENT DIV, EDMONTON, ALBERTA.

96. ALBERTA. DEPT. OF PUBLIC WORKS, SUPPLIES AND SERVICES, J. E. GREEN, T. R. ECCLES and DELTA ENVIRONMENTAL MANAGEMENT GROUP. 1989. STRATEGY FOR WILDLIFE HABITAT MITIGATION FOR THE OLDMAN RIVER DAM RESERVOIR.

97. ALBERTA. DEPT. OF PUBLIC WORKS, SUPPLY AND SERVICES, A. L. NILSON and J. E. GREEN. 1989. ACTION PLAN FOR WILDLIFE HABITAT MITIGATION FOR THE OLDMAN RIVER DAM RESERVOIR.

98. ALBERTA-PACIFIC ENVIRONMENT IMPACT ASSESSMENT REVIEW BOARD. 1989. THE ALBERTA-PACIFIC ENVIRONMENT IMPACT ASSESSMENT REVIEW BOARD PUBLIC HEARING FILED DOCUMENTS AT ATHABASCA, ALBERTA, NOVEMBER 17-18, 20-21, 1989. THE BOARD, EDMONTON, ALBERTA.

99. ALBERTA-PACIFIC ENVIRONMENT IMPACT ASSESSMENT REVIEW BOARD. 1989. THE ALBERTA-PACIFIC ENVIRONMENT IMPACT ASSESSMENT REVIEW BOARD PUBLIC HEARING FILED DOCUMENTS AT FORT MCMURRAY, ALBERTA, OCTOBER 30-31, NOVEMBER 25, 1989. THE BOARD, EDMONTON, ALBERTA.

100. ALBERTA-PACIFIC ENVIRONMENT IMPACT ASSESSMENT REVIEW BOARD. 1989. THE ALBERTA-PACIFIC ENVIRONMENT IMPACT ASSESSMENT REVIEW BOARD PUBLIC HEARING FILED DOCUMENTS AT GRASSLAND, ALBERTA, DECEMBER 7 AND 8, 1989. THE BOARD, EDMONTON, ALBERTA.

101. ALBRECHT, J. and T. B. KNOPP. 1985. OFF ROAD VEHICLES - ENVIRONMENTAL IMPACT - MANAGEMENT RESPONSE: A BIBLIOGRAPHY. AGRICULTURAL EXPERIMENT STATION, UNIVERSITY OF MINNESOTA. ST. PAUL, MINNESOTA. MISCELLANEOUS PUBLICATION NO. 35. III + 50PP.

102. ALBRECHT, J. 1992. TRAIL PLANNING, CONSTRUCTION AND MAINTENANCE. A BIBLIOGRAPHY SUPPLEMENT. MINNESOTA AGRICULTURAL STATION, UNIVERSITY OF MINNESOTA. MISCELLANEOUS PUBLICATION 76 - 1972. 3OPP. 
103. ALBRECHT, J. 1996. TRAIL PLANNING, CONSTRUCTION AND MAINTENANCE: A BIBLIOGRAPHY SUPPLEMENT, 1996. COLLEGE OF NATURAL RESOURCES AND MINNESOTA AGRICULTURAL EXPERIMENT STATION, UNIVERSITY OF MINNESOTA. ST. PAUL, MINNESOTA. STAFF PAPER SERIES NO. 118., DEPARTMENT OF FOREST RESOURCES. 29PP.

104. ALDRIDGE, R. D. and W. S. BROWN. 1995. MALE REPRODUCTIVE CYCLE, AGE AT MATURITY, AND COST OF REPRODUCTION IN THE TIMBER RATTLESNAKE (CROTALUS HORRIDUS). JOURNAL OF HERPETOLOGY 29 (3):399-407.

105. ALEXANDER, H. E. 1965. PROBLEMS AND PROGRESS IN STREAM PRESERVATION. TRANS. N. AMER. WILDL. NAT. RESOUR. CONF. 30:76-88.

106. ALGARD, G. A. 1968. DISTRIBUTION, TEMPERATURE AND POPULATION STUDIES OF SCELOPORUS GRACIOSUS GRACIOSUS IN YELLOWSTONE NATIONAL PARK. M.S. THESIS, MONTANA STATE UNIVERSITY, BOZEMAN, MT. 34 PP.

107. ALISAUSKAS, R. T. and C. D. ANKNEY. 1992. SPRING HABITAT USE AND DIETS OF MIDCONTINENT ADULT LESSER SNOW GEESE. JOURNAL OF WILDLIFE MANAGEMENT 56:43-54.

108. ALKON, P. U. 1969. EFFECT OF TYPE OF ROAD ON SUMMER ROADSIDE COUNTS OF COTTONTAILS. NEWYORK STATE DIV. OF FISH AND GAME. W-084-R.

109. ALLBRECHT, J. and D. SMITH. 1977. ENVIRONMENTAL EFFECTS OF OFF-ROAD VEHICLES: A SELECTED BIBLIOGRAPHY OF PUBLICATIONS IN THE UNIVERSITY OF MINNESOTA FORESTRY LIBRARY. UNIVERSITY OF MINNESOTA, ST. PAUL CAMPUS LIBRARIES. ST. PAUL, MINNESOTA. FOR. SERV. LIBR. BIBLIGR. SER. 2. 9PP.

110. ALLDREDGE, A. W. 1988. WILDLIFE AND SKI AREAS: LIVING TOGETHER. SKI AREA MANAGE. 27:61-62, 88-89.

111. ALLEN, E. O. 1976. MONTANA COOPERATIVE ELK-LOGGING STUDY. ANN. PROG. REPT., 1975 MONTANA DEPT. OF FISH AND GAME., 81 PP.

112. ALLEN, E. O. 1977. A NEW PERSPECTIVE FOR ELK HABITAT MANAGEMENT. PROC. WEST. ASSOC. FISH AND GAME COMM. P 142-4..

113. ALLEN, E. O. 1965. FOOD AND RANGE HABITS OF WHITETAIL DEER ON MISSOURI RIVER BOTTOMLANDS IN NORTHCENTRAL MONTANA. M.S. THESIS, MONTANA STATE UNIVERSITY, BOZEMAN, MT. 41 PP.

114. ALLEN, L., P. LONG and R. PERDUE. THE IMPACT OF TOURISM DEVELOPMENT ON RESIDENTS' PERCEPTIONS OF COMMUNITY LIFE. J. TRAVEL RES. 27:16-21.

115. ALLEN, R. B. 1985. RESEARCH AND MANAGEMENT IMPLICATIONS IN THE PURSUIT OF BLACK BEARS WITH TRAINED BEAR DOGS. M.S. THESIS, UNIVERSITY OF MONTANA, MISSOULA, MT. 51 PP.

116. ALLEN, R. E. and D. R. MCCULLOUGH. 1976. DEER-CAR ACCIDENTS IN SOUTHERN MICHIGAN. JOURNAL OF WILDLIFE MANAGEMENT 40:317-325.

117. ALLEN, S. H. and A. B. SARGEANT. 1993. DISPERSAL PATTERNS OF RED FOXES RELATIVE TO POPULATION DENSITY JOURNAL OF WILDLIFE MANAGEMENT 57:526-533.

118. ALT, G. L., G. J. JR. MATULA, F. W. ALT and J. S. LINDZEY. 1978. MOVEMENTS OF TRANSLOCATED NUISANCE BLACK BEARS OF NORTHEASTERN PENNSYLVANIA. PENNSYLVANIA COOPERATIVE WILDLIFE RESEARCH UNIT 209: $42-51$

119. ALT, K. L. 1980. ECOLOGY OF THE BREEDING BALD EAGLE AND OSPREY IN THE GRAND TETON-YELLOWSTONE NATIONAL PARKS COMPLEX. M.S. THESIS, MONTANA STATE UNIVERSITY, BOZEMAN, MT. 95 PP.

120. ALTIERI, M. A. 1990. HOW COMMON IS OUR COMMON FUTURE? CONSERVATION BIOLOGY 4 (1):102-3..

121. ALVAREZ, B. I. and H. FREAN. 1992. VERTEBRATES RUN OVER ON TWO ROADS IN OURENSE. FIRST REPORT. PAGES 239-251 IN LOPEZ,REDONDO, EDITOR. I JORNADAS PARA EL ESTUDIO Y PREVENCION DE LA MORTALIDAD DE 
VERTEBRADOS EN CARRETERAS, MADRID, 5 Y 6 DE OCTUBRE DE 1991. TOMO 2. [SESSIONS IN THE STUDY OF PREVENTION OF ROAD MORTALITIES OF VERTEBRATES, MADRID, 5 AND 6 OCTOBER, 1991. VOLUME 2.]. -COORDINADORA DE ORGANIZACCIONES DE DEFENSA, AMBIENTAL, MADRID.

122. ALVERSON, W. S., D. M. WALLER and S. L. SOLHEIM. 1988. FORESTS TOO DEER: EDGE EFFECTS IN NORTHERN WISCONSIN. CONSERVATION BIOLOGY 2 (4):348-58.

123. ALVORD, W. 1953. A STUDY OF SCALES FROM KNOWN-AGE TROUT. M.S. THESIS, MONTANA STATE COLLEGE, BOZEMAN, MT. 30 PP.

124. AMARASEKARE, P. 1993. POTENTIAL IMPACT OF MAMMALIAN NEST PREDATORS ON ENDEMIC FOREST BIRDS OF WESTERN MAUNA KEA, HAWAII. CONSERVATION BIOLOGY 7.(2):316-24.

125. AMBORSKI, R. L., T. G. I. SNIDER, R. L. THUNE and D. D. JR. CULLEY. 1983. A NON-HEMOLYTIC, GROUP B STREPTOCOCCUS INFECTION OF CULTURED BULLFROGS, RANA CATESBEIANA, IN BRAZIL. JOURNAL OF WILDLIFE DISEASES 19:180-184.

126. AMENT, R. J. 1995. PIONEER PLANT COMMUNITIES FIVE YEARS AFTER THE 1988 YELLOWSTONE FIRES. M.S. THESIS, MONTANA STATE UNIVERSITY, BOZEMAN, MT. 216 PP.

127. AMERICAN ACADEMY FOR THE ADVANCEMENT OF SCIENCE. 1974. ORV USE. SCIENCE 18:500-501.

128. AMERICAN ACADEMY OF POLITICAL AND SOCIAL SCIENCE. 1908. FEDERAL REGULATION OF INDUSTRY. THE ANNALS OF THE AMERICAN ACADEMY OF POLITICAL AND SOCIAL SCIENCE. VOL. XXXII, NO. 1: ANNALS OF THE AMERICAN ACADEMY OF POLITICAL AND SOCIAL SCIENCE V. 32, NO. 1. AMERICAN ACADEMY OF POLITICAL AND SOCIAL SCIENCE, PHILADELPHIA, PENNSYLVANIA.

129. AMERICAN ASSOCIATION FOR THE ADVANCEMENT OF SCIENCE, COMMITTEE ON ARID LANDS. 1974. OFF-ROAD VEHICLE USE. SCIENCE 184:500-501.

130. AMERICAN ASSOCIATION OF STATE HIGHWAY AND TRANSPORTATION OFFICIALS. 1976. A DESIGN GUIDE FOR WILDLIFE PROTECTION AND CONSERVATION FOR TRANSPORTATION FACILITIES. AMERICAN ASSOCIATION OF STATE HIGHWAY AND TRANSPORTATION OFFICIALS, WASHINGTON, D.C.

131. AMERICAN ASSOCIATION OF STATE HIGHWAY AND TRANSPORTATION OFFICIALS. 1976. DESIGN GUIDE FOR WLDLIFE PROTECTION AND CONSERVATION FOR TRANSPORTATION FACILITIES : PLANNING FOR WLDLIFE. AMERICAN ASSOCIATION OF STATE HIGHWAY AND TRANSPORTATION OFFICIALS, WASHINGTON, D.C.

132. AMERICAN LAW INSTITUTE-AMERICAN BAR ASSOCIATION COMMITTEE ON CONTINUING PROFESSIONAL EDUCATION and ENVIRONMENTAL LAW INSTITUTE. 1994. NATIONAL ENVIRONMENTAL POLICY ACT (NEPA) ECOSYSTEM ANALYSIS, AND ENVIRONMENTAL IMPACT ASSESSMENT APRIL 21-22, 1994, WASHINGTON, D.C. AMERICAN LAW INSTITUTE-AMERICAN BAR ASSOCIATION COMMITTEE ON CONTINUING PROFESSIONAL EDUCATION, PHILADELPHIA, PENNSYLVANIA.

133. AMOR, R. L. and P. L. STEVENS. 1976. SPREAD OF WEEDS FROM A ROADSIDE INTO SCLEROPHYLL FORESTS AT DARTMOUTH, AUSTRALIA. WEED RESEARCH 16:111-118.

134. AMSTRUP, S. C. 1993. HUMAN DISTURBANCES OF DENNING POLAR BEARS IN ALASKA. ARCTIC 46:246-250.

135. AMSTRUP, S. C. 1993. TITLE UNKNOWN. ARCTIC 46 ( 3 ):246-50.

136. AMSTRUP, S. C. and J. BEECHAM. 1976. ACTIVITY PATTERNS OF RADIO-COLLARED BLACK BEARS IN IDAHO. J. WILDL. MANAGE. 40 (2):340-8

137. AMSTRUP, S. C. and G. M. DURNER. 1995. SURVIVAL RATES OF RADIO-COLLARED FEMALE POLAR BEARS AND THEIR DEPENDENT YOUNG. CANADIAN JOURNAL OF ZOOLOGY 73(7):1312-22.

138. AMSTRUP, S. C. and R. L. PHILLIPS. 1978. EFFECTS OF COAL EXTRACTION AND RELATED DEVELOPMENT ON WLDLIFE POPULATIONS. ANN. PROG. REPT, WLDLF RES. WORK UNIT., 19 PP. 
139. ANDERS, F. J. and S. P. LEATHERMAN. 1987. DISTURBANCE OF BEACH SEDIMENT BY OFF-ROAD VEHICLES. ENVIRON. GEOL. WATER SCI. 9:183-189.

140. ANDERS, F. J. and S. P. LEATHERMAN. 1987. EFFECTS OF OFF-ROAD VEHICLES ON COASTAL FOREDUNES AT FIRE ISLAND, NEW YORK, USA. ENVIRONMENTAL MANAGEMENT 11:45-52.

141. ANDERSEN, B. J. 1990. AN ANALYSIS OF CHANGES IN PATCH AND CORRIDOR CHARACTERISTICS AS RELATED TO WILDLIFE HABITAT QUALITY, OLMSTED COUNTY, MINNESOTA.

142. ANDERSEN, D. E., O. J. RONGSTAD and W. R. MYTTON. 1985. LINE TRANSECT ANALYSIS OF RAPTOR ABUNDANCE ALONG ROADS. WILDL. SOC. BULL. 13 (4):533-9.

143. ANDERSEN, R. 1992. EFFECTS OF RESERVOIR CONSTRUCTION ON THE MOOSE'S MIGRATORY BEHAVIOR, SITE FIDELITY, AND SIZE OF THE SUMMER HOME RANGE. NINA (NORSK INSTITUTT FOR NATURFORSKNING FORSKNINGSRAPPORT) 0(30):1-27.

144. ANDERSEN, R., B. WISETH, P. PEDERSEN and V. JAREN. 1991. MOOSE-TRAIN COLLISIONS: EFFECTS OF ENVIRONMENTAL CONDITIONS. ALCES 27:79-84.

145. ANDERSON, D. W. 1988. DOSE-RESPONSE RELATIONSHIP BETWEEN HUMAN DISTURBANCE AND BROWN PELICAN BREEDING SUCCESS. WILDL. SOC. BULL. 16 (3):339-45.

146. ANDERSON, E. W. 1974. INDICATORS OF SOIL MOVEMENT ON RANGE WATERSHEDS. JOURNAL OF RANGE MANAGEMENT 27:244-247.

147. ANDERSON, L. and M. D. BRYANT. 1980. FISH PASSAGE AT ROAD CROSSINGS AN ANNOTATED BIBLIOGRAPHY. USDA FOREST SERVICE GENERAL TECHNICAL REPORT PNW: GENERAL TECHNICAL REPORT PNW 117. PACIFIC NORTHWEST FOREST AND RANGE EXPERIMENT STATION, FOREST SERVICE, U.S. DEPT. OF AGRICULTURE, PORTLAND, OREGON.

148. ANDERSON, N. J. 1994. GRIZZLY BEAR FOOD PRODUCTION ON CLEARCUTS WITHIN THE WESTERN AND NORHTWESTERN YELLOWSTONE ECOSYSTEM. M.S. THESIS, MONTANA STATE UNIVERSITY, BOZEMAN, MT. 73 PP.

149. ANDERSON, R. C. 1979. THE VALUE OF ROADSIDE VERGES TO WLDLIFE. TIGERPAPER 6(4):15-16.

150. ANDERSON, R. A., D. ASQUIN, P. JABLONSKI, ALBERTA and FOREST SERVICE. 1986. SIZING CROSSINGS FOR EASTERN SLOPE STREAMS A HANDBOOK OF THREE COMMON METHODS. ALBERTA FORESTRY, LANDS AND WLDLIFE, FOREST SERVICE, EDMONTON, ALBERTA.

151. ANDERSON, T. L. and P. J. HILL. 1995. WILDLIFE IN THE MARKETPLACE THE POLITICAL ECONOMY FORUM. POLITICAL ECONOMY FORUM. ROWMAN \& LITTLEFIELD, LANHAM, MARYLAND.

152. ANDERSON, W. L. 1978. WATERFOWL COLLISIONS WITH POWER LINES AT A COAL-FIRED POWER PLANT. WILDL. SOC. BULL. 6 (2):77-83.

153. ANDO, Y. 1993. NEST SITE SELECTION OF SIX HERON SPECIES IN A BREEDING COLONY. JAPANESE JOURNAL OF ORNITHOLOGY 41 (2):29-38.

154. ANDREASEN, B. 1984. UTILIZING THE RECREATION OPPORTUNITY SPECTRUM AS A TOOL IN LAND ALLOCATION DECISIONS INVOLVING ENERGY DEVELOPMENT AND WILDLIFE. PAGES 43-46 IN R. D. COMER, J. M. MERINO, J. W. MONARCH, C. PUSTMUELLER, M. STALMASTER, R. STOECKER, J. TODD, AND W. WRIGHT, EDITORS. ISSUES AND TECHNOLOGY IN THE MANAGEMENT OF IMPACTED WESTERN WILDLIFE -- PROCEEDINGS OF A NATIONAL SYMPOSIUM. THORNE ECOL. INST., BOULDER, COLORADO.

155. ANDREASSEN, H. P., S. HALLE and R. A. IMS. 1996. OPTIMAL WIDTH OF MOVEMENT CORRIDORS FOR ROOT VOLES: NOT TOO NARROW AND NOT TOO WIDE. JOURNAL OF APPLIED ECOLOGY 33:63-70.

156. ANDREASSEN, H. P., R. A. IMS and O. STEINSET. 1996. DISCONTINUOUS HABITAT CORRIDORS - EFFECTS ON MALE ROOT VOLE MOVEMENTS. JOURNAL OF APPLIED ECOLOGY 33(3):555-560. 
157. ANDREN, H. 1992. CORVID DENSITY AND NEST PREDATION IN RELATION TO FOREST FRAGMENTATION: A LANDSCAPE PERSPECTIVE. ECOLOGY 73 (3):794-804.

158. ANDREN, H. 1994. EFFECTS OF HABITAT FRAGMENTATION ON BIRDS AND MAMMALS IN LANDSCAPES WITH DIFFERENT PROPORTIONS OF SUITABLE HABITAT: A REVIEW. OIKOS 71(3):355-365.

159. ANDREN, $H$. and A. DELIN. 1994. HABITAT SELECTION IN THE EURASIAN RED SQUIRREL, SCIURUS VULGARIS, IN RELATION TO FOREST FRAGMENTATION. OIKOS 70 (1):43-8.

160. ANDREWS, A. 1990. FRAGMENTATION OF HABITAT BY ROADS AND UTILITY CORRIDORS, A REVIEW. AUSTRALIAN ZOOLOGIST $26: 130-141$.

161. ANDREWS, R. N. L. and P. F. NOWAK. 1980. OFF-ROAD VEHICLE USE: A MANAGEMENT CHALLENGE. U.S. DEPARTMENT OF AGRICULTURE, OFFICE OF ENVIRONMENTAL QUALITY. WASHINGTON, D.C. 348PP.

162. ANDRIAMASIMANANA, M. 1994. ECOETHOLOGICAL STUDY OF FREE-RANGING AYE-AYES (DAUBENTONIA MADAGASCARIENSIS) IN MADAGASCAR. FOLIA PRIMATOL (BASEL) 62 (1-3):37-45.

163. ANDRYK, T. A. 1983. ECOLOGY OF BIGHORN SHEEP IN RELATION TO OIL AND GAS DEVELOPMENT ALONG THE EAST SLOPE OF THE ROCKY MOUNTAINS, NORTHCENTRAL MONTANA. THESIS, MONTANA STATE UNIVERSITY, BOZEMAN, MONTANA. 100PP.

164. ANGELO, R. T. 1989. BIOLOGICAL CYCLING OF NITROGEN IN A ROCKY MOUNTAIN ALPINE LAKE, WITH EMPHASIS ON THE PHYSIOLOGICAL AND ECOLOGICAL EFFECTS OF ACIDIFICATION. PH.D. DISSERTATION, MONTANA STATE UNIVERSITY, BOZEMAN, MT. 253 PP.

165. ANGOLD, P. G. 1997. THE IMPACT OF A ROAD UPON ADJACENT HEATHLAND VEGETATION - EFFECTS ON PLANT SPECIES COMPOSITION. JOURNAL OF APPLIED ECOLOGY 34(2):409-417.

166. ANTHONY, R. G., R. W. FRENZEL, F. B. ISAACS and M. G. GARRETT. 1994. PROBABLE CAUSES OF NESTING FAILURES IN OREGON'S BALD EAGLE POPULATION. WILDL. SOC. BULL. 22(4):576-82.

167. ANTHONY, R. G. and F. B. ISAACS. 1989. CHARACTERISTICS OF BALD EAGLE NEST SITES IN OREGON. JOURNAL OF WILDLIFE MANAGEMENT 53:148-159.

168. ANZALONE, C. R., L. B. KATS and M. S. GORDON. 1998. EFFECTS OF SOLAR UV-B RADIATION ON EMBRYONIC DEVELOPMENT IN HYLA CADAVERINA, HYLA REGILLA, AND TARICHA TOROSA. CONSERVATION BIOLOGY 12:646-653.

169. AOI, T. 1987. HARVEST CHARACTERISTICS OF BROWN BEARS IN NORTHERN HOKKAIDO, JAPAN. INT. CONF. BEAR RES. AND MANAGE. 7:93-5

170. APPS, C. 1993. CUMULATIVE EFFECTS ASSESSMENT FOR LARGE CARNIVORES: A LITERATURE REVIEW AND DEVELOPMENT STRATEGY FOR THE CANADIAN ROCKIES. FACULTY OF ENVIRONMENTAL DESIGN, UNIVERSITY OF CALGARY. PREPARED FOR CANADIAN PARKS SERVICE, WESTERN REGION. 68PP.

171. APPS, C. 1997. IDENTIFICATION OF GRIZZLY BEAR LINKAGE ZONES ALONG THE HIGHWAY 3 CORRIDOR OF SOUTHEAST BRITISH COLUMBIA AND SOUTHWEST ALBERTA. ASPEN WILDLIFE RESEARCH, CALGARY, ALBERTA.

172. APPS, C. D. 1996. BOBCAT (LYNX RUFUS) HABITAT SELECTION AND SUITABILITY ASSESSMENT IN SOUTHEAST BRITISH COLUMBIA. M.E. DES. THESIS. UNIVERSITY OF CALGARY. CALGARY, ALBERTA.145PP.

173. APPS, C. D. 1997. IDENTIFICATION OF GRIZZLY BEAR LINKAGE ZONES ALONG HIGHWAY 3 CORRIDOR OF SOUTHEAST BRITISH COLUMBIA AND SOUTHWEST ALBERTA. PREPARED FOR B.C. MIN. ENVIRONMENT, LANDS, AND PARKS AND WWF CANADA AND U.S. 45PP.

174. ARADOTTIR, A. L. 1984. AMMONIA VOLATILIZATION FROM NATIVE GRASSLANDS AND FORESTS OF SOUTHWESTERN MONTANA. M.S. THESIS, MONTANA STATE UNIVERSITY, BOZEMAN, MT. 48 PP. 
175. ARANDA, Y., J. F. ORUETA and P. FANDOS. 1995. IMPACT OF HUNTING ON THE ESTIMATION OF DENSITY OF A MEDITERRANEAN RED DEER (CERVUS ELAPHUS) POPULATION FROM THE TRANSECT DATA. GIBIER FAUNE SAUVAGE $12(3): 231-46$.

176. ARCHIBALD, W. R., R. ELLIS and A. N. HAMILTON. 1987. RESPONSES OF GRIZZLY BEARS TO LOGGING TRUCK TRAFFIC IN THE KIMSQUIT RIVER VALLEY, BRITISH COLUMBIA. INTERNATIONAL CONFERENCE ON BEAR RESEARCH AND MANAGEMENT 7:251-257.

177. ARCTIC ENVIRONMENTAL INFORMATION AND DATA CENTER (ALASKA). 1979. AN ASSESSMENT OF ENVIRONMENTAL EFFECTS OF CONSTRUCTION OF THE TERROR LAKE HYDROELECTRIC FACILITY, KODIAK ISLAND, ALASKA. ARCTIC ENVIRONMENTAL INFORMATION AND DATA CENTER, ANCHORAGE, ALASKA.

178. ARENA, P. C., C. WARWICK and D. DUVALL. 1995. RATTLESNAKE ROUND-UPS. PAGES $313-324$ IN R. L. KNIGHT, AND K. J. GUTZWILLER, EDITORS. WILDLIFE AND RECREATIONISTS: COEXISTENCE THROUGH MANAGEMENT AND RESEARCH. ISLAND PRESS, WASHINGTON, D.C.

179. ARIZONA COMMISSION OF INDIAN AFFAIRS. 1962. INDIAN LAW AND ORDER AS PERTAINS TO HIGHWAY LAW FISH AND GAME LAW, BUREAU OF INDIAN AFFAIRS, WELFARE, LAND CLAIMS, WATER RIGHTS [AND] VOTING. PHOENIX, ARIZONA.

180. ARJO, W. M. 1998. THE EFFECTS OF RECOLONIZING WOLVES ON COYOTE POPULATIONS, MOVEMENTS, BEHAVIORS, AND FOOD HABITS. PH.D. DISSERTATION, UNIVERSITY OF MONTANA, MISSOULA, MT. 141 PP.

181. ARMBRUSTER, J. S. 1983. IMPACTS OF COAL SURFACE MINING ON 25 MIGRATORY BIRD SPECIES OF HIGH FEDERAL INTEREST. U.S. FISH AND WIDLIFE SERVICE. WASHINGTON, D.C. FWS/OBS 83/35. XIII + 348

182. ARMENTROUT, D. J. and R. J. BOYD. 1994. CONSEQUENCES OF HABITAT FRAGMENTATION ON WILD SHEEP METAPOPULATION MANAGEMENT WITHIN USA. P 149-58. IN: PYBUS M, ED. PROC. BIENN. SYMP. NORTH. WILD SHEEP AND GOAT COUNCIL; 2-6 MAY 1994.CRANBROOK, B.C. NORTH. WILD SHEEP AND GOAT COUNCIL.

183. ARMITAGE, D. 1995. AN INTEGRATIVE METHODOLOGICAL FRAMEWORK FOR SUSTAINABLE ENVIRONMENTAL PLANNING AND MANAGEMENT. ENVIRONMENTAL MANAGEMENT 19:469-479.

184. ARMSTRONG, E., D. EULER and G. RACEY. 1983. WHITE-TAILED DEER HABITAT AND COTTAGE DEVELOPMENT IN CENTRAL ONTARIO. JOURNAL OF WILDLIFE MANAGEMENT 47:605-612.

185. ARMSTRONG, J. J. 1992. AN EVALUATION OF THE EFFECTIVENESS OF SWAREFLEX DEER REFLECTORS. 9303RT368E. TRANSPORTATION RESEARCH LAB., ONTARIO MINISTRY OF TRANSPORTATION, DOWNSVIEW, ONTARIO.

186. ARNER, D. H., U.S. FISH AND WILDLIFE SERVICE, OFFICE OF BIOLOGICAL SERVICES, UNITED STATES, BIOLOGICAL SERVICES PROGRAM and NATIONAL POWER PLANT TEAM. 1977. TRANSMISSION LINE RIGHTS-OF-WAY MANAGEMENT. TOPICAL BRIEFS, FISH AND WILDLIFE RESOURCES AND ELECTRIC POWER GENERATION: FWS/OBS 2. 76/20.2. DEPT. OF THE INTERIOR, FISH AND WILDLIFE SERVICE, OFFICE OF BIOLOGICAL SERVICES, POWER PLANT PROJECT, NATIONAL POWER PLANT TEAM, ANN ARBOR, MICHIGAN.

187. ARNESON, R. D. 1969. PRIMARY PRODUCTIVITY STUDIES IN QUAKE LAKE, MONTANA. M.S. THESIS, MONTANA STATE UNIVERSITY, BOZEMAN, MT. 97 PP.

188. ARNOLD, D. A. 1978. CHARACTERISTICS AND COST OF HIGHWAY DEER KILLS. PAGES 92-101 IN KIRKPATRICK,C.M., EDITOR. THE 1978 JOHN S. WRIGHT FORESTRY CONFERENCE. DEPARTMENT OF FORESTRY AND NATURAL RESOURCES AND INDIANA COOPERATIVE EXTENSION SERVICE, PURDUE UNIVERSITY, LAFAYETTE, IN.

189. ARNOLD, D. A. 1979. DEER ON THE HIGHWAY. TRAFFIC SAFETY MAY. [PAGES UNKNOWN].:

190. ARNOLD, G. W., D. ALGAR, R. J. HOBBS and L. ATKINS. 1987. A SURVEY OF VEGETATION AND ITS RELATIONSHIP TO VERTEBRATE FAUNA PRESENT IN WINTER ON ROAD VERGES IN THE KELLERBERRIN DISTRICT, W.A. LAND MANAGE. TECH. REP. NO. 18. WESTERN AUSTRALIA DEPARTMENT OF CONSERVATION, [LOCATION OF PUBLICATION UNKNOWN].

191. ARNOLD, G. W. and J. R. WEELDENBURG. 1990. FACTORS DETERMINING THE NUMBER AND SPECIES OF BIRDS IN ROAD VERGES IN THE WHEATBELT OF WESTERN AUSTRALIA. BIOLOGICAL CONSERVATION 53(4):295-315. 
192. ARNOLD, G. W., J. R. WEELDENBURG and D. E. STEVEN. 1991. DISTRIBUTION AND ABUNDANCE OF TWO SPECIES OF KANGAROO IN REMNANTS OF NATIVE VEGETATION IN THE CENTRAL WHEATBELT OF WESTERN AUSTRALIA AND THE ROLE OF NATIVE VEGETATION ALONG ROAD VERGES AND FENCELINES AS LINKAGES. PAGES 273-280 IN SAUNDERS,D.A. AND HOBBS,R.J., EDITORS. NATURE CONSERVATION 2: THE ROLE OF CORRIDORS. SURRETY BEATTY AND SONS, CHIPPING NORTON, AUSTRALIA.

193. ARNOLD, T. W. 1994. A ROADSIDE TRANSECT FOR CENSUSING BREEDING COOTS AND GREBES. WILDL. SOC. BULL. $22(3): 437-43$.

194. ARNOULD, C., C. MALOSSE, J.-P. SIGNORET and C. DESCOINS. 1998. WHICH CHEMICAL CONSTITUENTS FROM DOG FECES ARE INVOLVED IN ITS FOOD REPELLENT EFFECT IN SHEEP? JOURNAL OF CHEMICAL ECOLOGY 24:559-576.

195. ARORA, B. M. and A. K. MALHOTRA. 1993. A COMPARATIVE STUDY OF RATE OF BIRTH AND MORTALITY IN LION-TAILED MACAQUE (MACACA SILENUS). INDIAN FORESTER 119(10):866-9.

196. ARTMANN, M. J. 1999. INFLUENCE OF UPLAND COVER ON OCCUPANCY RATES OF NEST STRUCTURES BY MALLARDS. M.S. THESIS, UNIVERSITY OF MONTANA, MISSOULA, MT. 37 PP.

197. ARVEY, W. D. and A. BURKHOLDER. 1990. STOCK ASSESSMENT OF NORTHERN PIKE IN THE VICINITY OF THE YUKON RIVER HAUL ROAD CROSSING, 1988 AND 1989. FISHERY MANUSCRIPT: FISHERY MANUSCRIPT (1990) NO. 90-1. ALASKA DEPT. OF FISH AND GAME, DIVISION OF SPORT FISH, ANCHORAGE, ALASKA.

198. ASH ENVIRONMENTAL DESIGN PARTNERSHIP INC. 1987. ENVIRONMENTAL DESIGN AND MANAGEMENT OF SKI AREAS IN SCOTLAND. A PRACTICAL HANDBOOK. UK COUNTRYSIDE COMMISSION FOR SCOTLAND AND UK HIGHLAND REGIONAL COUNCIL. PERTH, UK. 229PP.

199. ASH, G. R., L. HILDEBRAND and J. P. O'NEIL. 1987. FISHERIES MITIGATION PRE-ENGINEERING STUDIES - CROWSNEST RIVER FISH POPULATION SURVEYS DATA SUMMARY. ALBERTA DEPT. OF THE ENVIRONMENT PLANNING DIVISION AND R.L. \& L. ENVIRONMENTAL SERVICES LTD, EDMONTON, ALBERTA.

200. ASHLEY, E. P. and J. T. ROBINSON. 1996. ROAD MORTALITY OF AMPHIBIANS, REPTILES, AND OTHER WLDLIFE ON THE LONG POINT CAUSEWAY, LAKE ERIE, ONTARIO. CANADIAN FIELD NATURALIST 110:403-412.

201. ASHLEY, J. 1994. EFFECTS OF BOATING ON HARLEQUIN DUCKS: A REVIEW. GLACIER NATIONAL PARK, MONTANA. 8PP.

202. ASHLEY, M. V., D. J. MELNICK and D. WESTERN. 1990. CONSERVATION GENETICS OF THE BLACK RHINOCEROS (DICEROS BICORNIS), I: EVIDENCE FROM THE MITOCHONDRIAL DNA OF THREE POPULATIONS. CONSERVATION BIOLOGY 4 (1):71-7.

203. ASHLEY, P. 1992. GRAND COULEE DAM WILDLIFE MITIGATION PROGRAM SHARP-TAILED GROUSE PROGRAMMATIC MANAGEMENT PLAN, TRACY ROCK VICINITY, LINCOLN COUNTY, WASHINGTON. BONNEVILLE POWER ADMINISTRATION, PORTLAND, OREGON.

204. ASKINS, R. A. 1994. OPEN CORRIDORS IN A HEAVILY FORESTED LANDSCAPE: IMPACT ON SHRUBLAND AND FOREST-INTERIOR BIRDS. WLDLIFE SOCIETY BULLETIN 22:339-347.

205. ASKINS, R. A., J. F. LYNCH and R. GREENBERG. 1990. POPULATION DECLINES IN MIGRATORY BIRDS IN EASTERN NORTH AMERICA. CURRENT ORNITHOLOGY 7:1-57.

206. ASKINS, R. A., M. J. PHILBRICK and D. S. SUGENO. 1987. RELATIONSHIP BETWEEN THE REGIONAL ABUNDANCE OF FOREST AND THE COMPOSITION OF FOREST BIRD COMMUNITIES. BIOLOGICAL CONSERVATION 39:129-152.

207. ATKINS, A. P. 1960. CONSERVATION FROM A RANCHER'S VIEWPOINT. TRANS. N. AMER. WILDL. NAT. RESOUR. CONF. 25:14-21.

208. ATKINSON-WILLES, G. 1969. WILDFOWL AND RECREATION: A BALANCE OF REQUIREMENTS. BRITISH WATER SUPPLY 11:5-15. 
209. ATWATER, M. G. 1958. A TWO-YEAR STUDY OF RENESTING IN CANADA GEESE (BRANTA CANADENSIS) IN PHILLIPS COUNTY, MONTANA. M.S. THESIS, MONTANA STATE COLLEGE, BOZEMAN, MT. 23 PP.

210. ATWELL, G. C. 1959. AN EVALUATION OF MAGPIE PREDATION ON THE RING-NECKED PHEASANT. M.S. THESIS, MONTANA STATE UNIVERSITY, MISSOULA, MT. 74 PP.

211. AUERBACH, N., M. D. WALKER and D. A. WALKER. 1997. EFFECTS OF ROADSIDE DISTURBANCE ON SUBSTRATE AND VEGETATION PROPERTIES IN ARCTIC TUNDRA. ECOLOGICAL APPLICATIONS 7:218-235.

212. AUIDERWIJK, A. 1989. AMPHIBIANS AND REPTILE TUNNELS IN THE NETHERLANDS. PAGES 67-74 IN T. E. S. LANGTON, ED. AMPHIBIANS AND ROADS: PROCEEDINGS OF THE TOAD TUNNEL CONFERENCE. ACO POLYMER PRODUCTS LTD., SHEFFORD, BEDFORDSHIRE, ENGLAND.

213. AUKERMAN, R. and W. T. SPRINGER. 1976. EFFECTS OF RECREATION ON WATER QUALITY IN WILDLANDS. DEPARTMENT OF RECREATION RESOURCES, COLLEGE OF FORESTRY AND NATURAL RESOURCES, COLORADO STATE UNIVERSITY. EISENHOWER CONSORTIUM BULLETIN 2. 25PP.

214. AULT, J. W. I. 1982. QUANTITATIVE ESTIMATE OF BARN OWL NESTING HABITAT QUALITY. M.S. THESIS, OKLAHOMA COOPERATIVE WILDLIFE RESEARCH UNIT

215. AUMILLER, L. D. and C. A. MATT. 1994. MANAGEMENT OF MCNEIL RIVER STATE GAME SANCTUARY FOR VIEWING OF BROWN BEARS. INT. CONF. BEAR RES. AND MANAGE. 9:51-61

216. AUNE, K. and W. KASWORM. 1989. FINAL REPORT EAST FRONT GRIZZLY BEAR STUDY. MONTANA DEPARTMENT OF FISH, WILDLIFE AND PARKS, HELENA, MT. 332P.P.

217. AUNE, K., M. MADEL and C. HUNT. 1986. ROCKY MOUNTAIN FRONT GRIZZLY BEAR MONITORING AND INVESTIGATION. U.S. FISH AND WILDLIFE SERVICE, BUREAU OF LAND MANAGEMENT, U.S. FOREST SERVICE, MONTANA DEPT. FISH, WLDLIFE AND PARKS.175PP.

218. AUNE, K. and T. STIVERS. 1986. AVAILABILITY/UTILIZATION OF GRIZZLY BEAR HABITAT COMPONENTS ON THE ROCKY MOUNTAIN EAST FRONT. P. 99-? IN: EVANS, G.P.; K.E. CONTRERAS (EDS.). PROCEEDINGS OF THE GRIZZLY BEAR HABITAT SYMPOSIUM,-MISSOULA, MONTANA. APRIL 30-MAY 2,-1985.

219. AUNE, K. and T. STIVERS. 1985. ECOLOGICAL STUDIES OF THE GRIZZLY BEAR IN THE PINE BUTTE PRESERVE. MONT. DEPT. FISH WLDL. AND PARKS, HELENA. 154 PP.

220. AUNE, K. E. 1994. COMPARATIVE ECOLOGY OF BLACK AND GRIZZLY BEARS ON THE ROCKY MOUNTAIN FRONT, MONTANA. INT. CONF. BEAR RES. AND MANAGE. 9:365-74.

221. AUNE, K. E. 1992. COMPARATIVE ECOLOGY OF BLACK AND GRIZZLY BEARS ON THE ROCKY MOUNTAIN FRONT, MONTANA. :PP 1-22

222. AUNE, K. E. 1981. IMPACTS OF WINTER RECREATIONISTS ON WILDLIFE IN A PORTION OF YELLOWSTONE NATIONAL PARK, WYOMING. M.S. THESIS, MONTANA STATE UNIVERSITY, BOZEMAN, MT. 111 PP.

223. AUST, W. M., T. W. REISINGER, J. A. BURGER and B. J. STOKES. 1993. SOIL PHYSICAL AND HYDROLOGICAL CHANGES ASSOCIATED WITH LOGGING A WET PINE FLAT WITH WIDE TIRED SKIDDERS. SOUTH. J. APPL. FOR. 17:22-25.

224. AUSTEN, M. and T. RICHARDS. 2000. BASIC LEGAL DOCUMENTS ON INTERNATIONAL ANIMAL WELFARE AND WILDLIFE CONSERVATION. KLUWER LAW INTERNATIONAL, HAGUE, LONDON.

225. AUSTIN, M. and S. HERRERO. 1995. WOLVERINE TRAVEL ROUTES AND RESPONSE TO HUMAN-CONSTRUCTED LINEAR CORRIDORS IN THE KICKING HORSE PASS BETWEEN YOHO AND BANFF NATIONAL PARKS: PROGRESS REPORT ON THE 1994-1995 FIELD SEASON. 7PP.

226. AUSTIN, M. and S. HERRERO. 1995. WOLVERINE TRAVEL ROUTES AND RESPONSE TO HUMAN-CONSTRUCTED LINEAR CORRIDORS IN THE KICKING HORSE PASS BETWEEN YOHO AND BANFF NATIONAL PARKS. 
227. AUSTIN, R. R. 1973. HABITAT DIVERSITY AS RELATED TO PHEASANT USE ON A GAME MANAGEMENT AREA IN NORTHWESTERN MONTANA. M.S. THESIS, MONTANA STATE UNIVERSITY, BOZEMAN, MT. 63 PP.

228. AVERY, E. L. 1969. EFFECTS OF DOMESTIC SEWAGE ON AQUATIC INSECTS AND SALMONIDS OF THE EAST GALLATIN RIVER, MONTANA. M.S. THESIS, MONTANA STATE UNIVERSITY, BOZEMAN, MT. 23 PP.

229. AXYS ENVIRONMENTAL CONSULTING LTD. 1995. A COMPENDIUM OF PHYSICAL ACCESS CONTROL MEASURES FOR ROADS AND OTHER RIGHTS-OF-WAY. 27 PP.

230. AYE, P. P., R. M. NAKAMURA, T. R. SAWA and P. SILVA. 1995. MORTALITY OF OWLS IN HAWAII. ELEPAIO 5(2):9-12.

231. AYENI, A. O., D. T. LORDBANJOU and B. A. MAJEK. 1997. TITHONIA DIVERSIFOLIA (MEXICAN SUNFLOWER) IN SOUTH-WESTERN NIGERIA - OCCURRENCE AND GROWTH HABIT. WEED RESEARCH 37(6):443-449.

232. AYRES, J. M., D. DE MAGALHAES LIMA, E. DE SOUZA MARTINS and J. L. BARRRIOS. 1991. ON THE TRACK OF THE ROAD: CHANGES IN SUBSISTENCE HUNTING IN A BRAZILIAN AMAZONIAN VILLAGE. PAGES 82-92 IN ROBINSON,J.T. AND REDFORD, K.H., EDITORS. NEOTROPICAL WILDLIFE USE AND CONSERVATION. UNIVERSITY OF CHICAGO PRESS, CHICAGO.

233. AYRES, L. A., L. S. CHOW and D. M. GRABER. 1986. BLACK BEAR ACTIVITY PATTERNS AND HUMAN INDUCED MODIFICATIONS IN SEQUOIA NATIONAL PARK. INT. CONF. BEAR RES. AND MANAGE. 6:151-4

234. AZUMA, S. and H. TORII. 1980. IMPACT OF HUMAN ACTIVITIES ON SURVIVAL OF THE JAPANESE BLACK BEAR. INT. CONF. OF BEAR RES. AND MANAGE. 4:71-9.

235. B.C. HYDRO. 1983. ENVIRONMENTAL IMPACT ASSESSMENT OF CONSTRUCTION OF A NATURAL GAS PIPELINE ACROSS ROBERTS BANK. B.C. HYDRO, VANCOUVER, B.C.

236. B.C. HYDRO. 1976-1980. [HAT CREEK PROJECT ENVIRONMENTAL IMPACT STATEMENT SUPPORTING REPORTS]. --. BRITISH COLUMBIA HYDRO AND POWER AUTHORITY, BRITISH COLUMBIA.

237. B.C. MINISTRY OF ENVIRONMENT, LANDS AND PARKS. 1995. CONSERVATION OF GRIZZLY BEARS IN BRITISH COLUMBIA: BACKGROUND REPORT. 70 PP.

238. BABB, C. 1979. OFF-ROAD VEHICLES; A GROWING REALITY ON PUBLIC LANDS. OUR PUBLIC LANDS 29:4-8.

239. BABILONI, G. G. 1992. PROVISIONAL REPORT OF THE MORTALITY OF VERTEBRATES ON THE ROADS OF BARCELONA PROVINCE, SEPTEMBER 1991. PAGES [UNKNOWN] IN LOPEZ,REDONDO, EDITOR. I JORNADAS PARA EL ESTUDIO Y PREVENCION DE LA MORTALIDAD DE VERTEBRADOS EN CARRETERAS, MADRID, 5 Y 6 DE OCTUBRE DE 1991. TOMO 2. [SESSIONS IN THE STUDY OF PREVENTION OF ROAD MORTALITIES OF VERTEBRATES, MADRID, 5 AND 6 OCTOBER, 1991. VOLUME 2.]. COORDINADORA DE ORGANIZACCIONES DE DEFENSA. , AMBIENTAL, MADRID.

240. BACCUS, J. T. and J. K. HORTON. 1980. STUDIES OF THE RELATIONS BETWEEN VEHICLE TRAFFIC AND BIOTIC AND SEDIMENTARY PROCESSES AT PADRE ISLAND NATIONAL SEASHORE. PROC. OF THE CONF. ON SCI. RES. IN THE NAT. PARKS, 2D, 1979 9:307-346.

241. BACON, L. M. 1996. NESTING ECOLOGY OF THE INTERIOR LEAST TERN ON THE YELLOWSTONE RIVER, MONTANA. M.S. THESIS, MONTANA STATE UNIVERSITY, BOZEMAN, MT. 69 PP.

242. BADARACCO, R. J. 1976. ORVS: OFTEN ROUGH ON VISITORS. PARKS AND RECREATION 11:32-34/68-75.

243. BADER, M. 1989. HABITUATION IN YELLOWSTONE'S GRIZZLY BEARS: A SPECIAL PROBLEM IN WILDLIFE MANAGEMENT. WESTERN WILDLANDS 25:29.

244. BADER, M., T. BECHTOLD and M. GARRITY. 1996. THE CONSERVATION BIOLOGY ALTERNATIVE FOR GRIZZLY BEAR POPULATION RESTORATION IN THE GREATER SALMON-SELWAY REGION OF CENTRAL IDAHO AND WESTERN MONTANA. ALLIANCE FOR THE WILD ROCKIES SPECIAL REPORT NO.8. 27PP.. 
245. BAGGETT, D. L. 1995. IMPROVED INSTALLATION OF ARTIFICIAL CAVITIES FOR RED-COCKADED WOODPECKERS. WILDL. SOC. BULL. 23 (1):101-2.

246. BAGLEY, S. 1998. THE ROAD-RIPPER'S GUIDE TO WILDLAND ROAD REMOVAL. WILDANDS CENTER FOR PREVENTING ROADS. MISSOULA, MONTANA. 4OPP.

247. BAGLIEN, J. W. 1975. BIOLOGY AND HABITAT REQUIREMENTS OF THE NESTING GOLDEN EAGLE IN SOUTHWESTERN MONTANA. M.S. THESIS, MONTANA STATE UNIVERSITY, BOZEMAN, MT. 53 PP.

248. BAHARUDDIN, K., A. M. MOKHTARUDDIN and M. M. NIK. 1995. SURFACE RUNOFF AND SOIL LOSS FROM A SKID TRAIL AND A LOGGING ROAD IN A TROPICAL FOREST. JOURNAL OF TROPICAL FOREST SCIENCE 7 (4):558-69.

249. BAHILLO, M. M. and P. G. ORIZAOLA. 1992. PROVISIONAL REPORT OF THE MORTALITY OF VERTEBRATES ON THE ROADS OF CANTABRIA, SEPTEMBER 1991. PAGES [UNKNOWN] IN LOPEZ,REDONDO, EDITOR. I JORNADAS PARA EL ESTUDIO Y PREVENCION DE LA MORTALIDAD DE VERTEBRADOS EN CARRETERAS, MADRID, 5 Y 6 DE OCTUBRE DE 1991. TOMO 2. [SESSIONS IN THE STUDY OF PREVENTION OF ROAD MORTALITIES OF VERTEBRATES, MADRID, 5 AND 6 OCTOBER, 1991. VOLUME 2.]. COORDINADORA DE ORGANIZACCIONES DE DEFENSA., AMBIENTAL, MADRID.

250. BAHLS, L. L. 1971. ECOLOGY OF THE DIATOM COMMUNITY OF THE UPPER EAST GALLATIN RIVER, MONTANA WITH IN SITU EXPERIMENTS ON THE EFFECT OF CURRENT VELOCITY ON FEATURES OF THE AUFWÜCHS . PH.D. DISSERTATION, MONTANA STATE UNIVERSITY, BOZEMAN, MT. 145 PP.

251. BAHR, D. and A. YARMO. 1995. THE ROAD RIPPER'S GUIDE TO NATIONAL PARKS. ROAD REMOVAL IMPLEMENTATION PROJECT. HOUGHTON, MICHIGAN. 22PP.

252. BAILEY, E. D. 1960. BEHAVIOR OF THE RATTLESNAKE MULE DEER ON THEIR WINTER RANGE. PH.D. DISSERTATION, MONTANA STATE UNIVERSITY, MISSOULA, MT. 110 PP.

253. BAILEY, G. D. and S. A. L. PILGRIM. 1983. SOILS OF THE WHITE MOUNTAINS OF NEW HAMPSHIRE AND THEIR SUITABILITY FOR RECREATIONAL DEVELOPMENT. MOUNTAIN RES. DEVELOP. 3:53-60.

254. BAILEY, J. E. 1951. LIFE HISTORY AND ECOLOGY OF THE FRESHWATER SCULPIN COTTUS BAIRDII PUNCTULATUS IN SOUTHWESTERN MONTANA. M.S. THESIS, MONTANA STATE COLLEGE, BOZEMAN, MT. 42 PP.

255. BAILEY, T. N., E. E. BANGS, M. F. PORTNER, J. C. MALLOY and R. J. MCAVINCHEY. 1986. AN APPARENT OVEREXPLOITED LYNX POPULATION ON THE KENAI PENINSULA, ALASKA. J. WILDL. MANAGE. 50 (2):279-90

256. BAILEY, T. N., A. W. FRANZMANN, P. D. ARNESON and J. L. DAVIS. 1983. AN EVALUATION OF VISUAL LOCATION DATA FROM NECK-COLLARED MOOSE. JOURNAL OF WLDLIFE MANAGEMENT 47:25-30.

257. BAKER, C. O. and F. E. VOTAPKA. 1990. FISH PASSAGE THROUGH CULVERTS. TECHNOLOGY \& DEVELOPMENT CENTER, U.S. DEPT. OF TRANSPORTATION, FEDERAL HIGHWAY ADMINISTRATION, WASHINGTON, D.C.

258. BAKER, T. 1996. HABITAT: A LANDSCAPE ARCHITECTURE PERSPECTIVE. PAGES 228-234 IN EVINK,G., ZIEGLER,D., GARRETT,P., AND BERRY,J., EDITORS. TRANSPORTATION AND WLDLIFE: REDUCING WLDLIFE MORTALITY AND IMPROVING WLDLIFE PASSAGEWAYS ACROSS TRANSPORTATION CORRIDORS: PROCEEDINGS OF THE FLORIDA DEPARTMENT OF TRANSPORTATION/FEDERAL HIGHWAY ADMINISTRATION TRANSPORTATION-RELATED WILDLIFE MORTALITY SEMINAR; 1996 APRIL 30-MAY 2; ORLANDO, FL. FHWA-PD-96-041. U.S. DEPARTMENT OF TRANSPORTATION, FEDERAL HIGHWAY ADMINISTRATION, WASHINGTON, DC.

259. BAKER, W. J. 1987. THE EFFECTS OF OIL WELL SITES ON FOREST SPECIES OF BIRDS. THESIS, WESTERN MICHIGAN UNIVERSITY, KALAMAZOO, MICHIGAN. 67PP.

260. BAKER, W. L. 1994. RESTORATION OF LANDSCAPE STRUCTURE ALTERED BY FIRE SUPPRESSION. CONSERVATION BIOLOGY 8 (3):763-9.

261. BAKOWSKI, C. and M. KOZAKIEWICZ. 1988. THE EFFECT OF FOREST ROADS ON BANK VOLE AND YELLOW-NECKED MOUSE POPULATIONS. ACTA THERIOLOGICA 33(25):345-353. 
262. BALDWIN, M. F. and D. H. JR. STODDARD. 1973. THE OFF-ROAD VEHICLE AND ENVIRONMENTAL QUALITY. 2ND EDITION. THE CONSERVATION FOUNDATION. WASHINGTON, D.C. 61PP.

263. BALDWIN, M. F. 1970. THE OFF-ROAD VEHICLE AND ENVIRONMENTAL QUALITY. CONSERVATION FOUNDATION. WASHINGTON D.C. 52PP.

264. BALL, I. J. and S. K. BALL. 1991. EARTH-FILLED CULVERTS AS NEST SITES FOR WATERFOWL. PRAIRIE NATURALIST 23. $(2): 85-8$.

265. BALL, I. J., R. L. ENG and S. K. BALL. 1995. POPULATION DENSITY AND PRODUCTIVITY OF DUCKS ON LARGE GRASSLAND TRACTS IN NORTHCENTRAL MONTANA. WILDL. SOC. BULL. 23(4):767-73.

266. BALLARD, W. B., K. E. RONEY, L. A. AYRES and D. N. LARSEN. 1990. ESTIMATING GRIZZLY BEAR DENSITY IN RELATION TO DEVELOPMENT AND EXPLOITATION IN NORTHWEST ALASKA. INT. CONF. BEAR RES. AND MANAGE. 8:405-13.

267. BALLARD, W. B., J. S. WHITMAN and C. L. GARDNER. 1987. ECOLOGY OF AN EXPLOITED WOLF POPULATION IN SOUTH-CENTRAL ALASKA. WILDL. MONOGR. 98:1-54.

268. BALLASINA, D. 1989. TOADS ON ROADS IN BELGIUM. PAGES 83-86 IN LANGTON,T.E.S., EDITOR. AMPHIBIANS AND ROADS. PROCEEDINGS OF THE TOAD TUNNEL CONFERENCE; 1989 JANUARY 7-8; RENDSBURG, FEDERAL REPUBLIC OF GERMANY. ACO POLYMER PRODUCTS LTD., SHEFFORD, ENGLAND.

269. BALLON, P. 1985. STATEMENT ON PREPARATORY TECHNIQUES UNDERTAKEN IN FRANCE TO REDUCE THE IMPACT OF HIGHWAY CONSTRUCTION ON GAME UNGULATES. TRANSACTIONS OF THE CONGRESS OF THE INTERNATIONAL UNION OF GAME BIOLOGISTS 17:679-689.

270. BALLON, P. 1985. TITLE UNKNOWN. TRANS. CONGR. INT. UNION GAME BIOL. 17:679-89.

271. BANCI, V. 1994. WOLVERINE. P 99-127. IN: RUGGIERO, L.F., AUBRY, K.B., BUSKIRK, S.W., LYON, L.J., ZIELINSKI, W.J., (EDITORS). THE SCIENTIFIC BASIS FOR CONSERVING FOREST CARNIVORES: AMERICAN MARTEN, FISHER, LYNX, AND WOLVERINE IN THE WESTERN UNITED STATES. USDA FOREST SERVICE GENERAL TECHNICAL REPORT RM-254. USDA FOREST SERVICE.

272. BANCI, V., D. A. DEMARCHI and W. R. ARCHIBALD. 1994. EVALUATION OF THE POPULATION STATUS OF GRIZZLY BEARS IN CANADA. INT. CONF. BEAR RES. AND MANAGE. 9:129-42.

273. BANCROFT, G. T., A. M. STRONG and M. CARRINGTON. 1995. DEFORESTATION AND ITS EFFECTS ON FOREST-NESTING BIRDS IN THE FLORIDA KEYS. CONSERVATION BIOLOGY 9(4):835-44.

274. BAND, A.-L. 1996. POPULATION CHARACTERISTICS AND HABITAT USE OF PORCUPINES IN A PARTIALLY BURNED LANDSCAPE IN NORTHWESTERN WYOMING. M.S. THESIS, UNIVERSITY OF MONTANA, MISSOULA, MT. 54 PP.

275. BANDOW, F. L. 1969. OBSERVATIONS ON THE LIFE HISTORY OF THE YELLOW PERCH AND FISH POPULATION TRENDS IN CANYON FERRY RESERVOIR, MONTANA. M.S. THESIS, MONTANA STATE UNIVERSITY, BOZEMAN, MT. 32 PP.

276. BANFF-BOW VALLEY STUDY. 1996. BANFF-BOW VALLEY: AT THE CROSSROADS. SUMMARY REPORT OF THE BANFF-BOW VALLEY TASK FORCE. PREPARED FOR CANADIAN HERITAGE, OTTAWA, ON.

277. BANGS, E. E. and S. H. FRITTS. 1996. REINTRODUCING THE GRAY WOLF TO CENTRAL IDAHO AND YELLOWSTONE NATIONAL PARK. WILDL. SOC. BULL. 24:402-13.

278. BANGS, E. E., T. N. BAILEY and M. F. PORTNER. 1989. SURVIVAL RATES OF ADULT FEMALE MOOSE ON THE KENAI PENINSULA, ALASKA. JOURNAL OF WILDLIFE MANAGEMENT 53:557-563.

279. BANGS, E. E., T. H. SPRAKER, T. N. BAILEY and V. D. BERNS. 1982. EFFECTS OF INCREASED HUMAN POPULATIONS ON WILDLIFE RESOURCES OF THE KENAI PENINSULA, ALASKA. TRANSACTIONS NORTH AMERICAN WILDLIFE AND NATURAL RESOURCES CONFERENCE 47:605-616. 
280. BANKS, A. J. 1997. VARIATION AMONG HOST SPECIES IN PROBABILITY OF PARASITISM BY BROWN-HEADED COWBIRDS: THE ROLE OF EVERYDAY HOST ACTIVITY. M.S. THESIS, UNIVERSITY OF MONTANA, MISSOULA, MT. 55 PP.

281. BANKS, R. C. 1979. HUMAN RELATED MORTALITY OF BIRDS IN THE UNITED STATES. SPECIAL SCIENTIFIC REPORT WILDLIFE NO. 215. U.S. DEPARTMENT OF THE INTERIOR, FISH AND WILDLIFE SERVICE, WASHINGTON D.C..

282. BANKS, W. A., C. T. ADAMS and C. S. LOFGREN. 1990. DAMAGE TO NORTH CAROLINA AND FLORIDA HIGHWAYS BY RED IMPORTED FIRE ANTS (HYMENOPTERA: FORMICIDAE). FLORIDA ENTOMOLOGIST 3(1):198-199.

283. BARANCOK, P. and M. VARSAVOVA. 1996. THE INFLUENCE OF TOURISM ON THE NATURAL ENVIRONMENT OF THE BELIANSKE TATRY MOUNTAINS INVESTIGATED ON AN EDUCATIONAL HIKING PATH SITUATED IN THE LOCALITY OF MONKOVA DOLINA - KOPSKE SEDLO AND ITS NEAR SURROUNDINGS. EKOLOGIA BRATISLAVA 15:469-473.

284. BARFOOT, C. A. 1993. LONGITUDINAL DISTRIBUTION OF FISHES AND HABITAT IN LITTLE BEAVER CREEK, MONTANA. M.S. THESIS, MONTANA STATE UNIVERSITY, BOZEMAN, MT. 66 PP.

285. BARKLEY, P. W. and D. W. SECKLER. 1972. ECONOMIC GROWTH AND ENVIRONMENTAL DECAY, THE SOLUTION BECOMES THE PROBLEM. HARCOURT BRACE JOVANOVICH, INC.

286. BARNDT, S. A. 1996. THE BIOLOGY AND STATUS OF THE ARCTIC GRAYLING IN SUNNYSLOPE CANAL, MONTANA. M.S. THESIS, MONTANA STATE UNIVERSITY, BOZEMAN, MT. 136 PP.

287. BARNES, R. F. W., K. L. BARNES, M. P. T. ALERS and A. BLOM. 1991. MAN DETERMINES THE DISTRIBUTION OF ELEPHANTS IN THE RAIN FORESTS OF NORTHEASTERN GABON. AFRICAN JOURNAL OF ECOLOGY 29(1):54-63.

288. BARNES, R. F. W., A. BLOM and M. P. T. ALERS. 1995. A REVIEW OF THE STATUS OF FOREST ELEPHANTS LOXODONTA AFRICANA IN CENTRAL AFRICA. BIOLOGICAL CONSERVATION 71(2):125-32.

289. BARNES, V. G. JR. 1994. BROWN BEAR-HUMAN INTERACTIONS ASSOCIATED WITH DEER HUNTING ON KODIAK ISLAND. INT. CONF. BEAR RES. AND MANAGE. 9:63-73.

290. BARNES, V. G. JR. 1990. THE INFLUENCE OF SALMON AVAILABILITY ON MOVEMENTS AND RANGE OF BROWN BEARS ON SOUTHWEST KODIAK ISLAND. INT. CONF. BEAR RES. AND MANAGE. 8:305-13.

291. BARNETT, J. L., R. A. HOW and W. F. HUMPHREYS. 1978. THE USE OF HABITAT COMPONENTS BY SMALL MAMMALS IN EASTERN AUSTRALIA. AUSTRALIAN JOURNAL OF ECOLOGY 3:277-285.

292. BARRACLOUGH, M. E. 1954. BIOLOGY OF CANADA GEESE (BRANTA CANADENSIS MOFFITTI) IN THE FLATHEAD VALLEY OF MONTANA. M.S. THESIS, MONTANA STATE UNIVERSITY, MISSOULA, MT. 91 PP.

293. BARRAGAN, F. 1992. PROVISIONAL REPORT OF THE MORTALITY OF VERTEBRATES ON THE ROADS OF ASTURIAS, SEPTEMBER 1991. PAGES 101-109 IN LOPEZ,REDONDO, EDITOR. I JORNADAS PARA EL ESTUDIO Y PREVENCION DE LA MORTALIDAD DE VERTEBRADOS EN CARRETERAS, MADRID, 5 Y 6 DE OCTUBRE DE 1991. TOMO 2. [SESSIONS IN THE STUDY OF PREVENTION OF ROAD MORTALITIES OF VERTEBRATES, MADRID, 5 AND 6 OCTOBER, 1991. VOLUME 2.]. COORDINADORA DE ORGANIZACCIONES DE DEFENSA, AMBIENTAL, MADRID.

294. BARRASS, A. N. and L. F. COHN. 1983. PRELIMINARY RESULTS OF INHIBITION OF PHONOTAXIS BY HIGHWAY NOISE FOR SEVERAL SPECIES OF ANURANS (BUFONIDAE AND HYLIDAE). AMERICAN ZOOLOGIST 23:882.

295. BARRETT, D. E. 1996. TRAFFIC-NOISE IMPACT STUDY FOR LEAST BELL'S VIREO HABITAT ALONG CALIFORNIA STATE ROUTE 83. TRANSPORTATION RESEARCH RECORD 1559:3-7.

296. BARRETT, V. A. 1980. GENETIC COMPARISON OF TRUMPETER SWAN POPULATIONS (OLOR BUCCINATOR). M.S. THESIS, MONTANA STATE UNIVERSITY, BOZEMAN, MT. 101 PP.

297. BARRICK, L. S. 1984. KENAI RIVERBANK EROSION STUDY. ALASKA DEPARTMENT OF FISH \& GAME DIVISION OF FISHERIES REHABILITATION, ENHANCMENT AND DEVELOPMENT. JUNEAU, ALASKA. NUMBER 41. 82PP. 
298. BARRIER, M. J. and F. S. JR. BARKALOW. 1967. A RAPID TECHNIQUE FOR AGING GRAY SQUIRRELS IN WINTER PELAGE. J. WILDL. MANAGE. 31 (4):715-9.

299. BARRY, S. J. and H. B. SHAFFER. 1994. THE STATUS OF THE CALIFORNIA TIGER SALAMANDER (AMBYSTOMA CALIFORNIENSE) AT LAGUNITA: A 50-YEAR UPDATE. JOURNAL OF HERPETOLOGY 28:159-164.

300. BARRY, W. J. 1984. MANAGEMENT AND PROTECTION OF RIPARIAN ECOSYSTEMS IN THE STATE PARK SYSTEM. PAGES 758-766 IN R. E. WARNER AND K. M. HENDRIX, EDITORS. CALIFORNIA RIPARIAN SYSTEMS: ECOLOGY, CONSERVATION, AND PRODUCTIVE MANAGEMENT. UNIVERSITY OF CALIFORNIA PRESS, BERKELEY, CALIFORNIA.

301. BART, J., M. HOFSCHEN and B. G. PETERJOHN. 1995. RELIABILITY OF THE BREEDING BIRD SURVEY - EFFECTS OF RESTRICTING SURVEYS TO ROADS. AUK 112(3):758-761.

302. BARTELT, G. A. 1987. EFFECTS OF DISTURBANCE AND HUNTING ON THE BEHAVIOR OF CANADA GOOSE FAMILY GROUPS IN EASTCENTRAL WISCONSIN. J. WILDL. MANAGE. 51(3):517-22.

303. BARTO, W. P. 1974. THE AGRICULTURAL, FORESTRY, RECREATIONAL AND WILDLIFE OPPORTUNITY COST OF PIPELINES, HYDRO LINES AND HIGHWAYS. NATURAL RESOURCE INSTITUTE, UNIVERSITY OF MANITOBA, WINNIPEG, MANITOBA.

304. BARTO, W. P. 1977. THE AGRICULTURAL, FORESTRY, RECREATIONAL AND WILDLIFE OPPORTUNITY COST OF PIPELINES, HYDRO LINES AND HIGHWAYS. NATURAL RESOURCE INSTITUTE, UNIVERSITY OF MANITOBA, WINNIPEG, MANITOBA.

305. BASCOMPTE, J. and R. SOLE. 1996. HABITAT FRAGMENTATION AND EXTINCTION THRESHOLDS IN SPATIALLY EXPLICIT MODELS. JOURNAL OF ANIMAL ECOLOGY 65:465-473.

306. BASHORE, T. L. 1981. TITLE UNKNOWN. PH.D. DISSERTATION, PA. STATE UNIV. FROM DISS. ABSTR. INT. B SCI. ENG. 42(4):1293

307. BASHORE, T. L. and E. D. BELLIS. 1982. DEER ON PENNSYLVANIA AIRFIELDS: PROBLEMS AND MEANS OF CONTROL. WILDLIFE SOCIETY BULLETIN 10:386-388.

308. BASHORE, T. L., W. M. TZILKOWSKI and E. D. BELLIS. 1985. ANALYSIS OF DEER-VEHICLE COLLISION SITES IN PENNSYLVANIA. JOURNAL OF WILDLIFE MANAGEMENT 49(3):769-774.

309. BASILE, J. V. and T. N. LONNER. 1979. VEHICLE RESTRICTIONS INFLUENCE ELK AND HUNTER DISTRIBUTIONS. J. FORESTRY 77:155-9.

310. BASILE, J. V. and T. N. LONNER. 1979. VEHICLE RESTRICTIONS INFLUENCE ELK AND HUNTER DISTRIBUTION IN MONTANA. JOURNAL OF FORESTRY 77(3):155-159.

311. BATES, J. W. and M. O. MORETTI. 1994. GOLDEN EAGLE (AQUILA CHRYSAETOS) POPULATION ECOLOGY IN EASTERN UTAH. GREAT BASIN NATURALIST 54 (3):248-55.

312. BATY, G. R. 1995. RESOURCE PARTITIONING AND BROWSE USE BY SYMPATRIC ELK, MULE DEER AND WHITE-TAILED DEER ON A WINTER RANGE IN WESTERN MONTANA. M.S. THESIS, UNIVERSITY OF MONTANA, MISSOULA, MT. 228 PP.

313. BAUDVIN, H. 1997. BARN OWL (TYTO ALBA) AND LONG-EARED OWL (ASIO OTUS) MORTALITY ALONG MOTORWAYS IN BOURGOGNE-CHAMPAGNE: REPORT AND SUGGESTIONS. PAGES 58-61 IN SYMPOSIUM PROCEEDINGS: BIOLOGY AND CONSERVATION OF OWLS OF THE NORTHERN HEMISPHERE. U.S. FOREST SERVICE GENERAL TECHNICAL REPORT NC-190.

314. BAUMEISTER, T. R. 1993. ECOLOGY OF WHITE-TAILED DEER ON SUMMER-FALL RANGE IN NORTHCENTRAL IDAHO. M.S. THESIS, MONTANA STATE UNIVERSITY, BOZEMAN, MT. 81 PP.

315. BAUR, A. and B. BAUR. 1990. ARE ROADS BARRIERS TO DISPERSAL IN THE LAND SNAIL (ARIANTA ARBUSTORUM)? CANADIAN JOURNAL OF ZOOLOGY 68:613-617. 
316. BAUR, A. and B. BAUR. 1992. EFFECT OF CORRIDOR WIDTH ON ANIMAL DISPERSAL: A SIMULATION STUDY. GLOBAL ECOLOGY AND BIOGEOG. LETTERS 2: 52-6

317. BAYDACK, R. K. 1986. SHARP-TAILED GROUSE RESPONSE TO LEK DISTURBANCE IN THE CARBERRY SAND HILLS OF MANITOBA. DISSERTATION, COLORADO STATE UNIVERSITY, FORT COLLINS, COLORADO. 94PP.

318. BAYDACK, R. K. and D. A. HEIN. 1987. TOLERANCE OF SHARP-TAILED GROUSE TO LEK DISTURBANCE. WILDLIFE SOCIETY BULLETIN 15(4):535-539.

319. BAYDACK, R. K., H. CAMPA and J. B. HAUFLER. 1999. PRACTICAL APPROACHES TO THE CONSERVATION OF BIOLOGICAL DIVERSITY. ISLAND PRESS, WASHINGTON, D.C.

320. BAYFIELD, N. G. 1986. PENETRATION OF THE CAIRNGORMS MOUNTAINS, SCOTLAND, BY VEHICLE TRACKS AND FOOTPATH: IMPACTS AND RECOVERY. JOURNAL OF APPLIED ECOLOGY 10:635-644.

321. BAYFIELD, N. G. 1973. USE AND DETERIORATION OF SOME SCOTTISH HILL PATHS. PAGES 121-128 IN R. C. LUCAS, COMPILER. PROCEEDINGS OF THE NATIONAL WILERNESS RESEARCH CONFERENCE: CURRENT RESEARCH. USDA FOREST SERVICE, INTERMOUNTAIN RESEARCH STATION, OGDEN, UTAH.

322. BAYFIELD, N. G. and R. HEWSON. 1975. AUTOMATIC MONITORING OF TRAIL USE BY MOUNTAIN HARES. J. WILDL. MANAGE. 39 (1):214-7.

323. BAYFIELD, N. G., A. WATSON and G. R. MILLER. 1988. ASSESSING AND MANAGING THE EFFECTS OF RECREATIONAL USE OF BRITISH HILLS. PAGES 399-414 IN M. B. USHER AND D. B. A. THOMPSON, EDITORS. ECOLOGICAL CHANGES IN THE UPLANDS. SPECIAL PUBLICATION NUMBER 7 OF THE BRITISH ECOLOGICAL SOCIETY. BLACKWELL SCIENTIFIC PUBLICATIONS, OXFORD, ENGLAND.

324. BAYFIELD, N. G. 1971. SOME EFFECTS OF WALKING AND SKIING ON VEGETATION AT CAIRNGORM. PAGES 469-485 IN DUFFEY E. AND WATT A. S., THE SCIENTIFIC MANAGEMENT OF ANIMAL AND PLANT COMMUNITIES FOR CONSERVATION. BLACKWELL SCIENTIFIC PUBLICATIONS, OXFORD, ENGLAND.

325. BAYLESS, S. R. 1992. DUCK POPULATION RESPONSES TO WATER DEVELOPMENT IN NORTH CENTRAL MONTANA. M.S. THESIS, MONTANA STATE UNIVERSITY, BOZEMAN, MT. 69 PP.

326. BAYLESS, S. R. 1967. FOOD HABITS, RANGE USE AND HOME RANGE OF PRONGHORN ANTELOPE IN CENTRAL MONTANA DURING WINTER. M.S. THESIS, MONTANA STATE UNIVERSITY, BOZEMAN, MT. 65 PP.

327. BC ENVIRONMENT and WILDLIFE BRANCH. 1995. LARGE MAMMAL ROAD AND RAIL KILL, 1989-1993. MINISTRY OF ENVIRONMENT, LANDS AND PARKS, WLDLIFE BRANCH, VICTORIA, B.C.

328. BEAK CONSULTANTS. 1977. STUDIES OF POST-CONSTRUCTION IMPACTS OF LINEAR FACILITIES ON ENVIRONMENTAL ECOSYSTEMS. BEAK CONSULTANTS LTD, CALGARY, ALBERTA.

329. BEAK CONSULTANTS LTD. 1979. INTERACTIONS BETWEEN UNGULATES AND WINTER GAS WELL DRILLING OPERATIONS. PREPARED FOR MOBIL OIL CANADA LTD., CALGARY. UNPUBLISHED REPORT.

330. BEALL, R. C. 1970. IDENTIFICATION OF BIG-GAME ANIMALS ON SMALL CAMERA VERTICAL AERIAL PHOTOGRAPHY. M.S. THESIS, UNIVERSITY OF MONTANA, MISSOULA, MT. 87 PP.

331. BEALL, R. C. 1974. WINTER HABITAT SELECTION AND USE BY A WESTERN MONTANA ELK HERD. PH.D. DISSERTATION, UNIVERSITY OF MONTANA, MISSOULA, MT. 197 PP.

332. BEAR, C. 1983. EFFECTS OF ROADS ON WILDLIFE. UNPUBLISHED REPORT. UNIVERSITY OF FLORIDA, GAINESVILLE, FL.

333. BEAR, G. D. and G. W. JONES. 1973. HISTORY AND DISTRIBUTION OF BIGHORN SHEEP IN COLORADO. COLORADO DIVISION OF WILDLIFE. DENVER, COLORADO, USA. 232PP.

334. BEASOM, S. L. 1974. RELATIONSHIPS BETWEEN PREDATOR REMOVAL AND WHITE-TAILED DEER NET PRODUCTIVITY. J. WILDL. MANAGE. 38 (4):854-9. 
335.

336.

337.

EASOM, S. L. 1970. TURKEY PRODUCTIVITY IN TWO VEGETATIVE COMMUNITIES IN SOUTH TEXAS. J. WILDL. MANAGE. 34 (1):166-75.

BEATTIE, R. C., R. J. ASTON and A. G. P. MILNER. 1991. A FIELD STUDY OF FERTILIZATION AND DEVELOPMENT IN THE COMMON FROG RANA TEMPORARIA WITH PARTICULAR REFERENCE TO ACIDITY AND TEMPERATURE. JOURNAL OF APPLIED ECOLOGY 28:346-357.

BEAUCHAMP, B., B. WONE, S. BROS and M. KUTILEK. 1998. HABITAT USE OF THE FLAT-TAILED HORNED LIZARD (PHRYNOSOMA MCALLII) IN A DISTURBED ENVIRONMENT. JOURNAL OF HERPETOLOGY 32:210-216.

BEAUCHAMP, D. E. 1970. BIG GAME INVESTIGATIONS: BIG GAME MORTALITY STUDIES. CAL. W-051-R-15/WK.PL.01/JOB 03. CALIFORNIA DEPARTMENT OF FISH AND GAME, SACRAMENTO, CA.

BECHARD, M. J., R. L. KNIGHT, D. G. SMITH and R. E. FITZNER. 1990. NEST SITES AND HABITATS OF SYMPATRIC HAWKS (BUTEO SPP.) IN WASHINGTON. JOURNAL OF FIELD ORNITHOLOGY 61:159-170.

BECKEMEYER, R. J. 1996. DRAGONFLIES AS ROADKILL. ARGIA 8:19-20.

BECKER, B. W. 1972. PRONGHORN-CATTLE RANGE USE AND FOOD HABITS RELATIONSHIPS IN AN ENCLOSED SAGEBRUSH CONTROL AREA. M.S. THESIS, MONTANA STATE UNIVERSITY, BOZEMAN, MT. 57 PP.

BECKER, D. 1996. WILDLIFE AND WILDLIFE HABITAT IMPACT ISSUES AND MITIGATION OPTIONS FOR RECONSTRUCTION OF U.S. HIGHWAY 93 ON THE FLATHEAD INDIAN RESERVATION, MONTANA. PAGES 85-100 IN EVINK,G., ZIEGLER,D., GARRETT,P., AND BERRY,J., EDITORS. TRANSPORTATION AND WILDLIFE: REDUCING WILDLIFE MORTALITY AND IMPROVING WILDLIFE PASSAGEWAYS ACROSS TRANSPORTATION CORRIDORS: PROCEEDINGS OF THE FLORIDA DEPARTMENT OF TRANSPORTATION/FEDERAL HIGHWAY ADMINISTRATION TRANSPORTATION-RELATED WILDLIFE MORTALITY SEMINAR; 1996 APRIL 30-MAY 2; ORLANDO, FL. FHWA-PD-96-041. U.S. DEPARTMENT OF TRANSPORTATION, FEDERAL HIGHWAY ADMINISTRATION, WASHINGTON, DC.

BECKER, D., A. SOUKKALA and D. LIPSCOMB. 1993. WILDLIFE AND WILDLIFE HABITAT IMPACT ISSUES AND MITIGATION OPTIONS FOR RECONSTRUCTION OF U.S. HIGHWAY 93 ON THE FLATHEAD INDIAN RESERVATION. CONFEDERATED SALISH AND KOOTENAI TRIBAL WLDLIFE PROGRAM, PABLO, MT.

BECKER, D. M. 1996. WILDLIFE AND WILDLIFE HABITAT IMPACT ISSUES AND MITIGATION OPTIONS FOR RECONSTRUCTION OF U.S. HIGHWAY 93 ON THE FLATHEAD INDIAN RESERVATION. IN: GARY L. EVINK, PAUL GARRETT, DAVID ZEIGLER, AND JON BERRY, EDS. TRENDS IN ADDRESSING TRANSPORTATION RELATED WILDLIFE MORTALITYY: PROCEEDINGS OF THE TRANSPORTATION RELATED WILDLIFE MORTALITY SEMINAR. FL-ER-58-96. STATE OF FLORIDA, DEPT. TRANSPORT., ENVIRON. MANAGE. OFF., TALLAHASSEE.

5ECKER, D. M., A. M. SOUKKALA and D. J. LIPSCOMB. 1993. EVARO CORRIDOR WILDLIFE USE STUDY AND MITIGATION RECOMMENDATIONS; U.S. HIGHWAY 93 PROJECT. CONFEDERATED SALISH AND KOOTENAI TRIBAL WILDLIFE PROGRAM, PABLO, MT.

BECKER, D. M. 1983. REPRODUCTION ECOLOGY AND HABITAT UTILIZATION OF RICHARDSON'S MERLINS IN SOUTHWESTERN MONTANA. M.S. THESIS, UNIVERSITY OF MONTANA, MISSOULA, MT. 62 PP.

BECKER, E. F. and C. A. GRAUVOGEL. 1991. RELATIONSHIP OF REDUCED TRAIN SPEED ON MOOSE-TRAIN COLLISIONS IN ALASKA. ALCES 27:161-168.

BECKERT, J. R. 1979. ENVIRONMENTAL IMPACT STATEMENT: PROJECT F $19-1$ (04) WEST VALLEY HIGHWAY ANACONDA. U.S. DEPT. OF TRANSPORTATION FEDERAL HIGHWAY ADMN. REGION 8., 86 PP.

BEDFORD, G. 1991. RECORD OF ROAD KILL PREDATION BY THE FRESH WATER SNAKE (TROPIDONOPHIS MAIRII). HERPETOFAUNA 21(2):35-36.

BEDFORD, G. 1991. TWO RECORDS OF ROAD KILL PREDATION BY MULGA SNAKES (PSEUDECHIS AUSTRALIS). HERPETOFAUNA 21(2):39-40.

1. BEDFORD, G. and D. G. ANTHONY. 1995. ROAD KILL PREDATION BY THE BLACKHEADED PYTHON (ASPIDITES MELANOCEPHALUS). HERPETOFAUNA 25(1):53. 
352. BEEBY, A. and L. RICHMOND. 1987. ADAPTATION BY AN URBAN POPULATION OF THE SNAIL HELIX ASPERSA TO A DIET. CONTAMINATED WITH LEAD. ENVIRONMENTAL POLLUTION (SERIES A) 46:73-82.

353. BEECHAM, J. J. 1980. POPULATION CHARACTERISTICS, DENNING AND GROWTH PATTERNS OF BLACK BEARS IN IDAHO. PH.D. DISSERTATION, UNIVERSITY OF MONTANA, MISSOULA, MT. 101 PP.

354. BEEMAN, L. E. and M. R. PELTON. 1974. HOMING OF BLACK BEARS IN THE GREAT SMOKY MOUNTAINS NATIONAL PARK. INT. CONF. BEAR RES. AND MANAGE. 3:87-95.

355. BEEMAN, L. E. and M. R. PELTON. 1980. SEASONAL FOODS AND FEEDING ECOLOGY OF BLACK BEARS IN THE SMOKY MOUNTAINS. INT. CONF. BEAR RES. AND MANAGE. 4:141-7.

356. BEHLKE, C. E. 1991. FUNDAMENTALS OF CULVERT DESIGN FOR PASSAGE OF WEAK-SWIMMING FISH FINAL REPORT. ALASKA DEPT. OF TRANSPORTATION AND PUBLIC FACILITIES, UNITED STATES FEDERAL HIGHWAY ADMINISTRATION, UNITED STATES DEPT. OF TRANSPORTATION, FAIRBANKS, ALASKA.

357. BEHREND, D. F. and E. F. PATRIC. 1969. INFLUENCE OF SITE DISTURBANCE AND REMOVAL OF SHADE ON REGENERATION OF DEER BROWSE. J. WILDL. MANAGE. 33 (2):3948.

358. BEHREND, D. F. and R. A. LUBECK. 1968. SUMMER FLIGHT BEHAVIOR OF WHITE-TAILED DEER IN TWO ADIRONDACK FORESTS. JOURNAL OF WLDLIFE MANAGEMENT 32(3):615-618.

359. BEIER, P. 1995. DISPERSAL OF JUVENILE COUGARS IN FRAGMENTED HABITAT. JOURNAL OF WILDLIFE MANAGEMENT 59:228-237.

360. BEIER, P. and R. H. BARRETT. 1993. THE COUGAR IN THE SANTA ANA MOUNTAIN RANGE, CALIFORNIA. FINAL REPORT, UNIVERSITY OF CALIFORNIA, BERKELEY. 103 PP.

361. BEIER, P. and S. LOE. 1992. A CHECKLIST FOR EVALUATING IMPACTS TO WLDLIFE MOVEMENT CORRIDORS. WILDLIFE SOCIETY BULLETIN 20:434-440.

362. BEIER, P. 1993. DETERMINING MINIMUM HABITAT AREAS AND HABITAT CORRIDORS FOR COUGARS. CONSERVATION BIOLOGY 7:94-108.

363. BEKKER, G. J. 1998. HABITAT FRAGMENTATION AND INFRASTRUCTURE IN THE NETHERLANDS AND EUROPE. PAGES 151-165 IN EVINK,G., ZIEGLER,D., GARRETT,P., AND BERRY,J., EDITORS. PROCEEDINGS OF THE INTERNATIONAL CONFERENCE ON WLDLIFE ECOLOGY AND TRANSPORTATION; 1998 FEBRUARY 10-12; FT. MYERS, FL FLORIDA DEPARTMENT OF TRANSPORTATION, TALLAHASSEE, FL.

364. BELANGER, K. D., D. J. DIETERMAN and T. W. DEYO. 1990. PRE- AND POST- CONSTRUCTION WATER QUALITY MONITORING FOR HABITAT REHABILITATION AND EVALUATION PROJECTS AT BIG LAKE BAY, FINGER LAKES, LAKE ONALASKA, AND THE POOL 8 ISLANDS AREA OF THE UPPER MISSISSIPPI RIVER. U.S. FISH AND WILDLIFE SERVICE, ENVIRONMENTAL MANAGEMENT TECHNICAL CENTER, ONALASKA, WI, .

365. BELANGER, L. and J. BEDARD. 1990. ENERGETIC COST OF MAN-INDUCED DISTURBANCE TO STAGING SNOW GEESE. J. WILDL. MANAGE. 54 (1):36-41.

366. BELANGER, L. and J. BEDARD. 1989. RESPONSES OF STAGING GREATER SNOW GEESE TO HUMAN DISTURBANCE. J. WILDL. MANAGE. 53 (3):713-9.

367. BELANT, J. L. 1995. MOOSE COLLISIONS WITH VEHICLES AND TRAINS IN NORTHEASTERN MINNESOTA. ALCES $31: 45-52$.

368. BELDEN, R. C. 1988-1989. TITLE UNKNOWN. AUDUBON WILDL REPORT:515-33.

369. BELDEN, R. C., W. B. FRANKENBERGER, R. T. MCBRIDE and S. T. SCHWIKERT. 1988. PANTHER HABITAT USE IN SOUTHERN FLORIDA. JOURNAL OF WILDLIFE MANAGEMENT 52 (4):660-3 

WILDL. MANAGE. 57:388-97.

371. BELDEN, R. C., B. W. HAGEDORN and W. B. FRANKENBERGER. 1991. RESPONSES OF TRANSLOCATED MOUNTAIN LIONS TO HUMAN DISTURBANCE. PAGES 26 [ABSTRACT ONLY] IN C. E. BRAUN, EDITOR. MOUNTAIN LION-HUMAN INTERACTION, SYMPOSIUM AND WORKSHOP.

372. BELFORD, D. A. 1986. ABILITIES OF TROUT TO SWIM THROUGH HIGHWAY CULVERTS. M.S. THESIS, MONTANA STATE UNIVERSITY, BOZEMAN, MT. 67 PP.

373. BELIKOV, S. E. 1974. BEHAVIORAL ASPECTS OF THE POLAR BEAR, URSUS MARITIMUS. INT. CONF. BEAR RES. AND MANAGE. 3:37-40.

374. BELL, J. H., J. L. LAUER and J. M. PEEK. 1992. HABITAT USE PATTERNS OF WHITE-TAILED DEER, UMATILLA RIVER, OREGON. NORTHWEST SCIENCE 66:160-171.

375. BELL, K. L. and L. C. BLISS. 1973. ALPINE DISTURBANCE STUDIES: OLYMPIC NATIONAL PARK, U.S.A. BIOLOGICAL CONSERVATION 5:25-32.

BELL, M. C. and A. C. DE LACY. 1972. A COMPENDIUM ON THE SURVIVAL OF FISH PASSING THROUGH SPILLWAYS AND CONDUITS. FISHERIES ENGINEERING RESEARCH PROGRAM. PORTLAND, OREGON.

377. BELLIS, E. D. 1971. BEHAVIOR, ECOLOGY, AND MORTALITY OF WHITE-TAILED DEER ALONG A PENNSYLVANIA INTERSTATE HIGHWAY. RESEARCH PUBLICATION / INSTITUTE FOR RESEARCH ON LAND AND WATER RESOURCES. INSTITUTE FOR RESEARCH ON LAND AND WATER RESOURCES, PENNSYLVANIA STATE UNIVERSITY, UNIVERSITY PARK, PENNSYLVANIA.

BELLIS, E. D. and H. B. GRAVES. 1971. COLLISION OF VEHICLES WITH DEER STUDIED ON PENNSYLVANIA INTERSTATE ROAD SECTION. HIGHWAY RESEARCH NEWS 43:13-17.

379. BELLIS, E. D. and H. B. GRAVES. 1971. DEER MORTALITY ON A PENNSYLVANIA INTERSTATE HIGHWAY. JOURNAL OF WILDLIFE MANAGEMENT 35:232-237.

380. BELLIS, E. D. and H. B. GRAVES. 1978. HIGHWAY FENCES AS DETERRENTS TO VEHICLE-DEER COLLISIONS. TRANSPORTATION RESEARCH RECORD 674:53-58.

381. BELZ, A. 1988. WATERBIRDS AND HIGHWAYS. CHARADRIUS 24(2):111-112.

382. BENGSON, S. 1986. VIEWPOINT: VEHICULAR RECREATION USE ON PUBLIC LANDS. RANGELANDS 8:106-107.

383. BENNETT, A. F. 1990. HABITAT CORRIDORS AND THE CONSERVATION OF SMALL MAMMALS IN A FRAGMENTED FOREST ENVIRONMENT. LANDSCAPE ECOLOGY 4:109-122.

384. BENNETT, A. F. 1990. HABITAT CORRIDORS: THEIR ROLE IN WLDLIFE MANAGEMENT AND CONSERVATION. DEPARTMENT OF CONSERVATION AND ENVIRONMENT, VICTORIA, AUSTRALIA.

385. BENNETT, A. F. 1993. MICROHABITAT USE BY THE LONG-NOSE POTOROO, POTOROUS TRIDACTYLUS, AND OTHER SMALL MAMMALS IN REMNANT FOREST VEGETATION OF SOUTH-WESTERN VICTORIA. WILDLIFE RESEARCH 20 (3):267-85.

386. BENNETT, A. F. 1991. ROADS, ROADSIDES, AND WILDLIFE CONSERVATION: A REVIEW. PAGES 99-117 IN SAUNDERS, D.A. AND HOBBS, R.J., EDITORS. NATURE CONSERVATION 2: THE ROLE OF CORRIDORS. SURREY BEATTY AND SONS, CHIPPING NORTON, AUSTRALIA.

387. BENNETT, A. F., K. HENEIN and G. MERRIAM. 1994. CORRIDOR USE AND THE ELEMENTS OF CORRIDOR QUALITY: CHIPMUNKS AND FENCEROWS IN A FARMLAND MOSAIC. BIOLOGICAL CONSERVATION 68:155-165. 
389. BENSON, R. H. 1996. THE EFFECT OF ROADWAY TRAFFIC NOISE ON TERRITORY SELECTION BY GOLDEN-CHEEKED WARBLERS. JOURNAL OF THE ACOUSTICAL SOCIETY OF AMERICA 99(4/2):25-27.

390. BENTZ, J. A., W. HAY and D. BRIERLEY. 1986. RESOURCE INVENTORY AND LAND USE EVALUATIONS OF THE HINTON-JASPER CORRIDOR. PUBLICATION NO. T/134: PUBLICATION (ALBERTA. ALBERTA FORESTRY, LANDS AND WILDLIFE) T/134. ALBERTA FORESTRY, LANDS AND WILDLIFE, RESOURCE EVALUATION AND PLANNING DIVISION, EDMONTON, ALBERTA.

391. BENZON, T. A. and L. A. RICE. 1987. ROCKY MOUNTAIN GOAT POPULATION STATUS IN THE BLACK HILLS, SOUTH DAKOTA, 1985-1986. SOUTH DAKOTA DEP. GAME, FISH AND PARKS. PROG. REP. 87-4. 21PP.

392. BERESZYNSKI, A. 1980. STUDIES ON MORTALITY OF BIRDS KILLED ON PUBLIC ROADS. ROCZNIKI AKADEMII ROLNICZEJ W POZNANIU 22:3-10.

393. BERG, A. 1992. FACTORS AFFECTING NEST-SITE CHOICE AND REPRODUCTIVE SUCCESS OF CURLEWS NUMENIUS ARQUATA ON FARMLAND. IBIS 134 (1):44-51.

394. BERG, A. and T. PART. 1994. ABUNDANCE OF BREEDING FARMLAND BIRDS ON ARABLE AND SET-ASIDE FIELDS AT FOREST EDGES. ECOGRAPHY 17:147-152.

395. BERG, P. F. 1955. A STUDY OF WATERFOWL BROODS IN EASTERN MONTANA WITH SPECIAL REFERENCE TO MOVEMENTS AND THE RELATIONSHIP OF RESERVOIR FENCING TO PRODUCTION. M.S. THESIS, MONTANA STATE COLLEGE, BOZEMAN, MT. 31 PP.

396. BERG, R. L., L. L. MCDONALD and M. D. STRICKLAND. 1983. DISTRIBUTION OF MOUNTAINS LIONS IN WYOMING AS DETERMINED BY MAIL QUESTIONNAIRE. WLDLIFE SOCIETY BULLETIN 11:265-268.

397. BERG, R. K. 1974. LIMNOLOGY OF CLARK CANYON RESERVOIR, MONTANA. M.S. THESIS, MONTANA STATE UNIVERSITY, BOZEMAN, MT. 79 PP.

398. BERG, W. E. and D. W. KUEHN. 1982. ECOLOGY OF WOLVES IN NORTH-CENTRAL MINNESOTA. P 411. IN HARRINGTON, F.H., PAQUET, P.C. (EDS.). WOLVES OF THE WORLD: PERSPECTIVES OF BEHAVIOR, ECOLOGY, AND CONSERVATION. PARK RIDGE, NJ.: NOYLES PUBL.

399. BERGER, J. 1991. GREATER YELLOWSTONE'S NATIVE UNGULATES: MYTHS AND REALITIES. CONSERVATION BIOLOGY 5 (3):353-63.

400. BERGER, J. 1990. PERSISTENCE OF DIFFERENT-SIZED POPULATIONS: AN EMPIRICAL ASSESSMENT OF RAPID EXTINCTIONS IN BIGHORN SHEEP. CONSERVATION BIOLOGY 4(1):91-8.

401. BERGER, J. and J. D. WEHAUSEN. 1991. CONSEQUENCES OF A MAMMALIAN PREDATOR-PREY DISEQUILIBRIUM IN THE GREAT BASIN DESERT. CONSERVATION BIOLOGY 5 (2):244-8

402. BERGER, J. and D. DANEKE. 1988. EFFECTS OF AGRICULTURAL, INDUSTRIAL, AND RECREATIONAL EXPANSION ON FREQUENCY OF. WLDLIFE LAW VIOLATIONS IN THE CENTRAL ROCKY MOUNTAINS, USA. CONSERVATION BIOLOGY 2:283-289.

403. BERGERUD, A. T. 1974. DECLINE OF CARIBOU IN NORTH AMERICA FOLLOWING SETTLEMENT. J. WILDL. MANAGE. 38 (4):757-70.

404. BERGERUD, A. T. 1978. THE STATUS AND MANAGEMENT OF CARIBOU IN BRITISH COLUMBIA. BRITISH COLUMBIA FISH AND WILDLIFE BRANCH, VICTORIA, B.C.15OPP.

405. BERGERUD, A. T., R. D. JAKIMCHUK and D. R. CARRUTHERS. 1984. THE BUFFALO OF THE NORTH: CARIBOU (RANGIFER TARANDUS) AND HUMAN DEVELOPMENTS. ARCTIC 37:7-22.

406. BERGERUD, A. T. and L. RUSSELL. 1964. EVALUATION OF RUMEN FOOD ANALYSIS FOR NEWFOUNDLAND CARIBOU. J. WILDL. MANAGE. $28(4): 809-14$ 
407. BERGIN, T. M., L. B. BEST and K. E. FREEMARK. 1997. AN EXPERIMENTAL STUDY OF PREDATION ON ARTIFICIAL NESTS IN ROADSIDES ADJACENT TO AGRICULTURAL HABITATS IN IOWA. WILSON BULLETIN 109(3):437-448.

408. BERGMAN, R. D. 1973. USE OF SOUTHERN BOREAL LAKES BY POSTBREEDING CANVASBACKS AND REDHEADS. J. WILDL. MANAGE. 37 (2):160-70.

409. BERGMAN, R. D., R. L. HOWARD, K. F. ABRAHAM and M. W. WELLER. 1977. WATER BIRDS AND THEIR WETLAND RESOURCES IN RELATION TO OIL DEVELOPMENT AT STORKERSEN POINT, ALASKA. U.S. DEPT. INTERIOR, FISH WILDL. SERV. WASHINGTON, DC. RESOUR. PUB. 129. 38PP.

410. BERGSTROM, J. C., H. K. CORDELL, G. A. ASHLEY and A. E. WATSON. 1990. ECONOMIC IMPACTS OF RECREATIONAL SPENDING ON RURAL AREAS: A CASE STUDY. ECONOMIC DEVELOPMENT QUARTERLY 4:29-39.

411. BERINGER, J. J. 1986. HABITAT USE IN RESPONSE TO ROADS BY BLACK BEARS IN HARMON DEN, PISGAH NATIONAL FOREST, NORTH CAROLINA. M.S. THESIS, UNIVERSITY OF TENNESSEE, KNOXVILLE.

412. BERINGER, J. J., S. G. SEIBERT and M. R. PELTON. 1990. INCIDENCE OF ROAD CROSSING BY BLACK BEARS ON PISGAH NATIONAL FOREST, NORTH CAROLINA. INT. CONF. BEAR RES. AND MANAGE. $8: 85-92$.

413. BERKSON, J. M. 1996. MODELING THE RESTORATION OF A MATAPOPULATION: IMPLICATIONS FOR RESOURCE MANAGEMENT. PH.D. DISSERTATION, MONTANA STATE UNIVERSITY, BOZEMAN, MT. 149 PP.

414. BERNARDINO, F. S. JR. and G. H. DALRYMPLE. 1992. SEASONAL ACTIVITY AND ROAD MORTALITY OF THE SNAKES OF THE PA-HAY-OKEE WETLANDS OF EVERGLADES NATIONAL PARK. BIOLOGICAL CONSERVATION 62:71-75.

415. BERNARDINO, F. S. JR. and G. H. DALRYMPLE. 1992. SEASONAL ACTIVITY AND ROAD MORTALITY OF THE SNAKES OF THE PA-HAY-OKEE WETLANDS OF EVERGLADES NATIONAL PARK, USA. BIOLOGICAL CONSERVATION 62:71-75.

416. BERNER, K. L. 1985. WINTER AND SPRING HABITAT SELECTION BY WHITE-TAILED DEER IN A WESTERN MONTANA SECOND-GROWTH FOREST. M.S. THESIS, UNIVERSITY OF MONTANA, MISSOULA, MT. 98 PP.

417. BERRILL, M., S. BERTRAM, L. MCGILLIVRAY, M. KOLOHON and B. PAULI. 1994. EFFECTS OF LOW CONCENTRATIONS OF FOREST-USE PESTICIDES ON FROG EMBRYOS AND TADPOLES. ENVIRONMENTAL TOXICOLOGY AND CHEMISTRY $13(4): 657-64$.

418. BERRY, C. R. and S. C. JUNI. 2000. GUIDELINES FOR RESTORING AND CREATING WETLANDS ASSOCIATED WITH HIGHWAY PROJECTS IN SOUTH DAKOTA. B: BULLETIN (SOUTH DAKOTA AGRICULTURAL EXPERIMENT STATION) NO. 734. SOUTH DAKOTA STATE UNIVERSITY, DEPT. OF WILDLIFE AND FISHERIES SCIENCES, SOUTH DAKOTA COOPERATIVE FISH AND WILDLIFE RESEARCH UNIT/I=SOUTH DAKOTA, UNIVERSITY, BROOKINGS, SOUTH DAKOTA.

419. BERRY, K. H. 1986. DESERT TORTOISE (GOPHERUS AGASSIZII) RESEARCH IN CALIFORNIA, 1976-1985. HERPETOLOGICA 42:62-67.

420. BERRY, K. H. 1980. THE EFFECTS OF THE FOUR-WHEEL VEHICLES ON BIOLOGICAL RESOURCES. PAGES 231-233 IN R. N. L. ANDREWS AND P. F. NOWAK, EDITORS. OFF-ROAD VEHICLE USE: A MANAGEMENT CHALLENGE. U.S. DEPARTMENT OF AGRICULTURE, OFFICE OF ENVIRONMENTAL QUALITY. WASHINGTON, D.C. 348PP.

421. BERRY, K. H. 1986. INCIDENCE OF GUNSHOT DEATHS IN DESERT TORTOISE POPULATIONS IN CALIFORNIA. WILDLIFE SOCIETY BULLETIN 14:127-132.

422. BERRY, K. H. 1980. A REVIEW OF THE EFFECTS OF OFF-ROAD VEHICLES ON BIRDS AND OTHER VERTEBRATES. GEN. TECH. REP. INT-86. U.S. DEPARTMENT OF AGRICULTURE, FOREST SERVICE, OGDEN, UT.

423. BERRY, K. H. 1980. A REVIEW OF THE EFFECTS OF OFF-ROAD VEHICLES ON BIRDS AND OTHER VERTEBRATES PAGES 451-467 IN R. M. DEGRAAF AND N. G. N. G. TILGHAM, COMPILERS. WORKSHOP PROCEEDINGS: MANAGEMENT OF WESTERN FORESTS AND GRASSLANDS FOR NONGAME BIRDS. U.S. DEPT. AGRICULTURE, FOREST SERV., INTERMT. FOR. AND RANGE EXP. STN., OGDEN, UTAH.

424. BERRYMAN, J. H. 1972. THE PRINCIPLES OF PREDATOR CONTROL. J. WILDL. MANAGE.36 (2):395-400. 

RESOURCE USE. UTAH ST. UNIV., COLLEGE OF FOR., RANGE, AND WILDL. MGT., LOGAN. EXT. CIRC. 297, 15 PP.

426. BERTCH, B. 1991. MONITORING PROGRAM MITIGATION MEASURES: TRANS-CANADA HIGHWAY TWINNING. SUMMARY REPORT. UNPUBLISHED REPORT. PARKS CANADA, BANFF NATIONAL PARK WARDEN SERVICE, BANFF, ALBERTA.

427. BERTGES, W. C. 1974. RECREATIONAL VESSEL WASTE POLLLUTION. U.S. COAST GUARD. $150 P P$.

428. BERTHOUD, G. 1980. THE HEDGEHOG (ERINACEUS EUROPAEUS) AND THE ROADS. TERRE VIE 34(3):361-372.

429. BERWICK, S., K. MCNAMARA and D. DANEKE. 1986. THE EFFECTS OF RECREATION, ILLEGAL HARVEST, AND DEVELOPMENT ON ELK NEAR ASPEN, COLORADO. PAGES 270-275 IN R. D. COMER, G. T. BAUMANN, P. DAVIS, J. W. MONARCH, J. TODD, S. VANGYTENBEEK, D. WLLS, AND J. WOODLING, EDITORS. PROCEEDINGS II. ISSUES AND TECHNOLOGY IN THE MANAGEMENT OF IMPACTED WESTERN WILDLIFE: PROCEEDINGS OF A NATIONAL SYMPOSIUM. THORNE ECOL. INST., BOULDER, COLORADO.

430. BERWICK, S. H. 1968. OBSERVATIONS ON THE DECLINE OF THE ROCK CREEK, MONTANA, POPULATION OF BIGHORN SHEEP. THESIS, UNIVERSITY OF MONTANA, MISSOULA, MONTANA, USA. 245PP.

431. BERWICK, S. H., R. A. NISBET and K. L. REED. 1984. SPATIAL ANALYSIS FOR DETERMINING 'REGION-OF-INFLUENCE' WHEN PREDICTING IMPACTS ON WILDLIFE AND OTHER RESOURCES. PAGES 91-97 IN R. D. COMER, J. M. MERINO, J. W. MONARCH, C. PUSTMUELLER, M. STALMASTER, R. STOECKER, J. TODD, AND W. WRIGHT, EDITORS. ISSUES AND TECHNOLOGY IN THE MANAGEMENT OF IMPACTED WESTERN WILDLIFE -PROCEEDINGS OF A NATIONAL SYMPOSIUM. VOLUME TECH. PUBL. NO. 14. THORNE ECOL. INST., BOULDER, COLORADO

432. BERWICK, S. H. 1968. OBSERVATIONS OF THE DECLINE OF THE ROCK CREEK, MONTANA, POPULATION OF BIGHORN SHEEP. PH.D. DISSERTATION, UNIVERSITY OF MONTANA, MISSOULA, MT. 245 PP.

433. BESCHTA, R. 1978. LONG-TERM PATTERNS OF SEDIMENT PRODUCTION FOLLOWING ROAD CONSTRUCTION AND LOGGING IN THE OREGON COAST RANGE. WATER RESOURCES RESEARCH 14:1011-1016.

434. BESS, F. H. 1971. THE EFFECT OF SNOWMOBILE NOISE ON THE HEARING MECHANISM. PAGES 147-159 IN M. CHUBB, EDITOR. PROCEEDINGS OF THE SNOWMOBILE AND OFF THE ROAD VEHICLE RESEARCH SYMPOSIUM. SPONSORED BY THE DEPARTMENT OF PARK AND RECREATION RESOURCES, MICHIGAN STATE UNIVERSITY. EAST LANSING, MI.

435. BEST, L. B., K. E. FREEMARK, J. J. DINSMORE and M. CAMP. 1995. A REVIEW AND SYNTHESIS OF HABITAT USE BY BREEDING BIRDS IN AGRICULTURAL LANDSCAPES OF IOWA. AMERICAN MIDLAND NATURALIST 134 (1):1-29.

436. BEST, L. B., D. F. STAUFFER, A. R. GEIER, K. L. VARLAND, VOGLER J. P., R. B. DAHLGREN and R. Q. LANDERS. EFFECTS OF HABITAT ALTERATIONS ON RIPARIAN COMMUNITIES IN IOWA. IOWA COOPERATIVE WILDLIFE RESEARCH UNIT. 14-16-0008-1174

437. BEST, L. B. 1970. EFFECTS OF ECOLOGICAL CHANGES INDUCED BY VARIOUS SAGEBRUSH CONTROL TECHNIQUES ON NON-GAME BIRDS. M.S. THESIS, MONTANA STATE UNIVERSITY, BOZEMAN, MT. 74 PP.

438. BESWCK, B. L. 1991. COMMERCIAL TRUCKING IN KOOTENAY NATIONAL PARK: INITIAL ENVIRONMENTAL EVALUATION, FINAL REPORT. ENVIRONMENTAL ASSESSMENT DIVISION, WESTERN REGION, CANADIAN PARKS SERVICE. 62PP.

439. BETHLAHMY, N. 1967. EFFECT OF EXPOSURE AND LOGGING ON RUNOFF AND EROSION. USDI FOR. SERV.,INTERMOUNTAIN FOR. \& RANGE EXP. STA.,. RES. NOTE INT-617 PP.

440. BETSILL, C. W. 1976. COTTONTAIL RABBIT HABITAT UTILIZATION OF A SEEDED MECHANICALLY MAINTAINED POWER LINE RIGHT-OF-WAY. (PROC) 33RD SE FISH \& GAME COMM. CONF. FILE NO. 33-7

441. BEVANGER, K. 1994. AVIAN INTERACTIONS WITH A 66 KV POWER LINE NEAR BORREVANN, VESTFOLD, NORWAY. NINA (NORSK INSTITUTT FOR NATURFORSKNING) FORSKNINGSRAPPORT 0 (52):1-37. 
442. BEVANGER, K. 1994. BIRD INTERACTIONS WITH UTILITY STRUCTURES: COLLISION AND ELECTROCUTION, CAUSES AND MITIGATING MEASURES. IBIS $136(4): 412-25$.

443. BEVANGER, K. 1995. ESTIMATES AND POPULATION CONSEQUENCES OF TETRAONID MORTALITY CAUSED BY COLLISIONS WITH HIGH TENSION POWER LINES IN NORWAY. JOURNAL OF APPLIED ECOLOGY 32 (4):745-53.RESEARCH

444. BEVANGER, K. 1995. TETRAONID MORTALITY CAUSED BY COLLISIONS WITH POWERLINES IN BOREAL FOREST HABITATS IN CENTRAL NORWAY. FAUNA NORVEGICA SERIES C CINCLUS 18 (1):41-51.

445. BEVANGER, K. 1994. THREE QUESTIONS ON ENERGY TRANSMISSION AND AVIAN MORTALITY. FAUNA NORVEGICA SERIES C CINCLUS 17 (2):107-14.

446. BEYER, W. N. and J. MOORE. 1980. LEAD RESIDUES IN EASTERN TENT CATERPILLARS (MALACOSOMA AMERICANUM) AND THEIR HOST PLANT (PRUNUS SEROTINA) CLOSE TO A MAJOR HIGHWAY. ENVIRONMENTAL ENTOMOLOGY. 9(1):10-12

447. BIANCHI, D. R. 1963. THE EFFECTS OF SEDIMENTATION ON EGG SURVIVAL OF RAINBOW TROUT AND CUTTHROAT TROUT. M.S. THESIS, MONTANA STATE COLLEGE, BOZEMAN, MT. 28 PP.

448. BIDER, J. R. 1968. ANIMAL ACTIVITY IN UNCONTROLLED TERRESTRIAL COMMUNITIES AS DETERMINED BY A SAND TRANSECT TECHNIQUE. ECOLOGICAL MONOGRAPHS 38:269-308.

449. BIDER, J.R. and D. H. PIMLOTT. 1973. ACCESS TO HUNTING AREAS FROM MAJOR URBAN CENTRES AND BIG GAME KILLS IN QUEBEC. NINTH NORTH AMERICAN MOOSE CONFERENCE WORKSHOP:59-80

450. BIGELOW, P. E. 1991. EVALUATION OF GROWTH INTERRUPTION AS A MEANS OF MASS-MARKING HATCHERY TROUT. M.S. THESIS, MONTANA STATE UNIVERSITY, BOZEMAN, MT. 93 PP.

451. BIGGINS, D. E. 1978. EFFECTS OF COAL EXTRACTION AND RELATED DEVELOPMENT ON WLDLIFE POPULATIONS. ANN. PROG. REPT, WLDLF RES. WORK UNIT, DENVER WLDLF RES. CENTER., 9 PP.

452. BIGGINS, D. E. and R. L. PHILLIPS. 1977. EFFECTS OF COAL EXTRACTION AND RELATED DEVELOPMENT ON WLDLIFE POPULATIONS. ANNUAL PROGRESS REPORT, WILDLIFE RESEARCH WORK UNIT, DENVER WILDLIFE RESEARCH CENTER., 33 PP.

453. BIGGINS, D. E. and R. L. PHILLIPS. 1978. EFFECTS OF COAL STRIP MINING ON HABITAT USE AND ACTIVITY PATTERNS OF MULE DEER (ODOCOILEUS HEMIONUS) AND WHITE-TAILED DEER (O. VIRGINIANUS). DENVER WILDLIFE RESEARCH CENTER.

454. BIGGINS, D. E. and R. L. PHILLIPS. 1976. EFFECTS OF COAL STRIP MINING ON HABITAT USE AND ACTIVITY PATTERNS OF MULE DEER (ODOCOILEUS HEMIONUS). DENVER WILDLIFE RESEARCH CENTER.

455. BIGGINS, D. E. 1975. SEASONAL HABITAT SELECTION AND MOVEMENTS OF THE SPOTTED BEAR ELK HERD. M.S. THESIS, UNIVERSITY OF MONTANA, MISSOULA, MT. 90 PP.

456. BIGHORN ENVIRONMENTAL DESIGN LTD. 1996. CUMULATIVE EFFECTS AND ENVIRONMENTAL ASSESSMENT OF THE PROPOSED CHEVIOT MINE DEVELOPMENT: UNGULATES, SMALL MAMMALS, AVIFAUNA, AMPHIBIANS. PREPARED FOR CARDINAL RIVER COALS LTD. 154PP.

457. BIGINI, I. and R. TURINI. 1995. TROPHIC NICHE OF THE BARN OWL TYTO ALBA (SCOP.,1769) AND ANTHROPIC IMPACT: DATA FROM THE BORDER PLAIN OF MONTI PISANI AND FROM THE LUCCA SUBAPPENNINO (TUSCANY, ITALY). ATTI DEL MUSEO CIVICO DI STORIA NATURALE DI TRIESTE 46 (0):133-43.

458. BILDSTEIN, K. L. and I. L. JR. BRISBIN. 1990. LANDS FOR LONG-TERM RESEARCH IN CONSERVATION BIOLOGY. CONSERVATION BIOLOGY 4 (3):301-8.

459. BILLINGTON, H. L. 1991. EFFECT OF POPULATION SIZE ON GENETIC VARIATION IN A DIOECIOUS CONIFER. CONSERVATION BIOLOGY 5 (1):115-9. 
460. BINDERNAGEL, J. A. and R. C. ANDERSON. 1972. DISTRIBUTION OF THE MENINGEAL WORM IN WHITE-TAILED DEER IN CANADA. J. WILDL. MANAGE. 36 (4):1349-53.

461. BINKLEY, K. M. 1996. HABITAT SELECTION OF ADULT WALLEYE (STIZOSTEDION VITREUM) IN HOLTER RESERVOIR MISSOURI RIVER. M.S. THESIS, MONTANA STATE UNIVERSITY, BOZEMAN, MT. 119 PP.

462. BIODIVERSITY LEGAL FOUNDATION. 1996. REPORT AND FORMAL COMMENTS ON THE CURRENT AND POTENTIAL ADVERSE IMPACTS OF WINTER RECREATIONAL USE IN YELLOWSTONE NATIONAL PARK AND THE WINTER VISITOR USE MANAGEMENT PLANNING PROCESS BY THE U.S. PARK SERVICE. BIODIVERISTY LEGAL FOUNDATION. BOULDER, COLORADO. 132PP.

463. BIRDSALL, C. W., C. E. GRYE and A. ANDERSON. 1986. LEAD CONCENTRATIONS IN BULLFROG RANA CATESBEIANA AND GREEN FROG R. CLAMITANS TADPOLES INHABITING HIGHWAY DRAINAGES. ENVIRONMENTAL POLLUTION A 40:233-247.

464. BIRKAN, M., T. AVIGNON, F. REITZ and V. VIGNON. 1994. HIGHWAY EFFECTS ON BREEDING SUCCESS OF THE GREY PARTRIDGE (PERDIX PERDIX) IN A PLAIN OF LARGE-SCALE WHEAT FARMING. GIBIER FAUNE SAUVAGE 11 (3):207-18.

465. BIRKBY, J. L. 1983. INTERACTION OF WESTERN HARVESTER ANTS WITH SOUTHEASTERN MONTANA SOILS AND VEGETATION. M.S. THESIS, MONTANA STATE UNIVERSITY, BOZEMAN, MT. 35 PP.

466. BISBAL, F. J. 1993. HUMAN IMPACT ON THE CARNIVORES OF VENEZUELA. STUDIES ON NEOTROPICAL FAUNA AND ENVIRONMENT 28 (3):145-56.

467. BISHOP, C. G. 1953. AGE, GROWTH AND CONDITION OF TROUT IN PRICKLEY PEAR CREEK, MONTANA. M.S. THESIS, MONTANA STATE COLLEGE, BOZEMAN, MT. 22 PP.

468. BISMARK, M. 1991. POPULATION ANALYSIS OF LONGTAIL MACAQUES (MACACA FASCICULARIS) IN VARIOUS FOREST TYPES. BULETIN PENELITIAN HUTAN 0(532):1-10.

469. BISMARK, M. 1992. THE ROLE OF THE BEYOND NATURAL CONSERVATION IN CONSERVING OF MACACA FASCICULARIS POPULATION. BULETIN PENELITIAN HUTAN 0 (549):9-18.

470. BISSELL, G. and C. A. YDE. 1985. WILDLIFE AND WILDLIFE HABITAT MITIGATION PLAN FOR HUNGRY HORSE HYDROELECTRIC PROJECT. U.S. DEPT. OF ENERGY, BONNEVILLE POWER ADMINISTRATION, DIVISION OF FISH AND WILDLIFE ; MONTANA DEPT. OF FISH, WILDLIFE AND PARKS, PORTLAND, OREGON.

471. BJÄRVALL, A., F. SANDEGREN and P. WABAKKEN. 1990. LARGE HOME RANGES AND POSSIBLE EARLY SEXUAL MATURITY IN SCANDINAVIAN BEARS. INT. CONF. BEAR RES. AND MANAGE. 8:237-41.

472. BJORGE, R. 1984. WINTER HABITAT USE BY WOODLAND CARIBOU IN WEST CENTRAL ALBERTA WITH IMPLICATIONS FOR MANAGEMENT. IN: MEEHAN W.R., MERRELL R.R., HANLEY R.A., EDS. FISH AND WILDLIFE RELATIONSHIPS IN OLD GROWTH FORESTS. PROCEEDINGS OF AMERICAN INSTITUTE OF FISHERIES RESEARCH AND BIOLOGY SYMPOSIUM.

473. BJORKLUND, R. G. 1953. THE LAKE WHITEFISH, COREGONUS CLUPEAFORMIS (MITCHELL) IN FLATHEAD LAKE, MONTANA. PH.D. DISSERTATION, MONTANA STATE UNIVERSITY, MISSOULA, MT. 144 PP.

474. BJORNLIE, D. D. 2000. ECOLOGICAL EFFECTS OF WINTER ROAD GROOMING ON BISON IN YELLOWSTONE NATIONAL PARK. M.S. THESIS, MONTANA STATE UNIVERSITY, BOZEMAN, MT. 48 PP.

475. BJORNN, T. C. and P. D. DALKE. 1975. A SURVEY OF BEHAVIOR, PREFERENCES AND OPINIONS OF IDAHO HUNTERS. UNIV. OF IDAHO, MOSCOW, ID., 56 PP.

476. BLACK, H., R. J. SCHERZINGER and J. W. THOMAS. 1976. RELATIONSHIPS OF ROCKY MOUNTAIN ELK AND ROCKY MOUNTAIN MULE DEER HABITAT TO TIMBER MANAGEMENT IN THE BLUE MOUNTAINS OF OREGON AND WASHINGTON. PAGES 11-31 IN PROCEEDINGS OF THE ELK-LOGGING-ROADS SYMPOSIUM. FOREST, WILDLIFE AND RANGE EXPERIMENT STATION, UNIV. IDAHO, 
477. BLACKBURN, J. and M. B. DAVIS. 1994. OFF-ROAD VEHICLES: FUN AND/OR FOLLY. ASPI PUBLICATIONS. LIVINGSTON, KENTUCKY.

478. BLAIR, R. M., J. A. HAYS and L. BRUNETT. 1963. STREAM-CROSSING STRUCTURE DEER FENCE. JOURNAL OF WILDLIFE MANAGEMENT 27:129-132.

479. BLAIR, R. M., J. A. HAYS and L. BRUNETT. 1963. STREAM-CROSSING STRUCTURE FOR DEER FENCE. J. WLDL. MANAGE. 27: (1):129-32

480. BLAISDELL, J. A. and R. L. HUBBARD. 1956. AN OUTRIGGER TYPE DEER FENCE. FOREST RESEARCH NOTES 108:1-3

481. BLAKE, D., A. M. HUTSON, P. A. RACEY, J. RYDELL and J. R. SPEAKMAN. 1994. USE OF LAMPLIT ROADS BY FORAGING BATS IN SOUTHERN ENGLAND. JOURNAL OF ZOOLOGY 234(3):3-462.

482. BLANCHARD, B. M. 1983. GRIZZLY BEAR--HABITAT RELATIONSHIPS IN THE YELLOWSTONE AREA. INT. CONF. BEAR RES. AND MANAGE. 5:118-23.

483. BLANCHARD, B. M. 1987. SIZE AND GROWTH PATTERNS OF THE YELLOWSTONE GRIZZLY BEAR . INT. CONF. BEAR RES. AND MANAGE. 7:99-107.

484. BLANCHARD, B. M. 1978. GRIZZLY BEAR DISTRIBUTION IN RELATION TO HABITAT AREAS AND RECREATIONAL USE: CABIN CREEK. M.S. THESIS, MONTANA STATE UNIVERSITY, BOZEMAN, MT. 76 PP.

485. BLANCHARD, K. A. and M. C. MONROE. 1990. EFFECTIVE EDUCATIONAL STRATEGIES FOR REVERSING POPULATION DECLINES IN SEABIRDS. TRANS. N. AMER. WILDL. NAT. RESOUR. CONF. 55:108-117.

486. BLEICH, V. C., R. T. BOWYER, A. M. PAULI, M. C. NICHOLSON and R. W. ANTHES. 1994. MOUNTAIN SHEEP AND HELICOPTER SURVEYS: RAMIFICATIONS FOR THE CONSERVATION OF LARGE MAMMALS. BIOL CONSERV 70 (1):1-7

487. BLEICH, V. C., R. T. BOWYER, A. M. PAULI, R. L. VERNOY and R. W. ANTHES. 1990. RESPONSES OF MOUNTAIN SHEEP TO HELICOPTER SURVEYS. CALIF FISH GAME 76 (4):1997-204

488. BLEICH, V. C., J. D. WEHAUSEN and S. A. HOLL. 1990. DESERT-DWELLING MOUNTAIN SHEEP: CONSERVATION IMPLICATIONS OF A NATURALLY FRAGMENTED DISTRIBUTION. CONSERVATION BIOLOGY 4(4):383-390.

489. BLEM, C. R. and L. B. BLEM. 1991. CATION CONCENTRATIONS AND ACIDITY IN BREEDING PONDS OF THE SPOTTED SALAMANDER, AMBYSTOMA MACULATUM (SHAW) (AMPHIBIA: AMBYSTOMATIDAE), IN VIRGINIA. BRIMLEYANA $0(17): 67-76$.

490. BLIX, A. S. and J. W. LENTFER. 1992. NOISE AND VIBRATION LEVELS IN ARTIFICIAL POLAR BEAR DENS AS RELATED TO SELECTED PETROLEUM EXPLORATION AND DEVELOPMENT ACTIVITIES. ARCTIC 45:20-24.

491. BLIX, A. S. and J. W. LENTFER. 1992. TITLE UNKNOWN. ARCTIC 45 ((1):):20-4. ZOOLOGY; URSIDAE [URSUS MARITIMUS]; ANIMAL HABITATIONS; ANIMAL LIFE, HUMAN INTERFERENCE; ENVIRONMENTAL ISSUES; ENVIRONMENTAL DAMAGE DUE TO PHYSICAL FACTORS; NOISE; PETROLEUM, EXTRACTION; GEOLOGICAL DRILLING AND CORING; SEISMIC SURVEY METHODS; ROAD TRANSPORT, HAULAGE ; AIRCRAFT DISTURBANCE; ENVIRONMENTAL IMPACTS; INSTRUMENTS; MEASUREMENT; OIL WELL DRILLING; POLAR BEARS; SEISMIC EXPLORATION; SNOW; VEHICLES; VIBRATION; ICE CAVES; SEISMIC SURVEYS; SNOW COVER STABILITY; SNOW ACOUSTICS; ATTENUATION; ANIMALS; ECOLOGY/ZOOLOGY: MAMMALS IPETROLEUM, NATURAL GAS AND PIPELINES; SNOW; GLACIOLOGY; HYDROLOGY; ZOOLOGY; ECOLOGY AND ENVIRONMENTAL PROTECTION; SNOW; GLACIOLOGY; HYDROLOGY.

492. BLOCK, D. G. 1955. TROUT MIGRATION AND SPAWNING STUDIES ON THE NORTH FORK DRAINAGE OF THE FLATHEAD RIVER. M.S. THESIS, MONTANA STATE UNIVERSITY, MISSOULA, MT. 83 PP.

493. BLODGET, B. G. 1978. THE EFFECT OF OFF-ROAD VEHICLES ON LEAST TERNS AND OTHER SHOREBIRDS. THESIS, UNIVERSITY MASSACHUSETTS, AMHERST, MASSACHUSETTS. 79PP. 
494. BLOM, A., M. P. T. ALERS, A. T. C. FEISTNER, R. F. W. BARNES and K. L. BARNES. 1992. PRIMATES IN GABON: CURRENT STATUS AND DISTRIBUTION. ORYX $26(4): 223-34$.

495. BLOOM, P. H., M. D. MCCRARY and M. J. GIBSON. 1993. RED-SHOULDERED HAWK HOME-RANGE AND HABITAT USE IN SOUTHERN CALIFORNIA. J. WLDL. MANAGE. 57 (2):258-65.

496. BOAG, D. A. and V. LEWIN. 1980. EFFECTIVENESS OF THREE WATERFOWL DETERRENTS ON NATURAL AND POLLUTED PONDS. JOURNAL OF WILDLIFE MANAGEMENT 44:145-154.

497. BOARMAN, W. and M. SAZAKI. 1996. HIGHWAY MORTALITY IN DESERT TORTOISES AND SMALL VERTEBRATES: SUCCESS OF BARRIER FENCES AND CULVERTS. PAGES 169-173 IN G. EVINK, D. ZIEGLER, P. GARRETT, AND J. BERRY, EDITORS. HIGHWAYS AND MOVEMENT OF WILDLIFE: IMPROVING HABITAT CONNECTIONS AND WILDLIFE PASSAGEWAYS ACROSS HIGHWAY CORRIDORS. PROCEEDINGS OF THE FLORIDA DEPARTMENT OF TRANSPORTATION/FEDERAL HIGHWAY ADMINISTRATION TRANSPORTATION-RELATED WILLIFE MORTALITY SEMINAR,

498. BODIE, W. L. 1979. FACTORS AFFECTING PRONGHORN FAWN MORTALITYIN CENTRAL IDAHO. M.S. THESIS, UNIVERSITY OF MONTANA, MISSOULA, MT. 90 PP.

499. BOER, A. H. 1990. SPATIAL DISTRIBUTION OF MOOSE KILLS IN NEW BRUNSWICK. WILDLIFE SOCIETY BULLETIN 18:431-434.

500. BOER, A. H. 1990. SPATIAL DISTRIBUTION OF MOOSE KILLS IN NEW BRUSWICK. WLDL. SOC. BULL. 18:431-4

501. BOERTJE, R. D., W. C. GASAWAY, D. V. GRANGAARD and D. G. KELLEYHOUSE. 1988. PREDATION ON MOOSE AND CARIBOU BY RADIO-COLLARED GRIZZLY BEARS IN EAST CENTRAL ALASKA. CAN. J. ZOOL. 66: 2492-9

502. BOGGS, K. W. 1984. SUCCESSION IN RIPARIAN COMMUNITIES OF THE LOWER YELLOWSTONE RIVER, MONTANA. M.S. THESIS, MONTANA STATE UNIVERSITY, BOZEMAN, MT. 107 PP.

503. BOGUCKI, D. J., J. L. MALANCHUK and T. E. SCHENCK. 1975. IMPACT OF SHORT-TERM CAMPING ON GROUND-LEVEL VEGETATION. JOURNAL OF SOIL AND WATER CONSERVATION 30:231-232.

504. BOHNE, J. R. 1974. FOOD HABITS, SEASONAL DISTRIBUTION, AND HABITAT UTILIZATION OF ELK IN THE SOUTH FORK OF FISH CREEK, LOLO NATIONAL FOREST, MONTANA. M.S. THESIS, UNIVERSITY OF MONTANA, MISSOULA, MT. 187 PP.

505. BOILEAU, F., M. CRETE and J. HUOT. 1994. FOOD HABITS OF THE BLACK BEAR, URSUS AMERICANUS, AND HABITAT USE IN GASPESIE PARK, EASTERN QUEBEC. CANADIAN FIELD-NATURALIST108 (2):162-9.

506. BOINSKI, S. and L. SIROT. 1997. UNCERTAIN CONSERVATION STATUS OF SQUIRREL MONKEYS IN COSTA RICA, SAIMIRI OERSTEDI OERSTEDI AND SAIMIRI OERSTEDI CITRINELLUS. FOLIA PRIMATOLOGICA 68(3-5):181-193.

507. BOITANI, L. 1982. WOLF MANAGEMENT IN INTENSIVELY USED AREAS OF ITALY. P158-72. IN: HARRINGTON FH, PAQUET PC (EDS.). WOLVES OF THE WORLD: PERSPECTIVES OF BEHAVIOR, ECOLOGY, AND CONSERVATION. PARK RIDGE, NJ.: NOYLES PUBL..

508. BOKDAM, J. and M. F. WALLIS DE VRIES. 1992. FORAGE QUALITY AS A LIMITING FACTOR FOR CATTLE GRAZING IN ISOLATED DUTCH NATURE RESERVES. CONSERVATION BIOLOGY 6(3):399-408.

509. BOLES, B. 1975. BACKGROUND STUDY FOR FURBEARER MANAGEMENT IN THE MACKENZIE VALLEY N.W.T.

510. BOLES, B. K. 1973. PIPELINE-HIGHWAY FUR-BEARER STUDY FOR ENVIRONMENTAL-SOCIAL PROGRAM, NORTHERN PIPELINES PROGRESS REPORT II. ENVIRONMENTAL-SOCIAL PROGRAM, NORTHERN PIPELINES (CANADA), NORTHWEST TERRITORIES DIVISION OF GAME MANAGEMENT, N.W.T, YELLOWKNIFE, N.W.T..

511. BOLES, W. E., N. W. LONGMORE and M. C. THOMPSON. 1994. A RECENT SPECIMEN OF THE NIGHT PARROT GEOPSITTACUS OCCIDENTALIS. EMU 94 (1):37-40. 
512. BOLL, L. A. 1958. ELK NUTRITION - THE RESPONSE OF ELK CALVES TO VARIOUS WINTER DIETS UNDER CONTROLLED CONDITIONS. M.S. THESIS, MONTANA STATE UNIVERSITY, MISSOULA, MT. 101 PP.

513. BOLLINGER, J. 1974. EFFECT OF SNOWMOBILE NOISE ON DEER AND RABBITS IN THEIR NATURAL HABITAT. PAGES 80-85 IN D. F. HOLECECK, EDITOR. PROC. OF THE 1973 SNOWMOBILE AND OFF THE ROAD VEHICLE RESEARCH SYMPOSIUM. MICHIGAN STATE UNIVERSITY, DEPARTMENT OF PARK RECR. RESOURCES, EAST LANSING, MICHIGAN.

514. BOLLINGER, J. 1974. EFFECTS OF SNOWMOBILE TRAFFIC ON NON-FOREST VEGETATION AND GRASSES. PAGES 82-85 IN D.F. HOLECECK, EDITOR. PROC. OF THE 1973 SNOWMOBILE AND OFF THE ROAD VEHICLE RESEARCH SYMPOSIUM. MICHIGAN STATE UNIVERSITY, DEPT. PARK RECR. RESOURCES, EAST LANSING, MICHIGAN.

515. BONANNO, S. E. 1992. VEGETATION OF A LAKE ONTARIO DUNE BARRIER, OSWEGO AND JEFFERSON COUNTIES, NEW YORK, UNDER HIGH AND LOW RECREATION PRESSURE. THESIS, STATE UNIVERSITY NEW YORK, SYRACUSE, NEWYORK. 88PP.

516. BONAR, R. L. 1987. COQUIHALLA PHASE 11: MERRITT-KAMLOOPS HIGHWAY EXTENSION WILDLIFE IMPACT STUDY. 2ND YEAR REPORT. UNPUBLISHED REPORT. ALCES WILDLIFE RESEARCH, KAMLOOPS, B.C..

517. BONDS, B. 1996. YELLOWSTONE TO CODY RECONSTRUCTION PROJECT. PAGES 108-115 IN EVINK, G., ZIEGLER,D., GARRETT,P., AND BERRY,J., EDITORS. TRANSPORTATION AND WLDLIFE: REDUCING WILDLIFE MORTALITY AND IMPROVING WLDLIFE PASSAGEWAYS ACROSS TRANSPORTATION CORRIDORS: PROCEEDINGS OF THE FLORIDA DEPARTMENT OF TRANSPORTATION/FEDERAL HIGHWAY ADMINISTRATION TRANSPORTATION-RELATED WILDLIFE MORTALITY SEMINAR; 1996 APRIL 30-MAY 2; ORLANDO, FL. FHWA-PD-96-041. U.S. DEPARTMENT OF TRANSPORTATION, FEDERAL HIGHWAY ADMINISTRATION, WASHINGTON, DC.

518. BONINO, N. and E. FERNANDEZ. 1994. GENERAL DISTRIBUTION AND RELATIVE ABUNDANCE OF GUANACOS (LAMA GUANICOE) IN DIFFERENT ENVIRONMENTS OF TIERRA DEL FUEGO, ARGENTINA. ECOLOGIA AUSTRAL 4 (2):79-85.

519. BOONE, R. B. and M. L. HUNTER. 1996. USING DIFFUSION MODELS TO SIMULATE THE EFFECTS OF LAND USE ON GRIZZLY BEAR DISPERSAL IN THE ROCKY MOUNTAINS. LANDSCAPE ECOLOGY $11: 51-64$.

520. BOOTH, C. J. and P. REYNOLDS. 1984. GREAT SKUAS SCAVENGING ON ORKNEY ROADS. BRITISH BIRDS 7(8):358.

521. BOOTH, J. A. 1990. RUN TIMING AND SPAWNING DISTRIBUTION OF COHO SALMON IN THE KENAI RIVER, ALASKA AND THEIR RELATIONSHIP TO HARVEST STRATEGIES. M.S. THESIS, MONTANA STATE UNIVERSITY, BOZEMAN, MT. 103 PP.

522. BORCHERT, H. F. 1969. FORMICIDAE OF THE BEARPAW MOUNTAINS OF MONTANA. PH.D. DISSERTATION, MONTANA STATE UNIVERSITY, BOZEMAN, MT. 61 PP.

523. BORKOWSKI, R. 1997. LEAD POISONING AND INTESTINAL PERFORATIONS IN A SNAPPING TURTLE (CHELYDRA SERPENTINA) DUE TO FISHING GEAR INGESTION. J. ZOO WILDL. MED. 28:109-113.

524. BORTON, W. L. 1984. AN ANALYSIS OF DEER CROSSING WARNING SIGNS. TSD-550-84. MICHIGAN DEPARTMENT OF TRANSPORTATION, TRAFFIC AND SAFETY DIVISION, LANSING, MI.

525. BOSAKOWSKI, T., D. G. SMITH and R. SPEISER. 1992. NEST SITES AND HABITAT SELECTED BY COOPER'S HAWKS, ACCIPITER COOPERII, IN NORTHERN NEW JERSEY AND SOUTHEASTERN NEW YORK. CANADIAN FIELD-NATURALIST. 106(4)

526. BOSAKOWSKI, T., D. G. SMITH and R. SPEISER. 1992. NICHE OVERLAP OF TWO SYMPATRIC-NESTING HAWKS ACCIPITER SPP. IN THE NEW JERSEY-NEW YORK HIGHLANDS. ECOGRAPHY 15 (4):358-72.

527. BOSAKOWSKI, T., R. SPEISER, D. G. SMITH and L. J. NILES. 1993. LOSS OF COOPER'S HAWK NESTING HABITAT TO SUBURBAN DEVELOPMENT: INADEQUATE PROTECTION FOR A STATE-ENDANGERED SPECIES. JOURNAL OF RAPTOR RESEARCH27 (1):26-30. 
528. BOSCAGLI G. 1987. BROWN BEAR MORTALITY IN CENTRAL ITALY FROM 1970 TO 1984. INT. CONF. BEAR RES. AND MANAGE. 7:97-8

529. BOTTINI, M. 1987. ELK ROADKILLS ON THE TRANS CANADA HIGHWAY. DEPARTMENT OF FORESTRY, UNIVERSITY OF B.C.

530. BOTTINI, M. 1987. ELK ROADKILLS ON THE TRANS-CANADA HIGHWAY IN BANFF NATIONAL PARK. UNPUBLISHED REPORT. BANFF NATIONAL PARK, BANFF, ALBERTA.

531. BOTTINI, M. 1987. INITIAL EFFECTS OF HIGHWAY FENCING AND WILDLIFE UNDERPASSES ON ELK MOVEMENT AND BEHAVIOR IN BANFF NATIONAL PARK. DEPARTMENT OF FORESTRY, UNIVERSITY OF B.C.

532. BOTTINI, M. 1976. INITIAL EFFECTS OF HIGHWAY FENCING AND WILDLIFE UNDERPASSES ON ELK MOVEMENT AND BEHAVIOR IN BANFF NATIONAL PARK. UNPUBLISHED REPORT. THE UNIVERSITY OF BRITISH COLUMBIA, VANCOUVER, BC.

533. BOTTINI, M., H. FLYGARE and WOODS J.G. 1986. TWENTY-FOUR HOUR RELOCATIONS AND OBSERVATION OF ELK IN PHASE I AND PHASE II. PARKS CANADA, CALGARY. UNPUBLISHED REPORT

534. BOULANGER, J. G. and G. C. WHITE. 1990. A COMPARISON OF HOME-RANGE. ESTIMATORS USING MONTE CARLO SIMULATION. J. WILDL. MANAGE. 54 (2):310-5.

535. BOURGERON, P. S. 1988. ADVANTAGES AND LIMITATIONS OF ECOLOGICAL CLASSIFICATION FOR THE PROTECTION OF ECOSYSTEMS. CONSERVATION BIOLOGY 2 (2):218-20.

536. BOURQUIN, J. D. and A. MEYLAN. 1982. SMALL MAMMALS COMMUNITIES ALONG DIVIDED HIGHWAYS: FAUNAS AND EXAMPLES OF SPATIAL DISTRIBUTION OF MICROTUS ARVALIS (PALLAS). REVUE SUISSE ZOOLOGY 89(4):977-991. IN FRENCH.

537. BOUSQUET, K. R. 1996. HABITAT PREFERENCES OF SHARP-TAILED GROUSE BROODS ON THE CHARLES M. RUSSELL NATIONAL WILDLIFE REFUGE. M.S. THESIS, MONTANA STATE UNIVERSITY, BOZEMAN, MT. 65 PP.

538. BOUSSU, M. F. 1953. RELATIONSHIP BETWEEN TROUT POPULATIONS AND COVER ON A SMALL STREAM. M.S. THESIS, MONTANA STATE COLLEGE, BOZEMAN, MT. 26 PP.

539. 'BOVENG, P. L. 1985. EFFECTS OF NUTRIENT ENRICHMENT ON GEORGETOWN LAKE PLANT COMMUNITIES. M.S. THESIS, MONTANA STATE UNIVERSITY, BOZEMAN, MT. 75 PP.

540. BOVENG, P. L. 1993. VARIABILITY IN A CRABEATER SEAL POPULATION AND THE MARINE ECOSYSTEM NEAR THE ANTARCTIC PENINSULA. PH.D. DISSERTATION, MONTANA STATE UNIVERSITY, BOZEMAN, MT. 110 PP.

541. BOW CORRIDOR ECOSYSTEM ADVISORY GROUP, ALBERTA and ALBERTA ENVIRONMENT. 1999. GUIDELINES FOR HUMAN USE WITHIN WILDLIFE CORRIDORS AND HABITAT PATCHES IN THE BOW VALLEY (BANFF NATIONAL PARK TO SEEBE). ALBERTA ENVIRONMENT, EDMONTON, ALBERTA.

542. BOWERMAN, W. W. I., T. G. GRUBB, A. J. BATH, J. P. J. GIESY, G. A. DAWSON and R. K. ENNIS. 1993. POPULATION COMPOSITION AND PERCHING HABITAT OF WINTERING BALD EAGLES, HALIAEETUS LEUCOCEPHALUS, IN NORTHCENTRAL MICHIGAN. CANADIAN FIELD-NATURALIST107 (3):273-8.

543. BOWERS, M. A., K. GREGARIO, C. J. BRAME, S. F. MATTER and J. L. JR. DOOLEY. 1996. USE OF SPACE AND HABITATS BY MEADOW VOLES AT THE HOME RANGE, PATCH AND LANDSCAPE SCALES. OECOLOGIA 105:107-15.

544. BOWERSOX, A. L. 1998. EFFECTS OF FINE SEDIMENT ACCUMULATION ON EGG-TO-FRY SURVIVAL OF CUTTHROAT TROUT INHABITING A HIGHLY SEDIMENTED HEADWATER STREAM. M.S. THESIS, MONTANA STATE UNIVERSITY, BOZEMAN, MT. 75 PP.

545. BOWLES, A. E. 1995. RESPONSES OF WILDLIFE TO NOISE. PAGES 109-156 IN KNIGHT,R.L. AND GUTZWILER,K.J., EDITORS. WILDLIFE AND RECREATIONISTS: COEXISTENCE THROUGH MANAGEMENT AND RESEARCH. ISLAND PRESS, COVELO, CA. 
546. BOWLES, A. E. 1995. RESPONSES OF WILDLIFE TO NOISE: CHAPTER 8. R. L. KNIGHT AND K. J. GUTZWILLER, EDITORS. WILDLIFE AND RECREATIONISTS: COEXISTENCE THROUGH MANAGEMENT AND RESEARCH. ISLAND PRESS, WASHINGTON, D.C.

547. BOWLES, J. M. 1981. EFFECTS OF HUMAN DISTURBANCE ON THE SAND DUNES AT PINERY PROVINCIAL PARK. DISSERTATION, UNIVERSITY WESTERN ONTARIO, LONDON.

548. BOWN, R. R. 1988. BEAVER HABITAT ALONG RIVERS AND RESERVOIRS IN CENTRAL MONTANA. M.S. THESIS, UNIVERSITY OF MONTANA, MISSOULA, MT. 116 PP.

549. BOXALL, P. C., D. O. WATSON and J. ENGLIN. 1996. BACKCOUNTRY RECREATIONISTS' VALUATION OF FOREST AND PARK MANAGEMENT FEATURES IN WILDERNESS PARKS OF THE WESTERN CANADIAN SHIELD. CAN. J. FOR. RES. 26:982-990.

550. BÓYCE, D. A. JR. 1988. FACTORS AFFECTING PRAIRIE FALCON FLEDGLING PRODUCTIVITY IN THE MOJAVE DESERT, CALIFORNIA. PAGES 237-248 IN R. L. GLINSKI, B. G. PENDELTON, M. B. MOSS, M. N. LEFRANC, JR., B. A. MILLSAP, S. W. HOFFMAN, C. E. RUIBAL, D. L. KRAHE, AND D. L. OWENS, EDITORS. PROCEEDINGS OF THE SOUTHWEST RAPTOR MANAGEMENT SYMPOSIUM AND WORKSHOP. INST. WLDL. RES., NATIONAL WILDLIFE FEDERATION, WASHINGTON, D.C.

551. BOYCE, M. S. THE JACKSON ELK HERD: INTENSIVE WLDLIFE MANAGEMENT IN NORTH AMERICA. CAMBRIDGE UNIVERSITY PRESS, CAMBRIDGE.

552. BOYCE, M. S. 1991. MIGRATORY BEHAVIOR AND MANAGEMENT OF ELK (CERVUS ELAPHUS). APPL. ANIM. BEHAV. SCI. 29:239-250.

553. BOYD, D. 1982. FOOD HABITS AND SPATIAL RELATIONS OF COYOTES AND A LONE WOLF IN THE ROCKY MOUNTAINS. M.S. THESIS, UNIVERSITY OF MONTANA, MISSOULA, MT. 115 PP.

554. BOYD-HEGER, D. K. 1997. DISPERSAL, GENETIC RELATIONSHIPS, AND LANDSCAPE USE BY COLONIZING WOLVES IN THE CENTRAL ROCKY MOUNTAINS. PH.D. DISSERTATION, UNIVERSITY OF MONTÁNA, MISSOULA, MT. 184 PP.

555. BOYLE, S. A. and F. B. SAMSON. 1985. EFFECTS OF NONCONSUMPTIVE RECREATION ON WILDLIFE: A REVIEW. WILDLIFE SOCIETY BULLETIN 13(2):110-116.

556. BOYLE, S. A. and F. B. SAMSON. 1983. NONCONSUMPTIVE OUTDOOR RECREATION: AN ANNOTATED BIBLIOGRAPHY OF HUMAN-WILDLIFE INTERACTIONS. U.S. DEPARTMENT OF THE INTERIOR, FISH AND WILDLIFE SERVICE. WASHINGTON, D.C. SPEC. SCI. REP. - WILDL. NO. 252. 113PP.

557. BRAATEN, B. A. 1970. A COMPARATIVE STUDY OF ENZYMES AND OTHER CHARACTERISTICS OF VIBRID CHOLERAE GROWN IN DIVERSE MEDIA. PH.D. DISSERTATION, MONTANA STATE UNIVERSITY, BOZEMAN, MT. 54 PP.

558. BRACKNEY, A. W. and J. W. HUPP. 1993. AUTUMN DIET OF LESSER SNOW GEESE STAGING IN NORTHEASTERN ALASKA. J. WLDL. MANAGE. 57 (1):55-61.

559. BRADFORD, D. F., F. TABATABAI and D. M. GRABER. 1993. ISOLATION OF REMAINING POPULATIONS OF THE NATIVE FROG, RANA MUSCOSA, BY INTRODUCED FISHES IN SEQUOIA AND KINGS CANYON NATIONAL PARKS, CALIFORNIA. CONSERVATION BIOLOGY 7 (4):882-8.

560. BRADFORD, W. 1988. A PLAN TO REDUCE WLDLIFE MORTALITY ON TRANSPORTATION CORRIDORS IN JASPER NATIONAL PARK. PARKS CANADA, CALGARY. UNPUBLISHED REPORT

561. BRADFORD, W. and I. PHILLIPS. 1986. UNGULATE MORTALITIES (HIGHWAY AND RAILROAD) 1980-1986. BANFF NATIONAL PARK, PARKS CANADA, CALGARY.

562. BRADSHAW, B. S. 1969. SOME EFFECTS OF ACTH, STH, NORADRENALINE AND THYROID HORMONE ON YOUNG RATS STARVED AT TWO DIFFERENT TEMPERATURES. M.S. THESIS, MONTANA STATE UNIVERSITY, BOZEMAN, MT. 25 PP. 
563. BRADSHAW, C. J. A., S. BOUTIN and D. M. HEBERT. 1997. EFFECTS OF PETROLEUM EXPLORATION ON WOODLAND CARIBOU IN NORTHEASTERN ALBERTA. J. WILDL. MANAGE. 00(0):000-000 .

564. BRADSHAW, C. J. A. and D. M. HEBERT. 1996. WOODLAND CARIBOU POPULATION DECLINE IN ALBERTA: FACT OR FICTION? RANGIFER SPECIAL ISSUE NO.9:223-34.

565. BRADSHAW, C. J. A., D. M. HEBERT, A. B. RIPPIN and S. BOUTIN. 1995. WINTER PEATLAND HABITAT SELECTION BY WOODLAND CARIBOU IN NORTHEASTERN ALBERTA. CAN. J. ZOOL.73:1567-74.

566. BRAINERD, S. M. 1985. REPRODUCTIVE ECOLOGY OF THE BOBCAT AND LYNX IN WESTERN MONTANA. M.S. THESIS, UNIVERSITY OF MONTANA, MISSOULA, MT. 85 PP

567. BRAMBLE, W. C., R. H. YAHNER and W. R. BYRNES. 1994. NESTING OF BREEDING BIRDS ON AN ELECTRIC UTILITY LINE RIGHT-OF-WAY. JOURNAL OF ARBORICULTURE 20 (2):124-9.

568. BRAMBLETT, R. G. 1996. HABITATS AND MOVEMENTS OF PALLID AND SHOVELNOSE STUREON IN THE YELLOWSTONE AND MISSOURI RIVERS, MONTANA AND NORTH DAKOTA. PH.D. DISSERTATION, MONTANA STATE UNIVERSITY, BOZEMAN, MT. 210 PP.

569. BRAMMER, J. A. 1991. THE EFFETS OF SUPERSATURATION OF DISSOLVED GASSES ON AQUATIC INVERTEBRATES OF THE BIGHORN RIVER DOWNSTREAM OF YELLOWTAIL AFTERBAY DAM. M.S. THESIS, MONTANA STATE UNIVERSITY, BOZEMAN, MT. 136 PP.

570. BRAND, C. J., L. B. KEITH and C. A. FISCHER. 1976. LYNX RESPONSES TO CHANGING SNOWSHOE HARE DENSITIES IN CENTRAL ALBERTA. J. WILDL. MANAGE. 40 (3):416-28.

571. BRANDBORG, S. M. 1955. LIFE HISTORY AND MANAGEMENT OF THE MOUNTAIN GOAT IN IDAHO. WILDL. BULL. 2. IDAHO DEPT. OF FISH \& GAME., 142 PP.

572. BRANDENBURG, D. M. 1996. EFFECTS OF ROADS ON BEHAVIOR AND SURVIVAL OF BLACK BEARS IN COASTAL NORTH CAROLINA. M.S. THESIS, UNIVERSITY OF TENNESSEE, KNOXVILLE.

573. BRANDENBURG, D. M. 1996. EFFECTS OF ROADS ON BEHAVIOR OF BLACK BEARS IN COASTAL NORTH CAROLINA. M.S. THESIS, U. TENNESSEE, KNOXVILLE, TENN. 131PP.

574. BRANDENBURG, D. M., C. LOMBARDO and M. R. PELTON. 1995. REDUCING FALL MOVEMENTS ACROSS HIGH-SPEED HIGHWAYS IN A FRAGMENTED BLACK BEAR POPULATION(ABSTRACT). INT. CONF. BEAR RES. AND MANAGE. 10.

575. BRANDER, R. B. 1974. ECOLOGICAL IMPACTS OF OFF-ROAD RECREATION VEHICLES. PAGES 29-35 IN OUTDOOR RECREATION RESEARCH: APPLYING THE RESULTS. U.S. FOREST SERVICE. GENERAL TECHNICAL REPORT NC-9.

576. BRANNON, R. INFLUENCE OF ROADS AND DEVELOPMENT ON GRIZZLY BEARS IN YELLOWSTONE NATIONAL PARK. INTERAGENCY GRIZZLY BEAR STUDY TEAM REPORT.

577. BRANNON, R. D. 1984. INFLUENCE OF ROADS AND DEVELOPMENTS ON GRIZZLY BEARS IN YELLOWSTONE NATIONAL PARK. INTERAGENCY GRIZZLY BEAR STUDY, MONTANA STATE UNIVERSITY, BOZEMAN. 52PP.

578. BRATTON, J. K. 1981. EFFECTIVENESS OF THE CORPS' RESOURCE MANAGEMENT EFFORTS. TRANS. N. AMER. WILDL. NAT. RESOUR. CONF. 46:21-26.

579. BRATTON, S. P. 1985. EFFECTS OF DISTURBANCE BY VISITORS ON TWO WOODLAND ORCHID SPECIES IN GREAT SMOKY MOUNTAINS NATIONAL PARK, USA. BIOLOGICAL CONSERVATION 31:211-227.

580. BRATTON, S. P. 1994. LOGGING AND FRAGMENTATION OF BROADLEAVED DECIDUOUS FORESTS: ARE WE ASKING THE RIGHT ECOLOGICAL QUESTIONS? CONSERVATION BIOLOGY 8(1):295-7.

581. BRATTON, S. P., J. R. HAPEMAN and A. R. MAST. 1994. THE LOWER SUSQUEHANNA RIVER GORGE AND FLOODPLAIN (U.S.A.) AS A RIPARIAN REFUGIUM FOR VERNAL, FOREST-FLOOR HERBS. CONSERVATION BIOLOGY 8 
(4):1069-77.

582. BRATTSTROM, B. H. and M. C. BONDELLO. 1983. EFFECTS OF OFF-ROAD VEHICLE NOISE ON DESERT VERTEBRATES. PAGES 167-206 IN WEBB,R.H. AND WILSHIRE,H.G., EDITORS. ENVIRONMENTAL EFFECTS OF OFF-ROAD VEHICLES: IMPACT AND MANAGEMENT IN ARID REGIONS. SPRINGER-VERLAG, NEWYORK.

583. BRAUN, C. E. 1971. HABITAT REQUIREMENTS OF WHITE-TAILED PTARMIGAN. PROC. ANNUAL CONFERENCE WEST. ASSOC. STATE GAME AND FISH COMMS. 51:284-292.

584. BRAUN, C. E. and T. D. I. BECK. 1996. EFFECTS OF RESEARCH ON SAGE GROUSE MANAGEMENT. TRANS. N. AMER. WILDL. NAT. RESOUR. CONF. 61:429-436.

585. BRAUN, C. E. 1965. A SURVEY OF THE LAND VALUES DIRECTLY ATTRIBUTED TO WATERFOWL WITHIN THE CONTIGUOUS US. PH.D. DISSERTATION, UNIVERSITY OF MONTANA, MISSOULA, MT. 132 PP.

586. BRAUN, C. E., R. W. HOFFMAN and G. E. ROGERS. 1976. WINTERING AREAS AND WINTER ECOLOGY OF WHITE-TAILED PTARMIGAN IN COLORADO. O. B. COPE, EDITOR. SPECIAL REPORT NUMBER 38. COLORADO DIVISION OF WILDLIFE. STATE PUBLICATION CODE W-R-S-38-'76.

587. BRAUN, M. 1991. INFLUENCE OF THE ROADSIDE DESIGN ON THE BIOTOPE INTERLACING IN INTENSIVELY AGRICULTURALLY USED AREAS. THE EXAMPLE OF THE YELLOW-BUNTING AND THE CORN-BUNTING. FOREIGN TECHNOLOGY FACH INFORMATIONS ZENTRUM ENERGIE PHYSIK, [LOCATION OF PUBLISHER UNKNOWN].

588. BRAWLEY, K. C. 1977. DOMESTIC SHEEP MORTALITY DURING AND AFTER TESTS OF SEVERAL PREDATOR CONTROL METHODS. M.S. THESIS, UNIVERSITY OF MONTANA, MISSOULA, MT. 69 PP.

589. BRAZDA, A. R. 1952. ELK MIGRATION PATTERNS, AND SOME OF THE FACTORS AFFECTING MOVEMENTS IN THE GALLATIN RIVER DRAINAGE, MONTANA. M.S. THESIS, MONTANA STATE COLLEGE, BOZEMAN, MT. 42 PP.

590. BRCHAN, B. 1984. WLDLIFE VS. SAVERY COAL PROJECT. J. COLO.-WYO. ACAD. SCI. 16:44 (ABSTRACT ONLY).

591. BREHM, K. 1989. THE ACCEPTANCE OF 0.2-METER TUNNELS BY AMPHIBIANS DURING THEIR MIGRATION TO THE BREEDING SITE. PAGES 29-42 IN LANGTON,T.E.S., EDITOR. AMPHIBIANS AND ROADS. PROCEEDINGS OF THE TOAD TUNNEL CONFERENCE, 1989 JANUARY 7-8; RENDSBURG, FEDERAL REPUBLIC OF GERMANY ACO POLYMER PRODUCTS LTD, SHEFFORD, ENGLAND.

592. BREKKE, E. B. 1988. USING GIS TO DETERMINE THE EFFECTS OF CO2 DEVELOPMENT ON ELK CALVING IN SOUTH-CENTRAL COLORADO. U.S. DEPARTMENT OF THE INTERIOR, BUREAU OF LAND MANAGEMENT, BLM SCIENCE CENTER. DENVER, COLORADO. BLM TECHNICAL NOTE 381; BLM/YA/PT-88/002+6600. 36PP.

593. BRELSFORD, D. B. 1967. POTENTIAL FOR DEVELOPMENT OF WINTER TOURIST ATTRACTIONS IN PARK COUNTY, MONTANA. INDUSTRIAL DEVELOPMENT CENTER., 64 PP.

594. BREN, L. J. 1995. ASPECTS OF THE GEOMETRY OF RIPARIAN BUFFER STRIPS AND ITS SIGNIFICANCE TO FORESTRY OPERATIONS. FOREST ECOLOGY AND MANAGEMENT 75 (1-3):1-10.

595. BRENT, R. L., W. E. GORDON, W. R. BENNETT and D. A. BECKMAN. 1993. REPRODUCTIVE AND TERATOLOGIC EFFECTS OF ELECTROMAGNETIC FIELDS. REPROD TOXICOL 7 (6):535-80.

596. BRETT, F. L., T. R. TURNER, C. J. JOLLY and R. G. CAUBLE. 1982. TRAPPING BABOONS AND VERVET MONKEYS FROM WILD, FREE-RANGING POPULATIONS. J. WILDL. MANAGE. 46(1):164-74.

597. BREYEN, L. J. 1971. UNKNOWN TITLE. M.S. THESIS, UNIV. NEV. (LAS VEGAS). $96 P$.

598. BRIDGE, G. S. 1980. OFF-ROAD VEHICLES/ (ORV) IMPACT ON SOIL AND WATER CONSERVATION MEASURES INSTALLED BY THE SOIL CONSERVATION SERVICE (SCS) AND ITS COOPERATORS. PAGES 176-182 IN R. N. L. ANDREWS AND P. F. NOWAK, OFF-ROAD VEHICLE USE: A MANAGEMENT CHALLENGE. 
599. BRIGGS, M. A. 1994. PHYSICAL AND CHEMICAL FACTORS PROMOTING CYANOBACTERIAL ABUNDANCE IN A EUTROPHIC RESERVOIR. M.S. THESIS, MONTANA STATE UNIVERSITY, BOZEMAN, MT. 199 PP.

600. BRIGHT, P. W. 1993. HABITAT FRAGMENTATION - PROBLEMS AND PREDICTIONS FOR BRITISH MAMMALS. MAMMAL REVIEW 23:101-111.

601. BRINK, K. L. 1978. THE EFFECTS OF THE TRANS-ALASKA OIL PIPELINE ON BREEDING BIRD AND MICROTINE RODENT POPULATIONS AT FRANKLIN BLUFFS, AK. M.S. THESIS, UNIVERSITY OF MONTANA, MISSOULA, MT. 108 PP.

602. BRISTOW, K. D., J. A. WENNERLUND, R. E. SCHWEINBURG, R. J. OLDING and R. E. LEE. 1996. HABITAT USE AND MOVEMENTS OF DESERT BIGHORN SHEEP NEAR THE SILVER BELL MINE, ARIZONA: A FINAL REPORT. ARIZONA GAME AND FISH DEPT. 68PP.

603. BRITISH COLUMBIA, MINISTRY OF FISHERIES, M. S. PORTER, E. A. PARKINSON and J. S. ROSENFELD. 1998. MACROHABITAT USE AND PREDICTIVE MODELS OF FISH DISTRIBUTION IN THE BLACKWATER DRAINAGE. FISHERIES MANAGEMENT REPORT: FISHERIES MANAGEMENT REPORT (BRITISH COLUMBIA. MINISTRY OF FISHERIES) NO. 108.

604. BRITISH COLUMBIA, MINISTRY OF TRANSPORTATION AND HIGHWAYS and ENVIRONMENTAL SERVICES SECTION. WARS WILDLIFE ACCIDENT REPORTING SYSTEM ... ANNUAL REPORT.

605. BRITISH COLUMBIA HIGHWAY ENVIRONMENT BRANCH. 1995. WILDLIFE ACCIDENT REPORTING SYSTEM ANNUAL REPORT 1994. BRITISH COLUMBIA MIN. TRANSPORTATION AND HIGHWAYS.

606. BRITTEN, H. B., P. F. BRUSSARD and D. D. MURPHY. 1994. THE PENDING EXTINCTION OF THE UNCOMPAHGRE FRITILLARY BUTTERFLY. CONSERVATION BIOLOGY 8 (1):86-94.

607. BRITTEN, H. B. 1991. THE CONSERVATION BIOLOGY OF THE UNCOMPAHGRE FRITILLARY AND THE RELATED NORTHERN DINGY FRITILLARY. PH.D. DISSERTATION, MONTANA STATE UNIVERSITY, BOZEMAN, MT. 127 PP.

608. BRITTINGHAM, M. C. and S. A. TEMPLE. 1983. HAVE COWBIRDS CAUSED FOREST SONGBIRDS TO DECLINE?. BIOSCIENCE 33:31-35.

609. BRITTINGHAM, M. C. 1990. PROVIDING WETLANDS FOR WILDLIFE WHILE CONTROLLING STORMWATER. EXTENSION CIRCULAR / PENNSYLVANIA STATE UNIVERSITY. COOPERATIVE EXTENSION SERVICE ; 384: EXTENSION CIRCULAR (PENNSYLVANIA STATE UNIVERSITY. COOPERATIVE EXTENSION SERVICE : 1986) 384. PENNSYLVANIA STATE UNIVERSITY, COLLEGE OF AGRICULTURE, COOPERATIVE EXTENSION SERVICE, UNIVERSITY PARK, PENNSYLVANIA.

610. BRITTON, E. E. 1979. EVALUATION OF PUBLIC USE IMPACTS UPON NESTING SHOREBIRDS AND THE BEACH HABITAT ON CHINCOTEAGUE NATIONAL WILLIFE REFUGE. U.S. FISH AND WILDLIFE SERVICE. CHINCOTEAGUE, VIRGINIA. 37PP.

611. BROADBENT, S. 1974. SCAVENGERS ON WHEELS. SIERRA CLUB BULLETIN 59:9-11.

612. BROCKE, R. H., K. A. GUSTAFSON and L. B. FOX. 1992. RESTORATION OF LARGE PREDATORS: POTENTIAL AND PROBLEMS. P 303-15. IN: DECKER DJ, GOFF GR, SMITH CR, GROSS DW, EDS. CHALLENGES IN THE CONSERVATION OF BIOLOGICAL RESOURCES, A PRACTITIONER'S GUIDE. BOULDER, CO: WESTVIEW PRESS.

613. BROCKE, R. H., J. P. O'PEZIO and K. A. GUSTAFSON. 1988. A FOREST MANAGEMENT SCHEME MITIGATING IMPACT OF ROAD NETWORKS ON SENSITIVE WILDLIFE SPECIES. GEN-TECH-REP-NE-U-S-DEP-AGRIC-FOR-SERV-NORTHEAST-FOR-EXP-STN (140):13-7.

614. BROCKE, R. H., J. P. O'PEZIO and K. A. GUSTAFSON. 1990. A FOREST MANAGEMENT SCHEME MITIGATING IMPACT OF ROAD NETWORKS ON SENSITIVE WILDLIFE SPECIES . USDA FOREST SERVICE, NORTHEASTERN FOREST EXPERIMENT STATION . GENERAL TECHNICAL REPORT.

615. BROCKMANN, S. P. 1988. WINTER HABITAT SELECTION BY THE SEXES OF WHITE-TAILED DEER. M.S. THESIS, UNIVERSITY OF MONTANA, MISSOULA, MT. 102 PP. 
616. BRODHEAD, J. M. and P. J. GODFREY. 1977. OFF ROAD VEHICLE IMPACT IN CAPE COD NATIONAL SEASHORE: DISRUPTION AND RECOVERY OF DUNE VEGETATION. INT. J. BIOMETEOR. 21:299-306.

617. BRODY, A. J. 1984. HABITAT USE BY BLACK BEARS IN RELATION TO FOREST MANAGEMENT IN PISGAH NATIONAL FOREST, NORTH CAROLINA.. M.S. THESIS, UNIV. OF TENNESSEE, KNOXVILLE.123PP.

618. BRODY, A. J. and M. R. PELTON. 1989. EFFECTS OF ROADS ON BLACK BEAR MOVEMENTS IN WESTERN NORTH CAROLINA. WILL. SOC. BULL. 17:5-10.

619. BRODY, A. J. and J. N. STONE. 1987. TIMBER HARVEST AND BLACK BEAR POPULATION DYNAMICS IN A SOUTHERN APPALACHIAN FOREST. INT. CONF. BEAR RES. AND MANAGE.7:243-50

620. BROEKHUIZEN, S. and H. DERCKX. 1996. PASSAGES FOR BADGERS AND THEIR EFFICACY. ZEITSCHRIFT FUR JAGDWISSENSCHAFT 42(2):134-142. IN GERMAN..

621. BROEKHUIZEN, S. and H. DERCKX. 1996. PASSAGES FOR BADGERS AND THEIR EFFICACY [GERMAN]. ZEITSCHRIFT FUR JAGDWISSENSCHAFT $42: 134-142$.

622. BROMLEY, M. 1989. BEAR-PEOPLE CONFLICTS: PROC. SYMP. ON MANAGEMENT STRATEGIES; 1987 6-10 APR. 1989; YELLOWKNIFE, N.W.T. YELLOWKNIFE, N.W.T., N.W.T. DEPT. OF RENEWABLE RESOURCES.

623. BROMLEY, M. 1985. TITLE UNKNOWN. U.S. FOR. SERV. GEN. TECH. REP. INT-191.42PP.

624. BROMLEY, M. 1985. WILDLIFE MANAGEMENT IMPLICATIONS OF PETROLEUM EXPLORATION AND DEVELOPMENT IN WILDLAND ENVIRONMENTS. U.S. FOREST SERV., INTERMOUNTAIN RESEARCH STATION. OGDEN, UTAH. GENERAL TECHNICAL REPORT INT-191. I + 42PP.

625. BROMLEY, P. T. 1967. PREGNANCY, BIRTH, BEHAVIORAL DEVELOPMENT OF THE FAWN, AND TERRITORIALITY IN THE PRONGHORN (ANTILOCAPRA AMERICANA ORD) ON THE NATIONAL BISON RANGE, MOIESE, MONTANA. M.S. THESIS, UNIVERSITY OF MONTANA, MISSOULA, MT. 132 PP.

626. BROTHERS, T. S. and A. SPINGARN. 1992. FOREST FRAGMENTATION AND ALIEN PLANT INVASION OF CENTRAL INDIANA OLD-GROWTH FORESTS. CONSERVATION BIOLOGY 6 (1):91-100.

627. BROWDER, S. F. 1998. ASSEMBLAGES OF GRASSLAND BIRDS AS INDICATORS OF ENVIRONMENTAL CONDITION. M.S. THESIS, UNIVERSITY OF MONTANA, MISSOULA, MT. 82 PP.

628. BROWN, A. L. and J. A. LITVAITIS. 1995. HABITAT FEATURES ASSOCIATED WITH PREDATION OF NEW ENGLAND COTTONTAILS: WHAT SCALE IS APPROPRIATE? CANADIAN JOURNAL OF ZOOLOGY 73 (6):1005-11.

629. BROWN, C. T. and D. BINKLEY. 1994. EFFECT OF MANAGEMENT ON WATER QUALITY IN NORTH AMERICAN FORESTS. U.S. DEPARTMENT OF AGRICULTURE, FOREST SERVICE, ROCKY MOUNTAIN FOREST AND RANGE EXPERIMENT STATION, GEN. TECH. REP. GTR-RM-248. FT. COLLINS, CO.

630. BROWN, G. W. 1974. DISTRIBUTION AND POPULATION CHARACTERISTICS OF BIGHORN SHEEP NEAR THOMPSON FALLS IN NORTHWESTERN MONTANA. M.S. THESIS, UNIVERSITY OF MONTANA, MISSOULA, MT. 134 PP.

631. BROWN, H. A. 1975. TEMPERATURE AND DEVELOPMENT OF THE TAILED FROG, ASCAPHUS TRUEI. COMPARATIVE BIOCHEMISTRY AND PHYSIOLOGY 50A:397-405.

632. BROWN, L. and R. JONES. 1989. AN ANNOTATED BIBLIOGRAPHY ON THE INTERRELATIONSHIP OF ELK AND ROADS. BUREAU OF LAND MANAGEMENT, IDAHO STATE OFFICE. BOISE, IDAHO. IDAHO BLM TECHNICAL BULLETIN; TECH. BULL. 89-2 . 21PP.

633. BROWN, M. and J. J. DINSMORE. 1991. AREA-DEPENDENT CHANGES IN BIRD DENSITIES IN IOWA (USA) MARSHES. JOURNAL OF THE IOWA ACADEMY OF SCIENCE $98(3): 124-6$.

634. BROWN, P. E. and R. D. BERRY. 1991. BATS: HABITAT, IMPACTS AND MITIGATION. PAGES 26-30 IN PROCEEDINGS OF THE THORNE ECOLOGICAL INSTITUTE: ISSUES AND TECHNOLOGY IN THE MANAGMENT OF IMPACTED 
WILDLIFE. SNOWMASS, COLORADO.

635. BROWN, P. J. 1982. RECREATION OPPORTUNITY SPECTRUM WITH IMPLICATIONS FOR WILDLIFE-ORIENTED RECREATION. TRANS. N. AMER. WLDL. NAT. RESOUR. CONF. 47:705-711.

636. BROWN, R. J., M. N. BROWN and B. PESOTTO. 1986. BIRDS KILLED ON SOME SECONDARY ROADS IN WESTERN AUSTRALIA. CORELLA 0(4):118-122.

637. BROWN, R. L., W. T. SMITH and R. D. CAMERON. 1986. BIG GAME INVESTIGATIONS: DISTRIBUTION AND MOVEMENTS OF CARIBOU IN RELATION TO THE KUPARUK DEVELOPMENT AREA. AK W-021-2/JOB 3.30R. ALASKA DEPARTMENT OF FISH AND GAME, ANCHORAGE, AK.

638. BROWN, R. L., W. T. SMITH and R. D. CAMERON. 1986. BIG GAME INVESTIGATIONS: DISTRIBUTION AND MOVEMENTS OF CARIBOU IN RELATION TO THE KUPARUK DEVELOPMENT AREA. ALASKA DEPT. OF FISH AND GAME. AK W-021-2/JOB 3.30R.

639. BROWN, R. L. 1957. THE POPULATION ECOLOGY OF THE MAGPIE IN WESTERN MONTANA. M.S. THESIS, MONTANA STATE UNIVERSITY, MISSOULA, MT. 53 PP.

640. BROWN, T. L., D. J. DECKER and J. W. KELLEY. 1984. ACCESS TO PRIVATE LANDS FOR HUNTING IN NEW YORK: 1963-1980. WILDL. SOC. BULL. 12 (4):344-9.

641. BROWN, T. L. and G. A. HILL. 1973. THE NEW YORK SNOWMOBILER AND THE PRIVATE LANDOWNER. PAGES 33-39 IN PROCEEDINGS OF THE SNOWMOBILE AND OFF THE ROAD VEHICLE RESEARCH SYMPOSIUM.

642. BROWN, W. K. 1988. FALL CLASSIFICATION AND CAPTURE PROGRAM, GREATER JASPER ECOSYSTEM CARIBOU RESEARCH PROGRAM. PARKS CANADA, CALGARY: UNPUBLISHED REPORT.

643. BROWN, W. K. 1991. GREATER JASPER ECOSYSTEM CARIBOU RESEARCH PROJECT, PROGRESS REPORT, APRIL 1990 - JANUARY 1991. PARKS CANADA, CALGARY. UNPUBLISHED REPORT.

644. BROWN, W. K. 1989. GREATER JASPER ECOSYSTEM CARIBOU RESEARCH PROJECT, PROGRESS REPORT, MAY 1989 OCTOBER 1989. PARKS CANADA, CALGARY. UNPUBLISHED REPORT.

645. BROWN, W. K. 1990. GREATER JASPER ECOSYSTEM CARIBOU RESEARCH PROJECT, PROGRESS REPORT, NOVEMBER 1989 - MARCH 1990. PARKS CANADA, CALGARY. UNPUBLISHED REPORT.

646. BROWN, W. K. 1989. GREATER JASPER ECOSYSTEM CARIBOU RESEARCH PROJECT, PROGRESS REPORT, OCTOBER 1988 - APRIL 1989. PARKS CANADA, CALGARY. UNPUBLISHED REPORT.

647. BROWN, W. K. and I. ROSS. 1994. CARIBOU-VEHICLE COLLISIONS: A REVIEW OF METHODS TO REDUCE CARIBOU MORTALITY ON HIGHWAY 40, WEST-CENTRAL ALBERTA. TERRESTRIAL \& AQUATIC ENVIRONMENTAL MANAGERS LTD., CALGARY. 69PP.

648. BROWN, W. M. and R. C. DREWIEN. 1995. EVALUATION OF TWO POWER LINE MARKERS TO REDUCE CRANE AND WATERFOWL COLLISION MORTALITY. WLDL. SOC. BULL. 23 (2):217-27.

649. BROWN, W. M., R. C. DREWEN and E. G. BIZEAU. 1987. MORTALITY OF CRANES AND WATERFOWL FROM POWERLINE COLLISIONS IN THE SAN LUIS VALLEY, COLORADO. J. C. LEWIS AND J. W. ZIEWITZ, EDS. PROC. 1985 CRANE WORKSHOP. PLATTE RIVER WHOOPING CRANE MAINTENANCE TRUST AND U.S. FISH AND WILDLIFE SERVICE, GRAND ISLAND, NE :128-139.

650. BROWN, W. S. 1980. BLACK BEAR MOVEMENTS AND ACTIVITIES IN POCAHONTAS AND RANDOLPH COUNTIES, WEST VIRGINIA. THESIS, WEST VIRGINIA UNIVERSITY, MORGANTOWN, VIRGINIA. 91PP.

651. BROWNE, B. 1986. MONITORING PROGRAM MITIGATIVE MEASURES: TRANS-CANADA HIGHWAY TWINNING. PHASE IKM 0 - 11.4. THIRD PROGRESS REPORT. PARKS CANADA, BANFF NATIONAL PARK WARDEN SERVICE, BANFF, ALBERTA. 
652. BROWNE, B. 1984. WORK PLAN FOR WLDLIFE STUDY ALONG THE BOW VALLEY FROM SUNSHINE TURN-OFF TO CASTLE JUNCTION - TRANS-CANADA HIGHWAY TWINNING PHASE III. PARKS CANADA, BANFF NATIONAL PARK WARDEN SERVICE, BANFF, ALBERTA.

653. BROWNE, B., B. BERTCH and K. EVERTS. 1988. THE REQUIREMENT FOR WILDLIFE MITIGATION MEASURES FOR THE PROPOSED IMPROVEMENTS TO THE TRANS-CANADA HIGHWAY - SUNSHINE ROAD TO THE ICEFIELDS PARKWAY (KM 26 TO KM 75). UNPUBL.REPT. PARKS CANADA, BANFF NATIONAL PARK WARDEN SERVICE, BANFF, ALBERTA.

654. BROWNE, B. and J. WACKERLE. 1985. MONITORING PROGRAM - MITIGATIVE MEASURES. TRANS-CANADA HIGHWAY TWINNING. PHASE I - KM O - 11.4. SECOND PROGRESS REPORT. PARKS CANADA, BANFF NATIONAL PARK WARDEN SERVICE, BANFF, ALBERTA.

655. BROWNE, D. L. 1978. GENETIC VARIATION IN THE RAINBOW TROUT POPULATION IN THE FIREHOLE RIVER. M.S. THESIS, MONTANA STATE UNIVERSITY, BOZEMAN, MT. 44 PP.

656. BRUEGGEMAN, J. J. 1982. EARLY SPRING DISTRIBUTION OF BOWHEAD WHALES IN THE BERING SEA. J. WILDL. MANAGE. 46 (4):1036-44. BALAENA MYSTICETUS.

657. BRUNELLE, A. 1995. A 2.5 LITER 4WD COLLECTING NET FOR INSECTS AND PEDESTRIANS. ARGIA 7:21-22.

658. BRUNS, E. H. 1976. HIGHWAY KILLS OF DEER IN THE PINE LAKE AREA FROM APRIL,1974 TO AUGUST, 1976. ALBERTA FISH AND WILDLIFE DIVISION, EDMONTON. UNPUBLISHED REPORT

659. BRUNS, E. H. 1977. WINTER BEHAVIOR OF PRONGHORNS IN RELATION TO HABITAT. JOURNAL OF WILDLIFE MANAGEMENT 41:560-571.

660. BRUSNYK, L. M. and D. A. WESTWORTH. 1985. AN ASSESSMENT OF POST-CONSTRUCTION USE OF A PIPELINE CORRIDOR BY UNGULATES. PREPARED FOR NOVA, AN ALBERTA CORPORATION, ENVIRONMENTAL AFFAIRS, CALGARY

661. BRUSNYK, L. M. and D. A. WESTWORTH. 1986. UNGULATE MONITORING STUDIES IN THE COAL LAKE PROJECT AREA. PREPARED FOR ESSO RESOURCES CANADA, LTD.

662. BRUSNYK, L. M. and D. A. WESTWORTH. 1986. A WILDLIFE OVERVIEW OF THE SOARS LAKE PROJECT AREA. PREPARED FOR AMOCO CANADA PETROLEUM LTD.

663. BRUSNYK, L. M. and D. A. WESTWORTH. 1986. A WILDLIFE OVERVIEW OF THE WABASCA PROJECT AREA. PREPARED FOR AMOCO CANADA PETROLEUM LTD.

664. BRYAN, R. B. and M. C. JANSSON. 1973. PERCEPTION OF WILDLIFE HAZARD IN NATIONAL PARK USE. TRANS. N. AMER. WILDL. NAT. RESOUR. CONF. 38:281-294.

665. BRYANT, B. K. and I. WLLIAM. 1991. TITLE UNKNOWN. NATL. INST. URBAN WLDL. SYMP. SER. 2:53-8.

666. BUBENIK, A. B. 1982. PHYSIOLOGY. PAGES 125-179 IN J. W. THOMAS AND D. E. TOWEILL, EDITORS. ELK OF NORTH AMERICA. STACKPOLE BOOKS. HARRISBURG, PENNSYLVANIA. 698PP.

667. BUCHANAN, D. 1998. A CASE FOR SPACE. COLORADO OUTDOORS 47:21-24.

668. BUCHANAN, J. B. 1987. SEASONALITY IN THE OCCURRENCE OF LONG-TAILED WEASEL ROAD-KILLS. MURRELET 68(2):67-68.

669. BUCK, C. L. 1939. PATTERN CORRELATION OF MAMMALIAN TEETH AS A MEANS OF IDENTIFICATION. M.S. THESIS, MONTANA STATE COLLEGE, BOZEMAN, MT. 55 PP.

670. BUCK, D. H. 1956. EFFECTS OF TURBIDITY ON FISH AND FISHING. TRANS. N. AMER. WILDL. NAT. RESOUR. CONF. 21:249-261. 
671. BUCK, D. T. and R. DOBRICK. 1989. THE BEHAVIOUR OF MIGRATING ANURANS AT A TUNNEL AND FENCE SYSTEM. PAGES 137-143 IN LANGTON,T.E.S., EDITOR. AMPHIBIANS AND ROADS. PROCEEDINGS OF THE TOAD TUNNEL -CONFERENCE; 1989 JANUARY 7-8; RENDSBURG, FEDERAL REPUBLIC OF GERMANY ACO POLYMER PRODUCTS LTD., SHEFFORD, ENGLAND.

672. BUCKLEY, P. A. and F. G. BUCKLEY. 1978. GUIDELINES FOR PROTECTION AND MANAGEMENT OF COLONIALLY NESTING WATERBIRDS. U.S. NATIONAL PARK SERVICE, NORTH ATLANTIC REGIONAL OFFICE. BOSTON, MASSACHUSETTS. 52PP.

673. BUCSIS, R. A. 1974. ECOLOGICAL CHARACTERISTICS OF THE ARMSTSRONG MULE DEER WINTER RANGE, BRIDGER MOUNTAINS, MONTANA. M.S. THESIS, MONTANA STATE UNIVERSITY, BOZEMAN, MT. 104 PP.

674. BUDOWSKI, G. 1976. TOURISM AND ENVIRONMENTAL CONSERVATION: CONFLICT, COEXISTENCE, OR SYMBIOSIS? ENVIRON. CONSERV. 3:27-31.

675. BUEHLER, D. A. 1990. BALD EAGLE DISTRIBUTION, ABUNDANCE, ROOST USE AND RESPONSE TO HUMAN ACTIVITY ON THE NORTHERN CHESAPEAKE BAY, MARYLAND. DISSERTATION, VIRGINIA POLYTECH. INST. STATE UNIVERSITY, BLACKSBURG, VIRGINIA. 132PP.

676. BUEHLER, D. A., T. J. MERSMANN, J. D. FRASER and J. K. D. SEEGAR. 1991. NONBREEDING BALD EAGLE COMMUNAL AND SOLITARY ROOSTING BEHAVIOR AND ROOST HABITAT ON THE.NORTHERN CHESAPEAKE BAY. J. WILDL. MANAGE. 55 (2):273-81.

677. BUEHLER, D. A., T. J. MERSMANN, J. D. FRASER and J. K. D. SEEGAR. 1991. EFFECTS OF HUMAN ACTIVITY ON BALD EAGLE DISTRIBUTION ON THE NORTHERN CHESAPEAKE BAY. JOURNAL OF WILDLIFE MANAGEMENT $55: 282-290$.

678. BUGBEE, R. E. 1945. A NOTE ON THE MORTALITY OF SNAKES ON HIGHWAYS IN WESTERN KANSAS. TRANSACTIONS OF THE KANSAS ACADEMY OF SCIENCES 47:373-374.

679. BUHLMANN, K. A. 1995. HABITAT USE, TERRESTRIAL MOVEMENTS, AND CONSERVATION OF THE TURTLE, DEIROCHELYS RETICULARIA IN VIRGINIA. JOURNAL OF HERPETOLOGY 29(2):173-81.

680. BUICK, A. M. and D. C. PATON. 1989. IMPACT OF OFF-ROAD VEHICLES ON THE NESTING SUCCESS OF HOODED PLOVERS CHARADRIUS RUBRICOLLIS IN THE COORONG REGION OF SOUTH AUSTRALIA. EMU 89:159-172.

681. BULLAS, L. R. 1963. COUPLES MUTATIONS INVOLVING DIVERSE CHARACTERS IN SALMONELLA BLEGDAM. PH.D. DISSERTATION, MONTANA STATE COLLEGE, BOZEMAN, MT. 151 PP

682. BULLOCK, D. J., F. J. KERRIDGE, A. HANLON and R. W. ARNOLD. 1993. SHORT TERM RESPONSES OF DEER TO RECREATIONAL DISTURBANCES IN TWO DEER PARKS. JOURNAL OF ZOOLOGY (LONDON) 230:327-332.

683. BUNCH, T. D. and G. W. WORKMAN. 1993. SONIC BOOM/ANIMAL STRESS PROJECT REPORT ON ELK, ANTELOPE, AND ROCKY MOUNTAIN BIGHORN SHEEP. JOURNAL OF THE ACOUSTICAL SOCIETY OF AMERICA 4:2378.

684. BUNDE, D. E. 1965. FREE AMINO ACID CONTENT AND BIO-SYNTHESIS IN EGGS OF THE GRASSHOPPER A. ELLIOTTI DURING DEVELOPMENT. PH.D. DISSERTATION, MONTANA STATE UNIVERSITY, BOZEMAN, MT. 65 PP.

685. BUNNELL, F. L. 1995. FOREST-DWELLING VERTEBRATE FAUNAS AND NATURAL FIRE REGIMES IN BRITISH COLUMBIA: PATTERNS AND IMPLICATIONS FOR CONSERVATION. CONSERVATION BIOLOGY 9 (3):636-44.

686. BUNNELL, F. L. and D. E. N. TAIT. 1977. BEARS IN MODELS AND REALITY-IMPLICATIONS TO MANAGEMENT. INT. CONF. BEAR RES. AND MANAGE. 4:15-24

687. BUNYAN, R. 1989. MONITORING PROGRAM - MITIGATIVE MEASURES. TRANS-CANADA HIGHWAY TWINNING. PHASE II KM 11.4 - 27.0. FIRST PROGRESS REPORT. PARKS CANADA, BANFF NATIONAL PARK WARDEN SERVICE, BANFF, ALBERTA.

688. BUNYAN, R. 1990. MONITORING PROGRAM - WILDLIFE MITIGATION MEASURES: TRANS-CANADA HIGHWAY TWINNING. PHASE II - KM 11.4 - 27.0. FINAL REPORT. PARKS CANADA, BANFF NATIONAL PARK WARDEN SERVICE, BANFF, 
ALBERTA.

689. BURBANK, D. D. and M. SIGMAN. 1979. FISH, WILDLIFE, AND HABITAT RESOURCES AND THE POTENTIAL IMPACTS OF OIL TRANSPORTATION ALASKA HIGHWAY (DELTA JUNCTION TO CANADIAN BORDER). ALASKA. MARINE AND COASTAL HABITAT MANGEMENT, FAIRBANKS, ALASKA.

690. BURBRIDGE, W. R. and D. J. NEFF. 1976. COCONINO NATIONAL FOREST - ARIZONA GAME AND FISH DEPARTMENT COOPERATIVE ROADS - WILDLIFE STUDY. PAGES 45-57 IN PROC. ELK-LOGGING-ROADS SYMPOSIUM. ARIZ. GAME AND FISH DEPT., MOSCOW.

691. BURBRIDGE, W. R. and D. J. NEFF. 1976. TITLE UNKNOWN. P 44-57. IN: PROCEEDINGS OF THE ELK-LOGGING-ROADS SYMPOSIUM MOSCOW, IDAHO.

692. BURCH, C. W. 1984. ENVIRONMENTAL GUIDELINES FOR DIKE FIELDS. TECHNICAL REPORT: TECHNICAL REPORT (U.S. ARMY ENGINEER WATERWAYS EXPERIMENT STATION) E-844. VERSAR, INC AND U.S. ARMY ENGINEER WATERWAYS EXPERIMENT STATION, ENVIRONMENTAL \& WATER QUALITY OPERATIONAL STUDIES. AVAILABLE FROM NATIONAL TECHNICAL INFORMATION SERVICE, VICKSBURG, MISS, SPRINGFIELD, VA.

693. BURCHAM, M. 1990. WINTER HABITAT SELECTION BY ELK IN NORTHWESTERN MONTANA. M.S. THESIS, UNIVERSITY OF MONTANA, MISSOULA, MT. 46 PP.

694. BURCHAM, M. G., W. D. EDGE, L. J. LYON, C. L. MARCUM and K. T. WEBER. 1998. FINAL REPORT OF THE CHAMBERLAIN CREEK ELK STUDIES, 1977-1983 AND 1993-1996. SCHOOL OF FORESTRY, UNIVERSITY OF MONTANA. MISSOULA, MONTANA, USA. 260PP.

695. BURDICK, B. D. 1997. NATIVE AND NONNATIVE FISH USE OF TWO GRAVEL-PIT PONDS CONNECTED TO THE UPPER COLORADO RIVER AT 29-5/8 ROAD NEAR GRAND JUNCTION, COLORADO FINAL REPORT. RECOVERY PROGRAM FOR ENDANGERED FISH OF THE UPPER COLORADO RIVER BASIN. U.S. FISH AND WLDLIFE SERVICE, COLORADO RIVER FISHERY PROJECT, GRAND JUNCTION, COLORADO. MICROFORM: RECOVERY PROGRAM PROJECT NO. CAP-6-GP

696. BUREAU, M. J. 1992. MORTALITY AND SEASONAL DISTRIBUTION OF ELK IN AN AREA RECENTLY RECOLONIZED BY WOLVES. M.S. THESIS, UNIVERSITY OF MONTANA, MISSOULA, MT. 109 PP.

697. BURGER, C. and L. SWENSON. ENVIRONMENTAL SURVEILLANCE OF GRAVEL REMOVAL ON THE TRANS-ALASKA PIPELINE SYSTEM WITH RECOMMENDATIONS FOR FUTURE GRAVEL MINING.

698. BURGER, J. 1986. THE EFFECT OF HUMAN ACTIVITY ON SHOREBIRDS IN TWO COASTAL BAYS IN NORTHEASTERN UNITED STATES. ENVIRONMENTAL CONSERVATION 13:123-130.

699. BURGER, J. and M. GOCHFELD. 1992. VULNERABILITY AND MORTALITY OF YOUNG AUSTRALIAN MAGPIES ON ROADS. WILSON BULLETIN 04(2):365-367.

700. BURGER, J. and M. GOCHFELD. 1998. EFFECTS OF ECOTOURISTS ON BIRD BEHAVIOUR AT LOXAHATCHEE NATIONAL WILDLIFE REFUGE, FLORIDA. ENVIRONMENTAL CONSERVATION 25:13-21.

701. BURGER, L. D., L. W. JR. BURGER and J. FAABORG. 1994. EFFECTS OF PRAIRIE FRAGMENTATION ON PREDATION ON ARTIFICIAL NESTS. J. WILDL. MANAGE. 58 (2):249-54.

702. BURGESS, R. M. 1992. THE RELATIVE INFLUENCE OF OIL-DEVELOPMENT RELATED DISTURBANCE AND ENVIRONMENTAL FACTORS ON ACTIVITY BUDGETS OF BROOD-REARING SNOW GEESE AT HOWE ISLAND, ALASKA. [ABSTRACT]. PAGES 35 IN NORTH AMERICAN ARCTIC GOOSE CONFERENCE WORKSHOP NUMBER 7. BIOLOGICAL RESEARCH, FAIRBANKS, AK.

703. BURGIN, B. E. 1964. SECOND DEADLIEST DEERSLAYER - THE AUTOMOBILE. N.Y. STATE CONSERV. 19 (2):2-3.

704. BURKE, R. C. and J. A. SHERBURNE. 1982. MONITORING WILDLIFE POPULATIONS AND ACTIVITY ALONG I-95 IN NORTHERN MAINE BEFORE, DURING AND AFTER CONSTRUCTION. TRANSPORTATION RESEARCH RECORD 859:1-8. 
705. BURKETT, D. W. and B. C. THOMPSON. 1994. WILDLIFE ASSOCIATION WITH HUMAN-ALTERED WATER SOURCES IN SEMIARID VEGETATION COMMUNITIES. CONSERVATION BIOLOGY 8 (3):682-90.

706. BURKEY, T. V. 1993. EDGE EFFECTS IN SEED AND EGG PREDATION AT TWO NEOTROPICAL RAINFOREST SITES. BIOLOGICAL CONSERVATION 66:139-143.

707. BURKEY, T. V. 1989. EXTINCTION IN NATURE RESERVES: THE EFFECT OF FRAGMENTATION AND THE IMPORTANCE OF MIGRATION BETWEEN RESERVE FRAGMENTS. OIKOS: 55: ??-??.

708. BURKEY, T. V. 1995. EXTINCTION RATES IN ARCHIPELAGOES: IMPLICATIONS FOR POPULATIONS IN FRAGMENTED HABITATS. CONSERVATION BIOLOGY 9 (3):527-41.

709. BURKHALTER, D. E. 1975. EFFECTS OF PROLONGED EXPOSURE TO AMMONIA ON RAINBOW TROUT EGGS AND SAC FRY. M.S. THESIS, MONTANA STATE UNIVERSITY, BOZEMAN, MT. 67 PP.

710. BURKHALTER, D. E. 1979. THERMAL AND HYDRALIC CHARACTERISTICS OF A GEOTHERMALLY INFLUENCED TROUT STREAM : THE FIREHOLE RIVER OF YELLOWSTONE NATIONAL PARK. PH.D. DISSERTATION, MONTANA STATE UNIVERSITY, BOZEMAN, MT. 87 PP.

711. BURLEIGH, W. 1978. TITLE UNKNOWN. MONT. COOP. WILDLIFE RESEARCH UNIT UNPUBLISHED THESIS ABSTRACT. 3PP.

712. BURLEIGH, W. E. 1978. SEASONAL DISTRIBUTION AND HISTORICAL DECLINE OF THE ROCKY MOUNTAIN GOAT IN THE CABINET MOUNTAINS, MONTANA. M.S. THESIS, UNIVERSITY OF MONTANA, MISSOULA, MT. 110 PP.

713. BURLEY, J. B. 1995. INTERNATIONAL GREENWAYS: A RED RIVER VALLEY CASE STUDY. LANDSCAPE AND URBAN PLANNING 33 (1-3):195-210.

714. BURNETT, G. W. 1981. MOVEMENTS AND HABITAT UTILIZATION OF AMERICAN MARTEN IN GLACIER NATIONAL PARK WILDLIFE. M.S. THESIS, UNIVERSITY OF MONTANA, MISSOULA, MT. 130 PP.

715. BURNETT, S. E. 1992. EFFECTS OF A RAINFOREST ROAD ON MOVEMENTS OF SMALL MAMMALS: MECHANISMS AND IMPLICATIONS. WLDLIFE RESEARCH 19(1):95-104.

716. BURNS, D. C. 1973. PLECOPTERA OF THE WEST FORK OF THE WEST GALLATIN RIVER AND FACTORS INFLUENCING THEIR DISTRIBUTION. M.S. THESIS, MONTANA STATE UNIVERSITY, BOZEMAN, MT. 71 PP.

717. BURNS, J. E. 1986. MANAGING POLITICAL HABITAT FOR GRIZZLY BEAR RECOVERY. P 2-13. IN: EVANS GP, CONTRERAS KE. (EDS.) PROCEEDINGS OF THE GRIZZZLY BEAR HABITAT SYMPOSIUM. GEN. TECH. REP. INT-207. USDA FOREST SERVICE INTERMOUNTAIN RESEARCH STATION. OGDEN, UT. P

718. BURROUGHS, E. R. JR. 1964. FLOW METER FOR MEASURING GROUND WATER SEEPAGE FROM ROAD CUTS. USDA, INTERMOUNTAIN FOR_AND RANGE EXP. STA., OGDEN, UT.

719. BURROUGHS, E. R. JR. 1985. SURVEY OF SLOPE STABILITY PROBLEMS ON FOREST LANDS IN THE WEST. PAGES 5-16 IN USDA FOREST SERVICE, PROCEEDINGS OF A WORKSHOP ON SLOPE STABILITY: PROBLEMS AND SOLUTIONS IN FOREST MANAGEMENT.

720. BURROWS, R. C. 1992. THE EFFECTS OF ETHANOL EXPOSURE ON THE MORPHOLOGICAL DEVELOPMENT OF THE OCULOMOTOR NUCLEUS IN THE RAT. M.S. THESIS, MONTANA STATE UNIVERSITY, BOZEMAN, MT. 106 PP.

721. BURT, H. R. 1991. REINTRODUCTION OF GREATER PRAIRIE CHICKENS USING EGG SUBSTITUTION ON ARROWWOOD NATIONAL WILDLIFE REFUGE, NORTH DAKOTA. M.S. THESIS, MONTANA STATE UNIVERSITY, BOZEMAN, MT. 66 PP.

722. BURY, R. 1975. EFFECTS OF OFF-ROAD VEHICLES ON DESERT VERTEBRATES. BULLETIN OF THE ECOLOGICAL SOCIETY OF AMERICA 56:40.

723. BURY, R. B. 1978. DESERT TORTOISES AND OFF-ROAD VEHICLES: DO THEY MIX? IN M.C. TROTTER AND G. JACKSON JR., EDITORS. PROCEEDINGS OF THE 1978 SYMPOSIUM, THE DESERT TORTOISE COUNCIL. SAN DIEGO, 
CALIFORNIA. 126PP

724. BURY, R. B. 1980. WHAT WE KNOW AND DO NOT KNOW ABOUT OFF-ROAD VEHICLE IMPACTS ON WILDLIFE. PAGES 110-120 IN R. N. L. ANDREWS AND P. F. NOWAK, EDITORS. OFF-ROAD VEHICLE USE: A MANAGEMENT CHALLENGE. U.S. DEPARTMENT OF AGRICULTURE, OFFICE OF ENVIRONMENTAL QUALITY.

725. BURY, R. B. and P. S. CORN. 1995. HAVE DESERT TORTOISES UNDERGONE A LONG-TERM DECLINE IN ABUNDANCE? WILDL. SOC. BULL. $23(1): 41-7$.

726. BURY, R. B., R. A. LUCKENBACH and S. D. BUSACK. 1977. EFFECTS OF OFF-ROAD VEHICLES ON VERTEBRATES IN THE CALIFORNIA DESERT. WILDL. RES. REP. 8. U.S. FISH AND WILDLIFE SERVICE, WASHINGTON, DC.

727. BURY, R. B., R. A. LUCKENBACH and S. O. BUSACK. 1977. EFFECTS OF OFF-ROAD VEHICLES ON VERTEBRATES IN THE CALIFORNIA DESERT. PAGES 1-23 IN WILDLIFE RESEARCH REPORT 8. U.S. FISH AND WILDLIFE SERVICE. WASHINGTON, D.C.

728. BURY, R. B. and A. L. ROGER. 1983. VEHICULAR RECREATION IN ARID LAND DUNES: BIOTIC RESPONSES AND MANAGEMENT ALTERNATIVES. PAGES 207-221 IN WEBB,R.H. AND WILSHIRE,H.G., EDITORS. ENVIRONMENTAL EFFECTS OF OFF-ROAD VEHICLES: IMPACTS AND MANAGEMENT IN ARID REGIONS. SPRINGER-VERLAG, NEW YORK.

729. BURY, R. B., S. D. BUSACK and R. A. LUCKENBACH. 1977. EFFECTS OF OFF-ROAD VEHICLES ON VERTEBRATES IN THE CALIFORNIA DESERT. WILDLIFE RESEARCH REPORT (UNITED STATES. FISH AND WLDLIFE SERVICE) 8. UNITED STATES DEPT. OF THE INTERIOR, FISH AND WLDLIFE SERVICE, WASHINGTON, D.C.

730. BURY, R. B., R. A. LUCKENBACH and S. D. BUSACK. 1977. EFFECTS OF OFF-ROAD VEHICLES ON VERTEBRATES IN THE CALIFORNIA DESERT. WILDLIFE RESEARCH REPORT: WILDLIFE RESEARCH REPORT (U.S. FISH AND WLDLIFE SERVICE) 8. UNITED STATES DEPT. OF THE INTERIOR, FISH AND WILDLIFE SERVICE, WASHINGTON, D.C.

731. BURY, R. L. 1978. IMPACTS OF SNOWMOBILES ON WILDLIFE. TRANSACTIONS OF THE NORTH AMERICAN WILDLIFE NATURAL RESOURCE CONFERENCE 43:149-156.

732. BURY, R. L. 1976. OFF-ROAD RECREATION VEHICLES: RESEARCH RESULTS AND ADMINISTRATIVE REPORTS, AND TECHNICAL ARTICLES, 1970-1975. COUNCIL OF PLANNING LIBRARIANS, MONTICELLO, ILL., EXCH BIBLIO. 1067. $23 \mathrm{PP}$

733. BURY, R. L., S. F. MCCOOL and R. J. WENDLING. 1976. RESEARCH ON OFF-ROAD VEHICLES: A SUMMARY OF SELECTED REPORTS AND A COMPREHENSIVE BIBLIOGRAPHY. PAGES 234-272, IN: PROC. OF THE SOUTHERN STATES RECREATION RESEARCH APPLICATIONS WORKSHOP, 15-18 SEPTEMBER 1975, ASHEVILLE, NC. U.S. FOR, SERV. GEN. TECH. REP. SE-9

734. BURY, R. L. and ET AL. 1976. OFF-ROAD RECREATION VEHICLES--A RESEARCH SUMMARY, 1969-1975. TEXAS AGR. EXP. STATION, COLLEGE STA. MP-1277.

735. BURY, R. L. and L. D. GUSTKE. 1979. INTEREST GROUPS AND POLICY FORMULATION: THE CASE OF REGULATING OFF-ROAD VEHICLES. J. SOIL AND WATER CONS. 34:281-283.

736. BUSACK, S. D. and R. B. BURY. 1974. SOME EFFECTS OF OFF-ROAD VEHICLES AND SHEEP GRAZING ON LIZARD POPULATIONS IN THE MOJAVE DESERT. BIOLOGICAL CONSERVATION 6(3):179-183.

737. BUSH, B., R. COOPER-BROWNE and B. MARYAN. 1991. SOME SUGGESTIONS TO DECREASE REPTILE ROADKILLS IN RESERVES WITH EMPHASIS ON THE WESTERN AUSTRALIAN WHEATBELT . HERPETOFAUNA 21:23-25.

738. BUSKIRK, S. W. and L. F. RUGGIERO. 1994. AMERICAN MARTEN. P. 7-37. IN: RUGGIERO, L.F., AUBRY, K.B., BUSKIRK S.W., LYON, L.J., ZIELINSKI, W.J., (EDITORS). THE SCIENTIFIC BASIS FOR CONSERVING FOREST CARNIVORES: AMERICAN MARTEN, FISHER, LYNX, AND WOLVERINE IN THE WESTERN UNITED STATES. USDA FOREST SERVICE GENERAL TECHNICAL REPORT RM-254. USDA FOREST SERVICE

739. BUTCHER, D. 1972. SNOWMOBILES AND THE NATIONAL PARKS. AMERICAN FORESTS 78:28-31, 46-49. 
740. BUTCHER, G. A. 1981. STREAM CROSSING CHARACTERISTICS AND FISHERIES CONCERNS ALONG THE FOOTHILLS (NORTH B.C.) PIPELINE ROUTE. MINISTRY OF ENVIRONMENT, ASSESSMENT AND PLANNING DIVISION, -VICTORIA, B.C..

741. BUTLER, G. D. JR. and M. D. F. UDVARDY. 1966. BASKING BEHAVIOR OF THE HAWAIIAN MONK SEAL ON LAYSAN ISLAND. J. WILL. MANAGE. 30 (3):627-8.

742. BUTLER, M. A. 1996. THE VALIDITY OF USING ARTIFICIAL NESTS TO ASSESS NEST-PREDATION RATES IN PRAIRIE NESTING DUCKS. M.S. THESIS, MONTANA STATE UNIVERSITY, BOZEMAN, MT. 82 PP.

743. BUTLER, R. W. 1974. THE SOCIAL IMPLICATIONS OF TOURISM DEVELOPMENT. ANN. TOURISM RES. 2:107-111

744. BUTTS, T. W. 1980. DISTRIBUTION AND POPULATION CHARACTERISTICSOF THE UPPER ROCK CREEK BIGHORN SHEEP. M.S. THESIS, UNIVERSITY OF MONTANA, MISSOULA, MT. 120 PP

745. BYKOV AV and A. B. LYSIKOV. 1991. EFFECT OF MOLE ACTIVITY ON THE NATURE OF THE POLLUTION OF FOREST SOILS ADJACENT TO HIGHWAYS. POCHVOVEDENIE 0 (8):31-9.

746. BYORTH, P. A. 1990. AN EVALUATION OF YELLOWSTONE CUTTHROAT TROUT PRODUCTION IN THREE TRIBUTARIES OF THE YELLOWSTONE RIVER, MONTANA. M.S. THESIS, MONTANA STATE UNIVERSITY, BOZEMAN, MT. 57 PP.

747. BYRNE, S. 1973. THE EFFECT OF OFF-ROAD VEHICLE USE IN THE MOJAVE DESERT ON SMALL MAMMAL POPULATIONS. PAGES 64-77 (58-73?) IN K. H. BERRY, EDITOR. PRELIMINARY STUDIES ON THE EFFECTS OF OFF-ROAD VEHICLES ON THE NORTHWESTERN MOJAVE DESERT: A COLLECTION OF PAPERS. PRIVATELY PUBLISHED. RIDGECREST, CALIFORNIA.

748. CADA, J. D. 1968. POPULATIONS OF SMALL MAMMALS IN CENTRAL MONTANA WITH SPECIAL REFERENCE TO TENTATIVE SAGEBRUSH CONTROL SITES. M.S. THESIS, MONTANA STATE UNIVERSITY, BOZEMAN, MT. 52 PP.

749. CAIN, S. L. 1985. NESTING ACTIVITY TIME BUDGETS OF BALD EAGLES IN SOUTHEAST ALASKA. M.S. THESIS, UNIVERSITY OF MONTANA, MISSOULA, MT. 47 PP.

750. CAIRNS, A. L. and E. S. TELFER. 1980. HABITAT USE BY 4 SYMPATRIC UNGULATES IN BOREAL MIXEDWOOD FOREST. J. WILDL. MANAGE. $44(4): 849-57$.

751. CAIRNS, J., B. R. NIEDERLEHNER and D. R. ORVOS. 1992. ADVANCES IN MODERN ENVIRONMENTAL TOXICOLOGY. VOLUME 20: PREDICTING ECOSYSTEM RISK. PRINCETON, USA; PRINCETON SCIENTIFIC PUBLISHING CO. 347 PP.

752. CALE, P. 1990. THE VALUE OF ROAD RESERVES TO THE AVIFAUNA OF THE CENTRAL WHEATBELT OF WESTERN AUSTRALIA. PROCEEDING OF THE ECOLOGICAL SOCIETY OF AUSTRALIA 16:359-367.

753. CALEF, G. W., E. A. DEBOCK and G. M. LORTIE. 1976. THE REACTION OF BARREN-GROUND CARIBOU TO AIRCRAFT. ARCTIC 29:201-12

754. CALETRIO, G. J. 1992. PROVISIONAL REPORT OF THE MORTALITY OF VERTEBRATES ON THE ROADS OF VALENCIA, SEPTEMBER 1991. PAGES 222-230 IN LOPEZ,REDONDO, EDITOR. I JORNADAS PARA EL ESTUDIO Y PREVENCION DE LA MORTALIDAD DE VERTEBRADOS EN CARRETERAS, MADRID, 5 Y 6 DE OCTUBRE DE 1991. TOMO 2. [SESSIONS IN THE STUDY OF PREVENTION OF ROAD MORTALITIES OF VERTEBRATES, MADRID, 5 AND 6 OCTOBER, 1991. VOLUME 2.]. COORDINADORA DE ORGANIZACCIONES DE DEFENSA, AMBIENTAL, MADRID.

755. CALETRIO, J., J. M. FERNANDEZ, J. LOPEZ and F. ROVIRALTA. 1996. SPANISH NATIONAL INVENTORY ON ROAD MORTALITY OF VERTEBRATES. GLOBAL BIODIVERSITY 5:15-18.

756. CALIFORNIA DEPARTMENT OF PARKS AND RECREATION. 1990. OFF-HIGHWAY VEHICLE LITERATURE DATABASE. CALIFORNIA DEPARTMENT OF PARKS AND RECREATION, OFF-HIGHWAY MOTOR VEHICLE RECREATION DIVISION. 
757. CALIFORNIA RECREATIONAL TRAILS COMMITTEE. 1972. OFF-HIGHWAY VEHICLE STUDY. DEPARTMENT OF PARKS AND RECREATION. SACRAMENTO, CALIFORNIA. 5 VOLS.

758. CALIFORNIA STATE DEPARTMENT OF PARKS AND RECREATION. 1975. THE OFF-ROAD VEHICLE: A STUDY REPORT. STATE OF CALIFORNIA, DEPARTMENT OF PARKS AND RECREATION. SACRAMENTO, CALIFORNIA. 56PP.

759. CALLAS, R. L., D. B. KOCH and E. R. LOFT. 1993. PROCEEDINGS OF THE 1990 WESTERN STATES AND PROVINCES ELK WORKSHOP. CALIFORNIA DEPT. OF FISH AND GAME,

760. CALVO, R. N. and N. J. SILVY. 1996. KEY DEER MORTALITY, U.S. 1 IN THE FLORIDA KEYS. PAGES 287-296 IN EVINK, G., ZIEGLER,D., GARRETT,P., AND BERRY,J., EDITORS. TRANSPORTATION AND WILDLIFE: REDUCING WILDLIFE MORTALITY AND IMPROVING WILDLIFE PASSAGEWAYS ACROSS TRANSPORTATION CORRIDORS: PROCEEDINGS OF THE FLORIDA DEPARTMENT OF TRANSPORTATION/FEDERAL HIGHWAY ADMINISTRATION TRANSPORTATION-RELATED WILDLIFE MORTALITY SEMINAR; 1996 APRIL 30-MAY 2; ORLANDO, FL. FHWA-PD-96-041. U.S. DEPARTMENT OF TRANSPORTATION, FEDERAL HIGHWAY ADMINISTRATION, WASHINGTON, DC.

761. CAMARRA, J. J. 1986. CHANGES IN BROWN BEAR PREDATION ON LIVESTOCK IN THE WESTERN FRENCH PYRENEES FROM 1968 TO 1979. INT. CONF. BEAR RES. AND MANAGE.6:183-6..

762. CAMARRA, J. J. and J. M. PARDE. 1990. THE BROWN BEAR IN FRANCE--STATUS AND MANAGEMENT IN 1985. AQUILO,-SER.-ZOOL. 27:93-6

763. CAMBY, A. and C. MAIZERT. 1985. PERMEABILITE DES ROUTES ET AUTOROUTES VIS-A-VIS DES MAMMIFERES CARNIVORES: EXAMPLE DES ETUDES MENEES DANS LES LANDES DE GASCOGNE PAR RADIO-POURSUITE . PAGES 183-196 IN ROUTES ET FAUNE SAUVAGE. ACT. DU COLLOQUE. MIN. EQUIPE. LOGE. AMENAGE. TERR. TRANSP., STRASBOURG.

764. CAMERON, N. P. 1986. HYDROCARBON DEVELOPMENT, A YUKON PERSPECTIVE AN ANNOTATED BIBLIOGRAPHY OF SOURCES AVAILABLE IN THE YUKON ARCHIVES. 536PP.

765. CAMERON, R. D. 1992. DISTRIBUTION AND PRODUCTIVITY OF THE CENTRAL ARCTIC CARIBOU HERD IN RELATION TO PETROLEUM DEVELOPMENT: CASE HISTORY STUDIES WITH A NUTRITIONAL PERSPECTIVE. ALASKA DEPT. OF FISH AND GAME, DIVISION OF WILDLIFE CONSERVATION. PROJECT W-23-4, STUDY 3.35

766. CAMERON, R. D. 1993. DISTRIBUTION AND PRODUCTIVITY OF THE CENTRAL ARCTIC CARIBOU HERD IN RELATION TO PETROLEUM DEVELOPMENT: CASE HISTORY STUDIES WITH A NUTRITIONAL PERSPECTIVE. ALASKA DEPT. OF FISH AND GAME, DIVISION OF WILDLIFE CONSERVATION. PROJECT W-24-1, STUDY 3.35

767. CAMERON, R. D. 1983. ISSUE: CARIBOU AND PETROLEUM DEVELOPMENT IN ARCTIC ALASKA. ARCTIC 36:227-31.

768. CAMERON, R. D., E. A. LENART, D. J. REED, K. R. WHITTEN and W. T. SMITH. 1995. ABUNDANCE AND MOVEMENTS OF CARIBOU IN THE OILFIELD COMPLEX NEAR PRUDHOE BAY, ALASKA. RANGIFER 15(1):3-7.

769. CAMERON, R. D., D. J. REED, J. R. DAU and W. T. SMITH. 1992. REDISTRIBUTION OF CALVING CARIBOU IN RESPONSE TO OIL FIELD DEVELOPMENT ON THE ARCTIC SLOPE OF ALASKA. ARCTIC 45(4):338-342.

770. CAMERON, R. D. and W. T. SMITH. 1992. DISTRIBUTION AND PRODUCTIVITY OF THE CENTRAL ARCTIC CARIBOU HERD IN RELATION TO PETROLEUM DEVELOPMENT: CASE HISTORY STUDIES WITH A NUTRITIONAL PERSPECTIVE. ALASKA DEPT. OF FISH AND GAME, DIVISION OF WILDLIFE CONSERVATION. PROJECT W-23-5, STUDY 3.35

771. CAMERON, R. D. and W. T. SMITH. 1992. WLDLIFE RESEARCH AND MANAGEMENT. DISTRIBUTION AND PRODUCTIVITY OF THE CENTRAL ARCTIC CARIBOU HERD IN RELATION TO PETROLEUM DEVELOPMENT: CASE HISTORY STUDIES WITH A NUTRITIONAL PERSPECTIVE. AK W-023-5/STUDY 3.35. ALASKA DEPARTMENT OF FISH AND GAME, ANCHORAGE, AK.

772. CAMERON, R. D., W. T. SMITH and S. G. FANCY. 1990. DISTRIBUTION AND PRODUCTIVITY OF THE CENTRAL ARCTIC CARIBOU HERD IN RELATION TO PETROLEUM DEVELOPMENT. ALASKA DEPT. OF FISH AND GAME, DIVISION OF WILDLIFE CONSERVATION. PROJECTS W-23-2 \& W-23-3, STUDY 3.35

773. CAMERON, R. D., W. T. SMITH and S. G. FANCY. 1989. WILDLIFE RESEARCH AND MANAGEMENT. DISTRIBUTION AND PRODUCTIVITY OF THE CENTRAL ARCTIC CARIBOU HERD IN RELATION TO PETROLEUM DEVELOPMENT: 
774. CAMERON, R. D. and K. R. WHITTEN. 1982. ALASKA DEPT. OF FISH AND GAME: PROJECT PROGRESS REPORT 1. MOVEMENTS OF COLLARED CARIBOU IN RELATION TO PETROLEUM DEVELOPMENT OF ALASKA'S ARCTIC SLOPE 2. SURVEY-INVENTORY PROGRESS REPORT, CENTRAL ARCTIC HERD, 1980-81. ALASKA. FEDERAL AID IN WILDLIFE RESTORATION TECHNICAL REPORT. 25PP.

775. CAMERON, R. D. and K. R. WHITTEN. 1980. BIG GAME INVESTIGATIONS: EFFECTS OF THE TRANS-ALASKA PIPELINE ON CARIBOU MOVEMENTS. ALASKA DEPARTMENT OF FISH AND GAME, ANCHORAGE, AK.

776. CAMERON, R. D. and K. R. WHITTEN. 1980. INFLUENCE OF THE TRANS-ALASKA PIPELINE CORRIDOR ON THE LOCAL DISTRIBUTION OF CARIBOU. PAGES 475-484 IN ALASKA GAME MANAGEMENT INVESTIGATIONS NO. 2.

777. CAMERON, R. D. and K. R. WHITTEN. 1980. INFLUENCE OF THE TRANS-ALASKA PIPELINE CORRIDOR ON THE LOCAL DISTRIBUTION OF CARIBOU: ALASKA GAME MANAGEMENT AND INVESTIGATIONS. W-017-R. ALASKA DEPARTMENT OF FISH AND GAME, ANCHORAGE, AK.

778. CAMERON, R. D. and K. R. WHITTEN. 1978. JOINT STATE/FEDERAL FISH AND WILDLIFE ADVISORY TEAM: THIRD INTERIM REPORT ON THE EFFECTS OF THE TRANS-ALASKA PIPELINE ON CARIBOU MOVEMENTS. 22. 29PP.

779. CAMERON, R. D. and K. R. WHITTEN. 1977. UNPUBLISHED WLDLIFE REPORT. JOINT STATE/FED. FISH AND WILDLIFE ADVISORY TEAM. 10PP.

780. CAMERON, R. D., K. R. WHITTEN and W. T. SMITH. 1985. BIG GAME INVESTIGATIONS: EFFECTS OF THE TRANS-ALASKA PIPELINE ON THE DISTRIBUTION AND MOVEMENTS OF CARIBOU. ALASKA DEPARTMENT OF FISH AND GAME, ANCHORAGE, AK.

781. CAMERON, R. D., K. R. WHITTEN and W. T. SMITH. 1981. BIG GAME INVESTIGATIONS: RESPONSES OF CARIBOU TO PETROLEUM-RELATED DEVELOPMENT ON ALASKA'S ARCTIC SLOPE. ALASKA DEPARTMENT OF FISH AND GAME, ANCHORAGE, AK.

782. CAMERON, R. D., K. R. WHITTEN, W. T. SMITH and D. D. ROBY. 1979. CARIBOU DISTRIBUTION AND GROUP COMPOSITION ASSOCIATED WITH CONSTRUCTION OF THE TRANS ALASKA PIPELINE. CANADIAN FIELD NATURALIST 93 (2):155-62

783. CAMERON, R. D., K. R. WHITTEN, W. T. SMITH and D. D. ROBY. 1979. CARIBOU DISTRIBUTION AND GROUP COMPOSITION ASSOCIATED WITH CONSTRUCTION OF THE TRANS-ALASKAN PIPELINE. OTTAWA FIELD-NATURALISTS' CLUB. 93(2)

784. CAMP, M. and L. B. BEST. 1993. BIRD ABUNDANCE AND SPECIES RICHNESS IN ROADSIDES ADJACENT TO IOWA ROWCROP FIELDS. WILDLIFE SOCIETY BULLETIN 21(3):315-325.

785. CAMP, M. and L. B. BEST. 1994. NEST DENSITY AND NESTING SUCCESS OF BIRDS IN ROADSIDES ADJACENT TO ROWCROP FIELDS. AMERICAN MIDLAND NATURALIST 131(2):347-358.

786. CAMPANHA, R. A. D. C. and H. G. FOWLER. 1993. ROOSTING ASSEMBLAGES OF BATS IN ARENITIC CAVES IN REMNANT FRAGMENTS OF ATLANTIC FOREST IN SOUTHEASTERN BRAZIL. BIOTROPICA 25 (3):362-5.

787. CAMPBELL, B. and R. REMINGTON. 1981. INFLUENCE OF CONSTRUCTION ACTIVITIES ON WATER-USE PATTERNS OF DESERT BIGHORN SHEEP. WLDL. SOC. BULL. 9:63-65.

788. CAMPBELL, C. A. 1974. SURVIVAL OF REPTILES AND AMPHIBIANS IN URBAN ENVIRONMENTS. PAGES 61-66 IN SYMPOSIUM: WLDLIFE IN AN URBAN ENVIRONMENT. PLANNING AND RESOURCE DEVELOPMENT SERIES NO. 28. HOLDSWORTH NATURAL RESOURCES CENTER

789. CAMPBELL, C. S. and M. OGDEN. 1999. CONSTRUCTED WETLANDS IN THE SUSTAINABLE LANDSCAPE. WILEY, NEW YORK.

790. CAMPBELL, D. C. 1988. HAS THE WOLF BOUGHT A SHEEPSKIN COAT OR HAVE WATER RESOURCES AGENCIES BECOME LAMBS? TRANS. N. AMER. WILDL. NAT. RESOUR. CONF. 53:279-284. 
791. CAMPBELL, H. 1956. SNAKES FOUND DEAD ON THE ROADS OF NEW MEXICO . COPEIA 1956:124-125.

792. CAMPBELL, M. 1985. TRAFFIC IN TOADS. COUNTRYMAN 0(1):102-105.

793. CAMPBELL-MOHN, C. 1993. ENVIRONMENTAL LAW FROM RESOURCES TO RECOVERY. HORNBOOK SERIES. ENVIRONMENTAL LAW INSTITUTE. WEST PUB. CO, SAINT PAUL, MINNESOTA.

794. CAMPBELL, R. B. 1970. PRONGHORN, SHEEP AND CATTLE RANGE RELATIONSHIPS IN CARTER COUNTY, MONTANA. M.S. THESIS, MONTANA STATE UNIVERSITY, BOZEMAN, MT. 87 PP.

795. CAMPOS, Z. 1993. EFFECT OF HABITAT ON SURVIVAL OF EGGS AND SEX RATIO OF HATCHLINGS OF CAIMAN CROCODILUS YACARE IN THE PANTANAL, BRAZIL. JOURNAL OF HERPETOLOGY 27 (2):127-32.

796. CANADA, DEPT. OF FISHERIES AND OCEANS, G. A. MCKINNON and F. N. HNYTKA. 1988. EFFECT OF WINTER PIPELINE CONSTRUCTION ON THE FISHES AND FISH HABITAT OF HODGSON CREEK, NORTHWEST TERRITORIES.

797. CANADA, DEPT. OF FISHERIES AND OCEANS, S. C. SAMIS, M. D. NASSICHUK and B. J. REID. 1991. GUIDELINES FOR THE PROTECTION OF FISH AND FISH HABITAT DURING BRIDGE MAINTENANCE OPERATIONS IN BRITISH COLUMBIA.

798. CANADA, DEPT. OF FISHERIES AND OCEANS, SASKATCHEWAN and SASKATCHEWAN ENVIRONMENT AND RESOURCE MANAGEMENT. 1995. FISH HABITAT PROTECTION GUIDELINES. SASKATCHEWAN ENVIRONMENT AND RESOURCE MANAGEMENT, REGINA, SASKATCHEWAN.

799. CANADA and DEPT. OF INDIAN AFFAIRS AND NORTHERN DEVELOPMENT. 1982. INITIAL ENVIRONMENTAL EVALUATION FOR THE RECONSTRUCTION OF THE NORTH CANOL ROAD. DEPT. OF INDIAN AFFAIRS AND NORTHERN DEVELOPMENT, OTTAWA, ONTARIO.

800. CANADA, DEPT. OF PUBLIC WORKS, WESTERN REGION, PARKS CANADA, CANADIAN WILDLIFE SERVICE and LOMBARD NORTH GROUP LTD. 1975. ENVIRONMENTAL IMPACT STUDY OF TWINNING TRANSCANADA HIGHWAY THROUGH BANFF NATIONAL PARK. CALGARY, ALBERTA.

801. CANADA, ENVIRONMENTAL PROTECTION SERVICE, NORTHWEST REGION, BEAK CONSULTANTS, CANADA and DEPT. OF SUPPLY AND SERVICES. 1979. NORTHERN LINEAR FACILITIES IN CANADA A CATALOGUE OF ENVIRONMENTAL LITERATURE. ENVIRONMENT CANADA, ENVIRONMENTAL PROTECTION SERVICE, NORTHWEST REGION, OTTAWA, ONTARIO.

802. CANADA, FEDERAL ENVIRONMENTAL ASSESSMENT REVIEW OFFICE and FOOTHILLS PIPE LINES (SOUTH YUKON) LTD. 1981. DEVELOPMENT OF CONSTRUCTION SCHEDULES IN RELATION TO FISHERIES AND WILDLIFE ISSUES SUBMISSION 5-2 : ADDENDUM TO THE ENVIRONMENTAL IMPACT STATEMENT FOR THE YUKON SECTION OF THE ALASKA HIGHWAY GAS PIPELINE.

803. CANADA, FEDERAL ENVIRONMENTAL ASSESSMENT REVIEW OFFICE and FOOTHILLS PIPE LINES (SOUTH YUKON) LTD. 1981. EXPLOITATION OF FISH AND WLDLIFE SUBMISSION 5-4: ADDENDUM TO THE ENVIRONMENTAL IMPACT STATEMENT FOR THE YUKON SECTION OF THE ALASKA HIGHWAY GAS PIPELINE.

804. CANADA. DEPT. OF FISHERIES AND OCEANS, G. A. MCKINNON and F. N. HNYTKA. 1988. EFFECT OF WINTER PIPELINE CONSTRUCTION ON THE FISHES AND FISH HABITAT OF HODGSON CREEK, N.W.T. CANADIAN TECHNICAL REPORT OF FISHERIES AND AQUATIC SCIENCES. CANADA DEPT. OF FISHERIES AND OCEANS 1598.

805. CANADA. DEPT. OF FISHERIES AND OCEANS, S. C. SAMIS, M. D. NASSICHUK and B. J. REID. 1989. GUIDELINES FOR THE PROTECTION OF FISH AND FISH HABITAT DURING BRIDGE MAINTENANCE OPERATIONS IN BRITISH COLUMBIA. (1991). CANADIAN TECHNICAL REPORT OF FISHERIES AND AQUATIC SCIENCES. CANADA DEPT. OF FISHERIES AND OCEANS 1692

806. CANADA. DEPT. OF THE ENVIRONMENT. FISHERIES AND MARINE SERVICE. RESOURCE MANAGEMENT BRANCH. 1974. IMPACT ANALYSIS OF THE DEMPSTER HIGHWAY CULVERT ON THE PHYSICAL ENVIRONMENT AND FISH RESOURCES OF FROG CREEK. TECHNICAL REPORT SERIES NO. CEN T. CANADA DEPT. OF THE ENVIRONMENT FISHERIES AND MARINE SERVICE RESOURCE MANAGEMENT BRANCH 74-05.

807. CANADA. DEPT. OF THE ENVIRONMENT. FISHERIES AND MARINE SERVICE. RESOURCE MANAGEMENT BRANCH, R. L. DRYDEN and J. N. STEIN. 1975. GUIDELINES FOR THE PROTECTION OF THE FISH RESOURCES OF THE NORTHWEST TERRITORIES DURING HIGHWAY CONSTRUCTION AND OPERATION. TECHNICAL REPORT 
SERIES NO. CEN T. CANADA DEPT. OF THE ENVIRONMENT FISHERIES AND MARINE SERVICE RESOURCE MANAGEMENT BRANCH 75-01.

808. CANADIAN ARCTIC GAS STUDY LIMITED and ALASKAN ARCTIC GAS STUDY COMPANY. 1973. THE ARCTIC ENVIRONMENT A STUDY OF NORTHERN ECOSYSTEMS. ARCTIC GAS, TORONTO, ONTARIO.

809. CANADIAN HERITAGE PC. 1995. INITIAL ASSESSMENT OF PROPOSED IMPROVEMENTS TO THE TRANS CANADA HIGHWAY IN BANFF NATIONAL PARK: PHASE IIIA SUNSHINE INTERCHANGE TO CASTLE MOUNTAIN INTERCHANGE.

810. CANADIAN WILDLIFE FEDERATION. 1976. PIPELINE UPDATE NO. 1- APR. 26, 1976-. CANADIAN WILDLIFE FEDERATION, OTTOWA, ONTARIO.

811. CANADIAN WILDLIFE SERVICE and P. J. EWINS. 1994. ARTIFICIAL NEST STRUCTURE FOR OSPREYS: A CONSTRUCTION MANUAL.

812. CANADIAN WILDLIFE SERVICE, P. J. EWINS, ONTARIO and GREAT LAKES CLEANUP FUND. 1994. ARTIFICIAL NEST STRUCTURES FOR OSPREYS A CONSTRUCTION MANUAL.

813. CANELAS, L. D. 1989. FIRST ENVIRONMENTAL IMPACT ASSESSMENT OF A HIGHWAY IN PORTUGAL: REPERCUSSIONS OF EUROPEAN ECONOMIC COMMUNITY DIRECTIVE. ENVIRONMENTAL IMPACT ASSESSMENT REVIEW 9(4):391-397.

814. CANFIELD, J. E. 1984. ELK HABITAT USE AND THE IMPACT OF THE CONSTRUCTION AND ENERGIZATION OF A 50OKV POWERLINE ON THE NORTH BOULDER WINTER RANGE, MONTANA. THESIS, MONTANA STATE UNIVERSITY, BOZEMAN, MONTANA, USA. 130PP

815. CANFIELD, J. E. 1988. IMPACT MITIGATION AND MONITORING OF THE BPA 500 KV GARRISON-TAFT TRANSMISSION LINE: EFFECTS ON ELK SECURITY AND HUNTER OPPORTUNITY. MONTANA DEPT. OF FISH, WLDLIFE AND PARKS.

816. CANFIELD, J. E., L. J. LYON, J. M. HILLIS and M. J. THOMPSON. 1999. UNGULATES. PAGES 6.1-6.25 IN G. JOSLIN AND H. YOUMANS, COORDINATORS. THE EFFECTS OF RECREATION ON ROCKY MOUNTAIN WILDLIFE: A REVIEW FOR MONTANA. COMMITTEE ON EFFECTS OF RECREATION ON WILDLIFE. MONTANA CHAPTER OF THE WILDLIFE SOCIETY. 307PP.

817. CANFIELD, J. E., L. J. LYON and J. M. HILLIS. 1986. THE INFLUENCE OF VIEWING ANGLE ON ELK HIDING COVER IN YOUNG TIMBER STANDS. U.S.D.A. FOREST SERVICE, INTERMOUNTAIN RESEARCH STATION. OGDEN, UTAH. RESEARCH PAPER INT-371. 5PP.

818. CANFIELD, J. E. 1984. ELK HABITAT USE AND THE IMPACT OF THE CONSTRUCTION AND ENERGIZATION OF A 500-KV AC POWERLINE ON THE NORTH BOULDER WINTER RANGE, MONTANA. M.S. THESIS, MONTANA STATE UNIVERSITY, BOZEMAN, MT. 130 PP.

819. CANFIELD, P. J. 1991. A SURVEY OF KOALA ROAD KILLS IN NEW SOUTH WALES. JOURNAL OF WLDLIFE DISEASES 27:657-660.

820. CANTER, L. W., J. M. ROBERTSON and R. M. WESTCOTT. 1991. IDENTIFICATION AND EVALUATION OF BIOLOGICAL IMPACT MITIGATION MEASURES. JOURNAL OF ENVIRONMENTAL MANAGEMENT 33(1):35-50.

821. CANTERS, K. 1997. HABITAT FRAGMENTATION AND INFRASTRUCTURE-PROCEEDINGS OF THE INTERNATIONAL CONFERENCE ON HABITAT FRAGMENTATION, INFRASTRUCTURE AND THE ROLE OF ECOLOGICAL ENGINEERING. MINISTRY OF TRANSPORT, PUBLIC WORKS AND WATER MANAGEMENT, DELFT AND THE HAGUE, THE NETHERLANDS.

822. CAPP, J. C. 1967. COMPETITION AMONG BIGHORN SHEEP, ELK AND DEER IN ROCKY MOUNTAIN NATIONAL PARK, COLORADO. MS THESIS, COLORADO STATE UNIVERSITY. 132PP.

823. CARATTI, J. F. 1993. THE EFFECTS OF FREQUENCY-DEPENDENT CONSUMPTION ON COMPETITIVE ASSEMBLAGES. M.S. THESIS, UNIVERSITY OF MONTANA, MISSOULA, MT. 36 PP. 
824. CARBAUGH, B., J. P. VAUGHAN, E. D. BELLIS and H. B. GRAVES. 1975. DISTRIBUTION AND ACTIVITY OF WHITE-TAILED DEER ALONG AN INTERSTATE HIGHWAY. JOURNAL OF WILDLIFE MANAGEMENT 39(3):570-581.

825. CARBAUGH, B. T. 1970. ACTIVITY AND BEHAVIOR OF WHITE-TAILED DEER (ODOCOILEUS VIRGINIANUS) ALONG AN INTERSTATE HIGHWAY IN A FOREST REGION OF PENNSYLVANIA. PH.D. THESIS, PENNSYLVANIA STATE UNIVERSITY, UNIVERSITY PARK, PA.

826. CARBYN, L. N. 1974. WOLF POPULATION FLUCTUATIONS IN JASPER NATIONAL PARK, ALBERTA, CANADA. BIOLOGICAL CONSERVATION 6:94-101.

827. CARBYN, L. N. 1983. WOLF PREDATION OF ELK IN RIDING NATIONAL PARK, MANITOBA. JOURNAL OF WILDLIFE MANAGEMENT 47:977-988.

828. CARBYN, L. N. and D. PATRIQUIN. 1983. OBSERVATIONS OF HOME RANGE SIZES, MOVEMENTS, AND SOCIAL ORGANIZATION OF LYNX IN RIDING MOUNTAIN NATIONAL PARK, MANITOBA. CAN. FIELD NAT. 97 (3):262-7.

829. CARDINAL, P. J. 1980. HABITAT AND JUVENILE SALMONID POPULATIONS IN STREAMS IN LOGGED AND UNLOGGED AREAS OF SOUTHEAST ALASKA. M.S. THESIS, MONTANA STATE UNIVERSITY, BOZEMAN, MT. 115 PP.

830. CAREY, A. B., S. P. HORTON and B. L. BISWELL. 1992. NORTHERN SPOTTED OWLS: INFLUENCE OF PREY BASE AND LANDSCAPE CHARACTER. ECOLOGICAL MONOGRAPHS 62 (2):223-50.

831. CAREY, A. B. and K. C. PEELER. 1995. SPOTTED OWLS: RESOURCE AND SPACE USE ON MOSAIC LANDSCAPES. JOURNAL OF RAPTOR RESEARCH 29 (4):223-39.

832. CAREY, C. and C. J. BRYANT. 1995. POSSIBLE INTERRELATIONS AMONG ENVIRONMENTAL TOXICANTS, AMPHIBIAN DEVELOPMENT, AND DECLINE OF AMPHIBIAN POPULATIONS. ENVIRONMENTAL HEALTH PERSPECTIVES 103 :13-17.

833. CAREY, M. and P. WAGNER. 1996. SALMON PASSAGES AND OTHER WILDLIFE ACTIVITIES IN WASHINGTON STATE. PAGES 153-168 IN EVINK,G., ZIEGLER,D., GARRETT,P., AND BERRY,J., EDITORS. TRANSPORTATION AND WILDLIFE: REDUCING WILDLIFE MORTALITY AND IMPROVING WILDLIFE PASSAGEWAYS ACROSS TRANSPORTATION CORRIDORS: PROCEEDINGS OF THE FLORIDA DEPARTMENT OF TRANSPORTATION FEDERAL HIGHWAY ADMINISTRATION TRANSPORTATION-RELATED WILDLIFE MORTALITY SEMINAR; 1996 APRIL 30-MAY 2; ORLANDO, FL. FHWA-PD-96-041. U.S. DEPARTMENT OF TRANSPORTATION, FEDERAL HIGHWAY ADMINISTRATION, WASHINGTON, DC.

834. CAREY, M. 1998. PEREGRINE FALCONS AND THE WASHINGTON STATE DEPARTMENT OF TRANSPORTATION. PAGES 121-125 IN EVINK,G., ZIEGLER,D., GARRETT,P., AND BERRY,J., EDITORS. PROCEEDINGS OF THE INTERNATIONAL CONFERENCE ON WILLIFE ECOLOGY AND TRANSPORTATION; 1998 FEBRUARY 10-12; FT. MYERS, FL FLORIDA DEPARTMENT OF TRANSPORTATION, TALLAHASSEE, FL.

835. CARLON, J. 1996. RESPONSE OF BOOTED EAGLES TO HUMAN DISTURBANCE. BRIT. BIRDS 89:267-274.

836. CARLSEN, T. L. 1984. WATERFOWL NESTING ON ISLANDS IN TWO PONDS OF CANYON FERRY WLDLIFE MANAGEMENT AREA, MONTANA. M.S. THESIS, MONTANA STATE UNIVERSITY, BOZEMAN, MT. 91 PP.

837. CARLSON, A. and G. AULÉN. 1992. TERRITORIAL DYNAMICS IN AN ISOLATED WHITE-BACKED WOODPECKER (DENDROCOPOS LEUCOTOS) POPULATION. CONSERV. BIOL. 6(3):450-4.

838. CARLSON, J. E., J. D. MICHAEL and A. R. LAWRENCE. 1980. OFF-ROAD VEHICLE IMPACTS IN THE BIG CYPRESS NATIONAL PRESERVE. PROCEEDINGS OF THE SECOND CONFERENCE ON SCIENCE RESEARCH IN NATIONAL PARKS 9:347-386.

839. CAROTHERS, S. W. and S. W. AITCHISON. 1976. AN ECOLOGICAL SURVEY OF THE RIPARIAN ZONE OF THE COLORADO RIVER BETWEEN LEES FERRY AND THE GRAND WASH CLIFFS, ARIZONA. U.S. DEPARTMENT OF THE INTERIOR, NATIONAL PARK SERVICE. TECHNICAL REPORT NO.10. COLORADO RIVER RESEARCH PROGRAM. REPORT SERIES: GRAND CANYON NATIONAL PARK. 251PP.

840. CARPENTER, L. H., R. B. GILL, D. J. FREDDY and L. E. SANDERS. 1979. DISTRIBUTION AND MOVEMENTS OF MULE DEER IN MIDDLE PARK, COLORADO. COLORADO DIV. OF WILDLIFE. 
841. CARR, A. 1987. NEW PERSPECTIVES ON THE PELAGIC STAGE OF SEA TURTLE DEVELOPMENT. CONSERVATION BIOLOGY 1 (2):103-21.

842. CARR, M. H., P. D. ZWICK, T. HOCTOR, W. HARRELL, A. GOETHALS and M. BENEDICT. 1998. USING GIS FOR IDENTIFYING THE INTERFACE BETWEEN ECOLOGICAL GREENWAYS AND ROADWAY SYSTEMS AT THE STATE AND SUB-STATE SCALES. PAGES 68-77 IN EVINK, G., ZIEGLER,D., GARRETT,P., AND BERRY,J., EDITORS. PROCEEDINGS OF THE INTERNATIONAL CONFERENCE ON WILDLIFE ECOLOGY AND TRANSPORTATION; 1998 FEBRUARY 10-12; FT. MYERS, FL FLORIDA DEPARTMENT OF TRANSPORTATION, TALLAHASSEE, FL.

843. CARR, P. C. and M. R. PELTON. 1984. PROXIMITY OF ADULT FEMALE BLACK BEARS TO LIMITED ACCESS ROADS PROC. ANNU. CONF. SOUTHEAST. ASSOC. FISH WILDL. AGENCIES38:70-7.

844. CARRILES, H. 1990. BLACK BEARS IN THE NORTH FORK OF THE FLATHEAD VALLEY, MONTANA. M.S. THESIS, UNIVERSITY OF MONTANA, MISSOULA, MT. 164 PP.

845. CARROLL, J. P. and CRAWFORD R.D. 1991. ROADSIDE NESTING BY GRAY PARTRIDGE IN NORTH-CENTRAL NORTH DAKOTA. WLDL. SOC. BULL. 19 (3):286-91.

846. CARROLL, J. P., R. D. CRAWFORD and J. W. SCHULZ. 1995. GRAY PARTRIDGE WINTER HOME RANGE AND USE OF HABITAT IN NORTH DAKOTA. J. WILDL. MANAGE. 59 (1):98-103.

847. CARRUTHERS, D. R. and R. D. JAKIMCHUK. 1987. MIGRATORY MOVEMENTS OF THE NELCHINA CARIBOU HERD IN RELATION TO THE TRANS-ALASKA PIPELINE. WLDL. SOC. BULL. 15 (3):414-20.

848. CARSWELL, J. K., J. M. SYMONS and G. G. ROBECK. 1969. RESEARCH ON RECREATIONAL USE OF WATERSHEDS AND RESERVOIRS. JOURNAL OF THE AMERICAN WATER WORKS ASSOCIATION 61:297-304.

849. CARTER, A. R. 1994. RELATIVE IMPACT OF OFF-ROAD BICYCLE AND HIKER TRAFFIC ON SOILS: AN EXPERIMENTAL STUDY. UNIVERSITY OF BOULDER, COLORADO. RESEARCH PAPER. 116PP

850. CARTER, A. V. and C. G. TRAUTMAN. 1973. EFFECT OF PREDATOR CONTROL UPON PHEASANT NESTING SUCCESS 1966-1971 SOUTH DAKOTA. SO. DAKOTA DEPT. OF GAME, FISH AND PARKS.

851. CARTER, L. J. 1974. OFF-ROAD VEHICLES: A COMPROMISE PLAN FOR THE CALIFORNIA DESERT. SCIENCE 183:396-398.

852. CARTER, R. L. 1951. AN ENVIRONMENTAL ANALYSIS OF WINTER GAME RANGE IN WESTERN MONTANA. M.S. THESIS, MONTANA STATE UNIVERSITY, MISSOULA, MT. 103 PP.

853. CARTY, D. G. 1985. POTENTIAL IMPACTS OF ALTERING DISCHARGE PATTERN FROM HAUSER DAM, MISSOURI RIVER, ON YOUNG-OF-THE-YEAR BROWN TROUT AND RAINBOW TROUT. M.S. THESIS, MONTANA STATE UNIVERSITY, BOZEMAN, MT. 84 PP.

854. CARUFEL, L. H. 1961. OBSERVATIONS ON THE LIFE HISTORY AND TAXONOMY OF THE SAUGER (STIZOSTEDION CANADENSE SMITH) IN GARRISON RESERVOIR, NORTH DAKOTA. M.S. THESIS, MONTANA STATE COLLEGE, BOZEMAN, MT. 30 PP.

855. CARVER, G. 1989. AN EVALUATION OF LINEAR WILDLIFE OPENINGS. AL W-035-33/JOB A AND B/STUDY IV. ALABAMA GAME AND FISH DIVISION, MOBILE, AL.

856. CASAGANDRA, L. G. 1955. A STUDY OF BEAVER-WATERFOWL RELATIONS IN THE MOUNTAINOUS AREA OF BEAVERHEAD COUNTY, MONTANA. M.S. THESIS, MONTANA STATE COLLEGE, BOZEMAN, MT. 33 PP.

857. CASE, R. M. 1978. INTERSTATE HIGHWAY ROAD-KILLED ANIMALS: A DATA SOURCE FOR BIOLOGISTS. WILDLIFE SOCIETY BULLETIN 6(1):8-13.

858. CASE, R. M. and J. A. GLEIM. 1976. ROAD-KILLED ANIMALS ON INTERSTATE-80 IN NEBRASKA. PROCEEDINGS NEBRASKA ACADEMY OF SCIENCE 86:9-10. 
860. CASEY, D. 1990. NORTHWEST MONTANA WILDLIFE HABITAT ENHANCEMENT: HUNGARY HORSE ELK MITIGATION PROJECT. INTERIM REPORT.

861. CASEY, D. and P. R. MALTA. 1992. ELK MITIGATION. MONTANA DEPT. OF FISH, WILDLIFE, AND PARKS. PROJECT NO. $5125-2$

862. CASEY, D. and P. R. MALTA. 1991. NORTHWEST MONTANA WILDLIFE HABITAT ENHANCEMENT: HUNGRY HORSE ELK MITIGATION PROJECT. MONTANA DEPT. OF FISH, WLDLIFE, AND PARKS. PROJECT NO. 5125.2

863. CASHIN, G. E., J. R. DORNEY and C. J. RICHARDSON. 1992. WETLAND ALTERATION TRENDS ON THE NORTH CAROLINA COASTAL PLAIN. WETLANDS 12 (2):63-71.

864. CASSIRER, E. F., D. J. FREDDY and E. D. ABLES. 1992. ELK RESPONSES TO DISTURBANCE BY CROSS-COUNTRY SKIERS IN YELLOWSTONE NATIONAL PARK. WILDL. SOC. BULL. 20 (4):375-81.

865. CATCHPOLE, C. K. and J. F. PHILLIPS. 1992. TERRITORY QUALITY AND REPRODUCTIVE SUCCESS IN THE DARTFORD WARBLER SYLVIA UNDATA IN DORSET, ENGLAND. BIOLOGICAL CONSERVATION 61 (3):209-15.

866. CATCHPOLE, C. K. and TYDEMAN C. F. 1975. GRAVEL PITS AS NEW WETLAND HABITATS FOR THE CONSERVATION OF BREEDING BIRD COMMUNITIES. BIOL. CONSERV. 8:47-59.

867. CATLING, P. C. and R. J. BURT. 1995. STUDIES OF THE GROUND-DWELLING MAMMALS OF EUCALYPT FORESTS IN SOUTH-EASTERN NEW SOUTH WALES: THE EFFECT OF ENVIRONMENTAL VARIABLES ON DISTRIBUTION AND ABUNDANCE. WILDLIFE RESEARCH22 (6):669-85.

868. CATLING, P. C. and R. J. BURT. 1995. WHY ARE RED FOXES ABSENT FROM SOME EUCALYPT FORESTS IN EASTERN NEW SOUTH WALES? WILDLIFE RESEARCH 22 (5):535-46.

869. CATT, D. C., D. DUGAN, R. E. GREEN, R. MONCRIEFF, R. MOSS, N. PICOZZI, R. W. SUMMERS and G. A. TYLER. 1994. COLLISIONS AGAINST FENCES BY WOODLAND GROUSE IN SCOTLAND. FORESTRY (OXFORD) 67 (2):105-18.

870. CAUGHLEY, G. 1970. ERUPTION OF UNGULATE POPULATIONS, WITH EMPHASIS ON HIMALAYAN THAT IN NEW ZEALAND. ECOLOGY 51 (1):53-72.

871. CHABRECK, R. H., T. L. EDWARDS and G. LINSCOMBE. 1985. FACTORS AFFECTING THE DISTRIBUTION AND HARVEST OF RIVER OTTERS IN LOUISIANA. PROC. ANNU. CONF. SOUTHEAST. ASSOC. FISH AND WILDL. AGENCIES 39:520-527.

872. CHADWICK, D. H. 1973. MOUNTAIN GOAT ECOLOGY LOGGING RELATIONSHIPS IN THE BUNKER CREEK DRAINAGE OF WESTERN MONTANA. MONTANA FISH AND GAME DEPT., MONTANA.

873. CHADWICK, D. H. 1974. MOUNTAIN GOAT ECOLOGY--LOGGING RELATIONSHIPS IN THE BUNKER CREEK DRAINAGE OF WESTERN MONTANA. M.S. THESIS, UNIVERSITY OF MONTANA, MISSOULA, MT. 262 PP.

874. CHADWICK, J. W. 1974. THE EFFECTS OF IRON ON THE MACROINVERTEBRATES OF SODA BUTTE CREEK, MONTANA. M.S. THESIS, MONTANA STATE UNIVERSITY, BOZEMAN, MT. 40 PP.

875. CHAN, J. 1993. EVALUATION OF METHODS TO REDUCE ROAD MORTALITY OF RED-SIDED GARTER SNAKES AT NARCISSE WILDLIFE MANAGEMENT AREA. M.S. THESIS, UNIVERSITY OF MANITOBA, MANITOBA, CANADA.

876. CHAN-MCLEOD, A. C. A., R. G. WHITE and D. E. RUSSELL. 1995. BODY MASS AND COMPOSITION INDICES FOR FEMALE BARREN-GROUND CARIBOU. J. WILDL. MANAGE. 59(2):278-91.

877. CHANDLER, S. K., J. D. FRASER, D. A. BUEHLER and J. K. D. SEEGAR. 1995. PERCH TREES AND SHORELINE DEVELOPMENT AS PREDICTORS OF BALD EAGLE DISTRIBUTION ON CHESAPEAKE BAY. J. WILDL. MANAGE. 59 (2):325-32. 
878. CHANNING, C. H. 1958. HIGHWAY CASUALTIES OF BIRDS AND ANIMALS FOR ONE YEAR PERIOD. MURRELET 39:41-42.

879. CHAPMAN, N. G. and S. HARRIS. 1991. EVIDENCE THAT THE SEASONAL ANTLER CYCLE OF ADULT REEVES' MUNTJAC (MUNTIACUS REEVESI) IS NOT ASSOCIATED WITH REPRODUCTIVE QUIESCENCE. J REPROD FERTIL 92 (2):361-70.

880. CHAPMAN, R. C. 1977. THE EFFECTS OF HUMAN DISTURBANCE ON WOLVES. M.S. THESIS. UNIVERSITY OF ALASKA, FAIRBANKS, ALASKA.

881. CHARDON, J. P. and C. C. VOS. 1993. LOCATION OF TUNNELS FOR AMPHIBIANS IN THE NETHERLANDS. WAARNEMINGEN VAN AMFIBIEEN EN REPTIELEN IN NEDERLAND 1993:47-50.

882. CHARDON, P., C. VOS and H. DEVRIES. 1996. THE USE OF AMPHIBIAN TUNNELS UNDER ROADS. LEVENDE NATUUR 97:110-115.

883. CHASE, S. 1998. ROAD TO RECOVERY SALMON RESTORATION: THE REGIONAL APPROACH. PAGES 140-142 IN EVINK, G., ZIEGLER,D., GARRETT,P., AND BERRY,J., EDITORS. PROCEEDINGS OF THE INTERNATIONAL CONFERENCE ON WILDLIFE ECOLOGY AND TRANSPORTATION; 1998 FEBRUARY 10-12; FT. MYERS, FL FLORIDA DEPARTMENT OF TRANSPORTATION, TALLAHASSEE, FL.

884. CHASKO, G. G. and J. E. GATES. 1982. AVIAN HABITAT SUITABILITY ALONG A TRANSMISSION-LINE CORRIDOR IN AN OAK-HICKORY FOREST REGION. WILDL. MONOGR. 82:1-41.

885. CHASKO, G. G. and J. E. GATES. 1982. AVIAN HABITAT SUITABILITY ALONG A TRANSMISSION-LINE CORRIDOR IN AN OAK-HICKORY FOREST REGION. WILDLIFE MONOGRAPHS NO. 82. WILDLIFE SOCIETY, WASHINGTON, D.C.

886. CHAVEZ, J. F. 1986. GENETIC ANALYSIS OF GROWTH AND ITS RELATIONSHIP WITH LIFETIME PRODUCTION IN RAMBOUILLET, TARGHEE AND COLUMBIA EWES UNDER RANGE CONDITIONS OF MONTANA . PH.D. DISSERTATION, MONTANA STATE UNIVERSITY, BOZEMAN, MT. 116 PP.

887. CHEATER, A. J. 1995. THE WILDLIFE HABITAT, RECREATION, NON RECREATION AND REGENERATION TO WOODLAND OF DISUSED RAILWAY LINES. UNIVERSITY COLLEGE OF NORTH WALES, SCHOOL OF AGRICULTURAL AND FOREST SCIENCES

888. CHEN, J. 1991. EDGE EFFECTS: MICROCLIMATIC PATTERN AND BIOLOGICAL RESPONSES IN OLD-GROWTH DOUGLAS-FIR FORESTS. PHD THESIS, UNIVERSITY OF WASHINGTON . 187 PP.

889. CHEN, J., J. F. FRANKLIN and T. A. SPIES. 1995. GROWING-SEASON MICROCLIMATIC GRADIENTS FROM CLEARCUT EDGES INTO OLD-GROWTH DOUGLAS-FIR FORESTS. ECOLOGICAL APPLICATIONS 5 (1):74-86.

890. CHEN, M. Y. 1980. WALLEYE SPAWNING AND ROAD CONSTRUCTION HIGHWAY CREEK, LA RONGE. FISHERIES TECHNICAL REPORT / FISHERIES AND WILDLIFE BRANCH: FISHERIES TECHNICAL REPORT (SASKATCHEWAN. FISHERIES BRANCH) 80-5. SASKATCHEWAN FISHERIES LABORATORY, DEPT. OF TOURISM AND RENEWABLE RESOURCES, SASKATOON, SASKATCHEWAN

891. CHEN, T. 1997. INTEGRATION OF WIDLIFE CONSERVATION WITH LOCAL COMMUNITY DEVELPOMENT -- SANMIN AND TAOYUAN DISTRICS IN TAIWAN AS A CASE STUDY. PH.D. DISSERTATION, UNIVERSITY OF MONTANA, MISSOULA, MT. 129 PP.

892. CHERVICK, T. M. 1991. BIG GAME ANIMAL CROSSING STUDY ALONG AN OVERLAND COAL CONVEYOR STRUCTURE IN NORTHWEST COLORADO. PROC. ISSUES TECHNOL. MANAGE. IMPACTED WILDL. (THORNE ECOL. INST.) NO. 5:112-119.

893. CHESTER, D. N., D. F. STAUFFER, T. J. SMITH, D. R. LUUKKONEN and J. D. FRASER. 1990. HABITAT USE BY NONBREEDING BALD EAGLES IN NORTH CAROLINA. J. WILDL. MANAGE.54 (2):223-34.

894. CHESTER, J. M. 1980. FACTORS INFLUENCING HUMAN-GRIZZLY BEAR INTERACTIONS IN A BACKCOUNTRY SETTING. INT. CONF. BEAR RES. AND MANAGE. 4:351-7. 
895. CHESTER, J. M. 1976. HUMAN WILDLIFE INTERACTIONS IN THE GALLATIN RANGE, YELLOWSTONE NATIONAL PARK. M.S. THESIS. MONTANA STATE UNIVERSITY, BOZEMAN, MONTANA. 114PP.

896. CHESTER, J. M. 1976. HUMAN WILDLIFE INTERACTIONS IN THE GALLATIN RANGE, YELLOWSTONE NATIONAL PARK, 1973-1974. M.S. THESIS, MONTANA STATE UNIVERSITY, BOZEMAN, MT. 114 PP.

897. CHILD, K. N. 1984. RAILWAYS AND MOOSE IN THE CENTRAL INTERIOR OF BRITISH COLUMBIA: A RECURRENT MANAGEMENT PROBLEM. ALCES 19:118-135.

898. CHILD, K. N. 1974. REACTION OF CARIBOU TO VARIOUS TYPES OF SIMULATED PIPELINES AT PRUDHOE BAY, ALASKA. P 805-12. IN: GEIST V, WALTHER F. (EDS.) THE BEHAVIOUR OF UNGULATES AND ITS RELATION TO MANAGEMENT. MORGES, SWITZERLAND: IUCN (INTERNATIONAL UNION FOR THE CONSERVATION OF NATURE) NEW SERIES PUBL. 24.

899. CHILD, K. N., S. P. BARRY and D. A. AITKEN. 1991. MOOSE MORTALITY ON HIGHWAYS AND RAILWAYS IN BRITISH COLUMBIA. ALCES 27:41-49.

900. CHILD, K. N. and K. M. STUART. 1987. VEHICLE AND TRAIN COLLISION FATALITIES OF MOOSE: SOME MANAGEMENT AND SOCIO-ECONOMIC CONSIDERATIONS. SWEDISH WILDLIFE RESEARCH SUPPLEMENT 1:-[PAGES UNKNOWN]..

901. CHILDRESS, D. A. 1971. CANADA GOOSE PRODUCTION AND WATER LEVEL RELATIONSHIPS ON THE MADISON RIVER, MONTANA. M.S. THESIS, MONTANA STATE UNIVERSITY, BOZEMAN, MT. 35 PP.

902. CHILMAN, K. C., J. J. VOGEL and J. L. CONLEY. 1991. TURKEY BAY OFF-ROAD VEHICLE AREA AT LAND BETWEEN THE LAKES: MONITORING USE AND IMPACTS SINCE 1973. MOTORCYCLE INDUSTRY COUNCIL; LAND BETWEEN THE LAKES ASSOCIATION; LAND BETWEEN THE LAKES, TENNESSEE VALLEY AUTHORITY; DEPT. OF FORESTRY, SOUTHERN ILLINOIS UNIVERSITY. 36PP.

903. CHOATE, J. R., D. W. MOORE and J. K. FREY. 1991. DISPERSAL OF THE MEADOW JUMPING MOUSE IN NORTHERN KANSAS (USA). PRAIRIE NATURALIST 23(3):127-30.

904. CHOATE, J. S. 1967. FACTORS INFLUENCING NESTING SUCCESS OF EIDERS IN PENOBSCOT BAY, MAINE. J. WLDL. MANAGE. 31 (4):769-77.

905. CHRISTENSEN, A. G. 1986. CUMULATIVE EFFECTS ANALYSIS: ORIGINS, ACCEPTANCE, AND VALUE TO GRIZZLY BEAR MANAGEMENT. P 213-6. IN: G.P.-EVANS,-K.E.-CONTRERAS.(EDS.) GRIZZLY BEAR HABITAT SYMPOSIUM; 1985 APR 30-1985 MAY 2; MISSOULA, MT(USA).

906. CHRISTENSEN, A. G., L. J. LYON and T. N. LONNER. 1991. PROCEEDINGS OF ELK VULNERABILITY - A SYMPOSIUM; 1991 APRIL 10-12; BOZEMAN, MT. MONTANA STATE UNIVERSITY, BOZEMAN, MT.

907. CHRISTENSEN, A. G., L. J. LYON and J. W. UNSWORTH. 1993. ELK MANAGEMENT IN THE NORTHERN REGION: CONSIDERATIONS IN FOREST PLAN UPDATES OR REVISIONS. U.S. DEPT. OF AGRICULTURE, FOREST SERVICE, INTERMOUNTAIN RESEARCH STATION. OGDEN, UTAH. GENERAL TECHNICAL REPORT INT 303. 10PP.

908. CHRISTOFFERS, E. W. I. 1986. ECOLOGY OF THE GHOST CRAB OCYPODE QUADRATA (FABRICIUS) ON ASSATEAGUE ISLAND, MARYLAND AND THE IMPACTS OF VARIOUS HUMAN USES OF THE BEACH ON THEIR DISTRIBUTION AND ABUNDANCE. DISSERTATION; MICHIGAN STATE UNIVERSITY, EAST LANSING, MICHIGAN. 224PP.

909. CHRISTOPHER, C. 1991. ROAD MORTALITIES OF NORTHERN FLORIDA (USA)VERTEBRATES. FLORIDA SCIENTIST 54 (2):65-8.

910. CHUBB, M. 1971. PROCEEDINGS OF THE 1971 SNOWMOBILE AND OFF THE ROAD VEHICLE RESEARCH SYMPOSIUM. RECREATION RESEARCH AND PLANNING UNIT, PARK AND RECREATION RESOUR., MICHIGAN STATE UNIVERSITY. EAST LANSING, MICHIGAN. TECH. REP. NO. 8. 196PP.

911. CHUBBS, T. E. 1993. OBSERVATION OF CALF-HIDING BEHAVIOR BY FEMALE WOODLAND CARIBOU, RANGIFER TARANDUS CARIBOU, IN EAST-CENTRAL NEWFOUNDLAND. CANADIAN FIELD-NATURALIST 107 (3):368-70. 
913. CIBIEN, C., E. BIDEAU, B. BOISAUBERT, H. BIRAN and J. M. ANGIBAULT. 1995. SEASONAL DIET AND HABITAT USE IN FIELD ROE DEER (CAPREOLUS CAPREOLUS) IN THE PICARDIE REGION. GIBIER FAUNE SAUVAGE 12 (1):37-49.

914. CIESLAK, M. 1994. THE VULNERABILITY OF BREEDING BIRDS OF FOREST FRAGMENTATION. ACTA ORNITHOLOGICA (WARSAW) 29 (1):29-38.

915. CIFUENTES, T. A. and O. B. GARCIA. 1992. AMPHIBIA MORTALITY ON THE ROADS OF PONTEVEDRA PROVINCE. PAGES 231-238 IN LOPEZ,REDONDO, EDITOR. I JORNADAS PARA EL ESTUDIO Y PREVENCION DE LA MORTALIDAD DE VERTEBRADOS EN CARRETERAS, MADRID, 5 Y 6 DE OCTUBRE DE 1991. TOMO 2. [SESSIONS IN THE STUDY OF PREVENTION OF ROAD MORTALITIES OF VERTEBRATES, MADRID, 5 AND 6 OCTOBER, 1991. VOLUME 2.]. COORDINADORA DE ORGANIZACCIONES DE DEFENSA, AMBIENTAL, MADRID.

916. CITTA, J. J. 1999. HOW TO CHANGE THE GROWTH OF WLDLIFE POPULATIONS: APPLICATIONS AND EXPERIMENTAL TESTS OF DEMOGRAPHIC SENSITIVITY ANALYSIS. M.S. THESIS, UNIVERSITY OF MONTANA, MISSOULA, MT. $90 \mathrm{PP}$.

917. CLAAR, J. J., N. ANDERSON, D. BOYD, B. CONARD, G. HICKMAN, R. HOMPESCH, G. OLSON, H. IHSLE PAC, T. WITTINGER and $H$. YOUMANS. 1999. CARNIVORES. PAGES 7.1-7.63 IN G. JOSLIN AND H. YOUMANS, COORDINATORS. THE EFFECTS OF RECREATION ON ROCKY MOUNTAIN WILDLIFE: A REVIEW FOR MONTANA. COMMITTEE ON EFFECTS OF RECREATION ON WILDLIFE. MONTANA CHAPTER OF THE WILDLIFE SOCIETY. 307PP.

918. CLAAR, J. J., R. W. KLAVER and C. W. SERVHEEN. 1986. GRIZZLY BEAR MANAGEMENT ON THE FLATHEAD INDIAN RESERVATION, MONTANA. INT. CONF. BEAR RES. AND MANAGE. 6:203-8.

919. CLAMPITT, C. A. 1993. EFFECTS OF HUMAN DISTURBANCES ON PRAIRIES AND THE REGIONAL ENDEMIC ASTER CURTUS IN WESTERN WASHINGTON. NORTHWEST SCIENCE 67:163-169.

920. CLANCEY, C. G. 1978. THE FISH AND AQUATIC INVERTEBRATES IN SARPY CREEK, MONTANA. M.S. THESIS, MONTANA STATE UNIVERSITY, BOZEMAN, MT. 54 PP.

921. CLANCEY, T. P. 1983. EFFECTS OF RENOVATION ON THE SACAJAWEA PARK LAGOON SYSTEM IN LIVINGSTON, MONTANA. M.S. THESIS, MONTANA STATE UNIVERSITY, BOZEMAN, MT. 54 PP.

922. CLAPERS, A. 1992. MORTALITIES AND LIVE CROSSINGS BY ANIMALS ON THE ROADS OF MOIANES (DECEMBER 1990 AUGUST 1991). PAGES 322-326 IN LOPEZ,REDONDO, EDITOR. I JORNADAS PARA EL ESTUDIO Y PREVENCION DE LA MORTALIDAD DE VERTEBRADOS EN CARRETERAS, MADRID, 5 Y 6 DE OCTUBRE DE 1991. TOMO 2. [SESSIONS IN THE STUDY OF PREVENTION OF ROAD MORTALITIES OF VERTEBRATES, MADRID, 5 AND 6 OCTOBER, 1991. VOLUME 2.]. COORDINADORA DE ORGANIZACCIONES DE DEFENSA, AMBIENTAL, MADRID.

923. CLARIDGE, A. W. and D. B. LINDENMAYER. 1994. THE NEED FOR A MORE SOPHISTICATED APPROACH TOWARD WILDLIFE CORRIDOR DESIGN IN THE MULTIPLE-USE FORESTS OF SOUTHEASTERN AUSTRALIA: THE CASE FOR MAMMALS. PACIFIC CONSERVATION BIOLOGY 1(4):301-7.

924. CLARK, D. R. 1979. LEAD CONCENTRATIONS: BATS VS. TERRESTRIAL SMALL MAMMALS COLLECTED NEAR A MAJOR HIGHWAY. ENVIRONMENTAL SCIENCE AND TECHNOLOGY 13:338-340.

925. CLARK, D. R. 1992. ORGANOCHLORINES AND HEAVY METALS IN 17-YEAR CICADAS POSE NO APPARENT DIETARY THREAT TO BIRDS. ENVIRONMENTAL MONITORING AND ASSESSMENT 20:47-54.

926. CLARK, J. D., J. E. DUNN and K. G. SMITH. 1993. A MULTIVARIATE MODEL OF FEMALE BLACK BEAR HABITAT USE FOR A GEOGRAPHIC INFORMATION SYSTEM. JOURNAL OF WILDLIFE MANAGEMENT 57:519-526.

927. CLARK, K. L., D. L. EULER and E. ARMSTRONG. 1984. PREDICTING AVIAN COMMUNITY RESPONSE TO LAKESHORE COTTAGE DEVELOPMENT. JOURNAL OF WILDLIFE MANAGEMENT 48:1239-1247.

928. CLARK, L. and P. S. SHAH. 1993. CHEMICAL BIRD REPELLENTS: POSSIBLE USE IN CYANIDE PONDS. JOURNAL OF WILDLIFE MANAGEMENT 57 (3):657-64. 
929.

CLARK, R. N. 1980. RESEARCH ROLES AND PRIORITIES FOR EFFECTIVE MANAGEMENT OF OFF-ROAD RECREATION VEHICLES. PAGES 245-258 IN R. N. L. ANDREWS AND P. F. NOWAK, EDITORS. OFF-ROAD VEHICLE USE: A MANAGEMENT CHALLENGE. U.S. DEPARTMENT OF AGRICULTURE, OFFICE OF ENVIRONMENTAL QUALITY.

930. CLARK, R. N., D. R. GIBBONS and G. B. PAULEY. 1985. INFLUENCE OF FOREST AND RANGELAND MANAGEMENT ON ANADROMOUS FISH HABITAT IN WESTERN NORTH AMERICA. 10. INFLUENCES OF RECREATION. W. R. MEEHAN, TECHNICAL EDITOR. U.S. DEPT. AGRICULTURE, FOREST SERVICE, PACIFIC NORTHWEST FOREST AND RANGE EXPERIMENT STATION. PORTLAND, OREGON. GEN. TECH. REP. PNW-178. 31PP.

931. CLARK, T. W., E. D. AMATO, D. G. WHITTEMORE and A. H. HARVEY. 1991. POLICY AND PROGRAMS FOR ECOSYSTEM MANAGEMENT IN THE GREATER YELLOWSTONE ECOSYSTEM: AN ANALYSIS. CONSERVATION BIOLOGY 5 (3):412-22.

932. CLARK, W. D. and J. R. KARR. 1979. EFFECTS OF HIGHWAYS ON RED-WINGED BLACKBIRD AND HORNED LARK POPULATIONS. WILSON SOCIETY BULLETIN 91:143-145.

933. CLARK, W. D. and J. R. KARR. 1979. EFFECTS OF HIGHWAYS ON RED-WINGED BLACKBIRD AND MEADOWLARK POPULATIONS. WILSON BULL. 91:143-5.

934. CLARKSON, P. 1994. MANAGING WATERSHEDS FOR HARLEQUIN DUCKS. IN: AMERICAN RIVER MANAGEMENT SOCIETY, RIVERS WITHOUT BOUNDARIES SYMPOSIUM; 18-22 APR 1994; GRAND JUNCTION, COLORADO..

935. CLARKSON, P. 1992. A PRELIMINARY INVESTIGATION INTO THE STATUS AND DISTRIBUTION OF HARLEQUIN DUCKS IN JASPER NATIONAL PARK. UNPUBLISHED TECHNICAL REPORT. NATURAL RESOURCE CONSERVATION, JASPER NATIONAL PARK, ALBERTA.27PP.

936. CLAWSON, M. R. 1996. AN INVESTIGATION OF FACTORS THAT MAY AFFECT NEST SUCCESS IN CRP LANS AND OTHER GRASSLAND HABITATS IN AN AGRICULTURAL LANDSCAPE. M.S. THESIS, MONTANA STATE UNIVERSITY, BOZEMAN, MT. 45 PP.

937. CLAY, C. H. 1961. DESIGN OF FISHWAYS AND OTHER FISH FACILTIES INCLUDING FISH LOCKS, FISH ELEVATORS, FENCES \& BARRIER DAMS, FISH SCREENS, ARTIFICIAL SPAWNING CHANNELS. DEPARTMENT OF FISHERIES OF CANADA, OTTAWA, ONTARIO.

938. CLAY, C. H. 1995. DESIGN OF FISHWAYS AND OTHER FISH FACILITIES. 2ND ED. LEWIS PUBLISHERS, BOCA RATON, FLORIDA.

939. CLAYTON, R. L. 1989. WLDLIFE FENCING AND CONTROL ON THE OKANOGAN CONNECTOR HIGHWAY: A BENEFIT COST ANALYSIS. MINISTRY OF TRANSPORTATION AND HIGHWAYS ENVIRONMENTAL SERVICES SECTION, HIGHWAY ENGINEERING BRANCH, VICTORIA, BC.

940. CLEAVENGER, A. P. 1998. PERMEABILITY OF THE TRANS-CANADA HIGHWAY TO WILDLIFE IN BANFF NATIONAL PARK: IMPORTANCE OF CROSSING STRUCTURES AND FACTORS INFLUENCING THEIR EFFECTIVENESS. PAGES 109-119 IN EVINK,G., ZIEGLER,D., GARRETT,P., AND BERRY,J., EDITORS. PROCEEDINGS OF THE INTERNATIONAL CONFERENCE ON WLDLIFE ECOLOGY AND TRANSPORTATION; 1998 FEBRUARY 10-12; FT. MYERS, FL FLORIDA DEPARTMENT OF TRANSPORTATION, TALLAHASSEE, FL.

941. CLERGEAU, P. 1993. USE OF LANDSCAPE ECOLOGY CONCEPTS FOR THE DEVELOPMENT OF A NEW TYPE OF WILDLIFE PASSAGE. GIBIER FAUNE SAUVAGE 10:47-57.

942. CLEVEGENER, A. P. 1996. A MONITORING PLAN FOR WILDLIFE CROSSING STRUCTURE USE ALONG THE TRANS-CANADA HIGHWAY. PARKS CANADA, BANFF NATIONAL PARK WARDEN SERVICE, BANFF, ALBERTA.

943. CLEVEGENER, A.P. and K. WELLS. 1997. PROCEEDINGS OF THE SECOND ROADS RAILS AND THE ENVIRONMENT WORKSHOP; 1997 APRIL 9-10; REVELSTOKE, B.C. PARKS CANADA, BANFF NATIONAL PARK, BANFF, ALBERTA.

944. CLEVENGER, A. P. 1996. HIGHWAY EFFECTS ON WILDLIFE: A RESEARCH, MONITORING AND ADAPTIVE MITIGATION STUDY. PROGRESS REPORT \#1. PARKS CANADA, BANFF NATIONAL PARK WARDEN SERVICE, BANFF, ALBERTA. 
945. CLEVENGER, A. P. 1993. SPRING AND SUMMER FOOD HABITS AND HABITAT USE OF THE EUROPEAN PINE MARTEN (MARTES MARTES) ON THE ISLAND OF MINORCA, SPAIN. JOURNAL OF ZOOLOGY (LONDON) 229 (1):153-61.

946. CLEVENGER, A. P. 1997. WLDLIFE UNDERPASS USE BY UNGULATES AND LARGE CARNIVORES ALONG TMNNED SECTIONS OF THE TRANS-CANADA HIGHWAY IN BANFF NATIONAL PARK, 1995-1997. ALBERTA ENVIRONMENTAL PROTECTION, NATURAL RESOURCES SERVICE. CANMORE, ALBERTA:

947. CLEVENGER, A. P., F. J. PURROY and M. S. DE BURUAGA. 1987. STATUS OF THE BROWN BEAR IN THE CANTABRIAN MOUNTAINS, SPAIN. INT. CONF. BEAR RES. AND MANAGE. 7:1-8.

948. CLEVENGER, A. P., F. J. PURROY and M. R. PELTON. 1992. BROWN BEAR (URSUS ARCTOS L.) HABITAT USE IN THE CANTABRIAN MOUNTAINS, SPAIN. MAMMALIA 56(2):203-14.

949. CLEVENGER, A. P., F. J. PURROY and M. R. PELTON. 1990. MOVEMENT AND ACTIVITY PATTERNS OF A EUROPEAN BROWN BEAR IN THE CANTABRIAN MOUNTAINS, SPAIN. INT. CONF. BEAR RES. AND MANAGE. 8:205-11.

950. CLEVENGER, A. P., F. J. PURROY and M. A. CAMPOS. 1997. HABITAT ASSESSMENT OF A RELICT BROWN BEAR URSUS ARCTOS POPULATION IN NORTHERN SPAIN. BIOLOGICAL CONSERVATION $80: 17-22$.

951. CLOTHIER, W. D. 1952. FISH LOSS AND MOVEMENT IN IRRIGATION DIVERSIONS FROM THE WEST GALLATIN RIVER, MONTANA. M.S. THESIS, MONTANA STATE COLLEGE, BOZEMAN, MT. 32 PP.

952. CODONER, N. A. 1995. MORTALITY OF CONNECTICUT BIRDS ON ROADS AND AT BUILDINGS. CONNECTICUT WARBLER 5(3):89-98.

953. COFFIN, K. W. 1994. POPULATION CHARACTERISTICS AND WINTER HABITAT SELECTION BY PINE MARTEN IN SOUTHWEST MONTANA. M.S. THESIS, MONTANA STATE UNIVERSITY, BOZEMAN, MT. 94 PP.

954. COGGIN, J. L., A. GUTHRIE, M. CARPENTER, D. WHITE, J. HUFFER and O. BURKHOLDER. 1972. ROAD GAME POPULATION RELATIONSHIP STUDY. VIRGINIA COMM. OF GAME AND INLAND FISHERIES. PROJECT NO. VA. W-040-R-19/WK.PL.05/JOB C/FIN. 5PP.

955. COGGIN, J. L., A. GUTHRIE, M. CARPENTER, D. WHITE, J. HUFFER and O. BURKHOLDER. 1972. VIRGINIA UPLAND GAME INVESTIGATIONS: ROAD GAME POPULATION RELATIONSHIP STUDY. VIRGINIA COMM. OF GAME AND INLAND FISHERIES :5 PP.

956. COGGINS, V. 1976. CONTROLLED VEHICLE ACCESS DURING ELK SEASON IN THE CHESNIMNUS AREA, OREGON. PAGES 58-61 IN S. R. HIEB, EDITOR. PROCEEDINGS OF THE ELK-LOGGING-ROADS SYMPOSIUM. FORESTRY WILDLIFE AND RANGE EXPERIMENT STATION, UNIVERSITY OF IDAHO, MOSCOW, IDAHO, USA.

957. COHEN, A. S., R. BILLS, C. Z. COCQUYT and A. G. CALJON. 1993. THE IMPACT OF SEDIMENT POLLUTION ON BIODIVERSITY IN LAKE TANGANYIKA. CONSERVATION BIOLOGY 7 (3):667-77.

958. COKER, D. R. and D. E. CAPEN. 1995. LANDSCAPE-LEVEL HABITAT USE BY BROWN-HEADED COWBIRDS IN VERMONT. J. WILDL. MANAGE. 59 (4):631-7.

959. COLE, D. N. 1990. ECOLOGICAL IMPACTS OF WILDERNESS RECREATION AND THEIR MANAGEMENT. PAGES 425-466 IN J. C. HENDEE, G. H. STANKEY, AND R. C. LUCAS, EDITORS. WILDERNESS MANAGEMENT. NORTH AMERICAN PRESS. GOLDEN, COLORADO.

960. COLE, D. N. 1987. EFFECTS OF THREE SEASONS OF EXPERIMENTAL TRAMPLING ON FIVE MONTANE FOREST COMMUNITIES AND A GRASSLAND IN WESTERN MONTANA. JOURNAL OF APPLIED ECOLOGY 32:203-214.

961. COLE, D. N. 1995. EXPERIMENTAL TRAMPLING OF VEGETATION. I. RELATIONSHIP BETWEEN TRAMPLING INTENSITY AND VEGETATION RESPONSE. BIOLOGICAL CONSERVATION 20:247-270.

962. COLE, D. N. 1993. MINIMIZING CONFLICT BETWEEN RECREATION AND NATURE CONSERVATION. PAGES 105-122 IN D. S. SMITH AND P. C. HELMUND, EDITORS. ECOLOGY OF GREENWAYS: DESIGN AND FUNCTION OF LINEAR CONSERVATION AREAS. UNIVERSITY OF MINNESOTA PRESS, MINNEAPOLIS, MINNESOTA. 
963. COLE, D. N. 1981. VEGETATIONAL CHANGES ASSOCIATED WITH RECREATIONAL USE AND FIRE SUPPRESSION IN THE EAGLE CAP WILDERNESS, OREGON: SOME MANAGEMENT IMPLICATIONS. U.S.A. BIOLOGICAL CONSERVATION 40:219-244.

964. COLE, D. N. and R. L. KNIGHT. 1990. IMPACTS OF RECREATION ON BIODIVERSITY IN WLDERNESS. PAGES 33-40 IN WILDERNESS AREAS: THEIR IMPACTS; PROCEEDINGS OF A SYMPOSIUM. UTAH STATE UNIVERSITY, LOGAN, UTAH.

965. COLE, D. N. and D. R. SPILDIE. 1998. HIKER, HORSE AND LLAMA TRAMPLING EFFECTS ON NATIVE VEGETATION IN MONTANA, USA. JOURNAL OF ENVIRONMENTAL MANAGEMENT 53:61-71.

966. COLE, D. N. 1977. MAN'S IMPACT ON WILDERNESS VEGETATION: AN EXAMPLE FROM EAGLE CAP WILDERNESS, NORTHEASTERN OREGON. DISSERTATION, UNIVERSITY OF OREGON, EUGENE, OREGON. 307PP.

967. COLE, E. K., M. D. POPE and R. G. ANTHONY. 1997. EFFECTS OF ROAD MANAGEMENT ON MOVEMENT AND SURVIVAL OF ROOSEVELT ELK. JOURNAL OF WILDLIFE MANAGEMENT 61:1115-1126.

968. COLE, G. F. 1955. RANGE USE AND FOOD HABITS OF THE PRONGHORN ANTELOPE IN CENTRAL MONTANA WITH SPECIAL REFERENCE TO ALFALFA. M.S. THESIS, MONTANA STATE COLLEGE, BOZEMAN, MT. 75 PP.

969. COLEMAN, J. S. and J. D. FRASER. 1989. HABITAT USE AND HOME RANGES OF BLACK AND TURKEY VULTURES. J. WILDL. MANAGE. 53 (3):782-92.

970. COLLINS, W. B. 1979. FEEDING BEHAVIOR AND HABITAT SELECTION OF DEER AND ELK ON NORTHERN UTAH SUMMER RANGE. PH.D. THESIS. UTAH STATE UNIV., LOGAN, UTAH.112PP.

971. COLLINS, W. B., P. J. URNESS and D. D. AUSTIN. 1978. ELK DIETS AND ACTIVITIES ON DIFFERENT LODGEPOLE PINE HABITAT SEGMENTS. J. WILDL. MANAGE. 42 (4):799-810.

972. COLORADO DIVISION OF WILDLIFE. 1980. WILDLIFE RESEARCH REPORT. PART ONE. STATE OF COLORADO, DIVISION OF WILDLIFE, DENVER, CO.

973. COMMITTEE ON WLDLF. CONS. PLANNING. 1956. WILDLIFE AND RECREATION FOR THE FUTURE IN THE UNITED STATES. 46TH ANN. CONVENTION OF THE INTERNATIONAL ASSOC. OF GAME, FISH AND CONS. COMM., TORONTO, CANADA., 12 PP.

974. COMPTON, B. B., P. ZAGER and G. SERVHEEN. 1995. SURVIVAL AND MORTALITY OF TRANSLOCATED WOODLAND CARIBOU. WILDL. SOC. BULL. 23 (3):490-6.

975. COMPTON, B. B. 1986. DISTRIBUTION OF WHITE-TAILED DEER ALONG THE LOWER YELLOWSTONE RIVER. M.S. THESIS, MONTANA STATE UNIVERSITY, BOZEMAN, MT. 73 PP.

976. CONFER, J. L. and R. T. HOLMES. 1995. NEOTROPICAL MIGRANTS IN UNDISTURBED AND HUMAN-ALTERED FORESTS OF JAMAICA. WILSON BULLETIN 107 (4):577-89.

977. CONGDON, J. D., A. E. DUNHAM and R. C. VAN LOBEN SELS. 1993. DELAYED SEXUAL MATURITY AND DEMOGRAPHICS OF BLANDING S TURTLES (EMYDOIDEA BLANDINGII):IMPLICATIONS FOR CONSERVATION AND MANAGEMENT OF LONG-LIVED ORGANISMS. CONSERVATION BIOLOGY 7 (4):826-33.

978. CONNER, R. N. and C. S. ADKISSON. 1976. CONCENTRATION OF FORAGING COMMON RAVENS ALONG THE TRANS-CANADA HIGHWAY. CANADIAN FIELD-NATURALIST 90(4):496-497.

979. CONNER, R. N., R. G. HOOPER, H. S. CRAWFORD and H. S. MOSBY. 1975. WOODPECKER NESTING HABITAT IN CUT AND UNCUT WOODLANDS IN VIRGINIA. J. WILL. MANAGE. 39(1):144-50.

980. CONNER, R. N. and D. C. RUDOLPH. 1991. FOREST HABITAT LOSS, FRAGMENTATION, AND RED-COCKADED WOODPECKER POPULATIONS. WILSON BULLETIN 103 (3):446-57. 
981. CONNER, R. N., D. C. RUDOLPH, D. L. KULHAVY and A. E. SNOW. 1991. CAUSES OF MORTALITY OF RED-COCKADED WOODPECKER CAVITY TREES. J. WLDL. MANAGE. 55 (3):531-.7.

982. CONNOR, J. 1991. PROTECTING BIRDS OF PREY WITHIN ROCKY MOUNTAIN NATIONAL PARK FROM ROCK CLIMBING AND PARK BOUNDARY DEVELOPMENT. PAGES 14-16 IN PROC. ISSUES TECHNOL. MANAGE. IMPACTED WILDLIFE (THORNE ECOL. INST.) AND NO. 5 P. 14-16, ISSUES AND TECHNOLOGY IN THE MANAGEMENT OF IMPACTED WILDLIFE: PROCEEDINGS OF A NATIONAL SYMPOSIUM. THORNE ECOLOGICAL INSTITUTE,

983. CONNOR, W. P. 1988. EFFECTS OF GAS SUPERSATURATED WATER ON JUVENILE BROWN AND RAINBOW TROUT. M.S. THESIS, MONTANA STATE UNIVERSITY, BOZEMAN, MT. 96 PP.

984. CONOVER, M. R. 1994. PERCEPTIONS OF GRASS-ROOTS LEADERS OF THE AGRICULTURAL COMMUNITY ABOUT WILDLIFE DAMAGE ON THEIR FARMS AND RANCHES. WILDL. SOC. BULL.22 (1):94-100.

985. CONOVER, M. R., W. C. PITT, K. K. KESSLER, T. J. DUBOW and W. A. SANBORN. 1995. REVIEW OF HUMAN INJURIES, ILLNESSES, AND ECONOMIC LOSSES CAUSED BY WILDLIFE IN THE UNITED STATES. WILDLIFE SOCIETY BULLETIN 23(3):407-414.

986. CONRY, P. J. 1981. HABITAT SELECTION AND USE, MOVEMENTS, AND HOME RANGE OF MALAYSIAN SELADANY (BOS GAURUS HUBBACKI) ON A DISTURBED RANGE IN CENTRAL PAHANG, MALAYSIA. M.S. THESIS, UNIVERSITY OF MONTANA, MISSOULA, MT. 120 PP.

987. CONSTAN, K. J. 1967. FOOD HABITS, RANGE USE AND RELATIONSHIPS OF BIGHORN SHEEP TO MULE DEER AND ELK IN WINTER, GALLATIN CANYON, MONTANA. M.S. THESIS, MONTANA STATE UNIVERSITY, BOZEMAN, MT. 43 PP.

988. CONVISSER, M. 1979. MITIGATION OF TRANSPORTATION IMPACTS. PAGES 71-74 IN SWANSON,G.A., EDITOR. THE MITIGATION SYMPOSIUM: A NATIONAL WORKSHOP ON MITIGATION LOSSES OF FISH AND WLDLIFE HABITAT; 1979 JULY 16-20; FORT COLLINS, CO. GEN. TECH. REP. RM-65. U.S. DEPARTMENT OF AGRICULTURE, FOREST SERVICE, ROCKY MOUNTAIN RESEARCH STATION, FORT COLLINS, CO.

989. COOK, D. 1999. HIGHWAY 19 WILDLIFE DETERRENT PILOT STUDY BASE LINE MAPPING OF LAND USE AND WILDLIFE MOVEMENT. MINISTRY OF TRANSPORTATION AND HIGHWAYS, ENVIRONMENTAL SERVICES SECTION, VICTORIA, B.C..

990. COOK, J. G. and S. H. ANDERSON. 1990. USE OF HELICOPTERS FOR SURVEYS OF NESTING RED-SHOULDERED HAWKS. PRAIRIE NATURALIST 22:49-53.

991. COOK, K. E. and P. M. DAGGETT. 1995. HIGHWAY ROADKILL, SAFETY, AND ASSOCIATED ISSUES OF SAFETY AND IMPACT ON HIGHWAY ECOTONES. TASK FORCE ON NATURAL RESOURCES (A1F52), TRANSPORTATION RESEARCH BOARD, NATIONAL RESEARCH COUNCIL, [LOCATION OF PUBLICATION UNKNOWN].

992. COOK, R. P. and C. A. PINNOCK. 1987. RECREATING A HERPETOFAUNAL COMMUNITY AT GATEWAY NATIONAL RECREATION AREA, NEWYORK. PAGES 151-154 IN L.W. ADAMS, AND D.L. LEEDY, EDITORS. INTEGRATING MAN AND NATURE IN THE METROPOLITAN ENVIRONMENT. PROCEEDINGS OF THE NATIONAL SYMPOSIUM ON URBAN WILDLIFE. NATIONAL INST. FOR URBAN WILDLIFE, COLUMBIA, MARYLAND

993. COOKE, A. S. 1972. THE EFFECTS OF DDT, DIELDRIN AND 2,4-D ON AMPHIBIAN SPAWN AND TADPOLES . ENVIRONMENTAL POLLUTION 3:51-68.

994. COOKE, A. S. 1973. THE EFFECTS OF DDT, WHEN USED AS A MOSQUITO LARVICIDE, ON TADPOLES OF THE FROG RANA TEMPORARIA. ENVIRONMENTAL POLLUTION 5:259-273.

995. COOKE; A. S. 1977. EFFECTS OF FIELD APPLICATIONS OF THE HERBICIDES DIQUAT AND DICHLOBENIL ON AMPHIBIANS. HERPETOL. J. 7:37-41.

996. COOKE, A. S. 1997. MONITORING A BREEDING POPULATION OF CRESTED NEWTS (TRITURUS CRISTATUS) IN A HOUSING DEVELOPMENT . COPEIA 1973:647-652.

997. COOKE, A. S. 1988. MORTALITY OF TOADS (BUFO BUFO) ON ROADS NEAR A CAMBRIDGESHIRE BREEDING SITE. BRITISH HERPETOLOGICAL SOCIETY 6:29-30. 
998. COOKE, A. S. 1980. OBSERVATIONS ON HOW CLOSE CERTAIN PASSERINE SPECIES WILL TOLERATE AN APPROACHING HUMAN IN RURAL AND SUBURBAN AREAS. BIOLOGICAL CONSERVATION 18:85-88.

999. COOKE, A. S. 1973. RESPONSE OF RANA TEMPORARIA TADPOLES TO CHRONIC DOSES OF P, P'-DDT. ENVIRONMENTAL POLLUTION 12:43-50.

1000. COOKE, A. S. 1995. ROAD MORTALITY OF COMMON TOADS (BUFO BUFO) NEAR A BREEDING SITE, $1974-1994$. AMPHIBIA-REPTILIA $16(1): 87-90$.

1001. COOKE, K. 1982. GUIDELINES FOR SOCIALLY APPROPRIATE TOURISM DEVELOPMENT IN BRITISH COLUMBIA. J. TRAVEL RES. 21:22-28

1002. COOP, K. J. 1971. HABITAT USE, DISTRIBUTION, MOVEMENT AND ASSOCIATED BEHAVIOR OF ELK, LITTLE BELT MOUNTAINS, MONTANA. M.S. THESIS, MONTANA STATE UNIVERSITY, BOZEMAN, MT. 61 PP.

1003. COOPERRIDER, A. Y. 1969. COMPETITION FOR FOOD BETWEEN MULE DEER AND BIGHORN SHEEP ON ROCK CREEK WINTER RANGE, MONTANA. PH.D. DISSERTATION, UNIVERSITY OF MONTANA, MISSOULA, MT. 92 PP.

1004. COPE, M. G. 1992. DISTRIBUTION, HABITAT SELECTION AND SURVIVAL OF TRANSPLANTED COLUMBIAN SHARP-TAILED GROUSE (TYMPANUCHUS PHASIANELLUS COLUMBIANUS) IN THE TOBACCO VALLEY, MONTANA. M.S. THESIS, MONTANA STATE UNIVERSITY, BOZEMAN, MT. 60 PP.

1005. COPELAND, J. P. 1996. BIOLOGY OF THE WOLVERINE IN CENTRAL IDAHO. M.S. THESIS, UNIVERSITY OF IDAHO.

1006. CORBET, P. S. 1970. SNOWMOBILES: FOR PLEASURE, PROFIT, AND POLLUTION. ONT. NAT. 8:10-12.

1007. CORBETT, K. 1982. TOADS AND ROADS - CONSERVATION IN ACTION. FLYCATCHER 8:18-20.

1008. CORBETT, K. F. 1989. AMPHIBIAN FENCING. PAGES 183-190 IN LANGTON,T.E.S., EDITOR. AMPHIBIANS AND ROADS. PROCEEDINGS OF THE TOAD TUNNEL CONFERENCE; 1989 JANUARY 7-8; RENDSBURG, FEDERAL REPUBLIC OF GERMANY ACO POLYMER PRODUCTS LTD., SHEFFORD, ENGLAND.

1009. CORN, J. G. and M. G. RAPHAEL. 1992. HABITAT CHARACTERISTICS AT MARTEN SUBNIVEAN ACCESS SITES. JOURNAL OF WILDLIFE MANAGEMENT $56(3): 442-8$.

1010. CORNELI, P. S. 1980. PRONGHORN FAWN MORTALITY FOLLOWING COYOTE CONTROL ON THE NATIONAL BISON RANGE. M.S. THESIS, UNIVERSITY OF MONTANA, MISSOULA, MT. 69 PP.

1011. CORNETT, D. C. 1987. AN EVALUATION OF GOAL PROGRAMMING FOR MULTIPLE LAND USE PLANNING AT MINERAL KING, CALIFORNIA. DISSERTATION, UNIVERSITY OF CALIFORNIA, DAVIS, CALIFORNIA. 266PP.

1012. COSTAIN, W. B. 1989. HABITAT USE PATTERNS AND POPULATION TRENDS AMONG SHIRAS MOOSE IN A HEAVILY LOGGED REGION OF NORTHWEST MONTANA. M.S. THESIS, UNIVERSITY OF MONTANA, MISSOULA, MT. 258 PP.

1013. COSTAS, R. 1991. A SURVEY OF BIRD MORTALITY IN SEVERAL SOUTHWESTERN GALICIAN ROADS DURING SPRING AND SUMMER. CURSOS CONGRESS UNIVERSITY SANTIAGO COMPOSTELA 66:219-230.

1014. COTE, S. D. 1996. MOUNTAIN GOAT RESPONSES TO HELICOPTER DISTURBANCE. WLDL. SOC. BULL. 24 (4):681-5.

1015. COTRELL, C. 1997. ROADS AND HABITAT FRAGMENTATION. THE ROAD-RIPORTER JAN/FEB 1997:12-13.

1016. COTTAM, C. 1931. BIRDS AND MOTOR CARS IN SOUTH DAKOTA. WILSON BULLETIN 43:313-314.

1017. COTTER, R. C. and C. J. GRATTO. 1995. EFFECTS OF NEST AND BROOD VISITS AND RADIO TRANSMITTERS ON ROCK PTARMIGAN. J. WILDL. MANAGE. 59 (1):93-8.

1018. COTTS, N. R., E. F. REDENTE and R. SCHILLER. 1991. RESTORATION METHODS FOR ABANDONED ROADS AT LOWER ELEVATIONS IN GRAND TETON NATIONAL PARK, WYOMING. ARID SOIL RESEARCH AND REHABILITATION 5 
(4):235-50.

1019. COULSON, G. 1989. THE EFFECT OF DROUGHT ON ROAD MORTALITY OF MACROPODS. AUSTRALIAN WILDLIFE RESEARCH 16:79-83.

1020. COULSON, G. 1982. ROAD-KILLS OF MACROPODS ON A SECTION OF HIGHWAY IN CENTRAL VICTORIA. AUSTRALIAN WILDLIFE RESEARCH 9:21-26.

1021. COULSON, R. 1996. METHOD FOR MEASURING VEHICLE NOISE SOURCE HEIGHTS AND SUBSOURCE SPECTRA. TRANSPORTATION RESEARCH RECORD 1559:8-13.

1022. COULTER, M. C. and A. L. J. BRYAN. 1993. FORAGING ECOLOGY OF WOOD STORKS (MYCTERIA AMERICANA) IN EAST-CENTRAL GEORGIA: I. CHARACTERISTICS OF FORAGING SITES. COLONIAL WATERBIRDS 16 (1):59-70.

1023. COUNCIL ON ENVIRONMENTAL QUALITY. 1979. OFF-ROAD VEHICLES ON PUBLIC LANDS. COUNCIL ON ENVIRONMENTAL QUALITY. WASHINGTON, D.C.

1024. COWAN, I. M. 1974. MANAGEMENT IMPLICATIONS OF BEHAVIOR IN THE LARGE HERVIBOROUS MAMMALS. PAGES 921-934 IN V. GEIST AND F. WALTHER, EDITORS. THE BEHAVIOR OF UNGULATES AND ITS RELATION TO MANAGMENT. VOLUME 2. MORGES, SWITZERLAND. IUCN PUBL. NEW SER. 24.

1025. COWAN, P. E. and D. S. RHODES. 1992. RESTRICTING THE MOVEMENTS OF BRUSHTAIL POSSUMS (TRICHOSURUS VULPECULA) ON FARMLAND WITH ELECTRIC FENCING. WILDLIFE RESEARCH 19 (1):47-58.

1026. COWARDIN, L. M., D. S. GILMER and C. W. SHAIFFER. 1985. MALLARD RECRUITMENT IN THE AGRICULTURAL ENVIRONMENT OF NORTH DAKOTA. WLDL. MONOGR. 92:1-37.

1027. COWLES, C. J., D. J. HANSEN and J. D. HUBBARD. 1981. TYPES OF POTENTIAL EFFECTS OF OFFSHORE OIL AND GAS DEVELOPMENT ON MARINE MAMMALS AND ENDANGERED SPECIES OF THE NORTHERN BERING SEA AND ARCTIC OCEAN. U.S. DEPARTMENT OF THE INTERIOR, BUREAU OF LAND MANAGEMENT, ALASKA OUTER CONTINENTAL SHELF OFFICE. ANCHORAGE, ALASKA. TECHNICAL PAPER NUMBER 9. BLM-YK-TE-81-006. 23PP.

1028. CRABTREE, R. L., L. S. BROOME and M. L. WOLFE. 1989. EFFECTS OF HABITAT CHARACTERISTICS ON GADWALL NEST PREDATION AND NEST-SITE SELECTION. J. WILDL. MANAGE. 53 (1):129-37.

1029. CRAIG, V. E. 1952. A STORY OF FISH PRODUCTION AS IT APPLIES TO MONTANA. M.S. THESIS, MONTANA STATE COLLEGE, BOZEMAN, MT. 92 PP.

1030. CRAIGHEAD, D. J. 1980. SEX DIFFERENCES IN NEST CONSTRUCTION, INCUBATION, AND PARENTAL BEHAVIOR IN CAPTIVE AMERICAN GOLDEN EAGLES (AQUILA CHRYSAETOS). M.S. THESIS, UNIVERSITY OF MONTANA, MISSOULA, MT. 64 PP.

1031. CRAIGHEAD, F. C. JR. and D. P. MINDELL. 1981. NESTING RAPTORS IN WESTERN WYOMING,1947 AND 1975. J. WILDL. MANAGE. 45 (4):865-72.

1032. CRAIGHEAD, F. L. 1994. CONSERVATION GENETICS OF GRIZZLY BEARS. PH.D. DISSERTATION, MONTANA STATE UNIVERSITY, BOZEMAN, MT. 227 PP.

1033. CRAIGHEAD, J. C. and F. C. JR. CRAIGHEAD. 1972. GRIZZLY BEAR-MAN RELATIONSHIPS IN YELLOWSTONE NATIONAL PARK. INT. CONF. BEAR RES. AND MANAGE. 2:304-32.

1034. CRAIGHEAD, J. J., F. C. JR. CRAIGHEAD and J. SUMNER. 1974. REPRODUCTIVE CYCLES AND RATES IN THE GRIZZLY BEAR, URSUS ARCTOS HORRIBILIS, OF THE YELLOWSTONE ECOSYSTEM. INT. CONF. BEAR RES. AND MANAGE. 3:337-56.

1035. CRAIGHEAD, J. J. and D. S. STOCKSTAD. 1956. MEASURING HUNTING PRESSURE ON CANADA GEESE IN THE FLATHEAD VALLEY. TRANSACTIONS OF THE NORTH AMERICAN WILDLIFE AND NATURAL RESOURCES CONFERENCE $21: 210-238$. 
1036. CRAIGHEAD, J. J., J. S. SUMMER and J. A. MITCHELL. 1995. THE GRIZZLY BEARS OF YELLOWSTONE: THEIR ECOLOGY IN THE YELLOWSTONE ECOSYSTEM, 1959-1992. COVELO, CALIF.: ISLAND PRESS.

1037. CRAIGHEAD, J. J., J. S. SUMNER and G. B. SCAGGS. 1982. A DEFINITIVE SYSTEM FOR ANALYSIS OF GRIZZLY BEAR HABITAT AND OTHER WILDERNESS RESOURCES. WLDLIFE-WILDLANDS INSTITUTE MONOGRAPH NO. 1. UNIV. MONTANA FOUNDATION, MISSOULA.279PP.

1038. CRAMER, P. C. 1992. SMALL MAMMAL DIVERSITY AND ABUNDANCE IN DOUGLAS FIR OLD GROWTH FORESTS. M.S. THESIS, MONTANA STATE UNIVERSITY, BOZEMAN, MT. 64 PP.

1039. CRANSTON, J. H. I. 1986. LIGHT AND ELECTRON MICROSCOPIC CHARACTERIZATION OF MONOCLONAL ANTIBODIES RECOGNIZING NEURONAL CELL NUCLEI AND THE NEUROHYPOPHYSIS. M.S. THESIS, MONTANA STATE UNIVERSITY, BOZEMAN, MT. 63 PP.

1040. CRAVEN, S. R., G. A. BARTELT, D. H. RUSCH and R. E. TROST. 1986. DISTRIBUTION AND MOVEMENT OF CANADA GEESE IN RESPONSE TO MANAGEMENT CHANGES IN EAST CENTRAL WISCONSIN (USA) 1975-1981. WIS. DEP. OF NAT. RESOUR. TECH. BULL. 158:1-36.

1041. CRAWFORD, H. S. 1982. SEASONAL FOOD SELECTION AND DIGESTIBILITY BY TAME WHITE-TAILED DEER IN CENTRAL MAINE. J. WILDL. MANAGE. 46 (4):974-82.

1042. CREED, W. A., F. HABERLAND, B. E. KOHN and K. R. MCCAFFERY. 1984. HARVEST MANAGEMENT: THE WISCONSIN EXPERIENCE (CHAPTER 11). P 243-60. IN: HALLS, L.K.,(EDITOR). WHITE-TAILED DEER: ECOLOGY AND MANAGEMENT. HARRISBURG, PA: STACKPOLE BOOKS.

1043. CRENSHAW, J. G. 1985. CHARACTERISTICS OF BALD EAGLE COMMUNAL ROOSTS IN GLACIER NATIONAL PARK, MONTANA. M.S. THESIS, UNIVERSITY OF MONTANA, MISSOULA, MT. 92 PP.

1044. CRETE, M. and J. BEDARD. 1975. DAILY BROWSE CONSUMPTION BY MOOSE IN THE GASP PENINSULA, QUEBEC. J. WILDL. MANAGE. 39 (2):368-73.

1045. CRETE, M. and F. MESSIER. 1987. EVALUATION OF INDICES OF GRAY WOLF, CANIS LUPUS, DENSITY IN HARDWOOD-CONIFER FORESTS OF SOUTHWESTERN QUEBEC (CANADA). CANADIAN FIELD-NATURALIST 101 (2):147-52.

1046. CRISTOFFER, C. 1991. ROAD MORTALITIES OF NORTHERN FLORIDA VERTEBRATES. FLA.SCI. 54(2):65-68.

1047. CRISTOL, D. A., P. V. SWIZER, K. L. JOHNSON and L. S. WALKE. 1997. CROWS DO NOT USE AUTOMOBILES AS NUTCRACKERS: PUTTING AN ANECDOTE TO THE TEST. AUK 114(2):296-298.

1048. CROME, F., J. ISAACS and L. MOORE. 1994. THE UTILITY TO BIRDS AND MAMMALS OF REMNANT RIPARIAN VEGETATION AND ASSOCIATED WINDBREAKS IN THE TROPICAL QUEENSLAND UPLANDS. PACIFIC CONSERVATION BIOLOGY 1 (4):328-43.

1049. CROME, F. H. J. and G. C. RICHARDS. 1988. BATS AND GAPS: MICROCHIROPTERAN COMMUNITY STRUCTURE IN A QUEENSLAND RAINFOREST. ECOLOGY $69: 1960-1969$

1050. CRONIN, M. A., W. B. BALLARD, J. D. BRYAN, B. J. PIERSON and J. D. MCKENDRICK. 1998. NORTHERN ALASKA OIL FIELDS AND CARIBOU: A COMMENTARY. BIOLOGICAL CONSERVATION 83:195-208.

1051. CRONIN, M. A. 1986. GENETIC RELATIONSHIPS BETWEEN WHITE-TAILED DEER, MULE DEER AND OTHER LARGE MAMMALS INFERRED FROM MITOCHONDRIAL DNA ANALYSIS. M.S. THESIS, MONTANA STATE UNIVERSITY BOZEMAN, MT. 49 PP.

1052. CROOKS, K. R. 1994. DEN-SITE SELECTION IN THE ISLAND SPOTTED SKUNK OF SANTA CRUZ ISLAND, CALIFORNIA. SOUTHWESTERN NATURALIST 39:354-357.

1053. CROSS, H. J. 1965. THE ELK HERD OF THE EAST FORK OF THE BITTERROOT RIVER. M.S. THESIS, UNIVERSITY OF MONTANA, MISSOULA, MT. 95 PP. 
1054. CROSSLEY, J. C., M. P. MARIN, G. FERRANDO and L. A. RAGGI. 1994. ADAPTATIVE VARIATION OF SOME PHYSIOLOGICAL VALUES IN ALPACA (LAMA PACOS) LOCATED IN DIFFERENT ENVIRONMENTS. ARCHIVOS DE ZOOTECNIA 43 (163):215-23.

1055. CROUCH, G. L. 1968. FORAGE AVAILABILITY IN RELATION TO BROWSING OF DOUGLAS-FIR SEEDLINGS BY BLACK-TAILED DEER. J. WILDL. MANAGE. 32 (3):542-53.

1056. CROUCH, G. L. 1966. PREFERENCES OF BLACK-TAILED DEER FOR NATIVE FORAGE AND DOUGLAS-FIR SEEDLINGS. J. WILDL. MANAGE. 30 (3):471-5.

1057. CRUZ, A. and P. FAIRBAIRN. 1980. CONSERVATION OF NATURAL RESOURCES IN THE CARIBBEAN: THE AVIFAUNA OF JAMAICA. TRANS. N. AMER. WILDL. NAT. RESOUR. CONF. 45:438-444.

1058. CRYER, M., N. W. LINLEY, R. M. WARD, J. O. STRATFORD and P. F. RANDERSON. 1987. DISTURBANCE OF OVERWINTERING WILDFOWL BY ANGLERS AT TWO RESERVOIR SITES IN SOUTH WALES. BIRD STUDY 34:191-199.

1059. CUMMING, H. G. 1996. MANAGING FOR CARIBOU SURVIVAL IN A PARTITIONED HABITAT. RANGIFER SPECIAL ISSUE NO.9(171-180). CARIBOU, ONTARIO, FORESTRY, MOOSE, WOLF, GUIDELINES.

1060. CUMMING, H. G. 1981. TITLE UNKNOWN. SEASONS 21 (2):26-30.

1061. CUMMING, H. G. and D. B. BEANGE. 1993. SURVIVAL OF WOODLAND CARIBOU IN COMMERCIAL FOREST OF NORTHERN ONTARIO. FOREST CHRONICLE 69:579-88.

1062. CUMMING, H. G., D. B. BEANGE and G. LAVOIE. 1996. HABITAT PARTITIONING BETWEEN WOODLAND CARIBOU AND MOOSE IN ONTARIO: THE POTENTIAL ROLE OF SHARED PREDATION RISK. RANGIFER SPECIAL ISSUE NO.9:81-94.

1063. CUMMING, S. G., P. J. BURTON, S. PRAHACS and M. R. GARLAND. 1994. POTENTIAL CONFLICTS BETWEEN TIMBER SUPPLY AND HABITAT PROTECTION IN THE BOREAL MIXEDWOOD OF ALBERTA, CANADA: A SIMULATION STUDY. FOREST ECOLOGY AND MANAGEMENT 68 (2-3):281-302.

1064. CUMMINGS, J. R. and S. H. VESSEY. 1994. AGRICULTURAL INFLUENCES ON MOVEMENT PATTERNS OF WHITE-FOOTED MICE (PEROMYSCUS LEUCOPUS). AMERICAN MIDLAND NATURALIST 132 (2):209-18.

1065. CUMMINGS, M. S. 1961. HABITAT IMPROVEMENT FOR GAME. OREGON ST. GAME COMM. FED. AID IN WILDL. RESTORATION PROJ. W-38-D-9, FINAL REPT. 20 PP.

1066. CUMMINS, C. P. 1986. EFFECTS OF ALUMINUM AND LOW PH ON GROWTH AND DEVELOPMENT IN RANA TEMPORARIA TADPOLES. OECOLOGIA 69:248-252.

1067. CUNNINGHAM, S. C., H. LAYNE and S. JOSEPH. 1993. POSSIBLE EFFECTS OF THE REALIGNMENT OF U.S. HIGHWAY 93 ON MOVEMENTS OF DESERT BIGHORNS IN THE BLACK CANYON AREA. PAGES 83-100 IN ROWLANDS,P.G., VAN RIPER,C., AND SOGGE,M.K., EDITORS. PROCEEDINGS OF THE FIRST BIENNIAL CONFERENCE ON RESEARCH IN COLORADO PLATEAU NATIONAL PARKS, NORTHERN ARIZONA UNIVERSITY, FLAGSTAFF, 22-25 JULY 1991. PETER G. ROWLANDS, CHARLES VAN RIPER III, AND MARK K. SOGGE, EDITORS. U.S. NATL. PARK SERV. TRANS. PROC. U.S. NATIONAL PARK SERVICE, PHOENIX, AZ.

1068. CURATOLO, J. 1983. CARIBOU RESPONSE TO THE PIPELINE/ROAD COMPLEX IN THE KUPARUK OILFIELD, ALASKA. PROCEEDINGS OF THE ALASKA SCIENCE CONFERENCE 34:10-13.

1069. CURATOLO, J. A. 1985. SEXUAL SEGREGATION AND HABITAT USE BY THE CENTRAL ARCTIC CARIBOU HERD DURING SUMMER. MCGILL SUBARCT. RES. PAPER ( 40 ):193-8.

1070. CURATOLO, J. A. and S. M. MURPHY. 1986. THE EFFECTS OF PIPELINES, ROADS, AND TRAFFIC ON THE MOVEMENTS OF CARIBOU (RANGIFER TARANDUS). CANADIAN FIELD NATURALIST 100(2):218-224.

1071. CURNOW, E. E. 1969. THE HISTORY OF THE ERADICATION OF THE WOLF IN MONTANA. M.S. THESIS, UNIVERSITY OF MONTANA, MISSOULA, MT. 99 PP. 
1072. CURRY, G. N. 1991. THE INFLUENCE OF PROXIMITY TO PLANTATION EDGE ON DIVERSITY AND ABUNDANCE OF BIRD SPECIES IN AN EXOTIC PINE PLANTATION IN NORTHEASTERN NEW SOUTH WALES (AUSTRALIA). WLDLIFE RESEARCH 18(3):299-314.

1073. CURRY-LINDAHL, K. 1972. THE BROWN BEAR (URSUS ARCTOS) IN EUROPE: DECLINE, PRESENT DISTRIBUTION, BIOLOGY AND ECOLOGY. INT. CONF. BEAR RES. AND MANAGE. 2:74-83.

1074. CUSHING, B. S. 1983. RESPONSES OF POLAR BEARS TO HUMAN MENSTRUAL ODORS. INT. CONF. BEAR RES. AND MANAGE. 5:270-4.

1075. CUSHING, B. S. 1980. THE EFFECTS OF HUMAN MENSTRUATION AND OTHERSUBSTANCES ON THE POLAR BEAR. M.S THESIS, UNIVERSITY OF MONTANA, MISSOULA, MT. 49 PP.

1076. CUTLER, A. 1991. NESTED FAUNAS AND EXTINCTION IN FRAGMENTED HABITATS. CONSERVATION BIOLOGY 5 (4):496-505.

1077. CZECH, B. 1991. ELK BEHAVIOR IN RESPONSE TO HUMAN DISTURBANCE AT MOUNT ST. HELENS NATIONAL VOLCANIC MONUMENT. APPLIED ANIMAL BEHAVIOR SCIENCE 29:269-277.

1078. CZECH, B. and K. RAEDEKE. 1988. THE IMPACT OF RECREATIONAL VEHICLE TRAVEL ON ELK IN THE BLAST ZONE OF MT. ST. HELENS. PAGES 55-66 IN PROC. WESTERN STATES AND PROVINCES ELK WORKSHOP.

1079. D.A. WESTWORTH \& ASSOCIATES LTD. 1994. WILDLIFE STUDIES ALONG THE PRIMROSE PRODUCTION PIPELINE. PREPARED FOR AMOCO CANADA PETROLEUM COMPANY LTD. 7PP

1080. DAHL, T. E., C. E. JOHNSON and W. E. FRAYER. 1991. WETLANDS, STATUS AND TRENDS IN THE CONTERMINOUS UNITED STATES, MID-1970'S TO MID-1980'S FIRST UPDATE OF THE NATIONAL WETLANDS STATUS REPORT. U.S. DEPT. OF THE INTERIOR, FISH AND WILDLIFE SERVICE. FOR SALE BY THE U.S. G.P.O., SUPT. OF DOCS, WASHINGTON, D.C

1081. DAHLGREN, R. B. and C. E. KORSCHGEN. 1992. HUMAN DISTURBANCES OF WATERFOWL: AN ANNOTATED BIBLIOGRAPHY. U.S. FISH AND WLDLIFE SERVICE. WASHINGTON, D.C. RESOURCE PUBLICATION188. 62PP.

1082. DAHMER, T. D. 1978. STATUS AND ECOLOGY OF THE WILD ASIAN BUFFALO (BUBALUS BUBALIS L.) IN NEPAL. M.S. THESIS, UNIVERSITY OF MONTANA, MISSOULA, MT. 72 PP.

1083. DAILEY, N. S. 1978. ENVIRONMENTAL ASPECTS OF TRANSMISSION LINES A SELECTED ANNOTATED BIBLIOGRAPHY. OAK RIDGE NATIONAL LABORATORY, OAK RIDGE, TENNESSEE.

1084. DAILY, G. C. and P. R. EHRLICH. 1994. INFLUENCE OF SOCIAL STATUS ON INDIVIDUAL FORAGING AND COMMUNITY STRUCTURE IN A BIRD GUILD. OECOLOGIA (BERLIN) 100 (1-2):153-1650.

1085. DALBEY, S. R. 1994. EFFECTS OF ELECTROFISHING ON LONG-TERM GROWTH AND MORTALITY OF WLD RAINBOW TROUT. M.S. THESIS, MONTANA STATE UNIVERSITY, BOZEMAN, MT. 46 PP.

1086. DALE, D. and T. WEAVER. 1973. TRAMPLING EFFECTS ON VEGETATION OF THE TRAIL CORRIDOR OF NORTH ROCKY MOUNTAIN FORESTS. DEPARTMENT OF BOTANY, MONTANA STATE UNIVERSITY, BOZEMAN., 10 PP

1087. DALE, V. H., R. V. O'NEILL, F. SOUTHWORTH and M. PEDLOWSKI. 1994. MODELING EFFECTS OF LAND MANAGEMENT IN THE BRAZILIAN AMAZONIAN SETTLEMENT OF RONDONIA. CONSERVATION BIOLOGY 8 (1):196-206.

1088. DALE, V. H., S. M. PEARSON, H. L. OFFERMAN and R. V. O'NEILL. 1994. RELATING PATTERNS OF LAND-USE CHANGE TO FAUNAL BIODIVERSITY IN THE CENTRAL AMAZON. CONSERVATION BIOLOGY 8 (4):1027-36.

1089. DALKE, P. D., R. D. BEEMAN, F. J. KINDEL, R. J. ROBEL and T. R. WILLIAMS. 1965. USE OF SALT BY ELK IN IDAHO. J. WILDL. MANAGE. 29 (2):319-32.

1090. DALKE, P. D., D. B. PYRAH, D. C. STANTON, J. E. CRAWFORD and E. F. SCHLATTERER. 1963. ECOLOGY, PRODUCTIVITY, AND MANAGEMENT OF SAGE GROUSE IN IDAHO. J. WILDL. MANAGE. 27 (4):810-41. 
DALLE-MOLLE, J. and J. VAN HORN. 1991. OBSERVATION OF VEHICLE TRAFFIC INTERFERING WITH MIGRATION OF DALL'S SHEEP, OVIS DALLI DALLI, IN DENALI NATIONAL PARK, ALASKA. CANADIAN FIELD-NATURALIST $-105: 409-411$.

1092. DALLE-MOLLE, J. and J. VAN HORN. 1991. OBSERVATIONS OF VEHICLE TRAFFIC INTERFERING WITH MIGRATION OF DALL'S SHEEP, OVIS DALLI DALLI, IN DENALI NATIONAL PARK, ALASKA. CANADIAN FIELD NATURALIST. 105(3)

1093. DALRYMPLE, G. H. and N. G. REICHENBACH. 1984. MANAGEMENT OF AN ENDANGERED SPECIES OF SNAKE IN OHIO, USA. BIOLOGICAL CONSERVATION 30:195-200.

1094. DALTON, L. B. and M. C. STANGER. 1990. REFLECTOR EFFECTS ON DEER ROAD KILLS. UTAH DIVISION OF WILDLIFE RESOURCES, PRICE, UT.

1095. DAMAS AND SMITH LIMITED and PARKS CANADA. 1982. WILDLIFE MORTALITY IN TRANSPORTATION CORRIDORS IN CANADA'S NATIONAL PARKS IMPACT AND MITIGATION. THE COMPANY, OTTAWA, ONTARIO.

1096. DAMAS AND SMITH LTD. 1983. WILDLIFE MORTALITY IN TRANSPORTATION CORRIDORS IN CANADA'S NATIONAL PARKS: IMPACT AND MITIGATION. EXECUTIVE SUMMARY. PRODUCED FOR PARKS CANADA. 31PP.

1097. DAMAS AND SMITH LTD. 1983. WILDLIFE MORTALITY IN TRANSPORTATION CORRIDORS IN CANADA'S NATIONAL PARKS. VOLS. 1 AND 2. PREPARED FOR PARKS CANADA, CALGARY. PREPARED BY DAMAS AND SMITH LTD. UNPUBLISHED REPORT

1098. DAMAS AND SMITH LTD. 1981. WILDLIFE MORTALITY IN TRANSPORTATION CORRIDORS IN ELK ISLAND NATIONAL PARK. PREPARED FOR PARKS CANADA, CALGARY. PREPARED BY DAMAS AND SMITH LTD. UNPUBLISHED REPORT

1099. DAMAS \& SMITH and DAMAS AND SMITH LIMITED. 1980. WILLIFE MORTALITY IN TRANSPORTATION CORRIDORS IN CANADA'S NATIONAL PARKS IMPACT AND MITIGATION. DAMAS \& SMITH, OTTAWA, ONTARIO.

1100. DANE, B. G. 1979. CULVERT GUIDELINES : RECOMMENDATIONS FOR THE DESIGN AND INSTALLATION OF CULVERTS IN BRITISH COLUMBIA TO AVOID CONFLICT WITH ANADROMOUS FISH. 3RD. ED. MICROFORM: FISHERIES AND MARINE SERVICE TECHNICAL REPORT: TECHNICAL REPORT (CANADA. FISHERIES AND MARINE SERVICE) NO. 811. MICROMEDIA. LAND USE UNIT, HABITAT PROTECTION DIVISION, RESOURCE SERVICES BRANCH, CANADA FISHERIES AND MARINE SERVICE, PACIFIC REGION, VANCOUVER, B.C.

1101. DANE, B. G. 1981. CULVERT GUIDELINES RECOMMENDATIONS FOR THE DESIGN AND INSTALLATION OF CULVERTS IN BRITISH COLUMBIA TO AVOID CONFLICT WITH ANADROMOUS FISH. 4TH ED. FISHERIES AND MARINE SERVICE TECHNICAL REPORT: TECHNICAL REPORT (CANADA. FISHERIES AND MARINE SERVICE) 811. DEPT. OF FISHERIES AND ENVIRONMENT, PACIFIC REGION, FISHERIES AND MARINE SERVICE, VANCOUVER, B.C.

1102. DANE, B. G. 1978. A REVIEW AND RESOLUTION OF FISH PASSAGE PROBLEMS AT CULVERT SITES IN BRITISH COLUMBIA. 3RD ED. FISHERIES AND MARINE SERVICE TECHNICAL REPORT. DEPT. OF FISHERIES AND ENVIRONMENT, PACIFIC REGION, FISHERIES AND MARINE SERVICE, VANCOUVER, B.C.

1103. DANE, B. G. 1979. A REVIEW AND RESOLUTION OF FISH PASSAGE PROBLEMS AT CULVERT SITES IN BRITISH COLUMBIA. 3RD ED. MICROFROM FISHERIES AND MARINE SERVICE TECHNICAL REPORT: TECHNICAL REPORT (CANADA. FISHERIES AND MARINE SERVICE) NO. 810. MICROMEDIA. LAND USE UNIT, HABITAT PROTECTION DIVISION, RESOURCE SERVICES BRANCH, CANADA FISHERIES AND MARINE SERVICE, PACIFIC REGION, VANCOUVER, B.C.

1104. DANE, B. G. 1983. A REVIEW AND RESOLUTION OF FISH PASSAGE PROBLEMS AT CULVERT SITES IN BRITISH COLUMBIA. 4TH ED. FISHERIES AND MARINE SERVICE TECHNICAL REPORT: TECHNICAL REPORT (CANADA. FISHERIES AND MARINE SERVICE) 810. DEPT. OF FISHERIES AND ENVIRONMENT, PACIFIC REGION, FISHERIES AND MARINE SERVICE, VANCOUVER, B.C.

1105. DANEKE, D. E. 1980. THE FOOD HABITS, HEALTH, NUTRITION, DYNAMICS,AND HUNTING EFFECTS ON THE MIDDLE FORK ELK HERD, FLATHEAD, CO., MONTANA. M.S. THESIS, UNIVERSITY OF MONTANA, MISSOULA, MT. 74 PP.

1106. DANIELS, R. J. R. 1994. A LANDSCAPE APPROACH TO CONSERVATION OF BIRDS. JOURNAL OF BIOSCIENCES 19(4):503-509. 
1107. DARRALL, N. M. 1987. ENVIRONMENTAL CONCERNS IN RIGHTS-OF-WAY MANAGEMENT IN EUROPE. PAGES 587-591 IN BYRNES,W.R. AND HOLT,H.A., EDITORS. PROCEEDINGS OF THE FOURTH SYMPOSIUM ON ENVIRONMENTAL CONCERNS IN RIGHTS-OF-WAY MANAGEMENT .

1108. DARVEAU, M., P. BEAUCHESNE, L. BELANGER, J. HUOT and P. LARUE. 1995. RIPARIAN FOREST STRIPS AS HABITAT FOR BREEDING BIRDS IN BOREAL FOREST. J. WLDL. MANAGE. 59(1):67-78.

1109. DASMANN, R. F. and W. P. DASMANN. 1963. MULE DEER IN RELATION TO A CLIMATIC GRADIENT. J. WILDL. MANAGE. 27 (2):196-202.

1110. DASMANN, R. F. and A. S. MOSSMAN. 1962. ROAD STRIP COUNTS FOR ESTIMATING NUMBERS OF AFRICAN UNGULATES. J. WILDL. MANAGE. 26 (1):101-4.

1111. DAU, C. P. 1989. MANAGEMENT AND BIOLOGY OF BROWN BEARS AT COLD BAY, ALASKA. P.19-26. IN: BEAR-PEOPLE CONFLICTS--PROC. SYMP. ON MANAGE. STRATEGIES.

1112. DAU, J. R. and R. D. CAMERON. 1986. EFFECTS OF A ROAD SYSTEM ON CARIBOU DISTRIBUTION DURING CALVING. P 95-101. IN: GUNN A, MILLER FL, SKJENNEBERG S.(EDS.) PROCEEDINGS OF THE FOURTH INTERNATIONAL REINDEER/CARIBOU SYMPOSIUM. VOLUME SPECIAL ISSUE 1. HARSTAD, NORWAY; NORDIC COUNCIL FOR REINDEER RESEARCH.

1113. DAVEY, S. P. 1974. OFF-ROAD VEHICLES: ON OR OFF THE PUBLIC LANDS. TRANSACTIONS OF THE NORTH AMERICAN WILDLIFE AND NATURAL RESOURCES CONFERENCE 39:367-375.

1114. DAVID, L. M. and R. E. WARNER. 1981. ROADSIDE MANAGEMENT FOR PHEASANTS AND SONGBIRDS IN EAST-CENTRAL ILLINOIS. PAGES 63.1-63.8 IN TILLMAN,R.E., EDITOR. PROCEEDINGS OF THE SECOND SYMPOSIUM ON ENVIRONMENTAL CONCERNS IN RIGHTS-OF-WAY MANAGEMENT; 1979 OCTOBER 16-18; ANN ARBOR, MI UNIVERSITY OF MICHIGAN, ANN ARBOR.

1115. DAVIDSON, E. and M. FOX. 1974. EFFECTS OF OFF-ROAD MOTORCYCLE ACTIVITY ON MOJAVE DESERT VEGETATION AND SOIL. MADRANO 22:381-390.

1116. DAVIS, A. E. 1975. DEATH ON THE HIGHWAY. BRITISH COLUMBIA OUTDOORS FEBRUARY:29-31.

1117. DAVIS, J. M., T. J. ROPER and D. J. SHEPHERDSON. 1987. SEASONAL DISTRIBUTION OF ROAD KILLS IN THE EUROPEAN BADGER (MELES MELES). JOURNAL OF ZOOLOGY 211:525-529.

1118. DAVIS, J. R. 1992. NESTING AND BROOD ECOLOGY OF THE WILD TURKEY IN THE MOUNTAINS OF WESTERN NORTH CAROLINA (MELEAGRIS GALLAPAVO). PHD THESIS, CLEMSON UNIVERSITY. 187 PP.

1119. DAVIS, P. B. and C. R. HUMPHRYS. 1977. ECOLOGICAL EFFECTS OF HIGHWAY CONSTRUCTION UPON MICHIGAN WOODLOTS AND WETLANDS. SUMMARY OF STUDY FINDINGS PHASE 1 REPORT. FHWA/MI-7797417. MICHIGAN STATE UNIVERSITY, AGRICULTURAL EXPERIMENT STATION, EAST LANSING.

1120. DAVIS, W. B. 1940. MORTALITY OF WILDLIFE ON A TEXAS HIGHWAY. J. WLDL. MANAGE. 4 (1):90-1.

1121. DAVIS, W. H. 1934. THE AUTOMOBILE AS A DESTROYER OF LIFE. SCIENCE 79:504-505.

1122. DAVIS, W. L. 1988. IMPACT OF CHANNEL MODIFICATION AND HABITAT MITIGATION ON THE FISHERIES AT POOR FORK CUMBERLAND RIVER, CANEY CREEK, AND RIGHT FORK BEAVER CREEK. FISHERIES BULLETIN OF THE KENTUCKY DEPARTMENT OF FISH AND WILDLIFE RESOURCES NO. 84. DEPT. OF FISH AND WILDLIFE RESOURCES, FRANKFORT, KENTUCKY.

1123. DAVISON, A. W. 1971. THE EFFECTS OF DE-ICING SALT ON ROADSIDE VERGES. JOURNAL OF APPLIED ECOLOGY 8:555-561.

1124. DAWES, S. R. 1998. UTILIZATION OF FORAGE BY BISON IN THE GIBBON, MADISON, AND FIREHOLE AREAS OF YELLOWSTONE NATIONAL PARK. M.S. THESIS, MONTANA STATE UNIVERSITY, BOZEMAN, MT. 72 PP. 
1125. DAWSON, B. L. 1991. SOUTH AFRICAN ROAD RESERVES: VALUABLE CONSERVATION AREAS?. PAGES 119-130 IN SAUNDERS,D.A. AND HOBBS, R.J., EDITORS. NATURE CONSERVATION 2: THE ROLE OF CORRIDORS. SURREY -BEATTY AND SONS, CHIPPING NORTON, AUSTRALIA.

1126. DAY, A. R. and R. B. LEWIS. 1970. PASSAGE OF ANADROMOUS FISH THRU HIGHWAY DRAINAGE STRUCTURES FINAL REPORT. RESEARCH REPORT / CALIFORNIA DIVISION OF HIGHWAYS: RESEARCH REPORT (CALIFORNIA. DIVISION OF HIGHWAYS) 629110. CALIFORNIA DEPT. OF PUBLIC WORKS, DIVISION OF HIGHWAYS, CALIFORNIA.

1127. DAY, G. L. 1981. THE STATUS AND DISTRIBUTION OF WOLVES IN THENORTHERN ROCKY MOUNTAINS OF THE US . M.S. THESIS, UNIVERSITY OF MONTANA, MISSOULA, MT. 130 PP.

1128. DAY, K. E., K. E. HOLTZE, S. J. L. METCALFE, C. T. BISHOP and B. J. DUTKA. 1993. TOXICITY OF LEACHATE FROM AUTOMOBILE TIRES TO AQUATIC BIOTA. CHEMOSPHERE 27 (4):665-75.

1129. DAY, P. 1991. CONSERVING OUR DAILY BREAD. CONSERVATION BIOLOGY 5 (2):133-4.

1130. DAY, T. A. 1973. USE OF CLEARCUTS BY ELK IN THE LITTLE BELT MOUNTAINS, MONTANA. M.S. THESIS, MONTANA STATE UNIVERSITY, BOZEMAN, MT. 70 PP.

1131. DE BRUIJN, O. 1994. POPULATION ECOLOGY AND CONSERVATION OF THE BARN OWL TYTO ALBA IN FARMLAND HABITATS IN LIEMERS AND ACHTERHOEK (THE NETHERLANDS). ARDEA 82 (1):1-109.

1132. DE GRAAF, R. M. 1995. NEST PREDATION RATES IN MANAGED AND RESERVED EXTENSIVE NORTHERN HARDWOOD FORESTS. FOREST ECOLOGY AND MANAGEMENT 79(3):227-34.

1133. DE GROSBOIS, T., G. P. KERSHAW and J. R. EYTON. 1991. THE REGROWTH PRODUCTION AND ALLOCATION OF SALIX ARBUSCULOIDES IN THREE GROWING SEASONS FOLLOWING RIGHT-OF-WAY CLEARING. CANADIAN JOURNAL OF FOREST RESEARCH 21 (8):1171-9.

1134. DE JONG, J. 1995. HABITAT USE AND SPECIES RICHNESS OF BATS IN A PATCHY LANDSCAPE. ACTA THERIOLOGICA $40(3): 237-48$.

1135. DE JONG, J. and I. AHLEN. 1991. FACTORS AFFECTING THE DISTRIBUTION PATTERN OF BATS IN UPPLAND, CENTRAL SWEDEN. HOLARCTIC ECOLOGY 14 (2):92-6.

1136. DE-LA-CRUZ-ALEMAN, M. A. 1992. PROVISIONAL REPORT OF THE MORTALITY OF VERTEBRATES ON THE ROADS OF TOLEDO, SEPTEMBER 1991. PAGES 123-126 IN LOPEZ,REDONDO, EDITOR. I JORNADAS PARA EL ESTUDIO Y PREVENCION DE LA MORTALIDAD DE VERTEBRADOS EN CARRETERAS, MADRID, 5 Y 6 DE OCTUBRE DE 1991. TOMO 2. [SESSIONS IN THE STUDY OF PREVENTION OF ROAD MORTALITIES OF VERTEBRATES, MADRID, 5 AND 6 OCTOBER, 1991. VOLUME 2.]. COORDINADORA DE ORGANIZACCIONES DE DEFENSA, AMBIENTAL, MADRID.

1137. DE ROIA, D. M. 1993. FEEDING ECOLOGY OF NONBREEDING DUCKS ON STRIP-MINE SEDIMENT PONDS IN EAST-CENTRAL TEXAS. PHD THESIS, TEXAS A\&M UNIVERSITY. 72 PP.

1138. DE SANTO, R. S. and D. G. SMITH. 1993. AN INTRODUCTION TO ISSUES OF HABITAT FRAGMENTATION RELATIVE TO TRANSPORTATION CORRIDORS WITH SPECIAL REFERENCE OF HIGH-SPEED RAIL (HSR). ENVIRONMENTAL MANAGEMENT 17 (1):111-4.

1139. DE SMET, K. D. and M. P. CONRAD. 1991. STATUS, HABITAT REQUIREMENTS, AND ADAPTATIONS OF FERRUGINOUS HAWKS IN MANITOBA. PAGES 219-221 IN G. L. HOLROYD, G. BURNS, AND H. C. SMITH, EDITORS. PROCEEDINGS OF THE SECOND ENDANGERED SPECIES AND PRAIRIE CONSERVATION WORKSHOP. NATURAL HISTORY SECTION PROVINCIAL MUSEUM OF ALBERTA, EDMONTON, ALBERTA.

1140. DE VOS, A. 1958. SUMMER OBSERVATIONS ON MOOSE BEHAVIOR IN ONTARIO. JOURNAL OF MAMMALOGY. 39(1)

1141. DE VOS, A. 1949. TIMBER WOLVES KILLED BY CARS ON ONTARIO HIGHWAYS. JOURNAL OF MAMMALOGY 30 (1):197. 
1142. DE VOS, A. and R. H. BAILEY. 1970. THE EFFECT OF LOGGING AND INTENSIVE CAMPING ON VEGETATION IN RIDING MOUNTAIN NATIONAL PARK. FOR. CHRON. 46:49-55.

1143. DEAN, F. C. and D. M. TRACY. 1980. THE BEAR BIBLIOGRAPHY PROJECT. INT. CONF. BEAR RES. AND MANAGE. 4:13-4.

1144. DEAN, F. C. and D. M. TRACY. 1978. MCKINLEY'S SHUTTLE BUS SYSTEM AND THE MANAGEMENT OF TRAFFIC IMPACT ON WILDLIFE. P.263-270. IN: USFS RECREATIONAL IMPACT ON WILDLANDS CONF.; 1978 OCT 27-1978 OCT 29 SEATTLE, WASH. P 263-70.

1145. DEAN, FC. 1974. ASPECTS OF GRIZZLY BEAR POPULATION ECOLOGY IN MOUNT MCKINLEY NATIONAL PARK. INT. CONF. BEAR RES. AND MANAGE. 3:111-9.

1146. DEARDEN, B. L., R. E. PEGAU and R. M. HANSEN. 1975. PRECISION OF MICROHISTOLOGICAL ESTIMATES OF RUMINANT FOOD HABITS. J. WILDL. MANAGE. 39 (2):402-7.

1147. DEARDEN, P. and C. HALL. 1983. NON-CONSUMPTIVE RECREATION PRESSURES AND THE CASE OF THE VANCOUVER ISLAND MARMOT (MARMOTA VANCOUVERENSIS). ENVIRON. CONSERV. 10:63-66.

1148. DEBINSKI, D. M. 1991. INVENTORY OF MONITORIN OF BIODIVERSITY AN ASSESSMENT OF METHODS AND A CASE STUDY OF GLACIER NATIONAL PARK, MONTANA. PH.D. DISSERTATION, MONTANA STATE UNIVERSITY, BOZEMAN, MT. 269 PP.

1149. DEBLINGER, R. D., J. J. VASKE and M. P. DONNELLY. 1989. INTEGRATING ECOLOGICAL \& SOCIAL IMPACTS INTO BARRIER BEACH MANAGEMENT. PAGES 49-56 IN T. A. MORE, M. P. DONNELLY, A. R. GRAEFE, AND J. J. VASKE, EDITORS. PROCEEDINGS, 1989 NORTHEASTERN RECREATION RESEARCH SYMPOSIUM. U.S. DEPT. AGRICULTURE, FOREST SERV., NORTHEAST. FOR. EXP. STA., BROOMALL, PENNSYLVANIA.

1150. DEBOER, S. R. 1939. A STUDY OF WILDLIFE RESOURCES IN WYOMING. WYOMING STATE PLANNING AND WATER CONSERVATION BOARD, CHEYENNE, WYOMING.

1151. DECALESTA, D. S. 1990. FACTORS INFLUENCING NUMBER OF ROAD-KILLED DEER IN PENNSYLVANIA. JOURNAL OF THE PENNSYLVANIA ACADEMY OF SCIENCE 63(1-3):210-213.

1152. DECALESTA, D. S. 1990. TITLE UNKNOWN. J. PA. ACAD. SCI. 63 (1-3):210.

1153. DECASENAVE, J. L., J. P. PELOTTO and J. PROTOMASTRO. 1995. EDGE-INTERIOR DIFFERENCES IN VEGETATION STRUCTURE AND COMPOSITION IN A CHACO SEMI-ARID FOREST, ARGENTINA. FOREST ECOLOGY AND MANAGEMENT $72(1): 61-9$

1154. DECKER, B. S. 1989. EFFECTS OF HABITAT DISTURBANCE ON THE BEHAVIORAL ECOLOGY AND DEMOGRAPHICS OF THE TANA RIVER RED COLOBUS (COLOBUS BADIUS RUFOMITRATUS)(AFRICA). PHD THESIS, EMORY UNIVERSITY. 330 PP

1155. DECKER, D. 1987. A LIMITED SURVEY OF ROAD KILLS ON THE WARSAW-HAMILTON BLACKTOP. ILLINOIS BIRDS BIRDING 3(3):63-64.

1156. DECKER, T. and J. COOPER. 1991. EVALUATION OF DAMAGE BY BEAVERS TO HIGHWAYS AND THE ECONOMIC COSTS TO CITIES AND TOWNS IN MASSACHUSETTS. TECHNICAL REPORT: TECHNICAL REPORT (MASSACHUSETTS. DIVISION OF FISHERIES AND WILDLIFE) NO. 100. MASSACHUSETTS DIVISION OF FISHERIES \& WILDLIFE, WESTBORO, MASSACHUSETTS.

1157. DEFORGE, J. R. 1972. MAN'S INVASION INTO THE BIGHORN'S HABITAT. TRANS. DESERT BIGHORN COUNCIL 16:112-115.

1158. DEGN, H. J. 1985. ROAD-KILL OF TOADS (BUFO BUFO). FLORA OG FAUNA 1(1):17-21

1159. DEGRAAF, R. M. 1991. WINTER FORAGING GUILD STRUCTURE AND HABITAT ASSOCIATIONS IN SUBURBAN BIRD COMMUNITIES. LANDSCAPE AND URBAN PLANNING 21 (3):173-80. 
1160. DEGRAAF, R. M. and P. ANGELSTAM. 1993. EFFECTS OF TIMBER SIZE-CLASS ON PREDATION OF ARTIFICIAL NESTS IN EXTENSIVE FOREST. FOREST ECOLOGY AND MANAGEMENT 61 (1-2):127-36.

1161. DEL CAMPO, J. C., J. L. MARQUINEZ, J. NAVES and G. PALOMERO. 1990. THE BROWN BEAR IN THE CANTABRIAN MOUNTAINS. AQUILO,-SER.-ZOOL. 27:97-101.

1162. DEL FRATE, G. G. and T. H. SPRAKER. 1991. MOOSE VEHICLE INTERACTIONS AND AN ASSOCIATED PUBLIC AWARENESS PROGRAM ON THE KENAI PENINSULA, ALASKA. ALCES 27:1-7.

1163. DEL FRATE, G. G. and T. H. SPRAKER. 1991. MOOSE VEHICLE INTERACTIONS AND AN ASSOCIATED PUBLIC AWARENESS PROGRAM ON THE KENAI PENNINSULA, ALASKA. ALCES 27:1-7.

1164. DEL TREDICI, P., H. LING and G. YANG. 1992. THE GINKGOS OF TIAN MU SHAN. CONSERVATION BIOLOGY 6 (2):202-9.

1165. DELERAY, M. A. 1991. MOVEMENT AND UTILIZATION OF FLUVIAL HABITAT BY AGE-O ARCTIC GRAYLING, AND CHARACTERISTICS OF SPAWNING ADULTS, IN THE OUTLET OF DEER LAKE, GALLATIN COUNTY, MONTANA. M.S. THESIS, MONTANA STATE UNIVERSITY, .BOZEMAN, MT. 75 PP.

1166. DELLA-MORETTA, L. B. and H. C. HODGES. 1983. OFF-HIGHWAY TIRE/ROAD DAMAGE AND HEALING MECHANISMS. U.S FOR. SERV., EQUIP. DEV. CENTER. PROJECT RECORD 8371 1202. 9PP.

1167. DELLASALA, D. A. 1986. RESPONSE OF THREE SONGBIRD SPECIES TO FOREST DISTURBANCES IN LARGE TRACTS OF NORTHERN HARDWOODS. PHD THESIS, UNIVERSITY OF MICHIGAN. 87 PP.

1168. DEM'YANENKO, A. F., R. S. ZAKIROV and E. K. MENG. 1995. TECHNOLOGY FOR FIXATION OF MOVING SANDS IN ROAD CONSTRUCTION IN SANDY DESERTS. PROBLEMY OSVOENIYA PUSTYN'O (1):59-71.

1169. DEMARCHI, R. 1975. REPORT AND RECOMMENDATIONS OF THE WORKSHOP ON CALIFORNIA BIGHORN SHEEP. PAGES 143-163 IN J. B. TREFETHEN, EDITOR. THE WLD SHEEP IN MODERN NORTH AMERICA. BOONE AND CROCKET CLUB AND WINCHESTER.PRESS. NEWYORK, NEW YORK, USA.

1170. DEMARTIS, A. M. 1987. BIRDS KILLED BY TRAFFIC ON THE ROADS AND THEIR DENSITY. RIV.ITAL.ORNITOL. 57(3-4):193-205.

1171. DEMERS, C. L. and W. S. RICHARD. 1990. EFFECTS OF ROAD DEICING SALT ON CHLORIDE LEVELS IN FOUR ADIRONDACK STREAMS. WATER, AIR, SOIL POLLUTION 49(3/4):369-373.

1172. DEMERS, M. N. 1993. ROADSIDE DITCHES AS CORRIDORS FOR RANGE EXPANSION OF THE WESTERN HARVESTER ANT (POGONOMYRMEX-OCCIDENTALIS CRESSON). LANDSCAPE ECOLOGY 8(2):93-102.

1173. DEMERS, M. N., J. W. SIMPSON, R. E. J. BOERNER, A. SILVA, L. BERNS and F. ARTIGAS. 1995. FENCEROWS, EDGES, AND IMPLICATIONS OF CHANGING CONNECTIVITY ILLUSTRATED BY TWO CONTIGUOUS OHIO LANDSCAPES. CONSERVATION BIOLOGY 9 (5):1159-68.

1174. DEN BOER, P. J. 1979. THE SIGNIFICANCE OF DISPERSAL POWER FOR THE SURVIVAL OF SPECIES, WITH SPECIAL REFERENCE TO THE CARABID BEETLES IN A CULTIVATED COUNTRYSIDE. FORTSCHR.ZOOL 25:79-94.

1175. DENNEY, R. N. 1974. THE IMPACT OF UNCONTROLLED DOGS ON WLDLIFE AND LIVESTOCK. TRANSACTIONS OF THE NORTH AMERICAN WILDLIFE AND NATURAL RESOURCES CONFERENCE 39:257-291.

1176. DENNIS, R. L. 1986. MOTORWAYS AND CROSS-MOVEMENTS. AN INSECT 'MENTAL MAP' OF THE M56 IN CHESHIRE. BULLETIN OF THE AMATEUR ENTOMOLOGIST SOCIETY 45:228-243.

1177. DENNISTON, R. H. 1956. ECOLOGY, BEHAVIOR, AND POPULATION DYNAMICS OF THE WYOMING OR ROCKY MOUNTAIN MOOSE. ZOOLOGICA 41:105-18.

1178. DENNISTON, R. H. 1956. ECOLOGY, BEHAVIOR AND POPULATION DYNAMICS OF THE WYOMING OR ROCKY MOUNTAIN MOOSE, ALCES ALCES SHIRASI. ZOOLOGICA 41:105-118. 
1179. DENNY, M. 1994. HIGH BIRD MORTALITY AS A RESULT OF PAINTED LADY BUTTERFLY MIGRATION IN EASTERN OREGON, SPRING 1992. OREGON BIRDS 0(1):23.

1180. DENSON, H. S. 1987. ECOLOGY OF CANADA GEESE (BRANTA CANADENSIS) AT MEDICINE LAKE NATIONAL WIDLIFE REFUGE. M.S. THESIS, MONTANA STATE UNIVERSITY, BOZEMAN, MT. 87 PP.

1181. DENTON, J. W. 1973. A RADIO TELEMETRY SYSTEM FOR ELK; ITS USE AND EFFICIENCY. M.S. THESIS, UNIVERSITY OF MONTANA, MISSOULA, MT. 77 PP.

1182. DESANTO, R. S. and D. G. SMITH. 1993. AN INTRODUCTION TO ISSUES OF HABITAT FRAGMENTATION RELATIVE TO TRANSPORTATION CORRIDORS WITH SPECIAL REFERENCE TO HIGH SPEED RAIL. ENVIRONMENTAL MANAGEMENT 17(1):111-114.

1183. DESIMONE, R. M. 1975. INTERSPERSION OF COVER TYPES AS RELATED TO PHEASANT USE ON A GAME MANAGEMENT AREA IN SOUTH-CENTRAL MONTANA. M.S. THESIS, MONTANA STATE UNIVERSITY, BOZEMAN, MT. 43 PP.

1184. DESJARDINS, C. R. 1979. ECOLOGICAL MITIGATION: A VIABLE OPTION IN THE FEDERAL-AID HIGHWAY PROGRAM. U.S. DEPARTMENT OF AGRICULTURE, FOREST SERVICE, ROCKY MOUNTAIN RANGE AND EXPERIMENT STATION, GEN. TECH. REP. GTR-RM-65. FORT COLLINS, CO.

1185. DESMET-MOENS, H. 1982. THE INSECT FAUNA OF CANADA THISTLE CIRSIUM ARVENSE (L.) SCOP IN SOUTHERN MONTANA. M.S. THESIS, MONTANA STATE UNIVERSITY, BOZEMAN, MT. 51 PP.

1186. DETENBECK, N. E., P. W. DEVORE, G. J. NIEMI and A. LIMA. 1992. RECOVERY OF TEMPERATE STREAM FISH COMMUNITIES FROM DISTURBANCE: A REVIEW OF CASE STUDIES AND SYNTHESIS OF THEORY. ENVIRONMENTAL MANAGEMENT 16:33-53.

1187. DEVOS, A. 1949. TIMBER WOLVES (CANIS LUPIS LYCAON) KILLED BY CARS ON ONTARIO HIGHWAYS. JOURNAL OF MAMMALOGY 30:197.

1188. DEVOS, A. 1949. TIMBER WOLVES (CANIS LUPUS LYCAON) KILLED BY CARS ON ONTARIO HIGHWAYS. JOURNAL OF MAMMALOGY $30(1): 197$.

1189. DEXEL, R. 1989. INVESTIGATIONS INTO THE PROTECTION OF MIGRANT AMPHIBIANS FROM THE THREATS FROM ROAD TRAFFIC IN THE FEDERAL REPUBLIC OF GERMANY - A SUMMARY. PAGES 43-49 IN LANGTON,T.E.S., EDITOR. AMPHIBIANS AND ROADS. PROCEEDINGS OF THE TOAD TUNNEL CONFERENCE; 1989 JANUARY 7-8; RENDSBURG, FEDERAL REPUBLIC OF GERMANY. ACO POLYMER PRODUCTS LTD., SHEFFORD, ENGLAND.

1190. DEY, S. C. 1991. DEPREDATION BY WILDLIFE IN THE FRINGE AREAS OF NORTH BENGAL FORESTS WITH SPECIAL REFERENCE TO ELEPHANT DAMAGE. INDIAN FORESTER117 (10):901-8.

1191. DHINDSA, M. S., J. S. SANDHU and H. S. TOOR. 1988. ROADSIDE BIRDS IN PUNJAB (INDIA): RELATION TO MORTALITY FROM VEHICLES. ENVIRONMENTAL CONSERVATION 15:303-310.

1192. DIAMOND, J. M., K. D. BISHOP and S. VAN BALEN. 1987. BIRD SURVIVAL IN AN ISOLATED JAVAN WOODLAND: ISLAND OR MIRROR. CONSERVATION BIOLOGY 1 (2):132-42.

1193. DIAMOND, S. and P. FINNEGAN. 1993. HARLEQUIN DUCK ECOLOGY ON MONTANA'S ROCKY MOUNTAIN FRONT. USDA FOREST SERVICE, LEWIS AND CLARK NATIONAL FOREST.

1194. DICKERSON, L. M. 1939. THE PROBLEM OF WILLIFE DESTRUCTION BY AUTOMOBILE TRAFFIC. JOURNAL OF WILDLIFE MANAGEMENT 3:104-116.

1195. DICKSON, J. G. 1985. USDA FOREST SERVICE: MANAGEMENT, RESEARCH, AND COOPERATIVE FORESTRY FOR MULTIPLE BENEFITS. TRANSACTIONS OF THE NORTH AMERICAN WLDLIFE AND NATURAL RESOURCES CONFERENCE 50:215-220.

1196. DICKSON, R. C. and A. P. DICKSON. 1993. KESTRELS FEEDING ON ROAD CASUALTIES. SCOTTISH BIRDS $17(1): 56$. 
1197. DIDRIKSON, R. 1977. THE EFFECTS OF DISTURBANCE ON THE ACTIVITY PATTERNS, ENERGY BUDGETS AND PRODUCTIVITY OF WAPITI. ALBERTA FISH AND WILDLIFE DIVISION, EDMONTON. UNPUBLISHED REPORT.

1198. DIDRIKSON, R. 1978. FINAL REPORT ON DISTURBANCE STUDY AT ELK ISLAND NATIONAL PARK. ALBERTA FISH AND WILDLIFE DIVISION, EDMONTON. UNPUBLISHED REPORT.

1199. DIETRICH, N. L. 1993. LANDSCAPE PLANNING WITH WLDLIFE CORRIDORS TO INCREASE THE HABITAT VALUE OF MINED LAND (COAL MINES). D.ED, THESIS, TEXAS A\&M UNIVERSITY. 204 PP.

1200. DIETZ, D. R. 1975. STRIPMINING FOR WESTERN COAL: NOT NECESSARILY BAD. J. RANGE MANAG 28 (3):244-5.

1201. DIETZ, D. R. and J. R. TIGNER. 1968. EVALUATION OF TWO MAMMAL REPELLENTS APPLIED TO BROWSE SPECIES IN THE BLACK HILLS. JOURNAL OF WILDLIFE MANAGEMENT 32:109-114.

1202. DILLON, L. 1993. LITERATURE REVIEW OF WILDLIFE/NEHICLE COLLISIONS AND HIGHWAY 24 DEER/NEHICLE ACCIDENT ANALYSIS. ONTARIO MINISTRY OF TRANSPORTATION. , ONTARIO, CANADA.

1203. DILSAVER, L. M. 1977. THE EFFECTS OF INTERNATIONAL TOURISM: A BIBLIOGRAPHY. COUNCIL OF PLANNING LIBRARIES EXCHANGE BIBLIOGRAPHY 1410. WASHINGTON, D.C. 31PP.

1204. DIMEO, A. 1977. CORRECTING VERTICAL FISH BARRIERS. UNITED STATES DEPT. OF AGRICULTURE, FOREST SERVICE, EQUIPMENT DEVELOPMENT CENTER, MISSOULA, MONTANA.

1205. DIRZO, R. and M. C. GARCIA. 1992. RATES OF DEFORESTATION IN LOS TUXTLAS, A NEOTROPICAL AREA IN SOUTHEAST MEXICO. CONSERVATION BIOLOGY 6 (1):84-90.

1206. DISNEY, H. J. and P. J. FULLAGAR. 1978. A NOTE ON ROAD KILLS. CORELLA 2(5):89-90.

1207. DISNEY, M. and L. K. SPIEGEL. 1992. SOURCES AND RATES OF SAN JOAQUIN KIT FOX MORTALITY IN WESTERN KERN COUNTY, CALIFORNIA. TRANSACTIONS OF THE WESTERN SECTION OF THE WILDLIFE SOCIETY 28:73-82.

1208. DITTON, R. B. 1969. THE IDENTIFICATION AND CRITICAL ANALYSIS OF SELECTED LITERATURE DEALING WITH THE RECREATIONAL ASPECTS OF WATER RESOURCES USE, PLANNING, AND DEVELOPMENT. WATER RESOUR. CENT., UNIVERSITY OF IL. URBANA, IL. RES. REP. 23. 293PP

1209. DIXON, B. G. 1997. CUMULATIVE EFFECTS MODELING FOR GRIZZLY BEARS IN THE GREATER YELLOWSTONE ECOSYSTEM. M.S. THESIS, MONTANA STATE UNIVERSITY, BOZEMAN, MT. 192 PP.

1210. DIXON, C. C. 1965. THE WLDLIFE OF MANITOBA. M.S. THESIS, UNIVERSITY OF MONTANA, MISSOULA, MT. 224 PP.

1211. DIXON, G., D. MERCER, G. ROBINSON and J. PETERSON. 1976. OFF-ROAD VEHICLES - AN OVERVIEW. PAGES 75-87 IN OFF-ROAD VEHICLES: SOME POLICY, PLANNING AND MANAGEMENT CONSIDERATIONS. PROCEEDINGS OF THE NATIONAL SYMPOSIUM ON OFF-ROAD VEHICLES IN AUSTRALIA. AUSTRALIAN INSTITUTE OF PARKS AND RECREATION, NORTHCOTE, VIC.

1212. DIXON, K. R., G. A. FELDHAMER, J. E. GATES and D. M. HARMAN. 1984. TITLE UNKNOWN. P 602-5. IN: CRABTREE, A.F. (ED.) PROCEEDINGS OF THE THIRD INTERNATIONAL SYMPOSIUM ON ENVIRONMENTAL CONCERNS IN RIGHTS-OF-WAY MANAGEMENT.

1213. DIXON, N., C. SHAWYER and C. SPERRING. 1996. THE IMPACT OF ROAD MORTALITY ON BARN OWL POPULATIONS: ITS SIGNIFICANCE TO ROAD DEVELOPMENT SCHEMES. RAPTOR 23:37-40.

1214. DIZON, A. E., C. LOCKYER, W. F. PERRIN, D. P. DEMASTER and J. SISSON. 1992. RETHINKING THE STOCK CONCEPT: A PHYLOGEOGRAPHIC APPROACH. CONSERVATION BIOLOGY 6 (1):24-36.

1215. DOAK, D. 1989. SPOTTED OWLS AND OLD GROWTH LOGGING IN THE PACIFIC NORTHWEST. CONSERVATION BIOLOGY $3(4): 389-96$. 
1216. DOAK, D., P. KAREIVA and B. KLEPETKA. 1994. MODELING POPULATION VIABILITY FOR THE DESERT TORTOISE IN THE WESTERN MOJAVE DESERT. ECOLOGICAL APPLICATIONS 4(3):446-60.

1217. DOAK, D. F., P. C. MARINO and P. M. KREIVA. 1992. SPATIAL SCALE MEDIATES THE INFLUENCE OF HABITAT FRAGMENTATION ON DISPERSAL SUCCESS: IMPLICATIONS FOR CONSERVATION. THEORETICAL POPULATION BIOLOGY 41:315-336.

1218. DOAN, K. H. 1970. EFFECTS OF SNOWMOBILES ON FISH AND WILDLIFE RESOURCES. INTERNATIONAL ASSOCIATION OF GAME FISH CONSERVATION 60:97-103.

1219. DODD, C. K. 1990. EFFECTS OF HABITAT FRAGMENTATION ON A STREAM-DWELLING SPECIES, THE FLATTENED MUSK TURTLE. BIOL. CONSERV. 54:33-45.

1220. DODD, C. K. JR. 1990. REVIEW OF] AMPHIBIANS AND ROADS. CONSERVATION BIOLOGY 4 (2):210-1.

1221. DODD, C. K.JR.,, K. M. ENGE and J. N. STUART. 1989. REPTILES ON HIGHWAYS IN NORTH-CENTRAL ALABAMA, USA. JOURNAL OF HERPETOLOGY 23:197-200.

1222. DODDS, P. J. and M. MAURER. 1996. WILDLIFE HABITAT EVALUATION/UPLAND MITIGATION: THE PENNDOT PERSPECTIVE. PAGES 235-259 IN EVINK,G., ZIEGLER,D., GARRETT,P., AND BERRY,J., EDITORS. TRANSPORTATION AND WLDLIFE: REDUCING WLDLIFE MORTALITY AND IMPROVING WILDIFE PASSAGEWAYS ACROSS TRANSPORTATION CORRIDORS: PROCEEDINGS OF THE FLORIDA DEPARTMENT OF TRANSPORTATION/FEDERAL HIGHWAY ADMINISTRATION TRANSPORTATION-RELATED WLDLIFE MORTALITY SEMINAR; 1996 APRIL 30-MAY 2; ORLANDO, FL. FHWA-PD-96-041. U.S. DEPARTMENT OF TRANSPORTATION, FEDERAL HIGHWAY ADMINISTRATION, WASHINGTON, DC.

1223. DOERR, P. D., L. B. KEITH, D. H. RUSCH and C. A. FISCHER. 1974. CHARACTERISTICS OF WINTERFEEDING AGGREGATIONS OF RUFFED GROUSE IN ALBERTA. J. WLDL. MANAGE. 38 (4):601-15.

1224. DOLLOFF, C. A. 1983. THE RELATIONHIPS OF WOOD DEBRIS TOJUVENILE SALMONID PRODUCTION AND MICROHABITAT SELECTION IN SMALL SOUTHEAST ALASKA STREAMS. PH.D. DISSERTATION, MONTANA STATE UNIVERSITY, BOZEMAN, MT. 100 PP.

1225. DOMBECK, M. 1999. IT'S TIME TO ADDRESS ROADS. INNER VOICE 11:17.

1226. DOMBROWSKI, A., J. FRONCZAK, M. KOWALSKI and T. LIPPOMAN. 1991. POPULATION DENSITY AND HABITAT PREFERENCES OF OWLS STRIGIFORMES ON AGRICULTURAL AREAS OF MAZOWSZE LOWLAND (CENTRAL POLAND). ACTA ORNITHOLOGICA (WARSAW) 26 (1):39-54.

1227. DOME PETROLEUM LIMITED. 1978. A PIPELINE CORRIDOR FOR THE YUKON COASTAL PLAIN A REVIEW. CALGARY, ALBERTA.

1228. DOME PETROLEUM LTD. 1982. TITLE UNKNOWN. ARCTIC 1 (4):11-3

1229. DOMESTIC POLICY COUNCIL (U.S.), WORKING GROUP ON AMERICAN INDIANS AND ALASKA NATIVES, SUBGROUP ON ENVIRONMENT AND NATURAL RESOURCES and NATIVE AMERICAN FISH \& WILDLIFE SOCIETY. 1999. TRIBAL ENVIRONMENTAL \& NATURAL RESOURCE ASSISTANCE HANDBOOK. WHITE HOUSE DOMESTIC POLICY COUNCIL, WORING GROUP ON AMERICAN INDIANS AND ALASKA NATIVES, SUBGROUP ON ENVIRONMENT AND NATURAL RESOURCES AND THE NATIVE AMERICAN FISH \& WILDLIFE SOCIETY, WASHINGTON, D.C.

1230. DOMINION ECOLOGICAL CONSULTING LTD, JNMACKENZIE ENGINEERING LTD, ALBERTA, FISH AND WILDLIFE DIVISION, ALBERTA, ENVIRONMENTAL ENGINEERING SUPPORT SERVICES and PLANNING DIVISION. 1988. A STRATEGY FOR FISHERIES MITIGATION IN THE OLDMAN RIVER BASIN: ALBERTA ENVIRONMENT, PLANNING DIVISION, EDMONTON, ALBERTA.

1231. DOMINY, F. E. 1968. THE BUREAU OF RECLAMATION AND WATERFOWL. TRANS. N. AMER. WILDL. NAT. RESOUR. CONF. 33:63-78.

1232. DOMROSE, R. J. 1960. AGE AND GROWTH OF BROOK TROUT, SALVELINUS FONTINALUS, IN MONTANA. M.S. THESIS, MONTANA STATE COLLEGE, BOZEMAN, MT. 32 PP. 
1233. DONALDSON, J. L. and S. FLECK. 1980. AN ASSESSMENT OF POTENTIAL EFFECTS OF THE LIARD HIGHWAY ON MOOSE AND OTHER WLDLIFE POPULATIONS IN THE LOWER LIARD VALLEY. CONTRACT REPORT / N.W.T. WILDLIFE SERVICE: CONTRACT REPORT (NORTHWEST TERRITORIES. WILDLIFE SERVICE) NO. 2. NORTHWEST TERRITORIES WILDLIFE SERVICE, YELLOWKNIFE, N.W.T.

1234. DONAZAR, J. A., F. HIRALDO and J. BUSTAMANTE. 1993. FACTORS INFLUENCING NEST SITE SELECTION, BREEDING DENSITY AND BREEDING SUCCESS IN THE BEARDED VULTURE (GYPAETUS BARBATUS). JOURNAL OF APPLIED ECOLOGY 30(3):504-514.

1235. DONCASTER, C. P., T. MICOL and S. P. JENSEN. 1996. DETERMINING MINIMUM HABITAT REQUIREMENTS IN THEORY AND PRACTICE. OIKOS 75(2):335-339.

1236. DONIHEE, J. and P. A. GRAY. 1982. A REVIEW OF ROAD RELATED WILLIFE PROBLEMS AND THE ENVIRONMENTAL MANAGEMENT PROCESS IN THE NORTH. INFORMATION REPORT / NORTHWEST TERRITORIES, RENEWABLE RESOURCES, WILDLIFE SERVICE: INFORMATION REPORT (NORTHWEST TERRITORIES. WILDLIFE SERVICE) NO. 2. NORTHWEST TERRITORIES, RENEWABLE RESOURCES, YELLOWKNIFE, N.W.T. $20 P P$.

1237. DONOVAN, T. M., F. R. I. THOMPSON, J. FAABORG and J. R. PROBST. 1995. REPRODUCTIVE SUCCESS OF MIGRATORY BIRDS IN HABITAT SOURCES AND SINKS. CONSERVATION BIOLOGY 9(6):1380-95.

1238. DOOD, A. R., R. D. BRANNON and R. D. MACE. 1986. FINAL PROGRAMMATIC ENVIRONMENTAL IMPACT STATEMENT: THE GRIZZLY BEAR IN NORTHWESTERN MONTANA. MONTANA DEPT. FISH, WILDL., AND PARKS. HELENA, MT.

1239. DOOD, A. R. 1978. SUMMER MOVEMENTS, HABITAT USE, AND MORTALITY OF MULE DEER FAWNS IN THE MISSOURI RIVER BREAKS, MONTANA. M.S. THESIS, MONTANA STATE UNIVERSITY, BOZEMAN, MT. 57 PP.

1240. DORING, R. 1990. TITLE UNKNOWN. TRANS. CONGR. INT. UNION GAME BIOL.19(2):411-3.

1241. DORING, R. 1990. THE IMPACT OF HUMAN DISTURBANCE ON REGIONAL DISTRIBUTION PATTERNS OF RED DEER BROWSING. (IN GERMAN). TRANS. CONGR. INT. UNION GAME BIOL. [ENGLISH SUMMARY] 19:411-413.

1242. DORN, R. D. 1969. RELATIONS OF MOOSE, CATTLE, AND WILLOWS IN SOUTHWESTERN MONTANA. M.S. THESIS, MONTANA STATE UNIVERSITY, BOZEMAN, MT. 79 PP.

1243. DORRANCE, M. J., P. J. SAVAGE and D. E. HUFF. 1975. EFFECTS OF SNOMMOBILES ON WHITE-TAILED DEER. JOURNAL OF WILDLIFE MANAGEMENT 39:563-569.

1244. DOSSANTOS, J. M. 1985. COMPARATIVE FOOD HABITS AND HABITAT SELECTIONS OF MOUNTAIN WHITEFISH AND RAINBOW TROUT IN KOOTENAI RIVER, MONTANA. M.S. THESIS, MONTANA STATE UNIVERSITY, BOZEMAN, MT. 68 PP.

1245. DOTY, H. A., F. B. LEE and A. D. KRUSE. 1975. USE OF ELEVATED NEST BASKETS BY DUCKS. WLDL. SOC. BULL. 3 (2):68-73

1246. DOUCET, G. J., J. P. R. SARRAZIN and J. R. BIDER. 1974. USE OF HIGHWAY OVERPASS EMBANKMENTS BY THE WOODCHUCK, MARMOTA MONAX. CANADIAN FIELD-NATURALIST. 88(2)

1247. DOUCETTE, J. E. and K. D. KIMBALL. 1990. PASSIVE TRAIL MANAGEMENT IN NORTHEASTERN ALPINE ZONES: A CASE STUDY. PAGES 195-201 IN T. A. MORE, M. P. DONNELLY, A. R. GRAEFE, AND J. J. VASKE, EDITORS. PROCEEDINGS OF THE 1990 NORTHEASTERN RECREATION RESEARCH SYMPOSIUM. U.S. DEPT. AGRICULTURE, FOREST SERV., NORTHEAST. FOR. EXP. STA., BROOMALL, PENNSYLVANIA.

1248. DOUGLAS, C. L. 1972. HIGHWAYS AND THEIR IMPACT ON THE WLDLIFE OF THE PINYON-JUNIPER-OAK WOODLAND AND GRASSLAND IN NORTH-CENTRAL ARIZONA. PRESCOTT COLLEGE ECOLOGICAL SURVEY, PRESCOTT, ARIZONA.

1249. DOUGLASS, K. S., J. HAMANN and G. JOSLIN. 1999. VEGETATION, SOILS, WATER. PAGES 9.1-9.11 IN G. JOSLIN AND H. YOUMANS, COORDINATORS. THE EFFECTS OF RECREATION ON ROCKY MOUNTAIN WILDLIFE: A REVIEW FOR MONTANA. COMMITTEE ON EFFECTS OF RECREATION ON WILDLIFE. MONTANA CHAPTER OF THE WLDLIFE SOCIETY. 307PP. 
1250. DOUGLASS, R. J. 1977. EFFECTS OF WINTER ROAD ON SMALL MAMMALS. JOURNAL OF APPLIED ECOLOGY $14(3): 827-834$.

1251. DOUGLASS, R. J. 1984. THE USE OF RODENTS IN MONITORING ECOLOGICAL IMPACTS OF OIL SHALE DEVELOPMENT IN THE PICEANCE BASIN, COLORADO. PAGES 70-75 IN R. D. COMER, J. M. MERINO, J. W. MONARCH, C. PUSTMUELLER, M. STALMASTER, R. STOECKER, J. TODD, AND W. WRIGHT, EDITORS. ISSUES AND TECHNOLOGY IN THE MANAGEMENT OF IMPACTED WESTERN WILDLIFE -- PROCEEDINGS OF A NATIONAL SYMPOSIUM. VOLUME TECH. PUBL. NO. 14. THORNE ECOL. INST., BOULDER, COLORADO.

1252. DOUGLASS, R. J., K. S. DOUGLASS and L. ROSSI. 1992. ECOLOGICAL DISTRIBUTION OF BANK VOLES AND WOOD MICE IN DISTURBED HABITATS: PRELIMINARY RESULTS. ACTA THERIOLOGICA 37 (4):359-70.

1253. DOUGLASS, R. J. and J. ERNST. 1986. IMPACTS OF VEHICLE TRAFFIC ON COYOTE MOVEMENT IN WESTERN COLORADO. PAGES 296-300 IN R. D. COMER, T. G. BAUMANN, P. DAVIS, J. W. MONARCH, J. TODD, S. VANGYTENBEEK, D. WILLS, AND J. WOODLING, EDITORS. PROCEEDINGS II. ISSUES AND TECHNOLOGY IN THE MANAGEMENT OF IMPACTED WESTERN WILDLIFE: PROCEEDINGS OF A NATIONAL SYMPOSIUM. THORNE ECOL. INST., BOULDER, COLORADO.

1254. DOUGLASS, R. J. 1973. SPATIAL INTERACTIONS AND MICRO-HABITAT SELECTIONS OF TWO LOCALLY SYMPATRIC VOLES, MICROTUS MONTANUS AND MICROTUS PENNSYLVANICUS. PH.D. DISSERTATION, MONTANA STATE UNIVERSITY, BOZEMAN, MT. 48 PP.

1255. DOVERS, S. R. and T. W. NORTON. 1994. TOWARD AN ECOLOGICAL FRAMEWORK FOR SUSTAINABILITY: CONSIDERATIONS FOR ECOSYSTEM MANAGEMENT. PACIFIC CONSERVATION BIOLOGY [VOL. UNKNOWN](4):283-293.

1256. DOW, S. A. 1952. AN EVALUATION OF SOME CRITERIA FOR AGE DETERMINATION OF THE PRONGHORN (ANTILOCAPRA AMERICANA ORD). M.S. THESIS, MONTANA STATE UNIVERSITY, MISSOULA, MT. 52 PP.

1257. DOWD, C. 1992. EFFECT OF DEVELOPMENT OF BIRD SPECIES COMPOSITION OF TWO URBAN FORESTED WETLANDS IN STATEN ISLAND, NEW YORK. JOURNAL OF FIELD ORNITHOLOGY 63 (4):455-61.

1258. DOWLER, R. C. and G. A. SWANSON. 1982. HIGH MORTALITY OF CEDAR WAXWINGS ASSOCIATED WITH HIGHWAY PLANTINGS. WILSON BULLETIN 94:602-603.

1259. DOWNES, S. J., K. A. ASYDE and M. A. ELGAR. 1997. THE USE OF CORRIDORS BY MAMMALS IN FRAGMENTED AUSTRALIAN EUCALYPT FORESTS. CONSERVATION BIOLOGY 11(3):718-726.

1260. DOWNING, D. C. 2000. SPAWNING AND REARING ECOLOGY OF MADISON RIVER RAINBOW TROUT IN RELATION TO WHIRLING DISEASE INFECTION RISK. M.S. THESIS, MONTANA STATE UNIVERSITY, BOZEMAN, MT. 65 PP.

1261. DOWNS, C. C. 1995. AGE DETERMINATION, GROWTH, FECUNDITY AGE AT SEXUAL MATURITY AND LONGEVITY FOR ISOLATED, HEADWATER POPULATIONS OF WESTSLOPE CUTTHROAT TROUT. M.S. THESIS, MONTANA STATE UNIVERSITY, BOZEMAN, MT. 81 PP.

1262. DOYLE, M. B. 1980. PROGRESS IN ORV PLANNING AND MANAGEMENT OF USDA MANAGED LANDS: SNOWMOBILE USER'S PERSPECTIVE. PAGES 183-187 IN R. N. L. ANDREWS AND P. F. NOWAK, EDITORS. OFF-ROAD VEHICLE USE: A MANAGEMENT CHALLENGE. U.S. DEPARTMENT OF AGRICULTURE, OFFICE OF ENVIRONMENTAL QUALITY, WASHINGTON D.C.

1263. DREW, G. S. 1994. THE SCIENTIFIC METHOD REVISITED. CONSERVATION BIOLOGY 8(2):596-7.

1264. DREWS, C. 1995. ROAD KILLS OF ANIMALS BY PUBLIC TRAFFIC IN MIKUMI NATIONAL PARK, TANZANIA, WITH NOTES ON BABOON MORTALITY. AFRICAN JOURNAL OF ECOLOGY 33:89-100.

1265. DREYER, W. A. 1935. THE QUESTION OF WLDLIFE DESTRUCTION BY THE AUTOMOBILE. SCIENCE 82:439-440.

1266. DRIESSEN, M. M., S. A. MALLICK and G. J. HOCKING. 1996. HABITAT OF THE EASTERN BARRED BANDICOOT, PERAMELES GUNNII, IN TASMANIA: AN ANALYSIS OF ROAD-KILLS. WLDLIFE RESEARCH 23:721-727. 
1267. DROLET, C. A. 1976. DISTRIBUTION AND MOVEMENTS OF WHITE-TAILED DEER IN SOUTHERN NEW BRUNSWICK IN RELATION TO ENVIRONMENTAL FACTORS. CANADIAN FIELD NATURALIST 90 (2):123-36.

1268. DRONKERT-EGNEW, A. E. 1991. RIVER OTTER POPULATION STATUS AND HABITAT USE IN NORTHWESTERN MONTANA. M.S. THESIS, UNIVERSITY OF MONTANA, MISSOULA, MT. 112 PP.

1269. DRUCKENMILLER, P.S. 1998. OSTEOLOGY AND RELATIONSHIPS OF A PLESIOSAUR (SAUROPTERYGIA) FROM THE THERMOPOLIS SHALE (LOWER CRETACEOUS) OF MONTANA. M.S. THESIS, MONTANA STATE UNIVERSITY, BOZEMAN, MT. 91 PP.

1270. DRUMMOND, F. 1989. FACTORS INFLUENCING ROAD MORTALITY OF KEY DEER. M.S. THESIS, SOUTHERN ILLINOIS UNIVERSITY, CARBONDALE, IL.

1271. DRYDEN, R. L. 1974. IMPACT ANALYSIS OF THE DEMPSTER HIGHWAY CULVERT ON THE PHYSICAL ENVIRONMENT AND FISH RESOURCES OF FROG CREEK. FISHERIES AND MARINE SERVICE, FISHERIES OPERATIONS DIRECTORATE, CENTRAL REGION, WINNIPEG, MANITOBA. TECHNICAL REPORT SERIES / CANADA, FISHERIES AND MARINE SERVICE, RESOURCE MANAGEMENT BRANCH, CENTRAL REGION: TECHNICAL REPORT SERIES (CANADA. FISHERIES AND MARINE SERVICE. CENTRAL REGION. RESOURCE MANAGEMENT BRANCH) CEN T-74-5.

1272. DRYDEN, R. L. and J. N. STEIN. 1975. GUIDELINES FOR THE PROTECTION OF THE FISH RESOURCES OF THE NORTHWEST TERRITORIES DURING HIGHWAY CONSTRUCTION AND OPERATION. TECHNICAL REPORT SERIES / RESOURCE MANAGEMENT BRANCH, CENTRAL REGION: TECHNICAL REPORT SERIES (CANADA. FISHERIES AND MARINE SERVICE. CENTRAL REGION. RESOURCE MANAGEMENT BRANCH) CEN T-75-1. FISHERIES AND MARINE SERVICE, OTTAWA, ONTARIO.

1273. DUBOIS, K. L. 1979. AN INVENTORY OF THE AVIFAUNA IN THE LONG PINES OF SOUTHEASTERN MONTANA. M.S THESIS, MONTANA STATE UNIVERSITY, BOZEMAN, MT. 113 PP.

1274. DUBROVSKII, V. Y. and A. V. BYKOV. 1990. CHANGE IN CLAYEY SEMI-DESERT RODENT FAUNA OF THE TRANSVOLGA REGION (RUSSIAN SFSR, USSR) ALONG RAILWAY TRACT. BIOLOGICHESKIE NAUKI (MOSCOW) 0 (11):67-73.

1275. DUDLEY, J. P., N. A. Y. MENSAH and D. G. KPELLE. 1992. FOREST ELEPHANTS IN A RAINFOREST FRAGMENT: PRELIMINARY FINDINGS FROM A WLDLIFE CONSERVATION PROJECT IN SOUTHERN GHANA. AFRICAN JOURNAL OF ECOLOGY $30(2): 116-26$.

1276. DUFTY, A. C. 1994. HABITAT AND SPATIAL REQUIREMENTS OF THE EASTERN BARRED BANDICOOT (PERAMELES GUNNII) AT HAMILTON, VICTORIA. WILDLIFE RESEARCH 21(4):459-72.

1277. DUFTY, A. C. 1994. POPULATION DEMOGRAPHY OF THE EASTERN BARRED BANDICOOT (PERAMELES GUNNII) AT HAMILTON, VICTORIA. WILDLIFE RESEARCH 21:445-457.

1278. DUFTY, A. C. 1991. SOME POPULATION CHARACTERISTICS OF PERAMELES GUNNII IN VICTORIA (AUSTRALIA). WILDLIFE RESEARCH 18 (3):355-66.

1279. DUIKER, V. E. 1952. BLOOD SUGAR RESPONSE OF THE GOLDEN HAMSTER (CRICETUS AURATUS) TO INTRAPERITONEAL ADMINISTRATION OF ALLOXAN . M.S. THESIS, MONTANA STATE COLLEGE, BOZEMAN, MT. 27 PP.

1280. DUNCAN, E. A. 1975. THE ECOLOGY OF CURL-LEAF MOUNTAIN MAHOGANY (CERCOCARPUS LEDIFOLIUS NUTT.) IN SOUTHWESTERN MONTANA WITH SPECIAL REFERENCE TO USE BY MULE DEER. M.S. THESIS, MONTANA STATE UNIVERSITY, BOZEMAN, MT. 87 PP.

1281. DUNFORD, R. D. and R. B. OWEN. 1973. SUMMER BEHAVIOR OF IMMATURE RADIO-EQUIPPED WOODCOCK IN CENTRAL MAINE. J. WILDL. MANAGE. 37 (4):462-9.

1282. DUNFORTH, A. A. and F. P. ERRINGTON. 1964. CASUALTIES AMONG BIRDS ALONG A SELECTED ROAD IN WILTSHIRE. BIRD STUDY 11:168-182.

1283. DUNN, C. P., F. STEARNS, G. R. GUNTENSPERGEN and D. M. SHARPE. 1993. ECOLOGICAL BENEFITS OF THE CONSERVATION RESERVE PROGRAM. CONSERVATION BIOLOGY 7 (1):132-9. 
1284. DUNN, D. R. 1971. TRENDS IN SNOWMOBILE AND OFF-THE-ROAD VEHICLE LEGISLATION: EFFECTS ON USE AND ENVIRONMENTAL IMPACT. PAGES 164-169 IN SNOWMOBILE AND OFF THE ROAD VEHICLE RESEARCH SYMPOSIUM, PROC.

1285. DUNN, D. R. 1970. MOTORIZED RECREATION VEHICLES...ON BORROWED TIME. PARKS AND RECREATION 5:10-14, 46-52.

1286. DUNN, P. O. and S. J. HANNON. 1992. EFFECTS OF FOOD ABUNDANCE AND MALE PARENTAL CARE ON REPRODUCTIVE SUCCESS AND MONOGAMY IN TREE SWALLOWS. AUK109 (3):488-99.

1287. DUNNELL, C. W. 1980. PROTECTING AND REHABILITATING ORV USE AREAS. PAGES 100-102 IN OFF-ROAD VEHICLE USE: A MANAGEMENT CHALLENGE. MICH. EXT. SERV. 348PP.

1288. DURAN, V. and F. DEVILLEZ. 1995. IMPACT STUDY OF MOTORWAY AND RAILWAY PLANS: METHODOLOGICAL APPROACH ON FOREST VEGETATION AND HEDGES. BELGIAN JOURNAL OF BOTANY 128 (1):106-16.

1289. DURNER, G. M. and J. E. GATES. 1993. SPATIAL ECOLOGY OF BLACK RAT SNAKES ON REMINGTON FARMS, MARYLAND. JOURNAL OF WILDLIFE MANAGEMENT 57 (4):812-26.

1290. DUSEK, G. L. 1980. AN INVENTORY OF VEGETATION, WLDLIFE AND RECREATIONAL RESOURCES OF THE LONG PINES, MONTANA. FINAL REPT. USFWS, OFFICE OF BIOL. SERV.

1291. DUSEK, G. L. 1971. RANGE RELATIONSHIPS OF MULE DEER IN THE PRAIRIE HABITAT, NORTHCENTRAL MONTANA. M.S. THESIS, MONTANA STATE UNIVERSITY, BOZEMAN, MT. 63 PP.

1292. DWERNYCHUK, L. W. and D. A. BOAG. 1972. HOW VEGETATIVE COVER PROTECTS DUCK NESTS FROM EGG-EATING BIRDS. J. WILDL. MANAGE. 36 (3):955-8.

1293. DWYER, N. C. and G. W. TANNER. 1992. NESTING SUCCESS IN FLORIDA SANDHILL CRANES. WILSON BULLETIN 104:22-31.

1294. EALEY, D. M. and D. F. PENNER. 1984. HANLAN-ROBB GAS PLANT UNGULATE DISTURBANCE STUDY, 1980-1984: SUMMARY REPORT. PREPARED FOR GULF CANADA RESOURCES INC.; PREPARED BY MCCOURT MANAGEMENT LTD, CALGARY. UNPUBLISHED REPORT.

1295. EASON, G. 1989. MOOSE RESPONSE TO CUTTING AND 1 KM 2 BLOCK CUTTING. ALCES 25:63-74.

1296. EASON, G. 1989. TITLE UNKNOWN. ALCES 25:63-74.

1297. EASON, G. W. JR. and J. E. FAUTH. 1996. PATTERNS OF DIVERSITY: THE INFLUENCE OF ROADS AND FIREBREAKS ON THE DECLINING AMPHIBIAN POPULATION. BULLETIN OF THE SOUTH CAROLINA ACADEMY OF SCIENCE 58:90-94.

1298. EASTER-PILCHER, A. L. 1987. FORAGE UTILIZATION, HABITAT SELECTION, AND POPULATION INDICES OF BEAVER IN NORTHWESTERN MONTANA. M.S. THESIS, UNIVERSITY OF MONTANA, MISSOULA, MT. 88 PP.

1299. EASTER-PILCHER, A. L. 1993. ANALYSIS OF THE LISTING OF SPECIES AS ENDANGERED OR THREATENED UNDER THE ENDANGERED SPECIES ACT. PH.D. DISSERTATION, MONTANA STATE UNIVERSITY, BOZEMAN, MT. 196 PP.

1300. EBERHARDT, L. E., R. G. ANTHONY and W. H. RICKARD. 1989. MOVEMENT AND HABITAT USE BY GREAT BASIN CANADA GOOSE BROODS. J. WILDL. MANAGE. 53 (3):740-8.

1301. EBERHARDT, L. E., R. A. GARROTT and W. C. HANSON. 1983. DEN USE BY ARCTIC FOXES IN NORTHERN ALASKA. JOURNAL OF MAMMALOGY. 64(1)

1302. EBERHARDT, L. E., R. A. GARROTT and W. C. HANSON. 1983. WINTER MOVEMENTS OF ARCTIC FOXES, ALOPEX LAGOPUS, IN A PETROLEUM DEVELOPMENT AREA. THE CANADIAN FIELD-NATURALIST. 97(1) 
1303. EBERHARDT, L. E., W. C. HANSON, J. L. BENGTSON, R. A. GARROTT and E. E. HANSON. 1982. ARCTIC FOX HOME RANGE CHARACTERISTICS IN AN OIL-DEVELOPMENT AREA. J. WLDL. MANAGE. 46 (1):183-90

1304. EBERSOLE, J. J. 1985. VEGETATION DISTURBANCE AND RECOVERY AT THE OUMALIK OIL WELL, ARCTIC COASTAL PLAIN, ALASKA. DISSERTATION, UNIVERSITY OF COLORADO, BOULDER, COLORADO. 448PP.

1305. EBERT, D. W. 1993. DESERT BIGHORN MOVEMENTS AND HABITAT USE IN RELATION TO THE PROPOSED BLACK CANYON BRIDGE PROJECT, NEVADA (OVIS CANADENSIS). MS THESIS, UNIVERSITY OF NEVADA, LAS VEGAS. 184 PP.

1306. EBERT, P. N. RECENT CHANGES IN OREGON'S MULE DEER POPULATION AND MANAGEMENT. PROC. WEST. ASSOC. GAME AND FISH COMMISSIONERS 56:408-14.

1307. EBY, J. R. and L. R. BRIGHT. 1985. A DIGITAL GIS BASED ON LANDSAT AND OTHER DATA FOR ELK HABITAT EFFECTIVENESS ANALYSIS. P 855-64. IN: PROCEEDINGS-OF-THE-NINETEENTH-INTERNATIONAL-SYMPOSIUM-ON-REMOTE-SENSING-OF-ENVIRONMENT. VOLUME 2.

1308. ECCLES, R., G. SEARING, J. DUNCAN and C. THOMPSON. 1985. WILDLIFE MONITORING STUDIES ALONG THE NORMAN WELLS-ZAMA OIL PIPELINE, JANUARY - MARCH 1985. LGL LIMITED, ENVIRONMENTAL RESEARCH ASSOCIATES, CALGARY, ALBERTA. PREPARED FOR INTERPROVINCIAL PIPE LINE (NW) LIMITED. 7OPP.

1309. ECCLES, T. R. and J. A. DUNCAN. 1987. WILDLIFE MONITORING STUDIES ALONG THE NORMAN WELLS TO ZAMA OIL PIPELINE, NOVEMBER 1984 TO MAY 1987. NORMAN WELLS PIPE LINE PROJECT. INTERPROVINCIAL PIPE LINE (NW) LTD, EDMONTON, ALBERTA.

1310. ECCLES, T. R. and J. A. DUNCAN. 1986. WLDLIFE MONITORING STUDIES ALONG THE NORMAN WELLS-ZAMA OIL PIPELINE, APRIL 1985 TO MAY 1986. LGL LIMITED, ENVIRONMENTAL RESEARCH ASSOCIATES, CALGARY, ALBERTA. PREPARED FOR INTERPROVINCIAL PIPE LINE (NW) LIMITED. 48PP.

1311. ECCLES, T. R., G. E. HORNBECK and G. M. GOULET. 1991. REVIEW OF WOODLAND CARIBOU ECOLOGY AND IMPACTS FROM OIL AND GAS EXPLORATION AND DEVELOPMENT. DELTA ENVIRONMENTAL MANAGEMENT GROUP LIMITED. 51PP.

1312. ECHO, J. B. 1954. SOME ECOLOGICAL RELATIONSHIPS BETWEEN THE YELLOW PERCH, TROUT, AND OTHER FISH IN THOMPSON LAKES, MONTANA. M.S. THESIS, MONTANA STATE COLLEGE, BOZEMAN, MT. 20 PP.

1313. ECKSTEIN, R. G., T. F. O'BRIEN, O. J. RONGSTAD and J. G. BOLLINGER. 1979. SNOWMOBILE EFFECTS ON MOVEMENTS OF WHITE-TAILED DEER: A CASE-STUDY. ENVIRONMENTAL CONSERVATION 6(1):45-51.

1314. EDDY, T. A. 1986. MITIGATING WILDLIFE HABITAT LOSSES ON FEDERAL RESERVOIR CAMPSITES. PAGES 303 IN R. D. COMER, G. T. BAUMANN, P. DAVIS, J. W. MONARCH, J. TODD, S. VANGYTENBEEK, D. WLLS, AND J. WOODLING, EDITORS. PROCEEDINGS II. ISSUES AND TECHNOLOGY IN THE MANAGEMENT OF IMPACTED WESTERN WILDLIFE: PROCEEDINGS OF A NATIONAL SYMPOSIUM. THORNE ECOL. INST., BOULDER, COLORADO.

1315. EDGE, W. D. and C. L. MARCUM. 1989. DETERMINING ELK DISTRIBUTION WITH PELLET-GROUP AND TELEMETRY TECHNIQUES. J. WILDL. MANAGE. 53 (3):621-4.

1316. EDGE, W. D. and C. L. MARCUM. 1985. MOVEMENTS OF ELK IN RELATION TO LOGGING DISTURBANCES. J. WILDL. MANAGE. 49 (4):926-30.

1317. EDGE, W. D., C. L. MARCUM and S. L. OLSON. 1985. EFFECTS OF LOGGING ACTIVITIES ON HOME-RANGE FIDELITY OF ELK. J. WILDL. MANAGE. 49 (3):741-4.

1318. EDGE, W. D., S. L. OLSON-EDGE and L. L. IRWIN. 1990. PLANNING FOR WILDLIFE IN NATIONAL FORESTS: ELK AND MULE DEER HABITATS AS AN EXAMPLE. WILDLIFE SOCIETY BULLETIN 18:87-98.

1319. EDGE, W. D. 1982. DISTRIBUTION, HABITAT USE AND MOVEMENTS OF ELK IN RELATION TO ROADS AND HUMAN DISTURBANCE IN WESTERN MONTANA. THESIS, UNIVERSITY OF MONTANA, MISSOULA, MONTANA, USA. 
1320. EDGE, W. D. 1982. DISTRIBUTION, HABITAT USE AND MOVEMENTS OF ELK IN RELATION TO ROADS AND HUMAN DISTURBANCES IN WESTERN MONTANA. M.S. THESIS, UNIVERSITY OF MONTANA, MISSOULA, MT. 98 PP.

1321. EDGE, W. D. 1985. HABITAT USE AND FOOD HABITS OF ELK IN WESTERN MONTANA: A MULTIVARIATE APPROACH. DISSERTATION, UNIVERSITY OF MONTANA, MISSOULA, MONTANA. 75PP.

1322. EDGE, W. D. and C. L. MARCUM. 1991. TOPOGRAPHY AMELIORATES THE EFFECTS OF ROADS AND HUMAN DISTURBANCE ON ELK. PAGES 132-137 IN A. G. CHRISTENSEN, L. J. LYON, AND T. N. LONNER, COMPILERS. PROCEEDINGS OF THE ELK VULNERABILITY SYMPOSIUM. MONTANA STATE UNIVERSITY, BOZEMAN, MONTANA.

1323. EDGE, W. D., C. L. MARCUM and S. L. OLSON-EDGE. 1987. SUMMER HABITAT SELECTION BY ELK IN WESTERN MONTANA: A MULTIVARIATE APPROACH. JOURNAL OF WILDLIFE MANAGEMENT 51:844-851.

1324.

EDMONDS, E. J. and M. BLOOMFIELD. 1984. A STUDY OF WOODLAND CARIBOU(RANGIFER TARANDUS CARIBOU) IN WEST CENTRAL ALBERTA, 1979 TO 1983. ALBERTA ENERGY AND NAT. RESOUR., FISH AND WILDL. DIV., EDMONTON. 203PP.

1325. EDMONDS, E. J., K. SMITH, R. WYNES and R. QUINLAN. 1991. A MANAGEMENT PROGRAM TO RESTORE CARIBOU POPULATIONS IN WEST-CENTRAL ALBERTA. P 210-7.IN:BUTLER CE, MAHONEY SP, EDS. 4TH NORTH AMERICAN CARIBOU WORKSHOP PROC.; OCT31-NOV 3 1989; ST. JOHN'S, NEWFOUNDLAND. NEWFOUNDLAND AND LABRADOR WILDLIFE DIV.

1326.

EDMONDS, J. and D. HOBSON. 1995. EFFECTIVENESS OF MITIGATION PROGRAMS IMPLEMENTED TO DECREASE VEHICLE-RELATED MORTALITY OF WOODLAND CARIBOU IN WEST CENTRAL ALBERTA. NATURAL RESOURCES SERVICE, FISH AND WILDLIFE, EDSON, ALBERTA.

1327. EDMONDS, J. A. 1986. DRAFT RESTORATION PLAN FOR WOODLAND CARIBOU IN ALBERTA. ALBERTA FORESTRY, LANDS, AND WLDLIFE, FISH AND WILDLIFE DIVISION, EDMONTON. 74PP.

1328.

1331.

1332.

1334. 1335.

EDWARDS I. J. 1977. THE ECOLOGICAL IMPACT OF PEDESTRIAN TRAFFIC ON ALPINE VEGETATION IN KOSKIUSKO NATIONAL PARK. AUSTRALIAN FORESTRY 40:108-120.

EDWARDS, J. M. 1977. A SURVEY OF BIG GAME ANIMALS ON A PROPOSED STRIP MINING SITE AT SARPY CREEK IN SOUTHEASTERN MONTANA. M.S. THESIS, MONTANA STATE UNIVERSITY, BOZEMAN, MT. 63 PP.

EDWARDS, O. M. 1979. VEGETATION DISTURBANCE BY NATURAL FACTORS AND VISITOR IMPACT IN THE ALPINE ZONE OF MOUNT RAINIER NATIONAL PARK: IMPLICATIONS FOR MANAGEMENT. PAGES 101-106 IN R. ITTNER, D. R. POTTER, J. K. AGEE, AND S. ANSCHELL, EDITORS. RECREATIONAL IMPACT ON WILDLANDS. VOLUME R-6-001-1979. USDA FOREST SERVICE AND USDI NATIONAL PARK SERVICE, WASHINGTON D.C.

EDWARDS, R. W. and F. M. SLATER. 1981. IMPACT OF ROAD DEATHS ON WILDLIFE CONSERVATION. NAT WALES 17:153-156.

EDWARDS, R. Y. 1956. SNOW DEPTHS AND UNGULATE ABUNDANCE IN THE MOUNTAINS OF WESTERN CANADA. J. WILDL. MANAGE. 20 (2):159-68.

EGAN, E. S. and M. C. BRITTINGHAM. 1994. WINTER SURVIVAL RATES OF A SOUTHERN POPULATION OF BLACK-CAPPED CHICKADEES. WILSON BULLETIN 106 (3):514-21.

EGAN, J. L. 1958. SOME RELATIONSHIPS BETWEEN MULE DEER AND ALFALFA PRODUCTION IN POWDER RIVER COUNTY, MONTANA. M.S. THESIS, MONTANA STATE COLLEGE, BOZEMAN, MT. 34 PP.

EHMANN, H. and H. G. COGGER. 1985. AUSTRALIA'S ENDANGERED HERPETOFAUNA: A REVIEW OF CRITERIA AND POLICIES. PAGES 435-447 IN G. GRIGG, R. SHINE, AND H. EHMANN, EDITORS. THE BIOLOGY OF AUSTRALASIAN FROGS AND REPTILES. SURREY BEATTY AND SONS, SYDNEY

EHRLICH, R. M. and L. C. DRICKAMER. 1993. HABITATS USED FOR NESTING BY COOPER'S HAWKS (ACCIPITER COOPERII) IN SOUTHERN ILLINOIS. TRANSACTIONS OF THE ILLINOIS STATE ACADEMY OF SCIENCE 86 $(1-2): 51-62$. 
1337. EIDE, S. H., S. D. MILLER and M. A. CHIHULY. 1986. OIL PIPELINE CROSSING SITES UTILIZED IN WINTER BY MOOSE (ALCES ALCES), AND BY CARIBOU (RANGIFER TARANDUS), IN SOUTHCENTRAL ALASKA. CAN. FIELD-NAT. 100 (2):197-207.

1338. EINARSEN, A. S. 1937. EDUCATIONAL PHASES OF CONSERVATION RESEARCH. TRANS. N. AMER. WLDL. NAT. RESOUR. CONF. 2:119-125.

1339. EISLER, R. 1991. CYANIDE HAZARDS TO FISH, WILDLIFE, AND INVERTEBRATES: A SYNOPTIC REVIEW. U S FISH AND WILDLIFE SERVICE BIOLOGICAL REPORT85 (123):I-III, 1-55.

1340. EISNER, S. A. 1991. BALD EAGLES WINTERING ALONG THE COLUMBIA RIVER IN SOUTHCENTRAL WASHINGTON: FACTORS INFLUENCING DISTRIBUTION AND CHARACTERISTICS OF PERCH AND ROOST TREES. M.S. THESIS, UNIVERSITY OF MONTANA, MISSOULA, MT. 58 PP.

1341. ELGMORK, K. 1978. HUMAN IMPACT ON A BROWN BEAR POPULATION. BIOLOGICAL CONSERVATION 13 (2):81-103

1342. ELGMORK, K. 1974. A REMNANT BROWN BEAR POPULATION IN SOUTHERN NORWAY AND PROBLEMS OF ITS CONSERVATION. INT. CONF. BEAR RES. AND MANAGE. 3:281-97.

1343. ELGMORK, K. 1978. HUMAN IMPACT ON A BROWN BEAR POPULATION (URSUS ARCTOS L.). BIOLOGICAL CONSERVATION 13:81-103.

1344. ELKINGTON, J. B. 1977. THE IMPACT OF DEVELOPMENT PROJECTS ON ESTUARINE AND OTHER WETLAND ECOSYSTEMS. ENVIRONMENTAL CONSERVATION 4:135-144.

1345. ELLIG, L. J. 1953. WATERFOWL RELATIONSHIPS TO GREENFIELDS LAKE, TETON COUNTY, MONTANA. M.S. THESIS, MONTANA STATE COLLEGE, BOZEMAN, MT. 49 PP.

1346. ELLIS, D. H. 1973. DEVELOPMENT OF BEHAVIOR IN THE GOLDEN EAGLE. WILDLIFE MONOGRAPHS 70:1-94.

1347. ELLIS, J. A., W. R. EDWARDS and K. P. THOMAS. 1969. RESPONSES OF BOBWHITES TO MANAGEMENT IN ILLINOIS. J. WILDL. MANAGE. $33(4): 749-62$.

1348. ELLIS, R. I. 1965. MOVEMENTS AND CONCENTRATIONS OF MARKED ELK ON THE WINTER RANGE (NORTHERN YELLOWSTONE ELK HERD). M.S. THESIS, UNIVERSITY OF MONTANA, MISSOULA, MT. 93 PP.

1349. ELLISON, L. N. 1974. POPULATION CHARACTERISTICS OF ALASKAN SPRUCE GROUSE. J. WLDL. MANAGE. 38 (3):383-95.

1350. ELLSWORTH, J. C. 1989. ASSESSING WETLAND VISUAL QUALITY: COMPARATIVE APPROACHES AND MANAGEMENT IMPLICATIONS. PAGES 97-103 IN URBAN WETLANDS: PROCEEDINGS OF THE NATIONAL WETLANDS SYMPOSIUM. ASSOCIATION OF WETLAND MANAGERS, BERNE, NEWYORK.

1351. ELMORK, K. 1978. HUMAN IMPACT ON THE BROWN BEAR POPULATION (URSUS ARCTOS). BIOLOGICAL CONSERVATION 13:81-103.

1352. ELOWE, K. D. 1987. FACTORS AFFECTING BLACK BEAR REPRODUCTIVE SUCCESS AND CUB SURVIVAL IN MASSACHUSETTS. PHD THESIS, UNIVERSITY OF MASSACHUSETTS. 84 PP.

1353. ELOWE, K. D. and W. E. DODGE. 1989. FACTORS AFFECTING BLACK BEAR REPRODUCTIVE SUCCESS AND CUB SURVIVAL. J. WLDL. MANAGE. 53 (4):962-8.

1354. ELSER, A. A. 1967. FISH POPULATIONS OF A TROUT STREAM IN RELATION TO MAJOR HABITAT ZONES AND CHANNEL ALTERATIONS. M.S. THESIS, MONTANA STATE UNIVERSITY, BOZEMAN, MT. 27 PP.

1355. ELTRINGHAM, S. K. 1990. WILDLIFE CARRYING CAPACITIES IN RELATION TO HUMAN SETTLEMENT. KOEDOE 33:87-97.

1356. EMANUELSSON, U. 1985. RECREATION IMPACT ON MOUNTAINOUS AREAS IN NORTHERN SWEDEN. PAGES 63-73 IN N. G. BAYFIELD AND G. C. BARROW, EDITORS. THE ECOLOGICAL IMPACTS OF OUTDOOR RECREATION ON MOUNTAIN AREAS IN EUROPE AND NORTH AAAERICA. RECREATION ECOLOGY RESEARCH GROUP, WYE, 
ASHFORD, KENT, UK.

1357. EMERSON, R., D. MYRICK, G. NIELSON, J. REUSS, D. STUART, A. WLLIAMS and J. JEZESKI. 1973. IMPACTS OF LARGE RECREATIONAL DEVELOPMENTS UPON SEMI-PRIMITIVE ENVIRONMENTS. MT STATE UNIV., BOZEMAN., 92 PP.

1358. EMLEN, J. M., D. C. FREEMAN, M. B. BAIN and LI J. 1992. INTERACTION ASSESSMENT II: A TOOL FOR POPULATION AND COMMUNITY MANAGEMENT. J. WILDL. MANAGE. 56 (4):708-17.

1359. ENDERSON, J. H. 1974. STATUS OF THE PEREGRINE FALCON IN THE ROCKY MOUNTAINS IN 1973. AUK 91:727-736.

1360. ENDICOTT, C. L. 1996. RESPONSES OF RIPARIAN AND STREAM ECOSYSTEMS TO VARYING TIMING AND INTENSITY OF LIVESTOCK GRAZING IN CENTRAL MONTANA. M.S. THESIS, MONTANA STATE UNIVERSITY, BOZEMAN, MT. 115 PP.

1361. ENDRESS, R. C. 1967. HIGHWAY COORDINATION. ARIZ. GAME AND FISH DEPT. FED. AID REPORT PROJ. FW-16-R-6:49-53.

1362. ENG, R. L. 1952. A TWO-SUMMER STUDY OF THE EFFECTS ON BIRD POPULATIONS OF CHLORDANE BAIT AND ALDRIN SPRAY AS USED FOR GRASSHOPPER CONTROL. M.S. THESIS, MONTANA STATE COLLEGE, BOZEMAN, MT. 27 PP.

1363. ENGEL, E. and C. BRESSANUTTI. 1993. FUNCTIONALITY OF A NEW PROTECTION SITE FOR AMPHIBIANS IN THE KEHLEN TOWNSHIP. BULLETIN DE LA SOCIETE DES NATURALISTES LUXEMBOURGEOIS 1993:121-127.

1364. ENGELS, T. M. and C. W. SEXTON. 1994. NEGATIVE CORRELATION OF BLUE JAYS AND GOLDEN-CHEEKED WARBLERS NEAR AN URBANIZING AREA. CONSERVATION BIOLOGY 8(1):286-90.

1365. ENGLAND, A. S., J. A. ESTEP and W. R. HOLT. 1995. NEST SITE SELECTION AND REPRODUCTIVE PERFORMANCE OF URBAN NESTING SWAINSON'S HAWKS IN THE CENTRAL VALLEY OF CALIFORNIA. JOURNAL OF RAPTOR RESEARCH 29:179-186.

1366. ENGLAND, K. 1993. IDEAS ON OFF-HIGHWAY VEHICLE MANAGEMENT. CLEMSON UNIVERSITY, PROFESSIONAL DEVELOPMENT FOR OUTDOOR RECREATION MANAGEMENT PROGRAM. 1-24

1367. ENGLISH NATURE, PETERBOROUGH (GB). 1996. THE SIGNIFICANCE OF SECONDARY EFFECTS FROM ROADS AND ROAD TRANSPORT ON NATURE CONSERVATION.

1368. ENK, T. A. 1999. POPULATION DYNAMICS OF BIGHORN SHEEP ON THE BEARTOOTH WILDLIFE AREA, MONTANA. PH.D. DISSERTATION, MONTANA STATE UNIVERSITY, BOZEMAN, MT. 177 PP.

1369. ENOKSSON, B., P. ANGELSTAM and K. LARSSON. 1995. DECIDUOUS FOREST AND RESIDENT BIRDS: THE PROBLEM OF FRAGMENTATION WITHIN A CONIFEROUS FOREST LANDSCAPE. LANDSCAPE ECOLOGY 10 (5):267-75.

1370. ENSIGN, J. T. 1983. NEST SITE SELECTION, PRODUCTIVITY, AND FOOD HABITS OF FERRUGINOUS HAWKS IN SOUTHEASTERN MONTANA. M.S. THESIS, MONTANA STATE UNIVERSITY, BOZEMAN, MT. 85 PP.

1371. ENVIRONMENT PROTECTION BOARD, G. W. CALEF and CANADIAN ARCTIC GAS PIPELINE LIMITED. 1973. TOWARDS AN ENVIRONMENTAL IMPACT ASSESSMENT OF THE PORTION OF THE MACKENZIE GAS PIPELINE FROM ALASKA TO ALBERTA. INTERIM REPORT - ENVIRONMENT PROTECTION BOARD ; NO. 3: INTERIM REPORT (ENVIRONMENT PROTECTION BOARD) NO. 3. ENVIRONMENT PROTECTION BOARD, WINNIPEG, MANITOBA.

1372. ENVIRONMENTAL PROTECTION AGENCY. 1991. NONROAD ENGINE AND VEHICLE EMISSION STUDY - REPORT. OFFICE OF AIR AND RADIATION, U.S. ENVIRONMENTAL PROTECTION AGENCY. WASHINGTON, D.C. EPA 21A-2001.

1373. ENVIRONMENTAL, R. M. 1996. THE SIGNIFICANCE OF SECONDARY EFFECTS FROM ROADS AND ROAD TRANSPORT ON NATURE CONSERVATION. ENGLISH NATURE RESEARCH REPORT NO. 178 [VOL. UNKNOWN]:

1374. ERICKSON, G. L. 1972. THE ECOLOGY OF ROCKY MOUNTAIN BIGHORN SHEEP IN THE SUN RIVER AREA OF MONTANA WITH SPECIAL REFERENCE TO SUMMER FOOD HABITS AND RANGE MOVEMENTS . M.S. THESIS, MONTANA 
STATE UNIVERSITY, BOZEMAN, MT. 50 PP.

1375. ERICKSON, P. A., G. CAMOUGIS and E. J. ROBBINS. 1978. HIGHWAYS AND ECOLOGY: IMPACT ASSESSMENT AND MITIGATION. FHWA/RWE/OEP78/2. NEW ENGLAND RESEARCH, INC., WORCHESTER, MA.

1376. ERICSON, J. E. 1983. AERIAL PHOTO CENSUSING OF SANDHILL CRANES: DISTRIBUTIONAL EFFECTS OF INTERSTATE 80. PROCEEDINGS OF THE NORTH DAKOTA ACADEMY OF SCIENCE 37:105-108.

1377. ERWIN, R. M. 1980. BREEDING BIRD HABITAT USE BY TWO COLONIALLY NESTING WATERBIRDS IN TWO MID-ATLANTIC U.S. REGIONS UNDER DIFFERENT REGIMES OF HUMAN DISTURBANCE. BIOL. CONSERV. 18 (39-51).

1378. ERWIN, R. M. 1980. BREEDING HABITAT USE BY COLONIALLY NESTING WATERBIRDS IN TWO MID-ATLANTIC U.S. REGIONS UNDER DIFFERENT REGIMES OF HUMAN DISTURBANCE. BIOLOGICAL CONSERVATION 18:39-51.

1379. ERWIN, R. M. 1989. RESPONSES TO HUMAN INTRUDERS BY BIRDS NESTING IN COLONIES: EXPERIMENTAL RESULTS AND MANAGEMENT GUIDELINES. COLONIAL WATERBIRDS 12:104-108.

1380. ESHBAUGH, E. J. 1998. THE PHYTOCHROME GENE FAMILY IN LEGUMES (FABACEAE): EVIDENCE FOR A NEW LOCUS AND ANALYSIS OF EVOLUTIONARY RATES. M.S. THESIS, MONTANA STATE UNIVERSITY, BOZEMAN, MT. 66 PP.

1381. ESMOIL, B. J. and S. H. ANDERSON. 1995. WLDLIFE MORTALITY ASSOCIATED WITH OIL PITS IN WYOMING. PRAIRIE NATURALIST 27:81-88.

1382. ESPELAND, D. M. 1981. RABBIT RETINAL GLIAL CELLS AT THE VASCULAR AND INTERNAL LIMITING MEMBRANES : AN ELECTRON MICROSCOPIC STUDY USING EXTRACELLULAR STAINS AND TRACERS . M.S. THESIS, MONTANA STATE UNIVERSITY, BOZEMAN, MT. 88 PP.

1383. ESPMARK, Y. and R. LANGVATN. 1985. DEVELOPMENT AND HABITUATION OF CARDIAC AND BEHAVIORAL RESPONSES IN YOUNG RED DEER CALVES (CERVUS ELAPHUS) EXPOSED TO ALARM STIMULI. JOURNAL OF MAMMALOGY 66:702-711.

1384. ESTES, J. A., D. O. DUGGINS and G. B. RATHBUN. 1989. THE ECOLOGY OF EXTINCTIONS IN KELP FOREST COMMUNITIES. CONSERVATION BIOLOGY 3 (3):252-64.

1385. ESTES, R. D. and J. GODDARD. 1967. PREY SELECTION AND HUNTING BEHAVIOR OF THE AFRICAN WILD DOG. J. WILDL. MANAGE. 31 (1):52-70.

1386. ESTRADA, A., E. R. COATES and D. J. MERITT. 1993. BAT SPECIES RICHNESS AND ABUNDANCE IN TROPICAL RAIN FOREST FRAGMENTS AND IN AGRICULTURAL HABITATS AT LOS TUXTLAS, MEXICO. ECOGRAPHY 16 (4):309-18.

1387. ESTRADA, A., E. R. COATES and D. J. MERITT. 1994. NON FLYING MAMMALS AND LANDSCAPE CHANGES IN THE TROPICAL RAIN FOREST REGION OF LOS TUXTLAS, MEXICO. ECOGRAPHY 17 (3):229-41.

1388. ESTRADA, J. and X. RIERA. 1996. HIGH MORTALITY OF HIRUNDINIDAE ON ROADS IN AND AROUND THE EBRO DELTA IN SPRING 1992. BUTLLETI DEL GRUP CATALA D'ANELLAMENT 2:17-22.

1389. ETCHBERGER, R. C., P. R. KRAUSMAN and R. MAZAIKA. 1989. MOUNTAIN SHEEP HABITAT CHARACTERISTICS IN THE PUSCH RIDGE WILDERNESS, ARIZONA. J. WILDL. MANAGE.53 (4):902-7.

1390. EUSTACE, C. D. 1967. FOOD HABITS, RANGE USE AND RELATIONSHIPS BETWEEN ELK AND LIVESTOCK IN THE GRAVELY MOUNTAINS, MONTANA. M.S. THESIS, MONTANA STATE UNIVERSITY, BOZEMAN, MT. 55 PP.

1391. EVANS, D. L. 1982. STATUS REPORTS ON TWELVE RAPTORS. U.S. FISH AND WILDIFE SERVICE. WASHINGTON, D.C. SPECIAL SCIENTIFIC REPORT - WILDLIFE NO. 238.

1392. EVANS, H. F. 1960. A PRELIMINARY INVESTIGATION OF CARIBOU IN NORTHWESTERN UNITED STATES. M.S. THESIS, MONTANA STATE UNIVERSITY, MISSOULA, MT. 145 PP. 
1393. EVANS, L. C. 1983. IMPACT ASSESSMENT AND MITIGATION PLANNING WITH HABITAT EVALUATION MODELS.

1394. EVANS, R. D. and C. W. JR. WOLFE. 1967. WATERFOWL PRODUCTION IN THE RAINWATER BASIN AREA OF NEBRASKA. J. WILDL. MANAGE. 31 (4):788-94.

1395. EVANS, T. R., E. H. SMITH and J. GRIEB. 1954. A PROPOSED BLUE PRINT FOR UPLAND GAME HABITAT DEVELOPMENT EVALUATION PROJECTS. (PRES) GREAT PLAINS HABITAT CONF., HUTCHINSON, KS, SEPT 27, 28, $29 ., 16$ PP.

1396. EVDS. 1984. A REVIEW OF THE BANFF HIGHWAY PROJECT. PROJECT FOR THE COURSE IMPACT ASSESSMENT, EVDS 649. FACULTY OF ENVIRONMENT DESIGN, UNIVERSITY OF CALGARY, CALGARY

1397. EVENDEN, F. G. 1971. ANIMAL ROAD KILLS. ATL.NAT 26:36-37.

1398. EVERSMAN, S. T. 1968. A COMPARISON OF PLANT COMMUNITIES AND SUBSTRATES OF AVALANCHE AND NON-AVALANCHE AREAS IN SOUTH-CENTRAL MONTANA. M.S. THESIS, MONTANA STATE UNIVERSITY, BOZEMAN, MT. 39 PP.

1399. EVINK, G. 1998. ECOLOGICAL HIGHWAYS. PAGES 253-257 IN EVINK, G., ZIEGLER,D., GARRETT,P., AND BERRY,J., EDITORS. PROCEEDINGS OF THE INTERNATIONAL CONFERENCE ON WILDLIFE ECOLOGY AND TRANSPORTATION; 1998 FEBRUARY 10-12; FT. MYERS, FL FLORIDA DEPARTMENT OF TRANSPORTATION, TALLAHASSEE, FL.

1400. EVINK, G., D. ZIEGLER, P. GARRETT and J. BERRY. 1996. HIGHWAYS AND MOVEMENTS OF WILDLIFE: IMPROVING HABITAT CONNECTIONS AND WILDLIFE PASSAGEWAYS ACROSS HIGHWAY CORRIDORS. PROCEEDINGS OF THE FLORIDA DEPARTMENT OF TRANSPORTATION/FEDERAL HIGHWAY ADMINISTRATION TRANSPORTATION-RELATED WILDLIFE MORTALITY SEMINAR. U.S.DEPT. TRANSPORTATION, FEDERAL HIGHWAY ADMIN., WASHINGTON, D.C.

1401. EVINK, G. L. 1996. FLORIDA DEPARTMENT OF TRANSPORTATION INITIATIVES RELATED TO WILDLIFE MORTALITY. IN: GARY L. EVINK, PAUL GARRETT, DAVID ZEIGLER, AND JON BERRY, EDS. TRENDS IN ADDRESSING TRANSPORTATION RELATED WLDLIFE MORTALITY: PROCEEDINGS OF THE TRANSPORTATION RELATED WILDLIFE MORTALITY SEMINAR. FL-ER-58-96. STATE OF FLORIDA, DEPT. TRANSPORT., ENVIRON. MANAGE. OFF., TALLAHASSEE.

1402. EVINK, G. L. 1996. FLORIDA DEPARTMENT OF TRANSPORTATION INITIATIVES RELATED TO WILDLIFE MORTALITY. REPORT FROM THE ENVIRONMENTAL MANAGEMENT OFFICE. FLORIDA DEPARTMENT OF TRANSPORTATION , ORLANDO, FL.

1403. EVINK, G. L., D. ZIEGLER, P. GARRETT and J. BERRY. 1996. TRANSPORTATION AND WLDLIFE: REDUCING WILDLIFE MORTALITY AND IMPROVING WILDLIFE PASSAGEWAYS ACROSS TRANSPORTATION CORRIDORS: PROCEEDINGS OF THE FLORIDA DEPARTMENT OF TRANSPORTATION/FEDERAL HIGHWAY ADMINISTRATION TRANSPORTATION-RELATED WILDLIFE MORTALITY SEMINAR; 1996 APRIL 30-MAY 2; ORLANDO, FL. FHWA-PD-96-041. U.S. DEPARTMENT OF TRANSPORTATION, FEDERAL HIGHWAY ADMINISTRATION, WASHINGTON, DC.

1404. EVINK, G. 1998. 1998 INTERNATIONAL CONFERENCE: WILDLIFE ECOLOGY AND TRANSPORTATION. WRAP-UP SESSION: RECOMMENDATIONS FOR THE FUTURE. PAGES 258-259 IN EVINK,G., ZIEGLER,D., GARRETT,P., AND BERRY,J., EDITORS. PROCEEDINGS OF THE INTERNATIONAL CONFERENCE ON WILDLIFE ECOLOGY AND TRANSPORTATION; 1998 FEBRUARY 10-12; FT. MYERS, FL FLORIDA DEPARTMENT OF TRANSPORTATION, TALLAHASSEE, FL.

1405. EVINK, G., D. ZIEGLER, P. GARRETT and J. BERRY. 1996. PROCEEDING OF THE FLORIDA DEPARTMENT OF TRANSPORTATION/FEDERAL HIGHWAY ADMINISTRATION TRANSPORTATION-RELATED WLDLIFE MORTALITY SEMINAR. HIGHWAYS AND MOVEMENT OF WILDLIFE: IMPROVING HABITAT CONNECTIONS AND WILDLIFE PASSAGEWAYS ACROSS HIGHWAY CORRIDORS. U.S.DEPT. TRANSPORTATION, FEDERAL HIGHWAY ADMIN., WASHINGTON, D.C.

1406. EVINK, G. L. 1999. INTERNATIONAL CONFERENCE ON WILDLIFE ECOLOGY AND TRANSPORTATION: PROCEEDINGS OF THE INTERNATIONAL CONFERENCE ON WILDLIFE ECOLOGY AND TRANSPORTATION FEBRUARY 10-12, 1998, FORT MYERS, FLORIDA. U.S. DEPT. OF TRANSPORTATION, FEDERAL HIGHWAY ADMINISTRATION, WASHINGTON, D.C.

1407. EVINK, G. L., P. GARRETT, D. ZEIGLER and J. BERRY. 1998. PROCEEDINGS OF THE INTERNATIONAL CONFERENCE ON

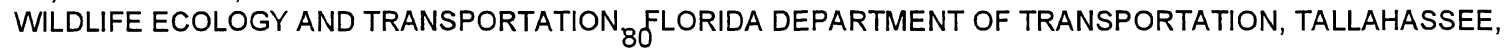


FLORIDA.

1408. EXECUTIVE ORDER 11644. 1972. USE OF OFF-ROAD VEHICLES ON THE PUBLIC LANDS. FEDERAL REGISTER 37:2877-2878 (FEBRUARY 9, 1972).

1409. FAANES, C. A. 1987. BIRD BEHAVIOR AND MORTALITY IN RELATION TO POWER LINES IN PRAIRIE HABITATS. U.S. FISH AND WILDLIFE SERVICE.

1410. FABOS, J. G. and J. AHERN. 1996. GREENWAYS THE BEGINNING OF AN INTERNATIONAL MOVEMENT. ELSEVIER, AMSTERDAM, NEW YORK.

1411. FACCIO, S. D. 1992. ACTIVITY PATTERNS AND HABITAT SELECTION OF REINTRODUCED FISHERS IN NORTHWEST CONNECTICUT. MS THESIS, SOUTHERN CONNECTICUT STATE UNIVERSITY. 61 PP.

1412. FAFARMAN, K. R. and R. J. WHYTE. 1979. FACTORS INFLUENCING NIGHTTIME ROADSIDE COUNTS OF COTTONTAIL RABBITS. J. WLDL. MANAGE. 43 (3):765-7.

1413. FAGEN, J. M. and R. FAGEN. 1994. BEAR-HUMAN INTERACTIONS AT PACK CREEK, ALASKA. INT. CONF. BEAR RES. AND MANAGE. 9:109-14.

1414. FAGEN, R. and J. FAGEN. 1990. PLAY BEHAVIOR OF BROWN BEARS (URSUS ARCTOS) AND HUMAN PRESENCE AT PACK CREEK, ADMIRALTY ISLAND, ALASKA. INT. CONF. BEAR RES. AND MANAGE. 8:315-9.

1415. FAGER, C. W. 1991. HARVEST DYNAMICS AND WINTER HABITAT USE OF THE PINE MARTEN IN SOUTHWEST MONTANA. M.S. THESIS, MONTANA STATE UNIVERSITY, BOZEMAN, MT. 73 PP.

1416. FAHEY, B. D. and R. J. COKER. 1989. FOREST ROAD EROSION IN THE GRANITE TERRAIN OF SOUTHWEST NELSON, NEW ZEALAND. JOURNAL OF HYDROLOGY(WELLINGTON NORTH) 28 (2):123-41.

1417. FAHEY, B. D. and R. J. COKER. 1992. SEDIMENT PRODUCTION FROM FOREST ROADS IN QUEEN CHARLOTTE FOREST AND POTENTIAL IMPACT ON MARINE WATER QUALITY, MARLBOROUGH SOUNDS, NEW ZEALAND. NEW ZEALAND JOURNAL OF MARINE AND FRESHWATER RESEARCH 26 (2):187-95.

1418. FAHRIG, L. and G. MERRIAM. 1994. CONSERVATION OF FRAGMENTED POPULATIONS. CONSERVATION BIOLOGY 8 (1):50-9..

1419. FAHRIG, L. and G. MERRIAM. 1985. HABITAT PATCH CONNECTIVITY AND POPULATION SURVIVAL. ECOLOGY 66:1762-1768.

1420. FAHRIG, L., J. H. PEDLAR, S. E. POPE, P. D. TAYLOR and J. F. WEGNER. 1995. EFFECT OF ROAD TRAFFIC ON AMPHIBIAN DENSITY. BIOLOGICAL CONSERVATION 73(3):177-182.

1421. FAIRMAN, L. L. 1966. MOVEMENTS, POPULATIONS, AND BEHAVIOR OF DEER ON A WESTERN MONTANA WINTER RANGE. M.S. THESIS, UNIVERSITY OF MONTANA, MISSOULA, MT.

1422. FALK, K. and S. MOLLER. 1988. STATUS OF THE PEREGRINE FALCON IN SOUTH GREENLAND: POPULATION DENSITY AND REPRODUCTION. PAGES 37-43 IN T. J. CADE, J. H. ENDERSON, C. G. THELANDER, AND C. M. WHITE, EDITORS. PEREGRINE FALCON POPULATIONS: THEIR MANAGEMENT AND RECOVERY. THE PEREGRINE FUND INC. BOISE, IDAHO. 949PP.

1423. FALK, N. W. 1975. FENCING AS A DETERRENT TO DEER MOVEMENT ALONG HIGHWAYS. PH.D. DISSERTATION, PENNSYLVANIA STATE UNIVERSITY, UNIVERSITY PARK, PA.

1424. FALK, N. W., H. B. GRAVES and E. D. BELLIS. 1978. HIGHWAY RIGHT-OF-WAY FENCES AS DEER DETERRENTS. JOURNAL OF WILLIFE MANAGEMENT 42:646-650.

1425. FAMINOW, C. W. 1993. NATIVE PRAIRIE RESTORATION ALONG TRANSMISSION LINE CORRIDORS IN SOUTHERN MANITOBA: A PLANNING FRAMEWORK. MNRM THESIS, THE UNIVERSITY OF MANITOBA. 151PP. ENVIRONMENTAL SCIENCES (0768). 
1426. FANCY, S. G. 1981. THE INFLUENCE OF INSECTS ON THE RESPONSES OF CARIBOU TO OIL DRILLING OPERATIONS.

1427. FANCY, S. G. 1983. MOVEMENTS AND ACTIVITY BUDGETS OF CARIBOU NEAR OIL DRILLING SITES IN THE SAGAVANIRKTOK RIVER FLOODPLAIN, ALASKA. ARCTIC 36(2):193-7.

1428. FANCY, S. G. 1982. REACTION OF BISON TO AERIAL SURVEYS IN INTERIOR ALASKA. CANADIAN FIELD-NATURALIST 96:91.

1429. FANCY, S. G., K. R. WHITTEN and D. E. RUSSELL. DEMOGRAPHY OF THE PORCUPINE CARIBOU HERD: 1983-1992. CAN. J. ZOOLOGY IN PRESS .

1430. FANCY, S. G. and R. G. WHITE. 1986. PREDICTING ENERGY EXPENDITURES FOR ACTIVITIES OF CARIBOU FROM HEART RATES. RANGIFER SPEC. ISSUE 1:123-130.

1431. FANCY, S. G. and R. G. WHITE. 1985. ENERGY EXPENDITURES BY CARIBOU WHILE CRATERING IN SNOW. JOURNAL OF WILDLIFE MANAGEMENT 49:987-993.

1432. FARDOE, B. K. 1982. AN EVALUATION OF BACKCOUNTRY HORSE USE AND RECREATION IMPACT IN THE PROPOSED KAKWA PROVINCIAL PARK. MASTERS OF ENVIRONMENTAL DESIGN PROJECT. UNIVERSITY OF CALGARY, CALGARY

1433. FARQUHARSON, E. 1986. RING ROADS AND BADGERS. EDINBURGH NATURAL HISTORY SOCIETY JOURNAL 1986:21-22.

1434. FASOLA, M., E. BENUSSI and T. BINO. 1997. ABANDONED BUILDINGS INCREASE NEST DENSITY OF RED-RUMPED SWALLOWS HIRUNDO DAURICA IN KARAVASTA AREA, ALBANIA. ALAUDA 65:279-281.

1435. FAVRE, D. S. 1991. WILLIFE LAW. 2ND ED. CASEBOOK SERIES: CASEBOOK SERIES (DETROIT, MICH.). LUPUS PUBLICATIONS, DETROIT, MICHIGAN.

1436. FEARNSIDE, P. M. 1987. DEFORESTATION AND INTERNATIONAL ECONOMIC DEVELOPMENT PROJECTS IN BRAZILIAN AMAZONIA. CONSERVATION BIOLOGY 1 (3):214-21.

1437. FEARNSIDE, P. M. and GABRIEL DE LIMA FERREIRA. 1984. ROADS IN RONDONIA: HIGHWAY CONSTRUCTION AND THE FARCE OF UNPROTECTED RESERVES IN BRAZIL'S AMAZONIAN FOREST. ENVIRONMENTAL CONSERVATION 11(4):358-360.

1438. FEDERAL REGISTER. 1998. ADMINISTRATION OF THE FOREST DEVELOPMENT TRANSPORTATION SYSTEM: MANAGEMENT REGULATIONS REVISION AND TEMPORARY SUSPENSION OF ROAD CONSTRUCTION IN ROADLESS AREAS; PROPOSED RULES. PART II, U.S. DEPARTMENT OF AGRICULTURE, FOREST SERVICE, 36 CFR PART 212 JANUARY 23, 1998:4349-4354.

1439. FEHLBERG, U. 1994. ECOLOGICAL BARRIER EFFECTS OF MOTORWAYS ON MAMMALIAN WILDLIFE. DTW (DEUTSCHE TIERAERZTLICHE WOCHENSCHRIFT) 101 (3):125-9.

1440. FEHLBERG, U. 1994. ECOLOGICAL BARRIER EFFECTS OF MOTORWAYS ON MAMMALIAN WILDLIFE - AN ANIMAL PROTECTION PROBLEM. DEUTSCHE TIERARZTLICHE WOCHENSCHRIFT $101: 125-129$ [IN GERMAN] .

1441. FEIGHLEY, H. P. 1981. STUDIES ON NATIVE SMALL MAMMALS AS INTERMEDIATE HOSTS OF ECHINOCOCCUS MULTILOCULARIS. M.S. THESIS, MONTANA STATE UNIVERSITY, BOZEMAN, MT. 50 PP.

1442. FEIST, F. G. 1968. BREEDING BIRD POPULATIONS IN RELATION TO PROPOSED SAGEBRUSH CONTROL IN CENTRAL MONTANA. M.S. THESIS, MONTANA STATE UNIVERSITY, BOZEMAN, MT. 41 PP.

1443. FELDHAMMER, G., J. GATES, D. HARMAN, A. LORANGER and K. DIXON. 1986. EFFECTS OF INTERSTATE HIGHWAY FENCING ON WHITE-TAILED DEER ACTIVITY. JOURNAL OF WILDLIFE MANAGEMENT 50(3):497-503.

1444. FELDMANN, R. and A. GEIGER. 1989. PROTECTION FOR AMPHIBIANS ON ROADS IN NORDRHEIN-WESTPHALIA. PAGES 51-57 IN LANGTON,T.E.S., EDITOR. AMPHIBIANS AND ROADS. PROCEEDINGS OF THE TOAD TUNNEL CONFERENCE; 1989 JANUARY 7-8; RENDSBURG, FEDERAL REPUBLIC OF GERMANY. ACO POLYMER 
PRODUCTS LTD., SHEFFORD, ENGLAND.

1445. FELIX, N. A., M. K. RAYNOLDS, J. C. JORGENSON and K. E. DUBOIS. 1992. RESISTANCE AND RESILIENCE OF TUNDRA PLANT COMMUNITIES TO DISTURBANCE BY WINTER SEISMIC VEHICLES. ARCTIC ALPINE RES. 24:69-77.

1446. FELLEY, D. L. 1995. RECRUITMENT AND SURVIVAL OF RING-NECKED PHEASANTS ON THE NAMPA STUDY AREA IN SOUTHWESTERN IDAHO. M.S. THESIS, UNIVERSITY OF MONTANA, MISSOULA, MT. 72 PP.

1447. FENTON, M. B., L. ACHARYA, D. AUDET, M. B. C. HICKEY, C. MERRIMAN, M. K. OBRIST, D. M. SYME and B. ADKINS. 1992. PHYLLOSTOMID BATS (CHIROPTERA: PHYLLOSTOMIDAE) AS INDICATORS OF HABITAT DISRUPTION IN THE NEOTROPICS. BIOTROPICA 24 (3):440-6.

1448. FERGUSON, M. A. D. 1980. UNGULATES AND CROSS-COUNTRY SKIING, ELK ISLAND NATIONAL PARK, ALBERTA. M.S. THESIS. UNIVERSITY OF WISCONSIN, MADISON, W.

1449. FERGUSON, M. A. D. and L. B. KEITH. 1982. INFLUENCE OF NORDIC SKIING ON DISTRIBUTION OF MOOSE AND ELK IN ELK ISLAND NATIONAL PARK, ALBERTA. CANADIAN FIELD NATURALIST 96:69-78.

1450. FERGUSON, T. C. 1994. EVALUATION OF A DOUBLE-SAMPLE POPULATION ESTIMATION TECHNIQUE ON ELK INHABITING SPRING RANGE IN WEST-CENTRAL IDAHO. M.S. THESIS, MONTANA STATE UNIVERSITY, BOZEMAN, MT. 79 PP.

1451. FERNANDEZ, C. 1993. THE CHOICE OF NESTING CLIFFS BY GOLDEN EAGLES AQUILA CHRYSAETOS: THE INFLUENCE OF ACCESSIBILITY AND DISTURBANCE BY HUMANS. ALAUDA 61 (2):105-10.SITE ORIENTATION/ WEATHER SPAIN.

1452. FERNANDEZ, C. and P. AZKONA. 1993. HUMAN DISTURBANCE AFFECTS PARENTAL CARE OF MARSH HARRIERS AND NUTRITIONAL STATUS OF NESTLINGS. J. WILDL. MANAGE. 57(3):602-8.

1453. FERNET, D. A. 1981. FISHERY RESOURCE INVESTIGATIONS ALONG THE ALASKA HIGHWAY GAS PIPELINE IN SOUTHERN YUKON TERRITORY, 1980. FOOTHILLS PIPE LINES (SOUTH YUKON). ENVIRONMENTAL SERVICES. FOOTHILLS PIPE LINES (SOUTH YUKON) LTD, CALGARY, ALBERTA.

1454. FERRARI, M. J. 1999. AN ASSESSMENT OF THE RISK OF INTERSPECIFIC TRANSMISSION OF BRUCELLA ABORTIS FROM BISON TO ELK ON THE MADISON-FIREHOLE WINTER RANGE. M.S. THESIS, MONTANA STATE UNIVERSITY, BOZEMAN, MT. 43 PP.

1455. FERRER, M. and M. HARTE. 1997. HABITAT SELECTION BY IMMATURE SPANISH IMPERIAL EAGLES DURING THE DISPERSAL PERIOD. JOURNAL OF APPLIED ECOLOGY 34(6):1359-1364.

1456. FERRER, M. and F. HIRALDO. 1991. EVALUATION OF MANAGEMENT TECHNIQUES FOR THE SPANISH IMPERIAL EAGLE. WILDL. SOC. BULL. $19(4): 436-42$.

1457. FERRER, M. and F. HIRALDO. 1992. MAN-INDUCED SEX-BIASED MORTALITY IN THE SPANISH IMPERIAL EAGLE. BIOLOGICAL CONSERVATION 60 (1):57-60.

1458. FERRERAS, P., J. J. ALDAMA, J. F. BELTRAN and M. DELIBES. 1992. RATES AND CAUSES OF MORTALITY IN A FRAGMENTED POPULATION OF IBERIAN LYNX FELIS PARDINA TEMMINCK, 1824. BIOLOGICAL CONSERVATION 61 (3):197-202.

1459. FERRIS, C. R. 1974. EFFECTS OF HIGHWAYS ON RED-TAILED HAWKS AND SPARROW HAWKS. M.S. THESIS, WEST VIRGINIA UNIVERSITY, MORGANTOWN.

1460. FERRIS, C. R. 1977. EFFECTS OF INTERSTATE 95 ON SONGBIRDS AND WHITE-TAILED DEER IN NORTHERN MAINE. M.S. THESIS, UNIVERSITY OF MAINE, ORONO, ME.

1461. FERRIS, C. R. 1979. EFFECTS OF THE INTERSTATE 95 ON BREEDING BIRDS IN NORTHERN MAINE. J. WILDL. MANAGE. 43 (2):421-7. 
1462. FERRIS, C. R., D. S. PALMAN and V. B. RICHENS. 1978. ECOLOGICAL IMPACT OF INTERSTATE 95 ON BIRDS AND MAMMALS IN NORTHERN MAINE, INTERIM REPORT 1975-77. TECH. REP. 77-12. MAINE DEPARTMENT OF TRANSPORTATION, MATERIALS RESEARCH DIVISION, BANGOR, ME.

1463. FERRIS, C. R. 1979. EFFECTS OF INTERSTATE 95 ON BREEDING BIRDS IN NORTHERN MAINE. JOURNAL OF WLDLIFE MANAGEMENT 43:421-427.

1464. FERRIS, R. M. and M. J. KUTILEK. 1989. RESPONSES OF BLACK-TAILED DEER TO OFF-HIGHWAY VEHICLES IN HOLLISTER HILLS STATE VEHICULAR RECREATION AREA HOLLISTER, CA. SAN JOSE STATE UNIVERSITY, DEPARTMENT OF BIOLOGICAL SCIENCES. SAN JOSE, CALIFORNIA, USA. 42PP.

1465. FEUCHTER, R. 1980. OFF-ROAD VEHICLE USE: THE U.S. FOREST SERVICE PERSPECTIVE. PAGES $148-155$ IN R. N. L. ANDREWS AND P. F. NOWAK, EDITORS. OFF-ROAD VEHICLE USE: A MANAGEMENT CHALLENGE .

1466. FIALKA, J. 1975. RUNNING WILD. NATIONAL WILDLIFE 13:36-40.

1467. FIMBEL, C. 1994. ECOLOGICAL CORRELATES OF SPECIES SUCCESS IN MODIFIED HABITATS MAY BE DISTURBANCEAND SITE-SPECIFIC: THE PRIMATES OF TIWAI ISLAND. CONSERVATION BIOLOGY 8 (1):106-13.

1468. FINDLAY, C. S. and J. HOULAHAN. 1997. ANTHROPOGENIC CORRELATES OF SPECIES RICHNESS IN SOUTHEASTERN ONTARIO WETLANDS. CONSERVATION BIOLOGY 11(4):1000-1009.

1469. FINK, R. J. 1995. THE NATURAL RESOURCES LAW MANUAL. SONREEL, SECTION OF NATURAL RESOURCES, ENERGY, AND ENVIRONMENTAL LAW, AMERICAN BAR ASSOCIATION, CHICAGO, ILLINOIS.

1470. FINNIS, R. G. 1960. ROAD CASUALTIES AMONG BIRDS. BIRD STUDY 7:21-32.

1471. FIREBAUGH, J. E. 1969. RELATIONSHIP OF MULE DEER TO LIVESTOCK ON SUMMER RANGE IN THE PRYOR MOUNTAINS, MONTANA. M.S. THESIS, MONTANA STATE UNIVERSITY, BOZEMAN, MT. 55 PP.

1472. FISCHER, C. and L. B. KEITH. 1974. POPULATION RESPONSES OF CENTRAL ALBERTA RUFFED GROUSE TO HUNTING. J. WILDL. MANAGE. 38 (4):585-600.

1473. FISHER, H. 1966. NATURAL BEAUTY AND THE ADMINISTRATION OF NATURAL RESOURCES. TRANS. N. AMER. WILDL. NAT. RESOUR. CONF. 31:26-33.

1474. FISHER, H. I., R. W. HIATT and W. BERGESON. 1947. THE VALIDITY OF THE ROADSIDE CENSUS AS APPLIED TO PHEASANTS. J. WILDL. MANAGE. 11 (3):205-26.

1475. FISHER, P. W. 1980. COMPARATIVE GENETICS OF RAINBOW TROUT FROM THE GEOTHERMALLY HEATED FIREHOLE RIVER, WYOMING. M.S. THESIS, MONTANA STATE UNIVERSITY, BOZEMAN, MT. 50 PP.

1476. FISK, E. J. 1975. LEAST TERN: BELEAGUERED, OPPORTUNISTIC, AND ROOF-NESTING. AMERICAN BIRDS 29:15-16.

1477. FITCH, L., H. VRIEND and E. GASSER. 1984. ABANDONED RAILROAD RIGHTS-OF-WAY IN THE SOUTHERN REGION AN ASSESSMENT. ALBERTA ENERGY AND NATURAL RESOURCES, FISH AND WILDLIFE DIVISION, .

1478. FITE, E. C. 1979. RESIDUES OF LEAD, MERCURY, AND ORGANOCHLORINEPESTICIDES IN WHISTLING SWANS, 1973. M.S. THESIS, UNIVERSITY OF MONTANA, MISSOULA, MT. 63 PP.

1479. FLAA, J. 1989. TRANS-CANADA HIGHWAY: PHASE IIIB WILDLIFE STUDY. REPORT TO BANFF NATIONAL PARK WARDEN SERVICE. BANFF NATIONAL PARK WARDEN SERVICE, BANFF, AB.

1480. FLAA, J. 1989. WILDLIFE STUDY, TRANS CANADA HIGHWAY, PHASE IIIB. PARKS CANADA, CALGARY. UNPUBLISHED REPORT.

1481. FLADE, M. and R. MANN. 1991. POPULATION TRENDS, MIGRATION PATTERNS AND BREEDING SUCCESS OF PASSERINES IN THE DUEPEN AREA NEAR WOLFSBURG: RESULTS OF16 YEARS RINGING WORK. VOGELWELT $112(5): 184-212$. 
1482. FLATH, D. L. 1970. REPRODUCTIVE SUCCESS OF CANADA GEESE IN THE BITTERROOT VALLEY, MONTANA. M.S. THESIS, UNIVERSITY OF MONTANA, MISSOULA, MT. 61 PP.

1483. FLATHEAD NATIONAL FOREST. 1975. USDA FOREST SERVICE ENVIRONMENTAL STATEMENT DRAFT, OIL \& GAS LEASE APPLICATIONS, EXPLORATION \& DEVELOPMENT. USDA, FOREST SERVICE.

1484. FLATHEAD NATIONAL FOREST. 1976. USDA FOREST SERVICE ENVIRONMENTAL STATEMENT FINAL, OIL \& GAS LEASE APPLICATIONS, EXPLORATION \& DEVELOPMENT. USDA, FOREST SERVICE.

1485. FLATHER, C. H. and J. R. SAUER. 1996. USING LANDSCAPE ECOLOGY TO TEST HYPOTHESES ABOUT LARGE-SCALE ABUNDANCE PATTERNS IN MIGRATORY BIRDS. ECOLOGY (WASHINGTON DC) 77 (1):28-35.

1486. FLETCHER, R. 1980. TITLE UNKNOWN. FOR. RES. WEST. 5-7.

1487. FLETEMEYER, J. R. 1991. THE NESTING IMPERATIVE: CONFLICTS BETWEEN HUMANS AND SEA TURTLES ON SOUTHEAST FLORIDA BEACHES. DISSERTATION, FLORIDA INTERNATIONAL UNIVERSITY, MIAMI, FLORIDA. 281PP.

1488. FLEURY, A. M. 1994. A FRAMEWORK FOR THE DESIGN OF WILDLIFE CONSERVATION CORRIDORS. MLA THESIS, UNIVERSITY OF GUELPH (CANADA) . 104 PP.

1489. FLOOK, D. R. 1964. RANGE RELATIONSHIPS OF SOME UNGULATES NATIVE TO BANFF AND JASPER NATIONAL PARKS, ALBERTA. P 119-28. IN: GRAZING IN TERRESTRIAL ENVIRONMENTS. LONDON: BLACKWELLS SCIENTIFIC PUBL.

1490. FLORIDA DEPARTMENT OF TRANSPORTATION. 1992. REPORT ON THE ANIMAL CROSSING STUDY. FLORIDA DEPARTMENT OF TRANSPORTATION, ENVIRONMENTAL MANAGEMENT OFFICE , TALLAHASSEE, FL.

1491. FLYGARE, H. 1978. SECTION B: TRANS-CANADA HIGHWAY EAST GATE TO BANFF/YOHO BOUNDARY, 19641977. PARKS CANADA, BANFF NATIONAL PARK WARDEN SERVICE , BANFF, ALBERTA.

1492. FLYGARE, H. 1978. SECTION C: UNGULATE CENSUS IN THE BOW VALLEY CORRIDOR - WINTER 1976-77. PARKS CANADA, BANFF NATIONAL PARK WARDEN SERVICE , BANFF, ALBERTA.

1493. FLYGARE, H. 1978. SECTION D: UNGULATE FORAGING AREAS IN THE BOW VALLEY CORRIDOR. PARKS CANADA, BANFF NATIONAL PARK WARDEN SERVICE , BANFF, ALBERTA.

1494. FLYGARE, H. 1978. SECTION E: TRANS-CANADA HIGHWAY WLDLIFE CROSSINGS, 1964-77. PARKS CANADA, BANFF NATIONAL PARK WARDEN SERVICE , BANFF, ALBERTA.

1495. FLYGARE, H. 1979. SECTION F, HIGHWAY-WLDLIFE RELATIONSHIPS: AN ANNOTATED BIBLIOGRAPHY. PARKS CANADA, BANFF NATIONAL PARK WARDEN SERVICE , BANFF, ALBERTA.

1496. FLYGARE, H. 1976. TRANS CANADA HIGHWAY ROCKY MOUNTAIN BIGHORN SHEEP VEHICLE MORTALITY. $1965-1975$. BANFF NATIONAL PARK, PARKS CANADA, CALGARY. UNPUBLISHED REPORT.

1497. FLYGARE, H. 1976. TRANS-CANADA HIGHWAY ROCKY MOUNTAIN BIGHORN SHEEP VEHICLE MORTALITY. UNPUBLISHED REPORT. BANFF NATIONAL PARK, BANFF, ALBERTA.

1498. FLYGARE, H. 1979. UNGULATE MORTALITY AND MITIGATED MEASURES - TRANS-CANADA HIGHWAY, BANFF NATIONAL PARK. PARKS CANADA, BANFF NATIONAL PARK WARDEN SERVICE, BANFF, ALBERTA

1499. FLYGARE, H. 1979. UNGULATE MORTALITY AND MITIGATIVE MEASURES, TRANS CANADA HIGHWAY, BANFF NATIONAL PARK, EAST GATE TO SUNSHINE TURNOFF. BANFF NATIONAL PARK, PARKS CANADA, CALGARY. UNPUBLISHED REPORT. 168PP.

1500. FLYGARE, H. 1919. UNGULATE TRAILS AND CROSSING AREAS, TRANS-CANADA HIGHWAY KM'S 13-27. UNPUBL.REPT.

1501. FLYGARE, H. 1977. WLDLIFE MORTALITY STATISTICS, HIGHWAY AND RAILROAD. BANFF NATIONAL PARK, $1964-1976$. BANFF NATIONAL PARK, PARKS CANADA, CALGARY. UNPUBLISHED REPORT. 
1502. FLYGARE, H. 1978. WILDLIFE MORTALITY STATISTICS HIGHWAYS AND RAILROAD, 1964-1977. BANFF NATIONAL PARK, PARKS CANADA, CALGARY. UNPUBLISHED REPORT.

1503. FLYGARE, H. 1978. WILDLIFE MORTALITY STATISTICS, SECTIONS A AND F. PARKS CANADA, BANFF NATIONAL PARK WARDEN SERVICE , BANFF, ALBERTA.

1504. FLYGARE, H. 1978. WLDLIFE MORTALITY STATISTICS, TRANS-CANADA HIGHWAY. PARKS CANADA, BANFF NATIONAL PARK WARDEN SERVICE , BANFF, ALBERTA.

1505. FLYGARE, H. 1978. WLDLIFE MORTALITY STUDY, SECTIONS A TO E, BANFF NATIONAL PARK. BANFF NATIONAL PARK, PARKS CANADA, CALGARY. UNPUBLISHED REPORT.

1506. FLYGARE, H. 1977. WILDLIFE MORTALITY STUDY, TRANS-CANADA HIGHWAY. PROGRESS REPORT. PARKS CANADA, BANFF NATIONAL PARK, BANFF, ALBERTA.

1507. FLYNN, R. W. 1983. DISTRIBUTION, STATUS AND FEEDING ECOLOGY OF THE SUMATRAN RHINOCEROS IN PENINSULA-MALAYSIA. M.S. THESIS, UNIVERSITY OF MONTANA, MISSOULA, MT. 186 PP.

1508. FOGELSONG, M. L. 1974. EFFECTS OF FLUORIDES ON PEROMYSCUS MANICULATUS IN GLACIER NATIONAL PARK. M.S. THESIS, MONTANA STATE UNIVERSITY, BOZEMAN, MT. 52 PP.

1509. FOLLMANN, E. H. 1989. THE IMPORTANCE OF ADVANCE PLANNING TO MINIMIZE BEAR-PEOPLE CONFLICTS DURING LARGE SCALE INDUSTRIAL AND TRANSPORTATION DEVELOPMENTS IN THE NORTH. PAGES 105-110 IN M. BROMLEY, EDITOR. BEAR-PEOPLE CONFLICTS: PROCEEDINGS OF A SYMPOSIUM ON MANAGEMENT STRATEGIES. NORTHWEST TERRITORIES DEPT. RENEW. RESOUR., YELLOWKNIFE.

1510. FOLLMANN, E. H. and J. L. HECHTEL. 1990. BEARS AND PIPELINE CONSTRUCTION IN ALASKA. ARCTIC 43:103-109.

1511. FONDELL, T. F. 1997. NEST DENSITY AND NEST SUCCESS OF GROUND-NESTING GRASSLAND BIRDS RELATIVE TO GRAZING IN WESTERN MONTANA. M.S. THESIS, UNIVERSITY OF MONTANA, MISSOULA, MT. 51 PP.

1512. FOOTHILLS PIPE LINES (SOUTH YUKON) LTD. 1981. ADDENDA TO THE ENVIRONMENTAL IMPACT STATEMENT FOR THE YUKON SECTION OF THE ALASKA HIGHWAY GAS PIPELINE. FOOTHILLS PIPE LINES (SOUTH YUKON) LTD, WHITEHORSE YUKON; CALGARY, ALBERTA.

1513. FOOTHILLS PIPE LINES (SOUTH YUKON) LTD. 1977-1978. ENVIRONMENTAL IMPACT STATEMENT FOR THE ALASKA HIGHWAY GAS PIPELINE PROJECT ANNEXES. THE COMPANY, WHITEHORSE, YUKON.

1514. FOOTHILLS PIPE LINES (SOUTH YUKON) LTD. 1981. THE ENVIRONMENTAL IMPACT STATEMENT FOR THE YUKON SECTION OF THE ALASKA HIGHWAY GAS PIPELINE ADDENDUM. FOOTHILLS PIPE LINES (SOUTH YUKON) LTD, WHITEHORSE, YUKON.

1515. FOOTHILLS PIPE LINES (YUKON) LTD and BEAK CONSULTANTS. 1980. SUMMARY OF FISHERIES INVESTIGATIONS OF NEW CROSSING LOCATIONS, ALASKA HIGHWAY GAS PIPELINE, YUKON TERRITORY, 1979. BEAK CONSULTANTS LTD, CALGARY, ALBERTA.

1516. FOPPEN, R. and R. REIJNEN. 1994. THE EFFECTS OF CAR TRAFFIC ON BREEDING BIRD POPULATIONS IN WOODLAND. II. BREEDING DISPERSAL OF MALE WILLOW WARBLERS (PHYLLOSCOPUS TROCHILUS) IN RELATION TO THE PROXIMITY OF A HIGHWAY. JOURNAL OF APPLIED ECOLOGY 31:95-101.

1517. FORAN, B. and WARDLE K. 1995. TRANSITIONS IN LAND USE AND THE PROBLEMS OF PLANNING: A CASE STUDY FROM THE MOUNTAINLANDS OF NEW ZEALAND. J. ENVIRON. MANAGE. 43:97-127.

1518. FORBES, B. C. 1992. TUNDRA DISTURBANCE STUDIES, I: LONG-TERM EFFECTS OF VEHICLES ON SPECIES RICHNESS AND BIOMASS. ENVIRONMENTAL CONSERVATION 19:48-58.

1519. FORBES, G. J. and J. B. THEBERGE. 1995. INFLUENCES OF A MIGRATORY DEER HERD ON WOLF MOVEMENTS AND MORTALITY IN AND NEAR ALGONQUIN PARK, ONTARIO. P 303-13.IN: CARBYN LN, FRITTS SH, SEIP DR (EDS.). ECOLOGY AND MANAGEMENT OF WOLVES IN A CHANGING WORLD. OCCAS. PUBL. NO. 35. , CANADIAN CIRCUMPOLAR INST., EDMONTON. 
1520. FORBES, G. J. and J. B. THEBERGE. 1993. MULTIPLE LANDSCAPE SCALES AND WINTER DISTRIBUTION OF MOOSE, ALCES ALCES, IN A FOREST ECOTONE. CANADIAN FIELD-NATURALIST 107 (2):201-7.

1521. FORBES, J. E. and A. B. SARGEANT. 1973. MORTALITY AMONG BIRDS, MAMMALS AND CERTAIN SNAKES ON 17 MILES OF MINNESOTA ROADS. THE LOON. 45(1):47

1522. FORBIS, L. A., T. G. GRUBB and W. D. ZEEDYK. 1985. 'EAGLE BEAGLES': A VOLUNTEER BALD EAGLE NEST WATCHER PROGRAM ON ARIZONA NATIONAL FORESTS. PAGES 246-254 IN THE BALD EAGLE IN CANADA. PROCEEDINGS OF THE 14TH BALD EAGLE DAYS. WHITE HORSE PLAINS PUBLISHERS, HEADINGLEY, MANITOBA.

1523. FORCELLA, F. 1977. FLORA, CHOROLOGY, BIOMASS AND PRODUCTIVITY OF THE PINUS ALBICAULIS-VACCINIUM SCOPARIUM ASSOCIATION. M.S. THESIS, MONTANA STATE UNIVERSITY, BOZEMAN, MT. 99 PP.

1524. FORD, S. G. 1980. EVALUATION OF HIGHWAY DEER KILL MITIGATION ON SIE/LAS-395. FINAL REPORT NO. FHWA/CA TP-80-01, CALIFORNIA DEPT. OF TRANSPORTATION, SACRAMENTO. 45 PP.

1525. FORD, S. G. 1980. EVALUATION OF HIGHWAY DEER KILL MITIGATION ON SIE/LAS-395 (1976-1979). FHWA/CA/TP-80-01. U.S. DEPARTMENT OF TRANSPORTATION, FEDERAL HIGHWAY ADMINISTRATION, WASHINGTON, DC.

1526. FORD, S. G. and S. L. VILLA. 1993. REFLECTOR USE AND THE EFFECT THEY HAVE ON THE NUMBER OF MULE DEER KILLED ON CALIFORNIA HIGHWAYS. FHWA/CA/PD-94/01. CALIFORNIA STATE DEPARTMENT OF TRANSPORTATION, SACRAMENTO, CA.

1527. FORIS, W. J. 1976. A COMPARISON OF DIATOMS ON HORIZONTAL AND VERTICAL SUBSTRATES IN GEORGETOWN LAKE, MONTANA. M.S. THESIS, MONTANA STATE UNIVERSITY, BOZEMAN, MT. 106 PP.

1528. FORMAN, K. J. 1993. INFLUENCE OF SKUNK REMOVAL ON NEST SUCCESS AND BREEDING POPULATIONS OF UPLAND NESTING DUCKS IN THE LOWER FLATHEAD VALLEY, MONTANA. M.S. THESIS, UNIVERSITY OF MONTANA, MISSOULA, MT. 60 PP.

1529. FORMAN, R. T. 1991. LANDSCAPE CORRIDORS: FROM THEORETICAL FOUNDATIONS TO PUBLIC POLICY. PAGES 71-84 IN SAUNDERS,D.A. AND HOBBS,R.J., EDITORS. NATURE CONSERVATION 2: THE ROLE OF CORRIDORS. SURREY BEATTY AND SONS, CHIPPING NORTON, AUSTRALIA.

1530. FORMAN, R. T. and S. K. COLLINGE. 1996. THE SPATIAL SOLUTION TO CONSERVING BIODIVERSITY IN LANDSCAPES AND REGIONS. PAGES 537-568 IN DEGRAFF,R.M. AND MILLER,R.I., EDITORS. CONSERVATION OF FAUNAL DIVERSITY IN FORESTED LANDSCAPES. CHAPMAN AND HALL, LONDON.

1531. FORMAN, R. T. and R. D. DEBLINGER. 1998. THE ECOLOGICAL ROAD-EFFECT ZONE FOR TRANSPORTATION PLANNING AND MASSACHUSETTS HIGHWAY EXAMPLE. PAGES 78-96 IN EVINK,G., ZIEGLER,D., GARRETT,P., AND BERRY,J., EDITORS. PROCEEDINGS OF THE INTERNATIONAL CONFERENCE ON WLDLIFE ECOLOGY AND TRANSPORTATION; 1998 FEBRUARY 10-12; FT. MYERS, FL FLORIDA DEPARTMENT OF TRANSPORTATION, TALLAHASSEE, FL.

1532. FORMAN, R. T. and A. M. HERSPERGER. 1996. ROAD ECOLOGY AND ROAD DENSITY IN DIFFERENT LANDSCAPES, WITH INTERNATIONAL PLANNING AND MITIGATION SOLUTIONS. PAGES 1-23 IN EVINK,G., ZIEGLER,D., GARRETT,P., AND BERRY,J., EDITORS. TRANSPORTATION AND WILDLIFE: REDUCING WILDLIFE MORTALITY AND IMPROVING WILDLIFE PASSAGEWAYS ACROSS TRANSPORTATION CORRIDORS: PROCEEDINGS OF THE FLORIDA DEPARTMENT OF TRANSPORTATION/FEDERAL HIGHWAY ADMINISTRATION TRANSPORTATION-RELATED WILDLIFE MORTALITY SEMINAR; 1996 APRIL 30-MAY 2; ORLANDO, FL. FHWA-PD-96-041. U.S. DEPARTMENT OF ADMINISTRATION, FEDERAL HIGHWAY ADMINISTRATION, WASHINGTON, DC.

1533. FORMAN, R. T. T. 1995. CORRIDORS. P 145-282. IN: FORMAN, RICHARD T. T.(AUTHOR). LAND MOSAICS: THE ECOLOGY OF LANDSCAPES AND REGIONS. NEW YORK, NY: CAMBRIDGE UNIVERSITY PRESS.

1534. FORMAN, R. T. T. 1983. CORRIDORS IN A LANDSCAPE: THEIR ECOLOGICAL STRUCTURE AND FUNCTION. EKOLOGIA 2 (4):375-87

1535. FORMAN, R. T. T. 1995. LAND MOSAICS: THE ECOLOGY OF LANDSCAPES AND REGIONS. CAMBRIDGE UNIVERSITY PRESS, CAMBRIDGE, MASS. 
1536. FORMAN, R. T. T. 1991. LANDSCAPE CORRIDORS: FROM THEORETICAL FOUNDATIONS TO PUBLIC POLICY. CHAPTER 8. IN. D. SAUNDERS AND R. HOBBS (EDS.). NATURE CONSERVANCY 2: THE ROLE OF CORRIDORS. SURREY -BEATTY AND SONS, CHIPPING NORTON.

1537. FORMAN, R. T. T. and M. GODRON. 1981. PATCHES AND STRUCTURAL COMPONENTS FOR A LANDSCAPE ECOLOGY. BIOSCIENCE 31: 733-9.

1538. FORMAN, R. T. T. and L. E. ALEXANDER. 1998. ROADS AND THEIR MAJOR ECOLOGICAL EFFECTS. ANNU. REV. ECOL. SYST. 29:207-231.

1539. FORNEY, K. A. and M. E. GILPIN. 1989. SPATIAL STRUCTURE AND POPULATION EXTINCTION: A STUDY WITH DROSOPHILA FLIES. CONSERVATION BIOLOGY 3 (1):45-51.

1540. FORRESTER, D. J. 1960. A PRELIMINARY INVESTIGATION OF THE PROTOSTRONGYLIN LUNGWORM-BIGHORN SHEEP RELATIONSHIPS IN MONTANA. PH.D. DISSERTATION, MONTANA STATE UNIVERSITY, MISSOULA, MT. 79 PP.

1541. FORSMAN, E. D., E. C. MESLOW and H. M. WIGHT. 1984. DISTRIBUTION AND BIOLOGY OF THE SPOTTED OWL IN OREGON. WILDL. MONOGR. 87:1-64.

1542. FORYS, E. A. and S. R. HUMPHREY. 1996. HOME RANGE AND MOVEMENTS OF THE LOWER KEYS MARSH RABBIT IN A HIGHLY FRAGMENTED HABITAT. JOURNAL OF MAMMALOGY 77(4):1042-1048.

1543. FOSS, A. J. 1962. ROCKY MOUNTAIN GOAT INVESTIGATIONS (POPULATION PHASE). MONTANA DEPT. OF FISH \& GAME. W-98-R-2, 26 PP.

1544. FOSS, A. J. 1962. A STUDY OF THE ROCKY MOUNTAIN GOAT IN MONTANA. M.S. THESIS, MONTANA STATE COLLEGE, BOZEMAN, MT. 26 PP.

1545. FOSTER, B. R. 1982. OBSERVABILITY AND HABITAT CHARACTERISTICS OF THE MOUNTAIN GOAT (OREAMNOS AMERICANUS BLAINVILLE, 1816) IN WEST-CENTRAL BRITISH COLUMBIA. THESIS, UNIVERSITY OF BRITISH COLUMBIA,

1546. FOSTER, B. R. and E. Y. RAHS. 1983. MOUNTAIN GOAT RESPONSE TO HYDROELECTRIC EXPLORATION IN NORTHWESTERN BRITISH COLUMBIA. ENVIRONMENTAL MANAGEMENT 7:189-197.

1547. FOSTER, B. R. and E. Y. RAHS. 1985. A STUDY OF CANYON-DWELLING MOUNTAIN GOATS IN RELATION TO PROPOSED HYDROELECTRIC DEVELOPMENT IN NORTHWEST BRITISH COLUMBIA, CANADA. BIOLOGICAL CONSERVATION 33:209-228.

1548. FOSTER, C. 1991. THE EFFECTS OF FOREST ROADS ON HUNTER AND WILDLIFE DISTRIBUTION. M.S. THESIS, WEST VIRGINIA UNIVERSITY, CHARLESTON.

1549. FOSTER, C. C. 1985. WILD TURKEY RESEARCH: THE IMPACT OF FOREST ROADS ON HUNTER AND WLDLIFE DISTRIBUTIONS. WW W-048-R-01/JOB I-8. WEST VIRGINIA GAME DEPARTMENT, CHARLESTON, WV.

1550. FOSTER, D. R. 1992. LAND-USE HISTORY (1730-1990) AND VEGETATION DYNAMICS IN CENTRAL NEW ENGLAND, USA. JOURNAL OF ECOLOGY 80 (4):753-71.

1551. FOSTER, M. and S. R. HUMPHREY. 1992. EFFECTIVENESS OF WILDLIFE CROSSINGS IN REDUCING ANIMAL AUTO COLLISIONS ON INTERSTATE 75, BIG CYPRESS SWAMP, FLORIDA. FLORIDA DEPARTMENT OF TRANSPORTATION. FL-ER-50-92 .

1552. FOSTER, M. L. and S. R. HUMPHREY. 1992. EFFECTIVENESS OF WILLIFE CROSSINGS IN REDUCING ANIMAL/AUTO COLLISIONS ON INTERSTATE 75, BIG CYPRESS SWAMP, FLORIDA. FL-ER-50-92. FLORIDA DEPARTMENT OF TRANSPORTATION, ORLANDO, FL.

1553. FOSTER, M. L. and S. R. HUMPHREY. 1995. USE OF HIGHWAY UNDERPASSES BY FLORIDA PANTHERS AND OTHER WILDLIFE. WILDLIFE SOCIETY BULLETIN 23:95-100. 
1554. FOUNTAIN, M. S. 1986. VEGETAL DEVELOPMENT ON ABANDONED OIL/GAS DRILLING SITES IN THE BIG THICKET NATIONAL PRESERVE. PAGES 288-293 IN D. L. KULHAVY AND R. N. CONNER, EDITORS. WILDERNESS AND -NATURAL AREAS IN THE EASTERN UNITED STATES: A MANAGEMENT CHALLENGE. CENTER FOR APPLIED STUDIES, SCHOOL OF FORESTRY, STEPHEN F. AUSTIN STATE UNIV., NACOGDOCHES, TEXAS.

1555. FOWLE, S. C. 1996. EFFECTS OF ROADKILL MORTALITY ON THE WESTERN PAINTED TURTLE (CHRYSEMYS PICTA BELLII) IN THE MISSION VALLEY, WESTERN MONTANA. PAGES 205-223 IN EVINK,G., ZIEGLER,D., GARRETT,P., AND BERRY,J., EDITORS. TRANSPORTATION AND WILDLIFE: REDUCING WILDLIFE MORTALITY AND IMPROVING WILDLIFE PASSAGEWAYS ACROSS TRANSPORTATION CORRIDORS: PROCEEDINGS OF THE FLORIDA DEPARTMENT OF TRANSPORTATION/FEDERAL HIGHWAY ADMINISTRATION TRANSPORTATION-RELATED WILDLIFE MORTALITY SEMINAR; 1996 APRIL 30-MAY 2; ORLANDO, FL. FHWA-P.D-96-041. U.S. DEPARTMENT OF TRANSPORTATION, FEDERAL HIGHWAY ADMINISTRATION, WASHINGTON, DC.

1556. FOWLE, S. C. 1996. THE PAINTED TURTLE IN THE MISSION VALLEY OF WESTERN MONTANA. M.S. THESIS, UNIVERSITY OF MONTANA, MISSOULA, MT. 101 PP.

1557. FOWLER, R. L. and R. L. BURY. 1973. VISITOR EVALUATIONS OF A DEVELOPED OUTDOOR RECREATION AREA ON A NATIONAL WILDLIFE REFUGE. TRANS. N. AMER. WLDL. NAT. RESOUR. CONF. 38:213-219.

1558. FOWLER, R. M. 1975. INVESTIGATION OF ANTICIPATED EFFECTS OF OAHE IRRIGATION UNIT DEVELOPMENT ON WILDLIFE HABITAT AND ASSOCIATED WLDLIFE POPULATIONS. SO. DAKOTA DEPT. OF GAME, FISH AND PARKS.

1559. FOWLER, R. M. 1974. INVESTIGATION OF ANTICIPATED EFFECTS OF OAHE IRRIGATION UNIT DEVELOPMENT ON WILDLIFE HABITAT AND ASSOCIATED WILDLIFE POPULATION 1973-74 SOUTH DAKOTA. SO. DAKOTA DEPT. OF GAME, FISH AND PARKS.

1560. FOX, A. D. and J. MADSEN. 1997. BEHAVIOURAL AND DISTRIBUTIONAL EFFECTS OF HUNTING DISTURBANCE ON WATERBIRDS IN EUROPE: IMPLICATIONS FOR REFUGE DESIGN. J. APPL. ECOL. 34:1-13.

1561. FOX, A. C. 1961. PARASITE INCIDENCE IN RELATION TO SIZE AND CONDITION OF TROUT FROM TWO MONTANA LAKES. M.S. THESIS, MONTANA STATE COLLEGE, BOZEMAN, MT. 16 PP.

1562. FOX, A. C. 1965. THE LIFE CYCLE OF BOLBOPHORUS CONFUSUS (KRAUSE, 1914) DUBOIS, 1935 (TREMOTODA: STRIGEOIDEA) AND THE EFFECTS OF THE METACERCARIAE ON FISH HOSTS. PH.D. DISSERTATION, MONTANA STATE UNIVERSITY, BOZEMAN, MT. 48 PP.

1563. FOX, B. J. 1982. THE INFLUENCE OF DISTURBANCE (FIRE, MINING) ON ANT AND SMALL MAMMAL SPECIES DIVERSITY IN AUSTRALIAN HEATHLAND. PAGES 213-219 IN C. E. CONRAD AND W. C. OECHEL, TECHNICAL COORDINATORS. PROCEEDINGS OF THE SYMPOSIUM ON DYNAMICS AND MANAGEMENT OF MEDITERRANEAN-TYPE ECOSYSTEMS. U.S. DEPT. AGRICULTURE, FOREST SERV., PACIFIC SOUTHWEST FOR. RANGE EXP. STA., BERKELEY, CALIFORNIA.

1564. FOX, B. J. and L. E. TWIGG. 1991. EXPERIMENTAL TRANSPLANTS OF MICE (PSEUDOMYS AND MUS) ON TO EARLY STAGES OF POST-MINING REGENERATION IN OPEN FOREST. AUSTRALIAN JOURNAL OF ECOLOGY 16 (3):281-8.

1565. FOX, J. L., K. J. RARDEKE and R. D. TABER. 1983. OFF-ROAD VEHICLES AND WLDLIFE IN WASHINGTON STATE: A PRELIMINARY SURVEY. SUBMITTED TO INTERAGENCY COMMITTEE FOR OUTDOOR RECREATION, OLYMPIA, WASHINGTON. COLLEGE OF FOREST RESOURCES, UNIVERSITY OF WASHINGTON.

1566. FOX, J. L., K. J. RAEDEKE and R. D. TABER. 1983. OFF-ROAD VEHICLES AND WILDLIFE IN WASHINGTON STATE A PRELIMINARY SURVEY, 1983. INTERAGENCY COMMITTEE FOR OUTDOOR RECREATION, OLYMPIA, WASHINGTON

1567. FRALEY, J. E. A. 1989. MITIGATION, COMPENSATION, AND FUTURE PROTECTION FOR FISH POPULATIONS AFFECTED BY HYDROPOWER DEVELOPMENT IN THE UPPER COLUMBIA SYSTEM, MONTANA, U.S.A. REGULATED RIVERS (U.K.) 3:3-18 JANUARY-APRIL 1989.

1568. FRALEY, J. J. 1978. EFFECTS OF ELEVATED SUMMER WATER TEMPERATURES BELOW ENNIS RESERVOIR ON THE MACROINVERTEBRATES OF THE MADISON RIVER, MONTANA. M.S. THESIS, MONTANA STATE UNIVERSITY, BOZEMAN, MT. 120 PP. 
1569. FRANCE, T. 1994. POLITICS, FOREST MANAGEMENT, AND BEARS. INT. CONF. BEAR RES. AND MANAGE. 9:523-8..

1570. FRANCHIMONT, J. 1993. USE BY BIRDS OF ROADS AS NAVIGATIONAL CUES. BRITISH BIRDS 6(1):17.

1571. FRANCIS, G. R. 1978. ROAD TRANSECTS TO RECORD THE OCCURRENCE OF FROGS AND TOADS IN WILMOT TOWNSHIP, WATERLOO REGION, SOUTHERN ONTARIO. ONTARIO FIELD BIOLOGY 32(1):1-12.

1572. FRANCIS, W. J. 1973. ACCURACY OF CENSUS METHODS OF TERRITORIAL RED-WINGED BLACKBIRDS. J. WILDL. MANAGE. 37 (1):98-102

1573. FRANCIS, W. J. 1968. TEMPERATURE AND HUMIDITY CONDITIONS IN POTENTIAL PHEASANT NESTING HABITAT. J. WILDL. MANAGE. 32 (1):36-46.

1574. FRANKLIN, J. and D. W. STEADMAN. 1991. THE POTENTIAL FOR CONSERVATION OF POLYNESIAN BIRDS THROUGH HABITAT MAPPING AND SPECIES TRANSLOCATION. CONSERVATION BIOLOGY 5 (4):506-21.

1575. FRANKLIN, W. L. and M. G. GARRETT. 1989. NONLETHAL CONTROL OF PRAIRIE DOG COLONY EXPANSION WITH VISUAL BARRIERS. WILDL. SOC. BULL. 17 (4):426-30.

1576. FRANZMANN, A. W. and P. D. ARNESON. 1976. MARROW FAT IN ALASKAN MOOSE FEMURS IN RELATION TO MORTALITY FACTORS. J. WLDL. MANAGE. 40 (2):336-9.

1577. FRASER, C. E. 1974. THE DEVELOPER'S ROLE IN PRESERVING WILDLIFE HABITATS. TRANS. N. AMER. WILDL. NAT. RESOUR. CONF. 39:56-62.

1578. FRASER, D. 1985. MAMMALS, BIRDS, AND BUTTERFLIES AT SODIUM SOURCES IN NORTHERN ONTARIO FORESTS. CAN. FIELD NAT. 99: 365-367.

1579. FRASER, D. 1979. SIGHTINGS OF MOOSE, DEER, AND BEARS ON ROADS IN NORTHERN ONTARIO. WILDLIFE SOCIETY BULLETIN 7(3):181-184.

1580. FRASER, D. and H. HRISTIENKO. 1982. MOOSE-VEHICLE ACCIDENTS IN ONTARIO: A REPUGNANT SOLUTION?. WILDLIFE SOCIETY BULLETIN 10:266-270.

1581. FRASER, D. and E. R. THOMAS. 1982. MOOSE-VEHICLE ACCIDENTS IN ONTARIO: RELATION TO HIGHWAY SALT. WILDLIFE SOCIETY BULLETIN 10(3):261-265.

1582. FRASER, J. D., L. D. FRENZEL and J. E. MATHISEN. 1985. THE IMPACT OF HUMAN ACTIVITIES ON BREEDING BALD EAGLES IN NORTH-CENTRAL MINNESOTA. J. WILDL. MANAGE. 49(3):585-92.

1583. FRAZER, C. F. 1992. FACTORS INFLUENCING THE HABITAT SELECTION OF BREEDING BIRDS IN HOOSIER NATIONAL FOREST, INDIANA: CLEARCUTTING AND EDGES. PHD THESIS, INDIANA. UNIVERSITY . 167 PP.

1584. FREDDY, D. J., W. M. BRONAUGH and M. C. FOWLER. 1986. RESPONSES OF MULE DEER TO DISTURBANCE BY PERSONS AFOOT AND SNOWMOBILES. WILLIFE SOCIETY BULLETIN 14(1):63-68.

1585. FREDDY, D. J. 1986. RESPONSES OF ADULT MULE DEER TO HUMAN HARASSMENT DURING WINTER. PAGES 286 IN R. D. COMER, T. G. BAUMANN, P. DAVIS, J. W. MONARCH, J. TODD, S. VANGYTENBEEK, D. WILLS, AND J. WOODLING, EDITORS. PROCEEDINGS II. ISSUES AND TECHNOLOGY IN THE MANAGEMENT OF IMPACTED WESTERN WILDLIFE. THORNE ECOLOGICAL INSTITUTE, BOULDER, COLORADO, USA.

1586. FREDENBERG, W. A. 1980. THE FISHERY FOR FALL-RUNNING RAINBOW TROUT IN THE MISSOURI RIVER NEAR TOWNSEND, MONTANA. M.S. THESIS, MONTANA STATE UNIVERSITY, BOZEMAN, MT. 62 PP.

1587. FREDERICK, G. P. 1991. EFFECTS OF FOREST ROADS ON GRIZZLY BEARS, ELK, AND GRAY WOLVES - A LITERATURE REVIEW. USDA FOREST SERVICE, KOOTENAI NATIONAL FOREST. LIBBY, MT. R1-91-73. 53PP.

1588. FREDERICK, R. B., W. R. CLARK and E. E. KLAAS. 1987. BEHAVIOR, ENERGETICS, AND MANAGEMENT OF REFUGING WATERFOWL: A SIMULATION MODEL. WLDL. MONOGR. 96:1-35. 
1589. FREDRICKSEN, R. L. 1970. EROSION AND SEDIMENTATION FOLLOWING ROAD CONSTRUCTION AND TIMBER HARVEST ON UNSTABLE SOILS IN THREE SMALL WESTERN OREGON WATERSHEDS. USDA FOREST SERVICE, PACIFIC -NORTHWEST FOREST AND RANGE EXPERIMENT STATION. RESEARCH PAPER PNW-104.

1590. FREE, J. B., D. GENNARD, J. H. STEVENSON and I. H. WILLIAMS. 1975. BENEFICIAL INSECTS PRESENT ON A MOTORWAY VERGE. BIOLOGICAL CONSERVATION 8:61-72.

1591. FREEDMAN, B., W. MAASS and P. PARFENOV. 1992. THE THREAD-LEAVED SUNDEW, DROSERA FILIFORMIS IN NOVA SCOTIA: AN ASSESSMENT OF RISKS OF A PROPOSAL TO MINE FUEL PEAT FROM ITS HABITAT. CANADIAN FIELD-NATURALIST. 106(4)

1592. FREEMAN, J. S. 1971. PRONGHORN RANGE USE AND RELATION TO LIVESTOCK IN SOUTHEASTERN MONTANA. M.S. THESIS, MONTANA STATE UNIVERSITY, BOZEMAN, MT. 45 PP.

1593. FRETTE, K. W. 1976. ANTIDROMIC AND ORTHODROMIC RESPONSES EVOKED IN CAT CEREBRAL CORTEX FOLLOWING BRAINSTEM STIMULATION : CONTRIBUTION OF THE PYRAMIDAL TRACT AND OTHER FIBER SYSTEMS . M.S. THESIS, MONTANA STATE UNIVERSITY, BOZEMAN, MT. 135 PP.

1594. FRIEDERICI, P. 1997. BIRDS AND AIRCRAFT: ON A COLLISION COURSE? LIVING BIRD 16:24-28.

1595. FRIEDMAN, J. M., M. L. SCOTT and W. M. J. LEWIS. 1995. RESTORATION OF RIPARIAN FOREST USING IRRIGATION, ARTIFICIAL DISTURBANCE, AND NATURAL SEED FALL. ENVIRONMENTALMANAGEMENT 19 (4):547-57.

1596. FRISINA, M. R. 1974. ECOLOGY OF BIGHORN SHEEP IN THE SUN RIVER AREA OF MONTANA DURING FALL AND SPRING. M.S. THESIS, MONTANA STATE UNIVERSITY, BOZEMAN, MT. 68 PP.

1597. FRISSELL, C. A., R. K. NAWA and R. F. NOSS. 1992. IS THERE ANY CONSERVATION BIOLOGY IN NEW PERSPECTIVES?: A RESPONSE TO SALWASSER. CONSERVATION BIOLOGY $6(3): 461-4$.

1598. FRITTS, S. H., E. E. BANGS and J. F. GORE. 1994. THE RELATIONSHIP OF WOLF RECOVERY TO HABITAT CONSERVATION AND BIODIVERSITY IN THE NORTHWESTERN UNITED STATES. LANDSCAPE AND URBAN PLANNING 28:23-32.

1599. FRITTS, S. H., W. J. PAUL and L. D. MECH. 1984. MOVEMENTS OF TRANSLOCATED WOLVES IN MINNESOTA. J. WILDL. MANAGE. 48 (3):709-21.

1600. FRITZEN, D. E., R. F. LABISKY, D. E. EASTON and J. C. KILGO. 1995. NOCTURNAL MOVEMENTS OF WHITE-TAILED DEER: IMPLICATIONS FOR REFINEMENT OF TRACK-COUNT SURVEYS. WLDL. SOC. BULL. 23 (2):187-93.

1601. FRITZEN, D. E. 1995. ECOLOGY AND BEHAVIOR OF MULE DEER ON THE ROSEBUD COAL MINE, MONTANA. PH.D. DISSERTATION, MONTANA STATE UNIVERSITY, BOZEMAN, MT. 143 PP.

1602. FRKOVIC, A., R. L. RUFF, L. CICNJAK and D. HUBER. 1987. BROWN BEAR MORTALITY DURING $1946-85$ IN GORSKI KOTAR, YUGOSLAVIA. INT. CONF. BEAR RES. AND MANAGE. 7:87-92

1603. FRUZÍNSKI, B. 1977. FEEDING HABITS OF PINK FOOTED GEESE (ANSER FABALIS BRACHYRYNCHUS) IN DENMARK DURING THE SPRING PASSAGE IN APRIL 1975. DANISH REVIEW OF GAME BIOLOGY 10:1-11.

1604. FRY, J. P. 1960. THE FOOD OF RAINBOW TROUT, BROWN TROUT AND BROOK TROUT FRY AND FINGERLINGS FROM FIVE SOUTHWESTERN MONTANA STREAMS. M.S. THESIS, MONTANA STATE COLLEGE, BOZEMAN, MT. 37 PP.

1605. FUHRMANN, R. T. 1998. DISTRIBUTION, MORPHOLOGY, AND HABITAT USE OF THE RED FOX IN THE NORTHERN YELLOWSTONE ECOSYSTEM. M.S. THESIS, MONTANA STATE COLLEGE, BOZEMAN, MT. 78 PP.

1606. FULLER, P. R. 1976. BROWSE PRODUCTION AND UTILIZATION ON SPOTTED BEAR MOUNTAIN WINTER RANGE AND SEASONAL MOVEMENTS OF THE SPOTTED BEAR ELK HERD. M.S. THESIS, UNIVERSITY OF MONTANA, MISSOULA, MT. 66 PP. 
1607. FULLER, T. K. 1990. DYNAMICS OF A DECLINING WHITE-TAILED DEER POPULATION IN NORTH CENTRAL MINNESOTA. WILDLIFE MONOGRAPHS 110:1-37.

1608. FULLER, T.K. 1997. GUIDELINES FOR GRAY WOLF MANAGEMENT IN THE NORTHERN GREAT LAKES REGION. 2ND EDITION. EDUCATIONAL PUBLICATION. INTERNATIONAL WOLF CENTER, ELY, MINNESOTA.

1609. FULLER, T. K. 1989. POPULATION DYNAMICS OF WOLVES IN NORTH-CENTRAL MINNESOTA. WILDL. MONOGR. 105:1-41.

1610. FULLER, T. K. 1989. POPULATIONS DYNAMICS OF WOLVES IN NORTH-CENTRAL MINNESOTA. WLDLIFE MONOGRAPHS 105:1-41.

1611. FULLER, T. K., W. E. BERG, G. L. RADDE, M. S. LENARZ and J. G. BLAIR. 1992. A HISTORY AND CURRENT ESTIMATE OF WOLF DISTRIBUTION AND NUMBERS IN MINNESOTA. WILDL. SOC. BULL 20 (1):42-55.

1612. FULLER, T. K. and L. B. KEITH. 1980. WOLF POPULATION DYNAMICS AND PREY RELATIONSHIPS IN NORTHEASTERN ALBERTA. J. WLDL. MANAGE. 44 (3):583-602

1613. FULLER, T. K. and W. L. ROBINSON. 1982. SOME EFFECTS OF WINTER SHIPPING ON MOVEMENTS OF MAMMALS ACROSS RIVER ICE. WILDL. SOC. BULL. 10 (2):156-60.

1614. FURNISS, M. J., T. D. ROELOFS and C. S. YEE. 1991. ROAD CONSTRUCTION AND MAINTENANCE. AMERICAN FISHERIES SOCIETY SPECIAL PUBLICATION 19:297-325.

1615. FUSARI, M. 1982. FEASIBILITY OF A HIGHWAY CROSSING SYSTEM FOR DESERT TORTOISES.. CALIFORNIA DEPT. TRANSPORTATION, SACRAMENTO. 41 PP.

1616. FUSARI, M. 1982. FEASIBILITY OF A HIGHWAY CROSSING SYSTEM FOR DESERT TORTOISES. FHWA/CA/TP-81/1. U.S. DEPARTMENT OF TRANSPORTATION, FEDERAL HIGHWAY ADMINISTRATION, WASHINGTON, DC.

1617. FUSARI, M. 1985. A STUDY OF THE REACTIONS OF DESERT TORTOISES TO DIFFERENT TYPES OF FENCING. DESERT TORTOISE COUNCIL PROCEEDINGS OF A SYMPOSIUM 1985:125-132.

1618. GABRIELSEN, G: W. and E. N. SMITH. 1995. PHYSIOLOGICAL RESPONSES OF WILDLIFE TO DISTURBANCE. PAGES 95-107 IN R. L. KNIGHT AND K. J. GUTZWILLER, EDITORS. WILDLIFE AND RECREATION: COEXISTENCE THROUGH MANAGEMENT AND RESEARCH. ISLAND PRESS. WASHINGTON, D.C.

1619. GAFFNEY, J. J. 1954. UTILIZATION OF THE MOUNTAIN WHITEFISH COREGONUS WILLIAMSONI IN MONTANA . M.S. THESIS, MONTANA STATE COLLEGE, BOZEMAN, MT. 35 PP.

1620. GAINES, D. 1974. REVIEW OF THE STATUS OF THE YELLOW-BILLED CUCKOO IN CALIFORNIA: SACRAMENTO VALLEY POPULATIONS. CONDOR 76:204-209.

1621. GAINES, E. P. and M. R. RYAN. 1988. PIPING PLOVER HABITAT USE AND REPRODUCTIVE SUCCESS IN NORTH DAKOTA. JOURNAL OF WLDLIFE MANAGEMENT 52:266-273.

1622. GAISLER, J. 1994. THE BATS PIPISTRELLUS KUHLI AND HYPSUGO SAVII ON THE ISLAND OF RAB (CROATIA). FOLIA ZOOLOGICA 43 (3):279-80.

1623. GALAN, O. F. 1992. PROVISIONAL REPORT OF THE MORTALITY OF VERTEBRATES ON THE ROADS OF CADIZ, SEPTEMBER 1991. PAGES 66-71 IN LOPEZ,REDONDO, EDITOR. I JORNADAS PARA EL ESTUDIO Y PREVENCION DE LA MORTALIDAD DE VERTEBRADOS EN CARRETERAS, MADRID, 5 Y 6 DE OCTUBRE DE 1991. TOMO 2. [SESSIONS IN THE STUDY OF PREVENTION OF ROAD MORTALITIES OF VERTEBRATES, MADRID, 5 AND 6 OCTOBER, 1991. VOLUME 2.]. COORDINADORA DE ORGANIZACCIONES DE DEFENSA, AMBIENTAL, MADRID.

1624. GANGLOFF, M. M. 1996. WINTER HABITAT AND DISTRIBUTION OF ARCTIC GRAYLING IN UPPER RED ROCK LAKE NATIONAL WILDLIFE REFUGE, MONTANA. M.S. THESIS, MONTANA STATE UNIVERSITY, BOZEMAN, MT. 101 PP.

1625. GANSKOPP, D., R. RALEIGH, M. SCHOTT and T. D. BRACKEN. 1991. BEHAVIOR OF CATTLE IN PENS EXPOSED TO PLUS OR MINUS 500 KV DC TRANSMISSION LINES. APPLIED ANIMAL BEHAVIOUR SCIENCE 30 (1-2):1-16. 
1627. GARBER, S. D. 1994. REPRODUCTIVE STRATEGIES, WINTER BEHAVIOR AND ECOLOGY, AND CONSERVATION OF THE NORTH AMERICAN WOOD TURTLE (CLEMMYS INSCULPTA). PHD THESIS, RUTGERS THE STATE UNIVERSITY OF NEW JERSEY - NEW BRUNSWICK. 199 PP

1628. GARBER, S. D. and J. BURGER. 1995. A 20-YR STUDY DOCUMENTING THE RELATIONSHIP BETWEEN TURTLE DECLINE AND HUMAN RECREATION. ECOLOGICAL APPLICATIONS 5:1151-1162.

1629. GARCIA, C. A. 1993. ACTIVITY PATTERN OF THE BROWN HOWLER MONKEY ALOUATTA FUSCA, GEOFFROY 1812, IN A FOREST FRAGMENT OF SOUTHEASTERN BRAZIL. PRIMATES 34(3):289-93.

1630. GARCIA, C. A. 1994. DIET OF THE BROWN HOWLER MONKEY ALOUATTA FUSCA, IN A SEMI-DECIDUOUS FOREST FRAGMENT OF SOUTHEASTERN BRAZIL. PRIMATES 35 (1):25-34.

1631. GARD, R. 1971. BROWN BEAR PREDATION ON SOCKEYE SALMON AT KARLUK LAKE, ALASKA. J. WILDL. MANAGE. 35 (2):193-204.

1632. GARDNER, W. M. 1977. THE EFFECTS OF HEAVY METALS ON THE DISTRIBUTION AND ABUNDANCE OF AQUATIC INSECTS IN THE BOULDER RIVER, MONTANA. M.S. THESIS, MONTANA STATE UNIVERSITY, BOZEMAN, MT. 84 PP.

1633. GARLAND, T. and V. G. BRADLEY. 1984. EFFECTS OF A HIGHWAY ON MOJAVE DESERT RODENT POPULATIONS. AMERICAN MIDLAND NATURALIST 111(1):47-56.

1634. GARNER, N. P. 1986. SEASONAL MOVEMENTS, HABITAT SELECTION, AND FOOD HABITS OF BLACK BEARS IN SHENANDOAH NATIONAL PARK, VIRGINIA. M.S. THESIS, VIRGINIA POLYTECHNIC INSTITUTE AND STATE UNIVERSITY. BLACKSBURG. 104PP.

1635. GARNER, N. P. 1986. SEASONAL MOVEMENTS, HABITAT SELECTION, AND FOOD HABITS OF BLACK BEARS (URSUS AMERICANUS) IN SHENANDOAH NATIONAL PARK, VIRGINIA. M.S. THESIS, VIRGINIA POLYTECHNIC INSTITUTE AND STATE UNIVERSITY, BLACKSBURG.104PP.

1636. GARNER, N. P. and M. R. VAUGHAN. 1989. BLACK BEAR - HUMAN INTERACTIONS IN SHENANDOAH NATIONAL PARK, VIRGINIA. PAGES 155-161 IN M. BROMLEY, EDITOR. BEAR-PEOPLE CONFLICTS: PROCEEDINGS OF A SYMPOSIUM ON MANAGEMENT STRATEGIES. NORTHWEST TERRITORIES DEPT. RENEW. RESOUR., YELLOWKNIFE.

1637. GARNER, N. P. and M. R. VAUGHAN. 1987. BLACK BEARS' USE OF ABANDONED HOMESITES IN SHENANDOAH NATIONAL PARK. INT. CONF. BEAR RES. AND MANAGE. 7:151-7

1638. GARRETT, P. A. 1973. THE DISTRIBUTION AND ABUNDANCE OF AQUATIC INSECTS IN THE MIDDLE WEST GALLATIN DRAINAGE. M.S. THESIS, MONTANA STATE UNIVERSITY, BOZEMAN, MT. 60 PP.

1639. GARRETT, P. A. 1983. RELATIONSHIPS BETWEEN BENTHIC COMMUNITIES, LAND USE, CHEMICAL DYNAMICS, AND TROPHIC STATE IN GEORGETOWN LAKE. PH.D. DISSERTATION, MONTANA STATE UNIVERSITY, BOZEMAN, MT. 149 PP

1640. GARROD, R. C., M. W. SHOESMITH and J. M. STEWART. 1981? RUMEN ANALYSES OF WHITE-TAILED DEER, ELK AND MOOSE KILLED BY HUNTERS AND VEHICLE COLLISIONS IN MANITOBA, 1975-1978. MANITOBA DEPT. OF NATURAL RESOURCES, WINNIPEG, MANITOBA. MANUSCRIPT REPORT NO. 81-5.

1641. GARTEN, C. T. J. 1995. DISPERSAL OF RADIOACTIVITY BY WLDLIFE FROM CONTAMINATED SITES IN A FORESTED LANDSCAPE. JOURNAL OF ENVIRONMENTAL RADIOACTIVITY 29 (2):137-56.

1642. GARY, H. L. 1975. WATERSHED MANAGEMENT PROBLEMS AND OPPORTUNITIES FOR THE COLORADO FRONT RANGE PONDEROSA PINE ZONE: THE STATUS OF OUR KNOWLEDGE. USDA FOREST SERVICE RESEARCH PAPER RM-139. 
1643. GASAWAY, W. C., R. O. STEPHENSON, J. L. DAVIS, P. E. K. SHEPHERD and O. E. BURRIS. 1983. INTERRELATIONSHIPS OF WOLVES, PREY, AND MAN IN INTERIOR ALASKKA. WILDL. MONOGR.84:1-50

1644. GATES, C. C. and R. J. HUDSON. 1979. EFFECTS OF POSTURE AND ACTIVITY ON METABOLIC RESPONSES OF WAPITI TO COLD. JOURNAL OF WLDLIFE MANAGEMENT 43:564-567.

1645. GATES, J. E. 1990. HIGHWAYS: THE SEARCH FOR SOLUTIONS. PAGES [UNKNOWN] IN LIEBERMAN,S.S., EDITOR. DEER MANAGEMENT IN AN URBANIZING REGION: PROBLEMS AND ALTERNATIVES TO TRADITIONAL MANAGEMENT. U.S. HUMANE SOCIETY., WASHINGTON, DC.

1646. GATES, J. E. 1991. POWERLINE CORRIDORS, EDGE EFFECTS, AND WILDLIFE IN FORESTED LANDSCAPES OF THE CENTRAL APPALACHIANS. P 14-32. IN: RODIEK, J.E., BOLEN, E.G., EDS. WILDLIFE AND HABITATS IN MANAGED LANDSCAPES. ISLAND PRESS

1647. GATES, J. E. and N. R. GIFFEN. 1991. NEOTROPICAL MIGRANT BIRDS AND EDGE EFFECTS AT A FOREST-STREAM ECOTONE. WILSON BULLETIN 103 (2):204-17.

1648. GATES, R. J. 1983. SAGE GROUSE, LAGOMORPH, AND PRONGHORN USE OF A SAGEBRUSH GRASSLAND BURN SITE ON THE IDAHO NATIONAL ENGINEERING LABORATORY. M.S. THESIS, MONTANA STATE UNIVERSITY, BOZEMAN, MT. 135 PP.

1649. GAVIN, A. 1976. WILDLIFE ON THE NORTH SLOPE. UNPUBLISHED ATLANTIC RICHFIELD COMPANY REPORT.

1650. GAZDA, R. J. 1994. DUCK PRODUCTIVITY AND NEST PREDATION IN SOUTHEASTERN IDAHO. M.S. THESIS, UNIVERSITY OF MONTANA, MISSOULA, MT. 60 PP.

1651. GEBHARDS, S. and J. FISHER. 1972. FISH PASSAGE AND CULVERT INSTALLATIONS. IDAHO FISH \& GAME DEPT, IDAHO.

1652. GEIS, A. F. 1954. THE FOOD CONSUMPTION AND RELATIVE DIGESTIBILITY OF VARIOUS WINTER DIETS FED TO ELK (CERVUS CANADENSIS NELSONI) UNDER CONTROLLED CONDITIONS. M.S. THESIS, MONTANA STATE UNIVERSITY, MISSOULA, MT. 68 PP.

1653. GEIST, V. 1970. A BEHAVIORAL APPROACH TO THE MANAGEMENT OF WLD UNGULATES. IN: DUFFEY E, WATT AS. (EDS.).THE SCIENTIFIC MANAGEMENT OF ANIMAL AND PLANT COMMUNITIES FOR CONSERVATION. 11TH SYMP. BRIT. ECOL. SOC. OXFORD, UK.: BLACKWELL SCI. PUBL. P 413-24.

1654. GEIST, V. 1971. HARASSMENT OF BIG GAME. IS IT HARMFUL? OILWEEK 22: 12-13

1655. GEIST, V. 1975. HARASSMENT OF LARGE MAMMALS AND BIRDS: WITH A CRITIQUE OF THE RESEARCH SUBMITTED BY ARCTIC GAS STUDY LTD. ON THIS SUBJECT. REPORT TO THE BERGER COMMISSION. UNIVERSITY OF CALGARY. CALGARY, AB. 62PP. + APPENDIX

1656. GEIST, V., R. E. STEMP and R. H. JOHNSON. 1985. HEART RATE TELEMETRY ON BIGHORN SHEEP (OVIS CANADENSIS) AS A MEANS TO INVESTIGATE DISTURBANCE. P.92-9. IN: THE ECOLOGICAL IMPACT OF OUTDOOR RECREATION ON MOUNTAIN AREAS IN EUROPE AND NORTH AMERICA.

1657. GEIST, V. and F. WALTHER. 1971. THE BEHAVIOR OF UNGULATES AND ITS RELATION TO MANAGEMENT. 2 VOLUMES. IUCN, SWITZERLAND.

1658. GEIST, V. 1968. ON DELAYED SOCIAL AND PHYSICAL MATURATION IN MOUNTAIN SHEEP. CAN. J. ZOOL. 46:899-904.

1659. GEL'TSER, Y. G. and V. Y. GEL'TSER. 1994. CHANGES IN ARABLE SOD-PODZOLIC SOIL CENOSES ASSOCIATED WITH PIPELINE CONSTRUCTION. EURASIAN SOIL SCIENCE 26 (4):37-47.

1660. GELEGIN, V. I. and N. G. IVLEVA. 1992. BIRDS ON HIGHWAYS. SIBIRSKII BIOLOGICHESKII ZHURNAL 1992(1):53-55.

1661. GENOT, J. C., D. LECCI, J. BONNET, G. KECK and A. VENANT. 1995. DATA ON THE CHEMICAL CONTAMINATION IN THE LITTLE OWL ATHENA NOCUTA (SCOP.) AND ITS EGGS, IN FRANCE. ALAUDA 63 (2):105-10. 
1662. GEOLOGICAL SOCIETY OF AMERICA, COMMITTEE ON ENVIRONMENT AND PUBLIC POLICY. 1977. IMPACTS AND MANAGEMENT OF OFF-ROAD VEHICLES. REPORT OF THE COMMITTEE ON ENVIRONMENT AND PUBLIC -POLICY. GEOLOGICAL SOCIETY OF AMERICA. BOULDER, COLORADO. 8PP.

1663. GEORGE, J. L., C. E. BRAUN, R. A. RYDER and E. DECKER. 1991. RESPONSE OF WATERBIRDS TO EXPERIMENTAL DISTURBANCES. PROCEEDINGS ISSUES TECHNOL. MANAGE. WILDL. (THORNE ECOL. INST.) NO. 5:52-59.

1664. GEORGE, J. L., R. G. WINGARD and W. L. PALMER. 1983. PENN STATE'S FIVE-ALIVE DEER FENCE. AMERICAN FORESTS [VOL. UNKNOWN]:

1665. GEORGE, R. R., J. B. JR. WOOLEY, J. M. KIENZLER, A. L. FARRIS and A. H. BERNER. 1980. EFFECT OF HUNTING SEASON LENGTH ON RING-NECKED PHEASANT POPULATIONS. WILDL. SOC. BULL. 8 (4):279-83.

1666. GEORGES, A. and M. ROSE. 1993. CONSERVATION BIOLOGY OF THE PIG-NOSED TURTLE, CARETTOCHELYS INSCULPTA. CHELONIAN CONSERVATION AND BIOLOGY 1 (1):3-12.

1667. GEOTHERM RESOUR COUNCIL. 1978. GEOTHERMAL DEVELOPMENT AND WLDLIFE BEHAVIOR. P 627-9. IN: GEOTHERM RESOUR COUNCIL 2ND ANNU CONFERENCE; 1978 JUL25-27

1668. GERALD, J. W. 1965. FOOD HABITS OF THE LONGNOSE DACE, RHINICHTHYS CATARACTAE . M.S. THESIS, MONTANA STATE UNIVERSITY, BOZEMAN, MT. 27 PP.

1669. GERMANO, D. J. and D. J. MORAFKA. 1996. DIURNAL ABOVEGROUND ACTIVITY BY THE FOSSORIAL SILVERY LEGLESS LIZARD, ANNIELLA PULCHRA. GREAT BASIN NATURALIST 56(4):379-380.

1670. GERRARD, P. N., J. M. GERRARD and G. R. BORTOLOTTI. 1985. THE IMPACT OF ROAD DEVELOPMENT AND TOURIST ACCESS ON A BALD EAGLE POPULATION AT BESNARD LAKE, SASKATCHEWAN. PAGES 160-165 IN THE BALD EAGLE IN CANADA. PROCEEDINGS OF THE 14TH BALD EAGLE DAYS. WHITE HORSE PLAINS PUBLISHERS, HEADINGLEY, MANITOBA.

1671. GERRODETTE, T. and W. G. GILMARTIN. 1990. DEMOGRAPHIC CONSEQUENCES OF CHANGED PUPPING AND HAULING SITES OF THE HAWAIIAN MONK SEAL. CONSERVATION BIOLOGY 4(4):423-30.

1672. GESE, E. M., O. J. RONGSTAD and W. R. MYTTON. 1988. HOME RANGE AND HABITAT USE OF COYOTES IN SOUTHEASTERN COLORADO. J. WILDL. MANAGE. 52 (4):640-6.

1673. GETZ, L. L. 1978. INFLUENCE OF INTERSTATE HIGHWAYS ON SMALL MAMMALS. PAGES 81-91 IN KIRKPATRICK,C.M., EDITOR. WLDLIFE AND PEOPLE. THE 1978 JOHN S. WRIGHT FORESTRY CONFERENCE. PURDUE RESEARCH FOUNDATION, WEST LAFAYETTE, IN.

1674. GETZ, L. L., L. B. BEST and M. PRATHER. 1977. LEAD IN URBAN AND RURAL SONG BIRDS. ENVIRONMENTAL POLLUTION 12:384-388.

1675. GETZ, L. L., F. R. COLE and D. L. GATES. 1978. INTERSTATE ROADSIDES AS DISPERSAL ROUTES FOR MICROTUS PENNSYLVANICUS. JOURNAL OF MAMMALOGY 59(1):208-212.

1676. GETZ, L. L., L. VERNER and M. PRATHER. 1977. LEAD CONCENTRATIONS IN SMALL MAMMALS LIVING NEAR HIGHWAYS. ENVIRONMENTAL POLLUTION 13:151-157.

1677. GIANNATOS, G. 1997. HUMAN RELATED FACTORS AFFECTING BROWN BEAR RECOVERY IN THE RHODOPI MOUNTAINS OF NORTHEASTERN GREECE. M.S. THESIS, UNIVERSITY OF MONTANA, MISSOULA, MT. 59 PP.

1678. GIBBONS, B. H. 1974. LAND USE: IS IT BIGGER THAN A BREADBOX? TRANS. N. AMER. WLDL. NAT. RESOUR. CONF. 39:41-47.

1679. GIBBS, J. P. 1998. AMPHIBIAN MOVEMENTS IN RESPONSE TO FOREST EDGES, ROADS, AND STREAMBEDS IN SOUTHERN NEW ENGLAND . JOURNAL OF WLDLIFE MANAGEMENT 62:584-589. 

POPULATIONS IN FOREST FRAGMENTS. CONSERVATION BIOLOGY4(2):193-6.

1681. GIBEAU, M. and S. HERRERO. 1998. ROADS, RAILS AND GRIZZLY BEARS IN THE BOW RIVER VALLEY, ALBERTA. PAGES 104-108 IN EVINK,G., ZIEGLER,D., GARRETT,P., AND BERRY,J., EDITORS. PROCEEDINGS OF THE INTERNATIONAL CONFERENCE ON WILLIFE ECOLOGY AND TRANSPORTATION; 1998 FEBRUARY 10-12; FT. MYERS, FL FLORIDA DEPARTMENT OF TRANSPORTATION, TALLAHASSEE, FL.

1682. GIBEAU, M. and K. HEUER. 1996. EFFECTS OF TRANSPORTATION CORRIDORS ON LARGE CARNIVORES IN THE BOW RIVER VALLEY, ALBERTA. PAGES 67-79 IN EVINK,G., ZIEGLER,D., GARRETT,P., AND BERRY,J., EDITORS. TRANSPORTATION AND WLDLIFE: REDUCING WLDLIFE MORTALITY AND IMPROVING WLDLIFE PASSAGEWAYS ACROSS TRANSPORTATION CORRIDORS: PROCEEDINGS OF THE FLORIDA DEPARTMENT OF TRANSPORTATION/FEDERAL HIGHWAY ADMINISTRATION TRANSPORTATION-RELATED WLDLIFE MORTALITY SEMINAR; 1996 APRIL 30-MAY 2; ORLANDO, FL. FHWA-PD-96-041. U.S. DEPARTMENT OF TRANSPORTATION, FEDERAL HIGHWAY ADMINISTRATION, WASHINGTON, DC.

1683. GIBEAU, M. L., S. HERRERO, J. KANSAS and B. BENN. 1996. GRIZZLY BEAR POPULATION AND HABITAT STATUS IN BANFF NATIONAL PARK. PAGES 6-1 IN GREEN,J., PACAS,C., CORNWELL,L., AND BAYLEY,S., EDITORS. ECOLOGICAL OUTLOOKS PROJECT. A CUMULATIVE EFFECTS ASSESSMENT AND FUTURES OUTLOOK OF THE BANFF BOW VALLEY. PREPARED FOR THE BANFF BOW VALLEY STUDY. DEPARTMENT OF CANADIAN HERITAGE, OTTAWA, ONTARIO.

1684.

GIBEAU, M. L., S. HERRERO, J. L. KANSAS and B. BENN. 1996. GRIZZLY BEAR POPULATION AND HABITAT STATUS IN BANFF NATIONAL PARK: A REPORT TO THE BOW VALLEY TASK FORCE. COMMITTEE ON RESOURCES AND THE ENVIRONMENT, UNIVERSITY OF CALGARY. 62PP.

1685.

GIBEAU, M. L. 1993. USE OF URBAN HABITATS BY COYOTES IN THE VICINITY OF BANFF, ALBERTA. M.S. THESIS, UNIVERSITY OF MONTANA, MISSOULA, MT. 66 PP.

1686.

GIDDINGS, B. J. 1986. HOME RANGE SIZE, MOVEMENTS AND HABITAT USE OF BOBCATS IN A PRAIRIE RANGELAND ENVIRONMENT . M.S. THESIS, MONTANA STATE UNIVERSITY, BOZEMAN, MT. 62 PP.

1687. GILBERT, B. K. 1989. BEHAVIOURAL PLASTICITY AND BEAR-HUMAN CONFLICTS. P 1-8.IN: BEAR-PEOPLE CONFLICTS--PROC. SYMP. ON MANAGE. STRATEGIES

1688. GILBERT, J. R. 1982. EVALUATION OF DEER MIRRORS FOR REDUCING DEER-VEHICLE COLLISIONS. FHWA-RD-82-061. $16 \mathrm{PP}$.

1689. GILBERT, M. 1998. THE AUSTRALIAN PARTNERSHIP APPROACH TO PROTECTING ROADSIDE HABITATS. PAGES 189-194 IN EVINK,G., ZIEGLER,D., GARRETT,P., AND BERRY,J., EDITORS. PROCEEDINGS OF THE INTERNATIONAL CONFERENCE ON WILDLIFE ECOLOGY AND TRANSPORTATION; 1998 FEBRUARY 10-12; FT. MYERS, FL FLORIDA DEPARTMENT OF TRANSPORTATION, TALLAHASSEE, FL.

1690. GILBERT, P. F., D. F. REED and T. M. POJAR. 1971. MIGRATORY DEER AND INTERSTATE 70 IN WESTERN COLORADO. PAGES 436-446 IN PROCEEDINGS OF THE 51ST ANNUAL CONFERENCE OF THE WESTERN ASSOCIATION OF STATE GAME AND FISH COMMISSION STATE OF COLORADO, GAME, FISH, AND PARKS DEPARTMENT, DENVER, CO.

1691. GILBERT, T. 1982. EVALUATION OF DEER MIRRORS FOR REDUCING DEER/VEHICLE COLLISIONS. FHWA/RD-82/061. U.S. DEPARTMENT OF TRANSPORTATION, FEDERAL HIGHWAY ADMINISTRATION, WASHINGTON, DC.

1692. GILBERT, T. 1998. TECHNICAL ASSISTANCE AND AGENCY COORDINATION ON WILLIFE AND HABITAT CONSERVATION ISSUES ASSOCIATED WITH HIGHWAY PROJECTS IN FLORIDA. PAGES 209-213 IN EVINK,G., ZIEGLER,D., GARRETT,P., AND BERRY,J., EDITORS. PROCEEDINGS OF THE INTERNATIONAL CONFERENCE ON WILDLIFE ECOLOGY AND TRANSPORTATION; 1998 FEBRUARY 10-12; FT. MYERS, FL FLORIDA DEPARTMENT OF TRANSPORTATION, TALLAHASSEE, FL.

1693. GILBERT, T. and J. WOODING. 1994. CHRONIC ROADKILL PROBLEM AREAS FOR BLACK BEAR IN FLORIDA. FLORIDA GAME AND FRESH WATER FISH COMMISSION , ORLANDO, FL.

1694. GILBERT, T. and J. WOODING. 1996. AN OVERVIEW OF BLACK BEAR ROADKILLS IN FLORIDA, 1976-1995. PAGES 308-322 IN EVINK,G., ZIEGLER,D., GARRETT,P., AND BERRY,J., EDITORS. TRANSPORTATION AND WLDLIFE: REDUCING WLDLIFE MORTALITY AND IMPROVING WILDLIFE PASSAGEWAYS ACROSS TRANSPORTATION CORRIDORS: PROCEEDINGS OF THE FLORIDG6 DEPARTMENT OF TRANSPORTATION/FEDERAL HIGHWAY 
ADMINISTRATION TRANSPORTATION-RELATED WLDLIFE MORTALITY SEMINAR; 1996 APRIL 30-MAY 2; ORLANDO, FL. FHWA-PD-96-041. U.S. DEPARTMENT OF TRANSPORTATION, FEDERAL HIGHWAY -ADMINISTRATION, WASHINGTON, DC.

1695. GILES, R. H., A. B. JONES and C. W. SMART. 1976. POWER, A COMPUTER SYSTEM FOR CORRIDOR LOCATION. RESEARCH DIVISION BULLETIN: RESEARCH DIVISION BULLETIN (VIRGINIA POLYTECHNIC INSTITUTE AND STATE UNIVERSITY. RESEARCH DIVISION) 117. OFFICE OF BIOLOGICAL SERVICES, FISH AND WILDLIFE SERVICE, U.S. DEPT. OF THE INTERIOR, WASHINGTON, D.C.

1696. GILL, G. B. 1972. ALTERATIONS OF THE IN VITRO DIGESTIBILITY OF DEER BROWSE AS AFFECTED BY SYSTEMATIC MIXING OF PAIRED SAMPLES. M.S. THESIS, UNIVERSITY OF MONTANA, MISSOULA, MT. 82 PP.

1697. GILL, J. A., W. J. SUTHERLAND and A. R. WATKINSON. 1996. A METHOD TO QUANTIFY THE EFFECTS OF HUMAN DISTURBANCE ON ANIMAL POPULATIONS. JOURNAL OF APPLIED ECOLOGY 33(4):786-792.

1698. GILL, R. B., L. H. CARPENTER, R. M. BARTMANN, D. L. BAKER and G. G. SCHOONVELD. 1983. FECAL ANALYSIS TO ESTIMATE MULE DEER DIETS. J. WILDL. MANAGE. 47 (4):902-15.

1699. GILLESPIE, D. M. 1966. POPULATION STUDIES OF FOUR SPECIES OF MOLLUSKS IN THE MADISON RIVER, YELLOWSTONE NATIONAL PARK. PH.D. DISSERTATION, MONTANA STATE UNIVERSITY, BOZEMAN, MT. 43 PP.

1700. GILLESPIE, R. L. 1992. DYNAMICS OF GRASSHOPPERS (ORTHOPTERA: ACRIDIDAE) AT A RANGELAND-CROP INTERFACE. PH.D. DISSERTATION, MONTANA STATE UNIVERSITY, BOZEMAN, MT. 111 PP.

1701. GILLETTE, D. A. and J. ADAMS. 1983. ACCELERATED WIND EROSION AND PREDICTION OF RATES. PAGES $97-109$ IN R. H. WEBB AND H. G. WILSHIRE, EDITORS. ENVIRONMENTAL EFFECTS OF OFF-ROAD VEHICLES .

1702. GILLIN, C. M., F. M. HAMMOND and C. M. PETERSON. 1994. EVALUATION OF AN AVERSIVE CONDITIONING TECHNIQUE USED ON FEMALE GRIZZLY BEARS IN THE YELLOWSTONE ECOSYSTEM. INT. CONF. BEAR RES. AND MANAGE. 9:503-12.

1703. GILLIN, C. 1989. RESPONSE OF ELK TO SEISMOGRAPH EXPLORATION IN THE WYOMING RANGE, WYOMING. THESIS, UNIVERSITY OF WYOMING, LARAMIE, WYOMING.

1704. GILMER, D. S. and R. E. STEWART. 1983. FERRUGINOUS HAWK POPULATIONS AND HABITAT USE IN NORTH DAKOTA. JOURNAL OF WLDLIFE MANAGEMENT 47:146-157.

1705. GIROUX, J. F., Y. BEDARD and J. BEDARD. 1984. HABITAT USE BY GREATER SNOW GEESE DURING THE BROOD REARING PERIOD. ARCTIC 37 (155-160).

1706. GITTINS, P. 1983. ROAD CASUALTIES SOLVE TOAD MYSTERIES. NEW SCIENTIST 97:158-162.

1707. GJERSING, F. M. 1971. A STUDY OF WATERFOWL PRODUCTION ON TWO REST ROTATION GRAZING UNITS IN NORTHCENTRAL MONTANA. M.S. THESIS, MONTANA STATE UNIVERSITY, BOZEMAN, MT. 42 PP.

1708. GLADFELTER, L. 1984. EFFECT OF WILDLIFE HIGHWAY WARNING REFLECTORS ON DEER-VEHICLE ACCIDENTS. IOWA DEPARTMENT OF TRANSPORTATION, HIGHWAY DIVISION, AMES, IOWA.

1709. GLAHOLT, R. D. 1984. AVAILABILITY OF CRITICAL PRONGHORN ANTELOPE HABITAT IN SOUTHERN ALBERTA AND ITS RELATION TO LAND USE. MASTERS OF ENVIRONMENT DESIGN. THESIS. UNIVERSITY OF CALGARY, CALGARY

1710. GLASS, R. J. 1989. HABITAT IMPROVEMENT COSTS ON STATE-OWNED WLDLIFE MANAGEMENT AREAS IN NEW YORK. U.S. DEPT. OF AGRICULTURE, FOREST SERVICE, NORTHEASTERN FOREST EXPERIMENT STATION, BROOMALL, PENNSYLVANIA. RESEARCH PAPER NE 621.

1711. GLAZIER, R. J. 1971. ECOLOGICAL AND MORPHOLOGICAL RELATIONSHIPS OF SUBSPECIES OF PEROMYSCUS MANICULATUS NEAR ST. MARY, MONTANA. M.S. THESIS, MONTANA STATE UNIVERSITY, BOZEMAN, MT. 41 PP. 
1712. GLEASON, J. S. and J. A. JENKS. 1993. FACTORS INFLUENCING DEER/VEHICLE MORTALITY IN EAST CENTRAL SOUTH DAKOTA. PRAIRIE NATURALIST 25 (4):281-8.

1713. GLEIM, J. A. and R. M. CASE. 1976. EFFECT OF VEGETATION ON ROAD-KILLED WILDLIFE ON INTERSTATE 80. PROCEEDINGS NEBRASKA ACADEMY OF SCIENCE 86:16-17.

1714. GLENN, S. M. and T. D. NUDDS. 1989. INSULAR BIOGEOGRAPHY OF MAMMALS IN CANADIAN PARKS. J. BIOGEOG.16: $261-8$

1715. GLICKSMAN, R. L. and G. C. COGGINS. 1995. MODERN PUBLIC LAND LAW IN A NUTSHELL. WEST NUTSHELL SERIES: NUTSHELL SERIES. WEST PUB. CO, SAINT PAUL, MINNESOTA.

1716. GLIWIEZ, J. 1990. WHAT CAN BE LEARNED ABOUT THE ROLE OF FOREST ISLANDS IN A LANDSCAPE FROM RODENT INVESTIGATIONS. WIADOMOSCI EKOLOGICZNE 36(1-2):21-36.

1717. GNIADEK, S. J. 1987. ELK AND CATTLE RELATIONSHIPS ON SUMMER RANGE IN SOUTHWESTERN MONTANA. M.S. THESIS, UNIVERSITY OF MONTANA, MISSOULA, MT. 40 PP.

1718. GOBEILLE, J. E. 1992. THE EFFECT OF FIRE ON MERRIM'S TURKEY BROOD HABITAT IN SOUTHEASTERN MONTANA. M.S. THESIS, MONTANA STATE UNIVERSITY, BOZEMAN, MT. 61 PP.

1719. GOCHFELD, M. 1978. TERNS IN TRAFFIC. KINGBIRD 26:63-80.

1720. GOCHFELD, M. 1976. WATERBIRD COLONIES OF LONG ISLAND, NEWYORK: 3. CEDAR BEACH TERNERY. NATURAL HISTORY 87:54-61.

1721. GODDARD, J. 1970. MOVEMENTS OF MOOSE IN A HEAVILY HUNTED AREA OF ONTARIO. J. WILDL. MANAGE. 34 (2):439-45.

1722.

GODFREY, P. J., J. BRODHEAD, H. WALKER, J. GILLIGAN and A. DAVIS. 1975. ECOLOGICAL EFFECTS OF OFF-ROAD VEHICLES IN CAPE COD NATIONAL SEASHORE, MASSACHUSETTS. (A PRELIMINARY REPORT). UNIVERSITY OF MASSACHUSETTS. AMHERST, MASSACHUSETTS. NATIONAL PARK SERVICE COOPERATIVE RESEARCH UNIT REPORT 6.

1723.

GODFREY, P. J., J. M. B. BRODHEAD, J. DIMAIO, J. M. GILLIGAN, D. REYNOLDS and B. G. BLODGET. 1975. THE ECOLOGICAL EFFECTS OF OFF-ROAD VEHICLES IN CAPE COD NATIONAL SEASHORE, MASSACHUSETTS (PHASE II). ANGERST NATIONAL PARK SERVICE COOPERATIVE RESEARCH UNIT. ANGERST NATIONAL PARK SERVICE COOP. RES. UNIT REPORT 18. 133

1724.

GODFREY, P. J. 1979. RESPONSE OF COASTAL ECOSYSTEMS TO THE MECHANICAL STRESS OF OFF-ROAD VEHICLES. BRITISH ECOLOGICAL SOCIETY SYMPOSIUM 19:641-642.

1725. GODFREY, P. J., S. P. LEATHERMAN and P. A. BUCKLEY. 1978. IMPACT OF OFF-ROAD VEHICLES ON COASTAL ECOSYSTEMS. PAGES 581-600 IN SYMPOSIUM ON TECHNICAL, ENVIRONMENTAL, SOCIOECONOMIC AND REGULATORY ASPECTS OF COASTAL ZONE MANAGEMENT. VOLUME 2. AMER. SOC. OF CIVIL ENG., NEW YORK.

1726. GODSHALL, T. 1976. TITLE UNKNOWN. PA. GAME NEWS 47 (5):39.

1727. GOETZ, E. J. and R. T. BUTTERFIELD. 1978. TITLE UNKNOWN. TRANS. NORTHEAST SECT. WILDL. SOC. 35:154-64.

1728. GOLD, A. L. 1997. HABITAT USE OF BLACK BEARS IN THE NORTHEAST CASCADES OF WASHINGTON. M.S. THESIS, UNIVERSITY OF MONTANA, MISSOULA, MT. 94 PP.

1729.

GOLDAN, D. S. 1982. BASELINE DATA ON VEGETATION, BREEDING BIRD POPULATIONS AND SMALL MAMMALS IN RELATION TO PROPOSED CONTOUR FURROWING IN SOUTHEASTERN MONTANA. M.S. THESIS, MONTANA STATE UNIVERSITY, BOZEMAN, MT. 29 PP.

1730. GOLDIN, M. R. 1993. EFFECTS OF HUMAN DISTURBANCE AND OFF-ROAD VEHICLES ON PIPING PLOVER REPRODUCTIVE SUCCESS AT BREEZY POINT, GATEWAY NATIONAL RECREATION AREA, NEW YORK. THESIS, 
1731. GOLDIN, M. R. 1993. EFFECTS OF HUMAN DISTURBANCE AND OFF-ROAD VEHICLES ON PIPING PLOVER REPRODUCTIVE SUCCESS AND BEHAVIOR AT BREEZY POINT, GATEWAY NATIONAL RECREATION AREA, NEW YORK.

1732. GOLDINGAY, R. and H. POSSINGHAM. 1995. AREA REQUIREMENTS FOR VIABLE POPULATIONS OF THE AUSTRALIAN GLIDING MARSUPIAL PETAURUS AUSTRALIS. BIOLOGICAL CONSERVATION 73 (2):161-7.

1733. GOLDSMITH, C. D. JR. and P. F. SCANLON. 1977. LEAD LEVELS IN SMALL MAMMALS AND SELECTED INVERTEBRATES ASSOCIATED WITH HIGHWAYS OF DIFFERENT TRAFFIC DENSITIES. BULLETIN OF ENVIRONMENTAL CONTAMINATION AND TOXICOLOGY 17:311-316.

1734. GONZALEZ, J. C. T. 1993. AN AVIFAUNAL SURVEY OF PUERTO GALERA, ORIENTAL MINDORO PROVINCE, PHILIPPINES. ASIA LIFE SCIENCES 2 (2):163-76.

1735. GONZALEZ, J. C. T. 1995. STATUS OF BIRDS AT THE U.P. LAGUNA LAND GRANT, LUZON, PHILIPPINES. JOURNAL OF THE YAMASHINA INSTITUTE FOR ORNITHOLOGY 27 (1):12-29.

1736. GONZALEZ, J. C. T. and A. T. L. DANS. 1994. MICROHABITATS OF ENDEMIC DIMINUTIVE FROGS AND SKINKS IN MOUNT MAKILING FOREST RESERVE, LUZON, PHILIPPINES. ASIA LIFE SCIENCES 3 (2):227-43.

1737. GOODCHILD, G. A. and S. METIKOSH. 1994. FISHERIES-RELATED INFORMATION REQUIREMENTS FOR PIPELINE WATER CROSSINGS. CANADIAN MANUSCRIPT REPORT OF FISHERIES AND AQUATIC SCIENCES 0 (2235):I-VIII, 1-18.

1738. GOODCHILD, M. F., B. O. PARKS and L. T. STEYAERT. 1993. ENVIRONMENTAL MODELING WITH GIS. OXFORD UNIVERSITY PRESS, NEW YORK.

1739. GOODHUE, L. D. and F. M. BAUMGARTNER. 1965. APPLICATIONS OF NEW BIRD CONTROL CHEMICALS. J. WLDL. MANAGE. 29 (4):830-7.

1740. GOODLOE, R. B., R. J. WARREN, E. G. COTHRAN, S. P. BRATTON and K. A. TREMBICKI. 1991. GENETIC VARIATION AND ITS MANAGEMENT APPLICATIONS IN EASTERN U.S. FERAL HORSES. J. WLDL. MANAGE. 55 (3):412-21.

1741. GOODLOE, S. 1986. VIEWPOINT: OFF-ROAD VEHICLE DAMAGE TO PUBLIC LANDS. RANGELANDS 8:107-108.

1742. GOODMAN, S. M., M. PIGEON and S. O'CONNOR. 1994. MASS MORTALITY OF MADAGASCAR RADIATED TORTOISE CAUSED BY ROAD CONSTRUCTION. ORYX 28(2):115-118.

1743. GOODSON, N. J. 1994. PERSISTENCE AND POPULATION SIZE IN MOUNTAIN SHEEP. CONS. BIOL. 8 (3):619-20.

1744. GOODSON, N. J., D. R. STEVENS and J. A. BAILEY. 1991. EFFECTS OF SNOW ON FORAGING ECOLOGY AND NUTRITION OF BIGHORN SHEEP. J. WILDL. MANAGE. 55 (2):214-22.

1745. GOODWIN, G. A. and A. L. WARD. 1976. MULE DEER MORTALITY ON INTERSTATE 80 IN WYOMING: CAUSES, PATTERNS AND RECOMMENDATIONS. U.S. DEPARTMENT OF AGRICULTURE, FOREST SERVICE, ROCKY MOUNTAIN RESEARCH STATION, RES. NOTE RM-332. FT. COLLINS, CO.

1746. GOODYEAR, C. P. 1977. ECOLOGICAL IMPLICATIONS OF ANTICIPATED ELECTRIC POWER DEVELOPMENT. DEPT. OF THE INTERIOR, FISH AND WILDLIFE SERVICE, OFFICE OF BIOLOGICAL SERVICE, POWER PLANT PROJECT, NATIONAL POWER PLANT TEAM, ANN ARBOR, MICHIGAN. TOPICAL BRIEFS, FISH AND WILDLIFE RESOURCES AND ELECTRIC POWER GENERATION: FWS/OBS ; 76/20.3 3.

1747. GOODYEAR, N. C. 1989. STUDYING FINE-SCALE HABITAT USE IN SMALL MAMMALS. J. WILDL. MANAGE. 53 (4):941-6.

1748. GOOSEM, M. 1993. CRITTERS, CARS, CARNAGE, CONNECTIVITY AND CULVERTS. REPERCUSSIONS OF RAINFOREST ROADS. NORTH QUEENSLAND NATURALIST 95:24-28.

1749. GORAN, W. D., L. L. RADKE and W. D. SEVERINGHAUS. 1983. OVERVIEW OF THE ECOLOGICAL EFFECTS OF TRACKED VEHICLES ON MAJOR U.S. (UNITED STATES) GRMY INSTALLATIONS. U.S. DEPT. DEFENSE, ARMY CORPS ENG., 
CONSTRUCT. ENG. RES. LAB. CHAMPAIGN, ILLINOIS. CERL-TR-N-142. 81PP.

1750. GORANSSON, G. and J. KARLSSON. 1979. CHANGES IN POPULATION DENSITIES AS MONITORED BY ANIMALS KILLED ON ROADS. NATURVARDSVERKET RAPPORT 151:120-125.

1751. GORANSSON, G., J. KARLSSON and A. LINDGREN. 1978. INFLUENCE OF ROADS ON THE SURROUNDING NATURE. 2. FAUNA. NO. SNV PM069. NATIONAL SWEDISH ENVIRONMENTAL PROTECTION BOARD, [LOCATION OF PUBLISHER UNKNOWN].

1752. GORDON, D. 1967. A REPORT ON THE EFFECTIVENESS OF VAN DE REE MIRRORS. 29THMIDWEST WILDL. CONF.; DECEMBER 11-14; MADISON WISCONSIN.

1753. GORDON, D. F. 1969. DEER MIRRORS: A CLEARER PICTURE. GAME INFORMATION LEAFLET NO.77. COLORADO DEPARTMENT OF NATURAL RESOURCES, DIVISION OF GAME, FISH AND PARKS , DENVER, CO.

1754. GORDON, D. F. 1969. EVALUATION OF DEER-HIGHWAY CROSSING SAFETY MEASURES. COLO. GAME, FISH AND PARKS, FED. AID REPT., PROJECT W-38-R-23.

1755. GORDON, F. A. 1968. RANGE RELATIONSHIPS OF ELK AND CATTLE ON ELK WINTER RANGE, CROW CREEK, MONTANA. M.S. THESIS, MONTANA STATE UNIVERSITY, BOZEMAN, MT. 52 PP.

1756. GORDON, K. 1932. RABBITS KILLED ON AN IDAHO HIGHWAY. JOURNAL OF MAMMALOGY 13:169-173.

1757. GORENZEL, W. P. and T. P. SALMON. 1995. CHARACTERISTICS OF AMERICAN CROW URBAN ROOTS IN CALIFORNIA. J. WILDL. MANAGE. 59 (4):638-45.

1758. GORGES, M. W. 1976. THE BENTHIC MACROINVERTEBRATES OF THE MUSSELSHELL RIVER, MONTANA. M.S. THESIS, MONTANA STATE UNIVERSITY, BOZEMAN, MT. 33 PP.

1759. GOSNER, K. L. and I. H. BLACK. 1957. THE EFFECTS OF ACIDITY ON THE DEVELOPMENT AND HATCHING OF NEW JERSEY FROGS . ECOLOGY 38:256-262.

1760. GOSSMANN, K. S. and D. EISFELD. 1990. THE SUITABILITY OF THE BLACK FOREST AS HABITAT FOR THE LYNX (LYNX LYNX, L. 1758). MITTEILUNGEN DES BADISCHENLANDESVEREINS FUER NATURKUNDE UND NATURSCHUTZ E VFREIBURG IM BREISGAU 15 (1):177-246.

1761. GOSSMANN, K. S. and D. EISFELD. 1990. THE SUITABILITY OF THE BLACK FOREST AS HABITAT FOR THE LYNX (LYNX LYNX L.). MITTEILUNGEN DES BADISCHEN LANDESVEREINS FUER NATURKUNDE UND NATURSCHUTZ E V FREIBURG IM BREISGAU 15(1):177-246.

1762. GOSZ, J. R. 1975. STREAM CHEMISTRY AS A TOOL IN EVALUATING SKI AREA DEVELOPMENT. PAGES $183-194$ IN MAN, LEISURE, AND WLDLANDS: A COMPLEX INTERACTION. PROCEEDINGS OF THE FIRST EISENHOWER CONSORTIUM RESEARCH SYMPOSIUM.

1763. GOTMARK, F. and M. AHLUND. 1984. DO FIELD OBSERVERS ATTRACT NEST PREDATORS AND INFLUENCE NESTING SUCCESS OF COMMON EIDERS? J. WILDL. MANAGE. 48 (2):381-7.

1764. GOTMARK, F., R. NEERGAARD and M. AHLUND. 1989. NESTING ECOLOGY AND MANAGEMENT OF THE ARCTIC LOON IN SWEDEN. J. WLDL. MANAGE. 53 (4):1025-31.

1765. GOTMARK, F., R. NEERGAARD and M. AHLUND. 1990. PREDATION OF ARTIFICIAL AND REAL ARCTIC LOON NESTS IN SWEDEN. J. WILDL. MANAGE. 54 (3):429-32.

1766. GOTO, M., T. INOUE and T. NARUSAWA. 1993. ECOLOGICAL STUDY ON THE CROW IN SHONAI DISTRICT: I. PRE-ROOSTING ASSEMBLY BEHAVIOUR AND SEASONAL SHIFTS IN ROOSTING IN TSURUOKA. JOURNAL OF THE YAMAGATA AGRICULTURE AND FORESTRY SOCIETY 0 (50):9-17.

1767. GRABHERR, G. 1985. DAMAGE TO VEGETATION BY RECREATION IN THE AUSTRIAN AND GERMAN ALPS. PAGES 74-91 IN N. G. BAYFIELD AND G. C. BARROW, EDITORS. THE ECOLOGICAL IMPACTS OF OUTDOOR RECREATION ON MOUNTAIN AREAS IN EUROPE AND NORTH AMERICA. RECREATION ECOLOGY RESEARCH GROUP, WYE, 
ASHFORD, KENT, UK.

1768. GRAGERA, D. F., M. A. CORBACHO and S. J. DE-AVALOS. 1992. PROVISIONAL REPORT OF THE MORTALITY OF VERTEBRATES ON THE ROADS OF BADAJOZ PROVINCE, SEPTEMBER 1991. PAGES 136-144 IN LOPEZ,REDONDO, EDITOR. I JORNADAS PARA EL ESTUDIO Y PREVENCION DE LA MORTALIDAD DE VERTEBRADOS EN CARRETERAS, MADRID, 5 Y 6 DE OCTUBRE DE 1991. TOMO 2. [SESSIONS IN THE STUDY OF PREVENTION OF ROAD MORTALITIES OF VERTEBRATES, MADRID, 5 AND 6 OCTOBER, 1991. VOLUME 2.]. COORDINADORA DE ORGANIZACCIONES DE DEFENSA, AMBIENTAL, MADRID.

1769. GRAHAM, D. C. 1978. GRIZZLY BEAR DISTRIBUTION, USE OF HABITATS, FOOD HABITS AND HABITAT CHARACTERIZATION IN PELICAN AND HAYDEN VALLEYS, YELLOWSTONE NATIONAL PARK. M.S. THESIS, MONTANA STATE UNIVERSITY, BOZEMAN, MT. 124 PP.

1770. GRAHAM, H. 1980. THE IMPACT OF MODERN MAN. PAGES 288-309 IN G. MONSON AND L. SUMNER, EDITORS. THE DESERT BIGHORN: ITS LIFE HISTORY, ECOLOGY AND MANAGEMENT. UNIVERSITY OF ARIZONA PRESS. TUCSON, ARIZONA, USA.

1771. GRAHAM, H. 1966. MULTIPLE USE COORDINATION ON THE SAN GORGINIO BIGHORN UNIT. TRANSACTIONS OF THE DESERT BIGHORN COUNCIL 10:71-77.

1772.

GRAHAM, R. L., C. T. HUNSAKER, R. V. O'NEILL and B. L. JACKSON. 1991. ECOLOGICAL RISK ASSESSMENT AT THE REGIONAL SCALE. ECOLOGICAL APPLICATIONS 1 (2):196-206.

1773. GRAHAM, R. J. 1955. BIOLOGY OF THE UTAH CHUB IN HEBGEN LAKE, MONTANA. M.S. THESIS, MONTANA STATE COLLEGE, BOZEMAN, MT. 32 PP.

1774. GRAHAM, T. 1980. WASHINGTON OFF-ROAD VEHICLE GUIDE. WASHINGTON DEPARTMENT OF NATURAL RESOURCES. OLYMPIA, WASHINGTON. 55PP.

1775. GRANDAGE, J. 1976. THE BUSHWALKER'S VIEWPOINT ON OFF-ROAD VEHICLES. PAGES 129-138 IN NATIONAL SYMPOSIUM ON OFF-ROAD VEHICLES IN AUSTRALIA.

GRANT, J. C. 1987. THE ECOLOGY OF BLACK-TAILED JACK RABBITS NEAR A SOLID RADIOACTIVE WASTE DISPOSAL SITE IN SOUTHEAST IDAHO. M.S. THESIS, UNIVERSITY OF MONTANA, MISSOULA, MT. 64 PP.

1777. GRAVES, H. B. and E. D. BELLIS. 1971. DEER AND MOTORISTS--CAN THEY COEXIST?. PENNSYLVANIA GAME NEWS 42(12):40-42.

1778.

GRAVES, H. B. and E. D. BELLIS. 1971. TITLE UNKNOWN. PA. GAME NEWS 42 (12):40-2.

1779.

GRAVES, H. B., E. D. BELLIS and W. M. KNUTH. 1972. CENSUSING WHITE-TAILED DEER BY AIRBORNE THERMAL INFRARED IMAGERY. J. WILDL. MANAGE. 36 (3):875-84.

1780. GRAY, C. J. 1995. MULE DEER HABITAT USE IN THE BENNETT HILLS, IDAHO. M.S. THESIS, MONTANA STATE UNIVERSITY, BOZEMAN, MT. 64 PP.

1781.

GRAYSON, R. B., S. R. HAYDON, M. D. A. YJAYASURIYA and B. L. FINLAYSON. 1993. WATER QUALITY IN MOUNTAIN ASH FORESTS - SEPARATING THE IMPACTS OF ROADS FROM THOSE OF LOGGING OPERATIONS. JOURNAL OF HYDROLOGY (AMSTERDAM) 150 (2-4):459-80.

GREATHOUSE, J. K. 1980. FIRST AND SECOND GENERATIONAL EFFECTS OF COLCHICINE ON C57 BLACK MICE. M.S. THESIS, MONTANA STATE UNIVERSITY, BOZEMAN, MT. 47 PP.

1783. GREEN, G. I., D. J. MATTSON and J. M. PEEK. 1997. SPRING FEEDING ON UNGULATE CARCASSES BY GRIZZLY BEARS IN YELLOWSTONE NATIONAL PARK. THE JOURNAL OF WLDLIFE MANAGEMENT 61:1040-1055.

1784. GREEN, J. E., M. RAINE, J. JORGENSON, T. CLEVENGER and T. HURD. 1997. THE MID-POINT INTERCHANGE PROJECT: ASSESSMENT OF THE PROPOSED MODIFICATIONS TO THE STEWART CREEK PRIMARY WILDLIFE MOVEMENT CORRIDOR AND RECOMMENDATIONS FOR MITIGATION. UNPUBLISHED REPORT. MID-POINT INTERCHANGE COMMITTEE, CANMORE, ALBERTA. 
1785. GREEN, R. E. and G. H. GRIFFITHS. 1994. USE OF PREFERRED NESTING HABITAT BY STONE CURLEWS BURHINUS OEDICNEMUS IN RELATION TO VEGETATION STRUCTURE. JOURNAL OF ZOOLOGY (LONDON) 233 (3):457-71.

1786. GREEN, R. E., P. E. OSBORNE and E. J. SEARS. 1994. THE DISTRIBUTION OF PASSERINE BIRDS IN HEDGEROWS DURING THE BREEDING SEASON IN RELATION TO CHARACTERISTICS OF THE HEDGEROW AND ADJACENT FARMLAND. JOURNAL OF APPLIED ECOLOGY 31 (4):677-92.

1787. GREENBERG, C. H., L. D. HARRIS and D. G. NEARY. 1995. A COMPARISON OF BIRD COMMUNITIES IN BURNED AND SALVAGE-LOGGED, CLEARCUT, AND FORESTED FLORIDA SAND PINE SCRUB. WLSON BULLETIN 107 (1):40-54.

1788. GREENBERG, C. H., D. G. NEARY and L. D. HARRIS. 1994. EFFECT OF HIGH-INTENSITY WILDFIRE AND SILVICULTURAL TREATMENTS ON REPTILE COMMUNITIES IN SAND- PINE SCRUB. CONSERVATION BIOLOGY 8(4):1047-1057.

1789. GREENE, J. 1985. TITLE UNKNOWN. DEFENDERS 60 (4):8-14.

1790. GREENFIELD, B. 1991. A REVIEW OF A METHOD OF RELATING HABITAT EFFECTIVENESS FOR ELK TO ROAD DENSITY. ALBERTA FORESTRY, LANDS \& WILDLIFE, LAND INFORMATION SERVICES, EDMONTON, ALBERTA.

1791. GREENHALL, A. M. 1973. INDIANA BAT: A CAVE-DWELLER IN TROUBLE. NATIONAL PARKS CONSERVATION MAGAZINE 47:14-17.

1792. GREENHOUSE, G. 1976. THE EVALUATION OF TOXIC EFFECTS OF CHEMICALS IN FRESHWATER BY USING FROG EMBRYOS AND LARVAE . ENVIRONMENTAL POLLUTION 11:303-315.

1793. GREENWALT, L. A. 1973. DEVELOPMENTS IN RECREATIONAL USE OF PUBLIC LANDS AND WATERS. TRANS. N. AMER. WILDL. NAT. RESOUR. CONF. 38:437-445.

1794. GREENWOOD, J. G. 1989. SANDWICH TERNS APPARENTLY USING ROADS AS NAVIGATIONAL CUES. BRITISH BIRDS 2(3):117.

1795. GREENWOOD, R. J., A. B. SARGEANT, D. H. JOHNSON, L. M. COWARDIN and T. L. SHAFFER. 1995. FACTORS ASSOCIATED WITH DUCK NEST SUCCESS IN THE PRAIRIE POTHOLE REGION OF CANADA. WILDLIFE MONOGRAPHS 0 (128):1-57.

1796. GREER, K. R. 1972. GRIZZLY BEAR MORTALITY AND STUDIES IN MONTANA. INT. CONF. BEAR RES. AND MANAGE. 2:53-66

1797. GREER, K. R. 1953. YEARLY FOOD HABITS OF THE RIVER OTTER IN THE THOMPSON LAKES REGION, NORTHWEST MONTANA. M.S. THESIS, MONTANA STATE COLLEGE, BOZEMAN, MT. 30 PP.

1798. GREER, S. Q. 1987. HOME RANGE, HABITAT USE, AND FOOD HABITS OF BLACK BEARS IN SOUTH-CENTRAL MONTANA. M.S. THESIS, MONTANA STATE UNIVERSITY, BOZEMAN, MT. 91 PP.

1799. GREGORI, J. 1987. BIRDS DYING ALSO ON ROADS. ACROCEPHALUS (LJUBLJANA) 31-32:19-22.

1800. GREGORY, S. K. 1983. SUBALPINE FORB COMMUNITY TYPES OF THE BRIDGER TETON NATIONAL FOREST, WYOMING. M.S. THESIS, MONTANA STATE UNIVERSITY, BOZEMAN, MT. 62 PP.

1801. GREISER, K. C. 1955. GONADOTROPHIC POTENCY OF MULE DEER PITUITARIES AND THE POSSIBLE CORRELATION WITH THE REPRODUCTIVE CYCLE. M.S. THESIS, MONTANA STATE UNIVERSITY, MISSOULA, MT. 56 PP.

1802. GRENIER, P. 1973. TITLE UNKNOWN. P. 155-194. IN: ADDISON, R. B., EDITOR. NINTH NORTH AM. MOOSE CONF. WORKSHOP; QUEBEC: ONT MINIST NAT RESOUR, FISH WILDL RES BRANCH AND WILDL BRANCH.

1803. GRENIER, P. A. 1974. TITLE UNKNOWN. NATURALISTE CANADIEN 101(5):737-54.

1804. GRIER, J. W. 1969. BALD EAGLE BEHAVIOR AND PRODUCTIVITY RESPONSES TO CLIMBING TO NESTS. J. WLDL. MANAGE. 33 (4):961-6. 
1805. GRIFFIN, D. P. 1971. A STUDY OF THE EAST GALLATIN RIVER, MONTANA, USING AN ALGAL BIOASSAY (BATCH METHOD) AND SOME PROBLEMS ENCOUNTERED. M.S. THESIS, MONTANA STATE UNIVERSITY, MISSOULA, - MT. 88 PP.

1806. GRIFFITHS, D. E. 1990. GREEN VEGETATION AND FECAL PROTEIN RELATIONSHIPS IN TWO SOUTHEASTERN MONTANA MULE DEER POPULATIONS. M.S. THESIS, MONTANA STATE UNIVERSITY, BOZEMAN, MT. 99 PP.

1807. GRISAK, G. G. 1996. THE STATUS AND DISTRIBUTION OF THE SICKLEFIN CHUB IN THE MIDDLE MISSOURI RIVER, MONTANA. M.S. THESIS, MONTANA STATE UNIVERSITY, BOZEMAN, MT. 77 PP.

1808. GRISCOM, B. 1994. WLDLIFE PROTECTED ALONG MANY RAIL-TRAILS. TRAILBLAZER :5-6.

1809. GRIST, R. R. and S. K. WLLIAMS. 1999. DEVELOPMENT OF A METHODOLOGY FOR DETERMINING OPTIMUM LOCATIONS FOR WILDLIFE CROSSINGS ON STATE HIGHWAYS USING A GEOGRAPHIC INFORMATION SYSTEMS APPROACH, WITH APPLICATION TO KEY DEER. ON BIG PINE KEY, FLORIDA. MICROFORM. DEPT. OF LANDSCAPE ARCHITECTURE, UNIVERSITY OF FLORIDA, GAINESVILLE, FLORIDA.

1810. GRKOVIC, N. 1976. MONTANA-IDAHO ELK MIGRATION AND KEY-USE AREA STUDY, SALMON, BEAVERHEAD, AND BITTERROOT NATIONAL FORESTS. M.S. THESIS, UNIVERSITY OF MONTANA, MISSOULA, MT. 128 PP.

1811. GROEBNER, D. J. and L. R. WILLIAM. 1988. USE OF ROADS AND CIRCADIAN MOVEMENT RATES OF A PAIR OF WOLVES. JOURNAL OF THE MINNESOTA ACADEMY OF SCIENCE 53(3):18-19.

1812. GRONINGER, J. W. and L. H. MCCORMICK. 1992. EFFECTS OF SOIL DISTURBANCE ON HAYSCENTED FERN ESTABLISHMENT. NORTH J APPL FOR. 9:29-31.

1813. GROOT BRUINDERINK, G. W. T. A. and E. HAZEBROEK. 1996. UNGULATE TRAFFIC COLLISIONS IN EUROPE. CONSERVATION BIOLOGY 10(4):1059-1067.

1814. GROSS, R. and A. H. UNDERHILL. 1977. STATE COMPREHENSIVE OUTDOOR RECREATION PLANS AS A VEHICLE FOR FISH AND WILDLIFE PLANNING. TRANS. N. AMER. WILDL. NAT. RESOUR. CONF. 42:203-206.

1815. GROSSE, W. J. 1992. THE PROTECTION AND MANAGEMENT OF OUR NATURAL RESOURCES, WLDLIFE, AND HABITAT. OCEANA PUBLICATIONS, DOBBS FERRY, NEWYORK.

1816. GROSSE, W. J. 1997. THE PROTECTION \& MANAGEMENT OF OUR NATURAL RESOURCES, WLDLIFE \& HABITAT. 2ND ED. OCEANA PUBLICATIONS, DOBBS FERRY, NEW YORK.

1817. GROVER, D. R. and P. J. SLATER. 1994. CONSERVATION VALUE TO BIRDS OF REMNANTS OF MELALEUCA FOREST IN SUBURBAN BRISBANE. WILDLIFE RESEARCH 21 (4):433-44.

1818. GROVER, K. E. and M. J. THOMPSON. 1986. FACTORS INFLUENCING SPRING FEEDING SITE SELECTION BY ELK IN THE ELKHORN MOUNTAINS, MONTANA. JOURNAL OF WLDLIFE MANAGEMENT. 50(3):466-470

1819. GROVER, K. E. and M. J. THOMPSON. 1986. FACTORS INFLUENCING SPRING FEEDING SITE SELECTION BY ELK (CERVUS ELAPHUS) IN THE ELKHORN MOUNTAINS, MONTANA (USA). JOURNAL OF WLDLIFE MANAGEMENT $50: 466-470$

1820. GROVER, K. E. 1983. ECOLOGY OF THE OSPREY ON THE UPPER MISSOURI RIVER, MONTANA. M.S. THESIS, MONTANA STATE UNIVERSITY, BOZEMAN, MT. 58 PP.

1821. GROVER, M. C. and L. A. DEFALCO. 1995. DESERT TORTOISE (GOPHERUS AGASSIZII): STATUS-OF-KNOWLEDGE OUTLINE WITH REFERENCES. U.S. DEPARTMENT OF AGRICULTURE, FOREST SERVICE, INTERMOUNTAIN RESEARCH STATION, GEN. TECH. REP. INT-316. OGDEN, UT.

1822. GRUBB, T. G., W. W. BOWERMAN, J. P. GIESY and G. A. DAWSON. 1992. RESPONSES OF BREEDING BALD EAGLES, HALIAEETUS LEUCOCEPHALIS, TO HUMAN ACTIVITIES IN NORTHCENTRAL MICHIGAN. CANADIAN FIELD-NATURALIST 106:443-453. 
1823. GRUBB, T. G. and R. M. KING. 1991. ASSESSING HUMAN DISTURBANCE OF BREEDING BALD EAGLES WITH CLASSIFICATION TREE MODELS. JOURNAL OF WILDLIFE MANAGEMENT 55:500-511.

1824. GRUE, C. E., D. J. HOFFMAN, W. N. BEYER and L. P. FRANSON. 1986. LEAD CONCENTRATIONS AND REPRODUCTIVE SUCCESS IN EUROPEAN STARLINGS (STURNUS VULGARIS) NESTING WITHIN HIGHWAY ROADSIDE VERGES. ENVIRONMENTAL POLLUTION (SERIES A) 42:157-182.

1825. GRUELL, G. E. and G. ROBY. 1976. ELK HABITAT RELATIONSHIPS BEFORE LOGGING ON BRIDGER-TETON NATIONAL FOREST, WYOMING. PAGES 110-121 IN PROC. ELK-LOGGING-ROADS SYMP. UNIVERSITY OF IDAHO, MOSCOW, IDAHO.

1826. GRUMBINE, R. E. 1994. WHAT IS ECOSYSTEM MANAGEMENT? CONSERVATION BIOLOGY 8 (1):27-38.

1827. GUMTOW, R. B. 1954. AN INVESTIGATION OF THE PERIPHYTON IN A RIFFLE OF THE WEST GALLATIN RIVER, MONTANA. M.S. THESIS, MONTANA STATE COLLEGE, BOZEMAN, MT. 29 PP.

1828. GUNATILLEKE, I. A. U. N. and C. V. S. GUNATILLEKE. 1990. DISTRIBUTION OF FLORISTIC RICHNESS AND ITS CONSERVATION IN SRI LANKA. CONSERVATION BIOLOGY 4 (1):21-31.

1829. GUNDERSON, D. R. 1966. STREAM MORPHOLOGY AND FISH POPULATIONS IN RELATION TO FLOOD PLAIN USE. M.S. THESIS, MONTANA STATE UNIVERSITY, BOZEMAN, MT. 21 PP.

1830. GUNDERSON, P. T. 1990. NESTING AND BROOD REARING ECOLOGY OF SHARP-TAILED GROUSE ON THE CHARLES M. RUSSELL NATIONAL WILDLIFE REFUGE, MONTANA. M.S. THESIS, MONTANA STATE UNIVERSITY, BOZEMAN, MT. 86 PP.

1831. GUNN, A. 1983. SUBMISSIONS TO THE BEAUFORT SEA ENVIRONMENTAL ASSESSMENT PANEL. DEPT. OF RENEWABLE RESOURCES, GOVERNMENT OF THE NORTHWEST TERRITORIES, YELLOWKNIFE

1832. GUNSON, J. R. 1995. ANALYSIS OF GRIZZLY BEAR MORTALITIES IN ALBERTA DURING1972-1994. ALBERTA ENV. PROT., NAT. RESOUR. SERV. OCCAS. PAPER NO. 16, WILDL. MANAGE. DIV. 101 PP.

1833. GUNTHER, K. A. 1994. BEAR MANAGEMENT IN YELLOWSTONE NATIONAL PARK, 1960-93. INT. CONF. BEAR RES. AND MANAGE. 9:549-60.

1834. GUNTHER, K. A. 1990. VISITOR IMPACT ON GRIZZLY BEAR ACTIVITY IN PELICAN VALLEY, YELLOWSTONE NATIONAL PARK. INT. CONF. BEAR RES. AND MANAGE. 8:73-8.

1835. GUNTHER, K. A., M. J. BIEL and H. L. ROBISON. 1998. FACTORS INFLUENCING THE FREQUENCY OF ROAD-KILLED WILDLIFE IN YELLOWSTONE NATIONAL PARK. PAGES $32-42$ IN G. L. EVINK, P. GARRETT, D. ZEIGLER, AND J. BERRY, EDITORS. PROCEEDINGS OF THE INTERNATIONAL CONFERENCE ON WLDLIFE ECOLOGY AND TRANSPORTATION. FLORIDA DEPARTMENT OF TRANSPORTATION, TALLAHASSEE, FLORIDA.

1836. GUNTHER, K. A. 1991. GRIZZLY BEAR ACTIVITY AND HUMAN-INDUCED MODIFICATIONS IN PELICAN VALLEY, YELLOWSTONE NATIONAL PARK. M.S. THESIS, MONTANA STATE UNIVERSITY, BOZEMAN, MT. 102 PP.

1837. GUSTAFSON, D. L. 1990. ECOLOGY OF AQUATIC INSECTS IN THE GALLATIN RIVER DRAINAGE. PH.D. DISSERTATION, MONTANA STATE UNIVERSITY, BOZEMAN, MT. 194 PP.

1838. GUSTAFSON, E. J., G. R. PARKER and S. E. BACKS. 1994. EVALUATING SPATIAL PATTERN OF WILDLIFE HABITAT: A CASE STUDY OF THE WIL TURKEY (MELEAGRIS GALLOPAVO). AMERICAN MIDLAND NATURALIST 131 (1):24-33.

1839. GUSTAFSON, J. AN EVALUATION OF LOW WATER CROSSINGS AT FISH STREAMS ALONG THE TRANS-ALASKA PIPELINE SYSTEM.

1840. GUTH, R. W. 1979. THE JUNK FOOD GUILD: BIRDS AND MAMMALS ON PICNIC GROUNDS AND IN RESIDENTIAL AREAS. ILLINOIS AUDUBON BULLETIN 189:3-7 . 
1841. GUTHERY, F. S., T. E. SHUPE, L. J. BAREISS and C. E. RUSSELL. 1987. RESPONSES OF SELECTED PLANTS TO HERBICIDE TREATMENT OF DISTURBED SOIL. WILDL. SOC. BULL. 15 (2):247-51.

1842. GUTTING, R. E. JR. 1974. THE ENVIRONMENTAL COSTS OF ORVS IN AMERICA. EDF LETTER, MAY 1974. 2 PP.

1843. GUTZWILLER, K. J. 1985. RIPARIAN-HABITAT USE BY BREEDING CAVITY-NESTING BIRDS IN SOUTHEASTERN WYOMING. PHD THESIS, UNIVERSITY OF WYOMING. 138 PP.

1844. GUTZWILLER, K. J. 1993. SERIAL MANAGEMENT EXPERIMENTS: AN ADAPTIVE APPROACH TO REDUCE RECREATIONAL IMPACTS ON WILDLIFE . TRANSACTIONS OF THE NORTH AMERICAN WILDLIFE AND NATURAL RESOURCES CONFERENCE 58:528-536.

1845. GUYOT, G. and J. CLOBERT. 1997. CONSERVATION MEASURES FOR A POPULATION OF HERMANN'S TORTOISE (TESTUDO HERMANNI) IN SOUTHERN FRANCE BISECTED BY A MAJOR HIGHWAY. BIOLOGICAL CONSERVATION 79:251-256.

1846. GUZEVICH, J. W. 1993. THE RELATIONSHIP OF PHYSICAL HABITAT TO THE DISTRIBUTION OF NORHTERN PIKE AND WALLEYE IN TWO MONTANA PRAIRIE STREAMS. M.S. THESIS, MONTANA STATE UNIVERSITY, BOZEMAN, MT. 94 PP.

1847. GUZMAN, H. M. 1991. RESTORATION OF CORAL REEFS IN PACIFIC COSTA RICA. CONSERVATION BIOLOGY 5 (2):189-95.

1848. HADDEN, D. A. 1987. GRIZZLY BEAR HABITAT ANALYSIS, SOUTHERN WHITEFISH RANGE, MONTANA. M.S. THESIS, UNIVERSITY OF MONTANA, MISSOULA, MT. 132 PP.

1849. HADLEY, K. S. 1994. THE ROLE OF DISTURBANCE, TOPOGRAPHY AND FOREST STRUCTURE IN THE DEVELOPMENT OF A MONTANE FOREST LANDSCAPE. BULLETIN OF THE TORREY BOTANICAL CLUB 121 (1):47-61.

1850. HAFFER, J. 1992. ON THE RIVER EFFECT IN SOME FOREST BIRDS OF SOUTHERN AMAZONIA. BOLETIM DO MUSEU PARAENSE EMILIO GOELDI SERIE ZOOLOGIA 8 (1):217-45.

1851. HAGAN, J. M., W. M. VANDER HAEGEN and P. S. MCKINLEY. 1996. THE EARLY DEVELOPMENT OF FOREST FRAGMENTATION EFFECTS ON BIRDS. CONSERVATION BIOLOGY10 (1):188-202.

1852. HAGLUND, B. M. 1972. ECOLOGICAL EFFECTS OF WEATHER MODIFICATION, BANGTAIL RIDGE, BRIDGER RANGE, MONTANA : RELATIONSHIPS OF POCKET GOPHERS (THOMOMYS TALPOIDES) TO TIME OF SNOW MELT. M.S. THESIS, MONTANA STATE UNIVERSITY, BOZEMAN, MT. 26 PP.

1853. HAIGHT, C. P. 1941. SOME OBSERVATIONS ON THE PREDATOR-PREY COMPLEX IN THE GALLATIN VALLEY. M.S. THESIS, MONTANA STATE COLLEGE, BOZEMAN, MT. 56 PP.

1854. HAILA, Y., I. K. HANSKI, J. NIEMELA, P. PUNTTILA, S. RAIVIO and H. TUKIA. 1994. FORESTRY AND THE BOREAL FAUNA: MATCHING MANAGEMENT WITH NATURAL FOREST DYNAMICS. ANNALES ZOOLOGICI FENNICI 31 (1):187-202.

1855. HAILA, Y., I. K. HANSKI and S. RAIVIO. 1993. TURNOVER OF BREEDING BIRDS IN SMALL FOREST FRAGMENTS: THE SAMPLING COLONIZATION HYPOTHESIS CORROBORATED. ECOLOGY 74 (3):71425.

1856. HAIM, A. and I. IZHAKI. 1994. CHANGES IN RODENT COMMUNITY DURING RECOVERY FROM FIRE: RELEVANCE TO CONSERVATION. BIODIVERSITY AND CONSERVATION 3 (7):573-85.

1857. HAKIM, S. 1992. SEASONAL RANGE AND HABITAT SELECTION BY WHITE-TAILED DEER IN NORTHWESTERN VIRGINIA. PH.D. DISSERTATION, UNIVERSITY OF MONTANA, MISSOULA, MT.

1858. HALE, J. B. and L. E. GREGG. 1976. WOODCOCK USE OF CLEARCUT ASPEN AREAS IN WISCONSIN. WILDL. SOC. BULL. $4(3): 111-5$.

1859. HALL, C. and P. DEARDEN. 1984. THE IMPACT OF 'NON-CONSUMPTIVE' RECREATION ON WILLIFE: AN ANNOTATED BIBLIOGRAPHY. VANCE BIBLIOGRAPHIES. MONTICELLO, ILLINOIS. PUBLIC ADMINISTRATION SERIES: BIBLIOGRAPHY \#P 1458. 45PP. 
1860. HALL, G. H. 1970. GREAT MOMENTS IN ACTION; THE STORY OF THE SUN LIFE FALCONS. CANADIAN FIELD NATURALIST 84(3):209-30.

1861. HALL, N. E. 1994. EFFECTS OF STRIPED SKUNK REMOVAL ON DUCK NEST SUCCESS IN THE MISSION VALLEY, MONTANA. M.S. THESIS, UNIVERSITY OF MONTANA, MISSOULA, MT. 64 PP.

1862. HALL, W. K. 1977. STATUS AND MANAGEMENT OF THE ROCKY MOUNTAIN GOAT(OREAMNOS AMERICANUS) IN THE PROVINCE OF ALBERTA. P 8-15. IN: SAMUEL, W., MACGREGOR, W.G., EDS.; PROC. FIRST INTERNATIONAL MOUNTAIN GOAT SYMPOSIUM 1977.FEB 19; KALISPELL, MONTANA.

1863. HALLE, S. 1993. WOOD MICE (APODEMUS SYLVATICUS L.) AS PIONEERS OF RECOLONIZATION IN A RECLAIMED AREA. OECOLOGIA (HEIDELBERG) 94 (1):120-7.

1864. HALLS, L. K., C. E. BOYD, D. W. LAY and P. D. GOODRUM. 1965. DEER FENCE CONSTRUCTION AND COSTS. JOURNAL OF WILDLIFE MANAGEMENT 29:885-888.

1865. HALVORSEN, G., R. BERGSTROM, J. DONS, L. ERIKSTAD, R. HALVORSEN, S. E. SLOREID and T. A. WIERSDALEN. 1993. NEW MAIN ROAD E 18 THROUGH BAMBLE, TELEMARK COUNTY -CONSEQUENCES FOR NATURAL RESOURCES. NINA (NORSK INSTITUTT FOR NATURFORSKNING) UTREDNING 0 (53):1-95.

1866. HAMANN, H. J., K. H. SCHMIDT and W. WLTSCHKO. 1995. BARRIER EFFECT OF A SUPERHIGHWAY ON HOLE-NESTING PASSERINES. VERHA.DTSCH.ZOOL.GES. 88(1):32-35.

1867. HAMEL, P. B., W. P. SMITH and J. W. WAHL. 1993. WINTERING BIRD POPULATIONS OF FRAGMENTED FOREST HABITAT IN THE CENTRAL BASIN, TENNESSEE. BIOLOGICAL CONSERVATION 66 (2):107-15.

1868. HAMEL, P. B. 1996. AGKISTRODON PISCIVORUS LEUCOSTOMA (WESTERN COTTONMOUTH). CARRION FEEDING. HERPETOLOGICAL REVIEW 27(3):143-145.

1869. HAMER, M. 1994. CAMERAS KEEP DEATH OFF. THE ROADS. NEW SCIENTIST 142(1920):9-14.

1870. HAMER, M. 1994. CARCASS COUNT REVEALS RISING DEATH TOLL ON THE ROADS. NEW SCIENTIST 141(19):8-13.

1871. HAMERSTROM, F., D. D. BERGER and F. N. JR. HAMERSTROM. 1965. THE EFFECT OF MAMMALS ON PRAIRIE CHICKENS ON BOOMING GROUNDS. J. WILDL. MANAGE. 29.(3):536-42.

1872. HAMILTON, A. N., W. R. ARCHIBALD and E. LOFROTH. 1986. PROGRESS REPORT-YEAR 4-1985, WORKING PLAN YEAR 5 1986 COASTAL GRIZZLY RESEARCH PROJECT. 92PP

1873. HAMILTON, A. L. 1978. SPRING, SUMMER, AND FALL USE OF STOCKPONDS BY CANADA GEESE IN SOUTHEASTERN MONTANA. M.S. THESIS, MONTANA STATE UNIVERSITY, BOZEMAN, MT. 64 PP.

1874. HAMILTON, G. D. 1980. WEST PATRICIA LAND USE PLAN. ONT FISH WILDL. REV.19 (1):7-10.

1875. HAMILTON, M. P. 1983. A FLORISTIC BASIS FOR THE MANAGEMENT OF RARE PLANTS AND THEIR COMMUNITIES IN THE SAN JACINTO MOUNTAINS, CALIFORNIA. DISSERTATION, CORNELL UNIVERSITY, ITHACA, NEW YORK. 206PP.

1876. HAMILTON, R. J. 1978. ECOLOGY OF THE BLACK BEAR IN SOUTHEASTERN NORTH CAROLINA. M.S. THESIS. UNIVERSITY OF GEORGIA, ATHENS. 214 PP.

1877. HAMLIN, K. L. 1974. ECOLOGICAL RELATIONSHIPS OF MULE DEER IN THE BRIDGER MOUNTAINS, MONTANA WITH SPECIAL REFERENCE TO DAILY AND SEASONAL MOVEMENTS. M.S. THESIS, MONTANA STATE UNIVERSITY, BOZEMAN, MT. 65 PP.

1878. HAMMER, K. J. 1986. AN ON-SITE STUDY OF THE EFFECTIVENESS OF THE U.S. FOREST SERVICE ROAD CLOSURE PROGRAM IN MANAGEMENT SITUATION ONE: GRIZZLY BEAR HABITAT, SWAN LAKE RANGER DISTRICT, FLATHEAD NATIONAL FOREST, MONTANA. SWAN VIEW COALITION, KALISPELL, MONTANA, AND RESOURCES LTD., POLEBRIDGE, MONTANA. UNPUBLISHED REPORT. 
1879. HAMMOND, F. M. 1983. TITLE UNKNOWN. M.S. THESIS, UNIVERSITY OF WYOMING.59 PP.

1880. HAMMOND, G. R. 1980. NUTRITIONAL CHARACTERISTICS OF THE VEGETATION OF CLEARCUT AND UNCUT SITES ON SUMMER-FALL ELK RANGE. M.S. THESIS, MONTANA STATE UNIVERSITY, BOZEMAN, MT. 71 PP.

1881. HAMOR, W. H., H. G. UHLIG and L. V. COMPTON. 1968. PONDS AND MARSHES FOR WILD DUCKS ON FARMS AND RANCHES IN THE NORTHERN PLAINS. FARMERS' BULL. NO. 2234, USDA, WASHINGTON, D.C., 16 PP.

1882. HAMPTON, P. D. 1981. THE WINTERING AND NESTING BEHAVIOR OF THE TRUMPETER SWAN. M.S. THESIS, UNIVERSITY OF MONTANA, MISSOULA, MT. 185 PP.

1883. HAMR, J. 1988. DISTURBANCE BEHAVIOR OF CHAMOIS IN ALPINE TOURIST AREA OF AUSTRIA. MOUNTAIN RESEARCH AND DEVELOPMENT 8:65-73.

1884. HANDY, M. J. 1997. OVERWINTER SURVIVAL OF WESTSLOPE CUTTHROAT TROUT IN CACHE CREEK, MONTANA. M.S. THESIS, MONTANA STATE UNIVERSITY, BOZEMAN, MT. 62 PP.

1885. HANLEY, P. T., J. E. HEMMING, J. W. MORSELL, T. A. MOREHOUSE, L. E. LEASK and G. S. HARRISON. 1983. A HANDBOOK FOR MANAGEMENT OF OIL AND GAS ACTIVITIES ON LANDS IN ALASKA: PETROLEUM INDUSTRY PRACTICES, ENVIRONMENTAL IMPACTS AND STIPULATIONS. U.S. FISH AND WILDLIFE SERVICE, DIVISION OF BIOLOGICAL SERVICES. WASHINGTON, D.C. FWS/OBS-80/23. 72PP.

1886. HANNA, P. 1982. THE IMPACT OF INTERSTATE HIGHWAY 84 ON THE SUBLETTE-BLACK PINE MIGRATORY DEER POPULATION. A 12-YEAR SUMMARY, WITH RECOMMENDATIONS FOR MITIGATION OF IDENTIFIABLE ADVERSE IMPACTS. PROJECT W-160. IDAHO DEPARTMENT OF FISH AND GAME, BOISE, ID.

1887. HANNA, P. 1982. THE IMPACT OF INTERSTATE HIGHWAY 84 ON THE SUBLETTE-BLACK PINE MIGRATORY DEER POPULATION. PROJECT W-160, FINAL REPORT. IDAHO DEPARTMENT OF FISH AND GAME.

1888. HANNA, T. D. 1992. THE EFFECT OF OXYGEN SUPPLEMENTATION ON THE TOXICITY OF AMMONIA (NH3) IN RAINBOW TROUT. M.S. THESIS, MONTANA STATE UNIVERSITY, BOZEMAN, MT. 51 PP.

1889. HANNAH, L., J. L. CARR and A. LANKERANI. 1995. HUMAN DISTURBANCE AND NATURAL HABITAT: A BIOME LEVEL ANALYSIS OF A GLOBAL DATA SET. BIODIVERSITY AND CONSERVATION 4 (2):128-55.

1890. HANOWSKI, J. A. M. and G. J. NIEMI. 1995. A COMPARISON OF ON- AND OFF-ROAD BIRD COUNTS - DO YOU NEED TO GO OFF ROAD TO COUNT BIRDS ACCURATELY. JOURNAL OF FIELD ORNITHOLOGY 66(4):469-483.

1891. HANSEN, A. J., S. L. GARMAN and B. MARKS. 1993. AN APPROACH FOR MANAGING VERTEBRATE DIVERSITY ACROSS MULTIPLE-USE LANDSCAPES. ECOLOGICAL APPLICATIONS 3 (3):481-96.

1892. HANSEN, A. J., W. C. MCCOMB, R. VEGA, M. G. RAPHAEL and M. HUNTER. 1995. BIRD HABITAT RELATIONSHIPS IN NATURAL AND MANAGED FORESTS IN THE WEST CASCADES OF OREGON. ECOLOGICAL APPLICATIONS 5 (3):555-69.

1893. HANSEN, A. J., M. V. STALMASTER and J. R. NEWMAN. 1980. HABITAT CHARACTERISTICS, FUNCTION, AND DESTRUCTION OF BALD EAGLE COMMUNAL ROOSTS IN WESTERN WASHINGTON. PAGES 221-229 IN R. L. KNIGHT, G. T. ALLEN, M. V. STALMASTER, AND C. W. SERVHEEN, EDITORS. PROCEEDINGS OF THE WASHINGTON BALD EAGLE SYMPOSIUM.

1894. HANSEN, A. J. and D. URBAN. 1992. AVIAN RESPONSE TO LANDSCAPE PATTERN: THE ROLE OF SPECIES' LIFE HISTORIES. LANDSCAPE ECOLOGY 7 (3):163-80.

1895. HANSEN, C. S. 1983. COSTS OF DEER RELATED AUTOMOTIVE ACCIDENTS. UNIVERSITY OF MICHIGAN TRANSPORTATION RESEARCH REVIEW 14:9-12.

1896. HANSEN, C. S. 1983. COSTS OF DEER-VEHICLE ACCIDENT IN MICHIGAN. WLDL. SOC. BULL. 11:161-4.

1897. HANSEN, C. S. 1983. COSTS OF DEER-VEHICLE ACCIDENTS IN MICHIGAN. WILDLIFE SOCIETY BULLETIN 11:161-164. 
1898. HANSEN, C. S. 1977. TITLE UNKNOWN. PH.D. DISSERTATION, UNIV. MICHIGAN.195PP. FROM DISS. ABSTR. INT. B SCI. ENG. 38(3):980.

1899. HANSEN, L. 1982. ROAD KILLS IN DENMARK. DAN.ORNITHOL.FOREN.TIDSSKR. 76(3-4):97-110.

1900. HANSEN, M. C. 1982. DESERT BIGHORN SHEEP: ANOTHER VIEW. WILDL. SOC. BULL.10 (2):133-40.

1901. HANSEN, M. C., G. W. GARNER and S. G. FANCY. 1992. COMPARISON OF 3 METHODS FOR EVALUATING ACTIVITY OF DALL'S SHEEP. J. WLDL. MANAGE. $56(4): 661-8$.

1902. HANSKI, I. L. and M. E. GILPIN. 1997. METAPOPULATION BIOLOGY: ECOLOGY, GENETICS, AND EVOLUTION. ACADEMIC PRESS, ORLANDO, FL.

1903. HANSON, W. C. 1981. CARIBOU ENCOUNTERS WITH PIPELINES IN NORTHERN ALASKA. CAN. FIELD NAT. 95 (1):57-63.

1904. HANSSON, L. 1991. DISPERSAL AND CONNECTIVITY IN METAPOPULATIONS. BIOLOGICAL JOURNAL OF THE LINNEAN SOCIETY 42:89-103.

1905. HANZEL, D. A. 1959. THE DISTRIBUTION OF THE CUTTHROAT TROUT (SALMO CLARKI) IN MONTANA. M.S. THESIS, MONTANA STATE UNIVERSITY, BOZEMAN, MT. 57 PP.

1906. HARDING, B. D. 1986. SHORT-EARED OWL MORTALITY ON ROADS. BRITISH BIRDS 9(8):403-404.

1907. HARDING, L. and J. A. NAGY. 1980. RESPONSES OF GRIZZLY BEARS TO HYDROCARBON EXPLORATION ON RICHARDS ISLAND, NORTHWEST TERRITORIES, CANADA. INTERNATIONAL CONFERENCE BEAR RESEARCH AND MANAGEMENT 4:277-280.

1908. HARE, C. 1974. METHODOLOGY FOR ESTIMATING EMISSIONS FROM OFF-HIGHWAY MOBILE SOURCES FOR THE RAPS PROGRAM. FINAL REPORT. SOUTHWEST RESEARCH INSTITUTE. SAN ANTONIO, TX.

1909. HARE, C. T. and K. J. SPRINGER. 1974. EXHAUST EMISSIONS FROM UNCONTROLLED VEHICLES AND RELATED EQUIPMENT USING INTERNAL COMBUSTION ENGINES: PART 7. SNOWMOBILES. SOUTHWEST RESEARCH INSTITUTE. OFFICE OF AIR AND WATER PROGRAMS, ENVIRONEMNTAL PROTECTION AGENCY. SAN ANTONIO, TX.

1910. HARGIS, C. D. and D. R. MCCULLOUGH. 1984. WNTER DIET AND HABITAT SELECTION OF MARTEN IN YOSEMITE NATIONAL PARK. J. WILDL. MANAGE. $48(1): 140-6$.

1911. HARKE, D. T. and A. R. JR. STICKLEY. 1968. SENSITIVE RESETTABLE ODOMETER AIDS ROADSIDE CENSUS OF RED-WINGED BLACKBIRDS. J. WILDL. MANAGE. 32 (3):635-6.

1912. HARMATA, A. R. 1984. BALD EAGLES OF THE SAN LUIS VALLEY, COLORADO: THEIR ECOLOGY AND SPRING MIGRATION. PH.D. DISSERTATION, MONTANA STATE UNIVERSITY, BOZEMAN, MT. 222 PP.

1913. HARMS, D. R. 1980. BLACK BEAR MANAGEMENT IN YOSEMITE NATIONAL PARK. INT. CONF. BEAR RES. AND MANAGE. 4:205-12.

1914. HARNIK, P. 1972. FUNMOBILE FOLLY. NATIONAL PARKS AND CONSERVATION MAG. 46:29-33.

1915. HARPER, D. M. and A. J. D. FERGUSON. 1995. THE ECOLOGICAL BASIS FOR RIVER MANAGEMENT. J. WILEY, CHICHESTER, NEW YORK.

1916. HARPER, J. A. and R. F. LABISKY. 1964. THE INFLUENCE OF CALCIUM ON THE DISTRIBUTION OF PHEASANTS IN ILLINOIS. J. WILDL. MANAGE. 28 (4):722-31.

1917. HARPER, S. J., E. K. BOLLINGER and G. W. BARRETT. 1993. EFFECTS OF HABITAT PATCH SHAPE ON POPULATION DYNAMICS OF MEADOW VOLES (MICROTUS PENNSYLVANICUS). J.MAMM.74(4):1045-55 
1918. HARPER, W. L. and D. N. LOUGHEED. 1988. A GUIDE FOR THE INSTALLATION OF 2.5 METER UNGULATE EXCLUSIONS FENCING ON HIGHWAY RIGHT-OF-WAYS. UNPUBLISHED REPORT. BRITISH COLUMBIA, MINISTRY OF -TRANSPORTATION, VANCOUVER, BC.

1919. HARRIGAN, K. E. 1992. CAUSES OF MORTALITY OF LITTLE PENGUINS EUDYPTULA MINOR IN VICTORIA. EMU 91 (5):273-7.

1920. HARRINGTON, F. H. 1996. HUMAN IMPACTS ON GEORGE RIVER CARIBOU. RANGIFER SPECIAL ISSUE NO.9:277-8.

1921. HARRINGTON, F. H. and A. M. VEITCH. 1991. SHORT-TERM IMPACTS OF LOW-LEVEL JET FIGHTER TRAINING ON CARIBOU IN LABRADOR. ARCTIC 44 (4):318-27.

1922. HARRIS, C. E. 1983. DIFFERENTIAL BEHAVIOR OF COYOTES WITH REGARD TO HOMERANGE LIMITS (UTAH, TEXAS). PHD THESIS, UTAH STATE UNIVERSITY. 134 PP.

1923. HARRIS, H. T. 1991. HABITAT USE BY DISPERSING AND TRANSPLANTED BEAVERS IN WESTERN MONTANA. M.S. THESIS, UNIVERSITY OF MONTANA, MISSOULA, MT. 40 PP.

1924. HARRIS, L. D. and J. SCHECK. 1991. FROM IMPLICATIONS TO APPLICATIONS: THE DISPERSAL CORRIDOR PRINCIPLE APPLIED TO THE CONSERVATION OF BIOLOGICAL DIVERSITY. PAGES 189-220 IN SAUNDERS,D.A. AND HOBBS,R.J., EDITORS. NATURE CONSERVATION 2: THE ROLE OF CORRIDORS. SURREY BEATTY AND SONS, CHIPPING NORTON, AUSTRALIA.

1925. HARRIS, L. D. and J. SCHECK. 1991. NEW INITIATIVES FOR WLDLIFE CONSERVATION: THE NEED FOR MOVEMENT CORRIDORS. PAGES 11-34 IN MACKINTOSH,G., EDITOR. PRESERVING COMMUNITIES AND CORRIDORS. DEFENDERS OF WILDLIFE, WASHINGTON, DC.

1926. HARRIS, L. D. and G. SILVA-LOPEZ. 1992. FOREST FRAGMENTATION AND THE CONSERVATION OF BIOLOGICAL DIVERSITY. PAGES 197-237 IN FIEDLER,P.L AND JAIN,S.K, EDITORS. CONSERVATION BIOLOGY: THE THEORY AND PRACTICE OF NATURE CONSERVATION, PRESERVATION AND MANAGEMENT. CHAPMAN AND HALL, NEW YORK.

1927. HARRIS, M. A. 1982. HABITAT UTILIZATION AMONG WOODPECKERS IN FOREST BURNS. M.S. THESIS, UNIVERSITY OF MONTANA, MISSOULA, MT. 63 PP.

1928. HARRIS, R. B. 1984. HARVEST AGE-STRUCTURE AS AN INDICATOR OF GRIZZLY BEAR POPULATION STATUS. M.S. THESIS, UNIVERSITY OF MONTANA, MISSOULA, MT. 204 PP.

1929. HARRIS, R. B. 1993. WILDLIFE CONSERVATION IN YENIUGOU, QINGHAI PROVINCE, CHINA. PH.D. DISSERTATION, UNIVERSITY OF MONTANA, MISSOULA, MT. 327 PP.

1930. HARRISON, D. J. 1986. COYOTE DISPERSAL, MORTALITY, AND SPATIAL RELATIONSHIPS WITH RED FOXES IN MAINE. PHD THESIS, UNIVERSITY OF MAINE. 125 PP.

1931. HARRISON, D. J. 1992. DISPERSAL CHARACTERISTICS OF JUVENILE COYOTES IN MAINE. J. WILDL. MANAGE. 56 (1):128-38.

1932. HARRISON, G., R. HOOPER and P. JACOBSEN. 1980. TRANS-CANADA HIGHWAY WILDLIFE MITIGATION MEASURES, BANFF NATIONAL PARK (EAST GATE TO BANFF TRAFFIC CIRCLE). PARKS CANADA, WESTERN REGION. , BANFF, ALBERTA.

1933. HARRISON, P. D. and M. I. DYER. 1984. LEAD IN MULE DEER FORAGE IN ROCKY MOUNTAIN NATIONAL PARK, COLORADO. J. WLDL. MANAGE. 48 (2):510-7.

1934. HARRISON, R., R. CLARK and G. STANKEY. 1980. PREDICTING IMPACT OF NOISE ON RECREATIONISTS. U.S. FOREST SERVICE. SAN DIMAS, CALIFORNIA. EQUIPMENT DEVELOPMENT CENTER PROJECT NO. 2688. REPORT 8023-1202. 32PP. + APPENDICES

1935. HARRISON, R. L. 1992. TOWARD A THEORY OF INTER-REFUGE CORRIDOR DESIGN. CONSER. BIO.: 6(2):293-5 
1936. HARRISON, R. T. 1980. ENVIRONMENTAL IMPACT OF OFF-ROAD MOTORCYCLES. PAGES 266-269 IN R. N. L. ANDREWS AND P. F. NOWAK, EDITORS. OFF-ROAD VEHICLE USE: A MANAGEMENT CHALLENGE. OFFICE OF -ENVIRONMENTAL QUALITY, U.S. DEPT. OF AGRICULTURE, SCHOOL OF NATURAL RESOURCES, UNIVERSITY OF MICHIGAN, UNIVERSITY OF MICHIGAN EXTENSION SERVICE.

1937. HARRISON, R. T., W. J. MAKEL and B. B. LAMOURE. 1993. SOUND LEVELS OF FIVE MOTORCYCLES TRAVELING OVER FOREST TRAILS: ROCK CREEK ORV AREA. U.S.D.A. FOREST SERVICE TECHNOLOGY AND DEVELOPMENT PROGRAM. 2300-RECREATION, 9323 1802--SDTDC. 7PP.

1938. HARRISON, R. 1976. ENVIRONMENTAL EFFECTS OF OFF-ROAD VEHICLES. FIELD NOTES 8:4-8.

1939. HARRISON, R. 1974. ALL-TERRAIN VEHICLE NOISE. U.S. FOR. SERV. EQUIP. DEV. CENT. ED \& T 2524. 7PP.

1940. HARRISON, R. 1975. IMPACT OF OFF-ROAD VEHICLE NOISE ON A NATIONAL FOREST. U.S. FOR. SERV. EQUIP. DEV. CENT. ED \& T REPORT 7120-6. 35PP.

1941. HARRISON, R. 1974. OFF-ROAD VEHICLE NOISE MEASUREMENTS AND EFFECTS. PAGES 135-146 IN SNOWMOBILE AND OFF THE ROAD VEHICLE RESEARCH SYMPOSIUM.

1942. HARRISON, R. 1974. SOUND PROPAGATION AND ANNOYANCE UNDER FOREST CONDITIONS. U.S. FOR. SERV. EQUIP. DEV. CENT. ED \& T REPORT 2428. 23PP.

1943. HARRISON, R. T. 1979. PREDICTING OFF-ROAD VEHICLE ACOUSTIC IMPACT ON FOREST RECREATION--A SIMPLIFIED METHOD. PAGES 120-137 IN RECREATIONAL IMPACT ON WLDLANDS. U.S. FOR. SERV. REGION 6, R-6-001,

1944. HARRISON, S. and J. SURGENOR. 1996. ISSUES OF CARIBOU MANAGEMENT IN NORTHEASTERN BRITISH COLUMBIA. RANGIFER SPECIAL ISSUE NO.9:127-30.

1945. HART, J. B. JR. 1982. ECOLOGICAL EFFECTS OF RECREATIONAL USE ON CAMPSITES. D. W. COUNTRYMAN AND D. M. SOFRANKO, EDITORS. GUIDING LAND USE DECISIONS. THE JOHNS HOPKINS UNIVERSITY PRESS, BALTIMORE, MARYLAND.

1946. HART, M. M. 1994. PAST AND PRESENT VEGETATIVE AND WLDLIFE DIVERSITY IN RELATION TO AN EXISTING RESERVE NETWORK: A GIS EVALUATION OF THE SEELEY-SWAN LANDSCAPE, NW MONTANA. M.S. THESIS, UNIVERSITY OF MONTANA, MISSOULA, MT. 288 PP.

1947. HARTESVELDT, R. J. 1965. AN INVESTIGATION OF THE EFFECT OF DIRECT HUMAN IMPACT AND OF ADVANCED PLANT SUCCESSION ON SEQUOIA GIGANTEA IN SEQUUOIA AND KINGS CANYON NATIONAL PARKS, CALIFORNIA. U.S. NATIONAL PARK SERVICE. SAN FRANSISCO, CALIFORNIA. FINAL CONTACT REPORT NO. 14-10-0434-1421. 82PP.

1948. HARTING, A. L. JR. 1985. RELATIONSHIPS BETWEEN ACTIVITY PATTERNS AND FORAGING STRATEGIES OF YELLOWSTONE GRIZZLY BEARS. M.S. THESIS, MONTANA STATE UNIVERSITY, BOZEMAN, MT. 103 PP.

1949. HARTLEY, D. R., D. H. ARNER and J. W. LIPE. 1984. TITLE UNKNOWN. P. 623-9. IN: PROCEEDINGS OF THE THIRD INTERNATIONAL SYMPOSIUM ON ENVIRONMENTAL CONCERNS IN RIGHTS-OF-WAY MANAGEMENT.

1950. HARTLEY, D. R. 1982. THE EFFECTS OF VARIOUS MAINTENANCE TECHNIQUES UPON RIGHTS-OF-WAY VEGETATION AND WILDLIFE UTILIZATION.

1951. HARTNIGK, K. C. 1984. THE MOSS MITES (ACARI: ORIBATEI) OF AN OAK-PINE FOREST SOIL IN BERLIN (WEST): COMPARISON OF 3 SAMPLING PLOTS DIFFERENTLY INFLUENCED BY ROAD CONSTRUCTION AND TRAFFIC. ZOOLOGISCHE BEITRAEGE 8(2):207-230.

1952. HARTSHORN, G. S. 1987. REVIEW OF] AMAZONIA RAIN FORESTS: ECOSYSTEM DISTURBANCE AND RECOVERY. CONSERVATION BIOLOGY 1 (3):267-8.

1953. HARTUNG, R. 1967. ENERGY METABOLISM IN OIL-COVERED DUCKS. JOURNAL OF WILDLIFE MANAGEMENT 31:798-804. 
1954. HARTUNG, R. and G. S. HUNT. 1966. TOXICITY OF SOME OILS TO WATERFOWL. JOURNAL OF WIDLIFE MANAGEMENT 30:564-570.

1955. HARTWIG, D. 1991. DETERMINATION OF TRAFFIC ACCIDENTS INVOLVING GAME IN1989 IN NORTH RHINE-WESTPHALIA (WEST GERMANY) BY THE POLICE DEPARTMENTS. ZEITSCHRIFT FUER JAGDWISSENSCHAFT 37 (1):55-62.

1956. HARTWIG, D. 1993. EVALUATION OF GAME CAUSED TRAFFIC ACCIDENTS ACCORDING TO THE STATISTICS OF NORTH RHINE-WESTPHALIA. ZEITSCHRIFT FUER JAGDWISSENSCHAFT 39 (1):22-33.

1957. HARVEY, M. J. 1980. STATUS OF THE ENDANGERED BATS MYOTIS SODALIS, M. GRISESCENS, AND PLECOTUS TOWNSENDII INGENS IN THE SOUTHERN OZARKS. PAGES 221-223 IN D. E. WILSON AND A. L. GARDNER, EDITORS. PROCEEDINGS, FIFTH INTERNATIONAL BAT RESEARCH CONFERENCE. TEXAS TECH PRESS, LUBBOCK, TEXAS.

1958. HARVEY, S. J. 1981. LIFE HISTORY AND REPRODUCTIVE STRATEGIES IN ARTEMISIA. M.S. THESIS, MONTANA STATE UNIVERSITY, BOZEMAN, MT. 132 PP.

1959. HARVEY, S. J. 1990. RESPONSES OF STEPPE PLANTS TO GRADIENTS OF WATER SOIL TEXTURE AND DISTURBANCE IN MONTANA, USA. PH.D. DISSERTATION, MONTANA STATE UNIVERSITY, BOZEMAN, MT. 103 PP.

1960. HARWOOD, J. 1977. SUMMER FEEDING ECOLOGY OF LESSER SNOW GEESE. J. WILDL. MANAGE. 41 (1):48-55.

1961. HASH, H. S. 1987. FURBEARING MAMMAL ECOLOGY STUDIES.

1962. HASKELL, D. G. 1995. A REEVALUATION OF THE EFFECTS OF FOREST FRAGMENTATION ON RATES OF BIRD-NEST PREDATION. CONSERVATION BIOLOGY 9 (5):1316-8.

1963. HASLINGER, H. 1989. MIGRATION OF TOADS DURING THE SPAWNING SEASON AT STALLAUER WEIHER LAKE, BAD TOLZ, BAVARIA. PAGES 181-182 IN LANGTON,T.E.S., EDITOR. AMPHIBIANS AND ROADS. PROCEEDINGS OF THE TOAD TUNNEL CONFERENCE; 1989 JANUARY 7-8; RENDSBURG, FEDERAL REPUBLIC OF GERMANY ACO POLYMER PRODUCTS LTD., SHEFFORD, ENGLAND.

1964. HASTINGS, B. C., B. K. GILBERT and D. L. TURNER. 1989. EFFECT OF BEARS EATING CAMPERS' FOOD ON HUMAN-BEAR INTERACTIONS. P. 15-18. IN: BEAR-PEOPLE CONFLICTS--PROC. SYMP. ON MANAGE. STRATEGIES.

1965. HATIER, K. G. 1995. EFFECTS OF HELPING BEHAVIORS ON COYOTE PACKS IN YELLOWSTONE NATIONAL PARK, WYOMING. M.S. THESIS, MONTANA STATE UNIVERSITY, BOZEMAN, MT. 78 PP.

1966. HATLER, D. F. 1985. CARIBOU POPULATION DISTINCTIONS IN THE SPATISIZI WILDERNESS PARK AREA, B.C. WORKSHOP ON CARIBOU RESEARCH AND MANAGEMENT IN BRITISH COLUMBIA; 6-7 NOV 1985 ; KAMLOOPS. B.C. BRITISH COLUMBIA MINISTRY OF ENVIRONMENT AND PARKS.

1967. HATLER, D. F. 1986. STUDIES OF RADIO COLLARED CARIBOU IN THE SPATSIZI WILDERNESS PARK, BRITISH COLUMBIA, 1980-1984. SPATSIZI ASSOC. FOR BIOLOGICAL RESEARCH, SMITHERS, B.C. 202PP.

1968. HAUG, E. 1985. MERLIN DEEDING ON ROAD-KILLS. RAPTOR RESEARCH 19(2/3):103-105.

1969. HAUGEN, G. N. 1969. LIFE HISTORY, HABITAT AND DISTRIBUTION OF THE LAKE STURGEON ACIPENSER FULVESCENS IN THE SOUTH SASKATCHEWAN RIVER. M.S. THESIS, MONTANA STATE UNIVERSITY, BOZEMAN, MT. 27 PP.

1970. HAUPT, H. F. and W. J. KIDD. 1963. LABORATORY METHODS FOR DETERMINING THE DOWNWARD MOVEMENT OF SEED ON ROAD FILLS. INTERMOUNTAIN FOR. AND RANGE EXP. STA., RES. NOTE INT-2, USDA, FOR. SERV., OGDEN, UT., 7 PP.

1971. HAUPT, H. F., H. C. RICKARD and L. E. FINN. 1963. EFFECT OF SEVERE RAINSTORMS ON INSLOPED AND OUTSLOPED ROADS. INTERMOUNTAIN FOR. AND RANGE EXP. STA., RES. NOTE NO. INT-1, USDA, FOR. SERV., OGDEN, UT., 8 PP. 
1972. HAUSER, W. J. 1968. LIFE HISTORY OF THE MOUNTAIN SUCKER (CATOSTOMUS PLAYRHYNCHUS) IN MONTANA. M.S. THESIS, MONTANA STATE UNIVERSITY, BOZEMAN, MT. 23 PP.

1973. HAUSRATH, A. R. 1974. AN OFF-ROAD VEHICLE MANAGEMENT PLAN FOR THE ALLEGHENY NATIONAL FOREST. SIERRA CLUB, PENNSYLVANIA CHAPTER. 1OPP.

1974. HAVEL, R. 1965-1966. SURVEYS AND MANAGEMENT OF DEER. NEBRASKA GAME, FORESTATION AND PARKS COMMISSION.

1975. HAVEL, R. and K. MENZEL. 1965. SURVEYS AND MANAGEMENT OF DEER, MARCH 1, 1964, TO FEBRUARY $28,1965$. NEBRASKA GAME, FORESTATION AND PARKS COMMISSION. WORK PLAN A-64

1976. HAVEL, R. and K. MENZEL. 1974. SURVEYS AND MANAGEMENT OF DEER, MARCH 1, 1973 THROUGH FEBRUARY 28, 1974. NEBRASKA GAME AND PARKS COMMISSION. WORK PLAN A-73

1977. HAVEL, R. and K. MENZEL. 1966. SURVEYS AND MANAGEMENT OF DEER, WORK PLAN A-65, MARCH 1965 THROUGH FEBRUARY 1966. NEBRASKA GAME, FORESTATION AND PARKS COMMISSION.

1978. HAVEL, R. and K. MENZEL. 1973. SURVEYS AND MANAGEMENT OF DEER, WORK PLAN A-72, MARCH 1972 THROUGH FEBRUARY 1973. NEBRASKA GAME AND PARKS COMMISSION.

1979. HAVERA, S. P., L. R. BOENS, M. M. GEORGI and R. T. SHEALY. 1992. HUMAN DISTURBANCE OF WATERFOWL ON KEOKUK POOL, MISSISSIPPI RIVER. WILDL. SOC. BULL. 20 (3):290-8.

1980. HAVLIN, J. 1987. MOTORWAYS AND BIRDS. FOLIA ZOOLOGY 36(2):137-153.

1981. HAVSTAD, P. K. 1987. THE IMPORTANCE OF MUCOSAL MAST IN THE HOST RESPONSE TO HYMENOLEPIS DIMHUTA IN NORMAL, WN, AND NUDE MICE. M.S. THESIS, MONTANA STATE UNIVERSITY, BOZEMAN, MT. 111 PP.

1982. HAWKINS, R. E., W. D. OOAG, O. U. KLIMSTRA, D. C. AUTRY and S. R. HIEB. 1970. SIGNIFICANT MORTALITY FACTORS OF DEER ON CRAB ORCHARD NATIONAL. MLDLIFE REFUGE. TRANSACTIONS OF THE ILLINOIS STATE ACADEMY OF SCIENCE 63:202-206.

1983. HAWLEY, V. D. 1955. THE ECOLOGY OF THE MARTEN IN GLACIER NATIONAL PARK. M.S. THESIS, MONTANA STATE UNIVERSITY, MISSOULA, MT. 131 PP.

1984. HAYDEN, B. 1975. SOME EFFECTS OF RURAL SUBDIVISIONS ON WILDLIFE AND WILDLIFE HABITAT AROUND LOLO, MONTANA. M.S. THESIS, UNIVERSITY OF MONTANA, MISSOULA, MT. 121 PP.

1985. HAYDEN, J. A. 1989. STATUS AND POPULATION DYNAMICS OF MOUNTAIN GOATS IN THE SNAKE RIVER RANGE, IDAHO. M.S. THESIS, UNIVERSITY OF MONTANA, MISSOULA, MT. 147 PP.

1986. HAYDEN-WING ASSOCIATES. 1990. RESPONSE OF ELK TO EXXON'S FIELD DEVELOPMENT IN THE RILEY RIDGE AREA OF WESTERN WYOMING 1979-1990. SHERIDAN, WY. 33PP. + APPENDIX

1987. HAYES, C. L. and P. R. KRAUSMAN. 1993. NOCTURNAL ACTIVITY OF FEMALE DESERT MULE DEER. J. WILDL. MANAGE. 57 (4):897-904.

1988. HAYES, S. G. and M. R. PELTON. 1994. HABITAT CHARACTERISTICS OF FEMALE BLACK BEAR DENS IN NORTHWESTERN ARKANSAS. INT. CONF. BEAR RES. AND MANAGE. 9:411-8.

1989. HAYNE, D. W. 1984. POPULATION DYNAMICS AND ANALYSIS (CHAPTER 9). P 203-210. IN: HALLS, L.K.,(EDITOR). WHITE-TAILED DEER: ECOLOGY AND MANAGEMENT. HARRISBURG, PA: STACKPOLE BOOKS.

1990. HAYNES, L. A. 1992. MOUNTAIN GOAT HABITAT OF WYOMING'S BEARTOOTH PLATEAU: IMPLICATIONS FOR MANAGEMENT. P 325-39. IN: EMMERICH J, HEPWORTH WG, EDS. PROC. BIENN. SYMP. NORTH. WILD SHEEP AND GOAT COUNCIL; APR 27-MAY1, 1992. CODY, WYOMING. NORTH. WILD SHEEP AND GOAT COUNCIL. 
1991. HAYNES, R. J. and W. D. KLIMSTRA. 1975. ILLINOIS LANDS SURFACE MINED FOR COAL. SOUTHERN ILLINOIS UNIV., COOPERATIVE WILDLIFE RESEARCH LAB., 201 PP.

1992. HAYSMITH, L. and J. D. HUNT. 1995. NATURE TOURISM: IMPACTS AND MANAGEMENT. PAGES 203-219 IN R. L. KNIGHT AND K. J. GUTZWLLER, EDITORS. WILDLIFE AND RECREATIONISTS: COEXISTENCE THROUGH MANAGEMENT AND RESEARCH. ISLAND PRESS. WASHINGTON, D.C.

1993. HAYWARD, G. D. 1989. HABITAT USE AND POPULATION BIOLOGY OF BOREAL OWLS IN THE NORTHERN ROCKY MOUNTAINS, USA (UNITED STATES). PHD THESIS, UNIVERSITY OF IDAHO. 127 PP.

1994. HAYWARD, G. D. PART III BOREAL OWLS. P 92-127. IN: FLAMMULATED, BOREAL, AND GREAT GRAY OWLS IN THE UNITED STATES: A TECHNICAL CONSERVATION ASSESSMENT. VOLUME GENERAL TECH. REPORT RM-253. USDA FOREST SERVICE.

1995. HEALEY, M. C. 1994. VARIATION IN THE LIFE HISTORY CHARACTERISTICS OF CHINOOK SALMON AND ITS RELEVANCE TO CONSERVATION OF THE SACRAMENTO WINTER RUN OF CHINOOK SALMON. CONSERVATION BIOLOGY 8 (3):876-7.

1996. HEATH, M. L. 1973. SMALL MAMMAL POPULATIONS IN CLEARCUTS OF VARIOUS AGES IN SOUTH CENTRAL MONTANA. M.S. THESIS, MONTANA STATE UNIVERSITY, BOZEMAN, MT. 33 PP.

1997. HEATH, R. 1974. THE ENVIRONMENTAL CONSEQUENCES OF THE OFF-ROAD VEHICLE: WITH PROFILES OF THE INDUSTRY AND THE ENTHUSIAST. DEFENDERS OF WILDLIFE AND FRIENDS OF THE EARTH. WASHINGTON, D.C. 36PP.

1998. HEATON, J. R. 1966. THE BENTHOS AND DRIFT FAUNA OF A RIFFLE IN THE MADISON RIVER, YELLOWSTONE NATIONAL PARK. PH.D. DISSERTATION, MONTANA STATE UNIVERSITY, BOZEMAN, MT. 59 PP.

1999. HEBERT, D. and T. SMITH. 1986. MOUNTAIN GOAT MANAGEMENT IN BRITISH COLUMBIA. PROC. FIFTH BIENN. SYMP. NORTHERN WLD SHEEP AND GOAT COUNCIL: 48-59. NORTHERN WILD SHEEP AND GOAT COUNCIL.

2000. HECHTEL, J. L. 1985. ACTIVITY AND FOOD HABITS OF BARREN-GROUND GRIZZLY BEARS IN ARCTIC ALASKA. M.S. THESIS, UNIVERSITY OF MONTANA, MISSOULA, MT. 74 PP.

2001. HECKMANN, R. 1970. COMPARATIVE MORPHOLOGY AND HOST-PARASITE STUDIES OF TRICHOPHYRA CLARKI ON CUTTHROAT TROUT (SALMO CLARKI). PH.D. DISSERTATION, MONTANA STATE UNIVERSITY, BOZEMAN, MT. 69 PP.

2002. HEDRICK, P. W. and P. S. MILLER. 1992. CONSERVATION GENETICS: TECHNIQUES AND FUNDAMENTALS. ECOLOGICAL APPLICATIONS $2(1): 30-46$.

2003. HEIMBERGER, M., D. EULER and J. BARR. 1983. THE IMPACT OF COTTAGE DEVELOPMENT ON COMMON LOON REPRODUCTIVE SUCCESS IN CENTRAL ONTARIO. WILSON BULLETIN 95:431-439.

2004. HEIN, E. W. and W. F. ANDELT. 1995. EVALUATION OF INDICES OF ABUNDANCE FOR AN UNEXPLOITED BADGER POPULATION. SOUTHWESTERN NATURALIST 40 (3):288-92.

2005. HEINEMEYER, K. S. 1993. TEMPORAL DYNAMICS IN THE MOVEMENTS, HABITAT USE, ACTIVITY, AND SPACING OF REINTRODUCED FISHERS IN NORTHWESTERN MONTANA. M.S. THESIS, UNIVERSITY OF MONTANA, MISSOULA, MT. 158 PP.

2006. HEINEN, J. T. 1992. COMPARISONS OF THE LEAF LITTER HERPETOFAUNA IN ABANDONED CACAO PLANTATIONS AND PRIMARY RAIN FOREST IN COSTA RICA: SOME IMPLICATIONS FOR FAUNAL RESTORATION. BIOTROPICA 24 (3):431-9.

2007. HELGATH, S. F. 1975. TRAIL DETERIORATION IN THE SELWAY-BITTERROOT WLDERNESS. U.S. FOREST SERVICE INTERMOUNTAIN FOREST AND RANGE EXPERIMENT STATION. OGDEN, UTAH. RESEARCH NOTE INT-193.

2008. HELLE, P., T. HELLE and H. LINDEN. 1994. CAPERCAILLIE (TETRAO UROGALLUS) LEKKING SITES IN FRAGMENTED FINNISH FOREST LANDSCAPE. SCANDINAVIAN JOURNAL OF FOREST RESEARCH 9 (4):386-96. 
2009. HELLGREN, E. C. and M. R. VAUGHAN. 1989. DEMOGRAPHIC ANALYSIS OF A BLACK BEAR POPULATION IN THE GREAT DISMAL SWAMP. J. WILDL. MANAGE. 53 (4):969-77.

2010. HELLGREN, E. C., M. R. VAUGHAN and D. F. STAUFFER. 1991. MACROHABITAT USE BY BLACK BEARS IN A SOUTHEASTERN USA WETLAND. JOURNAL OF WILDLIFE MANAGEMENT 55(3):442-448.

2011. HELLGREN, E. C., M. R. VAUGHAN and D. F. STAUfFER. 1991. MACROHABITAT USE BY BLACK BEARS IN A SOUTHEASTERN WETLAND. J. WILDL. MANAGE. 55 (3):442-8.

2012. HELLIWELL, D. R. 1976. THE EXTENT AND LOCATION OF NATURE CONSERVATION AREAS. ENVIRON CONSERV 3 (4):255-9

2013. HELWIG, L. L. 1957. THE VALUE OF CONIFERS AS A WINTER FEED FOR ELK (CERVUS CANADENSIS NELSONI) DETERMINED UNDER CONTROLLED CONDITIONS. M.S. THESIS, MONTANA STATE UNIVERSITY, MISSOULA, MT. 79 PP.

2014. HEMMING, J. E. 1967. MANDIBULAR DENTITION AND HORN DEVELOPMENT AS CRITERIA OF AGE IN THE DALL SHEEP, OVIS DALLI NELSON. M.S. THESIS, UNIVERSITY OF MONTANA, MISSOULA, MT. 42 PP.

2015. HENDEE, J. C., G. H. STANKEY and R. C. LUCAS. 1978. VISITOR MANAGEMENT: APPROACHES TO MANAGING WILDERNESS USE AND VISITOR BEHAVIOR. PAGES 313-339 IN J. C. HENDEE, G. H. STANKEY, AND R. C. LUCAS, WLDERNESS CARRYING CAPACITY AND VISITOR MANAGEMENT: APPROACHES TO MANAGING WILDERNESS USE AND VISITOR BEHAVIOR. U.S. FOREST SERVICE. WLDERNESS MANAGEMENT, MISC. PUBL. NO. 1365. 381PP.

2016. HENDERSON, M. T., G. MERRIAM and J. WEGNER. 1985. PATCHY ENVIRONMENTS AND SPECIES SURVIVAL: CHIPMUNKS IN AN AGRICULTURAL MOSAIC. CONSERV. BIOL. 31:95-105.

2017. HENDERSON, R. E. 1977. A WINTER STUDY OF COYOTE PREDATION ON WHITE-TAILED DEER IN THE MILLER CREEK DRAINAGE, MONTANA. M.S. THESIS, UNIVERSITY OF MONTANA, MISSOULA, MT. 50 PP.

2018. HENDERSON, S. J. 1997. EFFECTS OF FIRE ON AVIAN DISTRIBUTION AND PATTERNS OF ABUNDANCE OVER TWO VEGETATION TYPES IN SSOUTHWEST MONTANA: IMPLICATIONS FOR MANAGING FIRE FOR BIODIVERSITY. M.S. THESIS, MONTANA STATE UNIVERSITY, BOZEMAN, MT. 95 PP.

2019. HENDRICKSON, J., W. L. ROBINSON and L. D. MECH. 1975. STATUS OF THE WOLF IN MICHIGAN. AM. MIDL. NAT. 94:226-32

2020. HENEIN, K. and G. MERRIAM. 1990. THE ELEMENTS OF CONNECTIVITY WHERE CORRIDOR QUALITY IS VARIABLE. LANDSCAPE ECOLOGY 4:155-170.

2021. HENLE, K. and K. RIMPP. 1994. RESULTS OF A 26-YEAR SURVEY OF HERPETOFAUNA IN THE AREA OF RUTESHEIM AND RENNINGEN, COUNTY BOEBLINGEN, BADEN-WUERTTEMBERG. JAHRESHEFTE DER GESELLSCHAFT FUER NATURKUNDE IN WUERTTEMBERG 150 (0):193-221.

2022. HENNE, D. R. 1975. DOMESTIC SHEEP MORTALITY ON A WESTERN MONTANA RANCH. M.S. THESIS, UNIVERSITY OF MONTANA, MISSOULA, MT. 53 PP.

2023. HENNESSEY, L. E. 1998. AN EVALUATION OF YELLOWSTONE CUTTHROAT TROUT FRY RECRUITMENT RELATED TO WATER LEASES ON FOUR TRIBUTARIES OF THE YELLOWSTONE RIVER. M.S. THESIS, MONTANA STATE UNIVERSITY, BOZEMAN, MT. 90 PP.

2024. HENNY, C. J., M. A. BYRD, J. A. JACOBS, P. D. MCLAIN, M. R. TODD and B. F. HALLA. 1977. MID/ATLANTIC COAST OSPREY POPULATION: PRESENT NUMBERS, PRODUCTIVITY, POLLUTANT CONTAMINATION, AND STATUS. J. WLDL. MANAGE. 41 (2):254-65.

2025. HENRY, D. L., T. S. BASKETT, K. C. SADLER and W. R. GOFORTH. 1976. AGE AND SEX SELECTIVITY FOR TRAPPING PROCEDURES FOR MOURNING DOVES. J. WILDL. MANAGE. 40(1):122-5.

2026. HENRY, P. and H. C. EPAIN. 1989. AMPHIBIAN PROTECTION ON HIGHWAY A71 IN SOLOGNE, FRANCE. PAGES 191-192 IN LANGTON,T.E.S., EDITOR. AMPHIBIANS AND ROADS. PROCEEDINGS OF THE TOAD TUNNEL CONFERENCE; 
1989 JANUARY 7-8; RENDSBURG, FEDERAL REPUBLIC OF GERMANY ACO POLYMER PRODUCTS LTD, SHEFFORD, ENGLAND.

2027. HENSLER, M. E. 1987. A FILED EVALUATION OF FOUR STRAINS OF SALMO INTRODUCED INTO SEVEN MONTANA WATERS. M.S. THESIS, MONTANA STATE UNIVERSITY, BOZEMAN, MT. 61 PP.

2028. HENSON, P. 1993. BREEDING BEHAVIOR OF TRUMPETER SWANS (CYGNUS BUCCINATOR)AND IMPLICATIONS FOR MANAGEMENT. PHD. THESIS, UNIVERSITY OF MINNESOTA . 154PP.

2029. HENSON, P. and T. A. GRANT. 1991. THE EFFECTS OF HUMAN DISTURBANCE ON TRUMPETER SWAN BREEDING BEHAVIOR. WILDLIFE SOCIETY BULLETIN 19(3):248-57.

2030. HERBERT, J. T. 1977. AN INVENTORY OF THE BIRD POPULATION WITHIN THE SARPY CREEK DRAINAGE, SOUTHEASTERN MONTANA. M.S. THESIS, MONTANA STATE UNIVERSITY, BOZEMAN, MT. 81 PP.

2031. HERBSTRITT, R. L. and A. D. MARBLE. 1996. CURRENT STATE OF BIODIVERSITY IMPACT ANALYSIS IN STATE TRANSPORTATION AGENCIES. TRANSPORTATION RESEARCH RECORD 1559:51-63.

2032. HERN, A. 1988. ROAD MORTALITY OF THE LITTLE OWL (ATHENE NOCTUA) IN SPAIN. JOURNAL OF RAPTOR RESEARCH 22(3):81-84.

2033. HERRERO, S. 1985. BEAR ATTACKS: THEIR CAUSES AND AVOIDANCE. WINCHESTER PRESS, NEW CENTURY PUBLISHERS, INC. PISCATAWAY, NJ P 287PP.

2034. HERRERO, S. 1974. CONFLICTS BETWEEN MAN AND GRIZZLY BEARS IN THE NATIONAL PARKS OF NORTH AMERICA. INT. CONF. BEAR RES. AND MANAGE. 3:121-45.

2035. HERRERO, S. 1970. NEW DEVELOPMENTS PROPOSED FOR CANADA'S ROCKY MOUNTAIN NATIONAL PARKS. CANADIAN FIELD NATURALIST 84:333-42

2036. HERRERO, S. 1989. THE ROLE OF LEARNING IN SOME FATAL GRIZZLY BEAR ATTACKS ON PEOPLE. P 9-14. IN: BEAR-PEOPLE CONFLICTS--PROC. SYMP. ON MANAGE. STRATEGIES

2037. HERRERO, S. 1983. SOCIAL BEHAVIOUR OF BLACK BEARS AT A GARBAGE DUMP IN JASPER NATIONAL PARK. INT. CONF. BEAR RES. AND MANAGE. 5:54-70.

2038. HERRERO, S. and S. FLECK. 1990. INJURY TO PEOPLE INFLICTED BY BLACK, GRIZZLY OR POLAR BEARS: RECENT TRENDS AND NEW INSIGHTS. INT. CONF. BEAR RES. AND MANAGE. 8:25-32.

2039. HERRERO, S. and J. HERRERO. 1996. CHEVIOT MINE PROJECT: SPECIFIC AND CUMULATIVE ENVIRONMENTAL EFFECTS ANALYSIS FOR MAMMALIAN CARNIVORES. 122PP.

2040. HERRERO, S., W. MCCRORY and B. PELCHAT. 1986. USING GRIZZLY BEAR HABITAT EVALUATIONS TO LOCATE TRAILS AND CAMPSITES IN KANANASKIS PROVINCIAL PARK. INT. CONF. BEAR RES. MANAGE. 6:187-193.

2041. HERRIGES, J. D. 1986. MOVEMENT, ACTIVITY AND HABITAT USE OF WHITE-TAILED DEER ALONG THE LOWER YELLOWSTONE RIVER. M.S. THESIS, MONTANA STATE UNIVERSITY, BOZEMAN, MT. 134 PP.

2042. HERSHEY, T. J. and T. A. LEEGE. 1982. ELK MOVEMENTS AND HABITAT USE ON A MANAGED FOREST IN NORTH-CENTRAL IDAHO. IDAHO DEPARTMENT OF FISH AND GAME JOB COMPLETION REPORT. WLDLIFE BULLETIN NO. 10. 24 PP.

2043. HERSHEY, T. J. and T. A. LEEGE. 1982. ELK MOVEMENTS AND HABITAT USE ON A MANAGED FOREST IN NORTH-CENTRAL IDAHO. IDAHO DEPARMENT OF FISH AND GAME. 32PP.

2044. HERSHEY, T. J. and T. A. LEEGE. 1976. INFLUENCES OF LOGGING ON ELK SUMMER RANGE IN NORTH-CENTRAL IDAHO. IN: PROC. ELK-LOGGING-ROADS SYMPOSIUM. UNIV. IDAHO, MOSCOW, ID.

2045. HERSHEY, T. J. and T. A. LEEGE. 1976. INFLUENCES OF LOGGING ON ELK ON SUMMER RANGE IN NORTH-CENTRAL IDAHO. PAGES 73-80 IN PROCEEDINGS OF TH 
MOSCOW, IDAHO.

2046. HERVERT, J. J. and P. R. KRAUSMAN. 1986. DESERT MULE DEER USE OF WATER DEVELOPMENTS IN ARIZONA. J. WILDL. MANAGE. 50 (4):670-6.

2047. HERVIEUX, D., J. EDMONDS, R. BOONAR and J. MCCAMMON. 1996. SUCCESSFUL AND UNSUCCESSFUL ATTEMPTS TO RESOLVE CARIBOU MANAGEMENT AND TIMBER HARVESTING ISSUES IN WEST CENTRAL ALBERTA. RANGIFER SPECIAL ISSUE NO.9:185-90.

2048. HESKE, E. J. 1995. MAMMALIAN ABUNDANCES ON FOREST-FARM EDGES VERSUS FOREST INTERIORS IN SOUTHERN ILLINOIS: IS THERE AN EDGE EFFECT? JOURNAL OF MAMMALOGY 76 (2):562-8.

2049. HESS, G. R. 1994. CONSERVATION CORRIDORS AND CONTAGIOUS DISEASE: A CAUTIONARY NOTE. CONSERVATION BIOLOGY 8 (1):256-62.

2050. HEUER, K. 1995. WLDLIFE CORRIDORS AROUND DEVELOPED AREAS OF BANFF NATIONAL PARK. PROGRESS REPORT FOR PARKS CANADA. 78PP.

2051. HEUER, K. 1995. WLDLIFE CORRIDORS AROUND DEVELOPED AREAS OF BANFF NATIONAL PARK (1995 PROGRESS REPORT). PARKS CANADA, BANFF WARDEN SERVICE., BANFF, ALBERTA.

2052. HEUER, K., R. OWCHAR, D. DUKE and S. ANTONATION. 1998. WLDLIFE CORRIDORS AROUND DEVELOPED AREAS OF BANFF NATIONAL PARK. PROGRESS REPORT, WINTER 1996/1997. PARKS CANADA, BANFF NATIONAL PARK WARDEN SERVICE, BANFF, ALBERTA.

2053. HEUSMANN, H. W. 1973. HOW TO CREATE WLDLIFE HABITAT FROM HIGHWAY CONSTRUCTION. CATALYST 3(4):17-19.

2054. HEUSMANN, H. W. 1969. AN ANALYSIS OF THE POTENTIAL CREATION OF PRODUCTIVE WETLANDS BY INTERSTATE HIGHWAY CONSTRUCTION WITH EMPHASIS ON WATERFOWL MANAGEMENT. M.S. THESIS, UNIVERSITY OF MASSACHUSETTS, BOSTON.

2055. HEWITT, C. N. and M. B. RASHED. 1992. REMOVAL RATES OF SELECTED POLLUTANTS IN THE RUNOFF WATERS FROM A MAJOR RURAL HIGHWAY. WATER RESEARCH 26(3):311-9.

2056. HEWITT, D. G., A. CAIN, V. TUOVILA, D. B. SHINDLE and M. E. TEWES. 1998. IMPACTS OF AN EXPANDED HIGHWAY ON OCELOTS AND BOBCATS IN SOUTHERN TEXAS AND THEIR PREFERENCES FOR HIGHWAY CROSSINGS. PAGES 126-134 IN G. L. EVINK, P. GARRETT, D. ZEIGLER, AND J. BERRY, EDITORS. PROCEEDINGS OF THE INTERNATIONAL CONFERENCE ON WLDLIFE ECOLOGY AND TRANSPORTATION. FLORIDA DEPARTMENT OF TRANSPORTATION, TALLAHASSEE, FLORIDA.

2057. HEWITT, O. H. 1967. A ROAD-COUNT INDEX TO BREEDING POPULATIONS OF RED-WINGED BLACKBIRDS. J. WILDL. MANAGE. 31 (1):39-47.

2058. HIATT, G. S. and D. BAKER. 1981. EFFECTS OF OIL/GAS DRILLING ON ELK AND MULE DEER WINTER DISTRIBUTION ON CROOKS MOUNTAIN, WYOMING. UNPUBLISHED REPORT. WYOMING GAME AND FISH DEPARTMENT. SINCLAIR, WYOMING. 24PP.

2059. HICKS, A. C. 1993. USING ROAD-KILLS AS AN INDEX TO MOOSE POPULATION CHANGE. ALCES 29:243-247.

2060. HICKS, L. L. and J. M. ELDER. 1979. HUMAN DISTURBANCE OF SIERRA NEVADA BIGHORN SHEEP. J. WILDL. MANAGE. $43(4): 909-15$.

2061. HICKS, L. L. 1990. HABITAT USE OF WHITE-TAILED DEER IN RELATION TO WINTER RANGE SILVICULTURAL TREATMENTS IN THE THOMPSON RIVER DRAINAGE, NORTHWESTERN MONTANA. PH.D. DISSERTATION, UNIVERSITY OF MONTANA, MISSOULA, MT. 79 PP.

2062. HIEB, S. R. and J. M. PEEK. 1976. ELK-LOGGING-ROADS SYMPOSIUM: PROCEEDINGS OF THE ELK, LOGGING, ROADS SYMPOSIUM, MOSCOW, IDAHO, DECEMBER 16-17, 1975. FOREST, WILDLIFE AND RANGE EXPERIMENT STATION, UNIVESITY OF IDAHO, MOSCOW, IDAHO. 
2063. HILDEBRAND, B. D. 1979. HABITAT REQUIREMENTS OF MOLTING CANADA GEESE AT LIMA RESERVOIR, MONTANA. M.S. THESIS, MONTANA STATE UNIVERSITY, BOZEMAN, MT. 79 PP.

2064. HILDEBRAND, P. R. 1971. BIOLOGY OF WHITE-TAILED DEER ON WINTER RANGE IN THE SWAN VALLEY, MONTANA. M.S. THESIS, UNIVERSITY OF MONTANA, MISSOULA, MT. 91 PP.

2065. HILDEBRAND, S. G. and J. B. CANNON. 1993. ENVIRONMENTAL ANALYSIS THE NEPA EXPERIENCE. LEWIS PUBLISHERS, BOCA RATON, FLORIDA.

2066. HILL, C. W. JR. 1958. OBSERVATIONS ON THE LIFE HISTORIES OF THE COLUMBIA RIVER CHUB AND COLUMBIA SQUAWFISH IN WESTERN MONTANA. M.S. THESIS, MONTANA STATE COLLEGE, BOZEMAN, MT. 29 PP.

2067. HILL, D., D. HOCKIN and ET AL. 1997. BIRD DISTURBANCE: IMPROVING THE QUALITY AND UTILITY OF DISTURBANCE RESEARCH. JOURNAL OF APPLIED ECOLOGY 34:275-288.

2068. HILL, E. 1991. CARIBOU AND HYDROELECTRIC DEVELOPMENT. P 392-6. IN: BUTLER CE, MAHONEY SP, EDS. 4TH NORTH AMERICAN CARIBOU WORKSHOP PROC.; OCT31-NOV 31989 ; ST. JOHN'S, NEWFOUNDLAND. NEWFOUNDLAND AND LABRADOR WILDLIFE DIV.

2069. HILL, G. A. 1974. CENTRAL NEWYORK SNOWMOBILES AND PATTERN OF VEHICLE USE. JOURNAL OF LEISURE RESEARCH

2070. HILL, G. A. 1971. TOWARDS ENHANCING AND CONTROLLING RECREATIONAL SNOWMOBILING: A STUDY OF CENTRAL NEW YORK PARTICIPANTS AND VEHICLE USE. CORNELL UNIV. ITHACA, NY.

2071. HILL, G. 1993. CONSERVATION STRATEGIES FOR MANATEES AND SEA TURTLES IN THAILAND. M.S. THESIS, UNIVERSITY OF MONTANA, MISSOULA, MT.

2072. HILL, P. J. and R. E. MEINERS. 1998. WHO OWNS THE ENVIRONMENT?. POLITICAL ECONOMY FORUM. ROWMAN \& LITTLEFIELD, LANHAM, MARYLAND.

2073. HILL, S. R. JR. 1995. MIGRATORY CHRONOLOGY OF ADULT TIGER SALAMANDERS (AMBYSTOMA TIGRINUM) AND SURVEY OF LARVAE OF THE TIGER SALAMANDER IN THE NORTHERN RANGE OF YELLOWSTONE NATIONAL PARK. PH.D. DISSERTATION, MONTANA STATE UNIVERSITY, BOZEMAN, MT. 72 PP.

2074. HILL, W. J. 1965. OBSERVATIONS ON THE LIFE HISTORY AND MOVEMENT OF THE GOLDEYE HYODON ALOSOIDES IN MONTANA. M.S. THESIS, MONTANA STATE UNIVERSITY, BOZEMAN, MT. 13 PP.

2075. HILLIS, J. M., M. J. THOMPSON, J. E. CANFIELD, L. J. LYON, C. L. MARCUM, P. M. DOLAN and D. W. MCLEEREY. 1991 DEFINING ELK SECURITY: THE HILLIS PARADIGM. PAGES 38-43 IN A. G. CHRISTENSEN, L. J. LYON, AND T. N. LONNER, COMPILERS. PROCEEDINGS OF THE ELK VULNERABILITY SYMPOSIUM. MONTANA STATE UNIVERSITY, BOZEMAN, MONTANA.

2076. HILLMAN, L. L. and D. L. YOW. 1986. TIMBER MANAGEMENT FOR BLACK BEARS. PROC. EAST. WORKSHOP BLACK BEAR RES. AND MANAGE. 8:125-36.

2077. HINES, J. 1977. ENVIRONMENTALLY DISRUPTIVE ROAD CONSTRUCTION IN THE QU'APPELLE VALLEY. BLUE JAY 35(4):200-204.

2078. HINES, T. D. and R. M. CASE. 1991. DIET, HOME RANGE, MOVEMENTS, AND ACTIVITY PERIODS OF SWFT FOX IN NEBRASKA. PRAIRIE NAT. 23:131-138.

2079. HINES, T. D. and R. M. CASE. 1991. DIET HOME RANGE MOVEMENTS AND ACTIVITY PERIODS OF SWIFT FOX IN NEBRASKA, USA. PRAIRIE NATURALIST 23(3):131-138.

2080. HINMAN, R. 1974. THE IMPACT OF OIL DEVELOPMENT ON WILDLIFE POPULATIONS IN NORTHERN ALASKA. PROC. ANNU. CONF. WEST. ASSOC. STATE GAME FISH COMM.; 54:156-164 
2081. HINSLEY, S. A., P. E. BELLAMY, I. NEWTON and T. H. SPARKS. 1996. INFLUENCES OF POPULATION SIZE AND WOODLAND AREA ON BIRD SPECIES DISTRIBUTIONS IN SMALL WOODS. OECOLOGIA 105:100-6.

2082. HINZ, T. C. 1974. SEASONAL ACTIVITY, NUMBERS, AND DISTRIBUTION OF CANADA GEESE BRANTA CANADENSIS IN THE LOWER YELLOWSTONE VALLEY, MONTANA. M.S. THESIS, MONTANA STATE UNIVERSITY, BOZEMAN, MT. $88 \mathrm{PP}$.

2083. HIRST, S. M. 1969. ROAD-STRIP CENSUS TECHNIQUES FOR WILD UNGULATES IN AFRICAN WOODLAND. J. WILDL. MANAGE. 33 (1):40-8.

2084. HITCHCOCK, R. W. I. 1988. LIMITATIONS TO A RAINBOW TROUT POPULATION IN NORTH-CENTRAL MONTANA. M.S. THESIS, MONTANA STATE UNIVERSITY, BOZEMAN, MT. 131 PP.

2085. HITCHINGS, S. P. and T. J. BEEBEE. 1997. GENETIC SUBSTRUCTURING AS A RESULT OF BARRIERS TO GENE FLOW IN URBAN RANA TEMPORARIA (COMMON FROG) POPULATIONS: IMPLICATIONS FOR BIODIVERSITY CONSERVATION. HEREDITY 79:117-127.

2086. HJELJORD, O. 1973. MOUNTAIN GOAT FORAGE AND HABITAT PREFERENCE IN ALASKA. J. WILDL. MANAGE. 37 (3):353-62

2087. HO, Y. B. and K. M. TAI. 1988. ELEVATED LEVELS OF LEAD AND OTHER METALS IN ROADSIDE SOIL AND GRASS AND THEIR USE TO MONITOR AERIAL METAL DEPOSITIONS IN HONG KONG. ENVIRONMENTAL POLLUTION (SERIES A) $49: 37-51$

2088. HOAR, K. L. 1995. PARASITE LOADS AND THEIR RELATIONSHIP TO HERD HEALTH IN THE HIGHLANDS BIGHORN SHEEP HERD IN SOUTHWESTERN MONTANA. M.S. THESIS, MONTANA STATE UNIVERSITY, BOZEMAN, MT. 70 PP.

2089. HOBBS, N. T. 1989. LINKING ENERGY BALANCE TO SURVIVAL IN MULE DEER: DEVELOPMENT AND TEST OF A SIMULATION MODEL. WILDLIFE MONOGRAPHS 101:1-39.

2090. HOBBS, R. J. and L. F. HUENNEKE. 1992. DISTURBANCE, DIVERSITY, AND INVASION: IMPLICATIONS FOR CONSERVATION. CONSERVATION BIOLOGY 6 (3):324-37.

2091. HOBBS, R. J., B. M. J. HUSSEY and D. A. SAUNDERS. 1990. NATURE CONSERVATION: THE ROLE OF CORRIDORS. BULLETIN OF THE ECOLOGICAL SOCIETY OF AMERICA 1(1):48-49.

2092. HOCKIN, D., M. OUNSTED, M. GORMAN, D. HILL, V. KELLER and M. A. BARKER. 1992. EXAMINATION OF THE EFFECTS OF DISTURBANCE ON BIRDS WITH REFERENCE TO ITS IMPORTANCE IN ECOLOGICAL ASSESSMENT. J. ENVIRONMENTAL MANAGEMENT 36:253-386.

2093. HODGMAN, T. P., D. J. HARRISON, D. D. KATNIK and K. D. ELOWE. 1994. SURVIVAL IN AN INTENSIVELY TRAPPED MARTEN POPULATION IN MAINE. JOURNAL OF WILDLIFE MANAGEMENT 58(4):593-600.

2094. HODGSON, J. R. 1970. ECOLOGICAL DISTRIBUTION OF MICROTUS MONTANUS (PEALE) AND MICROTUS PENNSYLVANIUS (ORD) IN AN AREA OF GEOGRAPHIC SYMPATRY IN SOUTHWESTERN MONTANA. PH.D. DISSERTATION, MONTANA STATE UNIVERSITY, BOZEMAN, MT. 65 PP.

2095. HODSON, N. L. 1962. SOME NOTES ON THE CAUSES OF BIRD ROAD CAUSALITIES. BIRD STUDY 9:168-173.

2096. HODSON, N. L. 1966. A SURVEY OF ROAD MORTALITY IN MAMMALS (AND INCLUDING DATA FOR THE GRASS SNAKE AND COMMON FROG). LONDON: JOURNAL OF ZOOLOGY 148:576-579.

2097. HODSON, N. L. and D. W. SNOW. 1965. THE ROAD DEATHS ENQUIRY, 1960-1961. BIRD STUDY 12:168-172.

2098. HOEKMAN, S. T. 1999. NEST HABITAT SELECTION BY GRASSLAND BIRDS: THE ROLE OF VEGETATION STRUCTURE AND FLORISTICS. M.S. THESIS, UNIVERSITY OF MONTANA, MISSOULA, MT. 49 PP.

2099. HOFFMAN, A. J. and C. ALLIENDE. 1982. IMPACT OF TRAMPLING UPON THE VEGETATION OF ANDEAN AREAS IN CENTRAL CHILE. MOUNTAIN RESEARCH AND DEVELOPMENT 2:189-194. 
2100. HOFFMAN, N. J. 1997. DISTRIBUTION OF PICOIDES WOODPECKERS IN RELATION TO HABITAT DISTURBANCE WITHIN THE YELLOWSTONE AREA. M.S. THESIS, MONTANA STATE UNIVERSITY, BOZEMAN, MT. 74 PP.

2101. HOFSTRA, G. and R. HALL. 1971. INJURY ON ROADSIDE TREES: LEAF INJURY ON PINE AND WHITE CEDAR IN RELATION TO FOLIAR LEVELS OF SODIUM AND CHLORIDE. CANADIAN JOURNAL OF BOTANY 49:613-622.

2102. HOFSTRA, G. and D. W. SMITH. 1984. THE EFFECTS OF ROAD DEICING SALT ON THE LEVELS OF IONS IN ROADSIDE SOILS IN SOUTHERN ONTARIO. JOURNAL OF ENVIRONMENTAL MANAGEMENT 19(3):261-271.

2103. HOLBROOK, H. T. and M. R. VAUGHAN. 1985. INFLUENCE OF ROADS ON TURKEY MORTALITY. JOURNAL OF WILDLIFE MANAGMENT 49:611-614.

2104. HOLCROFT, A. C. 1986. ASPECTS OF BLACK BEAR ECOLOGY AND CAMPGROUND PLANNING IN SOUTHWESTERN ALBERTA. M. ENV. DES. PROJECT, UNIVERSITY OF CALGARY.90PP.

2105. HOLECEK, D. F. 1973. PROCEEDINGS OF THE SNOWMOBILE AND OFF-ROAD VEHICLE RESEARCH SYMPOSIUM. SPONSORED BY THE DEPARTMENT OF PARK AND RECREATION RESOURCES, MICHIGAN STATE UNIVERSITY. EAST LANSING, MI.

2106. HOLISOVA, V. and R. OBRTEL. 1986. VERTEBRATE CASUALTIES ON A MORAVIAN ROAD. PRIRODOVED.PR.USTAVU CESK.AKAD.VED.BRNE 20(9):1-43

2107. HOLLENBAUGH, W. C. 1974. SNOWMOBILES AND OFF-ROAD VEHICLES IN MONTANA: A REVIEW OF THE LITERATURE. MONTANA DEPARTMENT OF FISH AND GAME.

2108. HOLLENBECK, R. R. 1974. GROWTH RATES AND MOVEMENTS WITHIN A POPULATION OF RANA PRETIOSA PRETIOSA BAIRD AND GIRARD IN SOUTHCENTRAL MONTANA. PH.D. DISSERTATION, MONTANA STATE UNIVERSITY, BOZEMAN, MT. 66 PP.

2109. HOLLIFIELD, B. K. and R. W. DIMMICK. 1995. ARTHROPOD ABUNDANCE RELATIVE TO FOREST MANAGEMENT PRACTICES BENEFITING RUFFED GROUSE IN THE SOUTHERN APPALACHIANS. WLDL. SOC. BULL. 23 (4):756-64.

2110. HOLLIMAN, D. C. 1997. EASTERN BLUEBIRD (SIALIA SIALIS) STUDIES DURING THE CONSTRUCTION OF A GOLFING COMMUNITY IN NORTH SHELBY COUNTY, ALABAMA. ALA. BIRDLIFE 43:7-21.

2111. HOLLIS, G. E. 1975. THE EFFECT OF URBANIZATION ON FLOODS OF DIFFERENT RECURRENCE INTERVALS. WATER RESOURCES RESEARCH 11:431-435.

2112. HOLM, J. W. 1984. NEST SUCCESS AND COVER RELATIONSHIPS OF UPLAND-NESTING DUCKS IN NORTHCENTRAL MONTANA. M.S. THESIS, UNIVERSITY OF MONTANA, MISSOULA, MT. 35 PP.

2113. HOLMES, T. L., R. L. KNIGHT, L. STEGALL and G. R. CRAIG. 1993. RESPONSES OF WINTERING GRASSLAND RAPTORS TO HUMAN DISTURBANCE. WLDLIFE SOCIETY BULLETIN 21:461-468.

2114. HOLROYD, G. L. 1979. THE IMPACT OF HIGHWAY AND RAILROAD MORTALITY ON THE UNGULATE POPULATIONS IN THE BOW VALLEY, BANFF NATIONAL PARK. ENVIRONMENT CANADA, CANADIAN WILDLIFE SERVICE, OTTAWA, ONT. 11PP.

2115. HOLSWORTH, W. N. 1973. HUNTING EFFICIENCY AND WHITE-TAILED DEER DENSITY. J. WLDL. MANAGE. 37 (3):336-42

2116. HOLT, R. D. 1955. COMPARATIVE MORPHOLOGY OF THE ROCKY MOUNTAIN WHITEFISH (PROSOPIUM WILLIAMSONI). M.S. THESIS, MONTANA STATE COLLEGE, BOZEMAN, MT. 20 PP.

2117. HOLTON, G. D. 1952. A TROUT POPULATION STUDY ON A SMALL CREEK IN GALLATIN COUNTY, MONTANA. M.S. THESIS, MONTANA STATE COLLEGE, BOZEMAN, MT. 46 PP.

2118. HOLTZ, A. and H. W. REYNOLDS. 1980. IMPACT OF DRILLING ACTIVITIES ON UNGULATES WITHIN THE MIDDLE SANDHILLS OF THE SUFFIELD MILITARY RESERVE. DECEMBER 17,1979 AND YEAR-END REVIEW. CANADIAN 
WILDLIFE SERVICE, EDMONTON. UNPUBLISHED REPORT

2119. HOLZER, K. A. 1989. ECOLOGY OF MERRIAM'S WILD TURKEY IN THE HELENA NATIONAL FOREST. M.S. THESIS, MONTANA STATE UNIVERSITY, BOZEMAN, MT. 45 PP.

2120. HOME LUMBER (RETAIL DIVISION) LIMITED. THE GAME MIRRORS (HIGHWAY LIGHTING FOR THE PROTECTION OF WILDLIFE). SCARBOROUGH, ONTARIO, CANADA., 4 PP.

2121. HONEYAGER, A. T. 1992. THE POTENTIAL FOR TIMBER WOLF RECOVERY IN THE NICOLET NATIONAL FOREST AND ADJACENT AREAS. DISSERTATION, UNIVERSITY OF WISCONSIN, MILWAUKEE,WISCONSIN. $262 P P$.

2122. HOOD, B. R. 1995. A SURVEY OF FREE-RANGING AND CAPTIVE WILD UNGULATES FOR TUBERCULOSIS AND OTHER DISEASES. M.S. THESIS, MONTANA STATE UNIVERSITY, BOZEMAN, MT. 84 PP.

2123. HOOD, R. E. and J. M. INGLIS. 1974. BEHAVIORAL RESPONSES OF WHITE-TAILED DEER TO INTENSIVE RANCHING OPERATIONS. J. WLDL. MANAGE. 38 (3):488-98.

2124. HOOK, D. L. 1986. IMPACTS OF SEISMIC ACTIVITY ON BIGHORN MOVEMENTS AND HABITAT USE. PROC. FIFTH BIENN. SYMP. NORTH. WILD SHEEP AND GOAT COUNCIL 5:292-296.

2125. HOOK, D. L. 1986. IMPACTS OF SEISMIC ACTIVITY ON BIGHORN SHEEP MOVEMENTS AND HABITAT USE. PROC. FIFTH BIENN. SYMP. NORTH, WILD SHEEP AND GOAT COUNCIL:292-6.

2126. HOOK, D. L. 1973. PRODUCTION AND HABITAT USE BY CANADA GEESE AT FREEZEOUT LAKE, MONTANA. M.S. THESIS, MONTANA STATE UNIVERSITY, BOZEMAN, MT. 53 PP.

2127. HOOPER, R. G. 1977. NESTING HABITS OF COMMON RAVENS IN VIRGINIA. WLSON BULLETIN 89:233-242.

2128. HOOPES, E. M. 1993. RELATIONSHIPS BETWEEN HUMAN RECREATION AND PIPING PLOVER FORAGING ECOLOGY AND CHICK SURVIVAL. THESIS, UNIVERSITY OF MASSACHUSETTS, AMHERST, MASSACHUSETTS. XII + $106 P P$.

2129. HOOTEN, M. M. 1995. DISTINGUISHING FORMS OF STATISTICAL DENSITY DEPENDENCE AND INDEPENDENCE IN ANIMAL TIME SERIES DATA USING INFORMATION CRITERIA. PH.D. DISSERTATION, MONTANA STATE UNIVERSITY, BOZEMAN, MT. 150 PP.

2130. HOOVER, B. 1973. OFF-ROAD VEHICLE PROBLEMS ON FEDERAL LANDS. PAGES 37-49 IN PROCEEDINGS OF ANNUAL MEETING-ASSOCIATION OF MIDWEST FISH WILDLIFE COMMITTEE. VOLUME 40.

2131. HOOVER, R. L. and D. L. WILLS. 1984. MANAGING FORESTED LANDS FOR WLDLIFE. COLORADO DIVISION OF WILDLIFE IN COOPERATION WITH USDA FOREST SERVICE, ROCKY MOUNTAIN REGION. DENVER, COLORADO. 459PP.

2132. HOP, K. D., F. H. KENNETH and E. N. DAVID. 1989. VERTEBRATE WILDLIFE USE OF HIGHWAY BORROW PIT WETLANDS IN SOUTH DAKOTA. PROCEEDINGS OF THE SOUTH DAKOTA ACADEMY OF SCIENCE 68:47-54.

2133. HOPE, J. 1972. THE INVASION OF THE AWFUL ORVS. TRENDS 9:14-22.

2134. HOPE, J. 1979. THE REAL IMPACT OF OFF-ROAD VEHICLES ON PUBLIC LANDS. BACKPACKER 34 7:65-66.

2135. HOPE, J. P. 1987. BIRD SCAVENGERS ON GWYNEDD ROAD IN 1986. GWYNEDD BIRD REPORT 986:55-57.

2136. HOPPOP, O. and K. HOPPOP. 1995. THE INFLUENCE OF AGRICULTURE AND ROAD USAGE ON THE DISTRIBUTION OF COASTAL BIRD NESTS ON SALTMARSHES IN SCHLESWIG-HOLSTEIN (GERMANY). VOGELWARTE 38(2):76-88.

2137. HORAK, G. 1985. BIBLIOGRAPHY AND SELECTED CHARACTERISTICS OF MITIGATION STUDIES. WESTERN ENERGY AND LAND USE TEAM, DIVISION OF BIOLOGICAL SERVICES, RESEARCH AND DEVELOPMENT, FISH AND WILDLIFE SERVICE, U.S. DEPT. OF THE INTERIOR, WASHINGTON, D.C.

2138. HORAK, G. 1985. SUMMARIES OF SELECTED MITIGATION EVALUATION STUDIES. WESTERN ENERGY AND LAND USE TEAM, DIVISION OF BIOLOGICAL SERVICES, RESEARCH AND DEVELOPMENT, FISH AND WILDLIFE SERVICE, 
2139. HOREJSI, B. 1976. PROC. BIENN. SYMP. OF THE NORTHERN WILD SHEEP AND GOAT COUNCIL: 149-55. BIGHORN SHEEP, HARASSMENT.

2140. HOREJSI, B. 1979. SEISMIC OPERATIONS AND THEIR IMPACT ON LARGE MAMMALS: RESULTS OF A MONITORING PROGRAM. WESTERN WILDLIFE ENVIRONMENTS LTD. PREPARED FOR MOBIL OIL CANADA LTD., CALGARY. 86PP.

2141. HOREJSI, B. L. 1981. BEHAVIORAL RESPONSE OF BARREN-GROUND CARIBOU TO A MOVING VEHICLE. ARCTIC 34 (2):180-5.

2142. HOREJSI, B. L. 1981. BEHAVIORAL RESPONSE OF BARREN GROUND CARIBOU TO A MOVING VEHICLE. PAGES $313-324$ IN G. JOSLIN, EDITOR. PROCEEDINGS OF THE FIFTH NORTHERN WLD SHEEP AND GOAT COUNCIL. VOLUME 5. MONTANA DEPARTMENT OF FISH, WILDLIFE AND PARKS,

2143. HOREJSI, B. L. 1986. BIGHORN SHEEP, MOUNT ALLAN AND THE 1988 WINTER OLYMPICS: POLITICAL AND BIOLOGICAL REALITIES. PAGES 149-155 IN E. T. THORNE, EDITOR. PROCEEDINGS OF THE BIENNIAL SYMPOSIUM OF THE NORTHERN WILD SHEEP COUNCIL. JACKSON, WYOMING.

2144. HOREJSI, B. L. 1986. INDUSTRIAL AND AGRICULTURAL INCURSION INTO GRIZZLY BEAR HABITAT: THE ALBERTA STORY. P.116-123 IN: CONTRERAS GP, EVANS KE.PROCEEDINGS-GRIZZLY-BEAR-HABITAT-SYMPOSIUM,-MISSOULA,-MONTANA,APR 30-MAY 2, 1985 ; MISSOULA, MT

2145. HOREJSI, B. L. 1976. SOME THOUGHTS ON HARASSMENT AND BIGHORN SHEEP. ARCTIC 34:180-185.

2146. HOREJSI, B. L. 1989. UNCONTROLLED LAND-USE THREATENS AN INTERNATIONAL GRIZZLY BEAR POPULATION. CONSERVATION BIOLOGY 3 (3): 220-3

2147. HORKEL, J. D., R. S. LUTZ and N. J. SILVY. 1981. RIGHTS-OF-WAY AS HABITAT FOR THE ENDANGERED ATTWATER'S PRAIRIE CHICKEN. PAGES 65 IN TILLMAN,R.E., EDITOR. PROCEEDINGS OF SECOND SYMPOSIUM ON ENVIRONMENTAL CONCERNS IN RIGHTS-OF-WAY MANAGEMENT; 1979 OCTOBER 16-18; ANN ARBOR, MI. UNIVERSITY OF MICHIGAN, ANN ARBOR.

2148. HORNBECK, G. E. 1990. WILDLIFE MITIGATION ON HIGHWAY 40 FOR THE XV (1988)OLYMPIC WINTER GAMES. ALBERTA FISH AND WILDLIFE TECH. PUBL.

2149. HORNBECK, G. E. 1990. WILDLIFE MITIGATION ON HIGHWAY 40 FOR THE XV (1988) OLYMPIC WINTER GAMES. UNPUBLISHED REPORT. ALBERTA FISH AND WLDLIFE, EDMONTON, ALBERTA.

2150. HORNBECK, G. E. and T. R. ECCLES. 1991. POPULATION CHARACTERISTICS AND RANGE USE OF WOODLAND CARIBOU IN THE PEDIGREE AREA OF NORTHWESTERN ALBERTA. DELTA ENVIRONMENTAL MANAGEMENT GROUP, CALGARY. PREPARED FOR THE PEDIGREE CARIBOU STANDING COMMITTEE. 64PP.

2151. HORNBECK, G. E. and D. L. J. MOYLES. 1995. ECOLOGICAL ASPECTS OF WOODLAND CARIBOU IN THE PEDIGREE AREA OF NORTHWESTERN ALBERTA. AXYS ENVIRONMENTAL CONSULTING LTD., CALGARY, ALBERTA. 66PP.

2152. HORNBECK, G. E. 1989. MITIGATION PROGRAM FOR ELK ALONG HIGHWAY 40 DURING THE XV (1988) OLYMPIC WINTER GAMES. ALBERTA FORESTRY, LANDS AND WILDLIFE, FISH AND WILDLIFE, EDMONTON, ALBERTA. OCCASIONAL PAPER / WLDLIFE MANAGEMENT BRANCH: PUB. NO: OCCASIONAL PAPER (ALBERTA. WILDLIFE MANAGEMENT): PUBLICATION (ALBERTA. ALBERTA FORESTRY, LANDS AND WILDLIFE) NO. 5. NO. 1/262.

2153. HORNE, M. T. and W. A. DUNSON. 1994. EXCLUSION OF THE JEFFERSON SALAMANDER, AMBYSTOMA JEFFERSONIANUM, FROM SOME POTENTIAL BREEDING PONDS IN PENNSYLVANIA: EFFECTS OF PH, TEMPERATURE, AND METALS ON EMBRYONIC DEVELOPMENT. ARCHIVES OF ENVIRONMENTAL CONTAMINATION AND TOXICOLOGY 27:323-330.

2154. HORNOCKER, M. G. 1971. SUGGESTIONS FOR THE MANAGEMENT OF MOUNTAIN LIONS AS TROPHY SPECIES IN THE INTERMOUNTAIN REGION. PROC. WEST. ASSOC. STATE GAME AND FISH COMM.:399-402. 
2155. HORNOCKER, M. G. 1962. POPULATION CHARACTERISTICS AND SOCIAL REPRODUCTIVE BEHAVIOR OF THE GRIZZLY BEAR IN YELLOWSTONE NATIONAL PARK. PH.D. DISSERTATION, MONTANA STATE UNIVERSITY, MISSOULA, MT. 94 PP.

2156. HORNOCKER, M. G. and H. S. HASH. 1981. ECOLOGY OF THE WOLVERINE IN NORTHWESTERN MONTANA. CANADIAN JOURNAL OF ZOOLOGY 59:1286-1301.

2157. HORPESTAD, A. A. 1977. CHANGES IN ZOOPLANKTON SPECIES COMPOSITION IN NEWLY FILLED BIGHORN LAKE, MONTANA AND WYOMING. PH.D. DISSERTATION, MONTANA STATE UNIVERSITY, BOZEMAN, MT. 54 PP.

2158. HORPESTAD, A. A. 1969. FACTORS AFFECTING THE DISTRIBUTION AND ABUNDANCE OF AQUATIC MACROPHYTES IN PARTS OF THE MADISON, FIREHOLE AND GIBBON RIVERS. M.S. THESIS, MONTANA STATE UNIVERSITY, BOZEMAN, MT. 90 PP.

2159. HORVATH, B. Z. 1967. STUDIES ON THE DEVELOPMENT OF MUSCLE IN EMBRYOS OF AULOCARA ELLIOTTI (THOMAS) (ORTHOPTERA, ACRIDDIDAE) USING FLUORESCENT ANTIBODY TECHNIQUE. PH.D. DISSERTATION, MONTANA STATE UNIVERSITY, BOZEMAN, MT. 69 PP.

2160. HOUSTON, C. S. 1962. HAZARDS FACED BY COLONIAL BIRDS. BLUEJAY 20:74-77.

2161. HOWARD, K. W. F. and P. J. BECK. 1993. HYDROGEOCHEMICAL IMPLICATIONS OF GROUNDWATER CONTAMINATION BY ROAD DE-ICING CHEMICALS. JOURNAL OF CONTAMINANT HYDROLOGY 12 (3):245-68.

2162. HRUBES, R. J., K. P. CONNAUGHTON and R. W. SASSAMAN. 1979. ROADLESS AREA-INTENSIVE MANAGEMENT TRADEOFFS ON THE SIERRA NATIONAL FOREST, CALIFORNIA. U.S. FOREST SERVICE, PACIFIC SOUTHWEST FOREST AND RANGE EXPERIMENT STATION. BERKELEY, CALIFORNIA. RESEARCH PAPER PSW-149.

2163. HSU, M. and T. J. PETERLE. 1989. USE OF ARTIFICIAL NEST CAVITIES ALONG OHIO INTERSTATE HIGHWAYS BY BLUEBIRDS (SIALIA SIALIS) AND MICE (PEROMYSCUS). OHIO JOURNAL OF SCIENCE 89(2):44-52.

2164. HSU, M. T. 1984. ROADSIDE DEICING CHEMICAL ACCUMULATION AFTER 10 YEARS. TRANSPORTATION RESEARCH RECORD 969:36-40.

2165. HUBBARD, D. L. J. and W. M. BALFOUR. 1993. AN INVESTIGATION OF ENGINEERING AND ENVIRONMENTAL CONCERNS RELATING TO PROPOSED HIGHWAY CONSTRUCTION IN A KARSTTERRANE. ENVIRONMENTAL GEOLOGY 22 (4):326-9

2166. HUBBARD, I. M. 1962. A HEMATOLOGICAL STUDY ON THE ROCKY MOUNTAIN WHITEFISH (PROSOPIUM WILLIAMSONI). M.S. THESIS, MONTANA STATE COLLEGE, BOZEMAN, MT. 30 PP.

2167. HUBBS, A. H. and R. BOONSTRA. 1995. STUDY DESIGN TO ASSESS THE EFFECTS OF HIGHWAY MEDIAN BARRIERS ON WILDLIFE. MAT-94-03. RESEARCH AND DEVELOPMENT BRANCH, MINISTRY OF TRANSPORTATION, DOWNSVIEW, ONTARIO.

2168. HUBBS, A. H. and R. BOONSTRA. 1995. STUDY DESIGN TO ASSESS THE EFFECTS OF HIGHWAY MEDIAN BARRIERS ON WILDLIFE. RESEARCH AND DEVELOPMENT BRANCH, ONTARIO MINISTRY OF TRANSPORTATION, DOWNSVIEW, ONTARIO.

2169. HUBER, D., J. KUSAK and A. FRKOVIC. 1995. TRAFFIC KILLS OF BROWN BEARS IN GORSKIKOTAR, CROATIA (ABSTRACT). INT. CONF. BEAR RES. AND MANAGE. 10.

2170. HUBERT, G. F. 1991. COTTONTAIL RABBIT INVESTIGATIONS: COTTONTAIL RABBIT ROAD-KILL SURVEY. ILLINOIS DEPARTMENT OF CONSERVATION. IL W-099-R-3/JOB 1/STUDY I .

2171. HUBERT, G. F. 1991. COTTONTAIL RABBIT INVESTIGATIONS: COTTONTAIL RABBIT ROAD-KILL SURVEY. IL W-099-R-3 JOB 1/STUDY I. ILLINOIS DEPARTMENT OF CONSERVATION, [LOCATION OF PUBLISHER UNKNOWN].

2172. HUBERT, G. F. 1991. STRIPED SKUNK INVESTIGATIONS: STRIPED SKUNK ROAD-KILL SURVEY. IL W-099-R-3/JOB 1 STUDY XI. ILLINOIS DEPARTMENT OF CONSERVATION, [LOCATION OF PUBLISHER UNKNOWN]. 
2173. HUCKABEE, J. W., C. P. GOODYEAR and R. D. JONES. 1975. ACID ROCK IN THE GREAT SMOKIES: UNANTICIPATED IMPACT ON AQUATIC BIOTA OF ROAD CONSTRUCTION IN REGIONS OF SULFIDE MINERALIZATION.

- TRANSACTIONS OF THE AMERICAN FISHERIES SOCIETY 4:677-684.

2174. HUDSON, M. S. 1980. WATERFOWL PRODUCTION ON THREE AGE-CLASSES OF STOCK PONDS IN NORTHCENTRAL MONTANA. M.S. THESIS, MONTANA STATE UNIVERSITY, BOZEMAN, MT. 45 PP.

2175. HUDSON, P. 1956. THE MORPHOLOGY OF THE EMBRYONIC AND FETAL DEVELOPMENT OF THE ROCKY MOUNTAIN MULE DEER. M.S. THESIS, MONTANA STATE UNIVERSITY, MISSOULA, MT. 61 PP.

2176. HUDSON, R. J. 1976. ASSESSMENT OF THE IMPACT OF RESOURCE DEVELOPMENT ON WILD UNGULATES: A BIOENERGETIC INTERPRETATION. DEPARTMENT OF ANIMAL SCIENCE, UNIVERSITY OF ALBERTA, EDMONTON. UNPUBLISHED REPORT

2177. HUENNEKE, L. 1988. SCOPE PROGRAM ON BIOLOGICAL INVASIONS: A STATUS REPORT. CONSERVATION BIOLOGY 2 (1):8-10

2178. HUEPPOP, O. and K. HUEPPOP. 1995. THE INFLUENCE OF AGRICULTURE AND ROAD USAGE ON THE DISTRIBUTION OF COASTAL BIRD NESTS ON SALT MARSHES IN SCHLESWIG-HOLSTEIN(GERMANY). VOGELWARTE 38 (2):76-88.

2179. HUEY, L. M. 1941. MAMMALIAN INVASION ALONG THE HIGHWAY. JOURNAL OF MAMMALOGY 22:383-385.

2180. HUGHBANKS, D. L. 1993. EVALUATION OF A SPIKE ONLY REGULATION IN SOUTHEASTERN IDAHO. M.S. THESIS, MONTANA STATE UNIVERSITY, BOZEMAN, MT. 85 PP.

2181. HUGIE, R. D. 1982. BLACK BEAR ECOLOGY AND MANAGEMENT IN THE NORTHERN CONIFER-DECIDUOUS FORESTS OF MAINE. PH.D. DISSERTATION, UNIVERSITY OF MONTANA, MISSOULA, MT. 203 PP.

2182. HUHTA, E. 1995. EFFECTS OF SPATIAL SCALE AND VEGETATION COVER ON PREDATION OF ARTIFICIAL GROUND NESTS. WILDLIFE BIOLOGY 1 (2):73-80.

2183. HUIJSER, M. P., P. BERGERS and H. DE VRIES. 1998. HEDGEHOG TRAFFIC VICTIMS: HOW TO QUANTIFY EFFECTS ON THE POPULATION LEVEL AND THE PROSPECTS FOR MITIGATION. PAGES 171-180 IN EVINK,G., ZIEGLER,D. GARRETT,P., AND BERRY,J., EDITORS. PROCEEDINGS OF THE INTERNATIONAL CONFERENCE ON WILDLIFE ECOLOGY AND TRANSPORTATION; 1998 FEBRUARY 10-12; FT. MYERS, FL FLORIDA DEPARTMENT OF TRANSPORTATION, TALLAHASSEE, FL.

2184. HULL, C. N. 1979. A COMPARATIVE STUDY OF BIRD POPULATIONS ON A WOODED EXPRESSWAY MEDIAN. JACK-PINE WARBLER 57(4):184-189.

2185. HUMPHREYS, M. and N. J. PAPEX. 1967. EXPERIMENTAL CONTROL OF BIG GAME MIGRATIONS. FED. AID REPT.; PROJ. W-39-R-7.

2186. HUMPHRIES, D. H. 1975. IMPACT OF FERRY TERMINAL LOCATION AND ACCESS ROAD CONSTRUCTION ON FISH AND WILDLIFE RESOURCES OF GABRIOLA, IONA AND VANCOUVER ISLAND. HABITAT PROTECTION SECTION, FISH AND WILDLIFE BRANCH, VICTORIA, B.C..

2187. HUNG, D. H. 1995. STUDIES ON EROSION AMOUNT OF THE NEWLY-CONSTRUCTED FOREST ROAD. JOURNAL OF KOREAN FORESTRY SOCIETY 84 (3):319-32.

2188. HUNGERFORD, C. R. 1952. THE FOOD CONSUMPTION AND WEIGHT RESPONSE OF ELK (CERVUS CANADENSIS, NELSONI) UNDER WINTER CONDITIONS. PH.D. DISSERTATION, MONTANA STATE UNIVERSITY, MISSOULA, MT. $60 \mathrm{PP}$.

2189. HUNGERFORD, R. D. 1984. NATIVE SHRUBS: SUITABILITY FOR REVEGETATIN ROAD CUTS IN NORTHWESTERN MONTANA.

2190. HUNT, A., H. J. DICKENS and R. J. WHELAN. 1987. MOVEMENT OF MAMMALS THROUGH TUNNELS UNDER RAILWAY LINES. AUSTRALIAN ZOOLOGIST 24(2):89-93. 
2191. HUNT, B. and P. V. CLARKSON. 1993. THE DISTRIBUTION STATUS AND CONSERVATION NEEDS OF THE HARLEQUIN DUCK ON BREEDING RANGES IN THE CANADIAN ROCKY MOUNTAINS. JASPER NATIONAL PARK, JASPER, AB. 22PP.

2192. HUNT, C. E. 1978. LOCATION OF ENVIRONMENTALLY RESPONSIVE TRANSPORTATION CORRIDORS: CASE STUDY OF THE UPPER KANANASKIS VALLEY. M.S. THESIS. UNIVERSITY OF CALGARY, CALGARY.

2193. HUNT, C. L. 1984. BEHAVIORAL RESPONSES OF BEARS TO TESTS OF REPELLENTS, DETERRENTS, AND ADVERSIVE CONDITIONING. M.S. THESIS, UNIVERSITY OF MONTANA, MISSOULA, MT.

2194. HUNT, W. A. 1995. JASPER NATIONAL PARK HARLEQUIN DUCK RESEARCH PROJECT: PROGRESS REPORT - 1993 FIELD SEASON. JASPER WARDEN SERVICE BIOLOGICAL REPORT SERIES, NO.2. 52PP.

2195. HUNT, W. A. 1995. JASPER NATIONAL PARK, HARLEQUIN DUCK RESEARCH PROJECT PROGRESS REPORT - 1994 FIELD SEASON. JASPER WARDEN SERVICE, BIOLOGICAL REPORT SERIES, NO.3.

2196. HUNTER, J., R. J. GUTIERREZ and A. B. FRANKLIN. 1995. HABITAT CONFIGURATION AROUND SPOTTED OWL SITES IN NORTHWESTERN CALIFORNIA. CONDOR 97 (3):684-93.

2197. HUNTER, M. L. JR., G. L. JR. JACOBSON and T. I. WEBB. 1988. PALEOCOLOGY AND THE COARSE-FILTER APPROACH TO MAINTAINING BIOLOGICAL DIVERSITY. CONSERVATION BIOLOGY2 (4):375-85.

2198. HUNTLEY, J. C. 1980. EFFECTS OF UTILITY RIGHTS OF WAY MAINTENANCE UPON VEGETATION AND WILDLIFE HABITAT

2199. HURLEY, M. A. 1994. SUMMER-FALL ECOLOGY OF THE BLACKFOOT-CLEARWATER ELK HERD OF WESTERN MONTANA. THESIS, UNIVERSITY OF IDAHO, MOSCOW, IDAHO, USA. 138PP.

2200. HUSAIN, K. Z., M. K. RAHMAN, M. N. HAQUE and S. U. SARKER. 1992. ECOLOGY AND FOOD HABITS OF ROADSIDE BIRDS FROM CHITTAGONG TO TEKNAF. BANGLADESH JOURNAL OF ZOOLOGY 20 (1):71-85.

2201. HUTTO, R. L. 1989. THE EFFECT OF HABITAT ALTERATION ON MIGRATORY LAND BIRDS IN A WEST MEXICAN TROPICAL DECIDUOUS FOREST: A CONSERVATION PERSPECTIVE. CONSERVATION BIOLOGY 3 (2):138-48.

2202. HWONG, J. L., T. C. LIN, L. S. HWANG, Y. J. HSIA and S. C. CHI. 1994. EROSION CHARACTERISTICS OF LOGGING ROADS AND THE EVALUATION OF A SIMPLE SOIL AND WATER CONSERVATION SYSTEM. BULLETIN OF THE TAIWAN FORESTRY RESEARCH INSTITUTE NEW SERIES 9 (4):355-62.

2203. HYLGAARD, T. and M. J. LIDDLE. 1981. THE EFFECT OF HUMAN TRAMPLING ON A SAND DUNE ECOSYSTEM DOMINATED BY EMPETRUM NIGRUM. JOURNAL OF APPLIED ECOLOGY 18:559-569.

2204. HYNSON, J. 1982. HANDBOOK FOR PROTECTION OF FISH AND WILDLIFE FROM CONSTRUCTION OF FARM AND FOREST ROADS BEST MANAGEMENT PRACTICES FOR BUILDING ACTIVITIES ASSOCIATED WITH THE DISCHARGE OF DREDGED OR FILL MATERIAL. EASTERN ENERGY AND LAND USE TEAM, OFFICE OF BIOLOGICAL SERVICES, FISH AND WLDLIFE SERVICE, U.S. DEPT. OF THE INTERIOR, WASHINGTON, D.C. FWS OBS / U.S. FISH AND WLDLIFE SERVICE: FWS/OBS 82/18.

2205. HYNSON, J. R. 1985. ENVIRONMENTAL FEATURES FOR STREAMSIDE LEVEE PROJECTS. U.S. ARMY ENGINEER WATERWAYS EXPERIMENT STATION. AVAILABLE FROM NATIONAL TECHNICAL INFORMATION SERVICE, VICKSBURG, MISS, SPRINGFIELD, VA. TECHNICAL REPORT: TECHNICAL REPORT (U.S. ARMY ENGINEER WATERWAYS EXPERIMENT STATION) E-85-7.

2206. IHSLE, H. B. 1982. POPULATION ECOLOGY OF MULE DEER WITH EMPHASIS ON POTENTIAL IMPACTS OF GAS AND OIL DEVELOPMENT ALONG THE EAST FRONT OF THE ROCKY MOUNTAINS, NORTHCENTRAL MONTANA. M.S. THESIS, MONTANA STATE UNIVERSITY, BOZEMAN, MT. 85 PP.

2207. IIDA, S. and T. NAKASHIZUKA. 1995. FOREST FRAGMENTATION AND ITS EFFECT ON SPECIES DIVERSITY IN SUB-URBAN COPPICE FORESTS IN JAPAN. FOREST ECOLOGY AND MANAGEMENT73 (1-3):197-210.

2208. IKEDA, H. and K. OKUTOMI. 1990. EFFECTS OF HUMAN TRAMPLING ON MULTISPECIES COMPETITION ON EARLY-PHASE DEVELOPMENT OF A TREAD COMMUNITY. ECOLOGICAL RESEARCH 5:41-54. 
2209. ILLICH, I. P. and J. R. HASLETT. 1994. RESPONSES OF ASSEMBLAGES OF ORTHOPTERS TO MANAGEMENT AND USE OF SKI SLOPES ON UPPER SUB-ALPINE MEADOWS IN THE AUSTRIAN ALPS. OECOLOGIA 97:470-474.

2210. ILLINOIS DEPARTMENT OF CONSERVATION AND HOFFMAN, WILLIAMS, LAFEN, FLETCHER. 1990. ECONOMIC AND TAX IMPLICATIONS OF RAIL-TRAIL SYSTEMS. A REPORT PREPARED AS PART OF THE ILLINOIS RAILBANKING STUDY. SILVER SPRING, MARYLAND.

2211. ILLINOIS DEPARTMENT OF CONSERVATION AND HOFFMAN, WILLIAMS, LAFEN, FLETCHER. 1990. LANDOWNER AND COMMUNITY CONCERNS ABOUT ILLINOIS RAIL-TRAILS. A REPORT PREPARED AS PART OF THE ILLINOIS RAILBANKING STUDY. SILVER SPRING, MARYLAND.

2212. ILLNER, H. 1992. EFFECT OF ROADS WITH HEAVY TRAFFIC ON GREY PARTRIDGE DENSITY. GIBIER FAUNE SAUVAGE 9:467-80.

2213. ILLNER, H. 1992. EFFECT OF ROADS WITH HEAWY TRAFFIC ON GREY PARTRIDGE (PERDIX PERDIX) DENSITY. GIBIER FAUNE SAUVAGE 9:467-480.

2214. ILNER, H. 1992. ROAD DEATHS OF WESPHALIAN OWL; METHODOLOGICAL PROBLEMS, INFLUENCE OF ROAD TYPE AND POSSIBLE EFFECTS ON POPULATION LEVELS. PAGES 94-100 IN GALBRAITH,C.A., TAYLOR,I.R., AND PERCIVAL,S.M., EDITORS. THE ECOLOGY AND CONSERVATION OF EUROPEAN OWLS. PETERBOROUGH JOINT NATURE CONSERVATION COMMITTEE, PETERBOROUGH, UK.

2215. ILNER, H. 1992. RÖAD DEATHS OF WESTPHALIAN OWLS: METHODOLOGICAL PROBLEMS, INFLUENCE OF ROAD TYPE AND POSSIBLE EFFECTS ON POPULATION LEVELS. P94-100. IN: GALBRAITH CA, TAYLOR IR, PERCIVAL SM, EDS. THE ECOLOGY AND CONSERVATION OF EUROPEAN OWLS. PETERBOROUGH JOINT NATURE CONSERVATION COMMITTEE, PETERBOROUGH, U.K.

2216. IMS, R. A., J. ROLSTAD and P. WEGGE. 1993. PREDICTING SPACE USE RESPONSES TO HABITAT FRAGMENTATION: CAN VOLES MICROTUS OECONOMUS SERVE AS AN EXPERIMENT MODEL SYSTEM (EMS) FOR CAPERCAILLIE GROUSE TETRAO UROGALLUS IN BOREAL FOREST? BIOLOGICAL CONSERVATION 63 (3):261-8.

2217. INDIANA DEPARTMENT OF NATURAL RESOURCES. 1972. OFF THE ROAD VEHICLE STUDY. 13OPP.

2218. INGEBRIGTSEN, D. K. and J. R. LUDWIG. 1986. TITLE UNKNOWN. MINN. WILDL. REP.(3):6PP.

2219. INGEBRIGTSEN, D. K. and J. R. LUDWIG. 1986. EFFECTIVENESS OF SWAREFLEX WILDLIFE WARNING REFLECTORS IN REDUCING DEER-VEHICLE COLLISIONS IN MINNESOTA. MINNESOTA WILDLIFE REPORT 3. DEPT. OF NATURAL RESOURCES, SAINT PAUL, MINNESOTA.

2220. INGERSOLL, G., J. TURK, C. MCCLURE, S. LAWLOR, D. CLOW and A. MAST. 1997. SNOWPACK CHEMISTRY AS AN INDICATOR OF POLLUTANT EMISSION LEVELS FROM MOTORIZED WINTER VEHICLES IN YELLOWSTONE NATIONAL PARK. PAGES 103-113 IN WESTERN SNOW CONFERENCE. 65TH ANNUAL MEETING.

2221. INGLIS, G. and A. J. UNDERWOOD. 1992. COMMENTS ON SOME DESIGNS PROPOSED FOR EXPERIMENTS ON THE BIOLOGICAL IMPORTANCE OF CORRIDORS. CONSERVATION BIOLOGY 6(4):581-6.

2222. INGRALDI, MF. 1992. THE ECOLOGY OF RED-TAILED HAWKS IN AN URBAN/SUBURBAN ENVIRONMENT. MS THESIS, STATE UNIVERSITY OF NEW YORK COL. OF ENVIRONMENTAL SCIENCE \& FORESTRY. 89 PP.

2223. INGRAM, C. D. and P. B. DURST. 1987. MARKETING NATURE-ORIENTED TOURISM FOR RURAL DEVELOPMENT AND WILDLANDS MANAGEMENT IN DEVELOPING COUNTRIES: A BIBLIOGRAPHY. U.S. DEPT. AGRICULTURE, FOREST SERV., SOUTHEAST. FOR. EXP. STA. ASHEVILLE, NORTH CAROLINA. GEN. TECH. REP. SE-44. 54PP.

2224. INNS, H. 1991. TOADS ON ROADS. ADVICE FROM THE BRITISH HERPETOLOGICAL SOCIETY CONSERVATION COMMITTEE. COUNTRY-SIDE 7(8):42-43.

2225. INTERA ENVIRONMENTAL CONSULTANTS LTD. 1973. WHITECOURT ENVIRONMENTAL STUDY - 1973. CALGARY, ALBERTA. 
2226. INTERMOUNTAIN FOREST AND RANGE EXPERIMENT STATION. 1977. ANATOMY OF A MINE FROM PROSPECT TO PRODUCTION. SURFACE ENVIRONMENT MINING PROGRAM. INT-35

2227. INTERNATIONAL ENVIRONMENTAL CONSULTANTS LTD. 1982. RESULTS OF THE KAKWA WLDLIFE MONITORING PROGRAM: TO ESTABLISH THE EFFECTS OF AN EXPLORATORY DRILLING PROGRAM IN THE COPTON CREEK-KAKWA RIVER AREA OF ALBERTA. PREPARED FOR ESSO MINERALS CANADA. UNPUBLISHED REPORT

2228. INTERPROVINCIAL PIPE LINE (NM) LTD and AQUATIC ENVIRONMENTS LIMITED. 1982. AN ASSESSMENT OF THE FISHERIES RESOURCES OF THE GREAT BEAR AND MACKENZIE RIVERS IN THE VICINITY OF PROPOSED IPL PIPELINE CROSSINGS. INTERPROVINCIAL PIPE LINE (N.W.) LTD, CALGARY, ALBERTA.

2229. INTERPROVINCIAL PIPE LINE (NW) LTD and AQUATIC ENVIRONMENTS LIMITED. 1982. LATE WINTER SURVEYS OF AQUATIC RESOURCES ALONG THE IPL PIPELINE ROUTE NORMAN WELLS, NWT TO ZAMA TERMINAL, ALBERTA. INTERPROVINCIAL PIPE LINE (N.W.) LTD, CALGARY, ALBERTA.

2230. INTERPROVINCIAL PIPE LINE (NW) LTD and HARDY ASSOCIATES (1978) LTD. 1982. MITIGATIVE MEASURES FOR FISH RESOURCES IN THE VICINITY OF WATER CROSSINGS ALONG THE NORMAN WELLS TO ZAMA PIPELINE. INTERPROVINCIAL PIPE LINE (N.W.) LTD, CALGARY, ALBERTA.

2231. IRELAND, S. C. 1993. SEASONAL DISTRIBUTION AND HABITAT USE OF WESTSLOPE CUTTHROAT IN A SEDIMENT-RICH BASIN IN MONTANA. M.S. THESIS, MONTANA STATE UNIVERSITY, BOZEMAN, MT. 66 PP.

2232. IRWIN, L. L. 1975. DEER-MOOSE RELATIONSHIPS ON A BURN IN NORTHEASTERN MINNESOTA. J. WILDL. MANAGE. 39 (4):653-62.

2233. IRWIN, L. L. and C. GILLLIN. 1985. RESPONSE OF ELK TO SEISMIC EXPLORATION IN THE BRIDGER-TETON FOREST, WYOMING. PROGRESS REPORT, UNIVERSITY OF WYOMING, LARAMIE. 58PP.

2234. IRWIN, L. L. and J. M. PEEK. 1983. ELK HABITAT USE RELATIVE TO FOREST SUCCESSION IN IDAHO. J. WILDL. MANAGE. $47(3): 664-72$.

2235. IRWIN, L. L. and J. M. PEEK. 1979. RELATIONSHIP BETWEEN ROAD CLOSURE AND ELK BEHAVIOR IN NORTHERN IDAHO. PAGES 199-205 IN M. S. BOYCE AND L. D. HAYDEN-WNG, EDITORS. NORTH AMERICAN ELK: ECOLOGY, BEHAVIOR AND MANAGEMENT. UNIVERSITY OF WYOMING. LARAMIE, WYOMING, USA.

2236. ISAKOVIC, I. 1974. EFFECTS OF LAND USE AND OUTDOOR RECREATION ON GAME POPULATIONS. PAGES $351-356$ IN I. KJERNER AND P. BJURHOLM, EDITORS. PROCEEDINGS XITH INTERNATIONAL CONGRESS OF GAME BIOLOGISTS.

2237. ISHIGAKI, K. 1987. THE EFFECTS OF A HIGHWAY CONSTRUCTION THROUGH THE FOREST ON AVIFAUNA. RESEARCH BULLETIN OF THE COLLEGE OF EXPERIMENTAL FORESTRY, HOKKAIDO UNIVERSITY 44(2):823-832.

2238. ISHIGAKI, K. 1987. THE EFFECTS OF A HIGHWAY ON THE BEHAVIOUR OF BIRDS. RESEARCH BULLETIN OF THE COLLEGE OF EXPERIMENTAL FORESTRY, HOKKAIDO UNIVERSITY 44(2):809-821.

2239. ISTOMIN, A. V. 1994. PHENOTYPIC DIVERSITY IN CONTINUAL AND DISCRETE POPULATIONS OF THE BANK VOLE IN THE SOUTH TAIGA. ZH OBSHCH BIOL 55 (4-5):477-88.

2240. IVAN, J. S. 2000. EFFECTIVENESS OF COVERED TRACK PLATES FOR DETECTING AMERICAN MARTEN. M.S. THESIS, UNIVERSITY OF MONTANA, MISSOULA, MT. 68 PP.

2241. IVERSON, B. M., B. S. HINCKLEY, R. M. WEBB and B. HALLET. 1981. PHYSICAL EFFECTS OF VEHICULAR DISTURBANCE ON ARID LANDSCAPES. SCIENCE 212:915-917.

2242. IVERSON, R. M. 1980. PROCESSES OF ACCELERATED PLUVIAL EROSION ON DESERT HILLSLOPES MODIFIED BY VEHICULAR TRAFFIC. EARTH SURF PROC. 5:369-388.

2243. JACKMAN, A. H. THE IMPACT OF NEW HIGHWAYS UPON WILDERNESS AREAS. 
2245. JACKSON, J. A., C. R. FERRIS, J. B. CAVANAGH, S. N. MACRIGEANIS, D. C. FRANCISCO, C. B. WOODHOUSE and C. A. MCCONNELL. 1976. WLDLIFE USES OF RIGHT-OF-WAY MANAGEMENT. P 247-275. IN: MISS STATE UNIV SYMP ON ENVIRON CONCERNS IN RIGHTS-OF-WAY MANAGEMENT; 1976 JAN 6-1976 JAN 8; MISSISSIPPI.

2246. JACKSON, J. A. 1979. HIGHWAYS AND WILDLIFE--SOME CHALLENGES AND OPPORTUNITIES FOR MANAGEMENT. PAGES 566-571 IN SWANSON;G.A, EDITOR. THE MITIGATION SYMPOSIUM: A NATIONAL WORKSHOP ON MITIGATION LOSSES OF FISH AND WIDLIFE HABITAT; 1.979 JULY 16-20; FORT COLLINS, CO., U.S. FOR. SERV. GEN. TECH. REP.; RM-65. U.S. DEPARTMENT OF AGRICULTURE, FOREST SERVICE, ROCKY MOUNTAIN RESEARCH STATION, FORT COLLINS, CO.

2247. JACKSON, M. D. 1990. BEAVER DISPERSAL IN WESTERN MONTANA. M.S. THESIS, UNIVERSITY OF MONTANA, MISSOULA, MT. 79 PP.

2248. JACKSON, S. 1996. UNDERPASS SYSTEMS FOR AMPHIBIANS. PAGES 224-227 IN EVINK,G., ZIEGLER,D., GARRETT,P., AND BERRY,J., EDITORS. TRANSPORTATION AND WILDLIFE: REDUCING WILDLIFE MORTALITY AND IMPROVING WILDLIFE PASSAGEWAYS ACROSS TRANSPORTATION CORRIDORS: PROCEEDINGS OF THE FLORIDA DEPARTMENT OF TRANSPORTATION/FEDERAL HIGHWAY ADMINISTRATION TRANSPORTATION-RELATED WILDLIFE MORTALITY SEMINAR; 1996 APRIL 30-MAY 2; ORLANDO, FL. FHWA-PD-96-041. U.S. DEPARTMENT OF TRANSPORTATION, FEDERAL HIGHWAY ADMINISTRATION, WASHINGTON, DC.

2249. JACKSON, S. D. and T. F. TYNING. 1989. EFFECTIVENESS OF DRIFT FENCES AND TUNNELS FOR MOVING SPOTTED SALAMANDERS (AMBYSTOMA MACULATUM) UNDER ROADS. PAGES 93-98 IN LANGTON,T.E., EDITOR. AMPHIBIANS AND ROADS. PROCEEDINGS OF THE TOAD TUNNEL CONFERENCE; 1989 JANUARY 7-8; RENDSBURG, FEDERAL REPUBLIC OF GERMANY. ACO POLYMER PRODUCTS LTD., SHEFFORD, ENGLAND.

2250. JACKSON, S. D. and C. R. GRIFFIN. 1998. TOWARD A PRACTICAL STRATEGY FOR MITIGATING HIGHWAY IMPACTS ON WILDLIFE. PAGES 17-22 IN G. L. EVINK, P. GARRETT, D. ZEIGLER, AND J. BERRY, EDITORS. PROCEEDINGS OF THE INTERNATIONAL CONFERENCE ON WILDLIFE ECOLOGY AND TRANSPORTATION. FLORIDA DEPARTMENT OF TRANSPORTATION, TALLAHASSEE, FLORIDA.

2251. JACKSON, S. D. 1990. ECOLOGY OF MULE DEER ON A SAGEBRUSH-GRASSLAND HABITAT IN NORTHEASTERN MONTANA. M.S. THESIS, MONTANA STATE UNIVERSITY, BOZEMAN, MT. 111 PP.

2252. JACOBS, J. S. 1992. LODGEPOLE PINE RESPONSE TO STRESS TREATMENTS. PH.D. DISSERTATION, MONTANA STATE UNIVERSITY, BOZEMAN, MT. 75 PP.

2253. JACOBS, J. S. 1989. TEMPERATURE AND LIGHT EFFECTS ON SEEDLING PERFORMANCE OF PINUS ALBICAULIA. M.S. THESIS, MONTANA STATE UNIVERSITY, BOZEMAN, MT. 39 PP.

2254. JACOBSON, R. H. 1975. HUMORAL AND CELLULAR FACTORS IN THE IMMUNE ELIMINATION OF NIPPOSTRONGYLUS BRASILIENSIS FROM MICE. PH.D. DISSERTATION, MONTANA STATE UNIVERSITY, BOZEMAN, MT. 66 PP.

2255. JACOBSON, R. H. 1968. INCIDENCE AND DISTRIBUTION OF HEIMINTH PARASITES AND COCCIDA IN MONTANA CATTLE. M.S. THESIS, MONTANA STATE UNIVERSITY, BOZEMAN, MT. 48 PP.

2256.

JACOBSON, S. K. 1990. GRADUATE EDUCATION IN CONSERVATION BIOLOGY. CONSERVATION BIOLOGY 4 (4):431-40.

2257. JACOBSON, S. K. and A. F. LOPEZ. 1994. BIOLOGICAL IMPACTS OF ECOTOURISM: TOURISTS AND NESTING TURTLES IN TORTUGUERO NATIONAL PARK, COSTA RICA. WILDL. SOC. BULL.22 (3):414-9.

2258. JACOBSON, S. K. and R. ROBLES. 1992. ECOTOURISM, SUSTAINABLE DEVELOPMENT, AND CONSERVATION EDUCATION: DEVELOPMENT OF A TOUR GUIDE TRAINING PROGRAM IN TORTUGUERO, COSTA RICA. ENVIRON. MANAGE. 16:701-713

2259. JAHN, L. R. 1959. HIGHWAY MORTALITY AS AN INDEX OF DEER POPULATION CHANGE. JOURNAL OF WLDLIFE MANAGEMENT 23:187-179.

2260. JAHN, L. A. 1968. MOVEMENTS AND HOMING OF CUTTHROAT TROUT (SALMO CLARKI) FROM OPEN-WATER AREAS OF YELLOWSTONE LAKE . PH.D. DISSERTATION, MONTANA STATE UNIVERSITY, BOZEMAN, MT. 40 PP. 
2261. JAHN, L. A. 1966. MOVEMENTS OF THE CUTTHROAT TROUT (SALMO CLARKI RICHARDSON) IN YELLOWSTONE LAKE . M.S. THESIS, MONTANA STATE UNIVERSITY, BOZEMAN, MT. 19 PP.

2262. JAHRSDOERFER, S. E. and D. M. JR. LESLIE. 1988. TAMAULIPAN BRUSHLAND OF THE LOWER RIO GRANDE VALLEY OF SOUTH TEXAS: DESCRIPTION, HUMAN IMPACTS, AND MANAGEMENT OPTIONS. U.S. FISH AND WILDLIFE SERVICE. WASHINGTON, D.C. BIOL. REP. 88(36). 63PP.

2263. JAKIMCHUK, R. D. 1972? WILDLIFE STUDIES RELATED TO CONSTRUCTION AND OPERATION OF AN ARCTIC GAS PIPELINE. PETROLEUM SOCIETY OF CIM, PETROLEUM SOCIETY OF CIM PAPER NO. 7259.

2264. JAKOBER, M. J. 1995. AUTUMN AND WINTER MOVEMENT AND HABIAT USE OF RESIDENT BULL TROUT AND WESTSLOPE CUTTHROAT TROUT IN MONTANA. M.S. THESIS, MONTANA STATE UNIVERSITY, BOZEMAN, MT. 110 PP.

2265. JAKUBAS, W. J., R. A. GARROTT, P. J. WHITE and D. R. MERTENS. 1994. FIRE-INDUCED CHANGES IN THE NUTRITIONAL QUALITY OF LODGEPOLE PINE BARK. J. WILDL. MANAGE. 58(1):35-46.

2266. JALKOTZKY, M. G., P. I. ROSS and M. D. NASSERDEN. 1997. THE EFFECTS OF LINEAR DEVELOPMENTS ON WILDLIFE: A REVIEW OF SELECTED SCIENTIFIC LITERATURE. . CANADIAN ASSOCIATION OF PETROLEUM PRODUCERS, CALGARY, ALBERTA.

2267. JALKOTZY, M. G. 1996. THE DISPLACEMENT OF A GRIZZLY BEAR BY HELICOPTER LOGGING IN BANFF NATIONAL PARK. ARC WILDLIFE SERVICES LTD. UNPUBLISHED REPORT.5PP. + 3 FIGURES.

2268. JALKOTZY, M. G. 1996. ELK MONITORING IN THE VICINITY OF SHELL CALALTA CARBONDALE 6-12-6-3: JANUARY-MARCH 1996. ARC WILDLIFE SERVICES LTD., CALGARY 11PP.

2269. JALKOTZY, M. G. and P. I. ROSS. 1995. CARNIVORES AND UNGULATES IN THE SHEEP RIVER DRAINAGE: OBSERVATIONS OF WINTER USE ON SELECTED ROADS AND TRAILS 1990-1994. ARC WLDLIFE SERVICES LTD. UNPUBLISHED REPORT. 23PP.

2270. JALKOTZY, M. G. and P. I. ROSS. 1995. COUGAR RESPONSES TO HUMAN ACTIVITY AT SHEEP RIVER, ALBERTA. UNPUBLISHED REPORT, ARC WILDLIFE SERVICES LTD. 31PP.

2271. JALKOTZY, M. G., P. I. ROSS and J. G. GUNSON. 1992. MANAGEMENT PLAN FOR COUGARS IN ALBERTA. WILDLIFE MANAGEMENT PLANNING SERIES NUMBER 5. ALBERTA FORESTRY, LANDS, AND WILDLIFE, FISH AND WILDLIFE. 91 PP.

2272. JALKOTZY, M. G., I. ROSS and M. D. NASSERDEN. 1998. THE EFFECTS OF LINEAR DEVELOPMENT ON WILDLIFE A REVIEW OF SELECTED SCIENTIFIC LITERATURE. ARC WILDLIFE SERVICES LTD, CALGARY, ALBERTA.

2273. JAMES, A. R. C. 1996. SPATIAL SEPARATION OF CARIBOU FROM MOOSE IN NORTHEASTERN ALBERTA. 7TH NORTH AMERICAN CARIBOU CONFERENCE; 1996 AUG 19-1996 AUG 21; LAKEHEAD UNIVERSITY, THUNDER BAY, ONTARIO.

2274. JANKE, D. M. 1977. WHITE-TAILED DEER POPULATION CHARACTERISTICS, MOVEMENTS, AND WINTER SITE SELECTION IN WESTERN MONTANA. M.S. THESIS, UNIVERSITY OF MONTANA, MISSOULA, MT. 92 PP.

2275. JANSSEN, R. 1978. NOISE AND ANIMALS: PERSPECTIVES OF GOVERNMENT AND PUBLIC POLICY. PAGES 287-301 IN J. L. FLETCHER AND R. G. BUSNEL, EDITORS. EFFECTS OF NOISE ON WILLIFE. ACADEMIC PRESS. NEW YORK, NEW YORK.

2276. JANSSON, S. E., A. BOYD and T. DANIELS. 1996. ACCESS MANAGEMENT STRATEGIES AS DEVELOPED BY THE ALBERTA-PACIFIC FOREST MANAGEMENT TASK FORCE. ASPB ACCESS MANAGEMENT CONFERENCE. 10-11 APR 1996. CALGARY, ALBERTA.

2277. JANZEN, D. H. 1987. EDITORIAL. CONSERVATION BIOLOGY 1 (2):95-6.

2278. JAREN, V., R. ANDERSEN, M. ULLEBERG, P. H. PEDERSEN and B. WISETH. 1991. MOOSE-TRAIN COLLISIONS: THE EFFECTS OF VEGETATION REMOVAL WITH A COST-BENEFIT ANALYSIS. ALCES 27:93-99. 
2279. JAROSZ, W. 1994. HEAVY METALS CONTAMINATION OF GRASS GROWING AT THE ROAD EDGES. MEDYCYNA WETERYNARYJNA 50 (1):23-6.

2280. JARVINEN, J. A. and W. D. SCHMID. 1971. SNOWMOBILE USE AND WINTER MORTALITY OF SMALL MAMMALS. PAGES 131-141 IN M. CHUBB, EDITOR. PROCEEDINGS 1971 SNOWMOBILE AND OFF THE ROAD VEHICLE RESEARCH SYMPOSIUM. MICHIGAN STATE UNIVERSITY, DEPARTMENT OF PARK AND RECREATION RESOUR., EAST LANSING, MICHIGAN.

2281. JAVORSKY, L. D. 1984. THE TROUT FISHERY ON A REACH OF THE UPPER YELLOWSTONE RIVER, MONTANA, DURING 1982. M.S. THESIS, MONTANA STATE UNIVERSITY, BOZEMAN, MT. 45 PP.

2282. JAYEWARDENE, M. J. 1989. ROAD ACCIDENTS IN BIRD LIFE. LORIS 18(4):156-157.

2283. JEANES, E. D. 1996. BEHAVIORAL RESPONSES TO WATER CURRENT OF AGE-O ARCTIC GRAYLING FROM THE MADISON RIVER, AND THEIR USE OF STREAM HABITAT. M.S. THESIS, MONTANA STATE UNIVERSITY, BOZEMAN, MT. 60 PP.

2284. JEFFERIES, D. J. 1975. DIFFERENT ACTIVITY PATTERNS OF MALE AND FEMALE BADGERS (MELES MELES) AS SHOWN BY ROAD MORTALITY. LONDON: JOURNAL OF ZOOLOGY 177(4):504-506.

2285. JEFFERIES, D. J. and J. A. MITCHELL. 1993. RECOVERY PLANTS FOR BRITISH MAMMALS OF CONSERVATION IMPORTANCE, THEIR DESIGN AND VALUE. MAMMAL REVIEW 23:155-166.

2286. JEFFERIES, R. L., L. A. JENSEN and K. F. ABRAHAM. 1979. VEGETATIONAL DEVELOPMENT AND THE EFFECT OF GEESE ON VEGETATION AT LA PEROUSE BAY, MANITOBA. J. BOTANY 57:1439-50.

2287. JENKINS, K. 1996. TEXAS DEPARTMENT OF TRANSPORTATION WILDLIFE ACTIVITIES. PAGES 174-204 IN EVINK,G. ZIEGLER,D., GARRETT,P., AND BERRY,J., EDITORS. TRANSPORTATION AND WILDLIFE: REDUCING WILDLIFE MORTALITY AND IMPROVING WILDLIFE PASSAGEWAYS ACROSS TRANSPORTATION CORRIDORS: PROCEEDINGS OF THE FLORIDA DEPARTMENT OF TRANSPORTATION/FEDERAL HIGHWAY ADMINISTRATION TRANSPORTATION-RELATED WILDLIFE MORTALITY SEMINAR; 1996 APRIL 30-MAY 2; ORLANDO, FL. FHWA-PD-96-041. U.S. DEPARTMENT OF TRANSPORTATION, FEDERAL HIGHWAY ADMINISTRATION. WASHINGTON, DC.

2288. JENKINS, K. J. and E. E. STARKEY. 1984. HABITAT USE BY ROOSEVELT ELK IN UNMANAGED FORESTS OF THE HOH VALLEY, WASHINGTON. J.-WILDL.-MANAGE. 42 ( 2):642-5.

2289. JENKINS, K. J. and E. E. STARKEY. 1990. INFLUENCES OF ADJACENT FOREST MANAGEMENT ACTIVITIES ON MIGRATORY ELK OF MOUNT RANIER NATIONAL PARK. PACIFIC NORTHWEST REGION, NATIONAL PARK SERVICE: COOPERATIVE PARK STUDIES UNIT, COLLEGE OF FORESTRY. OREGON STATE UNIVERSITY. CPSU OSU 90-3. IX + 70PP.

2290. JENNERSTEN, O. 1988. POLLINATION IN DIANTHUS DELTOIDES (CARYOPHYLLACEAE):EFFECTS OF HABITAT FRAGMENTATION ON VISITATION AND SEED SET. CONSERVATION BIOLOGY2 (4):359-66.

2291. JENSE, G. K. 1982. UTAH BIG GAME INVESTIGATIONS AND MANAGEMENT RECOMMENDATIONS. UTAH DEPT. OF NATURAL RESOURCES.

2292. JENSEN, B. H. 1995. A PELOBATES FUSCUS POPULATION THREATENED BY ROAD CONSTRUCTION. MEMO.SOC.FAUNA FLORA FENN. 71(3-4):146.

2293. JENSEN, D. R. 1977. THE FISH CREEK HIGHWAY DEER PASSAGE PROJECT. IDAHO TRANSPORTATION DEPARTMENT. 13 PP.

2294. JENSEN, D. R. 1977. THE FISH CREEK HIGHWAY DEER PASSAGE PROJECT. UNPUBLISHED REPORT. IDAHO TRANSPORTATION DEPARTMENT, DISTRICT 5, POCATELLO, ID.

2295. JENSEN, K. C. 1988. NEST SITE SELECTION BY BALD EAGLES IN MONTANA. M.S. THESIS, MONTANA STATE UNIVERSITY, BOZEMAN, MT. 56 PP. 
2296. JENSEN, W. F., T. K. FULLER and W. L. ROBINSON. 1986. WOLF (CANIS LUPIS) DISTRIBUTION ON THE ONTARIO-MICHIGAN BORDER NEAR SAULT STE. MARIE. CANADIAN FIELD-NATURALIST 100:363-366.

2297. JENSEN, W. F., T. K. FULLER and W. L. ROBINSON. 1986. WOLF (CANIS LUPUS) DISTRIBUTION ON THE ONTARIO-MICHIGAN BORDER NEAR SAULT STE. MARIE. CANADIAN FIELD NATURALIST 100:363-366.

2298. JESSOP, C. S. 1974. A FURTHER EVALUATION OF THE FISH RESOURCES OF THE MACKENZIE RIVER VALLEY AS RELATED TO PIPELINE DEVELOPMENT. ENVIRONMENTAL-SOCIAL COMMITTEE, NORTHERN PIPELINES, TASK FORCE ON NORTHERN OIL DEVELOPMENT, OTTAWA, ONTARIO. QS-1555-000-EE-A1: REPORTS: REPORT (TASK FORCE ON NORTHERN OIL DEVELOPMENT (CANADA). ENVIRONMENTAL-SOCIAL COMMITTEE) 747.

2299. JESSUP, G. 1984. NORFOLK MAMMAL REPORT 1983, ROAD CASUALTY FIGURES. NORFOLK \& NORWICH NATURALISTS SOCIETY TRANSACTIONS 6(6):407-411.

2300. JHALA, Y. V. 1993. PREDATION ON BLACKBUCK BY WOLVES IN VELAVADAR NATIONAL PARK, GUJARAT, INDIA. CONSERVATION BIOLOGY 7 (4):874-81.

2301. JIMENEZ, M. D. 1992. ESTABLISHMENT OF AND PREY SELECTION BY A NEW WOLF PACK IN THE WIGWAM RIVER DRAINAGE. M.S. THESIS, UNIVERSITY OF MONTANA, MISSOULA, MT. 88 PP.

2302. JINGFORS, K. and A. GUNN. 1981. NWT WILDL. SERV. PROGRESS REPORT \#5. 44PP.

2303. JINGFORS, K., A. GUNN and F. L. MILLER. 1983. CARIBOU DISTURBANCE RESEARCH ON THE BEVERLY CALVING GROUNDS, NORTHWEST TERRITORIES, CANADA. ACTA ZOOL. FENN. 175:127-128.

2304. JINGFORS, K. T. 1982. SEASONAL ACTIVITY BUDGETS AND MOVEMENTS OF A REINTRODUCED ALASKAN MUSKOX HERD. JOURNAL OF WILDLIFE MANAGEMENT 46:344-350.

2305. JINGFORS, K. and A. GUNN. 1981. STUDY DESIGN TO MEASURE DISTRIBUTIONAL CHANGES OF BARREN-GROUND CARIBOU NEAR A WINTER ROAD. PROGRESS REPORT / NORTHWEST TERRITORIES WILDLIFE SERVICE: PROGRESS REPORT (NORTHWEST TERRITORIES. WILDLIFE SERVICE) NO. 5. NORTHWEST TERRITORIES WILDLIFE SERVICE, YELLOWKNIFE, N.W.T..

2306. JOBE, W. JR. 1980. OUTLOOK FOR IMPROVING THE MANAGEMENT FOR SNOWMOBILES. PAGES 188-190 IN R. N. L. ANDREWS AND P. F. NOWAK, EDITORS. OFF-ROAD VEHICLE USE: A MANAGEMENT CHALLENGE

2307. JOHANNESEN, E. and IMS. R.A. 1996. MODELING SURVIVAL RATES: HABITAT FRAGMENTATION AND DESTRUCTION IN ROOT VOLE EXPERIMENTAL POPULATIONS. ECOLOGY 77 (4):1196-209.

2308. JOHNS, A. D. 1991. RESPONSES OF AMAZONIAN RAIN FOREST BIRDS TO HABITAT MODIFICATION. JOURNAL OF TROPICAL ECOLOGY 7 (4):417-37.

2309. JOHNSEN, S. H. 1993. EVALUATION OF BIGHORN SHEEP IN THE TEN LAKES SCENIC AREA. M.S. THESIS, UNIVERSITY OF MONTANA, MISSOULA, MT. 118 PP.

2310. JOHNSINGH, A. J. T., S. N. PRASAD and S. P. GOYAL. 1990. CONSERVATION STATUS OF THE CHILA-MOTICHUR CORRIDOR FOR ELEPHANT MOVEMENT IN RAJAJI-CORBETT NATIONAL PARKS AREA, INDIA. BIOL. CONSERV. $51(125-138)$.

2311. JOHNSON B. R. 1992. MITIGATION OF VISITOR IMPACTS ON HIGH MONTANE RARE PLANT HABITAT: HABITAT PROTECTION THROUGH AN INTEGRATED STRATEGY OF DESIGN, INTERPRETATION AND RESTORATION. CRAGGY GARDENS, BLUE RIDGE PARKWAY, NORTH CAROLINA. THESIS, UNIVERSITY OF GEORGIA, ATHENS, GEORGIA.

2312. JOHNSON, B. K., L. D. HAYDEN-WING and D. C. LOCKMAN. 1990. RESPONSES OF ELK TO DEVELOPMENT OF EXXON'S RILEY RIDGE GAS FIELD IN WESTERN WYOMING. PAGES 42-55 IN PROCEEDINGS OF THE WESTERN STATES AND PROVINCES ELK WORKSHOP.

2313. JOHNSON, C. A. 1985. SIMULATED EFFECTS OF SUPPLEMENTAL WATER ON TWO GRASSLANDS, AGROPYRON SMITHII AND BOUTELOUA GRACILIS. M.S. THESIS, MONTANA STATE UNIVERSITY, BOZEMAN, MT. 79 PP. 
2314. JOHNSON, C. J. 1995. A METHOD FOR ESTIMATING THE DOLLAR VALUES OF LOST WILDLIFE DIVERSITY AND ABUNDANCE RESULTING FROM WLDLIFE-ROAD VEHICLE COLLISIONS. ECONOMIC ANALYSIS PROJECT - WORKING PAPER: ECONOMIC ANALYSIS: ECONOMIC ANALYSIS (BRITISH COLUMBIA. MINISTRY OF TRANSPORTATION AND HIGHWAYS). PROVINCE OF BRITISH COLUMBIA, MINISTRY OF TRANSPORTATION AND HIGHWAYS, PLANNING SERVICES BRANCH, VICTORIA, B.C..

2315. JOHNSON, D. R. 1985. MAN-CAUSED DEATHS OF MOUNTAIN CARIBOU IN SOUTHEASTERN BRITISH COLUMBIA. CANADIAN FIELD NATURALIST 99(4):542-544.

2316. JOHNSON, D. R. 1976. MOUNTAIN CARIBOU: THREATS TO SURVIVAL IN THE KOOTENAY PASS REGION, B.C. NORTHWEST SCIENCE 50:97-101.

2317. JOHNSON, D. R., D. R. MILLER and J. M. PEEK. 1977. GUIDELINES FOR HUMAN ACTIVITY WITHIN THE RANGE OF MOUNTAIN CARIBOU, SOUTH SELKIRK MOUNTAINS. UNIV. IDAHO FOREST, WLDLIFE AND RANGE EXPERIMENTAL STATION MISC. BULL. NO. 2 .

2318. JOHNSON, D. R. and M. C. TODD. 1977. SUMMER USE OF HIGHWAY CROSSING BY MOUNTAIN CARIBOU. CANADIAN FIELD-NATURALIST. 9(3)

2319. JOHNSON, D. E. 1999. RUFFED GROUSE PRODUCTIVITY AND HABITAT SELECTION AT THE BASE OF THE BEARTOOTH PLATEAU IN SOUTHCENTRAL MONTANA. M.S. THESIS, MONTANA STATE UNIVERSITY, BOZEMAN, MT. 78 PP.

2320. JOHNSON, D. E. 1950. BIOLOGY OF THE ELK CALF, CERVUS CANADENSIS NELSONI. M.S. THESIS, MONTANA STATE COLLEGE, BOZEMAN, MT. 52 PP.

2321. JOHNSON, D. R. and M. C. TODD. 1977. SUMMER USE OF A HIGHWAY CROSSING BY MOUNTAIN CARIBOU. CANADIAN FIELD NATURALIST 91(3):312-314.

2322. JOHNSON, E. A., K. MIYANISHI and J. M. H. WEIR. 1995. OLD-GROWTH, DISTURBANCE, AND ECOSYSTEM MANAGEMENT. CANADIAN JOURNAL OF BOTANY 73 (6):918-26.

2323. JOHNSON, H. E. 1961. OBSERVATIONS ON THE LIFE HISTORY AND MOVEMENT OF CUTTHROAT TROUT IN FLATHEAD RIVER DRAINAGE, MONTANA. M.S. THESIS, MONTANA STATE COLLEGE, BOZEMAN, MT. 24 PP.

2324. JOHNSON, J. L. 1992. EXPERIMENTAL MANIPULATION OF WHITE-TAILED DEER HABITAT ON A WINTER RANGE IN THE SWAN VALLEY, MONTANA. PH.D. DISSERTATION, UNIVERSITY OF MONTANA, MISSOULA, MT. 115 PP.

2325. JOHNSON, K. G. and M. R. PELTON. 1980. PREBAITING AND SNARING TECHNIQUES FOR BLACK BEARS. WILDL. SOC. BULL. 8 (1):46-54.

2326. JOHNSON, K. A. 1969. THE MIGRATION OF COTYLURUS ERRATICUS CERCARIAE (TREMATODA: STRIGEIDAE) IN RAINBOW TROUT (SALMO GAIRDNERI) AND THEIR EFFECTS ON THE HOST . M.S. THESIS, MONTANA STATE UNIVERSITY, BOZEMAN, MT. 29 PP.

2327. JOHNSON, K. M. 1990. AQUATIC VEGETATION, SALINITY, AQUATIC INVERTEBRATES, AND DUCK BROOD USE AT BOWDOIN NATIONAL WILDLIFE REFUGE, MONTANA. M.S. THESIS, MONTANA STATE UNIVERSITY, BOZEMAN, MT. 77 PP.

2328. JOHNSON, L. 1963. POPULATION DYNAMICS OF DEERMICE AND CHIPMUNKS IN FOUR FOREST TYPES IN WESTERN MONTANA. M.S. THESIS, MONTANA STATE UNIVERSITY, MISSOULA, MT. 99 PP.

2329. JOHNSON, M. K., H. WOFFORD and H. A. PEARSON. 1983. DIGESTION AND FRAGMENTATION: INFLUENCE ON HERBIVORE DIET ANALYSIS. J. WILDL. MANAGE. 47 (3):877-9.

2330. JOHNSON, R. F. JR. 1976. MORTALITY FACTORS AFFECTING A WHITE PELICAN POPULATION, CHASE LAKE NATIONAL WILDLIFE REFUGE, NORTH DAKOTA. THESIS, MICHIGAN TECHNOLOGICAL UNIVERSITY, FORESTRY DEPARTMENT, HOUGHTON, MICHIGAN. 74PP.

2331. JOHNSON, R. G. and S. A. TEMPLE. 1990. NEST PREDATION AND BROOD PARASITISM OF TALLGRASS PRAIRIE BIRDS. J. WILDL. MANAGE. 54 (1):106-11. 
2332. JOHNSON, R. R., K. F. HIGGINS, I. J. BALL and S. C. KOHN. 1994. WATERFOWL PRODUCTIVITY AND USE OF NESTING STRUCTURES IN THE PRAIRIE POTHOLE REGION. PRAIRIE NATURALIST 26(3):187-94.

2333. JOHNSON, R. R. and J. F. MCCORMICK. 1979. STRATEGIES FOR PROTECTION AND MANAGEMENT OF ELOODPLAIN WETLANDS AND OTHER RIPARIAN ECOSYSTEMS. USDA, FOREST SERVICE.

2334. JOHNSON, R. L. 1962. THE YIELD AND STANDING CROP OF FISH IN DAILEY LAKE, MONTANA. M.S. THESIS, MONTANA STATE COLLEGE, BOZEMAN, MT. 25 PP.

2335. JOHNSON, S. 1990. COLONIZATION AND HABITAT USE BY PACIFIC EIDERS OF THE ENDICOTT CAUSEWAY, BEAUFORT SEA, AK, 1988-1989. UNPUBLISHED REPORT, LGL LTD., SIDNEY, B.C.

2336. JOHNSON, S. R. 1995. FACTORS SUPPORTING ROAD REMOVAL AND/OR OBLITERATION. MEMO FROM FOREST HYDROLOGIST TO FIRE RECOVERY HYDROLOGISTS. KOOTENAI NATIONAL FOREST. 5PP.

2337. JOHNSON, S. R., D. R. HERTER and M. S. W. BRADSTREET. 1987. HABITAT USE AND REPRODUCTIVE SUCCESS OF PACIFIC EIDERS DURING A PERIOD OF INDUSTRIAL ACTIVITY. BIOL. CONSERV. 41 (77-90).

2338. JOHNSON, S. J. 1973. REPRODUCTIVE SUCCESS AND POST-FLEDGING BEHAVIOR OF RED-TAILED HAWKS (BUTEO JAMIACENSIS) IN THE GALLATIN VALLEY, MONTANA. PH.D. DISSERTATION, MONTANA STATE UNIVERSITY, BOZEMAN, MT. 61 PP.

2339. JOHNSON, T. K. 1984. IMPACT OF A SURFACE COAL MINE ON ELK CALVING: A PROGRESS REPORT. PAGES 133-137 IN R. D. COMER, J. M. MERINO, J. W. MONARCH, C. PUSTMUELLER, M. STALMASTER, R. STOECKER, J. TODD, AND W. WRIGHT, EDITORS. ISSUES AND TECHNOLOGY IN THE MANAGEMENT OF IMPACTED WESTERN WILDLIFE -PROCEEDINGS OF A NATIONAL SYMPOSIUM. VOLUME 14. THORNE ECOL. INST., BOULDER, COLORADO.

2340. JOHNSON, T. K. 1986. IMPACTS OF SURFACE COAL MINING ON CALVING ELK. PAGES 255-269 IN R. D. COMER, T. G. BAUMANN, P. DAVIS, J. W. MONARCH, J. TODD, S. VANGYTENBEEK, D. WLLS, AND J. WOODLING, EDITORS. PROCEEDINGS II. ISSUES AND TECHNOLOGY IN THE MANAGEMENT OF IMPACTED WESTERN WILDLIFE: PROCEEDINGS OF A NATIONAL SYMPOSIUM. THORNE ECOL. INST., BOULDER, COLORADO.

2341. JOHNSON, W. A. and A. W. TODD. 1985. FISHER BEHAVIOR IN PROXIMITY TO HUMAN ACTIVITY. CAN. FIELD NAT. 99:367-9.

2342. JOHNSON, W. C., R. K. SCHREIBER and R. L. BURGESS. 1977. DIVERSITY OF SMALL MAMMALS IN A POWERLINE RIGHT-OF-WAY AND ADJACENT FOREST IN EAST TENNESSEE. THE AMERICAN MIDLAND NATURALIST. 101(1)

2343. JOHNSON, W. A. and W. T. ARLEN. 1985. FISHER, MARTES PENNANTI, BEHAVIOR IN PROXIMITY TO HUMAN ACTIVITY. CANADIAN FIELD NATURALIST 99(3):367-369.

2344. JOKIMAKI, J. and J. SUHONEN. 1993. EFFECTS OF URBANIZATION ON THE BREEDING BIRD SPECIES RICHNESS IN FINLAND: A BIOGEOGRAPHICAL COMPARISON. ORNIS FENNICA 70 (2):71-7.

2345. JOLICOEUR, H. and M. CRETE. 1994. FAILURE TO REDUCE MOOSE-VEHICLE ACCIDENTS AFTER A PARTIAL DRAINAGE OF ROADSIDE SALT POOLS IN QUEBEC. ALCES 30:81-9.

2346. JONAS, R. J. 1964. ECOLOGY AND MANAGEMENT OF MERRIAM'S TURKEY IN THE LONG PINES, SOUTHEASTERN MONTANA. PH.D. DISSERTATION, MONTANA STATE COLLEGE, BOZEMAN, MT. 118 PP.

2347. JONES AND STOKES ASSOC., INC. 1989. ROCK CREEK OFF-ROAD VEHICLE/DEER STUDY. PREPARED FOR CA. DEPT. OF FISH AND GAME. CALIFORNIA DEPT. OF PARKS AND RECREATION AND ELDORADO NATIONAL FOREST. SACRAMENTO, CA. JSA 89-201.

2348. JONES, J. H. and N. S. SMITH. 1979. BOBCAT DENSITY AND PREY SELECTION IN CENTRAL ARIZONA. J. WILDL. MANAGE. $43(3): 666-72$

2349. JONES, M. and P. MCCART. 1975. FISHERIES SURVEYS OF PROPOSED BRIDGE CROSSINGS OF THE BOW RIVER WITHIN THE CITY OF CALGARY. AQUATIC ENVIRONMENTS LIMITED, CALGARY, ALBERTA. 
2350. JONES, M. B. and W. M. LONGHURST. 1958. OVERHANGING DEER FENCES. J. WILDL. MANAGE. 22 (3):325-6.

2351. JONES, P. H. 1980. BIRD SCAVENGERS ON ORKNEY ROADS. BRITISH BIRDS 73(12):561-568.

2352. JONES, P. N. 1992. COLUMBIA RIVER GORGE A COMPLETE GUIDE. MOUNTAINEERS, SEATTLE, WASHINGTON.

2353. JONES, T. S. 1990. FLOODPLAIN DISTRIBUTION OF FISHES OF THE BITTERROOT RIVER WITH EMPHASIS ON INTRODUCED POPULATIONS OF NORTHERN PIKE. M.S. THESIS, UNIVERSITY OF MONTANA, MISSOULA, MT. 69 PP.

2354. JONKEL, C. J., D. R. GRAY and B. HUBERT. 1975. IMMOBILIZING AND MARKING WILD MUSKOXEN IN ARCTIC CANADA. J. WILDL. MANAGE. 39 (1):112-7.

2355. JONKEL, C., R. KNIGHT, C. MARTINKA and R. RUSSELL. 1979. THE LAKE LOUISE AREA, GRIZZLY BEARS, AND DEVELOPMENT A SUMMARY STATE AND ANALYSIS. PARKS CANADA, BANFF, ALBERTA 4PP.

2356. JONKEL, C. J. 1959. AN ECOLOGICAL AND PHYSIOLOGICAL STUDY OF PINE MARTEN. PH.D. DISSERTATION, MONTANA STATE UNIVERSITY, MISSOULA, MT. 81 PP.

2357. JONKEL, G. M. 1954. A COMPARATIVE STUDY OF SURVIVAL OF FALL AND SPRING-RELEASED CHUKAR PARTRIDGES (ALECTORIS GRAECA CHUKAR). M.S. THESIS, MONTANA STATE UNIVERSITY, MISSOULA, MT. 70 PP.

2358. JONKER, P. M. 1984. SNOWMOBILERS, THEIR EXPERIENCE AND HABITAT PREFERENCES, AND THE IMPLICATIONS FOR WINTERING MOOSE IN MCLEAN CREEK AREA, ALBERTA. M.S. THESIS. UNIVERSITY OF CALGARY, CALGARY.

2359. JOPE, K. L. BEHAVIORAL ECOLOGY OF LEARNING IN BEARS. DRAFT TO INT. CONF. BEAR RES. AND MANAGE 14PP

2360. JOPE, K. L. 1985. IMPLICATIONS OF GRIZZLY BEAR HABITUATION TO HIKERS. WILDL. SOC. BULL. 13 (1):32-7.

2361. JOPE, K. L. and B. SHELBY. 1984. HIKER BEHAVIOR AND THE OUTCOME OF INTERACTIONS WITH GRIZZLY BEARS. LEISURE SCIENCES 6:257-70.

2362. JORDAN, M., K. RZEHAK and A. MARYANSKA. 1977. THE EFFECT OF TWO PESTICIDES, MIEDZIAN 50 AND GESAGARD 50 , ON THE DEVELOPMENT OF TADPOLES OF RANA TEMPORARIA . BULLETIN OF ENVIRONMENTAL CONTAMINATION AND TOXICOLOGY 17:349-354.

2363. JORDAN, R. H. and G. M. BURGHARDT. 1986. EMPLOYING AN ETHOGRAM TO DETECT REACTIVITY OF BLACK BEARS (URSUS AMERICANUS) TO THE PRESENCE OF HUMANS. ETHOLOGY 73:89-115.

2364. JORDAN, R. A. and B. DEBOER. 1996. WYOMING A SOURCE BOOK. 1ST ED. UNIVERSITY PRESS OF COLORADO, NIWOT, COLORADO.

2365. JORGENSEN, C. J. 1979. BEAR-LIVESTOCK INTERACTIONS, TARGHEE NATIONAL FOREST, WYOMING. M.S. THESIS, UNIVERSITY OF MONTANA, MISSOULA, MT. 162 PP.

2366. JORGENSEN, H. E. 1970. ECOLOGICAL ASPECTS OF THE LIFE HISTORY OF AGROPYRON SMITHII RYDB. IN CENTRAL MONTANA WITH RELATED EFFECTS OF SELECTIVE HERBICIDE TREATMENTS OF RANGELAND . PH.D. DISSERTATION, MONTANA STATE UNIVERSITY, BOZEMAN, MT. 173 PP.

2367. JORGENSEN, P. 1974. VEHICLE USE AT A DESERT BIGHORN WATERING AREA. TRANS. DESERT BIGHORN COUNCIL 18

2368. JORGENSON, J. T. 1988. ENVIRONMENTAL IMPACT OF THE 1988 WINTER OLYMPICS ON BIGHORN SHEEP OF MOUNT ALLAN. P 121-34. IN: SAMUEL WM, ED. BIENNIAL SYMPOSIUM OF THE NORTHERN WILD SHEEP AND GOAT COUNCIL; 11-15 APR. 1988;BANFF, ALBERTA. NORTHERN WILD SHEEP AND GOAT COUNCIL. BIGHORN SHEEP, ALBERTA, DISTRIBUTION, PRODUCTIVITY, SURVIVAL, ACTIVITY, LUNGWORM.

2369. JORGENSON, M. T. and M. R. JOYCE. 1994. SIX STRATEGIES FOR REHABILITATING LAND DISTURBED BY OIL DEVELOPMENT IN ARCTIC ALASKA. ARCTIC 47 (4):374-90. 
2370. JOSELYN, G. B. 1969. WLDLIFE. ESSENTIAL CONSIDERATION DETERMINING FUTURE HIGHWAY ROADSIDE MAINTENANCE POLICY. HIGHWAY RESEARCH RECORD 28:1-14.

2371. JOSELYN, G. B. and G. I. TATE. 1972. PRACTICAL ASPECTS OF MANAGING ROADSIDE COVER FOR NESTING PHEASANTS. J. WILDL. MANAGE. 36 (1):1-11.

2372. JOSELYN, G. B., J. E. WARNOCK and S. L. ETTER. 1968. MANIPULATION OF ROADSIDE COVER FOR NESTING PHEASANTS - A PRELIMINARY REPORT. J. WILDL. MANAGE. 32 (2):217-33.

2373. JOSHI, A. R., D. L. GARSHELIS and J. L. D. SMITH. 1995. HOME RANGES OF SLOTH BEARS IN NEPAL: IMPLICATIONS FOR CONSERVATION. JOURNAL OF WILDLIFE MANAGEMENT 59(2):204-14.

2374. JOSHUA, J. and A. J. T. JOHNSINGH. 1994. IMPACT OF BIOTIC DISTURBANCES ON THE HABITAT AND POPULATION OF THE ENDANGERED GRIZZLED GIANT SQUIRREL RATUFA MACROURA IN SOUTH INDIA. BIOLOGICAL CONSERVATION 68 (1):29-34.

2375. JOSLIN, G. 1986. MONTANA MOUNTAIN GOAT INVESTIGATIONS, ROCKY MOUNTAIN FRONT. MONTANA DEPT. OF FISH, WILDLIFE AND PARKS IN COOPERATION WITH KOOTENAI NATIONAL FOREST. 122PP.

2376. JOSLIN, G. 1980. MOUNTAIN GOAT HABITAT MANAGEMENT PLAN FOR THE CABINET MOUNTAINS. FINAL REPORT. MONTANA DEPT. FISH, WILDLIFE AND PARKS IN COOPERATION WITH U.S. FISH AND WILDLIFE SERVICE AND BUREAU OF LAND MANAGEMENT. 283PP

2377. JOSLIN, G. 1986. MOUNTAIN GOAT POPULATION CHANGES IN RELATION TO ENERGY EXPLORATION ALONG MONTANA'S ROCKY MOUNTAIN FRONT. PAGES 253-271 IN G. JOSLIN, EDITOR. PROCEEDINGS OF THE FIFTH NORTHERN WLD SHEEP AND GOAT COUNCIL.

2378. JOURDONNAIS, C. S. 1985. PRESCRIBED FIRE AND CATTLE GRAZING INFLUENCES ON THE VEGETATION AND ELK USE OF A ROUGH FESCUE COMMUNITY. M.S. THESIS, UNIVERSITY OF MONTANA, MISSOULA, MT. 100 PP.

2379. JOYAL, R. and B. SCHERRER. 1978. TITLE UNKNOWN. CAN. FIELD-NAT. 252-8.

2380. JOZSEF, R. K. 1980. CENOLOGICAL AND ECOLOGICAL INVESTIGATIONS ON BIRDS OF ROAD-SIDE MULBERRY TREES. AQUILA 87:79-93.

2381. KACHHWAHA, T. S. 1993. TEMPORAL AND MULTISENSOR APPROACH IN FOREST/NEGETATION MAPPING AND CORRIDOR IDENTIFICATION FOR EFFECTIVE MANAGEMENT OF RAJAJI NATIONAL PARK, UTTAR PRADESH, INDIA. INTERNATIONAL JOURNAL OF REMOTE SENSING 14 (17):3105-14.

2382. KACZENSKY, P. 1995. BEARS AND HIGHWAYS IN SLOVENIA. INTERNATIONAL BEAR NEWS 4:17-22.

2383. KACZENSKY, P., F. KNAUER, T. HUBER, M. JONOSOVIC and M. ADAMIC. 1994. THE LJUBLJANA-POSTOJNA HIGHWAY - A DEADLY BARRIER FOR BROWN BEARS IN SLOVENIA? IN: SYMPOSIUM 1994 IN POLAND: A COEXISTENCE OF LARGE PREDATORS AND MAN, POLAND.

2384. KAEDING, L. R. 1976. CONDITION, ANNULUS FORMATION, GROWTH, AND FOOD HABITS OF BROWN AND RAINBOW TROUT FROM HABITATS WITH CONTRASTING TEMPERATURE REGIMES ON THE FIREHOLE RIVER, YELLOWSTONE NATIONAL PARK. M.S. THESIS, MONTANA STATE UNIVERSITY, BOZEMAN, MT. 69 PP.

2385. KAHL, J. R. 1972. OSPREY MANAGEMENT ON THE LASSEN NATIONAL FOREST. PAGES 7-13 IN J. YOAKUM, EDITORS. TRANSACTIONS OF THE ANNUAL MEETING FOR THE WESTERN SECTION OF THE WLDLIFE SOCIETY AND THE CALIFORNIA-NEVADA CHAPTER OF THE AMERICAN FISHERIES SOCIETY. CAL-NEVA WILDLIFE, SMARTSVILLE, CALIFORNIA.

2386. KAHL, R. 1991. BOATING DISTURBANCE OF CANVASBACKS DURING MIGRATION AT LAKE POYGAN, WISCONSIN. WILDL. SOC. BULL. 19 (3):242-8.

2387. KAISER, G. L. 1971. POPULATION DYNAMICS OF ROTIFERS AND SOME FACTORS AFFECTING THEIR POPULATIONS IN CANYON FERRY. M.S. THESIS, MONTANA STATE UNIVERSITY, BOZEMAN, MT. 81 PP. 
2388. KAISER, M. S. and E. K. FRITZELL. 1984. EFFECTS OF RIVER RECREATIONISTS ON GREEN-BACKED HERON BEHAVIOR. J. WILDL. MANAGE. $48(2): 561-7$.

2389. KALTENBORN, B. P. and L. EMMELIN. 1993. TOURISM IN THE HIGH NORTH: MANAGEMENT CHALLENGES AND RECREATION OPPORTUNITY SPECTRUM PLANNING IN SVALBARD, NORWAY. ENVIRON. MANAGE. 17:41-50.

2390. KAMPS, G. F. 1969. WHITETAIL AND MULE DEER RELATIONSHIPS IN THE SNOWY MOUNTAINS OF CENTRAL MONTANA M.S. THESIS, MONTANA STATE UNIVERSITY, BOZEMAN, MT. 59 PP.

2391. KANSAS, J., M. RAINE and M. GIBEAU. 1989. ECOLOGICAL STUDIES OF BLACK BEARS IN BANFF NATIONAL PARK 1986-1988. FINAL REPORT. PREPARED FOR CANADIAN PARKS SERVICE, BANFF NATIONAL PARK. 135 PP.

2392. KANSAS, J. L. and R. M. RAINE. 1988. INTERACTIONS OF MOOSE AND DEER WITH LINEAR FACILITY STRUCTURES AND CORRIDORS IN THE COLD LAKE PRODUCTION PROJECT AREA. PREPARED FOR ESSO RESOURCES CANADA LTD. 34PP.

2393. KANSAS, J. L. and R. N. RIDDELL. 1995. GRIZZLY BEAR HABITAT MODEL FOR THE FOUR CONTIGUOUS MOUNTAIN NATIONAL PARKS: SECOND INTERATION. PREPARED FOR PARKS CANADA, BANFF NATIONAL PARK, BANFF, ALBERTA. 94 PP. + APP.

2394. KANTRUD, H. A. and K. F. HIGGINS. 1992. NEST AND NEST SITE CHARACTERISTICS OF SOME GROUND-NESTING, NON-PASSERINE BIRDS OF NORTHERN GRASSLANDS. PRAIRIE NATURALIST 24 (2):67-84.

2395. KARANTH, K..U. and M. E. SUNQUIST. 1991. POPULATION STRUCTURE, DENSITY AND BIOMASS OF LARGE HERBIVORES IN THE TROPICAL FORESTS OF NAGARAHOLE, INDIA. JOURNAL OF TROPICAL ECOLOGY 8 (1):21-35.

2396. KARASEK, G. L., M. D. SCOTT and J. M. PEEK. 1992. STATUS OF MOUNTAIN SHEEP IN MORGAN CREEK, EAST-CENTRAL IDAHO. P 68-82. IN: EMMERICH J, HEPWORTH WG, EDS. PROC. BIENN. SYMP. NORTH. WILD SHEEP AND GOAT COUNCIL; APR 27-MAY 1,.1992. CODY, WYOMING. NORTH. WILD SHEEP AND GOAT COUNCIL.

2397. KARASIUK, D. J. and D. M. MCILVEEN. 1977. TITLE UNKNOWN. CANADIAN WLDLIFE SERVICE UNPUBLISHED WILDLIFE REPORT. 54PP

2398. KAREIVA, P. and U. WENNERGREN. 1995. CONNECTING LANDSCAPE PATTERNS TO ECOSYSTEM AND POPULATION PROCESSES. NATURE (LONDON) 373 (6512):299-302.

2399. KARIEL, H. G. and P. E. KARIEL. 1988. TOURIST DEVELOPMENTS IN THE KANANASKIS VALLEY AREA, ALBERTA, CANADA, AND THE IMPACT OF THE 1988 WINTER OLYMPIC GAMES. MOUNTAIN RES. DEVELOP. 8:1-10.

2400. KARNOVSKY, N. J. 1997. THE FISH COMPONENT OF PYGOSCELIS PENGUIN DIETS. M.S. THESIS, MONTANA STATE UNIVERSITY, BOZEMAN, MT. 76 PP.

2401. KARR, J. R. 1990. AVIAN SURVIVAL RATES AND THE EXTINCTION PROCESS ON BARR COLORADO ISLAND, PANAMA. CONSERVATION BIOLOGY 4 (4):391-7.

2402. KARTANAS, E. 1996. BREEDING BIRD COMMUNITIES INHABITING VEGETATION BELTS ALONG MID-FIELD ROADS. ACTA UNIVERSITATIS NICOLAI COPERNICI BIOLOGIA 51:93-110.

2403. KARTHAUS, G. 1985. SCHUTZMASSEN FUR WANDERDE AMPHIBIEN VOR EINER GEFAHRDUNG DURCH DEN STRASSENVERKEHR-BOEBACHTUNGEN UND ERFAHRUGEN. NATUR LANDSCHAFT 60:242-7.

2404. KASTLER, M. A. 1998. ELK PREGNANCY, PRODUCTION, AND CALF SURVIVAL IN THE SOUTH FORK OF THE FLATHEAD RIVER, MONTANA. M.S. THESIS, MONTANA STATE UNIVERSITY, BOZEMAN, MT. 60 PP.

2405. KASWORM, W. F. 1986. GRIZZLY BEAR HABITAT SELECTION AND MOVEMENTS IN THE CABINET MOUNTAINS OF MONTANA. PROC. GRIZZLY BEAR HABITAT SYMPOSIUM :167.

2406. KASWORM, W. F. and T. MANLEY. 1990. ROAD AND TRAIL INFLUENCES ON GRIZZLY AND BLACK BEARS IN NORTHWEST MONTANA. INTERNATIONAL CONFERENCE ON BEAR RESEARCH AND MANAGEMENT 8:79-84. 
2407. KASWORM, W. F. and T. L. MANLEY. 1990. ROAD AND TRAIL INFLUENCES ON GRIZZLY BEARS AND BLACK BEARS IN NORTHWEST MONTANA. INT. CONF. BEAR RES. AND MANAGE. 8:79-84

2408. KASWORM, W. F. and T. J. THEIR. 1994. ADULT BLACK BEAR REPRODUCTION, SURVIVAL, AND MORTALITY SOURCES IN NORTHWEST MONTANA. INT. CONF. BEAR RES. AND MANAGE. 9:223-30.

2409. KASWORM, W. and T. MANLEY. 1988. GRIZZLY BEAR AND BLACK BEAR ECOLOGY IN THE CABINET MOUNTAINS OF NORTHWEST MONTANA. 122PP.

2410. KASWORM, W. F. 1981. DISTRIBUTION AND POPULATION CHARACTERISTICS OF MULE DEER ALONG THE EAST FRONT, NORTHCENTRAL MONTANA. M.S. THESIS, MONTANA STATE UNIVERSITY, BOZEMAN, MT. 73 PP.

2411. KATHREIN, J. W. 1950. A PARTIAL FISHERIES SURVEY OF THE MISSOURI RIVER BETWEEN HOLTER DAM AND CASCADE, MONTANA, WITH SPECIAL EMPHASIS ON GROWTH RATE OF TROUT AND SUCKERS. M.S. THESIS, MONTANA STATE COLLEGE, BOZEMAN, MT. 27 PP.

2412. KATNIK, D. D., D. J. HARRISON and T. P. HODGMAN. 1994. SPATIAL RELATIONS IN A HARVESTED POPULATION OF MARTEN IN MAINE. J. WILDL. MANAGE. 58 (4):600-7.

2413. KATOPODIS, C., P. R. ROBINSON and B. G. SUTHERLAND. 1978. A STUDY OF MODEL AND PROTOTYPE CULVERT BAFFLING FOR FISH PASSAGE. WESTERN REGION, FISHERIES AND MARINE SERVICE, DEPT. OF FISHERIES AND THE ENVIRONMENT, WINNIPEG, MANITOBA. FISHERIES AND MARINE SERVICE TECHNICAL REPORT: TECHNICAL REPORT (CANADA. FISHERIES AND MARINE SERVICE) 828.

2414. KATSURA, Y. 1997. ONTOGENY AND SEXUAL DIMORPHISM IN CHAMPSOSAURS (DIAPSIDA, CHORISTODERA). PH.D. DISSERTATION, MONTANA STATE UNIVERSITY, BOZEMAN, MT. 95 PP.

2415. KATTAN, G. H., L. H. ALVAREZ and M. GIRALDO. 1994. FOREST FRAGMENTATION AND BIRD EXTINCTIONS: SAN ANTONIO EIGHTY YEARS LATER. CONSERVATION BIOLOGY 8 (1):138-46.

2416. KATZ, M. 1966. WATER QUALITY AND ECONOMIC DEVELOPMENT: THE IMPORTANCE OF THE RECREATION INDUSTRY IN THE PACIFIC NORTHWEST. 7TH INDUSTRIAL AND ECON. DEVELOPMENT CONF., PULLMAN, WA., 8 PP.

2417. KATZMAN, L. M. 1998. EFFECTS OF PREDATION ON STATUS OF ARCTIC GRAYLING AT RED ROCK LAKES NATIONAL WILDLIFE REFUGE, MONTANA. M.S. THESIS, MONTANA STATE UNIVERSITY, BOZEMAN, MT. 207 PP

2418. KAUFMAN, L. 1988. MARINE BIODIVERSITY: THE SLEEPING DRAGON. EDITORIAL. CONSERVATION BIOLOGY 2 (4):307-8. .

2419. KAVANAGH, R. P., S. DEBUS, T. TWEEDIE and R. WEBSTER. 1995. DISTRIBUTION OF NOCTURNAL FOREST BIRDS AND MAMMALS IN NORTH-EASTERN NEW SOUTH WALES: RELATIONSHIPS WITH ENVIRONMENTAL VARIABLES AND MANAGEMENT HISTORY. WLDLIFE RESEARCH 22 (3):359-77.

2420. KAVANAGH, R. P. and M. MURRAY. 1996. HOME RANGE, HABITAT AND BEHAVIOUR OF THE MASKED OWLS (TYTO NOVAEHOLLANDIAE) NEAR NEWCASTLE, NEW SOUTH WALES. EMU 96:250-257.

2421. KAY, J. and AND STUDENTS. 1981. EVALUATING ENVIRONMENTAL IMPACTS OF OFF-ROAD VEHICLES. JOURNAL OF GEOGRAPHY 80:10-18.

2422. KAZANSKAYA, N. S. 1977. FORESTS NEAR MOSCOW AS TERRITORIES OF MASS RECREATION AND TOURISM. URBAN ECOLOGY 2:371-395.

2423. KEATING, K. A. 1982. POPULATION ECOLOGY OF ROCKY MOUNTAIN BIGHORN SHEEP IN THE UPPER YELLOWSTONE RIVER DRAINAGE, MONTANAMYOMING. M.S. THESIS, MONTANA STATE UNIVERSITY, BOZEMAN, MT. 79 PP.

2424. KEAY, J. A. and J. W. VAN WAGTENDONK. 1983. EFFECT OF YOSEMITE BACKCOUNTRY USE LEVELS ON INCIDENTS WITH BLACK BEARS. INT. CONF. BEAR RES. AND MANAGE. 5:307-11.

2425. KEDDY, P. A., A. J. SPAVOLD and J. K. CATHY. 1979. SNOWMOBILE IMPACT ON OLD FIELD AND MARSH VEGETATION IN NOVA SCOTIA, CANADA: AN EXPERIMENTAL STUDY. ENVIRONMENTAL MANAGEMENT 3(4):409-415. 
2426. KEHOE, N. M. 1995. GRIZZLY BEAR DISTRIBUTION IN THE NORTH FORK OF THE FLATHEAD RIVER VALLEY: A TEST OF THE LINKAGE ZONE PREDICTION MODEL. M.S. THESIS, UNIVERSITY OF MONTANA, MISSOULA, MT. 55 PP.

2427. KEISTER, G. P. JR. and R. G. O. E. J. ANTHONY. 1987. USE OF COMMUNAL ROOSTS AND FORAGING AREAS BY BALD EAGLES WINTERING IN THE KLAMATH BASIN. J. WILDL. MANAGE.51 (2):415-20.

2428. KEITER, R. B. 1988. NATURAL ECOSYSTEM MANAGEMENT IN PARK AND WILDERNESS AREAS: LOOKING AT THE LAW. J. K. AGEE AND D. R. JOHNSON, EDITORS. ECOSYSTEM MANAGEMENT FOR PARKS AND WILDERNESS. UNIVERSITY OF WASHINGTON PRESS. SEATTLE AND LONDON.

2429. KEITH, S. 1967. NEW BIRD RECORDS FROM ALASKA AND THE ALASKA HIGHWAY. CANADIAN FIELD-NATURALIST. 81(3)

2430. KEITT, T. H., D. L. URBAN and B. T. MILNE. 1997. DETECTING CRITICAL SCALES IN FRAGMENTED LANDSCAPES. CONSERVATION ECOLOGY (ONLINE) 1(1):4.

2431. KELLER, M. E. and S. H. ANDERSON. 1992. AVIAN USE OF HABITAT CONFIGURATIONS CREATED BY FOREST CUTTING IN SOUTHEASTERN WYOMING. CONDOR94 (1):55-65.

2432. KELLER, V. and H.P. PFISTER. 1996. WILDLIFE PASSAGES AS A MEANS OF MITIGATING EFFECTS OF HABITAT FRAGMENTATION BY ROADS AND RAILWAY LINES. IN: (PROC. OF A CONFERENCE) HABITAT FRAGMENTATION \& INFRASTRUCTURE; 1995. 18-21 SEP 1995 ;DEN HAAG, THE NETHERLANDS. SWISS ORNITHOLOGICAL INSTITUTE.

2433. KELLER, V. E. 1991. THE EFFECT OF DISTURBANCE FROM ROADS ON THE DISTRIBUTION OF FEEDING SITES OF GEESE (ANSER BRACHYRHYNCHUS, A. ANSER), WINTERING IN NORTH-EAST SCOTLAND. ARDEA 79:229-232.

2434. KELLER, V., H. G. BAUER, H. W. LEY and H. P. PFISTER. 1996. THE INFLUENCE OF WLDLIFE OVERPASSES FOR BIRDS. ORNITHOL.BEOB. 93(3):249-258.

2435. KELLY, B. M. 1993. ECOLOGY OF YELLOWSTONE CUTTHROAT TROUT AND AN EVALUATION OF POTENTIAL EFFECTS OF ANGLER WADING IN THE YELLOWSTONE RIVER. M.S. THESIS, MONTANA STATE UNIVERSITY, BOZEMAN, MT. 100 PP.

2436. KELLY, B. 1998. DANCERS OF THE SAGE. COLORADO OUTDOORS 47:16-19.

2437. KELLY, L. M. 1992. THE EFFECTS OF HUMAN DISTURBANCE MITIGATION ON COMMON LOON PRODUCTIVITY IN NORTHWESTERN MONTANA. PAGES 246-247 IN PROCEEDINGS FROM THE 1992 CONFERENCE ON THE LOON AND ITS ECOSYSTEM: STATUS, MANAGEMENT, AND ENVIRONMENTAL CONCERNS. AUGUST 22-24, 1992. MAINE AUDUBON SOCIETY, FALMOUTH, MAINE.

2438. KELLY, L. M. 1992. THE EFFECTS OF HUMAN DISTURBANCE ON COMMON LOON PRODUCTIVITY IN NOTHWESTERN MONTANA. M.S. THESIS, MONTANA STATE UNIVERSITY, BOZEMAN, MT. 65 PP.

2439. KELSALL, J.P. and K. SIMPSON. 1987. THE IMPACTS OF HIGHWAYS ON UNGULATES: A REVIEW AND SELECTED BIBLIOGRAPHY. KEYSTONE BIO-RESEARCH, SURREY, B.C..

2440. KELSALL, J. P. and K. SIMPSON. 1991. THE IMPACTS OF HIGHWAYS ON UNGULATES: A REVIEW AND SELECTED BIBLIOGRAPHY, ENVIRONMENTAL ASSESSMENT OF THE OKANOGAN CONNECTOR FREEWAY: PART 1. REPORT PREPARED BY KEYSTONE BIO-RESEARCH FOR B.C. MIN. OF HIGHWAYS, VICTORIA, B.C. 82PP.

2441. KENDALL, K. C. 1981. BEAR USE OF PINE NUTS. M.S. THESIS, MONTANA STATE UNIVERSITY, BOZEMAN, MT. 27 PP.

2442. KENNEDY, P. L. 1980. RAPTOR BASELINE STUDIES IN ENERGY DEVELOPMENT. WILDL. SOC. BULL. 8 (2):129-35..

2443. KENTISH, B. and M. WESTBROOKE. 1994. CROP AND GIZZARD CONTENTS OF A ROAD-DEAD MALLEEFOWL. EMU 94 (2):130-2.

2444. KERSTETTER, T. A. 1994. TAXONOMIC INVESTIGATION OF EIGERON LACKSCHEWITZII. M.S. THESIS, MONTANA STATE UNIVERSITY, BOZEMAN, MT. 90 PP. 
2445. KERTELL, K. 1996. RESPONSE OF PACIFIC LOONS TO IMPOUNDMENTS AT PRUDHOE BAY, ALASKA. ARCTIC 49 (4):356-66.

2446. KEY, C. H. 1979. MAMMALIAN UTILIZATION OF FLOODPLAIN HABITATS ALONG THE NORTH FORK OF THE FLATHEAD RIVER IN GLACIER NATIONAL PARK, MONTANA. M.S. THESIS, UNIVERSITY OF MONTANA, MISSOULA, MT. 151 PP.

2447. KHOKHLOV, A. N. 1981. BIRD MORTALITY ON ROADS. PRIRODA (MOSCOW) 981(9):51-55.

2448. KIDD, W. J. JR. and H. F. HAUPT. 1968. EFFECTS OF SEEDBED TREATMENT ON GRASS ESTABLISHMENT ON LOGGING ROADBEDS IN CENTRAL IDAHO.

2449. KIEFER, A., M. HUBERT, R. WOLFGANG, R. HUBERT and S. DETLEF. 1994. BATS AS TRAFFIC CASUALTIES IN GERMANY. BAT RESEARCH NEWS 35(1):28-32.

2450. KILBRIDE, K. M., J. A. CRAWFORD, K. L. BLAKELY and B. A. WILLIAMS. 1992. HABITAT USE BY BREEDING FEMALE CALIFORNIA QUAIL IN WESTERN OREGON. JOURNAL OF WILDLIFE MANAGEMENT 56:85-90.

2451. KIM, K., S. J. VENTURA, P. M. HARRIS, P. G. THUM and J. PREY. 1993. URBAN NON-POINT-SOURCE POLLUTION ASSESSMENT USING A GEOGRAPHICAL INFORMATION SYSTEM. JOURNAL OF ENVIRONMENTAL MANAGEMENT 39 (3):157-70.

2452. KIM, S. I. and D. H. OH. 1994. NOISE ATTENUATION EFFECTS OF TREES. JOURNAL OF KOREAN FORESTRY SOCIETY 83 (3):400-9.

2453. KIMMERER, R. W. 1983. VEGETATION DEVELOPMENT AND COMMUNITY DYNAMICS IN A DATED SERIES OF ABANDONED LEAD-ZINC MINES IN SOUTHWESTERN WISCONSIN. DISSERTATION, UNIVERSITY OF WISCONSIN, MADISON, WISCONSIN. 296PP.

2454. KINDEL, F. J. 1958. SALT IN THE MANAGEMENT OF ELK IN THE LOWER SELWAY RIVER DRAINAGE, IDAHO. MS THESIS. UNIVERSITY OF IDAHO, MOSCOW, IDAHO. 115 PP.

2455. KINDVALL, O. and I. AHLÈN. 1992. GEOMETRICAL FACTORS AND METAPOPULATION DYNAMICS OF THE BUSH CRICKET, METRIOPTERA BICOLOR PHILIPPI (ORTHOPTERA: TETTIGONIIDAE). CONSERVATION BIOLOGY 6 (4):520-9.

2456. KING, C. M., M. FLUX, J. G. INNES and B. M. FITZGERALD. 1996. POPULATION BIOLOGY OF SMALL MAMMALS IN PUREORA FOREST PARK: 1. CARNIVORES (MUSTELA ERMINEA, M. FURO, M. NIVALIS, AND FELIS CATUS). NEW ZEALAND J. ECOL. $20: 241-251$.

2457. KING, C. M., J. G. INNES, M. FLUX, M. O. KIMBERLEY, J. R. LEATHWICK and D. S. WLLIAMS. 1996. DISTRIBUTION AND ABUNDANCE OF SMALL MAMMALS IN RELATION TO HABITAT IN PUREORA FOREST PARK. NEW ZEALAND JOURNAL OF ECOLOGY 20(2):215-240.

2458. KING, J. W. and J. A. SAVIDGE. 1995. EFFECTS OF THE CONSERVATION RESERVE PROGRAM ON WILDLIFE IN SOUTHEAST NEBRASKA. WILDL. SOC. BULL. 23 (3):377-85.

2459. KING, M. M. 1985. BEHAVIORAL RESPONSE OF DESERT BIGHORN SHEEP TO HUMAN HARASSMENT: A COMPARISON OF DISTURBED AND UNDISTURBED POPULATIONS (UTAH). PHD THESIS, UTAH STATE UNIVERSITY, LOGAN, UTAH. 151 PP.

2460. KING, M. M. 1985. BEHAVIORAL RESPONSE OF DESERT BIGHORN SHEEP TO HUMAN HARASSMENT: A COMPARISON OF DISTURBED AND UNDISTURBED POPULATIONS. DISSERTATION, UTAH STATE UNIVERSITY, LOGAN, UTAH, USA. 135PP.

2461. KING, M. M. and G. W. WORKMAN. 1984. BEHAVIORAL RESPONSE OF DESERT BIGHORN SHEEP TO HUMAN HARASSMENT: A COMPARISON OF DISTURBED AND UNDISTURBED POPULATIONS. FOURTH YEAR FINAL REPORT. 136PP.

2462. KING, M. M. and G. W. WORKMAN. 1986. RESPONSE OF DESERT BIGHORN SHEEP TO HUMAN HARASSMENT: MANAGEMENT IMPLICATIONS. TRANSACTIONS OF THE NORTH AMERICAN WILLIFE AND NATURAL 
2463. KINNEAR, P. K. 1978. COMMON AND BLACK-HEADED GULLS FEEDING ON ROAD CORPSES. BRITISH BIRDS 71(2):80-85.

2464. KIRBY, R. E. 1985. THE IMPACT OF HUMAN ACTIVITY UPON WLDLIFE AND WILDIFE HABITAT. STATEMENT OF WORK. OIT, RESEARCH AND DEVELOPMENT, U.S. FISH AND WILDLIFE SERVICE. 3PP.

2465. KIRBY, R. E., J. H. RIECHMANN and M. E. SHOUGH. 1976. A PRELIMINARY REPORT ON MINNESOTA'S INNOVATIVE 1973 WATERFOWL SEASON. WILDL. SOC. BULL. 4 (2):55-63.

2466. KIRKPATRICK, J. F. and J. W. JR. TURNER. 1991. COMPENSATORY REPRODUCTION IN FERAL HORSES. J. WLDL. MANAGE. 55 (4):649-52.

2467. KIRKPATRICK, M. A. S. 1985. AN EXAMINATION OF CONSTITUTIVE DIRECT LIGHT DNA REPAIR AND INDUCIBILITY OF DNA REPAIR IN TWO THERMOPHILIC BACTERIA. M.S. THESIS, MONTANA STATE UNIVERSITY, BOZEMAN, MT. 68 PP.

2468. KIRKPATRICK, R. L. and D. P. KIBBE. 1971. NUTRITIVE RESTRICTION AND REPRODUCTIVE CHARACTERISTICS OF CAPTIVE COTTONTAIL RABBITS. J. WLDL. MANAGE. 35 (2):332-8.

2469. KIRSCH, J. B. 1962. RANGE USE, RELATIONSHIP TO LOGGING AND FOOD HABITS OF THE ELK IN THE LITTLE BELT MOUNTAINS, MONTANA. M.S. THESIS, MONTANA STATE COLLEGE, BOZEMAN, MT. 44 PP.

2470. KISSELL, R. E. JR. 1996. POPULATION DYNAMICS, FOOD HABITS, SEASONAL HABITAT USE, AND SPATIAL RELATIONSHIPS OF BIGHORN SHEEP, MULE DEER, AND FERAL HORSES IN THE PRYOR MOUNTAINS, MONTANAMYOMING. PH.D. DISSERTATION, MONTANA STATE UNIVERSITY, BOZEMAN, MT. 153 PP.

2471. KJENSMO, J. 1997. THE INFLUENCE OF ROAD SALTS ON THE SALINITY AND THE MEROMICTIC STABILITY OF LAKE SVINSJOEN, SOUTHEASTERN NORWAY. HYDROBIOLOGIA 347:151-158.

2472. KLARICH, D. A. 1977. PHYSIOLOGICAL ECOLOGY OF AQUATIC MACROPHYTES IN THE MADISON RIVER OF YELLOWSTONE NATIONAL PARK, WYOMING. PH.D. DISSERTATION, MONTANA STATE UNIVERSITY, BOZEMAN, MT. 295 PP.

2473. KLAUS, M. 1997. DISPERSAL OF MICROTUS RICHARDSONI IN THE BEARTOOTH MOUNTAINS OF MONTANA AND WYOMING. PH.D. DISSERTATION, MONTANA STATE UNIVERSITY, BOZEMAN, MT. 56 PP.

2474. KLAVER, R. W. 1979. A MANAGEMENT-ORIENTED STUDY OF THE ECOLOGY OF BIGHORN SHEEP IN THE BITTERROOT MOUNTAINS, MONTANA AND IDAHO. M.S. THESIS, UNIVERSITY OF MONTANA, MISSOULA, MT. 112 PP.

2475. KLEBENOW, D. A. 1962. ECOLOGY AND PRODUCTIVITY OF A MONTANE FOREST WINTER DEER RANGE, WESTERN MONTANA. PH.D. DISSERTATION, MONTANA STATE UNIVERSITY, MISSOULA, MT. 93 PP.

2476. KLEIN, D. R. 1979. THE ALASKA OIL PIPELINE IN RETROSPECT. TRANS. 44TH NORTH AMER. WLDL. AND NAT. RESOURC. CONF.: 235-46.

2477. KLEIN, D. R. 1991. CARIBOU IN THE CHANGING NORTH. APPL. ANIM. BEHAV. SCI. 29 (1-4):279-91.

2478. KLEIN, D. R. 1980. REACTION OF CARIBOU AND REINDEER TO OBSTRUCTIONS - A REASSESSMENT. PAGES 519-527 IN E. REIMERS, E. GAARE, AND S. SKJENNEBERG, EDITORS. PROCEEDING OF THE SECOND INTERNATIONAL REINDEER/CARIBOU SYMPOSIUM. DIREKTORATET FOR VILT OG FERSKVANNSFISK, TRONDHEIM, NORWAY.

2479. KLEIN, D. R. 1979. REACTION OF CARIBOU AND REINDEER TO OBSTRUCTIONS-AN ASSESSMENT. IN: REIMERS E, GAARE E, SKJENNEBERG S. (EDS.) PROC. SECOND INT. REINDEER/CARIBOU SYMP.; SEP 17, 1979; TRONDHEIM, NORWAY.

2480. KLEIN, D. R. 1971. REACTION OF REINDEER TO OBSTRUCTIONS AND DISTURBANCE. SCIENCE 173:393-8.

2481. KLEIN, D. R. 1971. REACTION OF REINDEER TO OBSTRUCTIONS AND DISTURBANCES. SCIENCE 173:393-398. 
2482. KLEIN, D. R. 1980. REACTIONS OF CARIBOU AND REINDEER TO OBSTRUCTIONS: A REASSESSMENT. P 519-27. IN: REIMERS E, GAARE E, SKJENNEBERG S, EDS. PROC. 2NDINTERNATIONAL REINDEER/CARIBOU SYMPOSIUM; 1979; TRONDHEIM, NORWAY. DIREKTORATET FOR VILT OG FERSKVANNSFISK.

2483. KLEIN, D. R. and L. A. KOLPASHCHIKOV. 1991. CURRENT STATUS OF THE SOVIET UNION'S LARGEST CARIBOU HERD. P 251-5. IN: BUTLER CE, MAHONEY SP, EDS. 4TH NORTH AMERICAN CARIBOU WORKSHOP PROC.; OCT 31-NOV 3 1989 ; ST. JOHN'S, NEWFOUNDLAND. NEWFOUNDLAND AND LABRADOR WLDLIFE DIV.

2484. KLEIN, M. L. 1989. EFFECTS OF HIGH LEVELS OF HUMAN VISITATION ON FORAGING WATERBIRDS AT J. N. 'DING' DARLING NATIONAL WILDLIFE REFUGE. FINAL RESEARCH REPORT. FLORIDA COOP. FISH WILDL. RES. UNIT, UNIV. FLORIDA. GAINESVILLE. FCFWRU WORK ORDER NO. 42. VII + 103PP.

2485. KLEIN, M. L. 1993. WATERBIRD BEHAVIORAL RESPONSES TO HUMAN DISTURBANCES. WLDL. SOC. BULL. 21 (1):31-9.

2486. KLEIN, M. L., S. R. HUMPHREY and H. F. PERCIVAL. 1995. EFFECTS OF ECOTOURISM ON DISTRIBUTION OF WATERBIRDS IN A WILDLIFE REFUGE. CONSERVATION BIOLOGY 9 (6):1454-65.

2487. KLEINSTAUBER, K. 1969. THE STATUS OF CLIFF NESTING PEREGRINES IN THE GERMAN DEMOCRATIC REPUBLIC. PAGES 209-216 IN J. J. HICKEY, EDITOR. PEREGRINE FALCON POPULATIONS: THEIR BIOLOGY AND DECLINE. UNIVERSITY OF WISCONSIN PRESS, MADISON, WISCONSIN.

2488. KLENAVIC, J. S. 1979. BANFF HIGHWAY PROJECT (EAST GATE TO KM 13). (FEARO) REPORT. FEDERAL ENVIRONMENTAL ASSESSMENT AND REVIEW OFFICE, [LOCATION OF PUBLISHER UNKNOWN].

2489. KLINE, N. C. and D. E. SWANN. 1998. QUANTIFYING WIDLIFE ROAD MORTALITY IN SAGUARO NATIONAL PARK. PAGES 23-31 IN G. L. EVINK, P. GARRETT, D. ZEIGLER, AND J. BERRY, EDITORS. PROCEEDINGS OF THE INTERNATIONAL CONFERENCE ON WLDLIFE ECOLOGY AND TRANSPORTATION. FLORIDA DEPARTMENT OF TRANSPORTATION, TALLAHASSEE, FLORIDA.

2490. KLINE, P. D. 1965. FACTORS INFLUENCING ROADSIDE COUNTS OF COTTONTAILS. JOURNAL OF WILLIFE MANAGEMENT $29: 665-670$.

2491. KLONGLAN, E. D. 1955. FACTORS INFLUENCING THE FALL ROADSIDE PHEASANT CENSUS IN IOWA. J. WILDL. MANAGE. $19(2): 254-62$.

2492. KNAPP, H. G. 1957. ASPECTS OF INSECT POPULATIONS OF THE BITTERROOT RIVER, MONTANA. M.S. THESIS, MONTANA STATE UNIVERSITY, MISSOULA, MT. 157 PP.

2493. KNAPP, S. J. 1972. RANGE USE OF MULE DEER PRIOR TO INITIATION OF REST ROTATION GRAZING FOR CATTLE ON THE FORT HOWES RANGER DISTRICT, CUSTER NATIONAL FOREST, MONTANA. M.S. THESIS, MONTANA STATE UNIVERSITY, BOZEMAN, MT. 50 PP.

2494. KNICK, S. T. and W. KASWORM. 1989. SHOOTING MORTALITY IN SMALL POPULATIONS OF GRIZZLY BEARS. WILDL. SOC. BULL. 17:11-5

2495. KNIGHT, D. E. 1982. ACCUMULATION OF DIETARY METHYL BY WALLEYE AND WHITE CRAPPIE IN THE TONGUE RIVER RESERVOIR, MONTANA. M.S. THESIS, MONTANA STATE UNIVERSITY, BOZEMAN, MT. 103 PP.

2496. KNIGHT, J. E. JR. 1980. EFFECT OF HYDROCARBON DEVELOPMENT ON ELK MOVEMENTS AND DISTRIBUTION IN NORTHERN MICHIGAN. DISSERTATION, UNIVERSITY OF MICHIGAN, ANN ARBOR, MICHIGAN. 88PP.

2497. KNIGHT, J. E. 1981. EFFECT OF OIL AND GAS DEVELOPMENT ON ELK MOVEMENTS AND DISTRIBUTION IN NORTHERN MICHIGAN. TRANS. N. AMER. WILL. NAT. RESOUR. CONF. 46:349-357.

2498. KNIGHT, J. C. 1975. THE LIMNOLOGY OF THE WEST THUMB OF YELLOWSTONE LAKE, YELLOWSTONE NATIONAL PARK, WYOMING. M.S. THESIS, MONTANA STATE UNIVERSITY, BOZEMAN, MT. 74 PP.

2499. KNIGHT, R. L. and D. N. COLE. 1995. WILDLIFE RESPONSES TO RECREATIONISTS. PAGES 51-69 IN R. L. KNIGHT AND K. J. GUTZWILLER, EDITORS. WILDLIFE AND RECREATIONISTS: COEXISTENCE THROUGH MANAGEMENT AND RESEARCH. ISLAND PRESS. WASHINGTON, D.C. 
2500. KNIGHT, R. L. and K. J. GUTZWLLER. 1995. WILDLIFE AND RECREATIONISTS: COEXISTENCE THROUGH MANAGEMENT AND RESEARCH. ISLAND PRESS. WASHINGTON, D.C. 348PP.

2501. KNIGHT, R. L. and J. Y. KAWASHIMA. 1993. RESPONSE OF RAVEN AND RED-TAILED HAWK POPULATIONS TO LINEAR RIGHT-OF-WAYS. JOURNAL OF WLDLIFE MANAGEMENT 57:266-271.

2502. KNIGHT, R. L. and J. Y. KAWASHIMA. 1993. RESPONSES OF RAVEN AND RED-TAILED HAWK POPULATIONS TO LINEAR RIGHT OF WAYS. JOURNAL OF WLDLIFE MANAGEMENT 57:266-271.

2503. KNIGHT, R. L., H. A. L. KNIGHT and R. J. CAMP. 1995. COMMON RAVENS AND NUMBER AND TYPE OF LINEAR RIGHTS-OF-WAY. BIOLOGICAL CONSERVATION 74(1):65-67.

2504. KNIGHT, R. L. and S. A. TEMPLE. 1995. ORIGIN OF WILDLIFE RESPONSES TO RECREATIONISTS. R. L. KNIGHT AND K. J. GUTZWILLER, EDITORS. WLDLIFE AND RECREATIONISTS: COEXISTENCE THROUGH MANAGEMENT AND RESEARCH. ISLAND PRESS. WASHINGTON, D.C.

2505. KNIGHT, R. R. and L. L. EBERHARDT. 1987. PROSPECTS FOR YELLOWSTONE GRIZZLY BEARS. INT. CONF. BEAR RES. AND MANAGE.7:45-50.

2506. KNIGHT, R. R. and L. L. EBERHART. 1985. POPULATION DYNAMICS OF YELLOWSTONE GRIZZLY BEARS. ECOLOGY 66:323-34.

2507. KNIGHT, R. L. 2000. FOREST FRAGMENTATION IN THE SOUTHERN ROCKY MOUNTAINS. UNIVERSITY PRESS OF COLORADO, BOULDER, COLORADO.

2508. KNIGHT, R. R. 1960. VEGETATIVE CHARACTERISTICS OF TWO WATER AREAS IN TETON COUNTY, MONTANA, IN RELATION TO WATERFOWL USAGE. M.S. THESIS, MONTANA STATE COLLEGE, BOZEMAN, MT. 38 PP.

2509. KNOBLACH, W. 1939. DEATH ON THE HIGHWAY. JOURNAL OF MAMMALOGY 20:508-509.

2510. KNOCHE, K. G. 1968. THE ECOLOGY OF THE RATTLESNAKE CREEK, MONTANA MULE DEER WINTER RANGE. M.S. THESIS, UNIVERSITY OF MONTANA, MISSOULA, MT. 152 PP.

2511. KNOPF, F. L., R. R. JOHNSON, T. RICH, F. B. SAMSON and R. C. SZARO. 1988. CONSERVATION OF RIPARIAN ECOSYSTEMS IN THE UNITED STATES. WILSON BULLETIN 100:272-284.

2512. KNOPF, F. L. and F. B. SAMSON. 1994. BIOLOGICAL DIVERSITY--SCIENCE AND ACTION. CONSERVATION BIOLOGY 8 (3):909-11.

2513. KNOPF, F. L. and F. B. SAMSON. 1994. SCALE PERSPECTIVES ON AVIAN DIVERSITY IN WESTERN RIPARIAN ECOSYSTEMS. CONSERVATION BIOLOGY $8(3): 669-76$.

2514. KNOPF, F. L., J. A. SEDGWICK and R. W. CANNON. 1988. GUILD STRUCTURE OF A RIPARIAN AVIFAUNA RELATIVE TO SEASONAL CATTLE GRAZING . J. WILDL. MANAGE. 52 (2):280-90.

2515. KNOWLES, C. J. 1982. HABITAT AFFINITY, POPULATIONS, AND CONTROL OF BLACK-TAILED PRAIRIE DOGS ON THE CHARLES M. RUSSELL NATIONAL WLDLIFE REFUGE. DISSERTATION, UNIVERSITY.OF MONTANA.

2516. KNOWLES, C. J. 1975. RANGE RELATIONSHIPS OF MULE DEER, ELK AND CATTLE IN A REST ROTATION GRAZING SYSTEM DURING SUMMER AND FALL. M.S. THESIS, MONTANA STATE UNIVERSITY, BOZEMAN, MT. 111 PP.

2517. KNOWLES, P. R. 1981. SEASONAL HABITAT SELECTION, MOVEMENTS, AND HOME RANGE SIZE OF BOBCATS (LYNX RUFUS) IN NORTH-CENTRAL MONTANA. M.S. THESIS, UNIVERSITY OF MONTANA, MISSOULA, MT. 52 PP.

2518. KNOWLTON, F. F. 1959. FOOD HABITS, MOVEMENTS AND POPULATION STRUCTURE OF MOOSE IN THE GRAVELLY MOUNTAINS, MONTANA. M.S. THESIS, MONTANA STATE COLLEGE, BOZEMAN, MT. 27 PP.

2519. KNUDESON, B. M. 1973. THE ECOLOGY OF POLAR BEARS ON NORTH TWIN ISLAND, NORTHWEST TERRITORIES. M.S. THESIS, UNIVERSITY OF MONTANA, MISSOULA, MT. 
2520. KNUTSON, R. M. 1987. FLATTENED FAUNA. A FIELD GUIDE TO COMMON ANIMALS OF ROADS, STREETS, AND HIGHWAYS. TEN SPEED PRESS, BERKELEY, CA.

2521. KNZIG, J. 1995. NO TO MOTORWAY PLAN. NATUROPA 79:27-30.

2522. KOCKELMAN, W. J. 1983. MANAGEMENT CONCEPTS. PAGES 399-446 IN R. H. WEBB AND H. G. WILSHIRE, ENVIRONMENTAL EFFECTS OF OFF-ROAD VEHICLES

2523. KOCKELMAN, W. J. 1983. MANAGEMENT PRACTICES. PAGES 447-494 IN R. H. WEBB AND H. G. WILSHIRE, ENVIRONMENTAL EFFECTS OF OFF-ROAD VEHICLES.

2524. KOCKELMAN, W. J. 1983. REGULATIONS AND EDUCATION. PAGES 495-514 IN R. H. WEBB AND H. G. WISHIRE, ENVIRONMENTAL EFFECTS OF OFF-ROAD VEHICLES.

2525. KOEBBE, M. J. 1985. FACTORS ALTERING CROSSED EXTENSOR REFLEX EXCITABILITY IN DECEREBRATE CATS. M.S. THESIS, MONTANA STATE UNIVERSITY, BOZEMAN, MT. 86 PP.

2526. KOEHLER, G. M. and K. B. AUBRY. 1994. LYNX. P 74-98. IN: RUGGIERO, L.F., AUBRY, K.B., BUSKIRK, S.W., LYON, L.J., ZIELINSKI, W.J., (EDITORS). THE SCIENTIFIC BASIS FOR CONSERVING FOREST CARNIVORES: AMERICAN MARTEN, FISHER, LYNX, AND WOLVERINE IN THE WESTERN UNITED STATES. USDA FOREST SERVICE: GENERAL TECHNICAL REPORT RM-254.USDA FOREST SERVICE

2527. KOEHLER, G. M. and J. D. BRITTELL. 1990. MANAGING SPRUCE FIRE HABITAT FOR LYNX AND SNOWSHOE HARES. J. FORESTRY 88:10-4.

2528. KOEHLER, G. M. and M. G. HORNOCKER. 1977. FIRE EFFECTS ON MARTEN HABITAT IN THE SELWAY-BITTERROOT WILDERNESS. J. WILDL. MANAGE. 41 (3):500-5.

2529. KOEHNE, J. L. 1991. WILDLIFE-RELATED TRAFFIC ACCIDENTS: A COMPARISON OF EXISTING AND PROPOSED MITIGATION MEASURES. UNIVERSITY OF WASHINGTON., SEATTLE, WA.

2530. KOGER, J. L. 1978. FACTORS AFFECTING THE CONSTRUCTION AND COST OF LOGGING ROADS. TECHNICAL NOTE DIVISION OF FORESTRY, FISHERIES, AND WILDLIFE DEVELOPMENT, TENNESSEE VALLEY AUTHORITY. TENNESSEE VALLEY AUTHORITY, DIVISION OF FORESTRY, FISHERIES, AND WILDLIFE DEVELOPMENT, NORRIS, TENNESSEE ; NO. B-27.

2531. KOLENOSKY, G. B. and S. M. STRATHEARN. 1987. WINTER DENNING OF BLACK BEARS IN EAST-CENTRAL ONTARIO. INT. CONF. BEAR RES. AND MANAGE. 7:305-16

2532. KOLODENKO, A. I. 1981. ON THE MORTALITY OF REPTILES AND AMPHIBIANS BY VEHICLES ON THE ROADS OF TURKMENISTAN. PAGES 68 IN DAREVSKIJ,I.S., ANANEVA,N.B., BARKAGAN,Z.S., BORKIN,L.Y., SOKOLOVA,T.M., AND SHCHERBAK,N.N., EDITORS. THE PROBLEMS OF HERPETOLOGY: ABSTRACTS. NAUKA, LENINGRAD.

2533. KOMBEREC, T. J. 1976. RANGE RELATIONSHIPS OF MULE DEER, ELK AND CATTLE ON A REST-ROTATION GRAZING SYSTEM DURING WINTER AND SPRING. M.S. THESIS, MONTANA STATE UNIVERSITY, BOZEMAN, MT. 79 PP.

2534. KONCERAK, W. 1996. DETERMINING THE EFFECTS OF FIRE RESTORATION ON ELK WINTER RANGE AND HIDING COVER. M.S. THESIS, UNIVERSITY OF MONTANA, MISSOULA, MT. 70 PP.

2535. KOPEC, L. L. 1981. THE MOVEMENTS, DISTRIBUTION, AND POPULATIONCHARACTERISTICS OF THE CUTOFF AREA BIGHORN SHEEP HERD. M.S. THESIS, UNIVERSITY OF MONTANA, MISSOULA, MT. 115 PP.

2536. KOPISCHKE, E. B. 1972. EFFECTS OF SNOWMOBILE ACTIVITY ON THE DISTRIBUTION OF WHITE-TAILED DEER IN SOUTH-CENTRAL MINNESOTA. MINN DEP. OF NAT. RES., GAME RES. PROJ. QUARTERLY REPORT 32(3):139-42.

2537. KOPISCHKE, E. D. and M. M. NELSON. 1966. GRIT AVAILABILITY AND PHEASANT DENSITIES IN MINNESOTA AND SOUTH DAKOTA. J. WILDL. MANAGE. 30 (2):269-75 
2538. KOPLIN, J. R. 1962. COMPETITION AND NICHE SEGREGATION IN THE GENUS MICROTUS. PH.D. DISSERTATION, MONTANA STATE UNIVERSITY, MISSOULA, MT. 66 PP.

2539. KORBEL, O. 1995. HINDERING OTTER (LUTRA LUTRA) ROAD KILLS. PART 2. IUCN OTTER SPECIALIST GROUP BULLETIN $1: 40-47$.

2540. KORN, H. 1993. DETECTING SMALL MAMMAL MOVEMENTS ACROSS ROADS WITH THE AID OF COLOURED BAIT. ZEITSCHRIFT FUER ANGEWANDTE ZOOLOGIE 79(3):371-376.

2541. KORN, H. 1992. RAPID REPOPULATION BY SMALL MAMMALS OF AN AREA ISOLATED BY ROADS. MAMMALIA 5(4):629-632.

2542. KORN, H. 1987. SEQUENTIAL LIFE-TRAPPING AND SNAP-TRAPPING OF RODENTS ON A WOODED ISLAND SURROUNDED BY ROADS. SAEUGETIERKUNDLICHE MITTEILUNGEN 3(1):7478.

2543. KORNACKER, P. M. 1993. POPULATION ECOLOGY OF LACERTA VIVIPARA ON A RAILWAY EMBANKMENT IN RHINELAND. SALAMANDRA $29(2): 97-118$.

2544. KORSCHGEN, C. E. and R. B. DAHLGREN. 1992. HUMAN DISTURBANCES OF WATERFOWL: CAUSES, EFFECTS, AND MANAGEMENT. U.S. FISH AND WILDLIFE SERVICE. U.S. FISH AND WILDLIFE SERVICE LEAFLET 13.2.15. 8PP.

2545. KORSCHGEN, C. E., L. S. GEORGE and W. L. GREEN. 1985. DISTURBANCE OF DIVING DUCKS BY BOATERS ON A MIGRATIONAL STAGING AREA. WILDL. SOC. BULL. 13 (3):290-6.

2546. KORSCHGEN, L. J., W. R. PORATH and O. TORGERSON. 1980. SPRING AND SUMMER FOODS OF DEER IN THE MISSOURI OZARKS. J. WLDL. MANAGE. 44 (1):89-97

2547. KOSKELA, K. and M. NIEMINEN. 1983. TITLE UNKNOWN. ACTA ZOOL. FENN. 175:163.

2548. KOSTELECKA-MYRCHA, A., J. ZUKOWSKI and E. OKSIEJCZUK. 1997. CHANGES IN THE RED BLOOD INDICES DURING NESTLING DEVELOPMENT OF THE TREE SPARROW (PASSER MONTANUS) IN AN URBAN ENVIRONMENT. IBIS 139(1):92-96.

2549. KOWARIK, I. and A. LANGER. 1994. VEGETATION OF A RAILWAY TERRITORY IN BERLIN (SCHOENEBERGER SUEDEGLAENDE) IN THE FOURTH SUCCESSION DECADE. VERHANDLUNGEN DES BOTANISCHEN VEREINS VON BERLIN UND BRANDENBURG $127(0): 5-43$.

2550. KOZAKIEWICZ, V. J. 1979. THE TROUT FISHERY OF THE LOWER BIG HOLE RIVER, MONTANA, DURING 1977 AND 1978. M.S. THESIS, MONTANA STATE UNIVERSITY, BOZEMAN, MT. 74 PP.

2551. KOZEL, R. M. and E. D. FLEHARTY. 1979. MOVEMENTS OF RODENTS ACROSS ROADS. SOUTHWESTERN NATURALIST 24:239-248.

2552. KRAFT, M. E. 1968. THE EFFECTS OF CONTROLLED DEWATERING ON A TROUT STREAM. M.S. THESIS, MONTANA STATE UNIVERSITY, BOZEMAN, MT. 31 PP.

2553. KRAFT, S. K. 1989. ECOLOGY OF MULE DEER IN THE UPPER MISSOURI RIVER BREAKS, MONTANA. M.S. THESIS, UNIVERSITY OF MONTANA, MISSOULA, MT. 83 PP.

2554. KRAHMER, R. W. 1989. SEASONAL HABITAT COMPONENTS OF WHITE-TAILED DEER IN NORTHWESTERN MONTANA. M.S. THESIS, UNIVERSITY OF MONTANA, MISSOULA, MT. 104 PP.

2555. KRAMER, M. G. 1997. ABIOTIC CONTROLS ON WINDTHROW AND FOREST DYNAMICS IN A COASTAL TEMPERATE RAINFOREST, KUIU ISLAND, SOUTHEAST ALASKA. M.S. THESIS, MONTANA STATE UNIVERSITY, BOZEMAN, MT. 79 PP.

2556. KRAPU, G. L. 1974. FOODS OF BREEDING PINTAILS IN NORTH DAKOTA. J. WILDL. MANAGE. 38 (3):408-17. 
2557. KRAPU, G. L., D. E. FACEY, E. K. FRITZELL and D. H. JOHNSON. 1984. HABITAT USE BY MIGRANT SANDHILL CRANES IN NEBRASKA. J. WLDL. MANAGE. 48 (2):407-17.

2558. KRAPU, G. L., K. J. REINECKE, D. G. JORDE and S. G. SIMPSON. 1995. SPRING-STAGING ECOLOGY OF MIDCONTINENT GREATER WHITE-FRONTED GEESE. J. WILDL. MANAGE. 59(4):736-46.

2559. KRATKY, J. 1995. VERTEBRATE CASUALTIES ON THE ROADS OF THE MIDDLE ELBE LOWLANDS. CASOPIS NARODNIHO MUZEA RADA PRIRODOVEDNA 164(1-4):91-97.

2560. KRATT, L. F. 1981. EVIDENCE OF ARCTIC GRAYLING (THYMALLUS ARCTICUS) SPAWNING IN A HIGHWAY CULVERT. THE CANADAIN FIELD-NATURALIST. 95(3)

2561. KRATT, L. F. 1981. FISHERIES RESOURCES OF SELECTED WATERCOURSES WITHIN THE INFLUENCE OF THE ALASKA HIGHWAY GAS PIPELINE IN SOUTHERN YUKON TERRITORY - UPDATE TO JANUARY 1, 1981. FOOTHILLS PIPE LINES (SOUTH YUKON) LTD, CALGARY, ALBERTA.

2562. KRATT, L. F. and D. A. FERNET. 1981. WINTER STUDIES OF SELECTED WATERCOURSES ALONG THE ALASKA HIGHWAY GAS PIPELINE IN SOUTHERN YUKON TERRITORY, 1981. FOOTHILLS PIPE LINES (SOUTH YUKON) LTD, CALGARY, ALBERTA.

2563. KRATTER, A. W. 1995. STATUS, HABITAT AND CONSERVATION OF THE RUFOUS-FRONTED ANTTHRUSH FORMICARIUS RUFIFRONS. BIRD CONSERVATION INTERNATIONAL 5 (2-3):391-404.

2564. KRATVILLE, S. P. 1989. ELK HABITAT SELECTION, DISTRIBUTION AND NUTRITION AS INFLUENCED BY CATTLE IN EAST-CENTRAL IDAHO. M.S. THESIS, UNIVERSITY OF MONTANA, MISSOULA, MT. 101 PP.

2565. KRAUSMAN, P. R. and R. C. ETCHBERGER. 1995. RESPONSE OF DESERT UNGULATES TO A WATER PROJECT IN ARIZONA. J. WILDL. MANAGE. 59 (2):292-300.

2566. KRAUSMAN, P. R., R. C. ETCHBERGER and R. M. LEE. 1993. PERSISTENCE OF MOUNTAIN SHEEP. CONSERVATION BIOLOGY 7 (2):219.

2567. KRAUSMAN, P. R. and J. J. HERVERT. 1983. MOUNTAIN SHEEP RESPONSES TO AERIAL SURVEYS. WILDL. SOC. BULL. 11:372-5

2568. KRAUSMAN, P. R. and B. D. LEOPOLD. 1986. THE IMPORTANCE OF SMALL POPULATIONS OF DESERT BIGHORN SHEEP. TRANS. N. AM. WILDL. AND NAT. RES. CONF. 51:52-61.

2569. KRAUSMAN, P. R., B. D. LEOPOLD and D. L. SCARBROUGH. 1986. DESERT MULE DEER RESPONSE TO AIRCRAFT. WILDL. SOC. BULL. 14:68-70.

2570. KREEGER, T. J., D. MONSON, V. B. KUECHLE, U. S. SEAL and J. R. TESTER. 1989. MONITORING HEART RATE AND BODY TEMPERATURE IN RED FOXES (VULPES VULPES). CAN. J. ZOOL. 67:2455-8.

2571. KREMEN, C., R. K. COLWELL, T. L. ERWIN, D. D. MURPHY, R. F. NOSS and M. A. SANJAYAN. 1993. TERRESTRIAL ARTHROPOD ASSEMBLAGES: THEIR USE IN CONSERVATION PLANNING. CONSERVATION BIOLOGY 7 (4):796-808.

2572. KRIKOWSKI, L. 1989. THE 'LIGHT AND DARK ZONES': TWO EXAMPLES OF TUNNEL AND FENCE SYSTEMS. PAGES 89-91 IN LANGTON,T.E.S., EDITOR. AMPHIBIANS AND ROADS. PROCEEDINGS OF THE TOAD TUNNEL CONFERENCE; 1989 JANUARY 7-8; RENDSBURG, FEDERAL REPUBLIC OF GERMANY ACO POLYMER PRODUCTS LTD., SHEFFORD, ENGLAND.

2573. KRIVDA, W. 1993. ROADS KILLS OF MIGRATING GARTER SNAKES AT THE PAS MANITOBA. BLUE JAY 51 (4):197-8.

2574. KRIVDA, W. 1993. ROAD KILLS OF MIGRATING GARTER SNAKES AT THE PAS, MANITOBA. BLUE JAY 51:197-198.

2575. KROODSMA, R. L. 1984. ECOLOGICAL FACTORS ASSOCIATED WITH DEGREE OF EDGE EFFECT IN BREEDING BIRDS. J. WILDL. MANAGE. $48(2): 418-25$. 
2576. KROODSMA, R. L. 1982. EDGE EFFECT ON BREEDING FOREST BIRDS ALONG A POWERLINE CORRIDOR. J. APPLIED ECOLOGY 19:361-70.

2577. KRUGER, H. H. and H. WOLFEL. 1991. BEHAVIORAL RESPONSE OF FALLOW DEER TO VARIOUS TYPES OF SIMULATED UNDERPASSES. XXTH CONGRESS OF THE INTERNATIONAL UNION OF GAME BIOLOGISTS, GODOLLO, HUNGARY.

2578. KRUUK, H. and J. W. CONROY. 1991. MORTALITY OF OTTERS (LUTRA LUTRA) IN SHETLAND. JOURNAL OF APPLIED ECOLOGY 28(1):83-94.

2579. KRUUK, H. and J. W. H. CONROY. 1991. MORTALITY OF OTTERS (LUTRA LUTRA) IN SHETLAND (SCOTLAND, UK). JOURNAL OF APPLIED ECOLOGY 28 (1):83-94.

2580. KUCERA, E. 1976. DEER FLUSHING DISTANCE AS RELATED TO OBSERVER'S MODE OF TRAVEL. WLDL. SOC. BULL. 4 (3):128-9.ODOCOILEUS VIRGINIANUS.

2581. KUCERA, T. E. and R. H. BARRETT. 1993. THE TRAILMASTER CAMERA SYSTEM FOR DETECTING WILDLIFE. WILDL. SOC. BULL. 21 (4):505-8.

2582. KUCERA, T. E. and C. MCCARTHY. 1988. HABITAT FRAGMENTATION AND MULE DEER MIGRATION CORRIDORS: A NEED FOR EVALUATION. TRANS. WEST. SECT. WILDL. SOC. 24:61-7.

2583. KUCHEL, C. R. 1977. SOME ASPECTS OF THE BEHAVIOR AND ECOLOGY OF HARLEQUIN DUCKS BREEDING IN GLACIER NATIONAL PARK, MONTANA. WILDLIFEBIOLOGY:163.

2584. KUCHEL, C. R. 1977. SOME ASPECTS OF BEHAVIOR AND ECOLOGY OF HARLEQUIN DUCKS BREEDING IN GLACIER NATIONAL PARK, MONTANA. M.S. THESIS, UNIVERSITY OF MONTANA, MISSOULA, MT. 163 PP.

2585. KUCHERUK, V. V. 1994. SPREADING OF BLACK RAT IN RUSSIA: SIBERIA AND FAR EAST. BYULLETEN' MOSKOVSKOGO OBSHCHESTVA ISPYTATELEI PRIRODY OTDEL BIOLOGICHESKII 99 (5):33-6.

2586. KUCK, L. 1980. IMPACTS OF HUNTING AND RESPONSE TO FIVE YEAR HUNTING CLOSURE ON IDAHO'S PAHSIMEROI RIVER MOUNTAIN GOAT HERD. P 520. IN: PROC. BIENN. SYMP. NORTHERN WILD SHEEP AND GOAT COUNCIL; 23-25 APR 1980 ; NORTHERN WILD SHEEP AND GOAT COUNCIL.

2587. KUCK, L. 1977. STATUS AND MANAGEMENT OF THE MOUNTAIN GOAT IN IDAHO. P 37-40.IN: SAMUEL WM, ED. BIENNIAL SYMPOSIUM OF THE NORTHERN WILD SHEEP AND GOAT COUNCIL; 11-15 APR. 1988; BANFF, ALBERTA. NORTHERN WLD SHEEP AND GOAT COUNCIL.

2588. KUCK, L. 1986. THE IMPACTS OF PHOSPHATE MINING ON BIG GAME IN IDAHO: A COOPERATIVE APPROACH TO CONFLICT RESOLUTION. TRANSACTIONS OF THE NORTH AMERICAN WLDLIFE AND NATURAL RESOURCES CONFERENCE 51:90-97.

2589. KUCK, L., G. L. HOMPLAND and E. H. MERRILL. 1985. ELK CALF RESPONSE TO SIMULATED MINE DISTURBANCE IN SOUTHEAST IDAHO. JOURNAL OF WILDLIFE MANAGEMENT 49:751-757.

2590. KUENNEN, T. 1989. NEW JERSEY'S I-78 PRESERVES MOUNTAIN HABITAT. ROADS AND BRIDGES FEBRUARY:69-73.

2591. KUFELD, R. C. 1972. FOODS EATEN BY THE ROCKY MOUNTAIN ELK. J. RANGE MANAGE. 26 (2):106-12.

2592. KUFELD, R. C. 1968. USE OF PAINT FOR MARKING DEER PELLET GROUPS. J. WILDL. MANAGE. 32 (3):592-6.

2593. KUJALA, Q. J. 1993. WINTER HABITAT SELECTION AND POPULATION STATUS OF PINE MARTIN IN SOUTHWEST MONTANA. M.S. THESIS, MONTANA STATE UNIVERSITY, BOZEMAN, MT. 58 PP.

2594. KUMMEROW, M. 1992. WEEDS IN THE WLDERNESS: A THREAT TO BIODIVERSITY. WESTERN WILDLIFE 18:12-17.

2595. KUNKEL, K. E. 1997. PREDATION BY WOLVES AND OTHER LARGE CARNIVORES IN NORTHWESTERN MONTANA AND SOUTHEASTERN BRITISH COLUMBIA. PH.D. DISSERTATION, UNIVERSITY OF MONTANA, MISSOULA, MT. 272 
2596. KUR'YANOV, V. K., A. D. LOZOVOI and M. S. SUKHOROSLOV. 1984. THE EFFECT OF A LORRY ROAD ON ELEMENTS OF THE ECOLOGICAL SYSTEM. LESNOI-ZHURNAL. 2:30-2.

2597. KURNAT, V. L. 1991. DUCK NEST SUCCESS IN MONTANA. M.S. THESIS, UNIVERSITY OF MONTANA, MISSOULA, MT. 64 PP.

2598. KUROSAWA, R. 1994. BIRD ABUNDANCE IN RELATION TO THE PAVEMENT RATE OF TOKYO. STRIX 13:155-164.

2599. KURVITS, A. K. 1989. THE IMPACTS OF NATURE TOURISM ON WILDLIFE: A CASE STUDY OF THE PEREGRINE FALCON IN THE NORTHWEST TERRITORIES. THESIS, YORK UNIVERSITY, NORTH YORK, ONTARIO, CANADA. 110PP.

2600. KUSAK, J., D. HUBER and A. FRKOVIC. 1998. LARGE CARNIVORES AND TRAFFIC KILLS IN CROATIA. JOURNAL OF WILDLIFE CONSERVATION [VOL. UNKNOWN]:

2601. KUSHLAN, J. A. 1979. EFFECTS OF HELICOPTER CENSUSES ON WADING BIRD COLONIES. J MANAGE. WILDL. 43 (3):756-60

2602. KUSLER, J. A. 1978. STRENGTHENING STATE WETLAND REGULATIONS. U.S. DEPT. OF THE INTERIOR.

2603. KUSLER, J. A., M. L. QUAMMEN and G. BROOKS. 1988. NATIONAL WETLAND SYMPOSIUM: PROCEEDINGS OF THE NATIONAL WETLAND SYMPOSIUM, MITIGATION OF IMPACTS AND LOSSES, NEW ORLEANS, LOUISIANA, OCTOBER 8-10, 1986. ASSOCIATION OF STATE WETLAND MANAGERS, BERNE, NEWYORK. ASWM TECHNICAL REPORT 3.

2604. KUSS, F. R. and A. R. GRAEFE. 1985. EFFECTS OF RECREATION TRAMPLING ON NATURAL AREA VEGETATION. JOURNAL OF LEISURE RESEARCH 17:165-183.

2605. KUSSY, E. V. 1982. WETLAND AND FLOODPLAIN PROTECTION AND THE FEDERAL-AID HIGHWAY PROGRAM. ENVIRONMENTAL LAW 13(1):161-264.

2606. KUZMIN, V. A. and V. M. PLYUSNIN. 1993. THE LANDSCAPE ECOLOGICAL FEATURES OF THE SUBARCTIC MOUNTAIN ZONE OF TRANSBAIKALIA. EKOLOGIA (BRATISLAVA) 12 (2):179-87.

2607. KVALE, C. T. 1980. PRELIMINARY PHOSPHATE MINING IMPACTS ON MULE DEER, ELK, AND MOOSE IN SOUTHEASTERN IDAHO. PROC. WEST. ASSOC. FISH AND WLDL. AGENCIES60:527-45.

2608. LAAKSO, M. 1949. FOOD HABITS OF THE YELLOWSTONE WHITEFISH PROSOPIUM WILLIAMSONI CISMONTANUS (JORDAN). M.S. THESIS, MONTANA STATE UNIVERSITY, BOZEMAN, MT. 26 PP.

2609. LABAR, G. W. 1970. MOVEMENT AND HOMING OF CUTTHROAT TROUT (SALMO CLARKI) IN BRIDGER AND CLEAR CREEKS, YELLOWSTONE NATIONAL PARK. PH.D. DISSERTATION, MONTANA STATE UNIVERSITY, BOZEMAN, MT. 29 PP.

2610. LACEY, R. M., R. S. BARAN and ET AL. 1981. EVALUATION OF LANDS FOR RECREATIONAL SNOWMOBILE USE (GUIDELINES FOR NATURAL RESOURCES MANAGEMENT AND LAND USE COMPATIBILITY). CONSTRUCTION ENGINEERING RESEARCH LAB (ARMY). CHAMPAIGN, ILLINOIS.

2611. LACKI, M. J. and R. A. LANCIA. 1986. EFFECTS OF WILD PIGS ON BEECH GROWTH IN GREAT SMOKY MOUNTAINS NATIONAL PARK. J. WILDL. MANAGE. 50 (4):655-9.

2612. LACY, R. C. and T. W. CLARK. 1993. SIMULATION MODELING OF AMERICAN MARTEN (MARTES AMERICANA) POPULATIONS: VULNERABILITY TO EXTINCTION. GREAT BASIN NATURALIST 53 (3):282-92.

2613. LACY, R. C. and D. B. LINDENMAYER. 1995. A SIMULATION STUDY OF THE IMPACTS OF POPULATION SUBDIVISION ON THE MOUNTAIN BRUSHTAIL POSSUM TRICHOSURUS CANINUS OGILBY (PHALANGERIDAE: MARSUPIALIA), IN SOUTH-EASTERN AUSTRALIA: II. LOSS OF GENETIC VARIATION WITHIN AND BETWEEN SUBPOPULATIONS. BIOLOGICAL CONSERVATION73 (2):131-42. 
2614. LAGRANGE, T. G., J. L. HANSEN, R. D. ANDREWS, A. W. HANCOCK and J. M. KIENZLER. 1995. ELECTRIC FENCE PREDATOR EXCLOSURE TO ENHANCE DUCK NESTING: A LONG-TERM CASE STUDY IN IOWA. WLDL. SOC BULL. 23 (2):261-6.

2615. LAGRO, J. A. J. and S. D. DEGLORIA. 1992. LAND USE DYNAMICS WITHIN AN URBANIZING NON-METROPOLITAN COUNTY IN NEWYORK STATE (USA). LANDSCAPE ECOLOGY 7 (4):275-89.

2616. LAICHAS, W. D. and T. M. MCFARLANE. 1982. TRAIL RIDING IN AMERICA: A GUIDE TO RECREATIONAL OFF-ROAD RIDING. AMERICAN MOTORCYCLIST ASSOCIATION, DIRECTIONS MARKETING CO. CINCINNATI, OHIO. 128PP.

2617. LAIDIG, K. J. and D. S. DOBKIN. 1995. SPATIAL OVERLAP AND HABITAT ASSOCIATIONS OF BARRED OWLS AND GREAT HORNED OWLS IN SOUTHERN NEW JERSEY. JOURNAL OF RAPTOR RESEARCH 29 (3):151-7.

2618. LAIDLAW, G. W. J. and M. B. FENTON. 1971. CONTROL OF NURSERY COLONY POPULATIONS OF BATS BY ARTIFICIAL LIGHT. J. WILDL. MANAGE. 35 (4):843-6.

2619. LAIKRE, L., R. ANDREN, H. O. LARSSON and N. RYMAN. 1996. INBREEDING DEPRESSION IN BROWN BEAR URSUS ARCTOS. BIOL. CONSERV. 76:69-72.

2620. LAIKRE, L. and N. RYMAN. 1991. INBREEDING DEPRESSION IN A CAPTIVE WOLF (CANIS LUPUS) POPULATION. CONSERVATION BIOLOGY 5 (1):33-40.

2621. LAIKRE, L., N. RYMAN and E. A. THOMPSON. 1993. HEREDITARY BLINDNESS IN A CAPTIVE WOLF (CANIS LUPUS) POPULATION: FREQUENCY REDUCTION OF A DELETERIOUS ALLELE IN RELATION TO GENE CONSERVATION. CONSERVATION BIOLOGY 7 (3):592-601.

2622. LAINE, I. I. 1966. TEMPERATURE EFFECTS ON THE OXYGEN CONSUMPTION DURING DEVELOPMENT OF AULUCARA ELLIOTTI (THOMAS). PH.D. DISSERTATION, MONTANA STATE UNIVERSITY, BOZEMAN, MT. 74 PP.

2623. LAING, M. E. 1992. HOW OFF-HIGHWAY VEHICLES AFFECT BIRDS. NATIONAL OFF-HIGHWAY VEHICLE CONSERVATION COUNCIL. TORRANCE, CALIFORNIA. FACT SHEET \#11, ORDER \# G7054. 2PP.

2624. LAING, M. E. 1992. HOW OFF-HIGHWAY VEHICLES AFFECT DEER. NATIONAL OFF-HIGHWAY VEHICLE CONSERVATION COUNCIL. FACT SHEET \#10, ORDER \# G7053

2625. LAING, M. E. 1992. HOW OFF-HIGHWAY VEHICLES AFFECT ELK. NATIONAL OFF-HIGHWAY VEHICLE CONSERVATION COUNCIL. FACT SHEET \#8, ORDER \# G7051. (OEA)

2626. LAING, M. E. 1992. HOW OFF-HIGHWAY VEHICLES AFFECT MOUNTAIN SHEEP. NATIONAL OFF-HIGHWAY VEHICLE CONSERVATION COUNCIL. FACT SHEET \#9, ORDER \# G7052.(OEA)

2627. LAING, S. P. and F. G. LINDZEY. 1993. PATTERNS OF REPLACEMENT OF RESIDENT COUGARS IN SOUTHERN UTAH. J. MAMM. 74(4): 1056-8

2628. LAINHART, R. D. 1973. INTERACTION OF SUBSTRATE PARTICLE AND SIZE AND OTHER HABITAT VARIABLES WITH THE MICRODISTRIBUTION OF BENTHOS IN A MONTANA SPRING-STREAM. PH.D. DISSERTATION, MONTANA STATE UNIVERSITY, BOZEMAN, MT. 123 PP.

2629. LALO, J. 1987. THE PROBLEM OF ROADKILL. AMERICAN FORESTS SEPT./OCT.:50-53.

2630. LAMA, L. 1998.

2631. LAMBERSON, R. H., R. MCKELVEY, B. R. NOON and C. VOSS. 1992. A DYNAMIC ANALYSIS OF NORTHERN SPOTTED OWL VIABILITY IN A FRAGMENTED FOREST LANDSCAPE. CONSERVATION BIOLOGY 6 (4):505-12.

2632. LAMBERT, F. R. 1993. TRADE, STATUS AND MANAGEMENT OF THREE PARROTS IN THE NORTH MOLUCCAS, INDONESIA: WHITE COCKATOO CACATUA ALBA, CHATTERING LORY LORIUS GARRULUS AND VIOLET-EARED LORY EOS SQUAMATA. BIRD CONSERVATION INTERNATIONAL 3 (2):145-68. 
2633. LAMBOROT, M. 1991. KARYOTYPIC VARIATION AMONG POPULATIONS OF LIOLAEMUS MONTICOLA (TROPIDURIDAE) SEPARATED BY RIVERINE BARRIERS IN THE ANDEAN RANGE. COPEIA 1991 (4):1044-59.

2634. LAND, D. and M. LOTZ. 1996. WILLIFE CROSSING DESIGNS AND USE BY FLORIDA PANTHERS AND OTHER WILDLIFE IN SOUTHWEST FLORIDA. PAGES 323-328 IN EVINK,G., ZIEGLER,D., GARRETT,P., AND BERRY,J., EDITORS. TRANSPORTATION AND WLDLIFE: REDUCING WLDLIFE MORTALITY AND IMPROVING WILDLIFE PASSAGEWAYS ACROSS TRANSPORTATION CORRIDORS: PROCEEDINGS OF THE FLORIDA DEPARTMENT OF TRANSPORTATION/FEDERAL HIGHWAY ADMINISTRATION TRANSPORTATION-RELATED WLDLIFE MORTALITY SEMINAR; 1996 APRIL 30-MAY 2; ORLANDO, FL. FHWA-PD-96-041. U.S. DEPARTMENT OF TRANSPORTATION, FEDERAL HIGHWAY ADMINISTRATION, WASHINGTON, DC.

2635. LANDENBERGER, C. E. 1991. AN EVALUATION OF THREE BACKCOUNTRY IMPACT ASSESSMENT METHODS. THESIS, STATE UNIVERSITY NEW YORK, SYRACUSE, NEW YORK. 112PP.

2636. LANDIN, M. C. 1978. NATIONAL PERSPECTIVE OF COLONIAL WATERBIRDS NESTING ON DREDGED MATERIAL ISLANDS. TRANS. N. AMER. WLDL. NAT. RESOUR. CONF. 43:89-99.

2637. LANGENAU, E. E. and M. L. RABE. 1987. DEER-VEHICLE ACCIDENTS IN MICHIGAN: A TASK FORCE REPORT. WILDLIFE DIV. REPORT NO. 3072. MICHIGAN DEPARTMENT OF NATURAL RESOURCES, WLDLIFE DIVISION, LANSING, MI.

2638. LANGENAU, E. E. and M. L. RABE. 1987. DEER-VEHICLE ACCIDENTS IN MICHIGAN: A TASKFORCE REPORT. REP. NO. 3072. 46 PP.

2639. LANGLEY, M. A. 1993. HABITAT SELECTION, MORTALITY AND POPULATION MONITORING OF SHIRAS MOOSE IN NORTH FORK FLATHEAD RIVER VALLEY, MONTANA. M.S. THESIS, UNIVERSITY OF MONTANA, MISSOULA, MT. 162 PP.

2640. LANGLEY, W. M., H. W. LIPPS and J. F. THEIS. 1989. RESPONSES OF KANSAS MOTORISTS TO SNAKE MODELS ON A RURAL HIGHWAY. TRANSACTIONS OF THE KANSAS ACADEMY OF SCIENCE 92:43-48.

2641. LANGTON, T. E. S. 1989. AMPHIBIANS AND ROADS. PROCEEDINGS OF THE TOAD TUNNEL CONFERENCE. RENDSBURG, FEDERAL REPUBLIC OF GERMANY, 7-8 JANUARY 1989. ACO POLYMER PRODUCTS, SHEFFORD BEDFORDSHIRE, UK. 202PP.

2642. LANGTON, T. E. S. 1989. AMPHIBIANS AND ROADS: PROCEEDINGS OF THE TOAD TUNNEL CONFERENCE; 1989 JANUARY 7-8; RENDSBURG, FEDERAL REPUBLIC OF GERMANY. ACO POLYMER PRODUCTS LTD., SHEFFORD, ENGLAND.

2643. LANGTON, T. E. S. 1989. REASON FOR PREVENTING AMPHIBIAN MORTALITY ON ROADS. PAGES 75-80 IN LANGTON,T.E.S., EDITOR. PROCEEDINGS OF THE TOAD TUNNEL CONFERENCE; 1989 JANUARY 7-8; RENDSBURG, FEDERAL REPUBLIC OF GERMANY ACO POLYMER PRODUCTS LTD., SHEFFORD, ENGLAND.

2644. LANGTON, T. E. S. 1989. TUNNELS AND TEMPERATURE: RESULTS FROM A STUDY OF A DRIFT FENCE AND TUNNEL SYSTEM FOR AMPHIBIANS AT HENLY-ON-THAMES, BUCKINGHAMSHIRE, ENGLAND. PAGES $145-152$ IN LANGTON,T.E., EDITOR. PROCEEDINGS OF THE TOAD TUNNEL CONFERENCE; 1989 JANUARY 7-8; RENDSBURG, FEDERAL REPUBLIC OF GERMANY ACO POLYMER PRODUCTS LTD., SHEFFORD, ENGLAND.

2645. LANGTON, T. E. S. 1989. TOAD TUNNEL CONFERENCE: AMPHIBIANS AND ROADS PROCEEDINGS OF THE TOAD TUNNEL CONFERENCE, RENDSBURG, FEDERAL REPUBLIC OF GERMANY, 7-8 JAN. 1989. ACO POLYMER PRODUCTS, SHEFFORD, BEDFORDSHIRE.

2646. LAPIN, M. and B. V. BARNES. 1995. USING THE LANDSCAPE ECOSYSTEM APPROACH TO ASSESS SPECIES AND ECOSYSTEM DIVERSITY. CONSERVATION BIOLOGY 9 (5):1148-58.

2647. LARSEN, T. 1985. POLAR BEAR DENNING AND CUB PRODUCTION IN SVALBARD, NORWAY. J. WILDL. MANAGE. 49 (2):320-6.

2648. LATHROP, E. W. 1983. THE EFFECT OF VEHICLE USE ON DESERT VEGETATION. PAGES 153-166 IN WEBB,R.H. AND WILSHIRE,H.G., EDITORS. ENVIRONMENTAL EFFECTS OF OFF-ROAD VEHICLES: IMPACTS AND MANAGEMENT IN ARID REGIONS. SPRINGER-VERLAG, NEW YORK. 
2649. LATTA, S. C., J. M. J. WUNDERLE, E. TERRANOVA and M. PAGAN. 1995. AN EXPERIMENTAL STUDY OF NEST PREDATION IN A SUBTROPICAL WET FOREST FOLLOWING HURRICANE DISTURBANCE. WILSON BULLETIN 107 (4):590-602.

2650. LAUGA, J. and J. JOACHIM. 1992. MODELING THE EFFECTS OF FOREST FRAGMENTATION ON CERTAIN SPECIES OF FOREST-BREEDING BIRDS. LANDSCAPE ECOLOGY 6 (3):183-93.

2651. LAURANCE, W. F. 1991. ECOLOGICAL CORRELATES OF EXTINCTION PRONENESS IN AUSTRALIAN TROPICAL RAIN FOREST MAMMALS. CONSERVATION BIOLOGY 5 (1):79-89.

2652. LAURANCE, W. F. 1994. RAINFOREST FRAGMENTATION AND THE STRUCTURE OF SMALL MAMMAL COMMUNITIES IN TROPICAL QUEENSLAND. BIOLOGICAL CONSERVATION 69(1):23-32.

2653. LAURANCE, W. F. and E. YENSEN. 1991. PREDICTING THE IMPACTS OF EDGE EFFECTS IN FRAGMENTED HABITATS. BIOL. CONSERV. 55:77-92.

2654. LAURSEN, K. 1981. BIRDS ON ROADSIDE VERGES AND THE EFFECT OF MOWING ON FREQUENCY AND DISTRIBUTION. BIOLOGICAL CONSERVATION 20:59-68.

2655. LAUTENSCHLAGER, R. A. 1993. RESPONSE OF WLDLIFE TO FOREST HERBICIDE APPLICATIONS IN NORTHERN CONIFEROUS ECOSYSTEMS. CANADIAN JOURNAL OF FOREST RESEARCH 23 (10):2286-99.

2656. LAVIGNE, G. R. 1976. WINTER RESPONSE OF DEER TO SNOWMOBILES AND SELECTED NATURAL FACTORS. M.S. THESIS. UNIVERSITY OF MAINE, ORONO, MAINE. 7OPP.

2657. LAVSUND, S. and F. SANDEGREN. 1991. MOOSE-VEHICLE RELATIONS IN SWEDEN: A REVIEW. ALCES 27:118-126.

2658. LAWS, J. M. 1995. SONG DEVELOPMENT BY FREE-LIVING YEARLING MALE LAZULI BUNTINGS (PASSERINA AMOENA). M.S. THESIS, UNIVERSITY OF MONTANA, MISSOULA, MT. 109 PP.

2659. LEACH, G. J. and H. F. RECHER. 1993. USE OF ROADSIDE REMNANTS OF SOFTWOOD SCRUB VEGETATION BY BIRDS IN SOUTH-EASTERN QUEENSLAND. WILDLIFE RESEARCH 20(2):233-249.

2660. LEACH, R. H. 1982. SUMMER RANGE ECOLOGY OF WHITE-TAILED DEER IN THE CONIFEROUS FORESTS OF NORTHWESTERN MONTANA. M.S. THESIS, UNIVERSITY OF MONTANA, MISSOULA, MT. 80 PP.

2661. LEATHE, S. A. 1980. THE POPULATION DYNAMICS AND PRODUCTION OF LIMNETIC CRUSTACEAN ZOOPLANKTON IN THE TONGUE RIVER RESERVOIR, MONTANA. M.S. THESIS, MONTANA STATE UNIVERSITY, BOZEMAN, MT. 148 PP.

2662. LEATHERMAN, S. P. and P. J. GODFREY. 1979. THE IMPACT OF OFF-ROAD VEHICLES ON COASTAL ECOSYSTEMS IN CAPE COD NATIONAL SEASHORE: AN OVERVIEW: FINAL REPORT. ENVIRON. INST., UNIV. MASSACHUSETTS. AMHERST. UM/NPSCRU REP. NO. 34, CONTRACT NO. CX-1600-5-001. XIV + 34PP.

2663. LEBERG, P. L. 1991. INFLUENCE OF FRAGMENTATION AND BOTTLENECKS ON GENETIC DIVERGENCE OF WILD TURKEY POPULATIONS. CONSERVATION BIOLOGY 5 (4):522-30.

2664. LEBLANC, R. 1991. THE AVERSIVE CONDITIONING OF A ROADSIDE HABITUATED GRIZZLY BEAR WITHIN BANFF PARK: PROGRESS REPORT 1991. 6 PP.

2665. LEBLANC, R. 1994. SMALL MAMMAL USE OF CULVERTS ALONG THE TRANS-CANADA HIGHWAY (PHASE III), BANFF NATIONAL PARK. PARKS CANADA, BANFF NATIONAL PARK WARDEN SERVICE, BANFF, ALBERTA. 22PP.

2666. LECHLEITNER, R. R. 1953. AN ANALYSIS OF SOME AGE CRITERIA IN A DOMESTIC AND WILD POPULATION OF MINK (MUSTELA VISON). PH.D. DISSERTATION, MONTANA STATE UNIVERSITY, MISSOULA, MT. 60 PP.

2667. LECKENBY, D. D. ELK USE AND AVAILABILITY OF COVER AND FORAGE COMPONENTS IN THE BLUE MOUNTAINS, NORTHWEST OREGON. OREGON DEPT. OF FISH AND WLDL. WILL. RES. REP. \#14. 40PP.

2668. LECKENBY, D., C. WHEATON and L. BRIGHT. 1991. ELK VULNERABILITY - THE OREGON SITUATION. PAGES 89-98 IN A. G. CHRISTENSEN, L. J. LYON, AND T. N. LONAF 
2669. LEE, J. E., G. C. WHITE, R. A. GARROTT, R. M. BARTMANN and A. W. ALLDREDGE. 1985. ACCESSING ACCURACY OF A RADIOTELEMETRY SYSTEM FOR ESTIMATING ANIMAL LOCATIONS. J. WLDL. MANAGE. 49 (3):659-63.

2670. LEE, N. K. TITLE UNKNOWN. M.S. THESIS, UNIV. MONTANA. 56 PP.

2671. LEE, N. K. 1984. EVALUATING ELK HABITAT IN TERMS OF COVER IN WEST-CENTRAL IDAHO. M.S. THESIS, UNIVERSITY OF MONTANA, MISSOULA, MT. 56 PP.

2672. LEE, S.-S. 1969. THERMAL INDUCTION OF BACTERIOPHAGE P1. PH.D. DISSERTATION, MONTANA STATE UNIVERSITY, BOZEMAN, MT. 26 PP.

2673. LEE, T. E. JR., J. W. BICKHAM and M. D. SCOTT. 1994. MITOCHONDRIAL DNA AND ALLOZYME ANALYSIS OF NORTH AMERICAN PRONGHORN POPULATIONS. J. WILDL. MANAGE.58 (2):307-18.

2674. LEEDY, D. H. 1979. AN ANNOTATED BIBLIOGRAPHY ON PLANNING AND MANAGEMENT FOR URBAN-SUBURBAN WILDLIFE. FEDERAL HIGHWAY ADMINISTRATION, OFFICE RES. DEVELOP. FHWA-RD-76-5. 417PP.

2675. LEEDY, D. H. 1975. HIGHWAY-WILDLIFE RELATIONSHIPS. VOL. 1. A STATE-OF-THE-ART REPORT. U.S. FISH AND WILDLIFE SERVICE. FWS/OBS-79/25. 265PP.

2676. LEEDY, D. H., T. M. FRANKLIN and C. E. HEKIMIAN. 1975. HIGHWAY-WILDLIFE RELATIONSHIPS. VOL. 2. AN ANNOTATED-BIBLIOGRAPHY. FEDERAL HIGHWAY ADMINISTRATION, OFFICE RES. DEVELOP. FHWA-RD-76-5. 417PP.

2677. LEEDY, D. L. 1975. HIGHWAY-WLDLIFE RELATIONSHIPS. U.S. DEPT. OF TRANSPORTATION, FEDERAL HIGHWAY ADMINISTRATION, OFFICES OF RESEARCH AND DEVELOPMENT, WASHINGTON, D.C. REPORT - FEDERAL HIGHWAY ADMINISTRATION ; NO. FHWA-RD-76-4.

2678. LEEDY, D. L. 1975. HIGHWAY-WILDLIFE RELATIONSHIPS, VOL. 1. A STATE OF THE ART REPORT. FHWA-RD-76-4. U.S. DEPARTMENT OF TRANSPORTATION, FEDERAL HIGHWAY ADMINISTRATION, WASHINGTON, DC.

2679. LEEDY, D. L. 1975. HIGHWAY-WILLIFE RELATIONSHIPS, VOL 2. AN ANNOTATED BIBLIOGRAPHY. FHWA-RD-76-5. U.S. DEPARTMENT OF TRANSPORTATION, FEDERAL HIGHWAY ADMINISTRATION, WASHINGTON, DC.

2680. LEEDY, D. L. 1975. HIGHWAY WILDLIFE RELATIONSHIPS. VOLUME 1. A STATE OF THE ART REPORT. U.S. DEPT. TRANSPORTATION, FEDERAL HIGHWAY ADMINISTRATION. REPORT NO. FHWA-RD-76-4. 183 PP.

2681. LEEDY, D. L. and L. W. ADAMS. 1982. WILDLIFE CONSIDERATIONS IN PLANNING AND MANAGING HIGHWAY CORRIDORS. FHWA-TS-82-212. U.S. DEPARTMENT OF TRANSPORTATION, FEDERAL HIGHWAY ADMINISTRATION, WASHINGTON, DC.

2682. LEEDY, D. L. and L. W. ADAMS. 1982. WILDLIFE CONSIDERATIONS IN PLANNING AND MANAGING HIGHWAY CORRIDORS. USER'S MANUAL. U.S. DEPARTMENT OF TRANSPORTATION, FEDERAL HIGHWAY ADMINISTRATION. REPORT NO. FHWA-TS-82-212.93.

2683. LEEDY, D. L., R. M. MAESTRO and T. M. FRANKLIN. 1978. PLANNING FOR WILDLIFE IN CITIES AND SUBURBS. FWS OBS77/66. URBAN WLDLIFE RESEARCH CENTER, INC., ELLICOTT CITY, MD.

2684. LEEDY, D. L. 1975. HIGHWAY-WLDLIFE RELATIONSHIPS FINAL REPORT. U.S. DEPT. OF TRANSPORTATION, FEDERAL HIGHWAY ADMINISTRATION, OFFICES OF RESEARCH AND DEVELOPMENT, WASHINGTON, D.C. FHWA-RD-: FHWA-RD: FHWA-RD NO. 76-4. NO. 76-5.

2685. LEEDY, D. L. 1982. WLDLIFE CONSIDERATIONS IN PLANNING AND MANAGING HIGHWAY CORRIDORS. URBAN WILDLIFE RESEARCH CENTER, INC, COLUMBIA, MARYLAND.

2686. LEEDY, D. L., T. M. FRANKLIN and E. C. HEKIMIAN. 1975. HIGHWAY-WILDLIFE RELATIONSHIPS. REPORT - FEDERAL HIGHWAY ADMINISTRATION, OFFICES OF RESEARCH AND DEVELOPMENT; NO. FHWA-RD-76-4/5. U.S. DEPT. OF TRANSPORTATION, FEDERAL HIGHWAY ADMINISTRATION, OFFICES OF RESEARCH AND DEVELOPMENT, 
WASHINGTON, D.C.

2687. LEEDY, R. R. 1972. THE STATUS OF PRAIRIE FALCONS IN WESTERN MONTANA: SPECIAL EMPHASIS ON POSSIBLE EFFECTS OF CHLORINATED HYDROCARBON INSECTICIDES. M.S. THESIS, UNIVERSITY OF MONTANA, MISSOULA, MT. 96 PP.

2688. LEEGE, T. A. GUIDELINES FOR EVALUATING AND MANAGING SUMMER ELK HABITAT.

2689. LEEGE, T. A. 1968. NATURAL MOVEMENTS OF BEAVERS IN SOUTHEASTERN IDAHO. J. WILDL. MANAGE. 32 (4):973-6.

2690. LEEGE, T. A. 1976. RELATIONSHIP OF LOGGING TO DECLINE OF PETE KING ELK HERD. PAGES 6-10 IN ELK-LOGGING-ROADS SYMPOSIUM PROCEEDINGS.

2691. LEEGE, T. A. 1976. RELATIONSHIP OF LOGGING TO DECLINE OF THE PETE KING ELK HERD. P 6-10. IN: HIEB SR, ED. PROC. ELK-LOGGING-ROADS SYMPOSIUM, MOSCOW, IDAHO. UNIVERSITY OF MOSCOW, MOSCOW, IDAHO.

2692. LEEGE, T. A. 1984. TITLE UNKNOWN. IDAHO DEPARTMENT OF FISH AND GAME WILDLIFE BULLETIN NO. 11. 47 PP.

2693. LEEGE, T. A. and R. M. WILLIAMS. 1967. BEAVER PRODUCTIVITY IN IDAHO. J. WILDL. MANAGE. 31 (2):326-32.

2694. LEEGE, T. A. 1984. GUIDELINES FOR EVALUATING AND MANAGING SUMMER ELK HABITAT IN NORTHERN IDAHO. IDAHO DEPARTMENT OF FISH AND GAME . BOISE, IDAHO. WILLIFE BULLETIN NO. 11. 35PP.

2695. LEES, A. T. 1988. THE EFFECTS OF RECREATIONAL ACTIVITY ON ELK DISTRIBUTION AND USE OF A PIPELINE RIGHT-OF-WAY. M.S. THESIS, UNIVERSITY OF CALGARY.

2696. LEES, A. T. 1989. THE EFFECT OF RECREATIONAL ACTIVITY ON ELK USE AND DISTRIBUTION ALONG A PIPELINE RIGHT-OF-WAY. PAGES 133-143 IN P. R. DAVIS, J. C. EMERICK, D. M. FINCH, S. Q. FOSTER, J. W. MONARCH, S. RUSH, O. THORNEII, AND J. TODD, EDITORS. PROCEEDINGS IV: ISSUES AND TECHNOLOGY IN THE MANAGEMENT OF IMPACTED WILDLIFE. THORNE ECOL. INST., BOULDER, COLORADO.

2697. LEESON, B. 1998. BRIDGING THE ROCKIES - BANFF'S ROADWAY FOR WILDLIFE. PAGES 120-121 IN EVINK, G., ZIEGLER,D., GARRETT,P., AND BERRY,J., EDITORS. PROCEEDINGS OF THE INTERNATIONAL CONFERENCE ON WILDLIFE ECOLOGY AND TRANSPORTATION; 1998 FEBRUARY 10-12; FT. MYERS, FL FLORIDA DEPARTMENT OF TRANSPORTATION, TALLAHASSEE, FL.

2698. LEESON, B. 1996. HIGHWAY CONFLICTS AND RESOLUTIONS IN BANFF NATIONAL PARK, ALBERTA. PAGES 80-84 IN EVINK,G., ZIEGLER,D., GARRETT,P., AND BERRY,J., EDITORS. TRANSPORTATION AND WILDLIFE: REDUCING WILDLIFE MORTALITY AND IMPROVING WILDLIFE PASSAGEWAYS ACROSS TRANSPORTATION CORRIDORS: PROCEEDINGS OF THE FLORIDA DEPARTMENT OF TRANSPORTATION/FEDERAL HIGHWAY ADMINISTRATION TRANSPORTATION-RELATED WILDLIFE MORTALITY SEMINAR; 1996 APRIL 30-MAY 2; ORLANDO, FL. FHWA-PD-96-041. U.S. DEPARTMENT OF TRANSPORTATION, FEDERAL HIGHWAY ADMINISTRATION, WASHINGTON, DC.

2699. LEESON, B. F. 1996. HIGHWAY CONFLICTS AND RESOLUTIONS IN BANFF NATIONAL PARK, ALBERTA, CANADA. IN: GARY L. EVINK, PAUL GARRETT, DAVID ZEIGLER, AND JON BERRY, EDS. TRENDS IN ADDRESSING TRANSPORTATION RELATED WILDIFE MORTALITY: PROCEEDINGS OF THE TRANSPORTATION RELATED WILDLIFE MORTALITY SEMINAR. FL-ER-58-96. STATE OF FLORIDA, DEPT. TRANSPORT., ENVIRON. MANAGE. OFF., TALLAHASSEE.

2700. LEGG, K. L. 1996. MOVEMENTS AND HABITAT USE OF BIGHORN SHEEP ALONG THE UPPER YELLOWSTONE RIVER VALLEY, MONTANA. M.S. THESIS, MONTANA STATE UNIVERSITY, BOZEMAN, MT. 73 PP.

2701. LEHMANN, V. W. and R. G. MAUERMANN. 1963. STATUS OF ATTWATER'S PRAIRIE CHICKEN. J. WILDL. MANAGE. 27 (4):712-25.

2702. LEHMKUHL, J. F. 1981. DISTRIBUTION AND HABITAT SELECTION IN THE NORTH GARNET MOUNTAINS OF WESTERN MONTANA. M.S. THESIS, UNIV. MONTANA. $130 \mathrm{PP}$. 
2703. LEHMKUHL, J. F. and M. G. RAPHAEL. 1993. HABITAT PATTERN AROUND NORTHERN SPOTTED OWL LOCATIONS ON THE OLYMPIC PENINSULA, WASHINGTON. JOURNAL OF WILDLIFE MANAGEMENT 57 (2):302-15.

2704. LEHMKUHL, J. F. 1981. DISTRIBUTION AND HABITAT SELECTION OF ELK IN THE NORTH GARNET MOUNTAINS OF WESTERN MONTANA. M.S. THESIS, UNIVERSITY OF MONTANA, MISSOULA, MT. 130 PP.

2705. LEHNERT, M. E. 1996. MULE DEER-HIGHWAY MORTALITY IN NORTHEASTERN UTAH: AN ANALYSIS OF POPULATION LEVEL IMPACTS AND A NEW MITIGATIVE SYSTEM. M.S. THESIS, UTAH STATE UNIVERSITY, LOGAN, UT.

2706. LEHNERT, M. E., L. ROMIN and J. A. BISSONETTE. 1996. MULE DEER AND HIGHWAY MORTALITY IN NORTHEASTERN UTAH: CAUSES, PATTERNS, AND A NEW MITIGATIVE TECHNIQUE. PAGES 101-107 IN EVINK,G., ZIEGLER,D. GARRETT,P., AND BERRY,J., EDITORS. TRANSPORTATION AND WLDLIFE: REDUCING WILDLIFE MORTALITY AND IMPROVING WLDLIFE PASSAGEWAYS ACROSS TRANSPORTATION CORRIDORS: PROCEEDINGS OF THE FLORIDA DEPARTMENT OF TRANSPORTATION/FEDERAL HIGHWAY ADMINISTRATION TRANSPORTATION-RELATED WILDLIFE MORTALITY SEMINAR; 1996 APRIL 30-MAY 2; ORLANDO, FL. FHWA-PD-96-041. U.S. DEPARTMENT OF TRANSPORTATION, FEDERAL HIGHWAY ADMINISTRATION, WASHINGTON, DC.

2707. LEHNERT, M. E., L. A. ROMIN and J. A. BISSONETTE. 1996. MULE DEER-HIGHWAY MORTALITY IN NORTHEASTERN UTAH: CAUSES, PATTERNS, AND A NEW MITIGATIVE TECHNIQUE. IN: EVINK GL, GARRETT P, ZEIGLER D, BERRY J, EDITORS. TRENDS IN ADDRESSING TRANSPORTATION RELATED WLDLIFE MORTALITY: PROCEEDINGS OF THE TRANSPORTATION RELATED WILDLIFE MORTALITY SEMINAR. STATE OF FLORIDA, DEPARTMENT OF TRANSPORTATION, ENVIRONMENTAL MANAGEMENT OFFICE, TALLAHASSEE, FLORIDA.

2708. LEHNERT, M. E. and J. A. BISSONETTE. 1997. EFFECTIVENESS OF HIGHWAY CROSSWALK STRUCTURES AT REDUCING DEER-VEHICLE COLLISIONS. WILDLIFE SOCIETY BULLETIN 25:809-818.

2709. LEHTIMAKI, R. 1981. FENCES FOR PROTECTION OF TRAFFIC AND DEER. LIIKENNETURVA 37:1-14.

2710. LEHTINEN, S. A. 1983. MOVEMENTS AND HABITAT USE OF RUFFED GROUSE IN THE BRIDGER MOUNTAINS, MONTANA. M.S. THESIS, MONTANA STATE UNIVERSITY, BOZEMAN, MT. 96 PP.

2711. LEIGHTON, D. 1988. HELPING THE ANIMALS CROSS THE ROAD. CANADIAN GEOGRAPHIC JOURNAL 108:22-28.

2712. LEIMGRUBER, P., W. J. MCSHEA and J. H. RAPPOLE. 1994. PREDATION ON ARTIFICIAL NESTS IN LARGE FOREST BLOCKS. J. WLDL. MANAGE. 58 (2):254-60.

2713. LEIMGRUBER, P., W. J. MCSHEA and G. D. SCHNELL. 1996. CHANGES IN FOREST COMPOSITION AND BIRD COMMUNITIES WITH DISTANCE FROM ROADS. BULLETIN OF THE ECOLOGICAL SOCIETY OF AMERICA 77(3 2):1-259.

2714. LEININGER, W. C. and G. F. PAYNE. 1979. THE EFFECTS OF OFF-ROAD VEHICLE TRAVEL ON RANGELAND IN SOUTHEAST MONTANA. MONTANA AGRICULTURAL EXPERIMENT STATION, MONTANA STATE UNIVERSITY. BOZEMAN, MONTANA. RESEARCH REPORT 153. 47PP.

2715. LELIEVRE, M. and J. B. SERODES. 1995. A NEW APPROACH FOR THE IDENTIFICATION OF ENVIRONMENT ISSUES AT STAKE IN A ROAD PROJECT. JOURNAL OF ENVIRONMENTAL MANAGEMENT 44 (3):221-31.

2716. LEMKE, T. O. 1975. MOVEMENT AND SEASONAL RANGES OF THE BURDETTE CREEK ELK HERD, AND AN INVESTIGATION OF SPORT HUNTING. M.S. THESIS, UNIVERSITY OF MONTANA, MISSOULA, MT. 127 PP.

2717. LEMON, V. C. 1986. ASSATEAGUE ISLAND: DYNAMICS AND MANAGEMENT POLICY. DISSERTATION, UNIVERSITY OF MARYLAND, COLLEGE PARK, MARYLAND. 128PP.

2718. LENG-EE, P. 1966. THE CONSERVATION OF PROTECTED LARGE MAMMALS IN THAILAND. M.S. THESIS, UNIVERSITY OF MONTANA, MISSOULA, MT. 114 PP.

2719. LENS, L. and A. A. DHONDT. 1994. EFFECTS OF HABITAT FRAGMENTATION ON THE TIMING OF CRESTED TIT PARUS CRISTATUS NATAL DISPERSAL. IBIS $136(2): 147-52$. 
2720. LENTFER, J. W. 1954. A TWO-YEAR STUDY OF THE ROCKY MOUNTAIN GOAT IN THE CRAZY MOUNTAINS, MONTANA. M.S. THESIS, MONTANA STATE COLLEGE, BOZEMAN, MT. 40 PP.

2721. LEONARD, R. D., R. BRENEMAN and R. FREY. 1990. A CASE HISTORY OF GRIZZLY BEAR MANAGEMENT IN THE SLIMS RIVER AREA, KLUANE NATIONAL PARK RESERVE, YUKON. INT. CONF. BEAR RES. AND MANAGE. 8:113-23.

2722. LEONARD, R. M. and E. B. FISH. 1974. AN AERIAL PHOTOGRAPHIC TECHNIQUE FOR CENSUSING LESSER SANDHILL CRANES. WILDL. SOC. BULL. 2 (4):191-5

2723. LEOPOLD, A. S. and F. F. DARLING. 1953. EFFECTS OF LAND USE ON MOOSE AND CARIBOU IN ALASKA. TRANS. N. AMER. WILDL. NAT. RESOUR. CONF. 18:553-562.

2724. LEOPOLD, L. B., F. E. CLARKE, B. B. HANSHAW and J. R. BALSLEY. 1971. A PROCEDURE FOR EVALUATING ENVIRONMENTAL IMPACT. U.S. GEOLOGICAL SURVEY. GEOLOGICAL SURVEY CIRCULAR 645

2725. LEPSCHI, B. J. 1992. BIRDS KILLED ON A PRIMARY ROAD IN SOUTHERN NEW SOUTH WALES. CORELLA 16(3):75-77.

2726. LEPTICH, D. J. and P. ZAGER. 1991. ROAD ACCESS MANAGEMENT EFFECTS ON ELK MORTALITY AND POPULATION DYNAMICS. PAGES 126-131 IN A. G. CHRISTENSEN, L. J. LYON, AND T. N. LONNER, COMPILERS. PROCEEDINGS OF THE ELK VULNERABILITY SYMPOSIUM. MONTANA STATE UNIVERSITY, BOZEMAN, MONTANA.

2727. LERE, M. E. 1982. THE LONG TERM EFFECTIVENESS OF 3 TYPES OF STREAM IMPROVEMENT STRUCTURES INSTALLED IN MONTANA STREAMS. M.S. THESIS, MONTANA STATE UNIVERSITY, BOZEMAN, MT. 99 PP.

2728. LESLIE, D. M. JR. 1977. TITLE UNKNOWN. M.S. THESIS, UNIV. NEV. (LAS VEGAS).100PP.

2729. LESLIE, D. M. JR. and C. L. DOUGLAS. 1980. HUMAN DISTURBANCE AT WATER SOURCES OF DESERT BIGHORN SHEEP. WILDLIFE SOCIETY BULLETIN 8:284-290.

2730. LESLIE, D. M. JR. and C. L. DOUGLAS. 1986. MODELING DEMOGRAPHICS OF BIGHORN SHEEP: CURRENT ABILITIES AND MISSING LINKS. TRANS. N. AMER. WILDL. NAT. RESOUR. CONF. 51:62-73.

2731. LESTER, A. N. 1980. NUMERICAL RESPONSE OF WOODPECKERS AND THEIR EFFECT ON MORTALITY OF MOUNTAIN PINE BEETLES IN LODGEPOLEPINE IN NORTHWESTERN MONTANA. M.S. THESIS, UNIVERSITY OF MONTANA, MISSOULA, MT. 103 PP.

2732. LEVENSON, H. and J. R. KOPLIN. 1984. EFFECTS OF HUMAN ACTIVITY ON PRODUCTIVITY OF NESTING OSPREYS. JOURNAL OF WLDLIFE MANAGEMENT 48:1374-1377.

2733. LEWIS, A. D. 1989. ROAD-KILLS AND OTHER RECORDS OF MAINLY SMALLER MAMMALS FROM KENYA: DATA FOR A KENYAN MAMMAL ATLAS. EANHS (EAST AFRRICAN NATURAL HISTORY SOCIETY) BULLETIN 19(2):20-22.

2734. LEWIS, S. L. 1967. PHYSICAL FACTORS INFLUENCING FISH POPULATIONS IN POOLS OF A TROUT STREAM. M.S. THESIS, MONTANA STATE UNIVERSITY, BOZEMAN, MT. 34 PP.

2735. LEWIS, S. T. 1998. EVALUATION OF HABITAT USE BY A TRANSPLANTED BIGHORN SHEEP HERD IN THE THEODORE ROOSEVELT NATIONAL PARK. M.S. THESIS, MONTANA STATE UNIVERSITY, BOZEMAN, MT. 65 PP.

2736. LEWIS, W. M., G. E. GUNNING, E. LYLES and W. L. BRIDGES. 1961. FOOD CHOICE OF LARGEMOUTH BASS AS A FUNCTION OF AVAILABILITY AND VULNERABILITY OF FOOD ITEMS. TRANSACTIONS OF THE AMERICAN FISHERIES SOCIETY 90:277-280.

2737. LI, X., M. YIQING, G. ZHONGXIN and L. FUYUAN. 1994. CHARACTERISTICS OF DENS AND SELECTION OF DENNING HABITAT FOR BEARS IN THE SOUTH XIAOXINGANLING MOUNTAINS, CHINA. INT. CONF. BEAR RES. AND MANAGE. 9:357-62.

2738. LICHT, D. S. and S. H. FRITTS. 1994. GRAY WOLF (CANIS LUPUS) OCCURRENCES IN THE DAKOTAS. AMERICAN MIDLAND NATURALIST 132 (1):74-81. 
2739. LICHTHARDT, J. J. 1986. EFFECTS OF SOIL TEXTURE AND SALINITY ON THE ESTABLISHMENT AND MORPHOLOGY OF TWELVE RANGE GRASSES. M.S. THESIS, MONTANA STATE UNIVERSITY, BOZEMAN, MT. 119 PP.

2740. LIDDLE, M. J. 1991. RECREATION ECOLOGY: EFFECTS OF TRAMPLING ON PLANTS AND CORALS. TRENDS IN ECOLOGY AND EVOLUTION (TREE) 6:13-17.

2741. LIEB, J. W. 1981. ACTIVITY, HEART RATE, AND ASSOCIATED ENERGY EXPENDITURE OF ELK IN WESTERN MONTANA. DISSERTATION, UNIVERSITY OF MONTANA, MISSOULA, MONTANA, USA. 239PP.

2742. LIEBELT, J. E. 1968. A SEROLOGICAL STUDY OF CUTTHROAT TROUT (SALMO CLARKI) FROM TRIBUTARIES AND THE OUTLET OF YELLOWSTONE LAKE. M.S. THESIS, MONTANA STATE UNIVERSITY, BOZEMAN, MT. 15 PP.

2743. LIEBELT, J. E. 1970. STUDIES ON THE BEHAVIOR AND LIFE HISTORY OF THE MOUNTAIN WHITEFISH (PROSOPIUM WILLIAMSONI GIRARD). PH.D. DISSERTATION, MONTANA STATE UNIVERSITY, BOZEMAN, MT. 45 PP.

2744. LIGHT, J. T. JR. 1970. A PROGRESS REPORT ON BIGHORN HABITAT MANAGEMENT IN THE SAN BERNADINO NATIONAL FOREST. TRANS. DESERT BIGHORN COUNCIL 14:9-13.

2745. LIGTVOET, W. and W. A. VAN. 1994. THE COLONIZATION OF THE ISLAND OF NOORD-BEVELAND (THE NETHERLANDS) BY THE COMMON VOLE MICROTUS ARVALIS, AND ITS CONSEQUENCES FOR THE ROOT VOLE M. OECONOMUS. LUTRA $37(1): 1-28$.

2746. LIKNES, G. A. 1981. THE FLUVIAL ARCTIC GRAYLING (THYMALLUS ARCTICUS) OF THE UPPER BIG HOLE RIVER DRAINAGE, MONTANA. M.S. THESIS, MONTANA STATE UNIVERSITY, BOZEMAN, MT. 59 PP.

2747. LILL, K., K. GRABOW and W. WIMMER. 1997. MONACHA CARTUSIANA (O.F. MUELLER 1774) IN SOUTHEAST LOWER SAXONY (GASTROPODA: HYGROMIIDAE). MITTEILUNGEN DER DEUTSCHEN MALAKOZOOLOGISCHEN GESELLSCHAFT 59:19-24.

2748. LIME, D. W. and C. T. CUSHWA. 1969. WILDLIFE ESTHETICS AND AUTO CAMPERS IN THE SUPERIOR NATIONAL FOREST. U.S. FOREST SERVICE. RESEARCH PAPER NC-32. 8PP.

2749. LIMPENS, H.-J. G. and K. KAPTEYN. 1991. BATS, THEIR BEHAVIOUR AND LINEAR LANDSCAPE ELEMENTS. MYOTIS MITTEILUNGSBLATT FUER FLEDERMAUSKUNDLER $9: 39-48$.

2750. LINDENMAYER, D. B. 1994. WILDLIFE CORRIDORS AND THE MITIGATION OF LOGGING IMPACTS ON FAUNA IN WOOD-PRODUCTION FORESTS IN SOUTH-EASTERN AUSTRALIA: A REVIEW. WILDLIFE RESEARCH 21 (3):323-40.

2751. LINDENMAYER, D. B., R. B. CUNNINGHAM, C. F. DONNELLY, B. E. TRIGGS and M. BELVEDERE. 1994. FACTORS INFLUENCING THE OCCURRENCE OF MAMMALS IN RETAINED LINEAR STRIPS (WILDLIFE CORRIDORS) AND CONTIGUOUS STANDS OF MONTANE ASH FOREST IN THE CENTRAL HIGHLANDS OF VICTORIA, SOUTHEASTERN AUSTRALIA. FOREST ECOLOGY AND MANAGEMENT 67(1-3):113-133.

2752. LINDENMAYER, D. B. and R. C. LACY. 1995. METAPOPULATION VIABILITY OF ARBOREAL MARSUPIALS IN FRAGMENTED OLD-GROWTH FORESTS: COMPARISON AMONG SPECIES. ECOLOGICAL APPLICATIONS 5 (1):183-99.

2753. LINDENMAYER, D. B. and R. C. LACY. 1995. METAPOPULATION VIABILITY OF LEADBEATER'S POSSUM, GYMNOBELIDEUS LEADBEATERI, IN FRAGMENTED OLD-GROWTH FORESTS. ECOLOGICAL APPLICATIONS 5 (1):164-82.

2754. LINDENMAYER, D. B. and H. A. NIX. 1993. ECOLOGICAL PRINCIPLES FOR THE DESIGN OF WILDLIFE CORRIDORS. CONSERVATION BIOLOGY $7(3): 627-30$.

2755. LINDENMAYER, D. 1993. WILDLIFE CORRIDORS AND THE MITIGATION OF LOGGING IMPACTS ON FAUNA IN WOOD PRODUCTION FORESTS IN SOUTH-EASTERN AUSTRALIA. WORKING PAPER / AUSTRALIAN NATIONAL UNIVERSITY, CENTRE FOR RESOURCE AND ENVIRONMENTAL STUDIES: WORKING PAPER (AUSTRALIAN NATIONAL UNIVERSITY. CENTRE FOR RESOURCE AND ENVIRONMENTAL STUDIES) 1993/4. AUSTRALIAN NATIONAL UNIVERSITY, CENTRE FOR RESOURCE AND ENVIRONMENTAL STUDIES, CANBERRA. 
2756. LINDZEY, J. S., G. L. ALT, C. R. MCLAUGHLIN and W. S. KORDEK. 1983. POPULATION RESPONSE OF PENNSYLVANIA BLACK BEARS TO HUNTING. INT. CONF. BEAR RES. AND MANAGE. 5:34-9.

2757. LINEHAN, J. R. 1992. WILDLIFE CORRIDOR DELINEATION FOR FISHER AND OTTER IN CENTRAL MASSACHUSETTS DEVELOPING A NETWORK APPROACH.

2758. LING, R. W., J. P. VANAMBERG and J. K. WERNER. 1986. POND ACIDITY AND ITS RELATIONSHIP TO LARVAL DEVELOPMENT OF AMBYSTOMA MACULATUM AND RANA SYLVATICA IN UPPER MICHIGAN. JOURNAL OF HERPETOLOGY 20:230-236.

2759. LINNELL, J. D. C. and R. ANDERSEN. 1995. SITE TENACITY IN ROE DEER: SHORT-TERM EFFECTS OF LOGGING. WILDL. SOC. BULL. 23 (1):31-5.

2760. LINSDALE, J. M. 1929. ROADWAYS AS THEY AFFECT BIRD LIFE. CONDOR 31:143-145.

2761. LISSNER, A. L., G. L. TAGHON, D. R. DIENER, S. C. SCHROETER and J. D. DIXON. 1991. RECOLONIZATION OF DEEP-WATER HARD-SUBSTRATE COMMUNITIES: POTENTIAL IMPACTS FROM OIL AND GAS DEVELOPMENT. ECOL. APPL. 1:258-267.

2762. LITTLE, C. E. 1990. GREENWAYS FOR AMERICA. JOHNS HOPKINS UNIVERSITY PRESS., BALTIMORE, MD.

2763. LITTLEBOY, G. 1997. DEVELOPMENT OF A WILDLIFE CORRIDOR PLANNING MODEL. ST. LUCIA, QLD..

2764. LITVAITIS, J. A. 1993. RESPONSE OF EARLY SUCCESSIONAL VERTEBRATES TO HISTORIC CHANGES IN LAND USE. CONSERVATION BIOLOGY 7 (4):866-73.

2765. LIU, Y. 1993. INTERNATIONAL HUNTING AND THE INVOLVEMENT OF LOCAL PEOPLE, DULAN, QINGHAI, PEOPLE'S REPUBLIC OF CHINA. M.S. THESIS, UNIVERSITY OF MONTANA, MISSOULA, MT. 73 PP.

2766. LIVEZEK, K. B. 1991. HOME RANGE HABITAT USE DISTURBANCE AND MORTALITY OF COLUMBIAN BLACK-TAILED DEER IN MENDOCINO NATIONAL FOREST. CALIFORNIA FISH AND GAME 77:201-209.

2767. LIVEZEY, B. C. 1980. EFFECTS OF SELECTED OBSERVER-RELATED FACTORS ON FATES OF DUCK NESTS. WILDL. SOC. BULL. 8 (2):123-8.

2768. LIVEZEY, K. B. 1979. SOCIAL BEHAVIOR OF ROCKY MOUNTAIN ELKAT THENATIONAL BISON RANGE. M.S. THESIS, UNIVERSITY OF MONTANA, MISSOULA, MT. 143 PP.

2769. LIVINGSTON, S. A., C. S. TODD, W. B. KROHN and R. B. OWEN. 1990. HABITAT MODELS FOR NESTING BALD EAGLES IN MAINE. J. WILDL. MANAGE. 54 (4):644-53.

2770. LIZANA, A. M. 1992. PROVISIONAL REPORT OF THE MORTALITY OF VERTEBRATES ON THE ROADS OF SALAMANCA PROVINCE, WITH ISOLATED DATA FROM SIERRA GREDOS AND ZAMORA PROVINCE, SEPTEMBER 1991. PAGES 115-117 IN LOPEZ,REDONDO, EDITOR. I JORNADAS PARA EL ESTUDIO Y PREVENCION DE LA MORTALIDAD DE VERTEBRADOS EN CARRETERAS, MADRID, 5 Y 6 DE OCTUBRE DE 1991. TOMO 2. [SESSIONS IN THE STUDY OF PREVENTION OF ROAD MORTALITIES OF VERTEBRATES, MADRID, 5 AND 6 OCTOBER, 1991. VOLUME 2.]. COORDINADORA DE ORGANIZACCIONES DE DEFENSA, AMBIENTAL, MADRID.

2771. LIZANA, M. 1993. MORTALITY OF AMPHIBIANS AND REPTILES ON HIGHWAYS: REPORT OF THE STUDY AHE-CODA. BOLETIN DE LA ASOCIACION HERPETOLOGICA ESPANOLA 1993:37-41.

2772. LLOYD, K. and S. FLECK. 1977. SOME ASPECTS OF THE ECOLOGY OF BLACK AND GRIZZLY BEARS IN SOUTHEASTERN BRITISH COLUMBIA. 55PP

2773. LOBUONO, L. P. 1988. ALLIGATOR ALLEY: PROTECTING NATURAL HABITAT. JOURNAL OF THE FLORIDA ENGINEERING SOCIETY FEBRUARY:14-16.

2774. LOCKARD, L. L. 1974. SOME ENVIRONMENTAL INFLUENCES ON EGG PRODUCTION IN BROWN TROUT FROM MONTANA STREAMS. M.S. THESIS, MONTANA STATE UNIVERSITY, BOZEMAN, MT. 28 PP. 
2775. LOCKHART, M. J., T. P. MCENEANEY and R. PHILLIPS. 1978. EFFECTS OF COAL EXTRACTION AND RELATED DEVELOPMENT ON WILLIFE POPULATIONS. ANN. PROG. REPT, WLDLF RES WORK UNIT., 19 PP.

2776. LODICO, N. J. 1973. ENVIRONMENTAL EFFECTS OF OFF-ROAD VEHICLES: A REVIEW OF THE LITERATURE. U.S.D.I. OFFICE OF THE SECRETARY. WASHINGTON, D.C. BIBLIOGRAPHY SERIES NO. 29

2777. LODICO, N. J. 1973. ENVIRONMENTAL EFFECTS OF VEHICLES: A REVIEW OF THE LITERATURE. U.S.D.I. RESEARCH SERVICES BRANCH, BIBLIOGRAPHIC SERVICE, OFFICE OF LIBRARY SERVICES. WASHINGTON, D.C. BIBLIOGRAPHY SERIES NO. 29. 112PP.

2778. LOEGERING, J. P. and J. D. FRASER. 1995. FACTORS AFFECTING PIPING PLOVER CHICK SURVIVAL IN DIFFERENT BROOD-REARING HABITATS . J. WILDL. MANAGE. 59 (4):646-55.

2779. LOEGERING, J. P. and J. D. FRASER. 1991. HUMAN IMPACTS ON BARRIER ISLAND PIPING PLOVERS. VA. J. SCI. $42: 172$.

2780. LOEWEN, A. 1967. REPORT ON THE USE OF SALT TO CONTROL SHEEP IN THE MIETTE AREA. JASPER NATIONAL PARK, PARKS CANADA, CALGARY. UNPUBLISHED REPORT.

2781. LOFT, E. R. and J. W. MENKE.: 1984. DEER USE AND HABITAT CHARACTERISTICS OF TRANSMISSION-LINE CORRIDORS IN A DOUGLAS-FIR FOREST. J. WILDL. MANAGE. 48(4):1311-6.

2782. LOGAN, K., L. SWEANOR and M. G. HORNOCKER. 1996. CHAPTER 3. COUGARPOPULATION DYNAMICS. P 22-113. IN: LOGAN KA, SWEANOR LL, RUTH TK, HORNOCKER MG. COUGARS OF THE SAN ANDRES MOUNTAINS, NEW MEXICO. HORNOCKER WILDLIFE INSTITUTE., P.O. BOX 3246, UNIVERSITY OF IDAHO, MOSCOW IDAHO 83843.

2783. LOGAN KA, I. L. S. R. 1986. CHARACTERISTICS OF A HUNTED MOUNTAIN LION POPULATION IN WYOMING. J. WILDL. MANAGE. 50 (4):648-54.

2784. LOGAN, S. 1986. TRANS CANADA HIGHWAY PHASE IIIA WILDLIFE STUDY. EFFECTS OF TRANSPORTATION. PARKS CANADA, CALGARY. UNPUBLISHED REPORT.

2785. LOGAN, S. M. 1961. WINTER OBSERVATIONS ON TROUT AND BOTTOM ORGANISMS IN BRIDGER CREEK SOUTHWESTERN MONTANA. M.S. THESIS, MONTANA STATE COLLEGE, BOZEMAN, MT. 30 PP.

2786. LOGAN, T. and G. EVINK. 1985. SAFER TRAVEL FOR THE FLORIDA PANTHER. FLORIDA NATURALIST 58(1):6-7.

2787. LOGAN T, E. G. 1985. SAFER TRAVEL FOR THE PANTHER. FLORIDA NAT. 58 (1):6-7.

2788. LOGGERS, C. O. 1990. FOOD HABITS AND POPULATION CHARACTERISTICS OF DORCAS GAZELLES, AND DISTRIBUTIONS AND STATUSES OF WLD UNGULATES IN MOROCCO. M.S. THESIS, UNIVERSITY OF MONTANA, MISSOULA, MT. 88 PP.

2789. LOHR, S. C. 1993. WETTED STREAM CHANNEL, FISH-FOOD ORGANISMS AND TROUT RELATIVE TO THE WETTED PERIMETER INFLECTION POINT INSTREAM FLOW METHOD. PH.D. DISSERTATION, MONTANA STATE UNIVERSITY, BOZEMAN, MT. 246 PP.

2790. LOKEMOEN, J. T., H. A. DOTY, D. E. SHARP and J. E. NEAVILLE. 1982. ELECTRIC FENCES TO REDUCE MAMMALIAN PREDATION ON WATERFOWL NESTS. WILDL. SOC. BULL. 10 (4):318-23.

2791. LOKEMOEN, J. T., H. F. DUEBBERT and D. E. SHARP. 1990. HOMING AND REPRODUCTIVE HABITS OF MALLARDS, GADWALLS, AND BLUE-WINGED TEAL. WILDL. MONOGR. 106:1-28.

2792. LOKEMOEN, J. T. 1962. THE PRODUCTIVITY OF THE RED-HEAD (AYTHYA AMERICANA) IN THE FLATHEAD VALLEY, MONTANA. M.S. THESIS, MONTANA STATE UNIVERSITY, MISSOULA, MT. 120 PP.

2793. LOKEMOEN JT, W. RO. 1993. AN ASSESSMENT OF PREDATOR BARRIERS AND PREDATOR CONTROL TO ENHANCE DUCK NEST SUCCESS ON PENINSULAS. WILDL. SOC. BULL. 21 (3):275-82. 
2794. LOMBARDO, C. A., D. M. BRANDENBURG and M. R. PELTON. 1995. HIGH INCIDENCE OF MORTALITY IN A SOUTHEASTERN BLACK BEAR POPULATION (ABSTRACT). INT. CONF. BEAR RES. AND MANAGE. 10.

2795. LONNER, T. N. 1975. ELK USE-HABITAT TYPE RELATIONSHIPS ON SUMMER AND FALL RANGE IN LONG TOM CREEK, SOUTHWESTERN MONTANA. (PRES.) ELK-LOGGING-ROADS SYMP., UNIV. OF IDAHO, MOSCOW, ID., 25 PP.

2796. LONNER, T. N. 1972. DISTRIBUTIONS AND SOME AGE RELATIONSHIPS OF KEY BROWSE PLANTS ON BIG GAME RANGE IN MONTANA. M.S. THESIS, MONTANA STATE UNIVERSITY, BOZEMAN, MT. 79 PP.

2797. LOOS, G. and P. KERLINGER. 1993. ROAD MORTALITY OF SAW-WHET AND SCREECH-OWLS ON THE CAPE MAY PENINSULA. JOURNAL OF RAPTOR RESEARCH 27 (4):210-3.

2798. LOOS, G. and P. KERLINGER. 1993. ROAD MORTALITY OF SAW-WHET AND SCREECH-OWLS ON THE CAPE MAY PENNINSULA. JOURNAL OF RAPTOR RESEARCH 27:210-213.

2799. LOPEZ, F. 1992. PROVISIONAL REPORT OF THE MORTALITY OF VERTEBRATES ON VARIOUS COASTAL ROADS OF HUELVA, SEPTEMBER 1991. PAGES 88-96 IN LOPEZ,REDONDO, EDITOR. I JORNADAS PARA EL ESTUDIO Y PREVENCION DE LA MORTALIDAD DE VERTEBRADOS EN CARRETERAS, MADRID, 5 Y 6 DE OCTUBRE DE 1991. TOMO 2. [SESSIONS IN THE STUDY OF PREVENTION OF ROAD MORTALITIES OF VERTEBRATES, MADRID, 5 AND 6 OCTOBER, 1991. VOLUME 2.]. COORDINADORA DE ORGANIZACCIONES DE DEFENSA, AMBIENTAL, MADRID.

2800. LOPEZ, R. J. 1992. HISTORICAL PERSPECTIVE OF STUDIES ON THE ENVIRONMENTAL IMPACT OF ROADS ON VERTEBRATES. PAGES 6-10 IN LOPEZ,REDONDO, EDITOR. I JORNADAS PARA EL ESTUDIO Y PREVENCION DE LA MORTALIDAD DE VERTEBRADOS EN CARRETERAS, MADRID, 5 Y 6 DE OCTUBRE DE 1991. TOMO 2. [SESSIONS IN THE STUDY OF PREVENTION OF ROAD MORTALITIES OF VERTEBRATES, MADRID, 5 AND 6 OCTOBER, 1991. VOLUME 2.]. COORDINADORA DE ORGANIZACCIONES DE DEFENSA, AMBIENTAL, MADRID.

2801. LOPEZ, R. J. 1992. PROVISIONAL REPORT OF THE MORTALITY OF VERTEBRATES ON THE ROADS OF MADRID PROVINCE, SEPTEMBER 1991. PAGES 168-179 IN LOPEZ,REDONDO, EDITOR. I JORNADAS PARA EL ESTUDIO Y PREVENCION DE LA MORTALIDAD DE VERTEBRADOS EN CARRETERAS, MADRID, 5 Y 6 DE OCTUBRE DE 1991. TOMO 2. [SESSIONS IN THE STUDY OF PREVENTION OF ROAD MORTALITIES OF VERTEBRATES, MADRID, 5 AND 6 OCTOBER, 1991. VOLUME 2.]. COORDINADORA DE ORGANIZACCIONES DE DEFENSA, AMBIENTAL, MADRID.

2802.

LOPEZ, R. J. and F. LOPEZ. 1992. PROVISIONAL RESULTS OF THE CONTINUING MORTALITY OF CHAMELEONS (CHAMAELEO CHAMAELEON) ON THE ROADS OF CADIZ, MALAGA AND HUELVA. PAGES 267-279 IN LOPEZ, REDONDO, EDITOR. I JORNADAS PARA EL ESTUDIO Y PREVENCION DE LA MORTALIDAD DE VERTEBRADOS EN CARRETERAS, MADRID, 5 Y 6 DE OCTUBRE DE 1991. TOMO 2. [SESSIONS IN THE STUDY OF PREVENTION OF ROAD MORTALITIES OF VERTEBRATES, MADRID, 5 AND 6 OCTOBER, 1991. VOLUME 2.]. COORDINADORA DE ORGANIZACCIONES DE DEFENSA, AMBIENTAL, MADRID.

2803. LORANG, K. D. 1979. WATERFOWL AND HUNTER USE OF FREEZEOUT LAKE GAME MANAGEMENT AREA, TETON COUNTY, MONTANA. M.S. THESIS, MONTANA STATE UNIVERSITY, BOZEMAN, MT. 79 PP.

2804. LORD, J. M. and D. A. NORTON. 1990. SCALE AND THE SPATIAL CONCEPT OF FRAGMENTATION. CONSERVATION BIOLOGY 4 (2):197-202.

2805. LORD, R. D. JR. 1959. COMPARISON OF EARLY MORNING AND SPOTLIGHT ROADSIDECENSUSES FOR COTTONTAILS. J. WILDL. MANAGE. 23 (4):458-60.

2806. LORD, R. D. JR. 1961. SEASONAL CHANGES IN ROADSIDE ACTIVITY OF COTTONTAILS. J. WLDL. MANAGE. 25 (2):206-9.

2807. LOSOS, E., J. HAYES, A. PHILLIPS, C. ALKIRE and D. WILOVE. 1993. TAXPAYERS DOUBLE BURDEN: FEDERAL RESOURCE SUBSIDIES AND ENDANGERED SPECIES. THE WILDERNESS SOCIETY'S BOLLE CENTER FOR ECOSYSTEM MANAGEMENT. 95PP.

2808. LOUGHRY, W. J. and C. M. MCDONOUGH. 1996. ARE ROAD KILLS VALID INDICATORS OF ARMADILLO POPULATION STRUCTURE?. AMERICAN MIDLAND NATURALIST 135(1):53-59.

2809. LOVAAS, A. L. 1957. MULE DEER FOOD HABITS AND RANGE USE IN THE LITTLE BELT MOUNTAINS, MONTANA. M.S. THESIS, MONTANA STATE COLLEGE, BOZEMAN, MT. 43 PP. 
2810. LOVALLO, M. J. 1993. BOBCAT BEHAVIOR AND HOME RANGE USE IN NORTHWEST WISCONSIN: IN REFERENCE TO CENSUSING POPULATIONS. M.S. THESIS, STEVENS POINT: UNIVERSITY OF WISCONSIN. $126 P P$.

2811. LOVALLO, M. J. and E. M. ANDERSON. 1996. BOBCAT MOVEMENTS AND HOME RANGES RELATIVE TO ROADS IN WISCONSIN. WILDL. SOC. BULL. 24:71-76.

2812. LOVE, L. D. 1964. SUMMER RECREATIONAL USE OF SELECTED NATIONAL FOREST CAMPGROUNDS IN THE CENTRAL ROCKY MOUNTAINS. FOREST SERVICE, U.S. DEPARTMENT OF AGRICULTURE.

2813. LOVVORN, J. R. and C. M. KIRKPATRICK. 1982. FIELD USE BY STAGING EASTERN GREATER SANDHILL CRANES. J. WILDL. MANAGE. 46 (1):99-108.

2814. LOWORN, J. R. and C. M. KIRKPATRICK. 1981. ROOSTING BEHAVIOR AND HABITAT OF MIGRANT GREATER SANDHILL CRANES. JOURNAL OF WILDLIFE MANAGEMENT 45:842-857.

2815. LUCKENBACH, R. A. 1978. IMPACTS OF ORVS: AN ANALYSIS OF OFF-ROAD VEHICLE USE ON DESERT AVIFAUNAS. FREMONTIA 2:3-11.

2816. LUCKENBACH, R. A. 1975. WHAT THE ORVS ARE DOING TO THE DESERT. TRANS. N. AM. WLDL. NAT. RES. CONF. 43:157-162.

2817. LUCKENBACH, R. A. 1978. AN ANALYSIS OF OFF-ROAD VEHICLE USE ON DESERT AVIFAUNAS. TRANSACTIONS OF THE NORTH AMERICAN WILDLIFE NATURAL RESOURCE CONFERENCE 43:157-162.

2818. LUCKENBACH, R. A. 1978. IMPACTS OF ORVS: AN ANALYSIS OF OFF-ROAD VEHICLE USE ON DESERT AVIFAUNAS. TRANSACTIONS OF THE NORTH AMERICAN WILDLIFE AND NATURAL RESOURCES CONFERENCE 43:157-162.

2819. LUCKENBACH, R. A. and R. B. BURY. 1983. EFFECTS OF OFF-ROAD VEHICLES ON THE BIOTA OF THE ALGODONES DUNES, IMPERIAL COUNTY, CALIFORNIA. JOURNAL OF APPLIED ECOLOGY 20(1):265-286.

2820. LUDWI, J. and T. BREMICKER. 1981. EVALUATION OF 2.4 METER FENCES AND ONE-WAY GATES FOR REDUCING DEER-VEHICLE COLLISIONS. MINNESOTA WILLIFE RESEARCH QUARTERLY 41(4):77-88.

2821. LUDWI, J. and T. BREMICKER. 1982. EVALUATION OF 2.4-METER FENCES AND ONE-WAY GATES FOR REDUCING DEER-VEHICLE COLLISIONS. MINNESOTA WLDL. RES. Q. 42(1):1-14.

2822. LUKEN, J. O., S. W. BEITING, S. K. KARETH, R. L. KUMLER, J. H. LIU and C. A. EITHER. 1992. BARK GIRDLING BY HERBIVORES AS A POTENTIAL BIOLOGICAL CONTROL OF BLACK LOCUST (ROBINIA PSEUDOACACIA) IN POWER-LINE CORRIDORS. TRANSACTIONS OF THE KENTUCKY ACADEMY OF SCIENCE 53 (1-2):26-8.

2823. LUKEN, J. O., A. C. HINTON and D. G. BAKER. 1991. ASSESSMENT OF FREQUENT CUTTING AS A PLANT COMMUNITY MANAGEMENT TECHNIQUE IN POWER-LINE CORRIDORS. ENVIRONMENTAL MANAGEMENT 15 (3):381-8.

2824. LUND, J. A. 1976. EVALUATION OF STREAM CHANNELIZATION AND MITIGATION ON THE FISHERY RESOURCES OF THE ST. REGIS RIVER, MONTANA. MONTANA COOPERATIVE FISHERY RESEARCH UNIT, U.S. FISH AND WILLIFE SERVICE, OFFICE OF BIOLOGICAL SERVICES, WASHINGTON, D.C.

2825. LUND, J. A. 1974. THE REPRODUCTION OF SALMONIDS IN THE INLETS OF ELK LAKE, MONTANA. M.S. THESIS, MONTANA STATE UNIVERSITY, BOZEMAN, MT. 43 PP.

2826. LUND, T. A. AMERICAN WILDLIFE LAW.

2827. LUOMA, S. N. 1970. A STUDY OF HIBERNATION IN THE WESTERN JUMPING MOUSE, ZAPUS PRINCEPS. M.S. THESIS, MONTANA STATE UNIVERSITY, BOZEMAN, MT. 39 PP.

2828. LUTZ, W. 1994. TRIAL RESULTS OF THE USE OF A 'DUFTZAUN' (SCENT FENCE) TO PREVENT GAME LOSSES DUE TO TRAFFIC ACCIDENTS. ZEITSCHRIFT FUER JAGDWISSENSCHAFT 40(2):91-108.

2829. LUUKKAINEN, H. 1989. ANIMAL SUBWAYS - VIEWS OF AN ANIMAL PROTECTIONIST AND GREEN POLITICIAN. PAGES 81-84 IN LANGTON,T.E.S., EDITOR. AMPHIBIANS AND ROADS. PROCEEDINGS OF THE TOAD TUNNEL 
CONFERENCE; 1989 JANUARY 7-8; RENDSBURG, FEDERAL REPUBLIC OF GERMANY ACO POLYMER PRODUCTS LTD., SHEFFORD, ENGLAND.

2830. LYDEN, R. S. 1973. FISHERMEN USE AND FISH HARVEST ON THE WEST GALLATIN RIVER, MONTANA. M.S. THESIS, MONTANA STATE UNIVERSITY, BOZEMAN, MT. 33 PP.

2831. LYNCH, G. M. 1973. INFLUENCE OF HUNTING ON AN ALBERTA MOOSE HERD. TRANS. N. AMERICAN MOOSE CONF. AND WORKSHOP 9: 123-135.

2832. LYNCH, J. C. 1977. COMPARATIVE GENETICS OF MONTANA AND ARCTIC GRAYLING, THYMALLUS ARCTICUS. M.S. THESIS, MONTANA STATE UNIVERSITY, BOZEMAN, MT. 136 PP.

2833. LYON, J. L., T. N. LONNER, J. P. WEIGAND, C. L. MARCUM, W. D. EDGE, J. D. JONES and MCCLEEREY. 1985. COORDINATING ELK AND TIMBER MANAGEMENT: FINAL REPORT OF THE MONTANA COOPERATIVE ELK-LOGGING STUDY, 1970-1985. MT W-120-R. MONTANA DEPARTMENT OF FISH, WILDLIFE, AND PARKS, BOZEMAN, MT.

2834. LYON, L. J. 1980. COORDINATING FORESTRY AND ELK MANAGEMENT. TRANS. N. AMER. WLDL. NAT. RES. CONF. 45:278-87.

2835. LYON, L. J. 1975. COORDINATING FORESTRY AND ELK MANAGEMENT IN MONTANA: INITIAL RECOMMENDATIONS. PRESENTED AT THE WLDLIFE MANAGEMENT INSTITUTE NORTH AM. WILDL. \& NAT. RESOURCE 4OTH CONF.; MAR 16-18; 1975 PITTSBURGH.

2836. LYON, L. J. 1984. FIELD TESTS OF ELKITIMBER COORDINATION GUIDELINES. USDA FOREST SERVICE RES. PAPER INT-325. 10PP.

2837. LYON, L. J. 1979. HABITAT EFFECTIVENESS FOR ELK AS INFLUENCED BY ROADS AND COVER. JOURNAL OF FORESTRY 77:658-660.

2838. LYON, L. J. 1990. HOW ELK AFFECT POLICY ON THE NATIONAL FORESTS. JOURNAL OF FORESTRY 81:592-595 + 613.

2839. LYON, L. J. 1979. INFLUENCES OF LOGGING AND WEATHER ON ELK DISTRIBUTION IN WESTERN MONTANA. USDA FOR. SERV. RES. PAP. INT-236. 11PP.

2840. LYON, L. J. 1966. PROBLEMS OF HABITAT MANAGEMENT FOR DEER AND ELK IN THE NORTHERN FORESTS. USDA FOR. SERV. RES. PAP. INT-24.

2841. LYON, L. J. 1983. ROAD DENSITY MODELS DESCRIBING HABITAT EFFECTIVENESS FOR ELK. JOURNAL OF FORESTRY $81: 592-595$

2842. LYON, L. J. 1983. ROAD DENSITY MODELS DESCRIBING HABITAT EFFECTIVENESS FOR ELK. BUGLE 7:7-16.

2843. LYON, L. J. and J. V. BASILE. 1979. INFLUENCES OF TIMBER HARVESTING AND RESIDUE MANAGEMENT ON BIG GAME. P 441-53. IN: SYMPOSIUM PROC. ENVIRONMENTAL CONSEQUENCES OF TIMBER HARVESTING SYMP.; SEP 11-13; 1979MISSOULA, MONTANA. USDA ET AL..

2844. LYON, L. J. and J. V. BASILLE. 1979. ENVIRONMENTAL CONSEQUENCES OF TIMBER HARVESTING SYMP. 1979 SEP 11-1979 SEP 13; MISSOULA, MONTANA. USDA ET AL.

2845. LYON, L. J. and J. E. CANFIELD. 1991. HABITAT SELECTION BY ROCKY MOUNTAIN ELK UNDER HUNTING SEASON STRESS. P 99-105. IN: CHRISTENSEN, A.G.//LYON, L.J.//LONNER, T.N. (COMPS). PROCEEDINGS: ELK VULNERABILITY SYMPOSIUM; 10-12 APR.1991. BOZEMAN, MT. MONTANA STATE UNIVERSITY, BOZEMAN, MT.

2846. LYON, L. J. and J. E. CANFIELD. 1991. HABITAT SELECTIONS BY ROCKY MOUNTAIN ELK UNDER HUNTING SEASON STRESS. PAGES 99-105 IN A. G. CHRISTENSEN, L. J. LYON, AND T. N. LONNER, COMPILERS. PROCEEDINGS OF THE ELK VULNERABILITY SYMPOSIUM. MONTANA STATE UNIVERSITY, BOZEMAN, MONTANA.

2847. LYON, L. J. and A. G. CHRISTENSEN. 1992. A PARTIAL GLOSSARY OF ELKMANAGEMENT TERMS. U.S. FOREST SERVICE, INTERMOUNTAIN RESEARCH STATION. OGDEN, UTAH. GENERAL TECHNICAL REPORT INT-GTR-288. 
6PP.

2848. LYON, L. J., T. N. LONNER, J. P. WEIGAND, C. L. MARCUM, W. D. EDGE, J. D. JONES and D. W. MCCLEEREY. 1985 COORDINATING ELK AND TIMBER MANAGEMENT: FINAL REPORT OF THE MONTANA COOPERATIVE ELK-LOGGING STUDY 1970-1985. MONTANA DEPARTMENT OF FISH, WLDLIFE AND PARKS, HELENA. 53PP.

2849. LYON, L. J. and A. L. WARD. 1982. ELK AND LAND MANAGEMENT (CHAPTER 11). P 443-77. IN: THOMAS, J.W., TOWEILL, D.E., (EDITORS). ELK OF NORTH AMERICA: ECOLOGY AND MANAGEMENT. HARRISBURG, PA: STACKPOLE BOOKS.

2850. LYON, L. J. and C. E. JENSEN. 1980. MANAGEMENT IMPLICATIONS OF ELK AND DEER USE OF CLEAR-CUTS IN MONTANA. JOURNAL OF WLDLIFE MANAGEMENT 44:352-362.

2851. LYSTER, S. 1985. INTERNATIONAL. WLDLIFE LAW AN ANALYSIS OF INTERNATIONAL TREATIES CONCERNED WITH THE CONSERVATION OF WLDLIFE. UNIVERSITY OF CAMBRIDGE, RESEARCH CENTRE FOR INTERNATIONAL LAW, NTERNATIONAL UNION FOR CONSERVATION OF NATURE AND NATURAL RESOURCES. GROTIUS PUBS, CAMBRIDGE.

2852. MACARTHUR, R. A. and V. GEIST. 1986. CARDIAC RESPONSE OF BIGHORN SHEEP TO TRAPPING AND RADIO INSTRUMENTATION. CANADIAN JOURNAL OF ZOOLOGY 64:1197-1200.

2853. MACARTHUR, R. A., V. GEIST and R. H. JOHNSTON. 1982. CARDIAC AND BEHAVIORAL RESPONSES OF MOUNTAIN SHEEP TO HUMAN DISTURBANCE. JOURNAL OF WILDLIFE MANAGEMENT 46:351-358.

2854. MACARTHUR, R. A., R. H. JOHNSTON and V. GEIST. 1979. FACTORS INFLUENCING HEART RATE IN FREE-RANGING BIGHORN SHEEP: A PHYSIOLOGICAL APPROACH TO THE STUDY OF WILDLIFE HARASSMENT. CANADIAN JOURNAL OF ZOOLOGY 57:2010-2021.

2855. MACCALLUM, B. 1988. SEASONAL AND SPATIAL DISTRIBUTION OF BIGHORN SHEEP AT AN OPEN PIT MINING SITE IN THE ALBERTA FOOTHILLS. P 106-20.IN: SAMUEL WM, ED. BIENNIAL SYMPOSIUM OF THE NORTHERN WILD SHEEP AND GOAT COUNCIL; 11-15 APR. 1988; BANFF, ALBERTA. NORTHERN WILD SHEEP AND GOAT COUNCIL.

2856. MACCALLUM, N. B. 1991. BIGHORN SHEEP USE OF AN OPEN PIT COAL MINE IN THE FOOTHILLS OF ALBERTA. ENVIRONMENTAL SCIENCE THESIS, FACULTY OF EVDS, UNIVERSITY OF CALGARY. 202PP.

2857. MACDONALD, L. A. 1998. CITIZEN PARTICIPATION IN TRANSPORTATION PLANNING-THE HABITAT FOR BEARS CAMPAIGN. PAGES 229-233 IN EVINK,G., ZIEGLER,D., GARRETT,P., AND BERRY,J., EDITORS. PROCEEDINGS OF THE INTERNATIONAL CONFERENCE ON WILDLIFE ECOLOGY AND TRANSPORTATION; 1998 FEBRUARY 10-12; FT. MYERS, FL FLORIDA DEPARTMENT OF TRANSPORTATION, TALLAHASSEE, FL.

2858. MACE, R., K. AUNE, W. KASWORM, R. KLAVER and J. CLAAR. 1987. INCIDENCE OF HUMAN CONFLICTS BY RESEARCH GRIZZLY BEARS. WILDL. SOC. BULL. 15 (2):170-3.

2859. MACE, R. and J. WALLER. 1997. FINAL REPORT: GRIZZLY BEAR ECOLOGY IN THE SWAN MOUNTAINS, MONTANA. MONTANA FISH, WLDLIFE AND PARKS. HELENA, MONTANA . 191PP.

2860. MACE, R. D. and T. L. MANLEY. 1992. SOUTH FORK FLATHEAD RIVER GRIZZLY BEAR PROJECT. PROGRESS REPORT FOR 1992. MONTANA DEPT. OF FISH, WILDLIFE AND PARKS UNPUBLISHED WLDLIFE REPORT:34PP.

2861. MACE, R. D., T. L. MANLEY and K. E. AUNE. 1994. FACTORS AFFECTING THE PHOTOGRAPHIC DETECTION RATE OF GRIZZLY BEARS IN THE SWAN MOUNTAINS, MONTANA. INT. CONF. BEAR RES. AND MANAGE. 9:245-51.

2862. MACE, R. D., T. L. MANLEY and S. RILEY. 1992. GRIZZLY BEAR RESPONSE TO FOREST ROAD DENSITIES AND TIMBER MANAGEMENT IN A MULTIPLE USE ENVIRONMENT, RESEARCH UPDATE. MONTANA DEPARTMENT OF FISH, WILDLIFE AND PARKS . KALISPELL, MONTANA. 17PP.

2863. MACE, R. D. and J. S. WALLER. 1996. GRIZZLY BEAR DISTRIBUTION AND HUMAN CONFLICTS WITHIN JEWEL BASIN HIKING AREA: SWAN MOUNTAINS, MONTANA. WLDLIFE SOCIETY BULL. 24 (3):461-7 
2864. MACE, R. U. 1974. APPLICATION OF VEHICLE RESTRICTIONS IN WLDLIFE MANAGEMENT. PROCEEDINGS OF THE WESTERN ASSOCIATION OF STATE GAME AND FISH COMMISSIONS 54:205-210.

2865. MACE, R. D. and J. S. WALLER. 1996. GRIZZLY BEAR DISTRIBUTION AND HUMAN CONFLICTS IN JEWEL BASIN HIKING AREA, SWAN MOUNTAINS, MONTANA. WILDL. SOC. BULL. 24:461-467.

2866. MACE, R. D., J. S. WALLER, T. L. MANLEY, L. J. LYON and H. ZUURING. 1996. RELATIONSHIPS. AMONG GRIZZLY BEARS, ROADS AND HABITAT IN THE SWAN MOUNTAINS, MONTANA. J. APPLIED ECOLOGY $33: 1395-1404$.

2867. MACE, R. D. 1984. IDENTIFICATION AND EVALUATION OF GRIZZLY BEAR HABITAT IN THE BOB MARSHALL WILDERNESS AREA, MONTANA. M.S. THESIS, UNIVERSITY OF MONTANA, MISSOULA, MT. 176 PP.

2868. MACGREGOR; W. G. 1977. STATUS OF THE MOUNTAIN GOAT IN BRITISH COLUMBIA. P24-8. IN: SAMUEL, W., MACGREGOR, W.G., EDS.; PROC. FIRST INTERNATIONAL MOUNTAIN GOAT SYMPOSIUM. 1977 FEB 19; KALISPELL, MONTANA.

2869. MACHAN, W. J. and R. D. FELDT. 1972. HUNTING RESULTS ON CROPLAND ADJUSTMENT PROGRAM LAND IN NORTHWESTERN INDIANA. J. WILDL. MANAGE. 36 (1):192-5.

2870. MACHUTCHON, A. G. and D. A. FERNET. 1981. SPRING FISHERIES INVESTIGATIONS OF SELECTED WATERCOURSES ALONG THE ALASKA HIGHWAY GAS PIPELINE IN SOUTHERN YUKON TERRITORY, 1981. FOOTHILLS PIPE LINES (SOUTH YUKON) LTD, CALGARY, ALBERTA.

2871. MACHUTCHON, A. G., S. HIMMER and C. A. BRYDEN. 1992. KHUTZEYMATEEN VALLEY GRIZZLY BEAR STUDY.

2872. MACINNES, C. D., R. A. DAVIS, R. N. JONES, B. C. LIEFF and A. J. PAKULAK. 1974. REPRODUCTIVE EFFICIENCY OF MCCONNELL RIVER SMALL CANADA GEESE. J. WILDL. MANAGE. 38 (4):686-707.

2873. MACINNES, C. D. and R. K. MISRA. 1972. PREDATION ON CANADA GOOSE NESTS AT MCCONNELL RIVER, NORTHWEST TERRITORIES. J. WILDL. MANAGE. 36 (2):414-22.

2874. MACIVOR, L. H. 1990. POPULATION DYNAMICS, BREEDING ECOLOGY, AND MANAGEMENT OF PIPING PLOVERS ON OUTER CAPE COD, MASSACHUSETTS. THESIS, UNIVERSITY MASSACHUSETTS, AMHERST, MASSACHUSETTS. 100PP.

2875. MACIVOR, L. H., S. M. MELVIN and C. R. GRIFFIN. 1990. EFFECTS OF RESEARCH ACTIVITY ON PIPING PLOVER NEST PREDATION. J. WILDL. MANAGE. 54 (3):443-7.

2876. MACK, J. A. 1990. BLACK BEAR DENS IN THE BEARTOOTH FACE, SOUTH-CENTRAL MONTANA. INT. CONF. BEAR RES. AND MANAGE. 8:273-7.

2877. MACK, J. A. 1988. ECOLOGY OF BLACK BEARS ON THE BEARTOOT FACE, SOUTH-CENTRAL MONTANA. M.S. THESIS, MONTANA STATE UNIVERSITY, BOZEMAN, MT. 119 PP.

2878. MACKENZIE, J. T. 1976. ON THE IMPACT OF PETROLEUM EXPLORATION AND DEVELOPMENT ON WILDLIFE IN THE ARCTIC, SUBARCTIC, AND ALPINE REGIONS. M.S. THESIS. UNIVERSITY OF CALGARY, CALGARY, AB. 120PP.

2879. MACKIE, R. J. 1981. INTERSPECIFIC RELATIONSHIPS (CHAPTER 13). P 487-507. IN: WALLMO, O.C., (EDITOR). MULE AND BLACK-TAILED DEER OF NORTH AMERICA. LINCOLN, NE: UNIVERSITY OF NEBRASKA PRESS.

2880. MACKIE, R. J., K. L. HAMLIN, C. J. KNOWLES, J. G. MUNDINGER and D. B. PYRAH. 1976-1977. STATEWIDE DEER RESEARCH. MONTANA DEPARTMENT OF FISH AND GAME.

2881. MACKIE, R. J. 1965. RANGE ECOLOGY AND RELATIONS OF MULE DEER, ELK AND CATTLE IN THE MISSOURI RIVER BREAKS, MONTANA. PH.D. DISSERTATION, MONTANA STATE UNIVERSITY, BOZEMAN, MT. 229 PP.

2882. MACNAMARA, L. G. 1951. METHODS OF POND AND LAKE CONSTRUCTION. PART II OF WATERFOWL MANAGEMENT ON SMALL AREAS. WILDL. MGT. INST., WASHINGTON, D.C., 84 PP. 
2883. MACPHEE, C. and F. J. WATTS. 1976. SWIMMING PERFORMANCE OF ARCTIC GRAYLING IN HIGHWAY CULVERTS FINAL REPORT TO U.S. FISH AND WILDLIFE SERVICE, ANCHORAGE, ALASKA. UNIVERSITY OF IDAHO, FOREST, WILDLIFE AND RANGE EXPERIMENT STATION, MOSCOW, IDAHO. CONTRACT NO. 14-16-001-5207, DATED SEPTEMBER 1, 1972, PROJECT PERIOD, SEPTEMBER 1, 1972 TO JUNE 30, 1976. BULLETIN

2884. MACPHEE, C. and F. J. WATTS. 1975. SWIMMING PERFORMANCE OF ARCTIC GRAYLING IN HIGHWAY CULVERTS PROGRESS REPORT TO U.S. FISH AND WILDLIFE SERVICE, ANCHORAGE, ALASKA. UNIVERSITY OF IDAHO, MOSCOW, IDAHO.

2885. MADDEN, E. M. 1996. PASSERINE COMMUNITIES AND BIRD-HABITAT RELATIONSHIPS ON PRESCRIBE-BURNED, MIXED GRASS PRAIRIE IN NORTH DAKOTA. M.S. THESIS, MONTANA STATE UNIVERSITY, BOZEMAN, MT. 153 PP.

2886. MADER, H. J. 1984. ANIMAL HABITAT ISOLATION BY ROADS AND AGRICULTURAL FIELDS . BIOLOGICAL CONSERVATION 29:81-96.

2887. MADER, H. J., C. SCHELL and P. KORNACKER. 1990. LINEAR BARRIERS TO ARTHROPOD MOVEMENTS IN THE LANDSCAPE. BIOLOGICAL CONSERVATION 54:209-222.

2888. MADER, T. R. 1998. TEMPORAL VARIATION IN LEOPARD SEAL PRESENCE AND PREDATION NEAR AN ANTARCTIC PENGUIN ROOKERY. M.S. THESIS, MONTANA STATE UNIVERSITY, BOZEMAN, MT. 46 PP.

2889. MADSEN, A. B. 1996. OTTER (LUTRA LUTRA) MORTALITY IN RELATION TO TRAFFIC, AND EXPERIENCE WITH NEWLY ESTABLISHED FAUNA PASSAGES AT EXISTING ROAD BRIDGES. LUTRA 39(2):76-88.

2890. MADSEN, A. B. 1990. OTTERS (LUTRA LUTRA) AND TRAFFIC. FLORA OG FAUNA 96:39-46.

2891. MADSEN, J. 1985. HABITAT SELECTION OF FARMLAND FEEDING GEESE IN WEST JUTLAND, DENMARK: AN EXAMPLE OF NICHE SHIFT. ORNIS SCANDINAVICA 16:140-144.

2892. MADSEN, J. 1985. IMPACT OF DISTURBANCES ON FIELD UTILIZATION OF PINK-FOOTED GEESE IN WEST JUTLAND, DENMÁRK. BIOLOGICAL CONSERVATION 33:53-63.

2893. MADSEN, J. 1985. IMPACT OF DISTURBANCE ON FIELD UTILIZATION OF PINK-FOOTED GEESE IN WEST JUTLAND, DENMARK. BIOLOGICAL CONSERVATION 33(1):53-63.

2894. MADSON, C. 1997. MATTERS OF LIFE AND DEATH. WYOMING WLDL. 61:28-33.

2895. MAEHR, D. S. 1992. FLORIDA PANTHER RESEARCH: FLORIDA PANTHER RECOVERY PLAN IMPLEMENTATION. FLORIDA PANTHER DISTRIBUTION AND CONSERVATION STRATEGY. FLORIDA GAME AND FRESHWATER FISH COMMISSION, [LOCATION OF PUBLICATION UNKNOWN].

2896. MAEHR, D. S. and J. A. COX. 1995. LANDSCAPE FEATURES AND PANTHERS IN FLORIDA. CONSERVATION BIOLOGY 9(5):1008-19.

2897. MAEHR, D. S., E. D. LAND and M. E. ROELKE. 1991. MORTALITY PATTERNS OF PANTHERS IN SOUTHWEST FLORIDA. PROCEEDINGS OF THE ANNUAL CONFERENCE OF THE SOUTHEASTERN ASSOCIATION OF FISH AND WLDLIFE AGENCIES 45:201-207.

2898. MAGEE, J. P. 1993. A BASIN APPROACH TO CHARACTERIZING SPAWNING AND FRY REARING HABITATS FOR WESTSLOPE CUTTHROAT TROUT IN A SEDIMENT-RICH BASIN, MONTANA. M.S. THESIS, MONTANA STATE UNIVERSITY, BOZEMAN, MT. 89 PP.

2899. MAGOUN, A. J. 1985. POPULATION CHARACTERISTICS, ECOLOGY, AND MANAGEMENT OF WOLVERINES IN NORTHWESTERN ALASKA. PH.D. THESIS. UNIV. ALASKA, FAIRBANKS, AK. 197PP.

2900. MAHN, S. 1968. GENETIC AND PHYSIOLOGICAL ASPECTS OF MATING BEHAVIOR IN JAPANESE QUAIL (COTURNIX COTURNIX JAPONICA) . PH.D. DISSERTATION, MONTANA STATE UNIVERSITY, BOZEMAN, MT. 157 PP.

2901. MAHONEY, S., B. TUCKER, S. FERGUSON, B. GREENE, E. MENCHENTON and L. RUSSELL. 1991. IMPACT OF THE HOPE BROOK GOLD MINE ON THE LA POILE CARIBOU HERD. P397-407.IN: BUTLER CE, MAHONEY SP, EDS. 4TH 
NORTH AMERICAN CARIBOU WORKSHOP PROC.; OCT 31-NOV 31989 ; ST. JOHN'S, NEWFOUNDLAND. NEWFOUNDLAND AND LABRADOR WILDLIFE DIV.

2902. MAINE COOPERATIVE WILDLIFE RESEARCH UNIT. 1983. WILDLIFE POPULATIONS UTILIZING RIGHT-OF-WAY HABITATS ALONG INTERSTATE 95 IN NORTHERN MAINE - FINAL REPORT. FHWA-ME-TP-83/5. MAINE DEPARTMENT OF TRANSPORTATION, MATERIALS AND RESEARCH DIVISION, MAINE COOPERATIVE WILDLIFE RESEARCH UNIT, BANGOR, ME.

2903. MAJ, M. E. 1983. ANALYSIS OF TRUMPETER SWAN HABITAT ON THE TARGHEE NATIONAL FOREST OF IDAHO AND WYOMING. M.S. THESIS, MONTANA STATE UNIVERSITY, BOZEMAN, MT. 102 PP.

2904. MAJUMDAR, S. K., R. P. BROOKS, F. J. BRENNER and R. W. JR. TINER. 1989. WETLANDS ECOLOGY AND CONSERVATION: EMPHASIS IN PENNSYLVANIA. PENNSYLVANIA ACADEMY OF SCIENCE. EASTON, PENNSYLVANIA.

2905. MAKEL, W. J. ALL-TERRAIN VEHICLES AND TRAIL BIKES IN THE FOREST: A MANAGEMENT APPROACH. USDA FOREST SERVICE ROCKY MOUNTAIN FOREST AND RANGE EXPERIMENTAL STATION LIBRARY.

2906. MAKELA, P. D. 1990. EFFECTS OF PRESCRIBED BURNING ON THE BURDETTE CREEK WINTER RANGE. M.S. THESIS, UNIVERSITY OF MONTANA, MISSOULA, MT. 112 PP.

2907. MALAHER, G. W. 1967. IMPROPER USE OF SNOW VEHICLES FOR HUNTING. TRANSACTIONS OF THE NORTH AMERICAN WLDLIFE AND NATURAL RESOURCES CONFERENCE 32:429-433.

2908. MALCOLM, J. M. 1982. BIRD COLLISIONS WITH A POWER TRANSMISSION LINE AND THEIR RELATION TO BOTULISM AT A MONTANA WETLAND. WILDL. SOC. BULL. 10 (4):297-304.

2909. MALIEPAARD, H. S. 1962. DEVELOPMENT OF A MOOSE HARVEST PLAN FOR THE COMMERCIAL FOREST ZONE, SASKATCHEWAN. M.S. THESIS, MONTANA STATE UNIVERSITY, MISSOULA, MT. 130 PP.

2910. MALIK, M. M. 1987. MANAGEMENT PLAN FOR WILD ARTIODACTYLS IN NORTH WEST FROTIER PROVINCE, PAKISTAN. M.S. THESIS, UNIVERSITY OF MONTANA, MISSOULA, MT. 142 PP.

2911. MALIK, M. M. 1994. WILDLIFE CONSERVATION THROUGH THE MANAGEMENT OF AVAILABLE HUMAN RESOURCES IN NWFP PAKISTAN. PH.D. DISSERTATION, UNIVERSITY OF MONTANA, MISSOULA, MT. 319 PP.

2912. MALLOY, J. C. 1981. THE EFFECTS OF 1080 BAITING ON COLUMBIAN GROUND SQUIRRELS AND NON-TARGET MAMMAL AND BIRD POPULATIONS. M.S. THESIS, UNIVERSITY OF MONTANA, MISSOULA, MT. 65 PP.

2913. MAMALIS, J. 1996. WILDLIFE USE OF HIGHWAY UNDERPASSES PHASE I \& II TRANS-CANADA HIGHWAY. PARKS CANADA, BANFF NATIONAL PARK WARDEN SERVICE, BANFF, ALBERTA.

2914. MAMALIS, J. 1995. WILDLIFE USE OF THE TRANS-CANADA HIGHWAY, PHASE III. PARKS CANADA, BANFF NATIONAL PARK WARDEN SERVICE, BANFF, ALBERTA.

2915. MANCI, K. M., D. N. GLADWIN, R. VILLELLA and M. G. CAVENDISH. 1988. EFFECTS OF AIRCRAFT NOISE AND SONIC BOOMS ON DOMESTIC ANIMALS AND WILDLIFE: A LITERATURE SYNTHESIS. U.S. FISH AND WILDL. SERV., NATL. ECOL. RES. CENT. 88PP.

2916. MANGELS, F. W. 1976. AQUATIC INSECTS IN SEDIMENT TRAPS. M.S. THESIS, MONTANA STATE UNIVERSITY, BOZEMAN, MT. 78 PP.

2917. MANITOBA, DEPT. OF NATURAL RESOURCES and A. J. DERKSEN. 1980. EVALUATION OF FISH PASSAGE THROUGH CULVERTS AT THE GOOSE CREEK ROAD CROSSING NEAR CHRURCHILL, MANITOBA IN APRIL AND MAY, 1977. MS REPORT (MANITOBA. DEPT. OF NATURAL RESOURCES) NO. 80-4.

2918. MANITOBA, MANITOBA NATURAL RESOURCES, CANADA and DEPT. OF FISHERIES AND OCEANS. 1996. MANITOBA STREAM CROSSING GUIDELINES FOR THE PROTECTION OF FISH AND FISH HABITAT. MANITOBA NATURAL RESOURCES. FISHERIES AND OCEANS CANADA, WNNIPEG, MANITOBA. 
2919. MANKIN, P. C. and R. E. WARNER. 1992. VULNERABILITY OF GROUND NESTS TO PREDATION ON AN AGRICULTURAL HABITAT ISLAND IN EAST-CENTRAL ILLINOIS. AMERICAN MIDLAND NATURALIST 128 (2):281-91.

2920. MANNAERT, P. 1978. THE MORTALITY OF SMALL ANIMALS ON ROADS. LUTRA 0(1-3):23-24.

2921. MANNAERT, P. 1979. THE MORTALITY OF SMALL MAMMALS ALONG HIGHWAYS. LUTRA 1(1-3):24-29.

2922. MANNER, J. D. 1975. THE CONTINUATION OF A STUDY OF VARIOUS CONTROL MEASURES FOR RIGHT-OF-WAY MANAGEMENT.

2923. MANSELL, W. D. 1971. ACCESSORY CORPORA LUTEA IN OVARIES OF WHITE-TAILED DEER. J. WILDL. MANAGE. 35 (2):369-74.

2924. MANSERGH, I. M. and D. J. SCOTTS. 1989. HABITAT CONTINUITY AND SOCIAL ORGANIZATION OF THE MOUNTAIN PYGMY-POSSUM RESTORED BY TUNNEL. JOURNAL OF WILDLIFE MANAGEMENT 53(3):701-707.

2925. MANTEY, J. M. and D. A. IMMELL. 1995. INFLUENCE OF ROADS ON BLACK BEAR DETECTIONS AT BAIT-STATIONS (ABSTRACT). INT. CONF. BEAR RES. AND MANAGE. 10.

2926. MANUWAL, D. A. 1968. BREEDING BIRD POPULATIONS IN THE CONIFEROUS FORESTS OF WESTERN MONTANA. PH.D. DISSERTATION, UNIVERSITY OF MONTANA, MISSSOULA, MT. 176 PP.

2927. MANVILLE, A. M. 1987. DEN SELECTION AND USE BY BLACK BEARS IN MICHIGAN'S NORTHERN LOWER PENINSULA. INT. CONF. BEAR RES. AND MANAGE. 7:317-22.

2928. MANVILLE, A. M. II. 1983. HUMAN IMPACT ON THE BLACK BEAR IN MICHIGAN'S LOWER PENINSULA. INT. CONF. BEAR RES. AND MANAGE. 5:20-33.

2929. MARBLE, H. P. 1968. RADIATION FROM BIG GAME AND BACKGROUND: A CONTROL STUDY FOR INFRARED SCANNER CENSUS. M.S. THESIS, UNIVERSITY OF MONTANA, MISSOULA, MT. 86 PP.

2930. MARCH, D. and C. ADAMS. 1973. A FRONT RANGE CONCEPT: THE NEED FOR THE NODDLES-RAMPART-SOUTH PLATTE RECREATION AREA. WILDLIFE-2000. AURORA, COLORADO. 112PP. + APPENDICIES

2931. MARCHAL-SEGAULT, D. and F. RAMADE. 1981. THE EFFECTS OF LINDANE, AN INSECTICIDE, ON HATCHING AND POSTEMBRYONIC DEVELOPMENT OF XENOPUS LAEVIS (DAUDIN) ANURAN AMPHIBIAN. ENVIRONMENTAL RESEARCH 24:250-258.

2932. MARCHANT, S. S. 1999. MINNESOTA'S RAILROAD RIGHTS-OF-WAY PRAIRIE REPORT TO THE 1999 LEGISLATURE. MINNESOTA DEPARTMENT OF NATURAL RESOURCES, SAINT PAUL, MINNESOTA. BIOLOGICAL REPORT MINNESOTA DEPT. OF NATURAL RESOURCES: BIOLOGICAL REPORT (SAINT PAUL, MINN.) NO. 61.

2933. MARCOUX, R. G. 1969. FISH POPULATIONS IN BIG SPRING CREEK, MONTANA. M.S. THESIS, MONTANA STATE UNIVERSITY, BOZEMAN, MT. 34 PP.

2934. MARCUM, C. L. 1976. HABITAT SELECTION AND USE DURING SUMMER AND FALL MONTHS BY A WESTERN MONTANA ELK HERD. PAGES 91-96 IN S. R. HIEB, EDITOR. PROCEEDINGS OF THE ELK-LOGGING-ROADS SYMPOSIUM. FORESTRY WILDLIFE AND RANGE EXPERIMENT STATION, UNIVERSITY OF IDAHO, MOSCOW, IDAHO, USA.

2935. MARCUM, C. L. 1975. SUMMER-FALL HABITAT SELECTION AND USE BY A MONTANA ELK HERD. PH.D. DISSERTATION, UNIV. MONTANA, MISSOULA, MT. 188PP.

2936. MARCUM, C. L. and W. D. EDGE. 1991. SEXUAL DIFFERENCES IN DISTRIBUTION OF ELK RELATIVE TO ROADS AND LOGGED AREAS IN WESTERN MONTANA. PAGES 142-148 IN A. G. CHRISTENSEN, L. J. LYON, AND T. N. LONNER, COMPILERS. PROCEEDINGS OF THE ELK VULNERABILITY SYMPOSIUM. MONTANA STATE UNIVERSITY, BOZEMAN, MONTANA.

2937. MARCUM, C. L., W. D. EDGE, M. D. SCOTT, J. F. LEHMKUHL and S. L. OLSON. 1984. FINAL REPORT OF THE CHAMBERLAIN CREEK ELK STUDY, 1975-1984. UNIV. OF MONTANA, SCHOOL OF FORESTRY. 
2938. MARCUM, C. L. 1975. SUMMER-FALL HABITAT SELECTION AND USE BY A WESTERN MONTANA ELK HERD. PH.D. DISSERTATION, UNIVERSITY OF MONTANA, MISSOULA, MT. 188 PP.

2939. MARCY, L. E. 1986. ENVIRONMENTAL IMPACT RESEARCH PROGRAM. IMPASSABLE WIRE FENCES: SECTION 5.2.3, U.S. ARMY CORPS OF ENGINEERS WILDLIFE RESOURCES MANAGEMENT MANUAL. WES/TR/EL-86-7. ARMY ENGINEER WATERWAYS EXPERIMENT STATION, ENVIRONMENTAL LAB, VICKSBURG, MS.

2940. MARINI, M. A., S. K. ROBINSON and E. J. HESKE. 1995. EDGE EFFECTS ON NEST PREDATION IN THE SHAWNEE NATIONAL FOREST, SOUTHERN ILLINOIS. BIOLOGICAL CONSERVATION 74(3):203-213.

2941. MARION, J. L. 1984. ECOLOGICAL CHANGES RESULTING FROM RECREATIONAL USE: A STUDY OF BACKCOUNTRY CAMPSITES IN THE BOUNDARY WATERS CANOE AREA. DISSERTATION, UNIVERSITY OF MINNESOTA, TWIN CITIES, MINNESOTA. 296PP.

2942. MARKHAM, B. J. 1976. GRANDE PRAIRIE-GRANDE CACHE TRANSPORTATION STUDY. WILDLIFE REPORT. ALBERTA FISH AND WILDLIFE DIVISION, EDMONTON. UNPUBLISHED REPORT.

2943. MARKHAM, B. J. 1978. MITIGATION OF THE EFFECTS OF PETROLEUM DEVELOPMENT ON WILDLIFE. PAPER PRESENTED AT P.I.T.S. ENVIRONMENTAL LEASE MANAGEMENT SEMINAR. HINTON, JUNE 12-26, 1978

2944. MARKHAM, D. 1996. THE SIGNIFICANCE OF SECONDARY EFFECTS FROM ROADS AND ROAD TRANSPORT ON NATURE CONSERVATION. ENGLISH NATURE REPORTS 78(MARCH):1-A4.

2945. MARKS, J. S. 1984. NEST SITE CHARACTERISTICS, REPRODUCTIVE SUCCESS, AND FOOD HABITS OF LONG-EARED OWLS IN SOUTHWESTERN IDAHO. M.S. THESIS, UNIVERSITY OF MONTANA, MISSOULA, MT. 91 PP.

2946. MARKS, V. A. S. 1986. SUMMER HABITAT USE BY COLUMBIAN SHARP-TAILED GROUSE IN WESTERN IDAHO. M.S. THESIS, MONTANA STATE UNIVERSITY, BOZEMAN, MT. 99 PP.

2947. MARKUSEN, A. S. 1963. GENETIC STUDIES ON A HEAT STABLE SURFACE ANTIGEN OF ESCHERICHIA COLI K12. PH.D. DISSERTATION, MONTANA STATE COLLEGE, BOZEMAN, MT. 48 PP.

2948. MARONE, L., V. L. DEL and E. PETENATTI. 1992. NESTING OF MONK PARAKEETS (MYIOPSITTA MONARCHA) ON ELECTRICAL POWER LINE POSTS IN ARGENTINA: MANAGEMENT IMPLICATIONS. ACTA ZOOLOGICA MEXICANA NUEVA SERIE 0 (52):15-23.

2949. MARR, N. V., W. D. EDGE, R. G. ANTHONY and R. VALBURG. 1995. SHEEP CARCASS AVAILABILITY AND USE BY BALD EAGLES. WILSON BULLETIN 107 (2):251-7.

2950. MARSHALL, W. J. 1978. PLANNING FOR WINTER RECREATION USE: A CASE STUDY OF ELK ISLAND NATIONAL PARK. M.S. THESIS. UNIVERSITY OF CALGARY, CALGARY

2951. MARTELL, A. M. and D. E. RUSSELL. 1985. 1ST NORTH AMERICAN CARIBOU WORKSHOP: NOGAP PROJECT NO. A.13: IMPACTS OF OIL AND GAS-RELATED ACTIVITIES ON CARIBOU.; SEPT 28- 29, 1983; WHITEHORSE, Y.T.. OTTAWA: CANADIAN WILDLIFE SERVICE. 68 PP.

2952. MARTIN, C. D. 1987. EFFECTIVENESS OF VARIOUS COMMUNICATIVE METHODS FOR CONTROLLING VISITOR REMOVAL OF PUMICE AT MOUNT ST. HELENS NATIONAL VOLCANIC MONUMENT. DISSERTATION, UNIVERSITY OF WASHINGTON, SEATTLE, WASHINGTON. 157PP.

2953. MARTIN, C. W. 1988. SOIL DISTURBANCE BY LOGGING IN NEW ENGLAND REVIEW AND MANAGEMENT RECOMMENDATIONS. NORTH. J. APPL. FOR. 5:30-34.

2954. MARTIN, C. L. 1975. CANYON FERRY RESERVOIR ZOOPLANKTON POPULATION DYNAMICS. M.S. THESIS, MONTANA STATE UNIVERSITY, BOZEMAN, MT. 50 PP.

2955. MARTIN, D. J. 1974. WILLIFE MORTALITY STATISTICS, HIGHWAY AND RAILWAY CAUSES, JASPER NATIONAL PARK 1966-1973. JASPER NATIONAL PARK, PARKS CANADA, CALGARY. UNPUBLISHED REPORT. 
2956. MARTIN, D. B. 1967. LIMNOLOGICAL STUDIES ON HEBGEN LAKE, MONTANA. PH.D. DISSERTATION, MONTANA STATE UNIVERSITY, BOZEMAN, MT. 126 PP.

2957. MARTIN, N. S. 1965. EFFECTS OF CHEMICAL CONTROL OF SAGEBRUSH ON THE OCCURRENCE OF SAGE GROUSE IN SOUTHWESTERN MONTANA. M.S. THESIS, MONTANA STATE UNIVERSITY, BOZEMAN, MT. 38 PP.

2958. MARTIN, P. A. E. 1979. PRODUCTIVITY AND TAXONOMY OF THE VACCINIUMGLOBULARE/ V. MEMBRANACEUM COMPLEX IN WESTERN MONTANA. M.S. THESIS, UNIVERSITY OF MONTANA, MISSOULA, MT. 136 PP.

2959. MARTIN, P. R. 1973. ECOLOGY OF SKUNKBUSH SUMAC (RHUS TRILOBATA NUTT.) IN MONTANA WITH SPECIAL REFERENCE TO USE BY MULE DEER. M.S. THESIS, MONTANA STATE UNIVERSITY, BOZEMAN, MT. 97 PP.

2960. MARTIN, S. K. 1980. ENVIRONMENTAL FACTORS AFFECTING HIGH ARCTIC SEA ICE HABITAT OF POLAR BEARS. M.S. THESIS, UNIVERSITY OF MONTANA, MISSOULA, MT. 127 PP.

2961. MARTIN, S. A. 1985. ECOLOGY OF THE ROCK CREEK BIGHORN SHEEP HERD BEARTOOTH MOUNTAINS, MONTANA. M.S. THESIS, MONTANA STATE UNIVERSITY, BOZEMAN, MT. 152 PP.

2962. MARTINEZ-ABRAIN, A. 1994. SEASONAL BIRD CASUALTIES ON A ROAD AT THE ALBUFERA LAGOON NATURAL PARK, E. SPAIN. DOANA ACTA VERTEBR. 21(1):90-95.

2963. MARTINEZ, C. 1994. HABITAT SELECTION BY THE LITTLE BUSTARD TETRAX TETRAX IN CULTIVATED AREAS OF CENTRAL SPAIN. BIOLOGICAL CONSERVATION 67 (2):125-8.

2964. MARTINKA, C. J. 1965. POPULATION STATUS, SOCIAL HABITS, MOVEMENT AND HABITAT RELATIONSHIPS OF THE SUMMER RESIDENT ELK OF JACKSON HOLE VALLEY, WYOMING. M.S. THESIS, MONTANA STATE UNIVERSITY, BOZEMAN, MT. 62 PP.

2965. MARTINKA, R. R. 1970. STRUCTURAL CHARACTERISTICS AND ECOLOGICAL RELATIONSHIPS OF MALE BLUE GROUSE (DENDRAGAPUS OBSCURUS [SAY]) TERRITORIES IN SOUTHWESTERN MONTANA. PH.D. DISSERTATION, MONTANA STATE UNIVERSITY, BOZEMAN, MT. 73 PP.

2966. MARTINSON, R. K. 1962. CHARACTERISTICS OF THE ACCIDENTAL DEER KILL IN OHIO. OHIO DIV. OF WILDLIFE PROJ. W-117-R .

2967. MARTZ, G. F. 1967. EFFECTS OF NESTING COVER REMOVAL ON BREEDING PUDDLE DUCKS. J. WLDL. MANAGE. 31 (2):236-47.

2968. MARZLUFF, J. M. 1997. EFFECTS OF URBANIZATION AND RECREATION ON SONGBIRDS. PAGES $89-102$ IN BLOCK,W.M. AND FINCH,D.M., EDITORS. SONGBIRD ECOLOGY IN SOUTHWESTERN PONDEROSA PINE FORESTS: A LITERATURE REVIEW. GEN. TECH. REP. RM-GTR-292. U.S. DEPARTMENT OF AGRICULTURE, FOREST SERVICE, ROCKY MOUNTAIN FOREST AND RANGE EXPERIMENT STATION, FT. COLLINS, CO.

2969. MASSEMIN, S., Y. LEMAHO and Y. HANDRICH. 1998. SEASONAL PATTERN IN AGE, SEX AND BODY CONDITION OF BARN OWLS (TYTO ALBA) KILLED ON MOTORWAYS. IBIS 140(1):70-75.

2970. MASSEMIN, S. and T. ZOM. 1998. HIGHWAY MORTALITY OF BARN OWLS IN NORTHEASTERN FRANCE. JOURNAL OF RAPTOR RESEARCH 32:229-232.

2971. MASSEMIN, S., Y. LE MAHO and Y. RICH. 1996. IDENTIFICATION OF THE ORIGINS OF BARN OWL (TYTO ALBA) KILLED OR INJURED ON MOTORWAYS AND THEIR NUTRITIONAL STATE. ALAUDA 64(1):56-57.

2972. MASSEY, A. 1982. ECOLOGY OF HOUSE MOUSE POPULATIONS CONFINED BY HIGHWAYS. JOURNAL OF THE ELISHA MITCHELL SCIENCE SOCIETY 98(3):135-143.

2973. MASSEY, C. I. 1971. A STUDY OF HEDGEHOG ROAD MORTALITY IN THE SEARBOROUGH DISTRICT, 1966-1971. LEEDS: NATURALIST 922(1):23 
2974. MASTERS, M. J. 1986. COMMON FACTORS AMONG SUCCESSFUL NATURE CENTERS. M.S. THESIS, UNIVERSITY OF MONTANA, MISSOULA, MT. 93 PP.

2975. MATCHETT, M. R. 1985. MOOSE-HABITAT RELATIONSHIPS IN THE YAAK RIVER DRAINAGE, NORTHWESTERN MONTANA. M.S. THESIS, UNIVERSITY OF MONTANA, MISSOULA, MT. 229 PP.

2976. MATHISEN, J. E. 1968. EFFECTS OF HUMAN DISTURBANCE ON NESTING BALD EAGLES. J. WILDL. MANAGE. 32 (1):1-6.

2977. MATLACK, G. R. 1993. SOCIOLOGICAL EDGE EFFECTS: SPATIAL DISTRIBUTION OF HUMAN IMPACT IN SUBURBAN FOREST FRAGMENTS. ENVIRONMENTAL MANAGEMENT 17(6):829-35.

2978. MATLOCK-COOLEY, S. J. 1993. INTERACTION BETWEEN DEERMICE, ANTELOPE BITTERBRUSH, AND CATTLE IN SW MONTANA. M.S. THESIS, MONTANA STATE UNIVERSITY, BOZEMAN, MT. 84 PP.

2979. MATSCHKE, G. H. 1984. POPULATION INFLUENCES (CHAPTER 7). P 169-88. IN: HALLS, L.K.,(EDITOR). WHITE-TAILED DEER: ECOLOGY AND MANAGEMENT. HARRISBURG, PA: STACKPOLE BOOKS.

2980. MATTESON, M. Y. 1992. DENNING ECOLOGY OF WOLVES IN NORTHWEST MONTANA AND SOUTHERN CANADIAN ROCKIES. M.S. THESIS, UNIVERSITY OF MONTANA, MISSOULA, MT. 65 PP.

2981. MATTHEWS, J. W. 1973. ECOLOGY OF BIGHORN SHEEP (OVIS CANADENSIS) ON WLDHORSE ISLAND, FLATHEAD LAKE, MONTANA. M.S. THESIS, UNIVERSITY OF MONTANA, MISSOULA, MT. 88 PP.

2982. MATTHEWS, W. L. 1976. MOVEMENT AND HOME RANGE OF COTTONTAIL RABBITS ALONG A POWER LINE RIGHT-OF-WAY MAINTAINED BY PERIODIC TREATMENTS WITH MECHANICAL MEANS. SOUTH CAROLINA WILDLIFE \& MARINE RESOURCES DEPT., DIV. OF GAME AND FRESHWATER FISHERIES. PROJ. NO. W-38, STUDY NO. 2, JOB NO. 2-1

2983. MATTHYSEN, E., F. ADRIAENSEN and A. A. DHONDT. 1995. DISPERSAL DISTANCES OF NUTHATCHES, SITTA EUROPAEA, IN HIGHLY FRAGMENTED FOREST HABITAT. OIKOS 72(3):375-81.

2984. MATTHYSEN, E., L. LENS, D. S. VAN, G. R. VERHEYEN, L. A. WAUTERS, F. ADRIAENSEN and A. A. DHONDT. 1995. DIVERSE EFFECTS OF FOREST FRAGMENTATION ON A NUMBER OF ANIMAL SPECIES. BELGIAN JOURNAL OF ZOOLOGY $125(1): 175-83$.

2985. MATTSON, D. J. 1990. HUMAN IMPACTS ON BEAR HABITAT USE. INT. CONF. BEAR RES. AND MANAGE. 8:33-56.

2986. MATTSON, D. J., S. HERRERO, R. G. WRIGHT and C. M. PEASE. 1996. DESIGNING AND MANAGING PROTECTED AREAS FOR GRIZZLY BEARS: HOW MUCH IS ENOUGH? P 133-64. IN: WRIGHT RG, ED. NATIONAL PARKS AND PROTECTED AREAS: THEIR ROLE IN ENVIRONMENTAL PROTECTION. BLACKWELL SCIENCE, CAMBRIDGE, MASS.

2987. MATTSON, D. J., S. HERRERO, R. G. WRIGHT and C. M. PEASE. 1996. SCIENCE AND MANAGEMENT OF ROCKY MOUNTAIN GRIZZLY BEARS. CONS. BIOL. 10 (4):1013-25.

2988. MATTSON, D. J. and R. R. KNIGHT. 1991. EFFECTS OF ACCESS ON HUMAN-CAUSED MORTALITY OF YELLOWSTONE GRIZZLY BEARS. REPORT 1991B, INTERAGENCY GRIZZLY BEAR STUDY TEAM, FORESTRY SCIENCES LAB, BOZEMAN, MT . 13PP

2989. MATTSON, D. J., R. R. KNIGHT and B. M. BLANCHARD. 1987. THE EFFECTS OF DEVELOPMENTS AND PRIMARY ROADS ON GRIZZLY BEAR HABITAT USE IN YELLOWSTONE NATIONAL PARK, WYOMING. INTERNATIONAL CONFERENCE ON BEAR RESEARCH AND MANAGEMENT 7:259-273.

2990. MATTSON, D. J. and D. P. REINHART. 1997. EXCAVATION OF RED SQUIRREL MIDDENS BY GRIZZLY BEARS IN THE WHITEBARK PINE ZONE. J. APPL. ECOL. 34:926-940.

2991. MATTSON, D. J., B. M. BLANCHARD and R. R. KNIGHT. 1992. YELLOWSTONE GRIZZLY BEAR MORTALITY, HUMAN HABITUATION, AND WHITEBARK PINE SEED CROPS. JOURNAL OF WLDLIFE MANAGEMENT 56:432-442. 
2992. MAURER, B. A. and HEYWOOD SG. 1993. GEOGRAPHIC RANGE FRAGMENTATION AND ABUNDANCE IN NEOTROPICAL MIGRATORY BIRDS. CONSERVATION BIOLOGY 7 (3):501-9.

2993. MAXELL, B. and G. HOKIT. 1999. AMPHIBIANS AND REPTILES. PAGES $2.1-2.29$ IN G. JOSLIN AND H. YOUMANS, COORDINATORS. THE EFFECTS OF RECREATION ON ROCKY MOUNTAIN WILDLIFE: A REVIEW FOR MONTANA. COMMITTEE ON EFFECTS OF RECREATION ON WLDLIFE. MONTANA CHAPTER OF THE WLDLIFE SOCIETY. 307PP.

2994. MAY, S. A. and T. W. NORTON. 1996. INFLUENCE OF FRAGMENTATION AND DISTURBANCE ON THE POTENTIAL IMPACT OF FERAL PREDATORS ON NATIVE FAUNA IN AUSTRALIAN FOREST ECOSYSTEMS . WILDLIFE RESEARCH 23 :387-400.

2995. MAYER, P. M. and D. S. LICHT. 1995. PERSISTENCE AND USE OF ARTIFICIAL PRAIRIE FALCON AERIES IN NORTH DAKOTA. WILDL. SOC. BULL. 23 (3):532-4.

2996. MAYHEW, W. W. 1983. CONFLICTS BETWEEN THE FRINGE-TOED LIZARD AND DEVELOPMENT IN THE COACHELLA VALLEY . CALIFORNIA-NEVADA WLDLIFE TRANSACTIONS 1983:144-147.

2997. MAYOL, J. 1992. MORTALITY OF TARENTOLA MAURITANICA ON THE RURAL ROADS OF MENORCA. PRELIMINARY NOTE. PAGES 280-281 IN LOPEZ,REDONDO, EDITOR. I JORNADAS PARA EL ESTUDIO Y PREVENCION DE LA MORTALIDAD DE VERTEBRADOS EN CARRETERAS, MADRID, 5 Y 6 DE OCTUBRE DE 1991. TOMO 2. [SESSIONS IN THE STUDY OF PREVENTION OF ROAD MORTALITIES OF VERTEBRATES, MADRID, 5 AND 6 OCTOBER, 1991. VOLUME 2.]. COORDINADORA DE ORGANIZACCIONES DE DEFENSA, AMBIENTAL, MADRID.

2998. MAZAIKA, R., P. R. KRAUSMAN and F. M. WHITING. 1988. A GATE SYSTEM FOR FEEDING CAPTIVE UNGULATES. J. WILDL. MANAGE. $52(4): 613-5$.

2999. MCARTHUR JOPE, K. L. 1983. HABITUATION OF GRIZZLY BEARS TO PEOPLE: A HYPOTHESIS. INT. CONF. BEAR RES. AND MANAGE. 5:322-7.

3000. MCARTHUR, K. L. 1981. FACTORS CONTRIBUTING TO EFFECTIVENESS OF BLACK BEAR TRANSPLANTS. J. WILDL. MANAGE. 45 (1):102-10.

3001. MCATEE, J. W. and D. L. DRAWE. 1980. HUMAN IMPACT ON BEACH AND FOREDUNE VEGETATION OF NORTH PADRE ISLAND, TEXAS. ENVIRON. MANAGEMENT 4:527-538.

3002. MCCAFFERY, K. R. 1976. DEER TRAIL COUNTS AS AN INDEX TO POPULATIONS AND HABITAT USE. J. WILDL. MANAGE. $40(2): 308-16$

3003. MCCAFFERY, K. R. 1973. ROAD KILLS SHOW TRENDS IN WISCONSIN DEER POPULATIONS. JOURNAL OF WILDLIFE MANAGEMENT 37:212-216.

3004. MCCAFFERY, K. R., J. E. ASHBRENNER and J. C. MOULTON. 1981. FOREST OPENING CONSTRUCTION AND IMPACTS IN NORTHERN WISCONSIN. WISCONSIN DEPARTMENT OF NATURAL RESOURCES. 44PP.

3005. MCCAFFERY, K. R., J. TRANETZKI and J. JR. PIECHURA. 1974. SUMMER FOODS OF DEER IN NORTHERN WISCONSIN. J. WILDL. MANAGE. 38 (2):215-20.

3006. MCCARTHY, J. J. 1973. RESPONSE OF NESTING CANADA GEESE (BRENTA CANADENSIS) TO ISLANDS IN STOCKDAMS IN NORTHCENTRAL MONTANA. M.S. THESIS, MONTANA STATE UNIVERSITY, BOZEMAN, MT. 36 PP.

3007. MCCARTHY, J. 1996. A FLORISTIC SURVEY OF THE PRYOR MOUNTAINS, MONTANA. M.S. THESIS, MONTANA STATE UNIVERSITY, BOZEMAN, MT. 93 PP.

3008. MCCARTHY, M. A. and M. A. BURGMAN. 1995. COPING WITH UNCERTAINTY IN FOREST WILDLIFE PLANNING. FOREST ECOLOGY AND MANAGEMENT 74 (1-3):23-36.

3009. MCCARTHY, T. M. and R. J. SEAVOY. 1994. REDUCING NONSPORT LOSSES ATTRIBUTABLE TO FOOD CONDITIONING: HUMAN AND BEAR BEHAVIOR MODIFICATION IN AN URBAN ENVIRONMENT. INT. CONF. BEAR RES. AND MANAGE. 9:75-84. 
3010. MCCARTY, C. W. and J. A. BAILEY. HABITAT REQUIREMENTS OF DESERT BIGHORN SHEEP. COLORADO DIV. OF WILDLIFE SPECIAL REPORT NUMBER 69. 27 PP.

3011. MCCAUGHEY, W. W. 1990. BIOTIC AND MICROSTITE FACTORS AFFECTING PINUS ALBICAULIS ESTABLISHMENT AND SURVIVAL. PH.D. DISSERTATION, MONTANA STATE UNIVERSITY, BOZEMAN, MT. 78 PP.

3012. MCCLANAHAN, T. R. and R. W. WOLFE. 1993. ACCELERATING FOREST SUCCESSION IN A FRAGMENTED LANDSCAPE: THE ROLE OF BIRDS AND PERCHES. CONSERVATION BIOLOGY 7 (2):279-88.

3013. MCCLAY, W. 1968. EFFECTS OF CONTROLLED FLOW REDUCTIONS ON AQUATIC INSECTS IN A STREAM RIFFLE. M.S. THESIS, MONTANA STATE UNIVERSITY, BOZEMAN, MT. 29 PP.

3014. MCCLEAVE, J. D. 1967. HOMING AND ORIENTATION OF CUTTHROAT TROUT (SALMO CLARKI) IN YELLOWSTONE LAKE, WITH SPECIAL REFERENCE TO OLFACTION AND VISION. PH.D. DISSERTATION, MONTANA STATE UNIVERSITY, BOZEMAN, MT. 62 PP.

3015. MCCLEAVE, J. D. 1963. MOVEMENT AND POPULATION OF THE MOTTLED SCULPIN (COTTUS BAIRDI GIRARD) IN A SMALL MONTANA STREAM. M.S. THESIS, MONTANA STATE COLLEGE, BOZEMAN, MT. 20 PP.

3016. MCCLELLAN, T. J. 1974. ECOLOGICAL RECOVERY OF REALIGNED STREAM CHANNELS. U.S. FEDERAL HIGHWAY ADMINISTRATION, REGION 10, PORTLAND, OR. FHWA-OR-74-1.

3017. MCCLELLAN, T. J. 1970. FISH PASSAGE THROUGH HIGHWAY CULVERTS : A FIELD EVALUATION. FEDERAL HIGHWAY ADMINISTRATION, WASHINGTON, D.C.

3018. MCCLELLAN, T. J. 1972. FISH PASSAGE THROUGH HIGHWAY CULVERTS A FIELD EVALUATION. NTIS, SPRINGFIELD, VIRGINIA.

3019. MCCLELLAND, B. R., L. S. YOUNG, P. T. MCCLELLAND, J. G. CRENSHAW, H. L. ALLEN and D. S. SHEA. 1994. MIGRATION ECOLOGY OF BALD EAGLES FROM AUTUMN CONCENTRATIONS IN GLACIER NATIONAL PARK, MONTANA. WILDL. MONOGR. 125:1-61.

3020. MCCLELLAND, P. T. 1992. ECOLOGY OF BALD EAGLES AT HUNGRY HORSE RESERVOIR, MONTANA. M.S. THESIS, UNIVERSITY OF MONTANA, MISSOULA, MT. 94 PP.

3021. MCCLURE, H. E. 1951. AN ANALYSIS OF ANIMAL VICTIMS ON NEBRASKA'S HIGHWAY. JOURNAL OF WILDLIFE MANAGEMENT 15:410-420.

3022. MCCLURE, H. E. 1951. AN ANALYSIS OF ANIMAL VICTIMS ON NEBRASKA'S HIGHWAYS. J. WILDL. MANAGE. 15 (4):410-20.

3023. MCCLURE, W. V. 1991. INITIAL EFFECTS OF STREAMBANK STABILIZATION ON A SMALL TROUT STREAM. M.S. THESIS, MONTANA STATE UNIVERSITY, BOZEMAN, MT. 93 PP.

3024. MCCOOL, S. F. and J. HARRIS. 1994. THE MONTANA TRAIL USERS STUDY. INSTITUTE FOR TOURISM AND RECREATION RESEARCH, SCHOOL OF FORESTRY, UNIVERSITY OF MONTANA, MISSOULA, MONTANA. 4OPP. RESEARCH REPORT 35.

3025. MCCOOL, S. F. 1978. SNOWMOBILES, ANIMALS AND MAN: INTERACTIONS AND MANAGEMENT ISSUES. TRANSACTIONS OF THE NORTH AMERICAN WILDLIFE AND NATURAL RESOURCES CONFERENCE 43:140-148.

3026. MCCORQUODALE, S. M., K. J. RAEDEKE and R. D. TABER. 1986. ELK HABITAT USE PATTERNS IN THE SHRUB-STEPPE OF WASHINGTON. J. WILDL. MANAGE. 50 (4):664-9.

3027. MCCORUODALE, S. M. 2000. HABITAT ECOLOGY AND VULNERABILITY TO HUNTING MORTALITY OF ELK IN THE CASCADE RANGE OF SOUTHCENTRAL WASHINGTON. PH.D. DISSERTATION, UNIVERSITY OF MONTANA, MISSOULA, MT. 129 PP.

3028. MCCOURT, K. H., J. D. FEIST, D. DOLL and J. J. RUSSELL. 1974. DISTURBANCE STUDIES OF CARIBOU AND OTHER MAMMALS IN THE YUKON AND ALASKA, 1972. BIOLOGICAL REPORT SERIES, VOLUME FIVE. PREPARED BY RENEWABLE RESOURCES CONSULTING SERVICES LTD.; CANADIAN ARCTIC GAS STUDY LIMITED; ALASKAN 
3029. MCCOY, M. and M. STONER. MOUNTAIN BIKE TRAILS: TECHNIQUES FOR DESIGN, CONSTRUCTION, AND MAINTENANCE. BIKECENTENNIAL. MISSOULA, MONTANA.

3030. MCCRAIN, G. R. 1991. HIGHWAYS AND POCOSINS IN NORTH CAROLINA: AN OVERVIEW. ENVIRONMENTAL SERVICES, INC. 11 (SPECIAL ISSUE):481-488.

3031. MCCREEDY, C. D. and H. P. JR. WEEKS. 1992. SODIUM PROVISION AND WILD COTTONTAIL RABBITS: MORPHOLOGICAL CHANGE IN ADRENAL GLANDS. J. WILDL. MANAGE. 56 (4):669-76.

3032. MCCUBBIN, R. N., A. B. CASE and D. A. ROWE. 1985. ENVIRONMENTAL GUIDELINES AND DESIGN CRITERIA FOR RESOURCE ROAD CONSTRUCTION. REV. CANADIAN FORESTRY SERVICE, DEPT. OF FISHERIES AND OCEANS, ST. JOHN'S, NEWFOUNDLAND.

3033. MCCUTCHEN, H. E. 1990. CRYPTIC BEHAVIOR OF BLACK BEARS (URSUS AMERICANUS) IN ROCKY MOUNTAIN NATIONAL PARK, COLORADO. INT. CONF. BEAR RES. AND MANAGE.8:65-72..

3034. MCCUTCHEN, H. E. 1966. AGING PRONGHORN ANTELOPE BY THE INCISOR CEMENTUM. M.S. THESIS, UNIVERSITY OF MONTANA, MISSOULA, MT. 49 PP.

3035. MCDONALD, M. G. 1988. GLENN HIGHWAY MOOSE MONITORING STUDY PROGRESS REPORT. SECOND ANNUAL PROGRESS REPORT. ALASKA DEPARTMENT OF FISH AND GAME, ANCHORAGE, AL.

3036. MCDONALD, M. G. 1989. GLENN HIGHWAY MOOSE MONITORING STUDY: SECOND ANNUAL PROGRESS REPORT. ALASKA DEPARTMENT OF FISH AND GAME. SUBMITTED TO THE ALASKA DEPARTMENT OF TRANSPORTATION AND PUBLIC FACILITIES.

3037. MCDONALD, M. G. 1991. HIGHWAY WIDENING EFFECTS ON MOOSE WINTER RANGE. ALCES 27:208-19.

3038. MCDONALD, M. G. 1991. MOOSE MOVEMENT AND MORTALITY ASSOCIATED WITH THE GLENN HIGHWAY EXPANSION, ANCHORAGE, ALASKA. ALCES 27:208-219.

3039. MCDONALD, M. G. 1980. WINTER RANGE UTILIZATION AND MOVEMENTS BY ELK ALONG THE MIDDLE FORK OF THE FLATHEAD RIVER, MONTANA. M.S. THESIS, UNIVERSITY OF MONTANA, MISSOULA, MT. 71 PP.

3040. MCDOUGAL, L. A., M. R. VAUGHAN and BROMLEY. 1990. WILD TURKEY AND ROAD RELATIONSHIPS ON A VIRGINIA NATIONAL FOREST. 6. VIRGINIA DEPARTMENT OF FISH AND WLDLIFE SCIENCE, BLACKSBURG, VA.

3041. MCENEANEY, T. P. and J. M. LOCKHART. 1979. THE EFFECTS OF COAL DEVELOPMENT ON THE ECOLOGY OF BREEDING GOLDEN EAGLES (AQUILA CHRYSAETOS). ANN. PROG. REPT., WLDLF RES. WORK UNIT, DENVER WLDLF RES. CENTER., 16 PP.

3042. MCEWAN, L. C. and D. H. HIRTH. 1979. SOUTHERN BALD EAGLE PRODUCTIVITY AND NEST SITE SELECTION. JOURNAL OF WILDLIFE MANAGEMENT 43:585-594.

3043. MCEWEN, D. N. 1978. TURKEY BAY OFF-ROAD VEHICLE AREA AT LAND BETWEEN THE LAKES: AN EXAMPLE OF NEW OPPORTUNITIES FOR MANAGERS AND RIDERS. SOUTH ILLINOIS UNIVERSITY DEPARTMENT OF RECREATION. CARBONDALE, ILLINOIS. RESEARCH REPORT NO. 1. 28PP.

3044. MCGAHAN, J. 1966. ECOLOGY OF THE GOLDEN EAGLE. PH.D. DISSERTATION, UNIVERSITY OF MONTANA, MISSOULA, MT. 78 PP.

3045. MCGARIGAL, K. 1988. HUMAN-EAGLE INTERACTIONS ON THE LOWER COLUMBIA RIVER. THESIS, OREGON STATE UNIVERSITY, CORVALLIS, OREGON. 115PP.

3046. MCGARIGAL, K. 1993. RELATIONSHIP BETWEEN LANDSCAPE STRUCTURE AND AVIAN ABUNDANCE PATTERNS IN THE OREGON COAST RANGE. PHD THESIS, OREGON STATE UNIVERSITY. 289 PP. 
3047. MCGARIGAL, K., R. G. ANTHONY and F. B. ISAACS. 1991. INTERACTIONS OF HUMANS AND BALD EAGLES ON THE COLUMBIA RIVER ESTUARY. WLDL. MONOGR. 115:1-47.

3048. MCGARIGAL, K. and W. C. MCCOMB. 1995. RELATIONSHIPS BETWEEN LANDSCAPE STRUCTURE AND BREEDING BIRDS IN THE OREGON COAST RANGE. ECOLOGICAL MONOGRAPHS 65 (3):235-60.

3049. MCGRATH, M. J., S. P. MAHONEY and D. W. FONG. 1991. SUMMER HOME RANGE SIZES AND HABITAT COMPOSITIONS OF WOODLAND CARIBOU INHABITING AN AREA SUBJECT TO LOGGING IN NEWFOUNDLAND. P 408-17. IN: BUTLER CE, MAHONEY SP, EDS. 4THNORTH AMERICAN CARIBOU WORKSHOP PROC.; OCT 31-NOV 31989 ; ST. JOHN'S, NEWFOUNDLAND. NEWFOUNDLAND AND LABRADOR WILDLIFE DIV.

3050. MCGRAW, R. L. I. 1997. TIMBER HARVEST EFFECTS ON META-MORPHOSED AND LARVAL LONG-TOED SALAMANDERS (AMBYSTOMA MACRODACTYLUM). M.S. THESIS, UNIVERSITY OF MONTANA, MISSOULA, MT. 74 PP.

3051. MCGREGOR, G. I. 1994. ENVIRONMENTAL LAW AND ENFORCEMENT. LEWS PUBLISHERS, BOCA RATON, RHODE ISLAND.

3052. MCGUIRE, D. L. 1984. COMMUNITY DEVELOPMENT AND SEASONAL SUCCESSION OF AQUATIC MACROINVERTEBRATES IN THE CANYON FERRY WILDLIFE MANAGEMENT AREA PONDS. M.S. THESIS, MONTANA STATE UNIVERSITY, BOZEMAN, MT. 77 PP.

3053. MCGURK, B. J. and D. R. FONG. 1995. EQUIVALENT ROADED AREA AS A MEASURE OF CUMULATIVE EFFECT OF LOGGING. ENVIRONMENTAL MANAGEMENT 19 (4):609-21.

3054. MCINTYRE, J. W. 1988. THE COMMON LOON: SPIRIT OF NORTHERN LAKES. UNIVERSITY OF MINNESOTA PRESS. MINNEAPOLIS, MINNESOTA. 228PP.

3055. MCINTYRE, J. W. 1979. STATUS OF COMMON LOONS IN NEW YORK FROM A HISTORICAL PERSPECTIVE. PAGES 117-121 IN S. A. SUTCLIFFE, EDITOR. PROCEEDINGS OF THE 2ND NORTH AMERICAN CONFERENCE ON COMMON LOON RESEARCH AND MANAGEMENT. AUDUBON SOCIETY OF NEW HAMPSHIRE, MEREDITH, N.H.

3056. MCINTYRE, S. and G. W. BARRETT. 1992. HABITAT VARIEGATION, AN ALTERNATIVE TO FRAGMENTATION. CONSERVATION BIOLOGY 6 (1):146-7.

3057. MCINTYRE, S. and S. LAVOREL. 1994. PREDICTING RICHNESS OF NATIVE, RARE, AND EXOTIC PLANTS IN RESPONSE TO HABITAT AND DISTURBANCE VARIABLES ACROSS A VARIEGATED LANDSCAPE. CONSERVATION BIOLOGY $8(2): 521-31$

3058. MCKENDRICK, J. 1986. RECORDING OF TUNDRA PLANT RESPONSES, VOL III. FINAL WELLSITE CLEANUP ON NATIONAL PETROLEUM RESERVE, ALASKA. NUEVA RECLAMATION CO., INC., ANCHORAGE, AK.

3059. MCKINNON, G. A. and F. N. HNYTKA. THE EFFECT OF WINTER PIPELINE CONSTRUCTION ON THE FISHES AND FISH HABITAT OF HODGSON CREEK, NWT.

3060. MCKINNON, G. A. and F. N. HNYTKA. 1979. A SURVEY OF THE FISH RESOURCES OF LIARD RIVER TRIBUTARIES AS RELATED TO HIGHWAY CONSTRUCTION AND OPERATION, 1976-77. MICROMEDIA. WESTERN REGION, FISHERIES AND MARINE SERVICE, CANADA DEPT. OF FISHERIES AND THE ENVIRONMENT, TORONTO, ONTARIO; WINNIPEG, MANITOBA. MICROFORM: FISHERIES AND MARINE SERVICE MANUSCRIPT REPORT: FISHERIES AND MARINE SERVICE MANUSCRIPT REPORT NO. 1483.

3061. MCLAREN, M. A. and E. G. JEFFREY. 1985. THE REACTIONS OF MUSKOXEN TO SNOWMOBILE HARASSMENT. ARCTIC 38(3):188-193

3062. MCLEAN, P. K. and M. R. PELTON. 1990. SOME DEMOGRAPHIC COMPARISONS OF WLDAND PANHANDLER BEARS IN THE SMOKY MOUNTAINS. INT. CONF. BEAR RES. AND MANAGE. 8:105-12.

3063. MCLEAN, PK. 1991. THE DEMOGRAPHIC AND MORPHOLOGICAL CHARACTERISTICS OF BLACK BEARS IN THE SMOKY MOUNTAINS. PHD THESIS, THE UNIVERSITY OF TENNESSEE..174 PP. 
3064. MCLELLAN, B. N. 1991. CURRENT STATUS AND LONG TERM THREATS TO GRIZZLY BEARS IN BRITISH COLUMBIA. COMMUNITY ACTION FOR ENDANGERED SPECIES :111-22

3065. MCLELLAN, B. N. 1989. DYNAMICS OF A GRIZZLY BEAR POPULATION DURING A PERIOD OF INDUSTRIAL RESOURCE EXTRACTION. I. DENSITY AND AGE-SEX COMPOSITION. CAN. J. ZOOL. 67:1856-1860.

3066. MCLELLAN, B. N. 1989. DYNAMICS OF A GRIZZLY BEAR POPULATION DURING A PERIOD OF INDUSTRIAL RESOURCE EXTRACTION. II. MORTALITY RATES AND CAUSES OF DEATH. CAN. J. ZOOL. 67:1861-1864

3067. MCLELLAN, B. N. 1989. DYNAMICS OF A GRIZZLY BEAR POPULATION DURING A PERIOD OF INDUSTRIAL RESOURCE EXTRACTION. III NATALITY AND RATE OF INCREASE. CAN. J. ZOOL. 67:1865-1868

3068. MCLELLAN, B. N. 1989. EFFECTS OF RESOURCE EXTRACTION INDUSTRIES ON BEHAVIOUS AND POPULATION DYNAMICS OF GRIZZLY BEARS IN THE FLATHEAD DRAINAGE, BRITISH COLUMBIA AND MONTANA. PH.D. DISSERTATION, UNIVERSITY OF BRITISH COLUMBIA, VANCOUVER, BC.

3069. MCLELLAN, B. N. 1990. RELATIONSHIPS BETWEEN HUMAN INDUSTRIAL ACTIVITY AND GRIZZLY BEARS. INT. CONF. BEAR RES. AND MANAGE. 8:57-64.

3070. MCLELLAN, B. N. TITLE UNKNOWN. PH.D. THESIS. UNIV. BRITISH COLUMBIA, VANCOUVER, B.C.

3071. MCLELLAN, B. N. and R. D. MACE. 1985. BEHAVIOR OF GRIZZLY BEARS IN RESPONSE TO ROADS, SEISMIC ACTIVITY AND PEOPLE. CANADIAN BORDER GRIZZLY PROJECT, UNIVERSITY OF BRITISH COLUMBIA, VANCOUVER. 53PP.

3072. MCLELLAN, B. N. and D. J. MARTIN. 1991. MANAGING FOREST ACCESS ROADS TO MEET WILDLIFE AND FISHERIES OBJECTIVES. P. E59-E62. IN: PROCEEDINGS WILDLIFE 91 WILDLIFE\& FORESTRY: TOWARDS A WORKING PARTNERSHIP.

3073. MCLELLAN, B. N. and D. M. SHACKLETON. 1988. GRIZZLY BEARS AND RESOURCE-EXTRACTION INDUSTRIES: EFFECTS OF ROADS ON BEHAVIOR, HABITAT USE AND DEMOGRAPHY . J. APPLIED ECOL. $25: 451-460$.

3074. MCLELLAN, B. N. and D. M. SHACKLETON. 1989. GRIZZLY BEARS AND RESOURCE-EXTRACTION INDUSTRIES: HABITAT DISPLACEMENT IN RESPONSE TO SEISMIC EXPLORATION, TIMBER HARVESTING AND ROAD MAINTENANCE. JOURNAL OF APPLIED ECOLOGY 26:371-380.

3075. MCLELLAN, B. N. and D. M. SHACKLETON. 1989. IMMEDIATE REACTIONS OF GRIZZLY BEARS TO HUMAN ACTIVITIES. WILDL. SOC. BULL. 17:269-274.

3076. MCMAHAN, C. A. 1966. SUITABILITY OF GRAZING ENCLOSURES FOR DEER AND LIVESTOCK RESEARCH ON THE KERR WILDLIFE MANAGEMENT AREA, TEXAS. J. WILDL. MANAGE.30(1):151-62

3077. MCMICHAEL, G. A. 1989. EFFECTS OF STREAM TEMPERATURE ON ANGLING SUCCESS FOR RAINBOW AND BROWN TROUT. M.S. THESIS, MONTANA STATE UNIVERSITY, BOZEMAN, MT. 130 PP.

3078. MCNAUGHT, D. A. 1985. PARK VISITORS ATTITUDES TOWARDS WOLF RECOVERY IN YELLOWSTONE NATIONAL PARK. M.S. THESIS, UNIVERSITY OF MONTANA, MISSOULA, MT. 103 PP.

3079. MCNAY, M. 1980. A STUDY OF THE CAUSES FOR POOR PRONGHORN FAWN:DOE RATIOS ON THE CHARLES SHELDON ANTELOPE REFUGE, NEVADA. M.S. THESIS, UNIVERSITY OF MONTANA, MISSOULA, MT. 128 PP.

3080. MCNAY, R. S. and J. M. VOLLER. 1995. MORTALITY CAUSES AND SURVIVAL ESTIMATES FOR ADULT FEMALE COLUMBIAN BLACK-TAILED DEER. JOURNAL OF WLDLIFE MANAGEMENT 59(1):138-46.

3081. MCRAE, M. 1997. ROAD KILL IN CAMEROON. NATURAL HISTORY 106(1):36-75.

3082. MCREYNOLDS, H. E. and R. E. RADTKE. 1978. THE IMPACT OF MOTORIZED HUMANS ON THE WILDLIFE OF FORESTED LANDS. PAGES 102-117 IN C. M. KILPATRICK, EDITOR. WLDLIFE AND PEOPLE. PROCEEDINGS OF THE 1978 JOHN S. WRIGHT FORESTRY CONFERENCE, 23-24 FEBRUARY 1978, PURDUE UNIVERSITY, WEST LAFAYETTE, 
INDIANA.

3083. MEAD, C. 1993. USE BY BIRDS OF ROADS FOR NAVIGATION. BRITISH BIRDS 86(8):375-376.

3084. MEAD, D. A. and L. E. MORGANTINI. 1988. DRILLING IN SHEEP COUNTRY: GAS DEVELOPMENT AT PRAIRIE BLUFF, ALBERTA. BIENN. SYMP. NORTH. WILD SHEEP AND GOAT COUNCIL 6:165-167.

3085. MEALEY, S. P., C. J. JONKEL and R. DEMARCHI. 1977. HABITAT CRITERIA FOR GRIZZLY BEAR MANAGEMENT. PROCEEDINGS XIII INTERNATIONAL CONGRESS OF GAME BIOLOGISTS: $276-88$

3086. MEALEY, S. P., C. J. JONKEL and R. DEMARCHI. 1977. TITLE UNKNOWN. P 276-88. IN: PETERLE, T.J., ED. XIIITH INT CONG GAME BIOLOGISTS; 1977 MAR 11-1977 MAR 15; ATLANTA, GA US.

3087. MEALEY, S. P. 1975. THE NATURAL FOOD HABITS OF FREE RANGING GRIZZLY BEARS IN YELLOWSTONE NATIONAL PARK, 1973-74. M.S. THESIS, MONTANA STATE UNIVERSITY, BOZEMAN, MT. 158 PP.

3088. MEANS, D. B., J. G. PALIS and M. GAGGETT. 1996. EFFECTS OF SLASH PINE SILVICULTURE ON A FLORIDA POPULATION OF FLATWOODS SALAMANDER. CONSERVATION BIOLOGY 10:426-437.

3089. MEANS, D. B. 1996. A PRELIMINARY CONSIDERATION OF HIGHWAY IMPACTS ON HERPETOFAUNA INHABITING SMALL ISOLATED WETLANDS IN THE SOUTHEASTERN U.S. COASTAL PLAIN. PAGES 297-307 IN EVINK G., D. ZIEGLER, P. GARRETT, AND J. BERRY, EDITORS. HIGHWAYS AND MOVEMENT OF WLDLIFE: IMPROVING HABITAT CONNECTIONS AND WILLIFE PASSAGEWAYS ACROSS HIGHWAY CORRIDORS. PROCEEDINGS OF THE FLORIDA DEPARTMENT OF TRANSPORTATION/FEDERAL HIGHWAY ADMINISTRATION TRANSPORTATION-RELATED WILDLIFE MORTALITY SEMINAR. ORLANDO, FLORIDA, APR 30- MAY 2, 1996

3090. MECH, L. D. 1995. THE CHALLENGE AND OPPORTUNITY OF RECOVERING WOLF POPULATIONS. CONSERVATION BIOLOGY 9 (2):270-8.

3091. MECH, L. D. 1977. PRODUCTIVITY, MORTALITY, AND POPULATION TREND OF WOLVES IN NORTHEASTERN MINNESOTA. J. MAMMAL. 58:559-74.

3092. MECH, L. D. 1967. TELEMETRY AS A TECHNIQUE IN THE STUDY OF PREDATION. J. WILDL. MANAGE. 31 (3):491-6.

3093. MECH, L. D. 1973. WOLF NUMBERS IN THE SUPERIOR NATIONAL FOREST OF MINNESOTA. USDA FOR. SERV. RES. PAP. NC-97.

3094. MECH, L. D. 1989. WOLF POPULATION SURVIVAL IN AN AREA OF HIGH ROAD DENSITY. AMERICAN MIDLAND NATURALIST 121:387-389.

3095. MECH, L. D., S. H. FRITTS and D. WAGNER. 1995. MINNESOTA WOLF DISPERSAL TO WISCONSIN AND MICHIGAN. AMERICAN MIDLAND NATURALIST 133 (2):368-70.

3096. MECH, L. D., U. S. SEAL and G. D. DELGIUDICE. 1987. USE OF URINE IN SNOW TO INDICATE CONDITION OF WOLVES. J. WILDL. MANAGE. 51 (1):10-3.

3097. MECH, L. D., S. H. FRITTS, G. L. RADDE and W. J. PAUL. 1988. WOLF DISTRIBUTION AND ROAD DENSITY IN MINNESOTA. WILDLIFE SOCIETY BULLETIN 16:85-87.

3098. MEDLEY, K. E. 1993. PRIMATE CONSERVATION ALONG THE TANA RIVER, KENYA: AN EXAMINATION OF THE FOREST HABITAT. CONSERVATION BIOLOGY 7 (1):109-21.

3099. MEGAHAN, W. F. and W. J. KIDD. 1972. EFFECTS OF LOGGING ROADS ON SEDIMENT PRODUCTION RATES IN THE IDAHO BATHOLITH. USDA FOREST SERVICE, INTERMOUNTAIN FOREST AND RANGE EXPERIMENT STATION. RESEARCH PAPER INT-123. 14PP

3100. MEGARGLE, D. J. 1997. TEMPORAL VARIATION IN FOOD SELECTION OF SHOVELNOSE STURGEON IN THE MISSOURI RIVER ABOVE FORT PECK RESERVOIR, MONTANA. M.S. THESIS, MONTANA STATE UNIVERSITY, BOZEMAN, MT. 127 PP. 
3101. MEIA, J. S. and J. M. WEBER. 1992. CHARACTERISTICS AND DISTRIBUTION OF BREEDING DENS OF THE RED FOX (VULPES VULPES) IN A MOUNTAINOUS HABITAT. ZEITSCHRIFT FUER SAEUGETIERKUNDE 57 (3):137-43

3102. MEIDINGER, R. R. 1998. EFFECT OF REDUCING THE AVAILABILITY OF MAGPIE NEST SITES ON DUCK NEST SUCCESS M.S. THESIS, UNIVERSITY OF MONTANA, MISSOULA, MT. 55 PP.

3103. MEIER, G. A. 1997. THE COLONIZATION OF MONTANA ROADSIDES BY NATIVE AND EXOTIC PLANTS. M.S. THESIS, MONTANA STATE UNIVERSITY, BOZEMAN, MT. 187 PP.

3104. MEILNICKA, B. 1991. TOURISM IN POLISH NATIONAL PARKS AND ITS INFLUENCE ON THEIR NATURE. OCHRONA PRZYRODY 49:163-174.

3105. MEINIG, H. 1989. EXPERIENCE AND PROBLEMS WITH A TOAD TUNNEL SYSTEM IN THE MITTELGEBIRGE REGION OF WEST GERMANY. PAGES 59-66 IN LANGTON,T.E.S., EDITOR. AMPHIBIANS AND ROADS. PROCEEDINGS OF THE TOAD TUNNEL CONFERENCE; 1989 JANUARY 7-8; RENDSBURG, FEDERAL REPUBLIC OF GERMANY ACO POLYMER PRODUCTS LTD., SHEFFORD, ENGLAND.

3106. MEITZ, S. N. 1994. LINKAGE ZONE IDENTIFICATION AND EVALUATION OF MANAGEMENT OPTIONS FOR GRIZZLY BEARS IN THE EVARO HILL AREA. M.S. THESIS, UNIVERSITY OF MONTANA, MISSOULA, MT.

3107. MELQUIST, W. E. and M. G. HORNOCKER. 1983. ECOLOGY OF RIVER OTTERS IN WEST CENTRAL IDAHO. WILDLIFE MONOGRAPHS 83:1-60.

3108. MELVIN, S. M., A. HECHT and C. R. GRIFFIN. 1994. PIPING PLOVER MORTALITIES CAUSED BY OFF-ROAD VEHICLES ON ATLANTIC COAST BEACHES. WLDL. SOC. BULL. $22(3): 409-14$.

3109. MELVIN, S. M., A. HECHT and C. R. GRIFFIN. 1994. PIPING PLOVER MORTALITIES CAUSED BY OFF-ROAD VEHICLES ON ATLANTIC COASTAL BEACHES. WLDLIFE SOCIETY BULLETIN 22:409-414.

3110. MELVIN, S. M. and S. A. TEMPLE. 1983. FALL MIGRATION AND MORTALITY OF INTERLAKE, MANITOBA SANDHILL CRANES IN NORTH DAKOTA. J. WLDL. MANAGE. 47 (3):805-17.

3111. MEMPHIS STATE UNIVERSITY. 1971. EFFECTS OF NOISE ON WILDLIFE AND OTHER ANIMALS. U.S. ENVIRONMENTAL PROTECTION AGENCY, OFFICE OF NOISE ABATEMENT AND CONTROL. WASHINGTON, D.C. NTID300.5. 74PP.

3112. MENDELSON, J. R. I. and W. B. JENNINGS. 1992. SHIFTS IN THE RELATIVE ABUNDANCE OF SNAKES IN A DESERT GRASSLAND. JOURNAL OF HERPETOLOGY 26(1):38-45.

3113. MENDELSSOHN, H. 1982. WOLVES IN ISRAEL. P 173-95. IN: HARRINGTON FH, PAQUET PC (EDS.). WOLVES OF THE WORLD: PERSPECTIVES OF BEHAVIOR, ECOLOGY, AND CONSERVATION. PARK RIDGE, NJ.: NOYLES PUBL.

3114. MENDENHALL, V. M. 1992. DISTRIBUTION, BREEDING RECORDS, AND CONSERVATION PROBLEMS OF THE MARBLED MURRELET IN ALASKA. PROCEEDINGS OF THE WESTERN FOUNDATION OF VERTEBRATE ZOOLOGY 5 (1):5-16.

3115. MENGES, E. S. 1990. POPULATION VIABILITY ANALYSIS FOR AN ENDANGERED PLANT. CONSERVATION BIOLOGY 4 (1):52-62.

3116. MENGES, E. S. 1991. SEED GERMINATION PERCENTAGE INCREASES WITH POPULATION SIZE IN A FRAGMENTED PRAIRIE SPECIES. CONSERVATION BIOLOGY 5 (2):158-64.

3117. MENKHORST, K. A. and J. C. Z. WOINARSKI. 1992. DISTRIBUTION OF MAMMALS IN MONSOON RAINFORESTS OF THE NORTHERN TERRITORY. WILDLIFE RESEARCH 19(3):295-316.

3118. MERENDINO, M. T., C. D. ANKNEY and D. G. DENNIS. 1993. INCREASING MALLARDS, DECREASING AMERICAN BLACK DUCKS: MORE EVIDENCE FOR CAUSE AND EFFECT. J. WILDL. MANAGE. 57 (2):199-208.

3119. MERRIAM, G. 1991. ARE CORRIDORS NECESSARY FOR THE MOVEMENT OF BIOTA?. PAGES 406-407 IN SAUNDERS,D.A. AND HOBBS,R.J., EDITORS. NATURE CONSERVATION 2: THE ROLE OF CORRIDORS. SURREY BEATTY AND SONS, CHIPPING NORTON, AUSTRALIA. 
3120. MERRIAM, G. 1991. CORRIDORS AND CONNECTIVITY: ANIMAL POPULATIONS IN HETEROGENEOUS ENVIRONMENTS. PAGES 133-142 IN SAUNDERS,D.A. AND HOBBS,R.J., EDITORS. NATURE CONSERVATION 2: THE ROLE OF -CORRIDORS. SURREY BEATTY AND SONS, CHIPPING NORTON, AUSTRALIA.

3121. MERRIAM, G. 1991. CORRIDORS AND CONNECTIVITY: ANIMAL POPULATIONS IN HETEROGENEOUS ENVIRONMENTS. CHAPTER 13. IN: SAUNDERS D, HOBBS R, EDS. NATURE CONSERVANCY 2: THE ROLE OF CORRIDORS. SURREY BEATTY AND SONS, CHIPPING NORTON.

3122. MERRIAM, G., M. KOZAKIEWICZ, E. TSUCHIYA and K. HAWLEY. 1989. BARRIERS AS BOUNDARIES FOR METAPOPULATIONS AND DEMES OF PEROMYSCUS LEUCOPUS IN FARM LANDSCAPES. LANDSCAPE ECOLOGY $2: 227-235$.

3123. MERRIAM, G. and A. LANOUE. 1990. CORRIDOR USE BY SMALL MAMMALS: FIELD MEASUREMENT FOR THREE EXPERIMENTAL TYPES OF PEROMYSCUS LEUCOPUS. LANDSCAPE ECOLOGY 4:123-31

3124. MERRIAM, L. C. JR., C. K. SMITH, D. E. MILLER, C. T. HUANG, J. C. I. TAPPEINER, K. GOECKERMANN, J. A. BLOEMENDAL and T. M. COSTELLO. 1973. NEWLY DEVELOPED CAMPSITES IN THE BOUNDARY WATERS CANOE AREA: A STUDY OF FIVE YEARS' USE. UNIVERSITY OF MINNESOTA AGRICULTURAL EXPERIMENT STATION. ST. PAUL, MINNESOTA. STATION BULLETIN 511, FORESTRY SERIES 14. 27PP.

3125. MERRILL, E. H., T. P. HEMKER, K. P. WOODRUFF and L. KUCK. 1994. IMPACTS.OF MINING FACILITIES ON FALL MIGRATION OF MULE DEER. WILDL. SOC. BULL. 22 (1):68-73.

3126. MESSNER, H. E., D. R. DIETZ and E. C. GARRETT. 1973. A MODIFICATION OF THE SLANTING DEER FENCE. J. RANGE MANAGE. 26 (3):233-5.

3127. MEYER, E. 1993. THE IMPACT OF SUMMER TOURISM AND WINTER TOURISM ON THE FAUNA OF ALPINE SOILS IN WESTERN AUSTRIA (OETZTAL ALPS, RATIKON). REVUE SUISSE DE ZOOLOGIE 100:519-527.

3128. MEYER, M., J. WOODFORD, S. GILLUM and T. DAULTON. 1997. SHORELAND ZONING REGULATIONS DO NOT ADEQUATELY PROTECT WLDLIFE HABITAT IN NORTHERN WISCONSIN. WISCONSIN DEPT. NAT RES. 82PP.

3129. MICHAEL, E. D. 1975. EFFECTS OF HIGHWAYS ON WILDLIFE. WVDOH 42. WEST VIRGINIA DEPARTMENT OF HIGHWAYS, CHARLESTON, WV.

3130. MICHAEL, E. D. 1978. MANAGEMENT OF HIGHWAY RIGHTS-OF-WAY FOR WILDLIFE. CONGR.THERIOL.INT. 2:51-54.

3131. MICHAEL, E. D. 1981. MANAGEMENT OF HIGHWAYS FOR WLDLIFE IN THE CENTRAL APPALACHIANS. PROCEEDINGS OF THE ANNUAL CONFERENCE OF THE SOUTHEASTERN ASSOCIATION OF FISH AND WLDLIFE AGENCIES $34: 442-448$

3132. MICHAEL, E. D. 1965. MOVEMENTS OF WHITE-TAILED DEER ON THE WELDER WILDLIFE REFUGE. J. WILDL. MANAGE. $29(1): 44-52$.

3133. MICHAEL, E. D. 1980. USE OF DIFFERENT ROADSIDE COVER PLANTINGS BY WILDLIFE. WEST VIRGINIA UNIVERSITY AGRICULTURAL EXPERIMENT STATION, MORGANTOWN, WEST VIRGINIA.

3134. MICHAEL, E. D. 1980. USE OF DIFFERENT ROADSIDE COVER PLANTINGS BY WLDLIFE. WVDOH/56; FHWAMW80/004 WEST VIRGINIA UNIVERSITY, DIVISION OF FORESTRY. SPONSORED BY WEST VIRGINIA DEPARTMENT OF HIGHWAYS AND FEDERAL HIGHWAY ADMINISTRATION, MORGANTOWN, WV.

3135. MICHAEL, E. D., C. R. FERRIS and E. G. HAVERLACK. 1976. EFFECTS OF HIGHWAY RIGHTS-OF-WAY ON BIRD POPULATIONS. PAGES 253-262 IN TILLMAN,R., EDITOR. PROCEEDINGS OF THE FIRST NATIONAL SYMPOSIUM ON ENVIRONMENTAL CONCERNS IN RIGHTS-OF-WAY MANAGEMENT MISSISSIPPI STATE UNIVERSITY, STARKVILLE.

3136. MICHAEL, E. D. 1978. EFFECTS OF HIGHWAY CONSTRUCTION ON GAME ANIMALS. PROCEEDINGS OF THE ANNUAL CONFERENCE OF THE SOUTHEASTERN ASSOCIATION OF FISH AND WILDLIFE AGENCIES 32:48-52. 
3137. MICHAEL, E. D. 1976. EFFECTS OF HIGHWAYS ON WILDLIFE. DIVISION OF FORESTRY, WEST VIRGINIA UNIVERSITY . MORGANTOWN, WW

3138. MICHAEL, E. D. 1979. VISIBILITY OF BIRDS ALONG INTERSTATE HIGHWAYS. REDSTART 46(2):82-87.

3139. MICHAEL, E. D. and C. TAYLOR. 1978. USE OF INTERSTATE HIGHWAY CUTS AS STARLING NESTING SITES. CONDOR 80(1):113-115

3140. MICHELMORE, F., K. BEARDSLEY, R. F. W. BARNES and H. I. DOUGLAS. 1994. A MODEL ILLUSTRATING THE CHANGES IN FOREST ELEPHANT NUMBERS CAUSED BY POACHING. AFRICAN JOURNAL OF ECOLOGY 32 (2):89-99.

3141. MICHIGAN DEPT. OF CONS. 1962. SUMMARY OF PITTMAN-ROBERTSON RESEARCH AND DEVELOPMENT REPORTS JULY 1, 1961 TO JUNE 30, 1962. BULL. NO. 35, 21 PP. MICHIGAN DEPT. OF CONS., GAME DIV., LANSING.

3142. MIDDLETON, B. A. 1992. HABITAT AND FOOD PREFERENCES OF GREYLAG AND BARHEADED GEESE WINTERING IN THE KEOLADEO NATIONAL PARK, INDIA. JOURNAL OF TROPICAL ECOLOGY 8 (2):181-93.

3143. MIERAU, G. W. and B. E. FAVARA. 1975. LEAD POISONING IN ROADSIDE POPULATIONS OF DEER MICE. ENVIRONMENTAL POLLUTION 8:55-64.

3144. MIGLETZ, J., J. K. FISH and J. L. GRAHAM. 1994. ROADWAY DELINEATION PRACTICES HANDBOOK. FEDERAL HIGHWAY ADMINISTRATION. AVAILABLE THROUGH THE NATIONAL TECHNICAL INFORMATION SERVICE, DISTRIBUTOR, WASHINGTON, D.C.

3145. MILLER, B., G. CEBALLOS and R. READING. 1994. THE PRAIRIE DOG AND BIOTIC DIVERSITY. CONSERVATION BIOLOGY $8(3): 677-81$.

3146. MILLER, B. K. and J. A. LITVAITIS. 1992. HABITAT SEGREGATION BY MOOSE IN A BOREAL FOREST ECOTONE. ACTA THERIOLOGICA 37:41-50.

3147. MILLER, B. K. and J. A. LITVAITIS. 1992. USE OF ROADSIDE SALT LICKS BY MOOSE, ALCES ALCES, IN NORTHERN NEW HAMPSHIRE. CANADIAN FIELD NATURALIST 106:112-117.

3148. MILLER, D. R. 1987. TITLE UNKNOWN. PROC. ANNU. CONF. SOUTHEAST. ASSOC. FISH WLDL. AGENCIES 41:474-6.

3149. MILLER, F. L. 1985. CARIBOU AND HUMAN ACTIVITY. IN: PROCEEDINGS OF THE 1STNORTH AMERICAN CARIBOU WORKSHOP, 28-29 SEP, 1983. WHITEHORSE, YUKON.

3150. MILLER, F. L. 1983. RESTRICTED CARIBOU HARVEST OF WELFARE -- NORTHERN NATIVE'S DILEMMA. IN: PULLIAINEN E, (ED.) PROCEEDINGS OF THE THIRD INTERNATIONAL THERIOLOGICAL CONGRESS, HELSINKI 15-20AUGUST-1982.-PART-VII.-

THIRD-INTERNATIONAL-REINDEER-CARIBOU-SYMPOSIUM,-SAARISELKAA-23-26-AUGUST-1982.

3151. MILLER, F. L. 1983. SOME PHYSICAL CHARACTERISTICS OF CARIBOU SPRING MIGRATION CROSSING SITES ON THE DEMPSTER HIGHWAY, YUKON TERRITORY. PROCEEDINGS OF THE ALASKA SCIENCE CONFERENCE 34:15-20.

3152. MILLER, F. L. 1983. TITLE UNKNOWN. PROC. ALASKA SCI. CONF. 34 (15).

3153. MILLER, F. L., C. J. JONKEL and E. C. GARRETT. 1972. GROUP COHESION AND LEADERSHIP RESPONSE BY BARREN-GROUND CARIBOU TO MAN-MADE BARRIERS. ARCTIC 25:193-201.

3154. MILLER, F. L., C. J. JONKEL and G. D. TESSIER. 1972. GROUP COHESION AND LEADERSHIP RESPONSE BY BARREN-GROUND CARIBOU TO MAN-MADE BARRIERS. ARCTIC 25:193-201.

3155. MILLER, G. and E. L. SMITH. 1985. HUMAN ACTIVITY IN DESERT BIGHORN SHEEP: WHAT DISTURBS SHEEP? TRANSACTIONS OF THE DESERT BIGHORN SHEEP COUNCIL 29:4-7.

3156. MILLER, G. D. 1987. FIELD TESTS OF POTENTIAL POLAR BEAR REPELLENTS. INT. CONF. BEAR RES. AND MANAGE. 7:383-90 
3157. MILLER, G. D. 1983. RESPONSES OF CAPTIVE GRIZZLY AND POLAR BEARS TO POTENTIAL REPELLENTS. INT. CONF. BEAR RES. AND MANAGE. 5:275-9.

3158. MILLER, G. D. 1980. BEHAVIORAL AND PHYSIOLOGICAL CHARACTERISTICS OF GRIZZLY AND POLAR BEARS, AND THEIR RELATION TO BEAR REPELLENT. M.S. THESIS, UNIVERSITY OF MONTANA, MISSOULA, MT. 106 PP.

3159. MILLER, J. R., L. A. JOYCE, R. L. KNIGHT and R. M. KING. 1996. FOREST ROADS AND LANDSCAPE STRUCTURE IN THE SOUTHERN ROCKY MOUNTAINS. LANDSCAPE ECOLOGY 11(2):115-127.

3160. MILLER, J. R. 1994. LANDSCAPE STRUCTURE AND ROAD DENSITY IN THE SOUTHERN ROCKY MOUNTAINS.

3161. MILLER, J. G. 1978. AN ECOLOGICAL STUDY OF CREEPING JUNIPER (JUNIPERUS HORIZONTALIS MOENCH.) IN MONTANA. M.S. THESIS, MONTANA STATE UNIVERSITY, BOZEMAN, MT. 154 PP.

3162. MILLER, L. C. 1971. SOME OBSERVATIONS IN MICHIGAN STATE PARKS FOLLOWING UNRESTRICTED SNOWMOBILING. PAGES 111-116 IN M. CHUBB, EDITOR. PROCEEDINGS OF THE SNOWMOBILE AND OFF THE ROAD VEHICLE RESEARCH SYMPOSIUM. SPONSORED BY THE DEPARTMENT OF PARK AND RECREATION RESOURCES, MICHIGAN STATE UNIVERSITY. EAST LANSING, MI.

3163. MILLER, M. G. 1980. THE INFLUENCE OF HABITAT FEATURES ON WATERFOWL PRODUCTIVITY ON STOCK RESERVOIRS IN SOUTH VALLEY COUNTY, MONTANA. M.S. THESIS, MONTANA STATE UNIVERSITY, BOZEMAN, MT. 43 PP.

3164. MILLER, S. D. and W: B. BALLARD. 1982. HOMING OF TRANSPLANTED ALASKAN BROWN BEARS. J. WILDL. MANAGE. 46 (4):869-76

3165. MILLER, S. D. and M. A. CHIHULY. 1987. CHARACTERISTICS OF NONSPORT BROWN BEAR DEATHS IN ALASKA. INT. CONF. BEAR RES. AND MANAGE. 7:51-8.

3166. MILLER, S. D. and J. SCHOEN. 1993. THE BROWN BEAR IN ALASKA

3167. MILLER, T. O. 1975. BIG GAME INVESTIGATIONS: FACTORS INFLUENCING BLACK BEAR HABITAT SELECTION ON CHEAT MOUNTAIN, WEST VIRGINIA. WEST VIRGINIA DEPARTMENT OF NATURAL RESOURCES, CHARLESTON.

3168. MILLER, T. O. 1975. FACTORS AFFECTING BLACK BEAR HABITAT SELECTION ON CHEAT MOUNTAIN, WEST VIRGINIA. THESIS M.S.67PP.

3169. MILLER, T. D. 1991. INFLUENCE OF INORGANIC AND ORGANIC NUTRIENT ENRICHMENT ON BLUE-GREEN ALGAL ACTIVITY AND RELATIVE BIOMASS IN A EUTROPHIC SOUTHWEST MONTANA RESERVOIR. M.S. THESIS, MONTANA STATE UNIVERSITY; BOZEMAN, MT. 115 PP.

3170. MILLS, L. S. 1993. EXTINCTIONS IN HABITAT REMNANTS: PROXIMATE MECHANISMS AND BIOGEOGRAPHIC CONSEQUENCES (OREGON, CLETHRIONOMYS CALIFORNICUS). PHD THESIS, UNIVERSITY OF CALIFORNIA, SANTA CRUZ . 219 PP.

3171. MILLSAP, B. A. and N. L. MAURICE. 1988. ROAD TRANSECT COUNTS FOR RAPTORS: HOW RELIABLE ARE THEY?. JOURNAL OF RAPTOR RESEARCH 22(1):8-16.

3172. MILLSPAUGH, J. J. 1995. SEASONAL MOVEMENTS, HABITAT USE PATTERNS AND THE EFFECTS OF HUMAN DISTURBANCES ON ELK IN CUSTER STATE PARK, SOUTH DAKOTA. THESIS, SOUTH DAKOTA STATE UNIVERSITY,

3173. MILNE, B. T., K. M. JOHNSTON and R. T. T. FORMAN. 1989. SCALE-DEPENDENT PROXIMITY OF WLDLIFE HABITAT IN A SPATIALLY-NEUTRAL BAYESIAN MODEL. LANDSCAPE ECOLOGY 2 (2):101-10.

3174. MILNER, G. B. 1995. MULE DEER HABITAT USE IN THE OWYHEE MOUNTAINS, IDAHO. M.S. THESIS, MONTANA STATE UNIVERSITY, BOZEMAN, MT. 51 PP.

3175. MINISTRY OF THE ENVIRONMENT, B. C. 1995. WLDLIFE ACCIDENT REPORTING SYSTEM (WARS) ANNUAL REPORT. HIGHWAY ENVIRONMENT BRANCH, VANCOUVER, B.C.. 
3176. MINNESOTA, DEPT. OF HIGHWAYS, UNITED STATES and FEDERAL HIGHWAY ADMINISTRATION. 1975. FINAL ENVIRONMENTAL STATEMENT FOR INTERSTATE HIGHWAY 90 (I-90) IN FARIBAULT COUNTY, MINNESOTA MINNESOTA PROJECT I 090-2 (), STATE PROJECT 2280 (IN THE VICINITY OF WALNUT LAKE), FROM 1.8 MILES WEST OF TRUNK HIGHWAY NO. 253 TO TRUNK HIGHWAY NO. 22. THE DEPARTMENT, SAINT PAUL, MINNESOTA.

3177. MINNESOTA, DEPT. OF NATURAL RESOURCES, D. K. INGEBRIGTSEN and J. R. LUDWIG. 1986. EFFECTIVENESS OF SWAREFLEX WLDLIFE WARNING REFLECTORS IN REDUCING DEER-VEHICLE COLLISIONS IN MINNESOTA. MINNESOTA WILDLIFE REPORT: MINNESOTA WILDLIFE REPORT 3. DEPT. OF NATURAL RESOURCES, SAINT PAUL, MINNESOTA.

3178. MIQUET, A. 1986. A CONTRIBUTION TO THE STUDY OF THE RELATION BETWEEN THE BLACK GROUSE (TETRAO TETRIX L., TETRAONIDAE) AND WINTER TOURISM IN HAUTE-TARENTAISE. ACTA OECOLOGICA 7:325-335 (IN FRENCH WITH ENGLISH ABSTRACT).

3179. MIRANDE, C. M., J. W. CARPENTER and A. M. BURKE. 1997. THE EFFECT OF DISTURBANCE ON THE REPRODUCTION AND MANAGEMENT OF CAPTIVE CRANES. PROC. NORTH AM. CRANE WORKSHOP 7:56-61.

3180. MITCHELL, J. and R. MAYER. 1997. DIGGINGS BY FERAL PIGS WITHIN THE WET TROPICS WORLD HERITAGE AREA OF NORTH QUEENSLAND. WILDLIFE RESEARCH 24(5):591-601.

3181. MITCHELL, J. L. 1957. A STUDY OF MINK MOVEMENTS AND POPULATIONS ON THE LOWER MADISON RIVER, MONTANA. M.S. THESIS, MONTANA STATE COLLEGE, BOZEMAN, MT. 19 PP.

3182. MITCHELL, J. E., J. H. SCHOMAKER and D. B. PROPST. 1977. OFF-ROAD VEHICLE USERS IN IDAHO DISTRIBUTION AND ACTIVITY. BULLETIN / COLLEGE OF FORESTRY, WILDLIFE AND RANGE SCIENCES: BULLETIN (UNIVERSITY OF IDAHO. FOREST, WILDLIFE, AND RANGE EXPERIMENT STATION) NO. 20. COLLEGE OF FORESTRY, WILDLIFE AND RANGE SCIENCES, UNIVERSITY OF IDAHO, MOSCOW, IDAHO.

3183. MITCHELL, M. S., K. S. KARRIKER, E. J. JONES and R. A. LANCIA. 1995. SMALL MAMMAL COMMUNITIES ASSOCIATED WITH PINE PLANTATION MANAGEMENT OF POCOSINS. J. WILDL. MANAGE. 59 (4):875-81.

3184. MITCHELL, S. 1994. EFFECTS OF A FOUR-WHEEL DRIVE ROAD ON RIPARIAN COMMUNITIES IN CANYONLANDS NATIONAL PARK, UTAH. JOURNAL OF THE COLORADO-WYOMING ACADEMY OF SCIENCE 26(1):36-41.

3185. MITRO, M. G. 1999. SAMPLING AND ANALYSIS TECHNIQUES AND THEIR APPLICATION FOR ESTIMATING RECRUITMENT OF JUVENILE RAINBOW TROUT IN THE HENRY'S FORK OF THE SNAKE RIVER, IDAHO. PH.D. DISSERTATION, MONTANA STATE UNIVERSITY, BOZEMAN, MT. 288 PP.

3186. MLADENOFF, D. J., T. A. SICKLEY, R. G. HAIGHT and A. P. WYDEVEN. 1995. A REGIONAL LANDSCAPE ANALYSIS AND PREDICTION OF FAVORABLE GRAY WOLF HABITAT IN THE NORTHERN GREAT LAKES REGION . CONSERVATION BIOLOGY $9: 279-294$.

3187. MLADENOFF, D. J. and F. STEARNS. 1993. EASTERN HEMLOCK REGENERATION AND DEER BROWSING IN THE NORTHERN GREAT LAKES REGION: A RE-EXAMINATION AND MODEL SIMULATION. CONSERVATION BIOLOGY 7 (4):889-900.

3188. MLADENOFF, D. J., M. A. WHITE, T. R. CROW and J. PASTOR. 1994. APPLYING PRINCIPLES OF LANDSCAPE DESIGN AND MANAGEMENT TO INTEGRATE OLD-GROWTH FOREST ENHANCEMENT. AND COMMODITY USE. CONSERVATION BIOLOGY $8(3): 752-62$.

3189. MLADENOFF, D. J., M. A. WHITE, J. PASTOR and T. R. CROW. 1993. COMPARING SPATIAL PATTERN IN UNALTERED OLD-GROWTH AND DISTURBED FOREST LANDSCAPES. ECOLOGICAL APPLICATIONS 3 (2):294-306.

3190. MOCCI, D. 1985. MORTALITY OF BIRDS ON THE ROADS AND THEIR DENSITY. PROCEEDINGS OF THE INTERNATIONAL ORNITHOLOGY CONGRESS 18:1147-1149.

3191. MOCK, P. J., M. GRISHAVER, D. KING, B. CROTHER, D. BOLGER and K. PRESTON. 1992. BALDWN OTAY RANCH WILDLIFE CORRIDOR STUDIES. OGDEN ENVIRONMENTAL SERV., SAN DIEGO, CALIF. 155PP. 
3192. MODAFFERI, R. D. 1991. TRAIN MOOSE-KILL IN ALASKA: CHARACTERISTICS AND RELATIONSHIP WITH SNOWPACK DEPTH AND MOOSE DISTRIBUTION IN LOWER SUSITNA VALLEY. ALCES 27:193-207.

3193. MOELLER, G. H. and J. H. ENGELKEN. 1972. WHAT FISHERMEN LOOK FOR IN A FISHING EXPERIENCE. J. WLDL. MANAGE. 36 (4):1253-7.

3194. MOEN, A. N., S. WHITTEMORE and B. BUXTON. 1982. EFFECTS OF DISTURBANCE BY SNOWMOBILES ON HEART RATE OF CAPTIVE WHITE-TAILED DEER. NEW YORK FISH AND GAME JOURNAL 29(2):176-183.

3195. MOGEN, J. T. 1996. STATUS AND BIOLOGY OF THE SPAWNING POPULATION OF RED ROCK LAKES ARCTIC GRAYLING. M.S. THESIS, MONTANA STATE UNIVERSITY, BOZEMAN, MT. 90 PP.

3196. MOHR, C. E. 1977. SURVIVAL: A TALE OF TWO BATS. PAGES 349-366 IN B. SLOANE, EDITOR. CAVERS, CAVES, AND CAVING. RUTGERS UNIVERSITY PRESS, NEW BRUNSWICK, NEW JERSEY.

3197. MOHR, C. E. 1976. THE WORLD OF THE BAT. J. B. LIPPINCOTT COMPANY. PHILADELPHIA, PENNSYLVANIA AND NEW YORK, NEW YORK. 162PP.

3198. MOHR, C. O. and L. W. ADAMS. 1963. RELATION OF FLEA INFESTATIONS TO SPACING BETWEEN COTTONTAIL RABBITS. J. WILDL. MANAGE. 27 (1):71-6.

3199. MOLLOHAN, C. M. and A. L. LECOUNT. 1989. PROBLEMS OF MAINTAINING VIABLE BLACK BEAR POPULATION IN A FRAGMENTED FOREST. USDA FS GTR RM-185. VOLUME 185. P149-59

3200. MONDA, M. J., J. T. RATTI and T. R. MCCABE. 1994. REPRODUCTIVE ECOLOGY OF TUNDRA SWANS ON THE ARCTIC NATIONAL WILDLIFE REFUGE, ALASKA. J. WILDL. MANAGE. 58(4):757-73.

3201. MONKKONEN, M. and D. A. WELSH. 1994. A BIOGEOGRAPHICAL HYPOTHESIS ON THE EFFECTS OF HUMAN CAUSED LANDSCAPE CHANGES ON THE FOREST BIRD COMMUNITIES OF EUROPE AND NORTH AMERICA. ANNALES ZOOLOGICI FENNICI 31 (1):61-70.

3202. MONSEN, S. B. 1972. SELECTING PLANTS TO REHABILITATE DISTURBED AREAS. USDA FOREST SERVICE, INTERMOUNTAIN FOREST AND RANGE EXPERIMENT STATION.

3203. MONSEN, S. B. and D. R. CHRISTENSEN. 1975. WOODY PLANTS FOR REHABILITATING RANGELANDS IN THE INTERMOUNTAIN REGION.

3204. MONSEN, S. B. and A. P. PLUMMER. 1978. PLANTS AND TREATMENT FOR REVEGETATION OF DISTURBED SITES IN THE INTERMOUNTAIN AREA.

3205. MONTAGNE, M. E. 1979. THE BLUNT-NOSED LEOPARD LIZARD HYBRID IN BALLINGER CANYON. CALIFORNIA-NEVADA WILDLIFE TRANSACTIONS 1979:174-176.

3206. MONTANA AUDOBON COUNCIL. 1993. PROTECTING MONTANA'S WETLANDS: AN OVERVIEW OF MONTANA'S SECTION 404 PROGRAM. MONTANA AUDOBON COUNCIL. HELENA, MONTANA. 30PP.

3207. MONTANA DEPT. OF FISH AND GAME. 1961. THE EFFECTS ON FISH AND GAME OF PROPOSED ROUTES FOR THE INTERSTATE HIGHWAY FROM HELENA TO THE VINCINITY OF WOLF CREEK, MONTANA. MONTANA DEPT. OF FISH AND GAME., 4 PP.

3208. MONTANA FISH, WLDLIFE AND PARKS. NO DATE. OFF-ROAD MONTANA: A SUMMARY OF OHV LAWS, REGULATIONS, AND TIPS FOR RESPONSIBLE OFF-ROADING. MONTANA FISH, WILDLIFE \& PARKS, PARKS DIVISION. HELENA, MONTANA. 14PP.

3209. MONTANA FISH, WLDLIFE AND PARKS. 1997. OHV PROGRAM ANNUAL REPORT JULY 1, 1996 JUNE $30,1997$. MONTANA FISH, WLDLIFE \& PARKS. HELENA, MONTANA. 16PP.

3210. MONTOPOLI, G. J. and D. A. ANDERSON. 1991. A LOGISTIC MODEL FOR THE CUMULATIVE EFFECTS OF HUMAN INTERVENTION ON BALD EAGLE HABITAT. JOURNAL OF WILDLIFE MANAGEMENT 55 (2):290-3. 
3211. MOOIJ, J. H. 1982. THE EFFECTS OF HIGHWAYS UPON THE AVIFAUNA ON AN OPEN LANDSCAPE OF THE LOWER RHINE (NORTH RHINE-WESTPHALIA), INQUIRY INTO THE BEHAVIOR OF WILD GEESE. CHARADRIUS 18(3/4):73-92.

3212. MOORE, R. and T. MILLS. 1977. AN ENVIRONMENTAL GUIDE TO WESTERN SURFACE MINING PART II: IMPACTS, MITIGATION, AND MONITORING. OFFICE OF BIOLOGICAL SERVICES, FISH AND WILDLIFE SERVICES, U.S. DEPT. OF THE INTERIOR.

3213. MOORE, R. and T. MILLS. 1977. AN ENVIRONMENTAL GUIDE TO WESTERN SURFACE MINING. PART TWO: IMPACTS, MITIGATION AND MONITORING. U.S.D.I., FISH AND WLDLF. SERV.

3214. MOORE, R. L. 1994. CONFLICTS ON MULTIPLE-USE TRAILS: SYNTHESIS OF THE LITERATURE AND STATE OF THE PRACTICE. FEDERAL HIGHWAY ADMINISTRATION. REPORT NO. FHWA-PD-94-031.

3215. MOORE, R. L. and A. R. GRAEFE. 1994. ATTACHMENTS TO RECREATION SETTINGS: THE CASE OF RAIL-TRAIL USERS. LEISURE SCIENCES 16:17-31.

3216. MOORE, R. L., A. R. GRAEFE, R. J. GITELSON and E. PORTER. 1992. THE IMPACTS OF RAIL-TRAILS: A STUDY OF THE USERS AND PROPERTY OWNERS FROM THREE TRAILS. RIVERS, TRAILS, AND CONSERVATION ASSISTANCE PROGRAM, NATIONAL PARK SERVICE. WASHINGTON, D.C.

3217. MOORE, R. L. K. 1987. DAILY AND SEASONAL ACTIVITY PATTERNS OF THE PIKA IN SOUTHWESTERN MONTANA . M.S. THESIS, MONTANA STATE UNIVERSITY, BOZEMAN, MT. 61 PP.

3218. MOORE, T. G. and M. MANGEL. 1996. TRAFFIC RELATED MORTALITY AND THE EFFECTS ON LOCAL POPULATIONS OF BARN OWLS. IN TRENDS IN ADDRESSING TRANSPORTATION RELATED WILDLIFE MORTALITY. PROCEEDINGS OF THE TRANSPORTATION RELATED WILDLIFE MORTALITY SEMINAR. FLORIDA DEPARTMENT OF TRANSPORTATION, TALLAHASSEE, FL-ER-58-96.

3219. MOORE, T. G. and M. MANGEL. 1996. TRAFFIC RELATED MORTALITY AND THE EFFECTS ON LOCAL POPULATIONS OF BARN OWLS (TYTO ALBA). PAGES 125-140 IN EVINK,G., ZIEGLER,D., GARRETT,P., AND BERRY,J., EDITORS. TRANSPORTATION AND WLDLIFE: REDUCING WLDLIFE MORTALITY AND IMPROVING WLDLIFE PASSAGEWAYS ACROSS TRANSPORTATION CORRIDORS: PROCEEDINGS OF THE FLORIDA DEPARTMENT OF TRANSPORTATION/FEDERAL HIGHWAY ADMINISTRATION TRANSPORTATION-RELATED WILDLIFE MORTALITY SEMINAR; 1996 APRIL 30-MAY 2; ORLANDO, FL. FHWA-PD-96-041. U.S. DEPARTMENT OF TRANSPORTATION, FEDERAL HIGHWAY ADMINISTRATION, WASHINGTON, DC.

3220. MORANT, P. D. and C. WINTER. 1983. CARRION FEEDING BY KELP GULLS (LARUS DOMINICANUS) IN PATAGONIA, ARGENTINA. CORMORANT 1(1-2):65-67.

3221. MOREHOUSE, T. A., R. A. CHILDEIS and L. E. LEASK. 1978. FISH AND WILDLIFE PROTECTION IN THE PLANNING AND CONSTRUCTION OF THE TRANS-ALASKA OIL PIPELINE. FWS/OBS 78/70. U.S. DEPT. OF THE INTERIOR, FISH AND WILDLIFE SERVICE,

3222. MORGAN, J. T. 1993. SUMMER HABITAT USE OF WHITE-TAILED DEER ON THE TALLY LAKE RANGER DISTRICT, FLATHEAD NATIONAL FOREST. PH.D. DISSERTATION, MONTANA STATE UNIVERSITY, BOZEMAN, MT. 103 PP.

3223. MORGAN, R. P. C. 1985. THE IMPACT OF RECREATION ON MOUNTAIN SOILS: TOWARDS A PREDICTIVE MODEL FOR SOIL EROSION. PAGES 112-121 IN N. G. BAYFIELD AND G. C. BARROW, EDITORS. THE ECOLOGICAL IMPACTS OF OUTDOOR RECREATION ON MOUNTAIN AREAS IN EUROPE AND NORTH AMERICA. RECREATION ECOLOGY RESEARCH GROUP, WYE, ASHFORD, KENT, UK.

3224. MORGANTINI, L. E. 1988. BEHAVIORAL ADAPTIVE STRATEGIES OF WAPITI IN THE CANADIAN ROCKY MOUNTAINS. PHD THESIS, DEPT. OF ANIMAL SCIENCES, UNIVERSITY OF ALBERTA.

3225. MORGANTINI, L. E. 1978. ECOLOGY AND BEHAVIOR OF THE BANFF YA-HA-TINDA ELK HERD AND THE EFFECTS OF HARASSMENT. PREPARED FOR PARKS CANADA, CALGARY; PREPARED BY DEPARTMENT OF ANIMAL SCIENCE, UNIVERSITY OF ALBERTA, EDMONTON. UNPUBLISHED REPORT.

3226. MORGANTINI, L. E. 1978. ECOLOGY AND BEHAVIOR OF THE BANFF YA HA TINDA ELK HERD. PROGRESS REPORT. ALBERTA FISH AND WILDLIFE DIVISION, EDMONTON. UNPUBLISHED REPORT. 
3227. MORGANTINI, L. E. 1996. ELK AND ACCESS RELATIONSHIPS IN THE PINCHER CREEK AND CASTLE-CARBONDALE SUBAREAS. ASPB ANNUAL MEETING: ACCESS MANAGEMENT IN ALBERTA; 1996 APR 10-1996 APR 11; CALGARY, ALBERTA

3228. MORGANTINI, L. E. 1991. ELK HABITAT IMPROVEMENT THROUGH TIMBER HARVESTING IN WEST CENTRAL ALBERTA. ABSTRACT FROM ALBERTA CHAPTER OF THE WILDLIFE SOCIETY,2ND ANNUAL MEETING. MARCH 23 AND 24 , 1991, EDMONTON.

3229. MORGANTINI, L. E. 1984. PIPELINE AND WILDLIFE. A WILDLIFE MONITORING STUDY DURING THE CONSTRUCTION OF THE HANLAN AND BRAZEAU GAS PIPELINES. PREPARED FOR CANTERRA ENERGY LIMITED. PREPARED BY WILDLAND RESOURCES CONSULTANTS. 58PP.

3230. MORGANTINI, L. E. 1991. PIPELINE CONSTRUCTION AND WILLIFE IN ALBERTA: IMPACT AND MITIGATION. INTER. SYMPOSIUM ON COLD REGION DEVELOPMENT. EDMONTON, ALBERTA.

3231. MORGANTINI, L. E. 1981. PIPELINE CONSTRUCTION AND WILDLIFE. RESULTS OF A MONITORING PROGRAM ALONG THE EDSON M/L. FIRST WINTER. 107PP.

3232. MORGANTINI, L. E. 1982. PIPELINE CONSTRUCTION AND WILDLIFE. WILD UNGULATE DISTRIBUTION ALONG THE GRANDE PRAIRIE LATERAL AND ELMWORTH PIPELINES. ONE YEAR AFTER CONSTRUCTION. PREPARED FOR NOVA CORPORATION. PREPARED BY WILDLAND RESOURCES CONSULTANTS. 91 PP.

3233. MORGANTINI, L. E. 1991. PRAIRIE BLUFF. BIGHORN SHEEP STUDY. FINAL REPORT PART1: SUMMARY AND CONCLUSIONS. PREPARED FOR SHELL CANADA LTD. PREPARED BY WILDLIFE RESOURCES CONSULTING.

3234. MORGANTINI, L. E. 1986. UNGULATE ENCOUNTERS WITH CONSTRUCTION MATERIALS(PIPE, BERMS, ETC.) DURING THE BUILDING OF AN UNDERGROUND GAS PIPELINE IN WESTERN ALBERTA. ALCES 21:215-30

3235. MORGANTINI, L. E. 1985. WILDLIFE MONITORING-IMPACT MITIGATION IN THE REGION SURROUNDING WELL SITE 5-23. SHEEP CREEK-PANTHER RIVER AREA. INTERIM REPORT PREPARED FOR CANTERRA ENERGY LTD. PREPARED BY WILDLIFE RESOURCES CONSULTING LTD., EDMONTON. 30 PP.

3236. MORGANTINI, L. E. and E. BRUNS. 1988. ATTRACTION OF BIGHORN SHEEP TO WELLSITES AND OTHER MAN-MADE MINERAL LICKS ALONG THE EASTERN SLOPES OF ALBERTA: A MANAGEMENT CONCERN. P 135-40. IN: SAMUEL WM, ED. BIENNIAL SYMPOSIUM OF THE NORTHERN WILD SHEEP AND GOAT COUNCIL; 11-15 APR. 1988; BANFF, ALBERTA. NORTHERN WLD SHEEP AND GOAT COUNCIL.

3237. MORGANTINI, L. E. and D. DOWNING. 1996. ACCESS ISSUES IN WESTCENTRAL ALBERTA: A FOREST MANAGEMENT PERSPECTIVE. ASPB ACCESS MANAGEMENT CONFERENCE; 10-11APR 1996; CALGARY. UNPUBLISHED MS.

3238. MORGANTINI, L. E., D. ESLINGER and P. M. WOODARD. 1989. ELK HABITA.T IMPROVEMENT THROUGH TIMBER HARVESTING IN WEST-CENTRAL ALBERTA. PP. 170-176. IN: PROCEEDINGS OF THE WESTERN STATES AND PROVINCES ELK WORKSHOP. WENATCHEE, WA.

3239. MORGANTINI, L. E. and R. J. HUDSON. 1985. CHANGES IN DIETS OF WAPITI DURING A HUNTING SEASON. JOURNAL OF RANGE MANAGEMENT 38: 77-79.

3240. MORGANTINI, L. E. and R. J. HUDSON. 1979. HUMAN DISTURBANCE AND HABITAT SELECTION IN ELK. PAGES 132-139 IN M. S. BOYCE AND L. D. HAYDEN-WING, EDITORS. NORTH AMERICAN ELK: ECOLOGY, BEHAVIOR AND MANAGEMENT. PROCEEDINGS OF A SYMPOSIUM ON ELK ECOLOGY AND MANAGEMENT. UNIVERSITY OF WYOMING, LARAMIE, WYOMING.

3241. MORGANTINI, L. E. and D. A. MEAD. 1990. INDUSTRIAL DEVELOPMENT ON PRIME BIGHORN SHEEP RANGE IN SOUTH-WEST ALBERTA. P 56-66. BAILEY JA, ED. BIENNIAL SYMPOSIUM OF THE NORTHERN WILD SHEEP AND GOAT COUNCIL; 14-18 APR 1990;CLARKSTON, WASH. NORTHERN WLD SHEEP AND GOAT COUNCIL.

3242. MORGANTINI, L. E. and C. D. OLSEN. 1983. PIPELINE CONSTRUCTION AND WILD UNGULATES. RESULTS OF A TWO YEAR MONITORING PROGRAM ALONG THE EDSON MAINLINE LOOP. REPORT PREPARED FOR NOVA, AN ALBERTA CORPORATION. PREPARED BY WILDLAND RESOURCES CONSULTANTS, EDMONTON. FISH AND WILDLIFE FILES, EDMONTON. 174 PP. 
3243. MORGANTINI, L. E. and B. WORBETS. 1988. BIGHORN SHEEP USE OF A GAS WELLSITE DURING SERVICING AND TESTING: A CASE STUDY OF IMPACT MITIGATION. P 159-64. IN: SAMUEL WM, ED. BIENNIAL SYMPOSIUM OF -THE NORTHERN WILD SHEEP AND GOAT COUNCIL; 11-15 APR. 1988; BANFF, ALBERTA. NORTHERN WILD SHEEP AND GOAT COUNCIL.

3244. MORGANTINI, L. E. 1982. PIPELINE CONSTRUCTION AND WILDLIFE. WILDLAND RESOURCES CONSULTANTS LTD, EDMONTON, ALBERTA.

3245. MORGANTINI, L. E. and B. W. WORBETS. 1988. BIGHORN SHEEP USE OF A GAS WELLSITE DURING SERVICING AND TESTING: A CASE STUDY OF IMPACT AND MITIGATION. BIENN. SYMP. NORTH. WILD SHEEP AND GOAT COUNCIL 6:159-164.

3246. MORITZ, W. E. 1988. WLDLIFE USE OF FIRE-DISTURBED AREAS IN SAGEBRUSH STEPPE ON THE IDAHO NATIONAL ENGINEERING LABORATORY. M.S. THESIS, MONTANA STATE UNIVERSITY, BOZEMAN, MT. 135 PP.

3247. MOROZ, P. 1991. MANAGING ACCESS TO AFFECT ELK VULNERABILITY. PAGES 138-141 IN A. G. CHRISTENSEN, L. J. LYON, AND T. N. LONNER, COMPS. PROC. ELK VULNERABILITY SYMP.

3248. MORRELL, T. E. and R. H. YAHNER. 1994. HABITAT CHARACTERISTICS OF GREAT HORNED OWLS IN SOUTHCENTRAL PENNSYLVANIA. JOURNAL OF RAPTOR RESEARCH 28 (3):16470.

3249. MORRIS, P. A., K. MEAKIN and S. SHARAFI. 1993. THE BEHAVIOUR AND SURVIVAL OF REHABILITATED HEDGEHOGS (ERINACEUS EUROPAEUS). ANIMAL WELFARE 2 (1):53-66.

3250. MORRIS, P. A. and M. J. MORRIS. 1989. DISTRIBUTION AND ABUNDANCE OF HEDGEHOGS (ERINACEUS EUROPAEUS) ON NEW ZEALAND ROADS. NEW ZEALAND JOURNAL OF ZOOLOGY 5(4):491-498.

3251. MORRIS, P. I. 1993. BLACK-HEADED GULLS FORAGING BEHIND MOTOR VEHICLE. BRITISH BIRDS 86:94.

3252. MORRIS, R. H. 1984. PLANNING RECREATION DEVELOPMENT AND WLDLIFE ENHANCEMENT IN A RIPARIAN ENVIRONMENT AT ORESTIMBA CREEK. PAGES 767-772 IN R. E. WARNER AND K. M. HENDRIX, EDITORS. CALIFORNIA RIPARIAN SYSTEMS: ECOLOGY, CONSERVATION, AND PRODUCTIVE MANAGEMENT. UNIVERSITY OF CALIFORNIA PRESS, BERKELEY, CALIFORNIA.

3253. MORRIS, R. L. and W. W. TANNER. 1969. THE ECOLOGY OF THE WESTERN SPOTTED FROG (RANA PRETIOSA PRETIOSA BAIRD AND GIRARD), A LIFE HISTORY STUDY. GREAT BASIN NATURALIST XXIX:45-81.

3254. MORRISON, J. R., W. J. DE VERGIE and A. W. ALLDREDGE. 1991. THE EFFECTS OF SKI AREA DEVELOPMENT ON GEOGRAPHIC USE PATTERNS OF ELK. PAGES 60 IN R. D. COMER, P. R. DAVIS, S. Q. FOSTER, C. V. GRANT, S. RUSH, O. I. THORNE, AND J. TODD, EDITORS. ISSUES AND TECHNOLOGY IN THE MANAGEMENT OF IMPACTED WILDLIFE. PROCEEDINGS OF A NATIONAL SYMPOSIUM. THORNE ECOLOGICAL INSTITUTE, BOULDER, COLORADO, USA.

3255. MORRISON, J. R., W. J. DE VERGIE, A. W. ALLDREDGE, A. E. BYRNE and W. W. ANDREE. 1995. THE EFFECTS OF SKI AREA EXPANSION ON ELK. WILDLIFE SOCIETY BULLETIN 23:481-489.

3256. MORRISON, J. A. 1957. ESTROUS BEHAVIOR, EMBRYOLOGICAL DEVELOPMENT, AND OVARIAN CHARACTERISTICS IN ELK OF KNOWN BREEDING HISTORY. PH.D. DISSERTATION, MONTANA STATE UNIVERSITY, MISSOULA, MT. 102 PP.

3257. MORRISON, M. L., B. G. MARCOT and R. W. MANNAN. 1992. CHAPTER 3: HABITAT FRAGMENTATION. P 41-97. IN: WILDLIFE-HABITAT RELATIONSHIPS: CONCEPTS AND APPLICATIONS. MADISON, WISCONSIN: UNIVERSITY OF WISCONSIN PRESS.

3258. MORRISON, M. L., L. S. MILLS and A. J. KUENZI. 1996. STUDY AND MANAGEMENT OF AN ISOLATED, RARE POPULATION: THE FRESNO KANGAROO RAT. WILDL. SOC. BULL. $24: 602-606$.

3259. MORRISON, R. I. G. and B. A. HARRINGTON. 1979. CRITICAL SHOREBIRD RESOURCES IN JAMES BAY AND EASTERN NORTH AMERICA. TRANSACTIONS OF THE NORTH AMERICAN WLDLIFE AND NATURAL RESOURCES CONFERENCE 44:498-507. 
3260. MORTENSEN, C. O. 1989. VISITOR USE IMPACTS WITHIN THE KNOBSTONE TRAIL CORRIDOR. JOURNAL OF SOIL AND WATER CONSERVATION 44:156-159.

3261. MORTON, J. M., A. C. FOWLER and R. L. KIRKPATRICK. 1989. TIME AND ENERGY BUDGETS OF AMERICAN BLACK DUCKS IN WINTER. J. WILDL. MANAGE. 53 (2):401-10.

3262. MORTON, M. A. 1976. NUTRITIONAL VALUES OF MAJOR MULE DEER WINTER FORAGE SPECIES IN THE BRIDGER MOUNTAINS, MONTANA. M.S. THESIS, MONTANA STATE UNIVERSITY, BOZEMAN, MT. 105 PP.

3263. MOSER, J. K., T. M. POJAR, T. N. WOODARD, W. B. ZIMMERMAN and D. F. REED. 1972. DEER UNDERPASS EVALUATION PROJECT NO. W-38-R-26, WORK PLAN NO. 15, JOB 6. STATE OF COLORADO, DIVISION OF WILDLIFE, DENVER, CO.

3264. MOSS, M. B., K. A. PATNODE and W. C. I. SUGG. 1987. GRIZZLY BEAR COMPENDIUM. INTERAGENCY GRIZZLY BEAR COMMITTEE. 540PP

3265. MUELLER, C. F. 1967. TEMPERATURE AND ENERGY CHARACTERISTICS OF THE SAGEBRUSH LIZARD IN YELLOWSTONE NATIONAL PARK. PH.D. DISSERTATION, MONTANA STATE UNIVERSITY, BOZEMAN, MT. 38 PP.

3266. MUELLER, M. E. 1985. FIELD EVALUATION OF FOUR STRAINS OF RAINBOW TROUT (SALMO GAIRDNERI). M.S. THESIS, MONTANA STATE UNIVERSITY, BOZEMAN, MT. 51 PP.

3267. MULLER, S. 1966. CIRCULATION ROUTIERE ET GIBIER. LA ROUTE ET LA CIRCULATIONS ROUTIERE 9 \& 10:1-12.

3268. MULLINS, M. S. 1991. BIOLOGY AND PREDATOR USE OF CISCO (CORGEONUS ARTEDI) IN FORT PECK RESERVOIR, MONTANA. M.S. THESIS, MONTANA STATE UNIVERSITY, BOZEMAN, MT. 68 PP.

3269. MUNDINGER, J. G. 1975. THE INFLUENCE OF REST-ROTATION GRAZING MANAGEMENT ON WATERFOWL PRODUCTION ON STOCK-WATER RESERVOIRS IN PHILLIPS COUNTY, MONTANA. M.S. THESIS, MONTANA STATE UNIVERSITY, BOZEMAN, MT. 100 PP.

3270. MUNDY, K. R. D. F. D. R. 1973. BACKGROUND FOR MANAGING GRIZZLY BEARS IN THE NATIONAL PARKS OF CANADA. CANADIAN WLDLIFE SERVICE REPORT SERIES NO. 22:1-32.

3271. MUNGUIRA, M. L. and J. A. THOMAS. 1992. USE OF ROAD VERGES BY BUTTERFLY AND BURNET POPULATIONS AND THE EFFECT OF ROADS ON ADULT DISPERSAL AND MORTALITY. JOURNAL OF APPLIED ECOLOGY 9(2):316-329.

3272. MUNOZ, A. and R. MURUA. 1990. CONTROL OF SMALL MAMMALS IN A PINE PLANTATION (CENTRAL CHILE) BY MODIFICATION OF THE HABITAT OF PREDATORS (TYTOALBA, STRIGIFORMES AND PSEUDALOPEX SP., CANIDAE). ACTA OECOLOGICA 11(2):251-62.

3273. MUNOZ, J. R. 1977. CAUSES OF SHEEP MORTALITY AT THE COOK RANCH, FLORENCEM MONTANA, $1975-76$. M.S. THESIS, UNIVERSITY OF MONTANA, MISSOULA, MT. 55 PP

3274. MUNTS, M. A. 1994. A COMPARISON OF BIRD COMMUNITIES FOLLOWING TWO METHODS OF TIMBER HARVESTS IN WESTERN MONTANA. M.S. THESIS, UNIVERSITY OF MONTANA, MISSOULA, MT. 49 PP.

3275. MUROSKY, D. L. and A. E. HASSAN. 1991. IMPACT OF TRACKED AND RUBBER TIRED SKIDDERS TRAFFIC ON A WETLAND SITE IN MISSISSIPPI. TRANS. AM. SOCIETY. AG. ENG. 34:322-327.

3276. MURPHY, D. D., K. E. FREAS and S. B. WEISS. 1990. AN ENVIRONMENT-METAPOPULATION APPROACH TO POPULATION VIABILITY ANALYSIS FOR A THREATENED INVERTEBRATE. CONSERVATION BIOLOGY 4 (1):41-51.

3277. MURPHY, K. M. 1983. RELATIONSHIPS BETWEEN A MOUNTAIN LION POPULATION AND HUNTING PRESSURE. M.S. THESIS, UNIVERSITY OF MONTANA, MISSOULA., MONTANA.

3278. MURPHY, K. M. 1983. RELATIONSHIPS BETWEEN A MOUNTAIN LION POPULATION AND HUNTING PRESSURE IN WESTERN MONTANA. M.S. THESIS, UNIVERSITY OF MONTANA, MISSOULA, MT. 45 PP. 
3279. MURPHY, R. K. 1993. HISTORY, NESTING BIOLOGY, AND PREDATION ECOLOGY OF RAPTORS IN THE MISSOURI COTEAU OF NORTHWESTERN NORTH DAKOTA. PH.D. DISSERTATION, MONTANA STATE UNIVERSITY, BOZEMAN, MT. 212 PP.

3280. MURPHY, S. M. and J. A. CURATOLO. 1987. ACTIVITY BUDGETS AND MOVEMENT RATES OF CARIBOU ENCOUNTERING PIPELINES, ROADS, AND TRAFFIC IN NORTHERN ALASKA (USA). CAN. J. OF ZOOLOGY 65 (10):2483-90.

3281. MURPHY, S. M. and J. A. CURATOLO. 1986. ACTIVITY BUDGETS AND MOVEMENTS OF CARIBOU ENCOUNTERING PIPELINES, ROADS AND TRAFFIC IN NORTHERN ALASKA. CANADIAN JOURNAL OF ZOOLOGY 65:2483-2490.

3282. MUSGRAVE, R. S. 1998. FEDERAL WLDLIFE LAWS HANDBOOK WITH RELATED LAWS. GOVERNMENT INSTITUTES, ROCKVILLE, MARYLAND.

3283. MUSKETT, C. J. and M. P. JONES. 1980. THE DISPERSAL OF LEAD, CADMIUM AND NICKEL FROM MOTOR VEHICLES AND EFFECTS ON ROADSIDE INVERTEBRATE MACROFAUNA. ENVIRONMENTAL POLLUTION (SERIES A) 23:231-242.

3284. MUSKETT, C. J. and M. P. JONES. 1981. SOIL RESPIRATORY ACTIVITY IN RELATION TO MOTOR VEHICLE POLLUTION 15:329-341.

3285. MUSSEHL, T. W. 1958. BLUE GROUSE PRODUCTION, MOVEMENTS AND POPULATIONS IN THE BRIDGER MOUNTAINS, MONTANA. M.S. THESIS, MONTANA STATE COLLEGE, BOZEMAN, MT. 34 PP.

3286. MUTZE, G. J. 1991. MOUSE PLAGUES IN SOUTH AUSTRALIAN CEREAL-GROWNG AREAS: III. CHANGES IN MOUSE ABUNDANCE DURING PLAGUE AND NON-PLAGUE YEARS AND THE ROLE OF REFUGIA. WILDLIFE RESEARCH 18 (5):593-604.

3287. MUZZI, D. and A. BISSET. 1990. EFFECTIVENESS OF ULTRASONIC WILDLIFE WARNING DEVICES TO REDUCE MOOSE FATALITIES ALONG RAILWAY CORRIDORS. ALCES 26:37-43.

3288. MYKYTKA, J. M. and M. R. PELTON. 1989. MANAGEMENT STRATEGIES FOR FLORIDA BLACK BEARS BASED ON HOME RANGE HABITAT COMPOSITION. UNPUBLISHED REPORT.

3289. MYRBERGET, S. 1968. JERVENS YNGLEHI (THE BREEDING DEN OF THE WOLVERINE). FAUNA (OSLO) 21:108-15.

3290. MYSTERUD, I. 1983. CHARACTERISTICS OF SUMMER BEDS OF EUROPEAN BROWN BEARS IN NORWAY. INT. CONF. BEAR RES. AND MANAGE. 5:208-22.

3291. MYSTERUD, I. 1980. BEDDING BEHAVIOR IN THE EUROPEAN BROWN BEAR. 31PP.

3292. NADEAU, M. S. 1987. HABITATS, TRAILS AND CAMPGROUND SITUATIONS ASSOCIATED WITH GRIZZLY BEAR-HUMAN CONFRONTATIONS IN GLACIER PARK, MONTANA. M.S. THESIS, UNIVERSITY OF MONTANA, MISSOULA, MT. 91 PP.

3293. NAGY, J. A., A. W. L. HAWLEY, M. W. BARRETT and J. W. NOLAN. 1989. POPULATION CHARACTERISTICS OF GRIZZLY BEARS AND BLACK BEARS IN WEST CENTRAL ALBERTA. AEC REPORT V88-R1, ALBERTA ENVIRONMENTAL CENTRE, VEGREVILLE, ALBERTA.

3294. NAGY, J. A. and R. H. RUSSELL. 1978. ECOLOGICAL STUDIES OF THE BOREAL FOREST GRIZZLY BEAR (URSUS ARCTOS L.). 72 PP.

3295. NAKACHI, A. 1995. SEASONAL ACTIVITY PATTERN OF THE COLUBRID SNAKE, CYCLOPHIOPS SEMICARINATUS, ON OKINAWAJIMA ISLAND, RYUKYU ARCHIPELAGO, JAPAN. JAPANESE JOURNAL OF HERPETOLOGY 16 (1):1-6.

3296. NAKAI, G. L. 1994. HABITAT USE AND EFFECTS OF HUMAN RECREATION ON MIGRANT SHOREBIRDS ON NEW ENGLAND BARRIER BEACHES . THESIS , UNIVERSITY OF MASSACHUSETTS, AMHERST, MASSACHUSETTS.

3297. NANKINOV, D. N. and N. M. TODOROV. 1983. BIRD CASUALTIES ON HIGHWAYS. THE SOVIET JOURNAL OF ECOLOGY 14:288-293. 
3298. NEAL, J. C., W. G. MONTAGUE and D. A. JAMES. 1993. CLIMBING BY BLACK RAT SNAKES ON CAVITY TREES OF RED-COCKADED WOODPECKERS. WILDL. SOC. BULL. 21 (2):160-5.

3299. NEALE, G. K. 2000. EFFECTS OF SNOW DEPTHS ON SEASONAL MOVEMENTS AND HOMERANGE DISTRIBUTIONS OF WOLVES, MOOSE, AND WOODLAND CARIBOU IN AND AROUND PUKASKWA NATIONAL PARK, ONTARIO, CANADA. M.S. THESIS, UNIVERSITY OF MONTANA, MISSOULA, MT. 76 PP.

3300. NEEDHAM, R. G. 1962. EFFECTS OF TOXAPHENE UPON PLANKTON AND AQUATIC INVERTEBRATES IN NORTH DAKOTA LAKES. M.S. THESIS, MONTANA STATE COLLEGE, BOZEMAN, MT. 41 PP.

3301. NEFF, D. I. 1972. STATEMDE INVESTIGATIONS PROJECT. EFFECTS OF MOTOR VEHICLE CLOSURE ON GAME POPULATIONS. ARIZONA GAME AND FISH DEPARTMENT. ARIZ. W-078-R-21/NK.PL.04/JOB 16/FIN. 10PP. MAP

3302. NEFF, D. J. 1977. STATEWIDE INVESTIGATIONS. EFFECTS OF MOTOR VEHICLE CLOSURE ON GAME POPULATIONS. ARIZONA GAME AND FISH DEPT. ARIZ. W-078-R-21/WK.PL.O4/JOB 16/FIN. 36PP

3303. NEFF, D. J. 1972. STATEWIDE INVESTIGATIONS: EFFECTS OF MOTOR VEHICLE CLOSURE ON GAME POPULATIONS. PROJECT NO.1973. ARIZONA GAME AND FISH DEPARTMENT, FLAGSTAFF, AZ.

3304. NEFF, D. J., ARIZONA, GAME AND FISH DEPT and RESEARCH DIVISION. 1977. EFFECTS OF MOTOR VEHICLE CLOSURE ON GAME POPULATIONS A FINAL REPORT. ARIZONA GAME AND FISH DEPARTMENT, RESEARCH DIVISION, PHOENIX, ARIZONA.

3305. NEGRO, J. J. and M. FERRER. 1995. MITIGATING MEASURES TO REDUCE ELECTROCUTION OF BIRDS ON POWER LINES: A COMMENT ON BEVANGER'S REVIEW. IBIS 137 (3):423-4.

3306. NEIL, P. H., R. W. HOFFMAN and R. B. GILL. 1975. EFFECTS OF HARASSMENT ON WILD ANIMALS - AN ANNOTATED BIBLIOGRAPHY OF SELECTED REFERENCES. COLORADO DIVISION OF WILDLIFE SPECIAL REPORT NO. 37. DENVER, COLORADO. STATE PUBLICATION CODE W-R-S-37-75. 21PP.

3307. NEIL, P. H., R. W. HOFFMAN and R. B. GILL. 1975. EFFECTS OF HARASSMENT ON WILD ANIMALS--AN ANNOTATED BIBLIOGRAPHY OF SELECTED REFERENCES. ARIZONA GAME AND FISH DEPT. SPECIAL REPORT 37. STATE OF COLORADO, DIVISION OF WILDLIFE, DENVER, CO.

3308. NEIL, P. H., R. W. HOFFMAN and R. B. GILL. 1975. EFFECTS OF HARASSMENT ON WILD ANIMALS AN ANNOTATED BIBLIOGRAPHY OF SELECTED REFERENCES. SPECIAL REPORT - COLORADO DIVISION OF WILDFLIFE ; NO. 37 : SPECIAL REPORT (COLORADO. DIVISION OF WILDLIFE) NO. 37. COLORADO DIVISION OF WILDLIFE, DENVER, COLORADO.

3309. NEILL, J. B. 1995. AN EVALUATION OF THE POPULATION BIOLOGY, GENETICS AND FUTURE VIABILITY OF THE BREEDING WOOD DUCK (AIX SPONSA) POPULATION AT ARROWWOOD NATIONAL WILDLIFE REFUGE. PH.D. DISSERTATION, MONTANA STATE UNIVERSITY, BOZEMAN, MT. 108 PP.

3310. NELLEMANN, C. and R. D. CAMERON. 1996. EFFECTS OF PETROLEUM DEVELOPMENT ON TERRAIN PREFERENCES OF CALVING CARIBOU. ARCTIC 49(1):23-28.

3311. NELLIS, C. H. and L. B. KEITH. 1968. HUNTING ACTIVITIES AND SUCCESS OF LYNXES IN ALBERTA. J. WILDL. MANAGE. $32(4): 718-22$.

3312. NELLIS, C. H. 1964. THE MULE DEER OF THE NATIONAL BISON RANGE: POPULATION DYNAMICS, FOOD HABITS, AND PHYSICAL CONDITION. PH.D. DISSERTATION, MONTANA STATE UNIVERSITY, MISSOULA, MT. 147 PP.

3313. NELSON, E. H. 1972. AN ANALYSIS OF COYOTE CALLING AS A GAME MANAGEMENT TECHNIQUE. M.S. THESIS, UNIVERSITY OF MONTANA, MISSOULA, MT. 69 PP.

3314. NELSON, F. A. 1976. THE EFFECTS OF METALS ON TROUT POPULATIONS IN THE UPPER BOULDER RIVER, MONTANA . M.S. THESIS, MONTANA STATE UNIVERSITY, BOZEMAN, MT. 60 PP.

3315. NELSON, G. C. and D. HELLERSTEIN. 1997. DO ROADS CAUSE DEFORESTATION - USING SATELLITE IMAGES IN ECONOMETRIC ANALYSIS OF LAND USE. AMERICAN JOURNAL OF AGRICULTURAL ECONOMICS 79(1):80-88. 
3316. NELSON, G. P. 1986. RESPONSE OF ELK TO 500KV TRANSMISSION LINE ON THE NORTH BOULDER WINTER RANGE, MONTANA. M.S. THESIS, MONTANA STATE UNIVERSITY, BOZEMAN, MT. 60 PP.

3317. NELSON, J. L. and B. J. MORRIS. 1994. NESTING REQUIREMENTS OF THE YELLOW-TAILED BLACK-COCKATOO, CALYPTORHYNCHUS FUNEREUS, IN EUCALYPTUS REGNANS FOREST, AND IMPLICATIONS FOR FOREST MANAGEMENT. WILDLIFE RESEARCH 21 (3):267-78.

3318. NELSON, M. L. 1999. EVALUATION OF THE POTENTIAL FOR RESIDENT BULL TROUT TO REESTABLISH THE MIGRATORY LIFE-FORM. M.S. THESIS, MONTANA STATE UNIVERSITY, BOZEMAN, MT. 72 PP.

3319. NELSON, P. H. 1953. LIFE HISTORY AND MANAGEMENT OF THE AMERICAN GRAYLING (THYMALLUS SIGNIFER TRICOLOR) IN MONTANA. M.S. THESIS, MONTANA STATE COLLEGE, BOZEMAN, MT. 45 PP.

3320. NERO, R. W. 1986. GREAT GREY OWLS APPARENTLY FEEDING ON FROGS ON ROADS AT NIGHT. BLUE JAY 4(3):189-190.

3321. NERO, R. W. 1981. HIGH MORTALITY OF GREAT GRAY OWLS IN MANITOBA - WINTER 1980-81. BLUE JAY 39:158-165.

3322. NESTLER, R. B. 1949. THE EFFECT OF SHADING UPON SEED PRODUCTION OF THE TRAILING LESPEDEZA. J. WILDL. MANAGE. $13(1): 142-4$.

3323. NEUHAUS, P. and B. MAININI. 1998. REACTIONS AND ADJUSTMENT OF ADULT AND YOUNG ALPINE MARMOTS MARMOTA MARMOTA TO INTENSE HIKING ACTIVITIES. WILDLIFE BIOLOGY 4:119-123.

3324. NEUMANN, P. W. and H. G. MERRIAM. 1972. ECOLOGICAL EFFECTS OF SNOWMOBILES. CANADIAN FIELD NATURALIST 86(3):207-212.

3325. NEW SOUTH WALES, DEPT. OF URBAN AFFAIRS AND PLANNING, NEW SOUTH WALES, NATIONAL PARKS AND WILDLIFE SERVICE and P. AND J. SMITH ECOLOGICAL CONSULTANTS. 2000. BONVILLE PROJECT PACIFIC HIGHWAY COFFS HARBOUR DIRECTOR-GENERAL'S REPORT, SECTION 115C OF THE ENVIRONMENTAL PLANNING AND ASSESSMENT ACT 1979. PUBLICATION /DEPT. OF URBAN AFFAIRS AND PLANNING: PUBLICATION (NEW SOUTH WALES. DEPT. OF URBAN AFFAIRS AND PLANNING) 2000/04. DEPT. OF URBAN AFFAIRS AND PLANNING, SYDNEY.

3326. NEWBAUER, J. J. I. 1985. GROWTH RESPONSE OF AGROPYRON SMITHII INDIVIDUALS TO INCREASED SUMMER WATER AVAILABILITY. M.S. THESIS, MONTANA STATE UNIVERSITY, BOZEMAN, MT. 43 PP.

3327. NEWBEY, B. J. and K. R. NEWBEY. 1987. BIRD DYNAMICS OF FOSTER ROAD RESERVE, NEAR ONGERUP, WESTERN AUSTRALIA. PAGES 341-345 IN SAUNDERS,D.A., ARNOLD,G.W., BURBIDGE,A.A., AND HOPKINS,A.J., EDITORS. NATURE CONSERVATION: THE ROLE OF REMNANTS OF NATIVE VEGETATION. SURREY BEATTY AND SONS, CHIPPING NORTON, AUSTRALIA.

3328. NEWELL, J. A. 1987. NESTING AND BROOD REARING ECOLOGY OF THE GREATER PRAIRIE CHICKEN IN THE SHEYENNE NATIONAL GRASSLANDS, NORTH DAKOTA. M.S. THESIS, MONTANA STATE UNIVERSITY, BOZEMAN, MT. 111 PP.

3329. NEWELL, R. L. 1970. PRODUCTIVITY OF MORRELL CREEK, A MOUNTAIN STREAM WITH AN INTERMITTENT FLOW SECTION, CLARK FORK DRAINAGE, MONTANA. PH.D. DISSERTATION, UNIVERSITY OF MONTANA, MISSOULA, MT. 89 PP.

3330. NEWMAN, D. E. 1959. FACTORS INFLUENCING THE WINTER ROADSIDE COUNT OF COTTONTAILS. J. WILDL. MANAGE. $23(3): 290-4$.

3331. NEMMAN, D. G. 1994. EFFECTS OF A MOUSE, MUS MUSCULUS, ERADICATION PROGRAMME AND HABITAT CHANGE ON LIZARD POPULATIONS OF MANA ISLAND, NEW ZEALAND, WITH SPECIAL REFERENCE TO MCGREGOR'S SKINK, CYCLODINA MACGREGORI. NEW ZEALAND JOURNAL OF ZOOLOGY 21 (4):443-56.

3332. NEWMARK, W. D. 1995. EXTINCTION OF MAMMAL POPULATIONS IN WESTERN NORTH AMERICAN NATIONAL PARKS. CONSERVATION BIOLOGY 9 (3):512-26.. 
3333. NEWMARK, W. D. 1987. A LAND-BRIDGE ISLAND PERSPECTIVE ON MAMMALIAN EXTINCTIONS IN WESTERN NORTH AMERICAN PARKS. NATURE 325: 430-2

3334. NEWMARK, W. D. 1993. THE ROLE AND DESIGN OF WILDLIFE CORRIDORS WITH EXAMPLES FROM TANZANIA. AMBIO 22(8):500-4

3335. NEWMARK, W. D. 1991. TROPICAL FOREST FRAGMENTATION AND THE LOCAL EXTINCTION OF UNDERSTORY BIRDS IN THE EASTERN USAMBARA MOUNTAINS, TANZANIA. CONSERVATION BIOLOGY 5 (1):67-78.

3336. NEWMARK, W. D., J. I. BOSHE, H. I. SARIKO and G. K. MAKUMBULE. 1996. EFFECTS OF A HIGHWAY ON LARGE MAMMALS IN MIKUMI NATIONAL PARK, TANZANIA. AFRICAN JOURNAL OF ECOLOGY 34(1):15-31.

3337. NEWTON, I. 1991. HABITAT VARIATION AND POPULATION REGULATION IN SPARROW HAWKS. IBIS 133 (SUPPL. 1):76-88.

3338. NEWTON, I., I. WILLIE and A. ASHER. 1991. MORTALITY CAUSES IN BRITISH BARN OWLS (TYTO ALBA) WITH A DISCUSSION OF ALDRIN-DIELDRIN POISONING. IBIS 133:162-169.

3339. NICHOLSON, L. 1978. THE EFFECTS OF ROADS ON DESERT TORTOISE POPULATIONS. DESERT TORTOISE COUNCIL PROCEEDINGS 1978:127-129.

3340. NICHOLSON, P. 1969. COUNTS OF ANIMAL CORPSES ON EAST SUFFOLK ROADS BETWEEN SEPTEMBER, 1966-SEPTEMBER, 1968. SUFFOLK NATURAL HISTORY 15:67-69.

3341. NICKERSON, C. J. 1995. THREADING THE EYE OF A NEEDLE ECONOMIC COMPATIBILITY BETWEEN DEVELOPMENT AND PRESERVATION IN A WILDLIFE CORRIDOR.

3342. NIELSEN, C. K., S. J. NELSON and W. F. PORTER. 1997. EMIGRATION OF DEER FROM A PARTIAL ENCLOSURE. WILDLIFE SOCIETY BULLETIN 25(2):282-290.

3343. NIELSEN, L. S. 1978. THE EFFECTS OF REST-ROTATION GRAZING ON THE DISTRIBUTION OF SHARP-TAILED GROUSE. M.S. THESIS, MONTANA STATE UNIVERSITY, BOZEMAN, MT. 52 PP.

3344. NIEMELÄ, J., D. LANGOR and J. R. SPENCE. 1993. EFFECTS OF CLEAR-CUT HARVESTING ON BOREAL GROUND-BEETLE ASSEMBLAGES (COLEOPTERA: CARABIDAE) IN WESTERN CANADA. CONSERVATION BIOLOGY 7 (3):551-61.

3345. NIEMINEN, M. and J. LEPPALUOTO. 1985. TRAFFIC DEATHS OF REINDEER IN FINLAND DURING 1974-1983. RANGIFER 5 (2):53-8.

3346. NIERING, W. A. 1987. VEGETATION DYNAMICS (SUCCESSION AND CLIMAX) IN RELATION TO PLANT COMMUNITY MANAGEMENT. CONSERVATION BIOLOGY 1 (4):287-95.

3347. NIX, P. G. and R. W. MARTIN. 1992. DETOXIFICATION AND RECLAMATION OF SUNCOR'S OIL SAND TAILINGS PONDS. ENVIRONMENTAL TOXICOLOGY AND WATER QUALITY 7 (2):171-88.

3348. NIXON, C. M., R. W. DONOHOE and T. NASH. 1974. OVERHARVEST OF FOX SQUIRRELS FROM TWO WOODLOTS IN WESTERN OHIO. J. WILDL. MANAGE. 38 (1):67-80.

3349. NIXON, C. M. and D. ETTER. 1995. MATERNAL AGE AND FAWN REARING SUCCESS FOR WHITE-TAILED DEER IN ILLINOIS. AMERICAN MIDLAND NATURALIST 133 (2):290-7.

3350. NIXON, C. M., L. P. HANSEN, P. A. BREWER and J. E. CHELSVIG. 1991. ECOLOGY OF WHITE-TAILED DEER IN AN INTENSIVELY FARMED REGION OF ILLINOIS (USA). WILDLIFE MONOGRAPHS 0 (118):5-78.

3351. NIXON, C. M., M. W. MCCLAIN and R. W. DONOHOE. 1980. EFFECTS OF CLEAR-CUTTING ON GRAY SQUIRRELS. J. WILDL. MANAGE. 44 (2):403-12.

3352. NOBEL, T. A. 1995. BIRDS AND POWER LINES: SELECTED INTERACTION AND MANAGEMENT ISSUES IN THE ELECTRIC UTILITY INDUSTRY. MA THESIS, PRESCOTT COLLEGE(MASTER OF ARTS PROGRAM). $176 P P$. 
3353. NORLING, B. S., S. H. ANDERSON and W. A. HUBERT. 1992. ROOST SITES USED BY SANDHILL CRANE STAGING ALONG THE PLATTE RIVER, NEBRASKA. GREAT BASIN NATURALIST 52(3):253-261.

3354. NORMAN, R., L. A. ROPER, P. D. OLSON and R. L. EVANS. USING WILDLIFE VALUES IN BENEFIT/COST ANALYSIS AND MITIGATION OF WLDLIFE LOSSES. COLORADO DIVISION OF WILDLIFE., 17 PP.

3355. NORMAN, T., A. FINEGAN and B. LEAN. 1998. THE ROLE OF FAUNA UNDERPASSES IN NEW SOUTH WALES. PAGES 195-208 IN EVINK,G., ZIEGLER,D., GARRETT,P., AND BERRY,J., EDITORS. PROCEEDINGS OF THE INTERNATIONAL CONFERENCE ON WLDLIFE ECOLOGY AND TRANSPORTATION; 1998 FEBRUARY 10-12; FT. MYERS, FL FLORIDA DEPARTMENT OF TRANSPORTATION, TALLAHASSEE, FL.

3356. NORTH CAROLINA and DIVISION OF HIGHWAYS. 1999. [US 64-264 IMPROVEMENTS, INCLUDING NEW CROATAN SOUND BRIDGE, FROM US 264 WEST OF MANNS HARBOR TO NC 345 SOUTH OF MANTEO, DARE COUNTY, F.A. PROJECT. MICROFORM] : NHF-64(6), STATE PROJECT: 8.T051401, T.I.P. PROJECT NO. R-2551. N.C. DEPT. OF TRANSPORTATION, DIVISION OF HIGHWAYS, RALEIGH, NORTH CAROLINA.

3357. NORTHRUP, R. D. 1991. SHARP-TAILED GROUSE HABITAT USE DURING FALL AND WINTER ON THE CHARLES M. RUSSELL NATIONAL WILDLIFE REFUGE, MONTANA. M.S. THESIS, MONTANA STATE UNIVERSITY, BOZEMAN, MT. 54 PP.

3358. NORTHWEST TERRITORIES and DEPT. OF RENEWABLE RESOURCES. 1983. ROAD RELATED WLDLIFE PROBLEMS. NORTHWEST TERRITORIES. DEPT. OF RENEWABLE RESOURCES. INFORMATION SERIES: INFORMATION SERIES (NORTHWEST TERRITORIES. DEPT. OF RENEWABLE RESOURCES) NO. 2.

3359. NORTHWEST TERRITORIES, WILDLIFE SERVICE, K. JINGFORS, A. GUNN, NORTHWEST TERRITORIES and DEPT. OF RENEWABLE RESOURCES. 1981. STUDY DESIGN TO MEASURE DISTRIBUTIONAL CHANGES OF BARREN-GROUND CARIBOU NEAR A WINTER ROAD. PROGRESS REPORT: PROGRESS REPORT (NORTHWEST TERRITORIES. WLDLIFE SERVICE) NO. 5. N.W.T. WLDLIFE SERVICE, YELLOWKNIFE, N.W.T..

3360. NOSS, R. F. 1990. CAN WE MAINTAIN BIOLOGICAL AND ECOLOGICAL INTEGRITY? CONSERVATION BIOLOGY 4 (3):241-3.

3361. NOSS, R. F. 1993. A CONSERVATION PLAN FOR THE OREGON COAST RANGE: SOME PRELIMINARY SUGGESTIONS. NATURAL AREAS JOURNAL 13(4):276-290.

3362. NOSS, R. F. 1987. CORRIDORS IN REAL LANDSCAPES: A REPLY TO SIMBERLOFF AND COX. CONSERVATION BIOLOGY 1 (2):159-64.

3363. NOSS, R. F. 1990. THE ECOLOGICAL EFFECTS OF ROADS - OR THE ROAD TO DESTRUCTION. PAGES 1-5 IN DAVIS,J., EDITOR. KILLING ROADS: A CITIZENS' PRIMER ON THE EFFECTS AND REMOVAL OF ROADS. EARTH FIRST! BIODIVERSITY PROJECT SPECIAL PUBLICATION, TUCSON, AZ.

3364. NOSS, R. F. 1985. LANDSCAPE CONSIDERATIONS IN REINTRODUCING AND MAINTAINING THE FLORIDA PANTHER: DESIGN OF APPROPRIATE PRESERVE NETWORKS. REPORT TO THE FLORIDA PANTHER TECHNICAL ADVISORY COUNCIL, TALLAHASSEE, FL.

3365. NOSS, R. F. 1995. MAINTAINING ECOLOGICAL INTEGRITY IN REPRESENTATIVE RESERVE NETWORKS. WORLD WILDLIFE FUND CANADANORLD WLDLIFE FUND-UNITED STATES DISCUSSION PAPER. 77PP.

3366. NOSS, R. F. 1993. [REVIEW OF] NATURE CONSERVATION 2: THE ROLE OF CORRIDORS. J. WILDL. MANAGE. 57 (1):191-2.

3367. NOSS, R. F. 1991. TITLE UNKNOWN. WILD EARTH 1 (1 ):18-24.

3368. NOSS, R. F. 1991. WILDERNESS RECOVERY: THINKING BIG IN RESTORATION ECOLOGY. ENVIRONMENTAL PROFESSIONAL $13(3): 225-34$.

3369. NOSS, R. F. 1993. WILLIFE CORRIDORS. PAGES 299-309 IN SMITH,D.S. AND HELLMUND,P.C., EDITORS. ECOLOGY OF GREENWAYS: DESIGN AND FUNCTION OF LINEAR CONSERVATION AREAS. UNIVERSITY OF MINNESOTA, MINNEAPOLIS, MN. 
3370. NOSS, R. F. and L. D. HARRIS. 1989. HABITAT CONNECTIVITY AND THE CONSERVATION OF BIOLOGICAL DIVERSITY: FLORIDA AS A CASE HISTORY. FORESTRY OF THE FRONTIER. P. 131-135.

3371. NOSS, R. F., H. B. QUIGLEY, M. G. HORNOCKER, T. MERRILL and P. C. PAQUET. 1996. CONSERVATION BIOLOGY AND CARNIVORE CONSERVATION IN THE ROCKY MOUNTAINS. CONSERVATION BIOLOGY 10(4):949-963.

3372. NOSS, R. F., H. B. QUIGLEY, M. G. HORNOCKER, T. MERRILL and P. C. PAQUET. 1996. CONSERVATION BIOLOGY AND CARNIVORE CONSERVATION IN THE ROCKY MOUNTAINS [REVIEW] . CONSERVATION BIOLOGY $10: 949-963$.

3373. NOSS, R. 1996. THE ECOLOGICAL EFFECTS OF ROADS. PAGES 2-12 IN ROAD-RIPPERS HANDBOOK. MISSOULA, MONTANA

3374. NOUR, N., E. MATTHYSEN and A. A. DHONDT. 1993. ARTIFICIAL NEST PREDATION AND HABITAT FRAGMENTATION: DIFFERENT TRENDS IN BIRD AND MAMMAL PREDATORS. ECOGRAPHY 16 (2):111-6.

3375. NOVAK, M. A. 1988. IMPACTS OF A FIRE-FLOOD ON PHYSICAL AND BIOLOGICAL CHARACTERISTICS OF A SMALL MOUNTAIN STREAM. M.S. THESIS, MONTANA STATE UNIVERSITY, BOZEMAN, MT. 98 PP.

3376. NOWAKOWSKI, J. J. 1994. THE IMPACT OF HUMAN PRESENCE ON THE NEST DISTRIBUTION OF BLACKBIRD TURDUS MERULA AND SONG THRUSH T. PHILOMELOS. ACTA ORNITHOLOGICCA (WARSAW) 29 (1):59-65.

3377. NOYCE, K. V. and P. L. COY. 1990. ABUNDANCE AND PRODUCTIVITY OF BEAR FOOD SPECIES IN DIFFERENT FOREST TYPES OF NORTH CENTRAL MINNESOTA. INT. CONF. BEAR RES. AND MANAGE. 8:169-81.

3378. NUNNEY, L. and D. R. ELAM. 1994. ESTIMATING THE EFFECTIVE POPULATION SIZE OF CONSERVED POPULATIONS. CONSERVATION BIOLOGY 8 (1):175-84.

3379. NYBERG, H. E. 1991. MONTANA WILDLIFE MITIGATION PROGRAM ANNUAL REPORT FY91. MONTANA DEPT. OF FISH, WILDLIFE, AND PARKS., 22 PP.

3380. NYBERG, H. 1993. MT WLDLIFE MITIGATION PROGRAM--MITIGATION COORDINATION. MONTANA DEPT. OF FISH, WILDLIFE, AND PARKS. PROJECT NO. 5102

3381. NYBERG, H. E., D. CASEY, J. VORE, P. MALTA and J. BROWN. 1994. MONTANA WILDLIFE MITIGATION PROGRAM ANNUAL REPORT FY93. MONTANA DEPT. OF FISH, WILDLIFE, AND PARKS., 31 PP.

3382. NYBERG, H. E. 1980. DISTRIBUTION, MOVEMENTS AND HABITAT USE OF MULE DEER ASSOCIATED WITH THE BRACKETT CREEK WINTER RANGE, BRIDGER MOUNTAINS, MONTANA. M.S. THESIS, MONTANA STATE UNIVERSITY, BOZEMAN, MT. 106 PP.

3383. O'CONNER, R. J. and J. FAABORG. 1992. THE RELATIVE ABUNDANCE OF THE BROWN-HEADED COWBIRD (MOLOTHRUS ATER) IN RELATION TO EXTERIOR AND INTERIOR EDGES IN FORESTS OF MISSOURI. TRANSACTIONS OF THE MISSOURI ACADEMY OF SCIENCE $26(0): 1-9$.

3384. O'CONNOR, K. S. 1987. ECOLOGY OF WHITE-TAILED DEER AND MULE DEER IN AGRICULTURAL LANDS IN THE GALLATIN VALLEY, MONTANA. M.S. THESIS, MONTANA STATE UNIVERSITY, BOZEMAN, MT. 67PP.

3385. O'FARRELL, M. J. and E. H. STUDIER. 1973. REPRODUCTION, GROWTH AND DEVELOPMENT IN MYOTIS THYSANODES AND M. LUCIFUGUS (CHIROPTERA: VESPERTILIONIDAE). ECOLOGY 54:18-30.

3386. O'FARRELL, T. P. 1981. BIOLOGICAL ASSESSMENT: POSSIBLE IMPACTS OF EXPLORATORY DRILLING IN SECTION 18B, NAVAL PETROLEUM RESERVE NO. 2, KERN COUNTY, CALIFORNIA ON THE ENDANGERED SAN JOAQUIN KIT FOX, BLUNT-NOSED LEOPARD LIZARD, AND OTHER SENSITIVE SPECIES. E G AND G ENERGY MEASUREMENTS, INC. GOLETA, CALIFORNIA. EGG-1183-2441. 42PP.

3387. O'FARRELL, T. P. 1984. CONSERVATION OF THE ENDANGERED SAN JOAQUIN KIT FOX VULPES MACROTIS MUTICA ON THE NAVAL PETROLEUM RESERVES, CALIFORNIA. ACTA ZOOL. FENN. 172:207-208.

3388. O'FARRELL, T. P. and M. L. SAULS. 1987. BIOLOGICAL SURVEY OF NAVAL PETROLEUM RESERVE NO. 2 (BUENA VISTA), KERN COUNTY, CALIFORNIA. E G \& G ENERGY MEASUREMENTS, INC. GOLETA, CALIFORNIA. EGG-10282-2166. 
108PP.

3389. O'GARA, B. W. and R. B. HARRIS. 1988. AGE AND CONDITION OF DEER KILLED BY PREDATORS AND AUTOMOBILES. JOURNAL OF WILDLIFE MANAGEMENT 52(2):316-320.

3390. O'GARA, B. W. 1968. A STUDY OF THE REPRODUCTIVE CYCLE OF THE FEMALE PRONGHORN (ANTILOCARPA AMERICANA ORD). PH.D. DISSERTATION, UNIVERSITY OF MONTANA, MISSOULA, MT.

3391. O'HALLORAN, P. L. 1961. DYNAMICS OF A REDUCED MAGPIE POPULATION. M.S. THESIS, MONTANA STATE UNIVERSITY, MISSOULA, MT. 78 PP.

3392. O'NEIL, T. A. and G. W. WITMER. 1991. ASSESSING CUMULATIVE IMPACTS TO ELK AND MULE DEER IN THE SALMON RIVER BASIN, IDAHO. IN: MUNGALL EC, ED. UNGULATE BEHAVIOR AND MANAGEMENT; 23-27 MAY 1988 ; TEXAS A\&M UNIVERSITY.

3393. O'NEIL, T. A. and G. W. WITMER. 1991. ASSESSING CUMULATIVE IMPACTS TO ELK AND MULE DEER IN THE SALMON RIVER BASIN, IDAHO. APPLIED ANIMAL BEHAVIOR SCIENCE 29:225-238.

3394. O'NEIL, T. A. and G. W. WITMER. 1991. TITLE UNKNOWN. APPL. ANIM. BEHAV. SCI. 29(1-4):225-38.

3395. O'NEIL, T. A. 1981. VALIDATION TESTING OF ELK MANAGEMENT GUIDELINES. M.S. THESIS, UNIVERSITY OF MONTANA, MISSOULA, MT. 93 PP.

3396. O'NEILL, D. H., R. J. ROBEL and A. D. DAYTON. 1983. LEAD CONTAMINATION NEAR KANSAS HIGHWAYS: IMPLICATIONS FOR WILDLIFE ENHANCEMENT PROGRAMS. WILDL. SOC. BULL.11 (2):152-60.

3397. O'NEILL, D. H. and J. R. ROBERT. 1985. FOOD HABITS OF MICROTUS, PEROMYSCUS, AND BLARINA ALONG KANSAS ROADSIDES: CAUSE FOR CAUTION IN ROADSIDE CONTAMINATION STUDIES. TRANSACTIONS OF THE KANSAS ACADEMY OF SCIENCE 88:40-45.

3398. OBERLE, F. 1997. ECOLOGICAL MANAGEMENT PILOT STUDY AT DAISHOWA-MARUBENI INTERNATIONAL LTD. THE ALBERTA WLDLIFER 7 (4):9-10.

3399. OBST, J. 1994. TREE NESTING BY THE GYRFALCON (FALCO RUSTICOLUS) IN THE WESTERN CANADIAN ARCTIC JOURNAL OF RAPTOR RESEARCH 28 (1):4-8.

3400. OELSCHLAGER, M. 1995. TAKING THE LAND ETHIC OUTDOORS: ITS IMPLICATIONS FOR RECREATION. PAGES 335-350 IN R. L. KNIGHT AND K. J. GUTZWILLER, EDITORS. WILDLIFE AND RECREATIONISTS: COEXISTENCE THROUGH MANAGEMENT AND RESEARCH. ISLAND PRESS. WASHINGTON, D.C. 372PP.

3401. OETTING, R. B. and J. F. CASSEL. 1971. WATERFOWL NESTING ON INTERSTATE HIGHWAY RIGHT-OF-WAY IN NORTH DAKOTA. JOURNAL OF WILDLIFE MANAGEMENT 35:774-781.

3402. OFFERDAHL, R. J. 1989. A DESCRIPTION OF THE MAJOR PLANT COMMUNITIES ON THE THEODORE ROOSEVLET MEMORIAL RANCH. M.S. THESIS, UNIVERSITY OF MONTANA, MISSOULA, MT. 107 PP.

3403. OFFERMAN, H. L., V. H. DALE, S. M. PEARSON, R. O. JR. BIERREGAARD and R. V. O'NEILL. 1995. EFFECTS OF FOREST FRAGMENTATION ON NEOTROPICAL FAUNA: CURRENT RESEARCH AND DATA AVAILABILITY. ENVIRON. REV. 3:191-211.

3404. OGBURN, C. JR. 1970. POPULATION AND RESOURCES: THE COMING COLLISION. THE POPUL. BULL. XXVI:3-36.

3405. OGLE, T. W. A., R. L. WAYSON and W. LINDEMAN. 1996. EFFECT OF VEHICLE SPEED ON SOUND FREQUENCY SPECTRA. TRANSPORTATION RESEARCH RECORD 1559:14-25.

3406. OGREN, H. A. 1954. A POPULATION STUDY OF THE ROCKY MOUNTAIN BIGHORN SHEEP (OVIS CANADENSIS CANADENSIS SHAW) ON WILDHORSE ISLAND. PH.D. DISSERTATION, MONTANA STATE UNIVERSITY, MISSOULA, MT. 77 PP. 
3407. OHLSSON, K. E., A. E. JR. ROBB, C. E. JR. GUINDON, M. JR. BAKER and L. J. SLASKI. 1981. MANAGEMENT PRACTICES FOR FISH AND WILDLIFE ON SURFACE MINED LANDS IN NORTHERN APPALACHIA. PAGES 517-520 IN D. H. - GRAVES, EDITOR. SYMPOSIUM ON SURFACE MINING, HYDROLOGY, SEDIMENTOLOGY AND RECLAMATION. OFF. ENGINEERING SERV., UNIVERSITY OF KENTUCKY, LEXINGTON, KENTUCKY.

3408. OKARMA, H. 1995. THE TROPHIC ECOLOGY OF WOLVES AND THEIR PREDATORY ROLE IN UNGULATE COMMUNITIES OF FOREST ECOSYSTEMS IN EUROPE. ACTA THERIOLOGICA 40(4):335-86.

3409. OKARMA H, J. B. J. W. K. Z. M. L. 1995. THE ROLES OF PREDATION, SNOW COVER, ACORN CROP, AND MAN-RELATED FACTORS ON UNGULATE MORTALITY IN BIALOWIEZA PRIMEVAL FOREST, POLAND. ACTA THERIOLOGICA4O (2):197-217.

3410. OKELLO, J. A. 1991. A REVIEW OF SOIL STRENGTH MEASUREMENT TECHNIQUES FOR PREDICTION OF TERRAIN VEHICLE PERFORMANCE. J. AGRIC. ENGINEER. RES. 50:129-155.

3411. OLBRICH, P. 1984. THE EFFECTIVENESS OF GAME WARNING REFLECTORS AND THE SUITABILITY OF GAME PASSAGES. ZEITSCHRIFT FUER JAGDWISSENSCHAFT 30(2):101-16.

3412. OLBRICH, P. 1984. A STUDY OF THE EFFECTIVENESS OF DEER WARNING REFLECTORS AND SUITABILITY OF DEER PASSAGE CORRIDORS. ZEITSCHRIFT FUR JAGDWISSENSCHAFT 30:101-116. IN GERMAN..

3413. OLDFIELD, M. L. 1988. THREATENED MAMMALS AFFECTED BY HUMAN EXPLOITATION OF THE FEMALE-OFFSPRING BOND. CONSERVATION BIOLOGY 2 (3):360.

3414. OLDHAM, R. S. 1989. POTENTIAL TUNNEL SYSTEMS AT ROAD DEVELOPMENTS IN ENGLAND. PAGES $155-174$ IN LANGTON,T.E.S., EDITOR. AMPHIBIANS AND ROADS. PROCEEDINGS OF THE TOAD TUNNEL CONFERENCE; 1989 JANUARY 7-8; RENDSBURG, FEDERAL REPUBLIC OF GERMANY ACO POLYMER PRODUCTS LTD., SHEFFORD, ENGLAND.

3415. OLEKSYN, J. and P. B. REICH. 1994. POLLUTION, HABITAT DESTRUCTION, AND BIODIVERSITY IN POLAND. CONSERVATION BIOLOGY 8 (4):943-60.

3416. OLENDORFF, R. R., D. D. BIBLES, M. T. DEAN, J. R. HAUGH and M. N. KOCHERT. 1989. RAPTOR HABITAT MANAGEMENT UNDER THE U.S. BUREAU OF LAND MANAGEMENT MULTIPLE USE MANDATE. RAPTOR RESEARCH FOUNDATION, INC. RAPTOR RESEARCH REPORTS NO. 8. 8OPP.

3417. OLENDORFF, R. R., A. D. MILLER and R. N. LEHMAN. 1981. SUGGESTED PRACTICES FOR RAPTOR PROTECTION ON POWER LINES. RAPTOR RESEARCH REPORT NO.4. RAPTOR RESEARCH FOUNDATION INC.

3418. OLENICKI, T. J. 1993. SEASONAL VARIATION OF FECAL NITROGEN AND FORAGE SUCCULENCE IN RELATION TO CONDICTION AND MOVEMENT OF TWO SOUTHEASTERN MONTANA MULE DEER POPULATIONS. M.S. THESIS MONTANA STATE UNIVERSITY, BOZEMAN, MT. 119 PP.

3419. OLSON, G. 1983. EFFECTS OF SEISMIC EXPLORATION ON SUMMERING ELK IN THE TWO MEDICINE-BADGER CREEK AREA, NORTHCENTRAL MONTANA. PAGES 23-42 IN J. MALCOM, EDITOR. MITIGATING THE IMPACTS OF MINERAL EXPLORATION AND DEVELOPMENT ON WILDLIFE. PROC. OF THE 1983 ANNUAL MEETING OF THE MONTANA CHAPTER OF THE WIDLIFE SOCIETY.

3420. OLSON, R. and F. C. ROHWER. 1998. EFFECTS OF HUMAN DISTURBANCE ON SUCCESS OF ARTIFICIAL DUCK NESTS. THE JOURNAL OF WILDLIFE MANAGEMENT 62:1142-1146.

3421. OLSON, R. E. 1968. THE LIFE CYCLE OF COTYLURUS ERRATICUS (RUDOLPHI, 1809) SZIDAT, 1928 (TREMATODA: STRIGEIDAE) AND THE EFFECT OF THE METACERCARIA ON RAINBOW TROUT (SALMO GAIRDNERI). PH.D. DISSERTATION, MONTANA STATE UNIVERSITY, BOZEMAN, MT. 42 PP.

3422.

OLSON, R. E. 1965. SOME EXPERIMENTAL FISH HOSTS OF THE STRIGEID TREMATODE BOLBOPHORUS CONFUSUS, AND EFFECTS OF TEMPERATURE ON THE CERCARIA AND METACERCARIA. M.S. THESIS, MONTANA STATE UNIVERSITY, BOZEMAN, MT. 26 PP.

3423. OLSON, S. L. 1984. DENSITY AND DISTRIBUTION, NEST SITE SELECTION AND ACTIVITY OF THE MOUNTAIN PLOVER ON THE CHARLES M. RUSSELL NATIONAL WILDLIFE REFUGE. M.S. THESIS, UNIVERSITY OF MONTANA, 
MISSOULA, MT. 62 PP.

3424. OLSON, T. L. and B. K. GILBERT. 1994. VARIABLE IMPACTS OF PEOPLE ON BROWN BEAR USE OF AN ALASKAN RIVER. INT. CONF. BEAR RES. AND MANAGE. 9:97-106.

3425. OLSON, T. L., B. K. GILBERT and R. C. SQUIBB. 1994. THE EFFECTS OF INCREASING HUMAN ACTIVITY ON BROWN BEAR USE OF AN ALASKAN RIVER (DRAFT). BIOLOGICAL CONSERVATION3OPP.

3426. OLSON, W. 1984. JUSTIFICATION FOR WILDLIFE UNDERPASS KM 18, T.C.H. BANFF NATIONAL PARK, PARKS CANADA, CALGARY. UNPUBLISHED REPORT.

3427. ONTARIO, MINISTRY OF TRANSPORTATION, RESEARCH AND DEVELOPMENT BRANCH, A. H. HUBBS and R. BOONSTRA. 1995. STUDY DESIGN TO ACCESS THE EFFECTS OF HIGHWAY MEDIAN BARRIERS ON WILDLIFE. ONTARIO. MINISTRY OF TRANSPORTATION. RESEARCH AND DEVELOPMENT BRANCH. MAT.

3428. ONTARIO MINISTRY OF TRANSPORTATION AND COMMUNICATION. 1987. WLDLIFE MITIGATION SURVEY: SUMMARY REPORT. ONTARIO MINISTRY OF TRANSPORTATION AND COMMUNICATION, OTTAWA, ONTARIO.

3429. ONYEANUSI, A. E. 1986. MEASUREMENTS OF IMPACT OF TOURIST OFF-ROAD DRIVING ON GRASSLANDS IN MASAI MARA NATIONAL RESERVE, KENYA: A SIMULATION APPROACH. ENVIIRONMENTAL CONSERVATION 13(4):325-329.

3430. OOSENBRUG, S. M., R. W. MCNEILY, E. W. MERCER and J. F. FOLINSBEE. 1986. TITLE UNKNOWN. ALCES 22:377-94.

3431. OOSENBRUG, S. M., E. W. MERCER and S. H. FERGUSON. 1991. MOOSE-VEHICLE COLLISIONS IN NEWFOUNDLAND MANAGEMENT CONSIDERATIONS FOR THE 1990'S. ALCES 27:220-225.

3432. OPDAM, P., R. FOPPEN, R. REIJNEN and A. SCHOTMAN. 1994. THE LANDSCAPE ECOLOGICAL APPROACH IN BIRD CONSERVATION: INTEGRATING THE METAPOPULATION CONCEPT INTO SPATIAL PLANNING. IBIS $137:$ S139-S146.

3433. OPDAM, P., R. VAN APELDOORN, A. SCHOTMAN and J. KALKHOVEN. 1993. POPULATION RESPONSES TO LANDSCAPE FRAGMENTATION. PAGES 147-171 IN VOS,C.C. AND OPDAM,P., EDITORS. LANDSCAPE ECOLOGY OF A STRESSED ENVIRONMENT. CHAPMAN AND HALL, LONDON.

3434. OPITZ, S. T. 1999. EFFECTS OF WHIRLING DISEASE ON RECRUITMENT OF BROWN TROUT IN THE RUBY RIVER AND POINDEXTER SLOUGH, MONTANA. M.S. THESIS, MONTANA STATE UNIVERSITY, BOZEMAN, MT. 97 PP.

3435. ORANGE COUNTY. 1991. FOOTHILL-TRABUCO SPECIFIC PLAN. ENVIRONMENTAL IMPACT REPORT 531. SANTA ANA, CALIFORNIA. 451PP.

3436. ORDE, C. J. and P. BARTELT. 1990. SUMMARY REPORT ON THE MONITORING OF THE EFFECTS OF LOGGING ON THE WOOD FROG (RANA SYLVATICA) AND ITS RIPARIAN HABITAT IN THE MEDICINE BOW NATIONAL FOREST. UNPUBLISHED REPORT. U.S. FOREST SERVICE, MEDICINE BOW NATIONAL FOREST, LARAMIE, WYOMING. 6 PP.

3437. ORR, D. W. 1989. ECOLOGICAL LITERACY. CONSERVATION BIOLOGY 3 (4):334-5.

3438. ORR, D. W. 1994. TECHNOLOGICAL FUNDAMENTALISM. CONSERVATION BIOLOGY 8(2):335-7.

3439. ORR, R. 1989. FISHWAYS, DESIGN AND FUNCTION WITH REFERENCE TO NORTH-TEMPERATE FRESHWATER FISH. UNIVERSITY OF ALBERTA, DEPT. OF ZOOLOGY, EDMONTON, ALBERTA.

3440. ORTHMEYER, D. L. 1987. SURVIVAL OF MALLARD BROODS ON BENTON LAKE NATIONAL WILDLIFE REFUGE, IN NORTH-CENTRAL MONTANA. M.S. THESIS, UNIVERSITY OF MONTANA, MISSOULA, MT. 58 PP.

3441. OSAWA, R. 1989. ROAD KILLS OF THE SWAMP WALLABY (WALLABIA BICOLOR) ON NORTH STRADBROKE ISLAND, SOUTHEAST QUEENSLAND, AUSTRALIA. AUSTRALIAN WILDLIFE RESEARCH 16:95-104. 
3442. OSBURN, W. S. THE IMPACT OF TWENTIETH-CENTURY TECHNOLOGY. LARGE-SCALE EXAMPLES. P.925-51

3443. OSTFELD, R. S. and R. H. MANSON. 1996. LONG-DISTANCE HOMING IN MEADOW VOLES, MICROTUS PENNSYLVANICUS. JOURNAL OF MAMMALOGY 77(3):870-873.

3444. OSTHEIMER, W. A. 1998. A BIOGEOGRAPHY OF MONTANA BLACK BEAR GENETICS. M.S. THESIS, MONTANA STATE UNIVERSITY, BOZEMAN, MT. 31 PP.

3445. OSTOVAR, K. 1998. IMPACTS OF HUMAN ACTIVITY ON BIGHORN SHEEP IN YELLOWSTONE NATIONAL PARK. M.S. THESIS, MONTANA STATE UNIVERSITY, BOZEMAN, MT. 78 PP.

3446. OSWALD, E. T. 1966. A SYNECOLOGICAL STUDY OF THE FORESTED MORAINES OF THE VALLEY FLOOR OF GRAND TETON NATIONAL PARK, WYOMING. PH.D. DISSERTATION, MONTANA STATE UNIVERSITY, BOZEMAN, MT. 101 PP.

3447. OSWALD, R. A. 1979. OBSERVATIONS OF DISTRIBUTION, ABUNDANCE AND PRODUCTION RELATED ASPECTS OF AQUATIC MACRO-INVERTEBRATES IN NATURAL THERMAL GRADIENTS . M.S. THESIS, MONTANA STATE UNIVERSITY, BOZEMAN, MT. 137 PP.

3448. OVERSKAUG, K., H. BROSETH and B. KNUTSEN. 1994. AREA AND HABITAT USE OF PINE MARTENS MARTES MARTES IN MID-NORWAY. LUTRA $37(2): 81-8$.

3449. OWEN, M. 1973. THE MANAGEMENT OF GRASSLAND AREAS FOR WINTERING GEESE. WILDFOWL 24:123-130.

3450. OWEN, M. and G. WILLIAMS. 1976. WINTER DISTRIBUTION AND HABITAT REQUIREMENTS OF WIDGEON IN BRITAIN. WILDFOWL 27:83-90.

3451. OWENS, M. 1972. MOVEMENTS AND FEEDING ECOLOGY OF WHITE-FRONTED GEESE AT THE NEW GROUNDS, SLIMBRIDGE. JOURNAL OF APPLIED ECOLOGY 9:385-396.

3452. OXLEY, D. J. and M. B. FENTON. 1976. THE HARM OUR ROADS DO TO NATURE AND WILDLIFE. CANADIAN GEOGRAPHIC JOURNAL 92(3):40-45.

3453. OXLEY, D. J., M. B. FENTON and G. R. CARMODY. 1974. THE EFFECTS OF ROADS ON POPULATIONS OF SMALL MAMMALS. JOURNAL OF APPLIED ECOLOGY 11:51-59.

3454. OZOGA, J. J. and E. M. HARGER. 1966. WINTER ACTIVITIES AND FEEDING HABITS OF NORTHERN MICHIGAN COYOTES. J. WILDL. MANAGE. $30(4): 809-18$.

3455. P. EBY \& ASSOCIATES LTD. 1977. AN OVERVIEW OF POTENTIAL IMPACTS OF GAS PIPELINE CONSTRUCTION AND OPERATION ON USE AND VALUE OF YUKON FISHERIES. P. EBY \& ASSOCIATES LTD, VANCOUVER, B.C.

3456. PAC, D. F. 1976. DISTRIBUTION, MOVEMENTS AND HABITAT USE DURING SPRING, SUMMER, AND FALL BY MULE DEER ASSOCIATED WITH THE ARMSTRONG WINTER RANGE, BRIDGER MOUNTAINS, MONTANA. M.S. THESIS, MONTANA STATE UNIVERSITY, BOZEMAN, MT. 121 PP.

3457. PAC, H. I., W. F. KASWORM, L. R. IRBY and R. J. MACKIE. ECOLOGY OF THE MULE DEER, ODOCOILEUS HEMIONUS, ALONG THE EAST FRONT OF THE ROCKY MOUNTAINS, MONTANA. CANADIAN FIELD NATURALIST. 102

3458. PACAS, C. J. and P. C. PAQUET. 1994. ANALYSIS OF BLACK BEAR HOME RANGE USING A GEOGRAPHIC INFORMATION SYSTEM. INT. CONF. BEAR RES. AND MANAGE. 9:419-25.

3459. PACKER, P. E. 1967. CRITERIA FOR DESIGNING AND LOCATING LOGGING ROADS TO CONTROL SEDIMENT. FOREST SCIENCE. 13(1):17

3460. PACKER, P. E. 1966. FOREST TREATMENT EFFECTS ON WATER QUALITY. PAGES 687-699 IN INTERNATIONAL SYMP. ON FOR. HYDROLOGY, PENNSYLVANIA ST. UNIV. 
3461. PACKER, P. E. and H. F. HAUPT. 1965. THE INFLUENCE OF ROADS ON WATER QUALITY CHARACTERISTICS. PAGES 112-115 IN PROC. SOC. AM. FOR., DETRIOT, MI.

3462. PACKER, P. P. and G. F. CHRISTENSEN. 1977. GUIDES FOR CONTROLLING SEDIMENT FROM SECONDARY LOGGING ROADS. INTERMOUNTAIN FOREST AND RANGE EXPERIMENT STATION.

3463. PADDING, P. I. 1993. WINTERING STRATEGIES AND TRANSMISSION LINE MORTALITY OF COMMON MERGANSERS IN LOWER SAGINAW BAY. PHD THESIS, MICHIGAN STATE UNIVERSITY. 68 PP.

3464. PADGETT, D. A. 1992. HYDROGEOLOGICAL VULNERABILITY OF HAZARDOUS MATERIALS TRANSPORTATION CORRIDORS IN FLORIDA. ENVIRONMENTAL PROFESSIONAL 14 (1):70-6

3465. PAFKO, F. and B. KOVACH. 1996. EXPERIENCE WTH DEER REFLECTORS. IN: EVINK GL, GARRETT P, ZEIGLER D, BERRY J, EDITORS. TRENDS IN ADDRESSING TRANSPORTATION RELATED WLDLIFE MORTALITY: PROCEEDINGS OF THE TRANSPORTATION RELATED WILDLIFE MORTALITY SEMINAR. STATE OF FLORIDA, DEPARTMENT OF TRANSPORTATION, ENVIRONMENTAL MANAGEMENT OFFICE, TALLAHASSEE, FLORIDA .

3466. PAFKO, F. and B. KOVACH. 1996. MINNESOTA EXPERIENCE WITH DEER REFLECTORS. PAGES $116-124$ IN EVINK,G., ZIEGLER,D., GARRETT,P., AND BERRY,J., EDITORS. TRANSPORTATION AND WILDLIFE: REDUCING WILDLIFE MORTALITY AND IMPROVING WILDLIFE PASSAGEWAYS ACROSS TRANSPORTATION CORRIDORS: PROCEEDINGS OF THE FLORIDA DEPARTMENT OF TRANSPORTATION/FEDERAL HIGHWAY ADMINISTRATION TRANSPORTATION-RELATED WILDLIFE MORTALITY SEMINAR; 1996 APRIL 30-MAY 2; ORLANDO, FL. FHWA-PD-96-041. U.S. DEPARTMENT OF TRANSPORTATION, FEDERAL HIGHWAY ADMINISTRATION, WASHINGTON, DC.

3467. PAGE, R. J. C., J. ROSS and S. D. LANGTON. 1994. SEASONALITY OF REPRODUCTION IN THE EUROPEAN BADGER MELES MELES IN SOUTH-WEST ENGLAND. JOURNAL OF ZOOLOGY(LONDON) 233 (1):69-91.

3468. PAGLIA, A. P., J. P. D. MARCO, F. M. COSTA, R. F. PEREIRA and G. LESSA. 1995. STRUCTURAL HETEROGENEITY AND DIVERSITY OF SMALL MAMMALS IN A SECONDARY FOREST FRAGMENT OF MINAS GERAIS, BRAZIL. REVISTA BRASILEIRA DE ZOOLOGIA 12 (1):67-79.

3469. PAIGE, L. C. 1990. POPULATION TRENDS OF SONGBIRDS IN WESTERN NORTH AMERICA. M.S. THESIS, UNIVERSITY OF MONTANA, MISSOULA, MT. 143 PP.

3470. PALACIOS, E. and E. MELLINK. 1996. STATUS OF THE LEAST TERN IN THE GULF OF CALIFORNIA. JOURNAL OF FIELD ORNITHOLOGY 67 (1):48-58.

3471. PALIS, J. G. 1994. ANURA: RANA UTRICULARIA (SOUTHERN LEOPARD FROG): ROAD MORTALITY. HERPETOLOGICAL REVIEW 25 (3):119.

3472. PALIS, J. G. 1994. RANA UTRICULARIA (SOUTHERN LEOPARD FROG) ROAD MORTALITY. HERPETOLOGICAL REVIEW 25(3):119-122.

3473. PALLISTER, G. L. 1974. THE SEASONAL DISTRIBUTION AND RANGE USE OF BIGHORN SHEEP IN THE BEARTOOTH MOUNTAINS, MONTANA WITH SPECIAL REFERENCE TO THE WEST ROSEBUD AND STILLWATER HERDS. M.S. THESIS, MONTANA STATE UNIVERSITY, BOZEMAN, MT. 67 PP.

3474. PALMAN, D. S. and V. B. RICHENS. 1979. EFFECTS OF INTERSTATE 95 ON SMALL AND MEDIUM-SIZED MAMMALS IN NORTHERN MAINE. NO. 26. UNIVERSITY OF MAINE, LIFE SCIENCES AND AGRICULTURAL EXPERIMENTAL STATION, ORONO, ME.

3475. PALMAN, D. S. 1977. ECOLOGICAL IMPACT OF INTERSTATE 95 ON SMALL AND MEDIUM SIZED MAMMALS IN NORTHERN MAINE. M.S. THESIS, UNIVERSITY OF MAINE, ORONO, ME.

3476. PALOMARES, F. and M. DELIBES. 1992. SOME PHYSICAL AND POPULATION CHARACTERISTICS OF EGYPTIAN MONGOOSES (HERPESTES ICHNEUMON L., 1758) IN SOUTHWESTERN SPAIN. ZEITSCHRIFT FUER SAEUGETIERKUNDE 57 (2):94-9

3477. PALOMARES, F., P. FERRERAS, J. M. FEDRIANI and M. DELIBES. 1996. SPATIAL RELATIONSHIPS BETWEEN IBERIAN LYNX AND OTHER CARNIVORES IN AN AREA OF SOUTH-WESTERN SPAIN. JOURNAL OF APPLIED ECOLOGY 
3478. PALOMARES, F., P. GAONA, P. FERRERAS and M. DELIBES. 1995. POSITIVE EFFECTS ON GAME SPECIES OF TOP PREDATORS BY CONTROLLING SMALLER PREDATOR POPULATIONS: AN EXAMPLE WITH LYNX, MONGOOSES, AND RABBITS. CONSERVATION BIOLOGY 9 (2):295-305.

3479. PALOMO-FERRER, J. J. 1992. PROVISIONAL REPORT OF THE MORTALITY OF VERTEBRATES ON THE ROADS OF CASTELLON, SEPTEMBER 1991. PAGES 195-211 IN LOPEZ,REDONDO, EDITOR. I JORNADAS PARA EL ESTUDIO Y PREVENCION DE LA MORTALIDAD DE VERTEBRADOS EN CARRETERAS, MADRID, 5 Y 6 DE OCTUBRE DE 1991. TOMO 2. [SESSIONS IN THE STUDY OF PREVENTION OF ROAD MORTALITIES OF VERTEBRATES, MADRID, 5 AND 6 OCTOBER, 1991. VOLUME 2.]. COORDINADORA DE ORGANIZACCIONES DE DEFENSA, AMBIENTAL, MADRID.

3480. PANETTA, F. D. 1991. NEGATIVE VALUES OF CORRIDORS. PAGES [UNKNOWN] IN SAUNDERS,D.A. AND HOBBS,R.J., EDITORS. NATURE CONSERVATION 2: THE ROLE OF CORRIDORS. SURREY BEATTY AND SONS, CHIPPING NORTON, AUSTRALIA.

3481. PANKAKOSKI, E., H. HYVARINEN, M. JALKANEN and I. KOIVISTO. 1993. ACCUMULATION OF HEAVY METALS IN THE MOLE IN FINLAND. ENVIRONMENTAL POLLUTION 80 (1):9-16.

3482. PAQUET, P. C. 1993. ECOLOGICAL STUDIES OF RECOLONIZING WOLVES IN THE CENTRAL CANADIAN ROCKY MOUNTAINS - SUMMARY REFERENCE DOCUMENT. JOHN/PAUL AND ASSOCIATES, CANMORE, ALBERTA.

3483. PAQUET, P. C. 1993. SUMMARY REFERENCE DOCUMENT--ECOLOGICAL STUDIES OF RECOLONIZING WOLVES IN THE CENTRAL CANADIAN ROCKY MOUNTAINS. JOHN/PAUL \&ASSOC. REP. FOR CAN. PARKS SERV., BANFF, AB. 176PP.

3484. PAQUET, P. C., C. CALLAGHAN and C. MCTAVISH. 1996. THE EFFECTS OF HUMAN INFLUENCE ON WOLVES IN THE BOW RIVER VALLEY OF BANFF NATIONAL PARK, ALBERTA. DRAFT MANUSCRIPT. 11PP.

3485. PAQUET, P. C. and C. CALLAHAN. 1996. EFFECTS OF LINEAR DEVELOPMENTS ON WINTER MOVEMENTS OF GRAY WOLVES IN THE BOW RIVER VALLEY OF BANFF NATIONAL PARK, ALBERTA. PAGES 46-66 IN EVINK, G., ZIEGLER,D., GARRETT,P., AND BERRY,J., EDITORS. TRANSPORTATION AND WILDLIFE: REDUCING WILDLIFE MORTALITY AND IMPROVING WILDLIFE PASSAGEWAYS ACROSS TRANSPORTATION CORRIDORS: PROCEEDINGS OF THE FLORIDA DEPARTMENT OF TRANSPORTATION/FEDERAL HIGHWAY ADMINISTRATION TRANSPORTATION-RELATED WILDLIFE MORTALITY SEMINAR; 1996 APRIL 30-MAY 2; ORLANDO, FL. FHWA-PD-96-041. U.S. DEPARTMENT OF TRANSPORTATION, FEDERAL HIGHWAY ADMINISTRATION, WASHINGTON, DC.

3486. PAQUET, P. C., M. GIBEAU, S. HERRERO, J. JORGENSON and J. GREEN. 1994. WILDLIFE CORRIDORS IN THE BOW RIVER VALLEY, ALBERTA. WILDLIFE CORRIDOR TASK FORCE, CANMORE, ALBERTA.

3487. PAQUET, P. C., M. L. GIBEAU, S. HERRERO, J. JORGENSON and J. GREEN. 1994. WILDLIFE CORRIDORS IN THE BOW RIVER VALLEY, ALBERTA: A STRATEGY FOR MAINTAINING WELL-DISTRIBUTED, VIABLE POPULATIONS OF WILDLIFE. A REPORT TO THE BOW RIVER VALLEY CORRIDOR TASK FORCE. 38PP.

3488. PAQUET, P. C. and A. HACKMAN. 1995. LARGE CARNIVORE CONSERVATION IN THE ROCKY MOUNTAINS: A LONG-TERM STRATEGY FOR MAINTAINING FREE-RANGING AND SELF-SUSTAINING POPULATIONS OF CARNIVORES. WORLD WILDLIFE FUND-CANADA, TORONTO, ONTARIO.

3489. PAQUET, P. C., J. WIERCZHOWSKI and C. CALLAGHAN. 1996. SUMMARY REPORT ON THE EFFECTS OF HUMAN ACTIVITY ON GRAY WOLVES IN THE BOW RIVER VALLEY, BANFF NATIONAL PARK, ALBERTA. REPORT TO THE BANFF BOW VALLEY TASK FORCE.126 PP. BANFF NATIONAL PARK WARDEN SERVICE, ALBERTA, CANADA.

3490. PAQUET, P. C., J. WIERCZHOWSKI and C. CALLAGHAN. 1996. SUMMARY REPORT ON THE EFFECTS OF HUMAN ACTIVITY ON GRAY WOLVES IN THE BOW RIVER VALLEY, BANFF NATIONAL PARK, ALBERTA. REPORT TO THE BANFF BOW VALLEY TASK FORCE. 126PP.

3491. PAQUET, P. C., J. WIERZCHOWSKI and C. CALLAGHAN. 1996. EFFECTS OF HUMAN ACTIVITY ON GRAY WOLVES IN THE BOW RIVER VALLEY, BANFF NATIONAL PARK, ALBERTA. CHAPTER 7 IN: GREEN, J., C. PACAS, S. BAYLEY, AND L. CORNWELL, EDITORS. A CUMULATIVE EFFECTS ASSESSMENT AND FUTURES OUTLOOK FOR THE BANFF BOW VALLEY. BANFF BOW VALLEY STUDY, DEPARTMENT OF CANADIAN HERITAGE. OTTAWA, ON. 
3492. PARIKESIT, P., D. W. LARSON and S. U. MATTHES. 1995. IMPACTS OF TRAILS ON CLIFF-EDGE FOREST STRUCTURE. CANADIAN JOURNAL OF BOTANY 73 (6):943-53.

3493. PARKER, G. R., D. G. KIMBALL and B. DALZELL. 1994. BIRD COMMUNITIES BREEDING IN SELECTED SPRUCE AND PINE PLANTATIONS IN NEW BRUNSWICK. CANADIAN FIELD-NATURALIST 108 (1):1-9.

3494. PARKER, J. 1980. GREAT BLUE HERONS IN NORTHWESTERN MONTANA: NESTING HABITAT USE AND THE EFFECTS OF HUMAN DISTURBANCE. M.S. THESIS, UNIVERSITY OF MONTANA, MISSOULA, MT. 82 PP.

3495. PARKER, K. L., C. T. ROBBINS and T. A. HANLEY. 1984. ENERGY EXPENDITURES FOR LOCOMOTION BY MULE DEER AND ELK. J. WILDL. MANAGE. 48 (2):474-88.

3496. PARNELL, J. F., D. G. AINLEY, H. BLOKPOEL, B. W. CAIN, T. W. CUSTER, J. L. DUSI, S. W. KRESS, J. A. KUSHLAN, W. E. SOUTHERN, L. E. STENZEL and B. C. THOMPSON. 1988. COLONIAL WATERBIRD MANAGEMENT IN NORTH AMERICA. COLON. WATERBIRDS 11:129-169.

3497. PARR, T. W. and J. M. WAY. 1988. MANAGEMENT OF ROADSIDE VEGETATION: THE LONG-TERM EFFECTS OF CUTTING. JOURNAL OF APPLIED ECOLOGY 25(3):1073-1087.

3498. PARRINELLO, P. J. 1995. GENETIC VARIATION IN MONTANA POPULATIONS OF THE RANGELAND GRASSHOPPER, MELANOPLUS SANGUINIPES. M.S. THESIS, MONTANA STATE UNIVERSITY, BOZEMAN, MT. 56 PP.

3499. PARUK, J. D. 1990. EFFECTS OF ROADSIDE MANAGEMENT PRACTICES ON BIRD RICHNESS AND REPRODUCTION. TRANS. ILL. STATE ACAD. SCI. 83:181-192.

3500. PARUK, J. D. 1992. REPRODUCTIVE SUCCESS OF UPLAND NESTING RED-WINGED BLACKBIRDS WITHIN AN INTERSTATE RIGHT-OF-WAY IN NORTHWESTERN ILLINOIS. TRANSACTIONS OF THE ILLINOIS STATE ACADEMY OF SCIENCE85 (3-4):201-4.

3501. PASCASIO-LOPEZ, J. M. 1992. PROVISIONAL REPORT OF THE MORTALITY OF VERTEBRATES ON THE ROADS OF CARTAGENA, SEPTEMBER 1991. PAGES 180-187 IN LOPEZ,REDONDO, EDITOR. I JORNADAS PARA EL ESTUDIO Y PREVENCION DE LA MORTALIDAD DE VERTEBRADOS EN CARRETERAS, MADRID, 5 Y 6 DE OCTUBRE DE 1991. TOMO 2. [SESSIONS IN THE STUDY OF PREVENTION OF ROAD MORTALITIES OF VERTEBRATES, MADRID, 5 AND 6 OCTOBER, 1991. VOLUME 2.]. COORDINADORA DE ORGANIZACCIONES DE DEFENSA, AMBIENTAL, MADRID.

3502. PASCUAL, J. A. 1994. NO EFFECTS OF A FOREST SPRAYING OF MALATHION ON BREEDING BLUE TITS (PARUS CAERULEUS). ENVIRONMENTAL TOXICOLOGY AND CHEMISTRY 13(7):1127-31.

3503. PASCUAL, J. A. and S. J. PERIS. 1992. EFFECTS OF FOREST SPRAYING WITH TWO APPLICATION RATES OF CYPERMETHRIN ON FOOD SUPPLY AND ON BREEDING SUCCESS OF THE BLUE TIT (PARUS CAERULEUS). ENVIRONMENTAL TOXICOLOGY AND CHEMISTRY 11 (9):1271-80.

3504. PATON, P. W. C. 1994. THE EFFECT OF EDGE ON AVIAN NEST SUCCESS: HOW STRONG IS THE EVIDENCE? CONSERVATION BIOLOGY 8 (1):17-26.

3505. PATTEN, D. T. 1991. HUMAN IMPACTS IN THE GREATER YELLOWSTONE ECOSYSTEM: EVALUATING SUSTAINABILITY GOALS AND ECO-REDEVELOPMENT. CONSERVATION BIOLOGY 5:405-411.

3506. PATTEN, R. B. 1981. AUTHOR'S REPLY ON ROAD KILLED DIPODOMYS. JOURNAL OF HERPETOLOGY 15(1):126-128.

3507. PATTEN, R. B. and H. B. BENJAMIN. 1980. A RATTLESNAKE (CROTALUS RUBER) FEEDS ON A ROAD-KILLED ANIMAL. JOURNAL OF HERPETOLOGY 14(1):111-112.

3508. PATTERSON, B. D. 1987. THE PRINCIPLE OF NESTED SUBSETS AND ITS IMPLICATIONS FOR BIOLOGICAL CONSERVATION. CONSERVATION BIOLOGY 1 (4):323-34.

3509. PATTERSON, M. E., J. D. FRASER and J. W. ROGGENBUCK. 1991. FACTORS AFFECTING PIPING PLOVER PRODUCTIVITY ON ASSATEAGUE ISLAND. J. WLDL. MANAGE. 55 (3):525-31. 
3510. PAULI, B. 1997. EFFECTS OF HIGHWAY SALTING ON AMPHIBIANS. ENVIRONMENT CANADA, OTTAWA, ONTARIO.

3511. PAULLIN, D. G. 1973. THE ECOLOGY OF SUBMERGED AQUATIC MACROPHYTES OF RED ROCK LAKES NATIONAL WILDLIFE REFUGE, MONTANA. M.S. THESIS, UNIVERSITY OF MONTANA, MISSOULA, MT. 171 PP.

3512. PAWAR, K. R., H. V. GHATE and M. KATDARE. 1983. EFFECT OF MALATHION ON EMBRYONIC DEVELOPMENT OF THE FROG MICROHYLA ORNATA (DUMERIL AND BIBRON). BULLETIN OF ENVIRONMENTAL CONTAMINANTS AND TOXICOLOGY 31: 170-176

3513. PAYNE, N. F. and F. BRYANT. 1994. TECHNIQUES FOR WILDLIFE HABITAT MANAGEMENT OF UPLANDS. MCGRAW-HILL BIOLOGICAL RESOURCE MANAGEMENT SERIES. MCGRAW-HILL, NEWYORK.

3514. PAYSON, E. M. 1996. GAP COLONIZATION IN GRASSLANDS OF THE NORTHERN GREAT PLAINS. M.S. THESIS, MONTANA STATE UNIVERSITY, BOZEMAN, MT. 97 PP.

3515. PEARL, M. 1992. [REVIEW OF] A ROAD MAP FOR CONSERVATIONISTS -- THE CONSERVATION ATLAS OF TROPICAL FORESTS: ASIA AND THE PACIFIC. CONSERVATION BIOLOGY 6 (2):305-6.

3516. PEARMAN, P. B., A. M. VELASCO and A. LOPEZ. 1995. TROPICAL AMPHIBIAN MONITORING: A COMPARISON OF METHODS FOR DETECTING INTER-SITE VARIATION IN SPECIES' COMPOSITION. HERPETOLOGICA 51 (3):325-37.

3517. PEARSON, D. C. 1986. THE DESERT TORTOISE AND ENERGY DEVELOPMENT IN SOUTHEASTERN CALIFORNIA . HERPETOLOGICA 42:58-59.

3518. PECK, S. V. 1972. THE ECOLOGY OF THE ROCKY MOUNTAIN GOAT IN THE SPANISH PEAKS AREA OF SOUTHWESTERN MONTANA. M.S. THESIS, MONTANA STATE UNIVERSITY, BOZEMAN, MT. 54 PP.

3519. PEDERSEN, R. J. 1985. ELK HABITAT USE OF AN UNLOGGED AND LOGGED FORESTED ENVIRONMENT (OREGON). PHD THESIS, UNIVERSITY OF IDAHO. 154 PP.

3520. PEDERSEN, R. J. 1979. MANAGEMENT AND IMPACTS OF ROADS IN RELATION TO ELK POPULATIONS, LOGGING AND ROAD CONSTRUCTION. IN: ITTNER R, ED. RECREATIONAL IMPACT ON WILDLANDS: CONFERENCE PROCEEDINGS ; $27-29$ OCT 1978 ; SEATTLE, WASHINGTON. U.S. FOREST SERVICE, PACIFIC NORTHWEST REGION, UNIVERSITY OF WASHINGTON.

3521. PEDERSEN, R. J., A. W. ADAMS and J. M. SKOVLIN. 1980. ELK HABITAT USE IN A LOGGED AND UNLOGGED FOREST ENVIRONMENT. OREGON DEPT. FISH WLDL., WILDLIFE RESEARCH REPORT \#9:121PP.

3522. PEDERSEN, R. J. 1979. MANAGEMENT AND IMPACTS OF ROADS IN RELATION TO ELK POPULATIONS. R. ITTNER, D. R. POTTER, J. K. AGEE, AND S. ANLSCHELL, EDITORS. CONFERENCE PROCEEDINGS: RECREATIONAL IMPACT ON WLDLANDS. USDA FOREST SERVICE, USDI NATIONAL PARK SERVICE, SEATTLE, WA.

3523. PEDEVILLANO, C. and R. G. WRIGHT. 1987. THE INFLUENCE OF VISITORS ON MOUNTAIN GOAT ACTIVITIES IN GLACIER NATIONAL PARK, MONTANA. BIOLOGICAL CONSERVATION 39:1-11.

3524. PEDEVILLANO, C. and R. G. WRIGHT. 1987. THE INFLUENCE OF VISITORS ON MOUNTAIN GOAT ACTIVITIES IN THE GLACIER NATIONAL PARK, MONTANA. BIOL. CONSERV. 39:1-12.

3525. PEDIGREE CARIBOU STANDING COMMITTEE, DELTA ENVIRONMENTAL MANAGEMENT GROUP LTD. 1991. CARIBOU PROTECTION PLAN FOR OIL AND GAS ACTIVITY IN THE PEDIGREE REGION OF NORTHWESTERN ALBERTA.

3526. PEEK, F. and E. D. BELLIS. 1969. DEER MOVEMENTS AND BEHAVIOR ALONG AN INTERSTATE HIGHWAY. HIGHWAY RESEARCH NEWS 36:36-42.

3527. PEEK, J. M. 1976. PROCEEDINGS OF THE ELK-LOGGING ROADS SYMPOSIUM. UNIV. OF IDAHO, MOSCOW, ID 83843 FOR. WILDL. AND RANGE EXP. STA., 142 PP. 
3528. PEEK, J. M., M. R. PELTON, H. D. PICTON, J. W. SCHOEN and P. ZAGER. 1987. GRIZZLY BEAR CONSERVATION AND MANAGEMENT: A REVIEW. WILL. SOC. BULL. 15:160-9.

3529. PEEK, J. M. 1961. REPRODUCTION OF MOOSE IN SOUTHWESTERN MONTANA. M.S. THESIS, MONTANA STATE COLLEGE, BOZEMAN, MT. 30 PP.

3530. PEETZ, A., M. A. NORCONK and W. G. KINZEY. 1992. PREDATION BY JAGUAR ON HOWLER MONKEYS (ALOUATTA SENICULUS) IN VENEZUELA. AMERICAN JOURNAL OF PRIMATOLOGY 28 (3):223-8.

3531. PEI, C.-J. 1990. THE REPRODUCTIVE BIOLOGY OF THE FORMOSAN REEVES' MUNTJAC (MUNTIACUS REEVESI MICRURUS) IN JIOU-JENG-YANG AREA, I-LAN, TAIWAN, R.O.C. (PH.D.). PH.D. DISSERTATION, UNIVERSITY OF MONTANA, MISSOULA, MT. 116 PP.

3532. PEIFFER, R. and J. B. PIR. 1994. THE FIRST RECORD OF THE LEISLER BAT (NYCTALUS LEISLERI, KUHL 1818) FOR LUXEMBOURG (MAMMALIA, CHIROPTERA). BULLETIN DE LA SOCIETE DES NATURALISTES LUXEMBOURGEOUIS 1994:209-213.

3533. PELTON, M. R., L. E. BEEMAN and D. C. EAGAR. 1980. DEN SELECTION BY BLACK BEARS IN THE GREAT SMOKY MOUNTAINS NATIONAL PARK. INT. CONF. BEAR RES. AND MANAGE. 4:149-51.

3534. PELUSO, N. L. 1992. THE IRONWOOD PROBLEM: (MIS)MANAGEMENT AND DEVELOPMENT OF AN EXTRACTIVE RAINFOREST PRODUCT. CONSERV. BIOL. 6 (2):210-9.

3535. PENDERGAST, B. and J. BINDERNAGEL. 1977. THE IMPACT OF EXPLORATION FOR COAL ON MOUNTAIN GOATS IN NORTHEASTERN BRITISH COLUMBIA. P 64-8. IN: SAMUEL W, MACGREGOR WG, EDS. PROC. FIRST INTERNATIONAL MOUNTAIN GOAT SYMPOSIUM ; 1977 FEB 19; KALISPELL, MONTANA. PROV. OF B.C., MIN. OF RECREATION AND CONSERVATION, FISH AND WILDLIFE BRANCH.

3536. PENDHARKAR, A. P. and S. P. GOYAL. 1995. GROUP SIZE AND COMPOSITION OF THE GRAY GORAL IN SIMBALBARA SANCTUARY AND DARPUR RESERVED FOREST, INDIA. JOURNAL OF MAMMALOGY 76 (3):906-11.

3537. PENGEROTH, D. M. 1991. CHARACTERISTICS OF A STRIPED SKUNK POPULATION IN THE MISSION VALLEY, MONTANA. M.S. THESIS, UNIVERSITY OF MONTANA, MISSOULA, MT. 87 PP.

3538. PENKAL, R. F. 1977. BLACK BASS POPULATIONS OF THE TONGUE RIVER RESERVOIR, MONTANA. M.S. THESIS, MONTANA STATE UNIVERSITY, BOZEMAN, MT. 11 PP.

3539. PENNER, D. F. 1988. BEHAVIOURAL RESPONSE AND HABITATION OF MOUNTAIN GOATS IN RELATION TO PETROLEUM EXPLORATION AT PINTO CREEK, ALBERTA. P 141-8. IN: SAMUEL WM, ED. BIENNIAL SYMPOSIUM OF THE NORTHERN WLD SHEEP AND GOAT COUNCIL; 11-15 APR. 1988; BANFF, ALBERTA. NORTHERN WLD SHEEP AND GOAT COUNCIL.

3540. PENNER, D. F. 1986. HABITUATION OF MOUNTAIN GOATS TO AUDITORY STIMULI PRIOR TO A SEISMIC PROGRAM AT PINTO CREEK, ALBERTA. ALBERTA FISH AND WLDLIFE DIVISION, EDMONTON. UNPUBLISHED REPORT. 48PP

3541. PENNER, D. F. 1985. WILDLIFE TRACKING STUDY - COLD LAKE PROJECT. UNPUBLISHED REPORT BY MCCOURT MANAGEMENT CONSULTANTS LTD. PREPARED FOR ESSO RESOURCES CANADA LTD.

3542. PENNER, D. F. and J. A. DUNCAN. 1983. MONITORING A GEOPHYSICAL PROGRAM AND ITS EFFECTS ON WILDLIFE, PARTICULARLY WOODLAND CARIBOU, NEAR MANNING ALBERTA. MCCOURT MANAGEMENT LTD. PREPARED FOR MOBIL OIL CANADA LTD. 137PP.

3543. PENNER, D. F., J. A. DUNCAN and P. S. JALKOTZY. 1983. MONITORING OF A GEOPHYSICAL EXPLORATION PROGRAM AND ITS EFFECT ON WOODLAND CARIBOU AND OTHER WILDLIFE NEAR MANNING, ALBERTA. PREPARED FOR HUSKY OIL OPERATIONS LTD.; PREPARED BY MCCOURT MANAGEMENT LTD., CALGARY. UNPUBLISHED REPORT.134PP

3544. PENNER, D. F. and P. S. JALKOTZY. 1984. ECOLOGICAL AND BEHAVIOURAL STUDIES ON MOUNTAIN GOATS AT PINTO CREEK, ALBERTA. PART I. ECOLOGICAL STUDIES. PART II. BEHAVIOURAL DISTURBANCE STUDIES. PART III. IMPACT ASSESSMENT. PREPARED FOR GULF CANADA RESOURCES INC., PREPARED BY MCCOURT MANAGEMENT LTD., CALGARY. UNPUBLISHED REPORT. PART I: 141PP., PART II: 75PP., PART III: 75PP. 
3545. PENNSYLVANIA, G. C. 1985. 1984 RECORDED HIGHWAY MORTALITY: DEER AND BEAR. PENNSYLVANIA GAME NEWS JUNE:40-41.

3546. PENNY, A. A. 1994. ROADS AND NATURE CONSERVATION: GUIDANCE ON IMPACTS, MITIGATION AND ENHANCEMENT. ENGLISH NATURE, PETERBOROUGH, U.K..

3547. PENNY, J. R. 1971. OFF-ROAD VEHICLES ON THE PUBLIC LANDS IN CALIFORNIA. PAGES 95-110 IN M. CHUBB, EDITOR. PROCEEDINGS OF THE 1971 SNOWMOBILE AND OFF THE ROAD VEHICLE RESEARCH SYMPOSIUM. MICHIGAN STATE UNIVERSITY,

3548. PERCIVAL, S. M. 1993. THE EFFECTS OF RESEEDING, FERTILIZER APPLICATION AND DISTURBANCE ON THE USE OF GRASSLANDS BY BARNACLE GEESE, AND THE IMPLICATIONS FOR REFUGE MANAGEMENT. JOURNAL OF APPLIED ECOLOGY $30(3): 437-43$.

3549. PERES, C. A. 1994. INDIGENOUS RESERVES AND NATURE CONSERVATION IN AMAZONIAN FORESTS. CONSERVATION BIOLOGY 8 (2):586-8.

3550. PERES, C. A. and J. W. TERBORGH. 1995. AMAZONIAN NATURE RESERVES: AN ANALYSIS OF THE DEFENSIBILITY STATUS OF EXISTING CONSERVATION UNITS AND DESIGN CRITERIA FOR THE FUTURE. CONSERVATION BIOLOGY 9 (1):34-46.

3551. PEREZ, F. L. 1991. PARTICLE SORTING DUE TO OFF-ROAD VEHICLE TRAFFIC IN A HIGH ANDEAN PARAMO. CATENA 18 $(3-4): 239-54$.

3552. PERLMETER, S. I. 1996. BATS AND BRIDGES: PATTERNS OF NIGHT ROOST ACTIVITY IN THE WLLAMETTE NATIONAL FOREST. PAGES 132-150 IN R. M. R. BARCLAY AND M. R. BRIGHAM, EDITORS. BATS AND FOREST SYMPOSIUM. RESEARCH BRANCH, BRITISH COLUMBIA MINISTRY OF FORESTS. VICTORIA, B.C.

3553. PERRY, C. and R. OVERLY. 1976. IMPACT OF ROADS ON BIG GAME DISTRIBUTION IN PORTIONS OF THE BLUE MOUNTAINS OF WASHINGTON. PAGES 62-68 IN S. R. HIEB, EDITOR. PROCEEDINGS OF THE ELK-LOGGING-ROADS SYMPOSIUM. FORESTRY WILDLIFE AND RANGE EXPERIMENT STATION, UNIVERSITY OF IDAHO, MOSCOW, IDAHO.

3554. PERRY, C. and R. OVERLY. 1976. IMPACTS OF ROADS ON BIG GAME DISTRIBUTIONS IN PORTIONS OF THE BLUE MOUNTAINS OF WASHINGTON. P 62-8. IN: HIEB SR, ED. PROC. ELK-LOGGING-ROADS SYMP.; 16-17 DEC 1975 ; MOSCOW, IDAHO. UNIVERSITY OF IDAHO.

3555. PERSSON, T. S. 1995. MANAGEMENT OF ROADSIDE VERGES: VEGETATION CHANGES AND SPECIES DIVERSITY. SVERIGES LANTBRUKSUNIVERSITET INSTITUTIONEN FOR EKOLOGI OCH MILJOVARD RAPPORT [VOL. UNKNOWN]:1-213.

3556. PESANT, A. R. 1987. SNOWMOBILING IMPACT ON SNOW AND SOIL PROPERTIES AND ON WINTER CEREAL CROPS. CANADIAN FIELD-NATURALIST 101:22-32.

3557. PETERMAN, L. G. 1972. THE BIOLOGY AND POPULATION CHARACTERISTICS OF THE ARCTIC GRAYLING IN LAKE AGNES, MONTANA. M.S. THESIS, MONTANA STATE UNIVERSITY, BOZEMAN, MT. 29 PP.

3558. PETERS, J. E. 1972. THE ECOLOGICAL IMPLICATIONS OF TRAIL USE, CYPRESS HILLS, ALBERTA. THESIS, UNIVERSITY OF ALBERTA, EDMONTON, ALBERTA. 159PP.

3559. PETERSON, J. G. 1969. THE FOOD HABITS AND SUMMER DISTRIBUTION OF JUVENILE SAGE GROUSE IN CENTRAL MONTANA. M.S. THESIS, MONTANA STATE UNIVERSITY, BOZEMAN, MT. 39 PP.

3560. PETERSON, N. W. 1970. THE YIELD OF WILD AND HATCHERY TROUT FROM BIG SPRING CREEK MONTANA. M.S. THESIS, MONTANA STATE UNIVERSITY, BOZEMAN, MT. 35 PP.

3561. PETERSON, R. O. 1977. MANAGEMENT IMPLICATION OF WOLF-MOOSE RESEARCH, ISLE ROYALE NATIONAL PARK, MICH. REPORT TO THE NATIONAL PARK SERVICE. 14PP. 
3562. PETERSON, R. O., J. D. WOOLINGTON and T. N. BAILEY. 1984. WOLVES OF THE KENAI PENINSULA, ALASKA. WILDL. MONOGR. 88:1-52

3563. PETERSON, R. P. 1987. A NEW BLUEBIRD NESTING STRUCTURE FOR HIGHWAY RIGHTS-OF-WAY. WILDLIFE SOCIETY BULLETIN 15(2):200-204.

3564. PETIT, L. J., D. R. PETIT and T. E. MARTIN. 1995. LANDSCAPE-LEVEL MANAGEMENT OF MIGRATORY BIRDS: LOOKING PAST THE TREES TO SEE THE FOREST. WIDL. SOC. BULL. 23(3):420-9.

3565. PETRABORG, W. H., E. G. WELLEIN and V. E. GUNVALSON. 1953. ROADSIDE DRUMMING COUNTS - A SPRING CENSUS METHOD FOR RUFFED GROUSE. J. WILDL. MANAGE. 17(3):292-5.

3566. PETRAK, V. M. 1988. CROSS-COUNTRY SKIING AND RED DEER (CERVUS ELAPHUS LINNE) IN THE EIFEL. ZEITSCHRIFT FÜR JAGDWSSENSCHAFT 34:105-114 (SUMMARY IN ENGLISH).

3567. PETRANKA, J. W. 1994. RESPONSE TO IMPACT OF TIMBER HARVESTING ON SALAMANDERS. CONSERVATION BIOLOGY 8 (1):302-4..

3568. PETTERSSON, R. B., J. P. BALL, K. E. RENHORN, P. A. ESSEEN and K. SJOBERG. 1995. INVERTEBRATE COMMUNITIES IN BOREAL FOREST CANOPIES AS INFLUENCED BY FORESTRY AND LICHENS WITH IMPLICATIONS FOR PASSERINE BIRDS. BIOLOGICAL CONSERVATION 74(1):57-63.

3569. PEYTON, B. 1987. HABITAT COMPONENTS OF THE SPECTACLED BEAR IN MACHU PICCHU, PERU. INT. CONF. BEAR RES. AND MANAGE. 7:127-33.

3570. PEYTON, B. 1984. SPECTACLED BEAR HABITAT USE IN THE HISTORICAL SANCTUARY OF MACHU PICCHU. M.S. THESIS, UNIVERSITY OF MONTANA, MISSOULA, MT. 196 PP.

3571. PFEIFER, M. 1997. BARRIER EFFECT OF HIGHWAYS AND EXPRESS ROADS ON WILDLIFE. UNPUBLISHED REPORT. LANDESJAGERSCHAFT, STELEMARK, AUSTRIA.

3572. PFISTER, C., B. A. HARRINGTON and M. LAVINE. 1992. THE IMPACT OF HUMAN DISTURBANCE ON SHOREBIRDS AT A MIGRATION STAGING AREA. BIOL. CONSERV. 60:115-126.

3573. PFISTER, H. P. and V. KELLER. 1995. ROADS AND WILDLIFE - ARE GREEN BRIDGES A SOLUTION? BAUEN FUR DIE LANDWIRTSCHAFT 1 (32):26-30.

3574. PFISTER, H. P., V. KELLER, H. RECK and B. GEORGII. 1997. BIOECOLOGICAL EFFECTS OF 'GREEN BRIDGES' ABOVE TRAFFIC CORRIDORS. PAGES 1-590 IN FORSCHUNG, STRASSENBAU UND STRASSENVERKEHRSTECHNIK 756. BUNDESMINISTERIUM FUR VERKEHR., BONN, GERMANY.

3575. PHELPS, D. E., B. JAMIESON and R. A. DEMARCHI. 1975. MOUNTAIN GOAT MANAGEMENT IN THE KOOTENAYS: I. THE HISTORY OF GOAT MANAGEMENT. BRITISH COLUMBIA FISH AND WLDLIFE BRANCH UNPUBLISHED WLDLIFE REPORT.

3576. PHELPS, J. S. 1981. THE SONORAN PRONGHORN. ARIZONA. GAME AND FISH DEPT. SPECIAL REPORT 10:23-7.

3577. PHILLIPS, M. and P. C. CATLING. 1991. HOME RANGE AND ACTIVITY PATTERNS OF RED FOXES IN NADGEE NATURE RESERVE. WILDLIFE RESEARCH $18: 677-686$.

3578. PHILLIPS, O., A. H. GENTRY, C. REYNEL, P. WILKIN and B. C. GALVEZ-DURAND. 1994. QUANTITATIVE ETHNOBOTANY AND AMAZONIAN CONSERVATION. CONSERVATION BIOLOGY 8(1):225-48.

3579. PHILLIPS, R. L., R. D. ANDREWS, G. L. STORM and R. A. BISHOP. 1972. DISPERSAL AND MORTALITY OF RED FOXES. JOURNAL OF WLDLIFE MANAGEMENT 36:237-248.

3580. PHILLIPS, R. L., W. E. BERG and D. B. SINIFF. 1973. MOOSE MOVEMENT PATTERNS AND RANGE USE IN NORTHWESTERN MINNESOTA. J. WILDL. MANAGE. 37 (3):266-78. 
3581. PHILLIPS, R. L. and A. E. BESKE. 1981. GOLDEN EAGLES AND COAL DEVELOPMENT IN THE EASTERN POWDER RIVER BASIN OF WYOMING.

3582. PHILLIPS, R. L. and A. E. BESKE. 1984. RESOLVING CONFLICTS BETWEEN ENERGY DEVELOPMENT AND NESTING GOLDEN EAGLES. PAGES 214-219 IN R. D. COMER, J. M. MERINO, J. W. MONARCH, C. PUSTMUELLER, M. STALMASTER, R. STOECKER, J. TODD, AND W. WRIGHT, EDITORS. ISSUES AND TECHNOLOGY IN THE MANAGEMENT OF IMPACTED WESTERN WILDLIFE: PROCEEDINGS OF A NATIONAL SYMPOSIUM. VOLUME 14. THORNE ECOL. INST., BOULDER, COLORADO.

3583. PHILLIPS, R. L., D. E. BIGGINS and A. B. HOAG. 1986. COAL SURFACE MINING AND SELECTED WILDLIFE - A 10-YEAR CASE STUDY NEAR DECKER, MONTANA. PAGES 235-245 IN R. D. COMER, T. G. BAUMANN, P. DAVIS, J. W. MONARCH, J. TODD, S. VANGYTENBEEK, D. WILLS, AND J. WOODLING, EDITORS. PROCEEDINGS II. ISSUES AND TECHNOLOGY IN THE MANAGEMENT OF IMPACTED WESTERN WILDLIFE: PROCEEDINGS OF A NATIONAL SYMPOSIUM. THORNE ECOL. INST., BOULDER, COLORADO.

3584. PICA, E., J. SMITH and G. KRIPKE. 1998. TRAILS OF DESTRUCTION: HOW OFF-ROAD VEHICLES GAIN ACCESS AND FUNDING ON PUBLIC LANDS. FRIENDS OF THE EARTH. WASHINGTON, D.C. 3OPP

3585. PICKETT, F. J. 1978. ECOLOGY OF THE DIATOM COMMUNITIES OF SODA BUTTE CREEK, MONTANA AND IRON SPRINGS CREEK, WYOMING. M.S. THESIS, MONTANA STATE UNIVERSITY, BOZEMAN, MT. 97 PP.

3586. PICTON, H. D. THE IMPACT OF A LARGE RECREATIONAL DEVELOPMENT ON A SEMI PRIMITIVE ENVIRONMENT BIG GAME STUDIES. DEPARTMENT OF ZOOLOGY AND ENTOMOLOGY MONTANA STATE UNIVERSITY BOZEMAN., 9 PP.

3587. PICTON, H. D. 1959. USE OF VEGETATION TYPES, MIGRATION, AND HUNTER HARVEST OF THE SUN RIVER ELK HERD. M.S. THESIS, MONTANA STATE COLLEGE, BOZEMAN, MT. 39 PP.

3588. PIERCE, B. E. 1963. DISTRIBUTION OF FISH IN A SMALL MOUNTAIN STREAM IN RELATION TO TEMPERATURE. M.S. THESIS, MONTANA STATE COLLEGE, BOZEMAN, MT. 16 PP.

3589. PILS, A. C. 1998. SAMPLING AND ANALYSIS METHODS FOR SNOW-URINE NUTRITIONAL ASSAYS. M.S. THESIS, MONTANA STATE UNIVERSITY, BOZEMAN, MT. 46 PP.

3590. PILS, C. M. and M. A. MARTIN. 1979. THE COST AND CHRONOLOGY OF WISCONSIN DEER-VEHICLE COLLISIONS. WISCONSIN DEPARTMENT OF NATURAL RESOURCES RESEARCH REPORT103:1-5.

3591. PILS, C. M. and M. A. MARTIN. 1979. THE COST AND CHRONOLOGY OF WISCONSIN DEER-VEHICLE COLLISIONS. RES. REP. 103. WISCONSIN DEPARTMENT OF NATURAL RESOURCES, [LOCATION OF PUBLISHER UNKNOWN].

3592. PIMENTEL, D. 1971. ECOLOGICAL EFFECTS OF PESTICIDES ON NON-TARGET SPECIES. OFFICE OF SCIENCE AND TECHNOLOGY, WASHINGTON, D.C.

3593. PIMM, S. L., J. DIAMOND, T. M. REED, G. J. RUSSELL and J. VERNER. 1993. TIMES TO EXTINCTION FOR SMALL POPULATIONS OF LARGE BIRDS. PROC NATL ACAD SCI U S A 90(22):10871-5.

3594. PINEDO-VASQUEZ, M., D. J. P. ZARIN and J. CHOTA-INUMA. 1990. USE-VALUES OF TREE SPECIES IN A COMMUNAL FOREST RESERVE IN NORTHEAST PERU. CONSERVATION BIOLOGY 4(4):405-16.

3595. PIPP, A. K. 1998. EFFECTS OF FOREST AGE VERSUS FOREST STRUCTURE ON EPIPHYTIC LICHEN BIOMASS AND DIVERSITY. M.S. THESIS, UNIVERSITY OF MONTANA, MISSOULA, MT. 84 PP.

3596. PLAGGEMEYER, J. B. 1995. EFFECTS OF OVERSTORY THINNING ON LODGEPOLE PINE UNDERSTORIES. M.S. THESIS, MONTANA STATE UNIVERSITY, BOZEMAN, MT. 77 PP.

3597. PLASS, W. T. 1967. LAND DISTURBANCES FROM STRIP-MINING IN EASTERN KENTUCKY, PRINCESS COAL RESERVE DISTRICT. USDA, FOR. SERV. NE FOR. EXP. STA., UPPER DARBY, PA. RES. NOTE NE-55,

3598. PLATTS, W. S. 1980. A PLEA FOR FISHERY HABITAT CLASSIFICATION. FISHERIES . 5(1) 
3599. PLUMPTON, D. L. and D. E. ANDERSEN. 1998. ANTHROPOGENIC EFFECTS ON WINTER BEHAVIOR OF FERRUGINOUS HAWKS. JOURNAL OF WILDLIFE MANAGEMENT 62:340-346.

3600. PLUMPTON, D. L. and R. S. LUTZ. 1993. INFLUENCE OF VEHICULAR TRAFFIC ON TIME BUDGETS OF NESTING BURROWING OWLS. JOURNAL OF WILDLIFE MANAGEMENT 57:612-616.

3601. PLUMPTON, D. L. and R. S. LUTZ. 1993. NESTING HABITAT USE BY BURROWING OWLS IN COLORADO. JOURNAL OF RAPTOR RESEARCH 27:175-179.

3602. POAGUE, K. L. 1994. CONVERTED RAILROAD CORRIDORS AS AVIAN HABITAT IN SOUTHEAST NEBRASKA.

3603. PODLOUCKY, R. 1989. PROTECTION OF AMPHIBIANS ON ROADS - EXAMPLES AND EXPERIENCES FROM LOWER SAXONY. PAGES 15-28 IN LANGTON,T.E.S., EDITOR. AMPHIBIANS AND ROADS. PROCEEDINGS OF THE TOAD TUNNEL CONFERENCE; 1989 JANUARY 7-8; RENDSBURG, FEDERAL REPUBLIC OF GERMANY. ACO POLYMER PRODUCTS LTD., SHEFFORD, ENGLAND.

3604. PODRUZNY, K. M. 1996. RADIOTELEMETRY ERROR: FACTORS AFFECTING BEARING ERROR AND THE ULTIMATE EFFECTS OF TRIANGULATION ERROR ON DETERMINING HABITAT USE. M.S. THESIS, MONTANA STATE UNIVERSITY, BOZEMAN, MT. 104 PP.

3605. PODRUZNY, S. R. 1999. GRIZZLY BEAR USE OF WHITEBARK PINE HABITATS IN THE WASHBURN RANGE. M.S. THESIS, MONTANA STATE UNIVERSITY, BOZEMAN, MT. 60 PP.

3606. POJAR, T. M. 1971. DEER-AUTO ACCIDENT INVESTIGATIONS. COLO. GAME, FISH AND PARKS DEPT., FED. AID REPT. PROJECT W-38-R-25. 317 PP.

3607. POJAR, T. M., R. A. PROSENCE, D. F. REED and T. N. WOODARD. 1975. EFFECTIVENESS OF A LIGHTED, ANIMATED DEER CROSSING SIGN. JOURNAL OF WILLIFE MANAGEMENT 39:87-91.

3608. POJAR, T. M., D. F. REED and T. C. RESEIGH. 1972. HIGHWAY CONSTRUCTION-MOTORIST AND DEER SAFETY. COLO. GAME, FISH AND PARKS DEPT. PROJ. W-38-R.

3609. POJAR, T. M., D. F. REED and T. C. RESEIGH. 1972. HIGHWAY CONSTRUCTION; MOTORIST AND DEER SAFETY. PROCEEDINGS OF THE WESTERN ASSOCIATION OF STATE GAME AND FISH COMMISSIONS 52:268-271.

3610. POJAR, T. M., T. M. WOODARD and D. F. REED. 1973. EFFECTS OF HIGHWAY LIGHTING ON NUMBER OF DEER KILLED BY VEHICLES. COLORADO DIV. WILDL. GAME RESEARCH REPORT: PROJECT NO. W-38-R-27:185-92.

3611. POL, M. V. 1993. ECOLOGY OF JUVENILE YELLOW PERCH IN LOLO BAY, FLATHEAD LAKE, MONTANA. M.S. THESIS, UNIVERSITY OF MONTANA, MISSOULA, MT. 73 PP.

3612. POLL, D. M. 1989. WILDLIFE MORTALITY ON THE KOOTENAY PARKWAY: KOOTENAY NATIONAL PARK. ENVIRONMENT CANADA, CANADIAN PARKS SERVICE. 104PP.

3613. POLLARD, R. H., W. B. BALLARD, L. E. NOEL and M. A. CRONIN. 1996. PARASITIC INSECT ABUNDANCE AND MICROCLIMATE OF GRAVEL PADS AND TUNDRA WITHIN THE PRUDHOE BAY OIL FIELD, ALASKA, IN RELATION TO USE BY CARIBOU, RANGIFER TARANDUS GRANTI. CANADIAN FIELD NATURALIST 110(4):649-658.

3614. POLLARD, R. H., W. B. BALLARD, L. E. NOEL and M. A. CRONIN. 1996. SUMMER DISTRIBUTION OF CARIBOU, RANGIFER TARANDUS GRANTI, IN THE AREA OF THE PRUDHOE BAY OIL FIELD, ALASKA, 1990-1994. CANADIAN FIELD NATURALIST 110(4):659-674.

3615. POND, D. B. 1982. THE PATHOLOGY AND CROSS-INFECTIVITY OF SARCOCYSTIS SPP. IN MULE DEER, WHITE-TAILED DEER, AND ELK. M.S. THESIS, UNIVERSITY OF MONTANA, MISSOULA, MT. 39 PP.

3616. PONTES, A. R. M. and M. CRUZ. 1995. HOME RANGE, INTERGROUP TRANSFERS, AND REPRODUCTIVE STATUS OF COMMON MARMOSETS CALLITHRIX JACCHUS IN A FOREST FRAGMENT IN NORTH-EASTERN BRAZIL. PRIMATES 36 (3):335-47. 
3617. POOLE, D. A. 1952. A STUDY OF THE TOXIC POTENTIALS OF DUCK BOTULISM IN ARTIFICIALLY FLOODED AREAS. M.S. THESIS, MONTANA STATE UNIVERSITY, MISSOULA, MT. 89 PP.

3618. POORE, M. D. 1973. THE FISHERY RESOURCE OF MYSTIC LAKE, MONTANA. M.S. THESIS, MONTANA STATE UNIVERSITY, BOZEMAN, MT. 31 PP.

3619. POPPLETON, W. B. 1969. HIGHWAY COORDINATION. ARIZ. GAME AND FISH DEPT., FED. AID REPT. PROJECT FW-16-R-8:45-52.

3620. PORATH, W. R. and O. TORGENSON. 1975. DEER POPULATION TREND MEASUREMENTS. MISSOURI DEPT. OF CONSERVATION, COLUMBIA P-R REPORT W-13-R-29. 19PP.

3621. PORNELUZI, P., J. C. BEDNARZ, L. J. GOODRICH, N. ZAWADA and J. HOOVER. 1993. REPRODUCTIVE PERFORMANCE OF TERRITORIAL OVENBIRDS OCCUPYING FOREST FRAGMENTS AND A CONTIGUOUS FOREST IN PENNSYLVANIA. CONSERVATION BIOLOGY 7 (3):618-22.

3622. PORT, G. R. and J. R. THOMPSON. 1980. OUTBREAKS OF INSECT HERBIVORES ON PLANTS ALONG MOTORWAYS IN THE UNITED KINGDOM. JOURNAL OF ANIMAL ECOLOGY 17:649-656.

3623. PORTECK, K. G., A. E. MILLER and D. L. HAM. 1995. COMPARISON OF ALTERNATIVE MAINTENANCE TREATMENTS FOR AN ELECTRIC TRANSMISSION RIGHT-OF-WAY ON STEEP MOUNTAINOUS TERRAIN. JOURNAL OF ARBORICULTURE 21 (3):168-74.

3624. PORTER, T. R., D. M. ROSENBERG and D. K. MCGOWAN. 1974. WINTER STUDIES OF THE EFFECTS OF A HIGHWAY CROSSING ON THE FISH AND BENTHOS OF THE MARTIN RIVER, N.W.T. FISHERIES AND MARINE SERVICE, OTTAWA, ONTARIO. TECHNICAL REPORT SERIES / RESOURCE MANAGEMENT BRANCH, CENTRAL REGION: TECHNICAL REPORT SERIES (CANADA. FISHERIES AND MARINE SERVICE. CENTRAL REGION. RESOURCE MANAGEMENT BRANCH) CEN T-74-3.

3625. PORTILLO, M., N. URDANETA and H. URDANETA. 1994. NERIUM OLEANDER AS AN INDICATOR OF ENVIRONMENTAL CONTAMINATION BY LEAD IN THE NORTHERN PART OF MARACAIBO, ZULIA STATE, VENEZUELA. BOLETIN DEL CENTRO DE INVESTIGACIONES BIOLOGICAS UNIVERSIDAD DEL ZULIA 28 (1):33-45.

3626. PORTILLO, M. M. 1992. PROVISIONAL REPORT OF THE MORTALITY OF VERTEBRATES ON THE ROADS OF SEVILLA, SEPTEMBER 1991. PAGES 97-100 IN LOPEZ,REDONDO, EDITOR. I JORNADAS PARA EL ESTUDIO Y PREVENCION DE LA MORTALIDAD DE VERTEBRADOS EN CARRETERAS, MADRID, 5 Y 6 DE OCTUBRE DE 1991. TOMO 2. [SESSIONS IN THE STUDY OF PREVENTION OF ROAD MORTALITIES OF VERTEBRATES, MADRID, 5 AND 6 OCTOBER, 1991. VOLUME 2.]. COORDINADORA DE ORGANIZACCIONES DE DEFENSA, AMBIENTAL, MADRID.

3627. POSEWIT, J. A. 1961. OBSERVATIONS ON THE FISH POPULATION OF WILLOW CREEK RESERVOIR, MONTANA. M.S. THESIS, MONTANA STATE COLLEGE, BOZEMAN, MT. 29 PP.

3628. POSTON, H. J. 1977. WATERFOWL POPULATIONS OBSERVED ALONG THE PROPOSED GAS PIPELINE ROUTE RICHARDS ISLAND TO N.W.T. - ALBERTA BORDER. CANADIAN WILDLIFE SERVICE, OTTAWA, ONTARIO.

3629. POSTOVIT, H. R. and B. C. POSTOVIT. 1987. IMPACTS AND MITIGATION TECHNIQUES. PAGES 183-208 IN B. A. G. PENDLETON, B. A. MILLSAP, K. W. CLINE, AND D. M. BIRD, EDITORS. RAPTOR MANAGEMENT TECHNIQUES MANUAL. NATIONAL WILDLIFE FEDERATION. WASHINGTON, D.C. SCIENTIFIC TECHNICAL SERVICE NO. 10.

3630. POTOLICKI, G. D. 1987. MONITORING OF ANIMAL KILLS ON CN TWIN TRACK WITHIN JASPER NATIONAL PARK, REPORT \#3. PREPARED BY CANADIAN NATIONAL ENVIRONMENTAL SUPERVISOR, EDMONTON. UNPUBLISHED REPORT.

3631. POTVIN, F. and J. HUOT. 1983. ESTIMATING CARRYING CAPACITY OF A WHITE-TAILED DEER WINTERING AREA IN QUEBEC. J. WILDL. MANAGE. 47 (2):463-75.

3632. POULSEN, B. O. 1994. MOVEMENTS OF SINGLE BIRDS AND MIXED-SPECIES FLOCKS BETWEEN ISOLATED FRAGMENTS OF CLOUD FOREST IN ECUADOR. STUDIES ON NEOTROPICAL FAUNA AND ENVIRONMENT 29 (3):149-60.

3633. POUNDS, J. A. and M. L. CRUMP. 1994. AMPHIBIAN DECLINES AND CLIMATE DISTURBANCE: THE CASE OF THE GOLDEN TOAD AND THE HARLEQUIN FROG. CONSERVATION BIOLOGY 8 (1):72-85. 
3634. POWELL, G. V. N. and R. D. BJORK. 1994. IMPLICATIONS OF ALTITUDINAL MIGRATION FOR CONSERVATION STRATEGIES TO PROTECT TROPICAL BIODIVERSITY: A CASE STUDY OF THE RESPLENDENT QUETZAL PHAROMACRUS MOCINNO AT MONTEVERDE, COSTA RICA. BIRD CONSERVATION INTERNATIONAL 4 (2-3):161-74.

3635. POWELL, R. A. 1993. THE FISHER: LIFE HISTORY, ECOLOGY, AND BEHAVIOR. UNIVERSITY OF MINNESOTA PRESS, MINNEAPOLIS, MN. 237PP.

3636. POWELL, R. A. 1977. HUNTING BEHAVIOR, ECOLOGICAL ENERGETICS, AND PREDATOR-PREY COMMUNITY STABILITY OF THE FISHER . PH.D. THESIS, UNIVERSITY OF CHICAGO, CHICAGO, IL. 132PP .

3637. POWELL, R. A. and W. J. ZIELINSKI. 1994. FISHER. P 38-73. IN: RUGGIERO, L.F., AUBRY, K.B., BUSKIRK, S.W., LYON, L.J., ZIELINSKI, W.J., (EDITORS). THE SCIENTIFIC BASIS FOR CONSERVING FOREST CARNIVORES: AMERICAN MARTEN, FISHER, LYNX, AND WOLVERINE IN THE WESTERN UNITED STATES. USDA FOREST SERVICE GENERAL TECHNICAL REPORT RM-254. USDA FOREST SERVICE.

3638. POWER, J. A. and E. G. SCHUSTER. 1975. OFF-ROAD VEHICLE LAW \& IDAHO AN ORV PLANNING AID. INFORMATION SERIES - COLLEGE OF FORESTRY, WLDLIFE AND RANGE SCIENCES ; NO. 11. FOREST, WILLIFE AND RANGE EXPERIMENT STATION, UNIVERSITY OF IDAHO, MOSCOW, IDAHO.

3639. PRAVECEK, J. J. 1995. EFFECT OF DIET ON BODY COMPOSITION AND PHYSICAL ABILITY OF INTENSIVELY CULTURED WALLEYE FINGERLINGS. M.S. THESIS, MONTANA STATE UNIVERSITY, BOZEMAN, MT. 67 PP.

3640. PRESIDENTE, P. J. A. 1968. INFECTIVITY AND IMMUNOGENIC CAPABILITY OF DICTYOCAULUS SPECIES FROM ELK AND CATTLE IN EXPERIMENTALLY INFECTED BOVINE CALVES . M.S. THESIS, MONTANA STATE UNIVERSITY, BOZEMAN, MT. 41 PP.

3641. PRICE, M. F. 1991. AN ASSESSMENT OF PATTERNS OF USE AND MANAGEMENT OF MOUNTAIN FORESTS IN COLORADO, USA: IMPLICATIONS FOR FUTURE POLICIES. PAGES 34-52 IN N. G. BAYFIELD AND G. C. BARROW, EDITORS. THE ECOLOGICAL IMPACTS OF OUTDOOR RECREATION ON MOUNTAIN AREAS IN EUROPE AND NORTH AMERICA. RECREATION ECOLOGY RESEARCH GROUP, WYE, ASHFORD, KENT, UK.

3642. PRICE, M. F. 1985. A REVIEW OF RESEARCH INTO THE IMPACTS OF RECREATION ON ALPINE VEGETATION IN WESTERN NORTH AMERICA. MOUNTAIN RESEARCH AND DEVELOPMENT 11:57-64.

3643. PRICE, M. V. and P. R. ENDO. 1989. ESTIMATING THE DISTRIBUTION AND ABUNDANCE OF A CRYPTIC SPECIES, DIPODOMYS STEPHENSI (RODENTIA: HETEROMYIDAE), AND IMPLICATIONS FOR MANAGEMENT. CONSERVATION BIOLOGY 3 (3):293-301.

3644. PRICE, M. V., P. A. KELLY and R. L. GOLDINGAY. 1994. DISTANCES MOVED BY STEPHEN'S KANGAROO RAT (DIPODOMYS STEPHENSI MERRIAM) AND IMPLICATION FOR CONSERVATION. JOURNAL OF MAMMALOGY 75 (4):929-39.

3645. PRIMACK, R. B. and S. L. MIAO. 1992. DISPERSAL CAN LIMIT LOCAL PLANT DISTRIBUTION. CONSERVATION BIOLOGY 6 (4):513-9.

3646. PRINDIVILLE, G. E. and M. R. RYAN. 1988. PIPING PLOVER HABITAT USE AND REPRODUCTIVE SUCCESS IN NORTH DAKOTA (USA). JOURNAL OF WILDLIFE MANAGEMENT 52:266-273.

3647. PRISM ENVIRONMENTAL MANAGEMENT CONSULTANTS LTD. 1984. HABITAT ENHANCEMENT AND THE PETROLEUM INDUSTRY.

3648. PRISM ENVIRONMENTAL MANAGEMENT CONSULTANTS LTD. 1982. A REVIEW OF PETROLEUM INDUSTRY OPERATIONS AND OTHER LAND USE ACTIVITIES AFFECTING WILDLIFE. PRODUCED FOR THE CANADIAN PETROLEUM ASSOC. 233PP.

3649. PROBER, S. M. and A. H. D. BROWN. 1994. CONSERVATION OF THE GRASSY WHITE BOXWOOD LANDS: POPULATION GENETICS AND FRAGMENTATION OF EUCALYPTUS ALBENS. CONSERVATION BIOLOGY 8 (4):1003-13.

3650. PROFERA, J. and C. E. BRAUN. 1986. DEVELOPMENT OF SAGE GROUSE PUBLIC VIEWING TOURS IN NORTH PARK, COLORADO. J. COLO.-WYO. ACAD. SCI. 17:36 (ABSTRACT ONLY). 
3651. PROFERA, J. and C. E. BRAUN. 1985. SAGE GROUSE PUBLIC VIEWING TOUR DEVELOPMENT IN NORTH PARK, COLORADO. PAGES 306 IN R. D. COMER, T. G. BAUMANN, P.'DAVIS, J. W. MONARCH, J. TODD, S. - VANGYTENBEEK, D. WLLS, AND J. WOODLING, EDITORS. PROCEEDINGS II. ISSUES AND TECHNOLOGY IN THE MANAGEMENT OF IMPACTED WESTERN WILDLIFE: PROCEEDINGS OF A NATIONAL SYMPOSIUM. THORNE ECOL. INST., BOULDER, COLORADO.

3652. PROPST, D. B., J. H. SCHOMAKER and J. E. MITCHELL. 1977. ATTITUDES OF IDAHO OFF-ROAD VEHICLE USERS AND MANAGERS. BULLETIN / COLLEGE OF FORESTRY, WILDLIFE AND RANGE SCIENCES, UNIVERSITY OF IDAHO: BULLETIN (UNIVERSITY OF IDAHO. COLLEGE OF FORESTRY, WLDLIFE AND RANGE SCIENCES) NO. 23. COLLEGE OF FORESTRY, WILDLIFE AND RANGE SCIENCES, UNIVERSITY OF IDAHO, MOSCOW, IDAHO.

3653. PROULX, G. and R. K. DRESCHER. 1993. DISTRIBUTION OF THE LONG-TAILED WEASEL, MUSTELA FRENATA LONGICAUDA, IN ALBERTA AS DETERMINED BY QUESTIONNAIRES AND INTERVIEWS. CANADIAN FIELD-NATURALIST 107 (2):186-91.

3654. PROULX, G., A. J. KOLENOSKY, M. J. BADRY, P. J. COLE and R. K. DRESCHER. 1994. A SNOWSHOE HARE SNARE SYSTEM TO MINIMIZE CAPTURE OF MARTEN. WLDL. SOC. BULL. 22(4):639-43.

3655. PRUITT, W. O. 1971. SNOWMOBILES AND ALL-TERRAIN VEHICLES. CONFERENCE ON SNOWMOBILES AND ALL-TERRAIN VEHICLES. UNIVERSITY OF WESTERN ONTARIO, DEPARTMENT OF ZOOLOGY RESEARCH REPORT, UNIVERSITY OF MANITOBA. WINNIPEG, CANADA.

3656. PRZYBYLSKI, Z. 1979. THE EFFECTS OF AUTOMOBILE EXHAUST GASSES ON THE ARTHROPODS OF CULTIVATED PLANTS, MEADOWS AND ORCHARDS. ENVIRONMENTAL POLLUTION 19:157-161.

3657. PUCHLERZ, T. and C. SERVHEEN. 1994. GRIZZLY BEAR/MOTORIZED ACCESS MANAGEMENT. INTERAGENCY GRIZZLY BEAR COMMITTEE TASKFORCE REPORT. U.S. FISH AND WILDLIFE SERVICE, MISSOULA, MT.

3658. PUGLISI, M. J. 1974. PENNSYLVANIA CONDUCTS STUDY OF 1974 VEHICLE-DEER COLLISIONS. TRAFFIC SAFETY $74: 25-29$.

3659. PUGLISI, M. J., J. S. LINDZEY and E. D. BELLIS. 1974. FACTORS ASSOCIATED WITH HIGHWAY MORTALITY OF WHITE-TAILED DEER. JOURNAL OF WILDLIFE MANAGEMENT 38:799-807.

3660. PUKY, M. 1987. TOADS ON ROADS CAMPAIGN - HUNGARY. HERPETOFAUNA NEWS 1987:3-5.

3661. PURDY, K. G., G. R. GOFF, D. J. DECKER, G. A. POMERANTZ and N. A. CONNELLY. 1987. A GUIDE TO MANAGING HUMAN ACTIVITY ON NATIONAL WLDLIFE REFUGES. HUMAN DIMENSIONS RESEARCH UNIT DEPT. OF NATURAL RESOURCES. CORNELL UNIVERSITY, ITHACA, NEW YORK AND U.S. FISH AND WILDLIFE SERVICE, OFFICE OF INFORMATION TRANSFER, FORT COLLINS, COLORADO. 57PP.

3662. PURKETT, C. A. JR. 1950. GROWTH RATE OF TROUT IN RELATION TO ELEVATION AND TEMPERATURE. M.S. THESIS, MONTANA STATE COLLEGE, BOZEMAN, MT. 33 PP.

3663. PURVES, H. D., C. A. WHITE and P. C. PAQUET. 1992. WOLF AND GRIZZLY BEAR HABITAT USE AND DISPLACEMENT BY HUMAN USE IN BANFF, YOHO, AND KOOTENAY NATIONAL PARKS: A PRELIMINARY ANALYSIS. HERITAGE RESOURCES CONSERVATION, CANADIAN PARKS SERVICE. BANFF, ALBERTA.

3664. PUTMAN, R. J. 1997. DEER AND ROAD TRAFFIC ACCIDENTS - OPTIONS FOR MANAGEMENT. JOURNAL OF ENVIRONMENTAL MANAGEMENT 51(1):43-57.

3665. PYLE, C. 1994. INTERACTIONS BETWEEN DISPERSAL BEHAVIOR AND LANDSCAPE PATTERN MODELED WITH A FOCUS ON MATRIX MODIFICATION IN A PACIFIC NORTHWEST CONTEXT. PHD THESIS, UNIVERSITY OF WASHINGTON 155PP.

3666. QUARLES, H. D., R. B. HANAWALT and W. E. ODUM. 1974. LEAD IN SMALL MAMMALS, PLANTS, AND SOIL AT VARYING DISTANCES FROM A HIGHWAY. JOURNAL OF APPLIED ECOLOGY 11:937-949.

3667. QUEAL, L. M. 1968. EFFECTIVENESS OF ROADSIDE MIRRORS IN CONTROLLING DEER-CAR ACCIDENTS. MICHIGAN DEPARTMENT OF CONSERVATION, RESEARCH AND DEVELOPMENT REPORT N0137:1-9 
3668. QUEAL, L. M. 1968. EFFECTIVENESS OF ROADSIDE MIRRORS IN CONTROLLING DEER-CAR ACCIDENTS. RESEARCH AND DEVELOPMENT REPORT NO. 137. MICHIGAN DEPARTMENT OF NATURAL RESOURCES, LANSING, MI.

3669. QUENE, E. and J. GROTENHUIS. 1994. BIRD CASUALTIES ON ROADS IN THE PROVINCE OF DRENTHE: AN UPDATE. DRENTSE VOGELS 1994:73-81.

3670. QUIGLEY, H. B. and P. G. J. CRAWSHAW. 1992. A CONSERVATION PLAN FOR THE JAGUAR PANTHERA ONCA IN THE PANTANAL REGION OF.BRAZIL. BIOLOGICAL CONSERVATION 61 (3):149-57.

3671. QUINN, J. F. and A. HASTINGS. 1987. DEER-VEHICLE ACCIDENTS. COLORADO GAME RESEARCH REVIEW 7:8-12.

3672. QUINN, J. F., C. L. WOLIN and M. L. JUDGE. 1989. AN EXPERIMENTAL ANALYSIS OF PATCH SIZE, HABITAT SUBDIVISION, AND EXTINCTION IN A MARINE INTERTIDAL SNAIL. CONSERVATION BIOLOGY 3 (3):242-51.

3673. R L \& L ENVIRONMENTAL SERVICES, ALBERTA, DEPT. OF THE ENVIRONMENT and PLANNING DIVISION. 1988. FISHERIES MITIGATION STUDIES CASTLE RIVER NUTRIENT ENRICHMENT, 1988 : DATA SUMMARY. THE COMPANY, EDMONTON, ALBERTA.

3674. RABENBERG, M. J. 1982. ECOLOGY AND POPULATION DYNAMICS OF MALLARDS WINTERING IN THE COLUMBIA BASIN M.S. THESIS, UNIVERSITY OF MONTANA, MISSOULA, MT. 135 PP.

3675. RACEY, G. D. and D. L. EULER. 1983. CHANGES IN MINK HABITAT AND FOOD SELECTION AS INFLUENCED BY COTTAGE DEVELOPMENT IN CENTRAL ONTARIO. JOURNAL APPLIED ECOLOGY 20:387-402.

3676. RACHAEL, J. S. 1992. MORTALITY AND SEASONAL DISTRIBUTION OF WHITE-TAILED DEER IN AN AREA RECENTLY RECOLONIZED BY WOLVES. M.S. THESIS, UNIVERSITY OF MONTANA, MISSOULA, MT. 115 PP.

3677. RACINE, C. H. and G. M. AHLSTRAND. 1991. THAW RESPONSE OF TUSSOCK-SHRUB TUNDRA TO EXPERIMENTAL ALL-TERRAIN VEHICLE DISTURBANCES IN SOUTH-CENTRAL ALASKA. ARCTIC 44:31-37.

3678. RACINE, C. H. and L. A. JOHNSON. 1988. EFFECTS OF ALL-TERRAIN VEHICLE TRAFFIC ON TUNDRA TERRAIN NEAR ANAKTUVUK PASS, ALASKA. COLD REGIONS RES. ENG. LAB. REP. HANOVER, NEW HAMPSHIRE. CRREL-SR-88-17. 18PP.

3679. RADA, R. G. 1974. AN INVESTIGATION INTO THE TROPHIC STATUS OF CANYON FERRY RESERVOIR MONTANA. PH.D. DISSERTATION, MONTANA STATE UNIVERSITY, BOZEMAN, MT. 126 PP.

3680. RADCLIFFE, E. J. 1974. WLDLIFE CONSIDERATIONS FOR THE HIGHWAY DESIGNER. JOURNAL OF THE INSTITUTE OF MUNICIPAL ENGINEERS 101:289-294.

3681. RADO, R. and J. TERKEL. 1989. A RADIO-TRACKING SYSTEM FOR SUBTERRANEAN RODENTS. J. WLDL. MANAGE. 53 (4):946-9.

3682. RAHRER, J. F. 1963. AGE AND GROWTH OF FOUR SPECIES OF FISH, FLATHEAD LAKE, MONTANA. M.S. THESIS, MONTANA STATE COLLEGE, BOZEMAN, MT. 16 PP.

3683. RAINES, M. R. 1988. HYDROCARBON DEVELOPMENT, A YUKON PERSPECTIVE AN ANNOTATED BIBLIOGRAPHY OF SOURCES AVAILABLE IN THE YUKON ARCHIVES, VOLUME TWO. 569PP.

3684. RAJSKA, J. E. 1992. DEMOGRAPHY OF WOODLAND RODENTS IN FRAGMENTED HABITAT. ACTA THERIOLOGICA 37 $(1-2): 73-90$.

3685. RALLS, K., J. BALLOU and A. R. TEMPLETON. ESTIMATES OF LETHAL EQUIVALENTS AND THE COST OF INBREEDING IN MAMMALS. CONSERV. BIOL. 2:185-93.

3686. RALLS, K., K. BRUGGER and J. BULLOU. 1979. INBREEDING AND JUVENILE MORTALITY IN SMALL POPULATIONS OF UNGULATES. SCIENCE 206 (30):1101-3.

3687. RAMAKKA, J. M. 1988. IMPACTS AND MITIGATION OF MINERAL DEVELOPMENT ON RAPTORS IN THE SOUTHWEST. PAGES 335-340 IN R. L. GLINSKI, B. G. PENDELFON, M. B. MOSS, M. N. LEFRANC, JR., B. A. MILLSAP, S. W. 
HOFFMAN, C. E. RUIBAL, D. L. KRAHE, AND D. L. OWENS, EDITORS. PROCEEDINGS OF THE SOUTHWEST RAPTOR MANAGEMENT SYMPOSIUM AND WORKSHOP. INST. WILDL. RES., NATIONAL WLDLIFE FEDERATION, - WASHINGTON, DC.

3688. RANDOLPH, C. L. 1984. VALIDITY OF THE WETTED-PERIMETER METHOD FOR RECOMMENDING INSTREAM FLOWS FOR RAINBOW TROUT IN A SMALL STREAM. M.S. THESIS, MONTANA STATE UNIVERSITY, BOZEMAN, MT. 95 PP.

3689. RANNEY, J. W., M. C. BRUNNER and J. B. LEVENSON. 1981. THE IMPORTANCE OF EDGE IN THE STRUCTURE AND DYNAMICS OF FOREST ISLANDS. PAGES [UNKNOWN] IN BURGESS, R.L. AND SHARPE,D.M., EDITORS. FOREST ISLAND DYNAMICS IN MAN-DOMINATED LANDSCAPES. SPRINGER-VERLAG., NEW YORK.

3690. RATCLIFFE, D. A. 1969. POPULATION TRENDS OF THE PEREGRINE FALCON IN GREAT BRITAIN. PAGES 239-269 IN J. J. HICKEY, EDITOR. PEREGRINE FALCON POPULATIONS: THEIR BIOLOGY AND DECLINE. UNIVERSITY OF WISCONSIN, MADISON, WISCONSIN.

3691. RATCLIFFE, J. 1983. WHY DID THE TOAD CROSS THE ROAD?. WILLIFE (LONDON) 5(8):304-307.

3692. RATCLIFFE, J. 1984. WLDLIFE AND HIGHWAYS. HIGHWAYS AND TRANSPORTATION 31(11):19-21.

3693. RATTI, J. T. and K. P. REESE. 1988. PRELIMINARY TEST OF THE ECOLOGICAL TRAP HYPOTHESIS. J. WILDL. MANAGE. $52(3): 484-91$.

3694. RAUSCHER, R. L. 2000. SPECIES ACCOUNTS OF SELECTED BUREAU OF LAND MANAGEMENT SENSITIVE STATUS SPECIES IN MONTANA. MONTNA FISH, WLDLIFE AND PARKS, NONGAME PROGRAM (CD)

3695. RAUSCHER, R. L. 2000. SPECIES ACCOUNTS OF SELECTED BUREAU OF LAND MANAGEMENT SENSITIVE STATUS SPECIES IN MONTANA. MONTANA FISH, WILDLIFE AND PARKS, NONGAME PROGRAM (CD).

3696. RAUSCHER, R. L. 1995. DEER USE OF IRRIGATED ALFALFA ALONG THE YELLOWSTONE RIVER, CUSTER COUNTY, MONTANA. M.S. THESIS, MONTANA STATE UNIVERSITY, BOZEMAN, MT. 50 PP.

3697. RAUTENSTRAUCH, K. R. 1987. ECOLOGY OF DESERT MULE DEER IN SOUTHWEST ARIZONA. PHD THESIS, THE UNIVERSITY OF ARIZONA. 48 PP.

3698. RAVEN, C. L. 1999. EVOLUTIONARY UNITS IN WILDLIFE: A CASE STUDY OF THE BALD EAGLE. PH.D. DISSERTATION, MONTANA STATE UNIVERSITY, BOZEMAN, MT. 88 PP.

3699. RAVKIN, YU. S. 1985. ANTHROPOGENIC TRANSFORMATIONS OF AVIAN COMMUNITIES IN THE USSR FOREST ZONE. PROCEEDINGS OF THE INTERNATIONAL ONITHOLOGICAL CONGRESS 18:580-583.

3700. RAYMOND, R. B. and R. B. FORBES. 1975. LEAD IN HAIR OF URBAN AND RURAL SMALL MAMMALS. BULL. ENVIRON. CONTAM. TOXICOL. 13:551-553.

3701. READING, C. J. 1989. OPPORTUNISTIC PREDATION OF COMMON TOADS (BUFO BUFO) AT A DRIFT FENCE IN SOUTHERN ENGLAND. PAGES 105-112 IN LANGTON,T.E., EDITOR. AMPHIBIANS AND ROADS. PROCEEDINGS OF THE TOAD TUNNEL CONFERENCE; 1989 JANUARY 7-8; RENDSBURG, FEDERAL REPUBLIC OF GERMANY. ACO POLYMER PRODUCTS LTD., SHEFFORD, ENGLAND.

3702. READING, R. P. and R. MATCHETT. 1997. ATTRIBUTES OF BLACK-TAILED PRAIRIE DOG COLONIES IN NORTH CENTRAL MONTANA. JOURNAL OF WLDLIFE MANAGEMENT 61(3):664-673.

3703. REAM, C. H. 1978. HUMAN-WILLIFE CONFLICTS IN BACKCOUNTRY: POSSIBLE SOLUTIONS. P. 153-163. IN: USFS RECREATIONAL IMPACT ON WILDLANDS CONF.; OCT 27-1978 OCT 29; SEATTLE, WA.

3704. REAM, R. R. 1976. IDAHO FALLS DISTRICT OFF-ROAD VEHICLE SURVEY. WILDERNESS INSTITUTE, SCHOOL OF FORESTRY, UNIVERSITY OF MONTANA. MISSOULA, MONTANA.

3705. RECHER, H. F. and D. L. SERVENTY. 1991. LONG TERM CHANGES IN THE RELATIVE ABUNDANCES OF BIRDS IN KINGS PARK, PERTH, WESTERN AUSTRALIA. CONSERVATION BIOLOGY 5 (1):90-102. 
3706. RECK, $H$. and G. KAULE. 1993. ROADS AND HABITATS: AN ANALYSIS OF THE EFFECTS DUE TO ROADS ON PLANTS, ANIMALS AND THEIR HABITATS. INSTITUT FUR LANDSCHAFTSPLANUNG UND OKOLOGIE, UNIVERSITAT STUTTGART, STUTTGART, GERMANY.

3707. REED, A. 1975. REPRODUCTIVE OUTPUT OF BLACK DUCKS IN THE ST. LAWRENCE ESTUARY. J. WLDL. MANAGE. 39 (2):243-55

3708. REED, D. F. 1981. CONFLICTS WITH CIVILIZATION. P 509-35. IN: WALLMO OC, ED. MULE AND BLACK-TAILED DEER OF NORTH AMERICA. LINCOLN, NE: UNIV. NEBRASKA PRESS.

3709. REED, D. F. 1976. DEER-AUTO ACCIDENT INVESTIGATIONS: EVALUATION OF DEER UNDERPASSES. STATE OF COLORADO, DIVISION OF WILDLIFE, DENVER, CO.

3710. REED, D. F. 1979. DEER-AUTO INVESTIGATIONS: DEER VEHICLE ACCIDENTS STATEWIDE AND METHODS AND DEVICES TO REDUCE THEM. COLO. W-125-R-5NK.P1.01/JOB 01. STATE OF COLORADO, DIVISION OF WILDLIFE, DENVER, CO.

3711. REED, D. F. 1971. DEER-ELK INVESTIGATIONS: DEER UNDERPASS EVALUATION. STATE OF COLORADO, GAME, FISH, AND PARKS DEPARTMENT, DENVER, CO.

3712. REED, D. F. 1971. DEER UNDERPASS EVALUATION. COLO. GAME, FISH AND PARKS DEPT. FED. AID PROJ. REPT. W-38-R-25:10 PP.

3713. REED, D. F. 1973. DEER UNDERPASS EVALUATION. COLO. DIV. OF WLDLIFE, FISH AND PARKS, FED. AID REPT., PROJ. W-38-R-27. 177-84.

3714. REED, D. F., T. BECK and T. N. WOODARD. 1982. METHODS OF REDUCING DEER-VEHICLE ACCIDENTS: BENEFIT COST ANALYSIS. WILDLIFE SOCIETY BULLETIN 10(4):349-354.

3715. REED, D. F., K. R. KINCAID and T. D. I. BECK. 1979. MIGRATORY MULE DEER FALL FROM HIGHWAY CLIFFS. J. WILDL. MANAGE. $43(1): 272$.

3716. REED, D. F., T. M. POJAR and T. N. WOODARD. 1974. MULE DEER RESPONSES TO DEER GUARDS. JOURNAL OF RANGE MANAGEMENT 27:111-113.

3717. REED, D. F., T. M. POJAR and T. N. WOODARD. 1974. USE OF ONE-WAY GATES BY MULE DEER. JOURNAL OF WILDLIFE MANAGEMENT 38:9-15.

3718. REED, D. F. and T. N. WOODARD. 1981. EFFECTIVENESS OF HIGHWAY LIGHTING IN REDUCING DEER-VEHICLE ACCIDENTS. JOURNAL OF WLDLIFE MANAGEMENT 45 (3):721-6.

3719. REED, D. F., T. N. WOODARD and T. D. BECK. 1977. HIGHWAY LIGHTING TO PREVENT DEER-AUTO ACCIDENTS. CDOH-P R-R-77-5; FHWAICO-77-5. STATE OF COLORADO, DIVISION OF HIGHWAYS, DIVISION OF WILDLIFE, DENVER, CO.

3720. REED, D. F., T. N. WOODARD and T. D. BECK. 1979. REGIONAL DEER-VEHICLE RESEARCH. STATE OF COLORADO, DIVISION OF WILDLIFE, DENVER, CO.

3721. REED, D. F., T. N. WOODARD and T. D. I. BECK. 1979. REGIONAL DEER-VEHICLE ACCIDENT RESEARCH. U.S. DEPARTMENT OF TRANSPORTATION, FEDERAL HIGHWAY ADMINISTRATION REPORT NO. FHWA-RD-79-11. 61PP.

3722. REED, D. F. 1981. MULE DEER BEHAVIOR AT A HIGHWAY UNDERPASS EXIT. JOURNAL OF WILDLIFE MANAGEMENT 45:542-543.

3723. REED, D. F. 1969. TECHNIQUES FOR DETERMINING POTENTIALLY CRITICAL DEER HIGHWAY CROSSINGS. COLORADO DEPT. OF NATURAL RESOURCES, DIVISION OF GAME FISH AND PARKS, DENVER, COLORADO. OUTDOOR FACTS NO. 73. 
3724. REED, D. F., T. N. WOODARD and T. D. I. BECK. 1979. REGIONAL DEER-VEHICLE ACCIDENT RESEARCH FINAL REPORT. COLORADO DIVISION OF WLDLIFE, DENVER; SPRINGFIELD, VA.

3725. REED, D. F., T. N. WOODARD and T. M. POJAR. 1975. BEHAVIORAL RESPONSE OF MULE DEER TO A HIGHWAY UNDERPASS. JOURNAL OF WLDLIFE MANAGEMENT 39:361-367.

3726. REED, J. R. 1977. STREAM COMMUNITY RESPONSE TO ROAD CONSTRUCTION SEDIMENTS. BULLETIN NO.97. VIRGINIA POLYTECHNIC INSTITUTE AND STATE UNIV, BLACKSBURG, WATER RESOURCES RESEARCH CENTER, .

3727. REED, R. A., J. JOHNSON-BARNARD and W. L. BAKER. 1996. CONTRIBUTION OF ROADS TO FOREST FRAGMENTATION IN THE ROCKY MOUNTAINS. CONSERVATION BIOLOGY 10(4):1098-1106.

3728. REED, T. 1996. THE VIEW FROM THE BT. WYO. WLDL. 60:10-15.

3729. REEVE, A. F. and S. H. ANDERSON. 1993. INEFFECTIVENESS OF SWAREFLEX REFLECTORS AT REDUCING DEER-VEHICLE COLLISIONS. WLDLIFE SOCIETY BULLETIN 21:349-354.

3730. REEVES, H. M., F. G. COOCH and R. E. MUNRO. 1976. MONITORING ARCTIC HABITAT AND GOOSE PRODUCTION BY SATELLITE IMAGERY. J. WILDL. MANAGE. 40 (3):532-41.

3731. REEVES, R. R. 1977. THE PROBLEM OF GRAY WHALE HARASSMENT AT THE BREEDING LAGOONS AND DURING MIGRATION. NTIS REPORT PB-272 506, OCT 77(64)

3732. REH, W. 1989. INVESTIGATIONS INTO THE INFLUENCE OF ROADS ON THE GENETIC STRUCTURE OF POPULATIONS OF THE COMMON FROG (RANA TEMPORARIA). PAGES 101-103 IN LANGTON,T.E., EDITOR. AMPHIBIANS AND ROADS. PROCEEDINGS OF THE TOAD TUNNEL CONFERENCE; 1989 JANUARY 7-8; RENDSBURG, FEDERAL REPUBLIC OF GERMANY. ACO POLYMER PRODUCTS LTD., SHEFFORD, ENGLAND.

3733. REH, W. and A. SEITZ. 1990. THE INFLUENCE OF LAND USE ON THE GENETIC STRUCTURE OF POPULATIONS OF THE COMMON FROG, RANA TEMPORARIA. BIOLOGICAL CONSERVATION 54:239-249.

3734. REHWINKEL, B. J. 1975. THE FISHERY FOR PADDLEFISH AT INTAKE, MONTANA, DURING 1973 AND 1974. M.S. THESIS, MONTANA STATE UNIVERSITY, BOZEMAN, MT. 36 PP.

3735. REICHEL, J. D. 1976. COYOTE-PREY RELATIONSHIPS ON THE NATIONAL BISON RANGE. M.S. THESIS, UNIVERSITY OF MONTANA, MISSOULA, MT. 94 PP.

3736. REICHELT, L. R. 1973. CHARACTERISTICS OF ELK CALVING SITES ALONG THE WEST FORK OF THE MADISON RIVER, MONTANA. M.S. THESIS, MONTANA STATE UNIVERSITY, BOZEMAN, MT. 39 PP.

3737. REICHHOLF, J. 1986. POPULATION DYNAMICS OF DOMESTIC CATS (FELIS SYLVESTRIS CATUS) IN SOUTHEASTERN BAVARIA: RESULTS OF 10 YEARS OF ROAD KILL STATISTICS. SAEUGETIERKD.MITT. 33(2\&3):264-266.

3738. REICHHOLF, J. 1983. IS THERE AN INFLUENCE OF THE TRAFFIC-CAUSED ROAD MORTALITY ON THE POPULATION DYNAMICS OF THE EUROPEAN HEDGEHOG (ERINACEUS EUROPAEUS)?. SPIXANA 6(1):87-91.

3739. REID, D. G., T. CODE and S. HERRERO. 1984. MOVEMENT PATTERNS OF RIVER OTTERS IN RELATION TO OIL AND GAS FIELD CORRIDORS. DEPT. OF BIOLOGY, UNIV. OF CALGARY. PREPARED FOR IMPERIAL OIL LTD., CALGARY. 63 PP.

3740. REID, D. G. and M. LEUNG. 1995. AN ASSESSMENT OF IMPACTS ON WILDLIFE BEHAVIOR OF A HELIPORTABLE SEISMIC EXPLORATION PROGRAM, WITH A RECORD OF HABITAT SUITABILITY AND USE: AMOCO GRAHAM STRIKE 1995. WILD TRACKS ECOLOGICAL CONSULTING, P.O. BOX 185, HOUSTON, B.C. VOJ 1Z027. PREPARED FOR THE HALFWAY RIVER FIRST NATION. 41PP.

3741. REID, D. S. 1980. MITIGATION AND COMPENSATION FOR FISH AND WLDLIFE LOSSES DURING RESOURCE DEVELOPMENTS IN BRITISH COLUMBIA AND ALBERTA. 
3742. REID, J. W. and I. A. BOWLES. 1997. REDUCING THE IMPACTS OF ROADS ON TROPICAL FORESTS. ENVIRONMENT 39(8):10.

3743. REID, L. M. and T. DUNNE. 1984. SEDIMENT PRODUCTION FROM FOREST ROAD SURFACES. WATER RESOURCES RESEARCH 20:1753-1761.

3744. REID, N. J. 1966. PUBLIC VIEW OF WILDLIFE. PAGES 77-80 IN: TOWARDS A NEW RELATIONSHIP OF MAN AND NATURE IN TEMPERATE LANDS. PART 1: ECOLOGICAL IMPACT OF RECREATION AND TOURISM UPON TEMPERATE ENVIRONMENTS. IUCN TENTH TECHNICAL MEETING, 26-30 JUNE 1966, LUCERNE, SWITZERLAND, IUCN PUBL. NEW SERV. 7, MORGES, SWITZERLAND

3745. REID, W. V. 1988. POPULATION DYNAMICS OF THE GLAUCOUS-WINGED GULL. J. WLLL. MANAGE. 52 (4):763-70.

3746. REIFENBERGER, J. C. 1974. RANGE AND MOVEMENTS OF WEST VIRGINIA BLACK BEAR DURING SUMMER AND AUTUMN 1973. P 139-42. IN: PROC. EASTERN WORKSHOP BLACK BEAR MANAGE. AND RES. \#2 (1974).

3747. REIJNEN, R. and R. FOPPEN. 1991. EFFECT OF ROAD TRAFFIC ON THE BREEDING SITE-TENACITY OF MALE WLLOW WARBLERS (PHYLLOSCOPUS TROCHILUS). JOURNAL FUER ORNITHOLOGIE 132 (3):291-6.

3748. REIJNEN, R. and R. FOPPEN. 1994. THE EFFECTS OF CAR TRAFFIC ON BREEDING BIRD POPULATIONS IN WOODLAND. I. EVIDENCE OF REDUCED HABITAT QUALITY FOR WILLOW WARBLERS (PHYLLOSCOPUS TROCHILUS) BREEDING CLOSE TO A HIGHWAY. JOURNAL OF APPLIED ECOLOGY 31:85-94.

3749. REIJNEN, R. and R. FOPPEN. 1995. THE EFFECTS OF CAR TRAFFIC ON BREEDING BIRD POPULATIONS IN WOODLAND. IV. INFLUENCE OF POPULATION SIZE ON THE REDUCTION OF DENSITY CLOSE TO A HIGHWAY. JOURNAL OF APPLIED ECOLOGY 32(3):481-491.

3750. REIJNEN, R., R. FOPPEN, C. T. BRAAK and J. THISSEN. 1995. THE EFFECTS OF CAR TRAFFIC ON BREEDING BIRD POPULATIONS IN WOODLAND. III. REDUCTION OF DENSITY IN RELATION TO THE PROXIMITY OF MAIN ROADS. JOURNAL OF APPLIED ECOLOGY 32:187-202.

3751. REIJNEN, R., R. FOPPEN and H. MEEUWSEN. 1996. THE EFFECTS OF TRAFFIC ON THE DENSITY OF BREEDING BIRDS IN DUTCH AGRICULTURAL GRASSLANDS. BIOLOGICAL CONSERVATION 75:255-260.

3752. REIJNEN, R., J. B. THISSEN and G. J. BEKKER. 1987. EFFECTS OF ROAD TRAFFIC ON WOODLAND BREEDING BIRD POPULATIONS. ACTA OECOLOGIA GENERALIS 8(2):312-313.

3753. REIJNEN, R., R. FOPPEN and G. VEENBAAS. 1997. DISTURBANCE BY TRAFFIC OF BREEDING BIRDS: EVALUATION OF THE EFFECT AND CONSIDERATIONS IN PLANNING AND MANAGING ROAD CORRIDORS. BIODIVERSITY AND CONSERVATION 6:567-581.

3754. REILAND, E. W. 1997. FISH LOSS TO IRRIGATION CANALS AND METHODS TO REDUCE THESE LOSSES ON THE WEST GALLATIN RIVER, MONTANA. M.S. THESIS, MONTANA STATE UNIVERSITY, BOZEMAN, MT. 170 PP.

3755. REILLY, R. E. and H. E. GREEN. 1974. DEER MORTALITY ON A MICHIGAN INTERSTATE HIGHWAY. JOURNAL OF WILDLIFE MANAGEMENT 38:16-19.

3756. REINER, D. C. 1996. ESTIMATING BEAR HABITAT QUALITY IN SOUTHEASTERN BRITISH COLUMBIA BY MEASURING CHANGES IN BEAR BODY CONDITION. M.S. THESIS, UNIVERSITY OF MONTANA, MISSOULA, MT. 81 PP.

3757. REINHART, D. P. and D. J. MATTSON. 1990. BEAR USE OF CUTTHROAT TROUT SPAWNING STREAMS IN YELLOWSTONE NATIONAL PARK. INT. CONF. BEAR RES. AND MANAGE. 8:343-50..

3758. REINHART, D. P. 1990. GRIZZLY BEAR HABITAT USE ON CUTTHROAT TROUT SPAWNING STREAMS IN TRIBUTARIES OF YELLOWSTONE LAKE. M.S. THESIS, MONTANA STATE UNIVERSITY, BOZEMAN, MT. 128 PP.

3759. REINHOLD, J. 1987. TRAFFIC VICTIMS. REVIEW OF METHODS OF ROAD KILL STUDY. AMOEBA 987(3):21-23. 

HABITAT: LANDSCAPE EVALUATION. JOURNAL OF WILDLIFE MANAGEMENT 61:517-524.

3761. RENEWABLE RESOURCES CONSULTING SERVICES. 1973. MACKENZIE HIGHWAY ENVIRONMENTAL OVERVIEW STUDY. VOLUME 1. RENEWABLE RESOURCES CONSULTING SERVICES LTD, EDMONTON, ALBERTA.

3762. REOLID-COLLADO, J. M. and J. F. ZAMORA-SALMERON. 1992. PROVISIONAL REPORT OF THE MORTALITY OF VERTEBRATES ON THE ROADS OF ALBACETE, SEPTEMBER 1991. PAGES 118-122 IN LOPEZ,REDONDO, EDITOR. I JORNADAS PARA EL ESTUDIO Y PREVENCION DE LA MORTALIDAD DE VERTEBRADOS EN CARRETERAS, MADRID, 5 Y 6 DE OCTUBRE DE 1991. TOMO 2. [SESSIONS IN THE STUDY OF PREVENTION OF ROAD MORTALITIES OF VERTEBRATES, MADRID, 5 AND 6 OCTOBER, 1991. VOLUME 2.]. COORDINADORA DE ORGANIZACCIONES DE DEFENSA, AMBIENTAL, MADRID.

3763. REPA, P. 1991. AMPHIBIAN AND REPTILIAN CASUALTIES ON WEST BOHEMIAN ROADS. ZPRAVY MUZEI ZAPADOCESKEHO KRAJE 1:81-84.

3764. REPO, S. and K. LOYTTYNIEMI. 1985. THE EFFECT OF IMMEDIATE ENVIRONMENT ON ALCES ALCES DAMAGE IN YOUNG SCOTS PINE PLANTATIONS. FOLIA-FORESTALIA,-INSTITUTUM-FORESTALE-FENNIAE 626:14PP.

3765. RESTANI, M. 1989. RESOURCE PARTITIONING AMONG THREE SPECIES OF HAWKS IN THE CENTENNIAL VALLEY, MONTANA. M.S. THESIS, MONTANA STATE UNIVERSITY, BOZEMAN; MT. 86 PP.

3766. REVENKO, I. A. 1994. BROWN BEAR (URSUS ARCTOS PISCATOR) REACTION TO HUMANS ON KAMCHATKA. INT. CONF. BEAR RES. AND MANAGE. 9:107-8.

3767. REYNOLDS, H. G. 1966. USE OF OPENINGS IN SPRUCE-FIR FORESTS OF ARIZONA BY ELK, DEER, AND CATTLE. USDA FOR. SERV. RES. NOTE RM-66. ROCKY MTN. FOR. RANGE EXP. STA., FT. COLLINS, CO. 4PP.

3768. REYNOLDS, H. V. 1981. NORTH SLOPE GRIZZLY BEAR STUDIES. VOL. II. 27PP

3769. REYNOLDS, H. V. 1969. POPULATION STATUS OF THE GOLDEN EAGLE IN SOUTHCENTRAL MONTANA. M.S. THESIS, UNIVERSITY OF MONTANA, MISSOULA, MT. 61 PP.

3770. REYNOLDS, P. E., H. V. REYNOLDS III and E. H. FOLLMAN. 1986. RESPONSES OF GRIZZLY BEARS TO SEISMIC SURVEYS IN NORTHERN ALASKA. INT. CONF. BEAR RES. MANAGE. 6:169-175.

3771. REZENDES, V. S. 1997. WLLLIFE MANAGEMENT ISSUES CONCERNING THE MANAGEMENT OF BISON AND ELK HERDS IN YELLOWSTONE NATIONAL PARK. STATEMENT OF VICTOR S. REZENDES, DIRECTOR, ENERGY, RESOURCES, AND SCIENCE ISSUES, RESOURCES, COMMUNITY, AND ECONOMIC DEVELOPMENT DIVISION, BEFORE THE SUBCOMMITTEE ON NATIONAL PARKS, HISTORIC PRESERVATION AND RECREATION, COMMITTEE ON ENERGY AND NATURAL RESOURCES, U.S. SENATE. MICROFORM: TESTIMONY GAO T-RCED-97-200.UNITED STATES GENERAL ACCOUNTING OFFICE, WASHINGTON, D.C.

3772. RICE, C. G., T. E. KUCERA and R. H. BARRETT. 1995. TRAILMASTER CAMERA SYSTEM. WLDL. SOC. BULL. 23 (1):110-3.

3773. RICE, C. R. 1983. A CONTINUATION STUDY OF THE IMPACT OF TENNESSEE STATE ROUTE 29 UPON THE AVIAN POPULATIONS OF AN ADJACENT FLOODPLAIN. TENNESSEE TECHNICAL JOURNAL 18:65-71.

3774. RICH, A. C., D. S. DOBKIN and L. J. NILES. 1994. DEFINING FOREST FRAGMENTATION BY CORRIDOR WIDTH - THE INFLUENCE OF NARROW FOREST-DIVIDING CORRIDORS ON FOREST-NESTING BIRDS IN SOUTHERN NEW JERSEY. CONSERVATION BIOLOGY 8(4):1109-1121.

3775. RICH, C. F. JR. 1996. INFLUENCE OF ABIOTIC AND BIOTIC FACTORS ON OCCURRENCE OF RESIDENT BULL TROUT IN FRAGMENTED HABITATS, WESTERN MONTANA. M.S. THESIS, MONTANA STATE UNIVERSITY, BOZEMAN, MT. $53 \mathrm{PP}$.

3776. RICHARD, J. E. 1966. A STUDY OF THE BIG GAME ANIMALS OF THE FLATHEAD INDIAN RESERVATION, MONTANA. M.S. THESIS, UNIVERSITY OF MONTANA, MISSOULA, MT. 93 PP. 
3777. RICHARDS, S. J.; K. R. MCDONALD and R. A. ALFORD. 1993. DECLINES IN POPULATIONS OF AUSTRALIA'S ENDEMIC TROPICAL RAINFOREST FROGS. PACIFIC CONSERVATION BIOLOGY 1(1):66-77.

3778. RICHARDSON, A. H. 1974. DEER HARVEST REGULATION STUDY, 1973. SD DEPARTMENT OF GAME, FISH AND PARKS.

3779. RICHARDSON, J. H., R. F. SHORE, J. R. TREWEEK and S. B. C. LARKIN. 1997. ARE MAJOR ROADS A BARRIER TO SMALL MAMMALS?. JOURNAL OF ZOOLOGY 243:840-846.

3780. RICHARDSON, J. H., R. F. SHORE, J. R. TREWEEK and S. C. LARKIN. 1997. ARE MAJOR ROADS A BARRIER TO SMALL MAMMALS. J. ZOOLOGY $243: 840-846$.

3781. RICHENS, V. B. 1967. CHARACTERISTICS OF MULE DEER HERDS AND THEIR RANGE IN NORTHEASTERN UTAH. J. WILDL. MANAGE. 31 (4):651-66.

3782. RICHENS, V. B. and G. R. LAVIGNE. 1978. RESPONSE OF WHITE-TAILED DEER TO SNOWMOBILES AND SNOWMOBILE TRAILS IN MAINE. CANADIAN FIELD NATURALIST 92(4):334-344.

3783. RICHTER, A. R., S. R. HUMPHREY, J. B. COPE and V. JR. BRACK. 1993. MODIFIED CAVE ENTRANCES: THERMAL EFFECT ON BODY MASS AND RESULTING DECLINE OF ENDANGERED INDIANA BATS (MYOTIS SODALIS). CONSERVATION BIOLOGY 7 (2):407-15.

3784. RICKART, E. A. 1993. DIVERSITY PATTERNS OF MAMMALS ALONG ELEVATIONAL AND DISTURBANCE GRADIENTS IN THE PHILIPPINES: IMPLICATIONS FOR CONSERVATION. ASIA LIFE SCIENCES 2 (2):251-60.

3785. RIDEOUT, D. L. 1993. MANAGING HUMAN POPULATION IMPACTS ON WILDLIFE IN A RAPIDLY URBANIZING AREA: A CASE STUDY OF THE CITY OF CARLSBAD, CALIFORNIA. TRANSACTIONS OF THE NORTH AMERICAN WILDLIFE AND NATURAL RESOURCES CONFERENCE 58:158-164.

3786. RIEWE, R. R. 1979. INTERACTIONS BETWEEN WLDLIFE, TRAPPER-HUNTERS AND SEISMIC LINES IN THE MACKENZIE VALLEY REGION, N.W.T., CANADA: PART I, AUBRY-COLVILLE LAKES. ENVIRONMENTAL STUDIES NO.9. PREPARED FOR THE ARCTIC LAND USE RESEARCH PROGRAM, NORTHERN ENVIRONMENTAL PROTECTION AND RENEWABLE RESOURCES BRANCH, DEPARTMENT OF INDIAN AFFAIRS AND NORTHERN DEVELOPMENT, GOV'T. OF CANADA.

3787. RIFFELL, S. K. 1997. ROAD MORTALITY OF DRAGONFLIES IN A FRESHWATER COASTAL WETLAND: AN EXAMPLE OF UNCOUPLED LANDSCAPE ELEMENTS. [ABSTRACT]. ABSTRACT FOR THIRTEENTH ANNUAL MEETING OF THE U.S. REGIONAL ASSOCIATION, INTERNATIONAL ASSOCIATION FOR LANDSCAPE ECOLOGY; 1998 MARCH 17-21; EAST LANSING, MI. MICHIGAN STATE UNIVERSITY, EAST LANSING.

3788. RIGGS, V. L. 1978. AGE AND GROWTH OF WALLEYE AND SAUGER OF THE TONGUE RIVER RESERVOIR, MONTANA M.S. THESIS, MONTANA STATE UNIVERSITY, BOZEMAN, MT. 53 PP.

3789. RILEY, C. W. 1996. EVALUATION OF TROUT SPAWNING GRAVEL RESTORATION IN A PLACER-MINED MONTANA STREAM. M.S. THESIS, MONTANA STATE UNIVERSITY, BOZEMAN, MT. 97 PP.

3790. RILEY, S. J., K. AUNE, R. D. MACE and M. J. MADEL. 1994. TRANSLOCATION OF NUISANCE GRIZZLY BEARS IN NORTHWESTERN MONTANA. INT. CONF. BEAR RES. AND MANAGE. 9:567-73.

3791. RILEY, S. J. 1982. SURVIVAL AND BEHAVIOR OF RADIO-COLLARED MULE DEER FAWNS DURING SUMMERS, 1978-1980, IN THE MISSOURI RIVER BREAKS, MONTANA. M.S. THESIS, MONTANA STATE UNIVERSITY, BOZEMAN, MT. 59 PP.

3792. RIPPIN, A. B., C. EDEY, D. HEBERT and J. KNETEMAN. 1996. A COOPERATIVE INDUSTRY -GOVERNMENT WOODLAND CARIBOU RESEARCH PROGRAM IN NORTHEASTERN ALBERTA. RANGIFER SPECIAL ISSUE NO.9:181-4.

3793. RIPPLE, W. J., G. A. BRADSHAW and T. A. SPIES. 1991. MEASURING FOREST LANDSCAPE PATTERNS IN THE CASCADE RANGE OF OREGON, USA. BIOLOGICAL CONSERVATION 57 (1):73-88.

3794. RISDAHL, G. L. 1988. ECOLOGY AND REPRODUCTION OF BOBCATS IN SOUTHEASTERN MONTANA DURING A PERIOD OF LOW LAGOMORPH DENSITY. M.S. THESIS, MONTANA STATE UNIVERSITY, BOZEMAN, MT. 100 PP. 
3795. RISWAN, S. and L. HARTANTI. 1995. HUMAN IMPACTS ON TROPICAL FOREST DYNAMICS. VEGETATIO 121(1-2):41-52.

3796. RITCHIE, R. J. 1991. EFFECTS OF OIL DEVELOPMENT ON PROVIDING NESTING OPPORTUNITIES FOR GYRFALCONS AND ROUGH-LEGGED HAWKS IN NORTHERN ALASKA. CONDOR 93:180-4.

3797. RITTER, J. T. 1978. VISITOR ACCESS OVER COASTAL WATERWAYS. P.253-256. IN: USFS RECREATIONAL IMPACT ON WILDLANDS CONF.; 1978 OCT 27-1978 OCT 29; SEATTLE, WASH.

3798. ROBBINS, C. S., D. K. DAWSON and B. A. DOWELL. 1989. HABITAT AREA REQUIREMENTS OF BREEDING FOREST BIRDS OF THE MIDDLE ATLANTIC STATES. WLDL. MONOGR. 103:1-34.

3799. ROBERTS, B. C. 1995. BEST MANAGEMENT PRACTICES FOR EROSION AND SEDIMENT CONTROL. FHWA-FLP-94-005. U.S. DEPARTMENT OF TRANSPORTATION, FEDERAL HIGHWAY ADMINISTRATION, WASHINGTON, DC.

3800. ROBERTS, B. C. 1988. POTENTIAL INFLUENCE OF RECREATIONAL USE ON NELSON SPRING CREEK, MONTANA. M.S. THESIS, MONTANA STATE UNIVERSITY, BOZEMAN, MT. 79 PP.

3801. ROBERTS, D. A. 1970. ANTELOPE RANGE USE, FOOD HABITS, AND BEHAVIOR IN RELATION TO SAGEBRUSH ERADICATION. M.S. THESIS, MONTANA STATE UNIVERSITY, BOZEMAN, MT. 56 PP.

3802. ROBERTS, W. N.D. DECLINES IN AMPHIBIAN POPULATIONS IN ALBERTA. P 14-6. IN: BISHOP, C.A., PETT, K.E., EDITORS. DECLINES IN AMPHIBIAN POPULATION: DESIGNING A NATURAL MONITORING STRATEGY: CWS OCC. PAPER NO.76.

3803. ROBERTSON, C. P. J. and S. HARRIS. 1995. THE CONDITION AND SURVIVAL AFTER RELEASE OF CAPTIVE-REARED FOX CUBS. ANIMAL WELFARE 4 (4):281-94.

3804. ROBERTSON, R. J. and N. J. FLOOD. 1980. EFFECTS OF RECREATIONAL USE OF SHORELINES ON BREEDING BIRD POPULATIONS. CANADIAN FIELD NATURALIST 94:131-138.

3805. ROBINSON, J. G. 1993. THE LIMITS TO CARING: SUSTAINABLE LIVING AND THE LOSS OF BIODIVERSITY. CONSERVATION BIOLOGY 7 (1):20-8.

3806. ROBINSON, J. W. 1966. OBSERVATIONS ON THE LIFE HISTORY MOVEMENT, AND HARVEST OF THE PADDLEFISH POLYODON SPATHULA, IN MONTANA. M.S. THESIS, MONTANA STATE UNIVERSITY, BOZEMAN, MT. 17 PP.

3807. ROBINSON, R. W. 1970. THE DISTRIBUTION, RATE OF SYNTHESIS AND CHARACTERIZATION OF PROTEIN FROM THE EGGS OF AULOCARA ELLIOTTI (THOMAS) (ORTHOPTERA, ACRIDIDAE) DURING DEVELOPMENT . PH.D. DISSERTATION, MONTANA STATE UNIVERSITY, BOZEMAN, MT. 86 PP.

3808. ROBINSON, S. K., F. R. I. THOMPSON, T. M. DONOVAN, D. R. WHITEHEAD and J. FAABORG. 1995. REGIONAL FOREST FRAGMENTATION AND THE NESTING SUCCESS OF MIGRATORY BIRDS. SCIENCE (WASHINGTON D C) 267 (5206):1987-90.

3809. ROBINSON, S. K. and D. S. WILCOVE. 1994. FOREST FRAGMENTATION IN THE TEMPERATE ZONE AND ITS EFFECTS ON MIGRATORY SONGBIRDS. BIRD CONSERVATION INTERNATIONAL 4(2-3):233-249.

3810. ROBLEE, K. J. 1987. THE USE OF THE T-CULVERT GUARD TO PROTECT ROAD CULVERTS FROM PLUGGING DAMAGE BY BEAVERS. PROCEEDINGS OF THE EASTERN WLDLIFE DAMAGE CONTROL CONFERENCE 3:25-33.

3811. ROBY, D. 1978. BEHAVIORAL PATTERNS OF BARREN GROUND CARIBOU OF THE CENTRAL ARCTIC HERD ADJACENT TO THE TRANS ALASKA OIL PIPELINE. M. SC. THESIS.: UNIVERSITY OF FAIRBANKS, FAIRBANKS, ALASKA. $199 P$.

3812. ROBY, E. F. 1950. A TWO-YEAR STUDY OF PHEASANT STOCKING IN THE GALLATIN VALLEY, MONTANA. M.S. THESIS, MONTANA STATE COLLEGE, BOZEMAN, MT. 36 PP.

3813. ROCHA, C. F. D. and H. G. BERGALLO. 1992. POPULATION DECREASE: THE CASE OF LIOLAEMUS LUTZAE, AN ENDEMIC LIZARD OF SOUTHEASTERN BRAZIL. CIENCIA ECULTURA (SAO PAULO) 44 (1):52-4 
3814. ROCKE, T. E. 1995. QUARTERLY WILDLIFE MORTALITY REPORT. JOURNAL OF WILDLIFE DISEASES VOL. 31 :.

3815. ROCKY MOUNTAIN FOREST AND RANGE EXPERIMENT STATION (FORT COLLINS, COLO.). 1979. MITIGATION SYMPOSIUM: THE MITIGATION SYMPOSIUM A NATIONAL WORKSHOP ON MITIGATING LOSSES OF FISH AND WILDLIFE HABITATS, JULY 16-20, 1979, COLORADO STATE UNIVERSITY, FORT COLLINS, COLORADO. USDA FOREST SERVICE GENERAL TECHNICAL REPORT RM ; 65: GENERAL TECHNICAL REPORT RM 65. DEPT. OF AGRICULTURE, FOREST SERVICE, ROCKY MOUNTAIN FOREST AND RANGE EXPERIMENT STATION, FORT COLLINS, COLORADO.

3816. RODDA, G. H. 1990. HIGHWAY MADNESS REVISITED: ROADKILLED IGUANA IGUANA IN THE LLANOS OF VENEZUELA. JOURNAL OF HERPETOLOGY 24:209-211.

3817. RODGERS, J. A. JR. and H. T. SMITH. 1995. SET-BACK DISTANCES TO PROTECT NESTING BIRD COLONIES FROM HUMAN DISTURBANCE IN FLORIDA. CONSERVATION BIOLOGY 9(1):89-99.

3818. RODGERS, J. A. and H. T. SMITH. 1997. BUFFER ZONE DISTANCES TO PROTECT FORAGING AND LOAFING WATERBIRDS FROM HUMAN DISTURBANCE IN FLORIDA. WILDLIFE SOCIETY BULLETIN 25:139-145.

3819. RODRIGUES, R. and M. MILLER. 1991. BIRD USE OF ABANDONED GRAVEL PADS IN ARCTIC ALASKA. LGL ALASKA RESEARCH ASSOCIATES INC., ANCHORAGE.

3820. RODRIGUEZ, A., G. CREMA and M. DELIBES. 1996. USE OF NON-TERRESTRIAL PASSAGES ACROSS A HIGH-SPEED RAILWAY BY TERRESTRIAL VERTEBRATES. J. APPLIED ECOLOGY 33:1527-40.

3821. RODRIGUEZ, A., G. CREMA and M. DELIBES. 1996. USE OF NON-WLDLIFE PASSAGES ACROSS A HIGH SPEED RAILWAY BY TERRESTRIAL VERTEBRATES. JOURNAL OF APPLIED ECOLOGY 33(6):1527-1540.

3822. RODRIGUEZ, A., G. CREMA and M. DELIBES. 1997. FACTORS AFFECTING CROSSING OF RED FOXES AND WLDCATS THROUGH NON-WILDLIFE PASSAGES ACROSS A HIGH-SPEED RAILWAY. ECOGRAPHY 20:287-294.

3823. RODRIGUEZ, R. A. 1992. PROVISIONAL REPORT OF THE MORTALITY OF VERTEBRATES ON THE ROADS OF CORDOBA, SEPTEMBER 1991. PAGES 72-78 IN LOPEZ,REDONDO, EDITOR. I JORNADAS PARA EL ESTUDIO Y PREVENCION DE LA MORTALIDAD DE VERTEBRADOS EN CARRETERAS, MADRID, 5 Y 6 DE OCTUBRE DE 1991. TOMO 2. [SESSIONS IN THE STUDY OF PREVENTION OF ROAD MORTALITIES OF VERTEBRATES, MADRID, 5 AND 6 OCTOBER, 1991. VOLUME 2.]. COORDINADORA DE ORGANIZACCIONES DE DEFENSA, AMBIENTAL, MADRID.

3824. ROE, N. A. 1981. AN UNGULATE MONITORING STUDY, WINTER 1980-81, DURING CONSTRUCTION OF THE GRANDE PRAIRIE LATERAL AND ELMWORTH LOOP PIPELINES. PREPARED FOR NOVA, AN ALBERTA CORPORATION, CALGARY; PREPARED BY ENVIRONMENTAL MANAGEMENT ASSOCIATES, CALGARY. UNPUBLISHED REPORT.

3825. ROEMHILD, G. R. 1961. STUDIES ON THE EGGS OF THE GRASSHOPPER SPECIES AULOCARA ELLIOTTI THOMAS. PH.D. DISSERTATION, MONTANA STATE UNIVERSITY, BOZEMAN, MT. 94 PP.

3826. ROGERS, L. L., D. W. KUEHN, A. W. ERICKSON, E. M. HARGER, L. J. VERME and J. J. OZOGA. 1974. CHARACTERISTICS AND MANAGEMENT OF BLACK BEARS THAT FEED IN GARBAGE DUMPS, CAMPGROUNDS OR RESIDENTIAL AREAS. INT. CONF. BEAR RES. AND MANAGE. 3:169-75.

3827. ROLLEY, R. E. and L. B. KEITH. MOOSE POPULATION DYNAMICS AND WINTER HABITAT USE AT ROCHESTER, ALBERTA 1965-1979. CAN. FIELD NAT. 94 (1):9-18.

3828. ROLLEY, R. E. and L. E. LEHMAN. 1992. RELATIONSHIPS AMONG RACCOON ROAD-KILL SURVEYS, HARVESTS, AND TRAFFIC. WILDL. SOC. BULL. 20 (3):313-8.

3829. ROLSTAD, J., P. WEGGE and I. GJERDE. 1991. CUMULATIVE IMPACT OF HABITAT FRAGMENTATION: LESSONS FROM 12 YEARS OF CAPERCAILLIE RESEARCH AT VARALDSKOGEN, NORWAY. FAUNA (OSLO) 44 (1):90-104.

3830. ROMIN, L. A. and J. A. BISSONETTE. 1996. DEER-VEHICLE COLLISIONS: STATUS OF STATE MONITORING ACTIVITIES AND MITIGATION EFFORTS. WILDLIFE SOCIETY BULLETIN 24:276-283.

3831. ROMIN, L. A. and J. A. BISSONETTE. 1996. TEMPORAL AND SPATIAL DISTRIBUTION OF HIGHWAY MORTALITY OF MULE DEER ON NEWLY CONSTRUCTED ROADS AT JORDANELLE RESERVOIR, UTAH. GREAT BASIN NATURALIST 
56(1):1-11

3832. ROMIN, L. A. and L. B. DALTON. 1992. LACK OF RESPONSE BY MULE DEER TO WLDLIFE WARNING WHISTLES. WILDLIFE SOCIETY BULLETIN 20:382-384.

3833. ROMINGER, E. M. and J. L. OLDEMEYER. 1989. EARLY-WINTER HABITAT OF WOODLAND CARIBOU, SELKIRK MOUNTAINS, BRITISH COLUMBIA. J. WLDL. MANAGE. 53 (1):238-43.

3834. RONGSTAD, O. J. 1980. RESEARCH NEEDS ON ENVIRONMENTAL IMPACTS OF SNOWMOBILES. PAGES 220-227 IN R. N. L. ANDREWS AND P. F. NOWAK, EDITORS. OFF-ROAD VEHICLE USE: A MANAGEMENT CHALLENGE. U.S. DEPARTMENT OF AGRICULTURE, OFFICE OF ENVIRONMENTAL QUALITY. WASHINGTON, D.C.

3835. ROOF, J. and J. WOODING. 1996. EVALUATION OF THE S.R. 46 WILDLIFE CROSSING IN LAKE COUNTY, FLORIDA. PAGES 329-336 IN EVINK, G., ZIEGLER,D., GARRETT,P., AND BERRY,J., EDITORS. TRANSPORTATION AND WILDLIFE: REDUCING WILDLIFE MORTALITY AND IMPROVING WILDLIFE PASSAGEWAYS ACROSS TRANSPORTATION CORRIDORS: PROCEEDINGS OF THE FLORIDA DEPARTMENT OF TRANSPORTATION FEDERAL HIGHWAY ADMINISTRATION TRANSPORTATION-RELATED WILDLIFE MORTALITY SEMINAR; 1996 APRIL 30-MAY 2; ORLANDO, FL. FHWA-PD-96-041. U.S. DEPARTMENT OF TRANSPORTATION, FEDERAL HIGHWAY ADMINISTRATION, WASHINGTON, DC.

3836. ROSE, B. J. 1956. AN EVALUATION OF TWO INTRODUCTIONS OF MERRIAM'S WILD TURKEY INTO MONTANA. M.S. THESIS, MONTANA STATE COLLEGE, BOZEMAN, MT. 37 PP.

3837. ROSE, D. and E. GEISLER. 1991. IMPACTS OF PRESENT AND POTENTIAL FOREST ROAD SYSTEMS ON TIMBER, TOURISM, WLDLIFE, AND AESTHETIC RESOURCES.

3838. ROSE, S. C. 1982. BEAR MAULINGS IN ALASKA. ALASKA MED. 24 (3):29-32

3839. ROSELL, C., J. PARPAL, R. CAMPENY, S. JOVE, A. PASQUINA and J. M. VELASCO. 1995. MITIGATION OF BARRIER EFFECT OF LINEAR INFRASTRUCTURES ON WLDLIFE. IN PROCEEDINGS OF HABITAT FRAGMENTATION AND INFRASTRUCTURE; 1995 SEPTEMBER 17-21; MAASTRICHT, THE NETHERLANDS

3840. ROSEN, P. C. and C. H. LOWE. 1994. HIGHWAY MORTALITY OF SNAKES IN THE SONORAN DESERT OF SOUTHERN ARIZONA. BIOLOGICAL CONSERVATION 68(2):143-148.

3841. ROSENBERG, D. K. 1994. EFFICACY OF BIOLOGICAL CORRIDORS. PHD THESIS, OREGON STATE UNIVERSITY. 141 PP.

3842. ROSENBERG, G. A. 1976. REGULATION OF OFF-ROAD VEHICLES. ENVIRONMENTAL AFFAIRS 5:175-206.

3843. ROSGAARD, A. I. JR. 1981. ECOLOGY OF THE MULE DEER ASSOCIATED WITH THE BRACKETT CREEK WINTER RANGE IN THE BRIDGER MOUNTAINS, MONTANA. M.S. THESIS, MONTANA STATE UNIVERSITY, BOZEMAN, MT. 76 PP.

3844. ROSS, C. and A. SRIVASTAVA. 1994. FACTORS INFLUENCING THE POPULATION DENSITY OF THE HANUMAN LANGUR (PRESBYTIS ENTELLUS) IN SARISKA TIGER RESERVE. PRIMATES 35(3):361-7.

3845. ROSS, P. I. and M. G. JALKOTZY. 1992. CHARACTERISTICS OF A HUNTED POPULATION OF COUGARS IN SOUTHWESTERN ALBERTA. J. WLDL. MANAGE. 56 (3):417-26.

3846. ROSS, P. I., M. G. JALKOTZY and J. R. GUNSON. 1996. THE QUOTA SYSTEM OF COUGAR HARVEST MANAGEMENT IN ALBERTA. WLDLIFE SOCIETY BULLETIN 24 (3):490-4.

3847. ROSSELL, C. R. JR. and J. A. LITVAITIS. 1994. APPLICATION OF HARVEST DATA TO EXAMINE RESPONSES OF BLACK BEARS TO LAND-USE CHANGES. INT. CONF. BEAR RES. AND MANAGE.9:275-81.

3848. ROST, G. R. 1975. RESPONSE OF DEER AND ELK TO ROADS. THESIS, COLORADO STATE UNIVERSITY, FORT COLLINS, COLORADO, USA. 51PP.

3849. ROST, G. R. and J. A. BAILEY. 1979. DISTRIBUTION OF MULE DEER AND ELK IN RELATION TO ROADS. JOURNAL OF WILDLIFE MANAGEMENT 43:634-641. 
3850. ROST, G. R. and J. A. BAILEY. 1974. RESPONSES OF DEER AND ELK TO ROADS ON THE ROOSEVELT NATIONAL FOREST. DEPARTMENT OF FISH AND WILDLIFE BIOLOGY, COLORADO STATE UNIVERSITY. FORT COLLINS, COLORADO. 19PP.

3851. ROTAR, J. P. and M. ADAMIC. WILDLIFE-TRAFFIC RELATIONS IN SLOVENIA: PROBLEMS ARISING WITH THE CONSTRUCTION OF MOTORWAY NETWORK AND POSSIBILITIES OF THEIR MITIGATION. DEPARTMENT OF FORESTRY, BIOTECHNICAL FACULTY, UNIVERSITY OF LJUBLJANA.

3852. ROTH, H. U. 1983. DIEL ACTIVITY OF A REMNANT POPULATION OF EUROPEAN BROWN BEARS. INT. CONF. BEAR RES. AND MANAGE. 5:223-9.

3853. ROTH, H. U. 1974. STATUS OF THE LAST BROWN BEARS OF THE ALPS IN TRENTINO, ITALY. INT. CONF. BEAR RES. AND MANAGE. 3:307-8.

3854. ROTH, H. U. and D. HUBER. 1986. DIEL ACTIVITY OF BROWN BEARS IN PLITVICE LAKES NATIONAL PARK, YUGOSLAVIA. INT. CONF. BEAR RES. AND MANAGE. 6:177-81.

3855. ROTH, R. R. and R. K. JOHNSON. 1993. LONG-TERM DYNAMICS OF A WOOD THRUSH POPULATION BREEDING IN A FOREST FRAGMENT. AUK $110(1): 37-48$.

3856. ROTHWEILER, R. A. 1960. FOOD HABITS, MOVEMENTS AND NESTING GULLS ON A WATERFOWL AREA, FREEZEOUT LAKE, TETON COUNTY, MONTANA. M.S. THESIS, MONTANA STATE COLLEGE, BOZEMAN, MT. 29 PP.

3857. ROUSE, R. A. 1957. ELK FOOD HABITS, RANGE USE AND MOVEMENTS, GRAVELLY MOUNTAINS, MONTANA. M.S. THESIS, MONTANA STATE COLLEGE, BOZEMAN, MT. 29 PP.

3858. ROWE, C. L., O. M. KINNEY and J. D. CONGDON. 1998. ORAL DEFORMITIES IN TADPOLES OF THE BULLFROG (RANA CATESBEIANA) CAUSED BY CONDITIONS IN A POLLUTED HABITAT. COPEIA 1998:244-246.

3859. ROWE, J. S. 1981. AN UNGULATE MONITORING STUDY, WINTER 1980-81, DURING CONSTRUCTION OF THE GRANDE PRAIRIE LATERAL AND ELMSWORTH LOOP PIPELINES. ENVIRONMENTAL MANAGEMENT ASSOC., CALGARY. 53PP.

3860. ROWE, S., K. KAVANAGH and T. IACOBELLI. 1993. A PROTECTED AREAS GAP ANALYSIS METHODOLOGY: PLANNING FOR THE CONSERVATION OF BIODIVERSITY. WORLD WILDLIFE FUND: CANADA, ENDANGERED SPACES CAMPAIGN. 68PP.

3861. ROWELL, M. J. and L. Z. FLORENCE. 1993. CHARACTERISTICS ASSOCIATED WITH DIFFERENCES BETWEEN UNDISTURBED AND INDUSTRIALLY-DISTURBED SOILS. SOIL BIOLOGY AND BIOCHEMISTRY 25 (11):1499-511.

3862. ROWLAND, M. M. 1998. THE STARKEY HABITAT DATABASE FOR UNGULATE RESEARCH CONSTRUCTION DOCUMENTATION, AND USE. U.S. DEPT. OF AGRICULTURE, FOREST SERVICE, PACIFIC NORTHWEST RESEARCH STATION, PORTLAND, OREGON. GENERAL TECHNICAL REPORT PNW 430.

3863. ROY, J. L. 1992. ECOLOGY OF REINTRODUCTED ROCKY MOUNTAIN BIGHORN SHEEP FOLLOWING TWO TRANSPLANTS IN THE SOUTHERN MADISON RANGE, MONTANA. M.S. THESIS, MONTANA STATE UNIVERSITY, BOZEMAN, MT. $102 \mathrm{PP}$.

3864. ROY, K. D. 1991. ECOLOGY OF REINTRODUCED FISHERS IN THE CABINET MOUNTAINS OF NORTHWEST MONTANA. M.S. THESIS, UNIVERSITY OF MONTANA, MISSOULA, MT. 94 PP.

3865. ROY, L. D. and M. J. DORRANCE. 1985. COYOTE MOVEMENTS, HABITAT USE, AND VULNERABILITY IN CENTRAL ALBERTA. J. WLDL. MANAGE. 49 (2):307-13.

3866. ROY, M. J. 1992. A TRANSITION IN WESTERN FURBEARER POLICY: MANAGEMENT AS A NON-ECONOMIC RESOURCE. M.S. THESIS, UNIVERSITY OF MONTANA, MISSOULA, MT. 81 PP.

3867. ROY, M. M. 1998. EVOLVING HUMAN ATTITUDES AND MANAGEMENT POLICY IN JAPANESE WLDLIFE MANAGEMENT: A CASE STUDY OF THE ASIATIC BLACK BEAR. M.S. THESIS, UNIVERSITY OF MONTANA, MISSOULA, MT. 91 PP. 
3868. ROYBAL, J. P. 1998. WINTER MORTALITY IN THE NORTHERN YELLOWSTONE ELK HERD 1988-1990. M.S. THESIS, MONTANA STATE UNIVERSITY, BOZEMAN, MT. 191 PP.

3869. RUBY, D. E., J. R. SPOTILA, S. K. MARTIN and S. J. KEMP. 1994. BEHAVIORAL RESPONSES TO BARRIERS BY DESERT TORTOISES: IMPLICATIONS FOR WILDLIFE MANAGEMENT. HERPETOLOGICAL MONOGRAPHS [VOL. UNKNOWN]:144-160.

3870. RUDEL, T. K. 1983. ROADS, SPECULATORS, AND COLONIZATION IN THE ECUADORIAN AMAZON. HUM.ECOL. 11(4):385-403.

3871. RUDNICKY, T. C. and M. L. J. HUNTER. 1993. REVERSING THE FRAGMENTATION PERSPECTIVE: EFFECTS OF CLEARCUT SIZE ON BIRD SPECIES RICHNESS IN MAINE. ECOLOGICAL APPLICATIONS 3 (2):357-66.

3872. RUDNICKY, T. C. and M. L. JR. HUNTER. 1993. AVIAN NEST PREDATION IN CLEARCUTS, FORESTS, AND EDGES IN A FOREST-DOMINATED LANDSCAPE. J. WILDL. MANAGE. 57(2):358-64.

3873. RUDOLPH, D. C. and S. J. BURGDORF. 1997. TIMBER RATTLESNAKES AND LOUISIANA PINE SNAKES OF THE WEST GULF COASTAL PLAIN: HYPOTHESES OF DECLINE. TEXAS JOURNAL OF SCIENCE 49(3):111-122.

3874. RUDOLPH, D. C., S. J. BURGDORF, R. N. CONNER and J. G. DICKSON. 1998. THE IMPACT OF ROADS ON THE TIMBER RATTLESNAKE (CROTALUS HORRIDUS), IN EASTERN TEXAS. PAGES 236-240 IN EVINK,G., ZIEGLER,D., GARRETT,P., AND BERRY,J., EDITORS. PROCEEDINGS OF THE INTERNATIONAL CONFERENCE ON WILDLIFE ECOLOGY AND TRANSPORTATION; 1998 FEBRUARY 10-12; FT. MYERS, FL FLORIDA DEPARTMENT OF TRANSPORTATION, TALLAHASSEE, FL.

3875. RUDOLPH, D. C. and R. N. CONNER. 1994. FOREST FRAGMENTATION AND RED-COCKADED WOODPECKER POPULATION: AN ANALYSIS AT INTERMEDIATE SCALE. JOURNAL OF FIELD ORNITHOLOGY 65 (3):365-75.

3876. RUEDIGER, B. 1996. THE RELATIONSHIP BETWEEN RARE CARNIVORES AND HIGHWAYS. PAGES 24-38 IN EVINK,G., ZIEGLER,D., GARRETT,P., AND BERRY,J., EDITORS. TRANSPORTATION AND WILDLIFE: REDUCING WILDLIFE MORTALITY AND IMPROVING WILDLIFE PASSAGEWAYS ACROSS TRANSPORTATION CORRIDORS: PROCEEDINGS OF THE FLORIDA DEPARTMENT OF TRANSPORTATION/FEDERAL HIGHWAY ADMINISTRATION TRANSPORTATION-RELATED WILDLIFE MORTALITY SEMINAR; 1996 APRIL 30-MAY 2; ORLANDO, FL. FHWA-PD-96-041. U.S. DEPARTMENT OF TRANSPORTATION, FEDERAL HIGHWAY ADMINISTRATION, WASHINGTON, DC.

3877. RUEDIGER, B. 1998. RARE CARNIVORES AND HIGHWAYS - MOVING INTO THE 21ST CENTURY. PAGES 10-16 IN G. L. EVINK, P. GARRETT, D. ZEIGLER, AND J. BERRY, EDITORS. PROCEEDINGS OF THE INTERNATIONAL CONFERENCE ON WILDLIFE ECOLOGY AND TRANSPORTATION. FLORIDA DEPARTMENT OF TRANSPORTATION, TALLAHASSEE, FLORIDA.

3878. RUEDIGER, W. and S. MEALEY. 1978. COORDINATION GUIDELINES FOR TIMBER HARVESTING IN GRIZZLY BEAR HABITAT IN NORTHWESTERN MONTANA. USDA FOREST SERV. UNPUBLISHED WILDLIFE REPORT .

3879. RUEFENACHT, B. and R. L. KNIGHT. 1995. INFLUENCES OF CORRIDOR CONTINUITY AND WITTH ON SURVIVAL AND MOVEMENT OF DEERMICE (PEROMYSCUS MANICULATUS). BIOLOGICAL CONSERVATION 71(3):269-274.

3880. RUFF, R. L. 1963. A STUDY OF THE PREDATORY EFFECTS OF A REDUCEDMAGPIE POPULATION ON THE RING-NECKED PHEASANT. PH.D. DISSERTATION, MONTANA STATE UNIVERSITY, MISSOULA, MT. 96 PP.

3881. RUGGIERO, L. F., K. B. AUBRY, S. W. BUSKIRK, L. J. LYON and W. J. E. ZIELINSKI. 1994. THE SCIENTIFIC BASIS FOR CONSERVING FOREST CARNIVORES: AMERICAN MARTEN, FISHER, LYNX, AND WOLVERINE IN THE WESTERN UNITED STATES. USDA FOREST SERVICE GENERAL TECHNICAL REPORT RM-254. USDA FOREST SERVICE. 184PP

3882. RUGGIERO, R. G. 1992. SEASONAL FORAGE UTILIZATION BY ELEPHANTS IN CENTRAL AFRICA. AFRICAN JOURNAL OF ECOLOGY 30 (2):137-48.

3883. RUHLE, D. 1995. POPULATION TRENDS AND PROTECTION OF THE OSPREY PANDION HALIAETUS IN NIEDERLAUSITZ, BRANDENBURG, GERMANY. VOGELWELT $116(4): 187-90$. 
3884. RUNDQUIST, V. M. 1973. AVIAN ECOLOGY ON STOCK PONDS IN TWO VEGETATIONAL TYPES IN NORTHCENTRAL MONTANA. PH.D. DISSERTATION, MONTANA STATE UNIVERSITY, BOZEMAN, MT. 116 PP.

3885. RUPERT, D. R. 1995. USE OF SPENT MUSHROOM SUBSTRATE IN STABILIZING DISTURBED AND COMMERCIAL SITES. COMPOST SCIENCE \& UTILIZATION $3(1): 80-3$

3886. RUSSELL, C. F. 1978. A MOVEMENT BARRIER USEFUL IN POPULATION STUDIES OF SMALL MAMMALS. AMERICAN MIDLAND NATURALIST 100:400-402.

3887. RUSSELL, D. 1982. TRANSACTIONS OF THE FORTY-SIXTH FEDERAL-PROVINCIAL WILDL CONF.; 1982 . JUN 1-1982 JUN 4; WHITEHORSE, YT. ENVIRONMENT CANADA, CAN. WLDL. SERV.

3888. RUSSELL, D. E., A. M. MARTELL and W. A. C. NIXON. 1993. RANGE ECOLOGY OF THE PORCUPINE CARIBOU HERD IN CANADA. RANGIFER SPECIAL ISSUE 8:1-167.

3889. RUSSELL, D. E., D. VAN DE WETTERING, R. G. WHITE and K. L. GERHART. 1996. OIL AND THE PORCUPINE CARIBOU HERD: CAN WE QUANTIFY THE IMPACTS? RANGIFER SPECIAL ISSUENO.9:255-8.

3890. RUSSELL, H. N. 1938. A NOTES ON HIGHWAY MORTALITY. WILSON BULLETIN 50:205-206.

3891. RUSSELL, K. R. 1980. WILDMIS A WILDLIFE MITIGATION AND MANAGEMENT PLANNING SYSTEM : DEMONSTRATED ON OIL SHALE DEVELOPMENT : FINAL ADMINISTRATIVE REPORT. COLORADO COOPERATIVE WILDLIFE RESEARCH UNIT, COLORADO STATE UNIVERSITY, FORT COLLINS, COLORADO.

3892. RUSSELL, R. H., J. W. NOLAN, N. G. WOODY and A. M. PEARSON. 1978. A STUDY OF THE GRIZZLY BEAR (URSUS ARCTOS) IN JASPER NATIONAL PARK. CANADIAN WILDLIFE SERVICE 95PP.

3893. RUSZ, P. J., H. H. PRINCE, R. D. RUSZ and G. A. DAWSON. 1986. BIRD COLLISIONS WITH TRANSMISSION LINES NEAR A POWER PLANT COOLING POND. WILDL. SOC. BULL. 14(4):441-4.

3894. RUTH, T., K. LOGAN, L. SWEANOR and M. G. HORNOCKER. 1996. CHAPTER 7.EVALUATING COUGAR TRANSLOCATION IN NEW MEXICO. P 250-80. IN: LOGAN KA, SWEANOR LL, RUTH TK, HORNOCKER MG. COUGARS OF THE SAN ANDRES MOUNTAINS, NEW MEXICO. HORNOCKER WLDLIFE INSTITUTE., P.O. BOX 3246, UNIVERSITY OF IDAHO, MOSCOW IDAHO 83843.

3895. RUTH, T. K. 1991. MOUNTAIN LION USE OF AN AREA OF HIGH RECREATIONAL DEVELOPMENT IN BIG BEND NATIONAL PARK, TEXAS. THESIS, TEXAS A\&M UNIVERSITY, COLLEGE STATION, TEXAS.

3896. RUTTER, A. J. and J. R. THOMPSON. 1986. THE SALINITY OF MOTORWAY SOILS. III. SIMULATION OF THE EFFECTS OF SALT USAGE AND RAINFALL ON SODIUM AND CHLORIDE CONCENTRATIONS IN THE SOIL OF CENTRAL RESERVES. JOURNAL OF APPLIED ECOLOGY 23:281-297.

3897. RYAN, M. R., R. B. RENKEN and J. J. DINSMORE. 1984. MARBLED GODWIT HABITAT SELECTION IN THE NORTHERN PRAIRIE REGION. J. WILDL. MANAGE. 48 (4):1205-18.

3898. RYAN, S. E. and G. E. GRANT. 1991. DOWNSTREAM EFFECTS OF TIMBER HARVESTING ON CHANNEL MORPHOLOGY IN ELK.RIVER BASIN, OREGON. J. ENVIRON. QUAL. 20:60-72.

3899. RYDELL, J. 1992. EXPLOITATION OF INSECTS AROUND STREETLAMPS BY BATS IN SWEDEN. FUNDAMENTAL AND APPLIED NEMATOLOGY 6(6):744-750.

3900. RYDELL, J. 1991. SEASONAL USE OF ILLUMINATED AREAS BY FORAGING NORTHERN BATS EPTESICUS NILSSONI. HOLARCTIC ECOLOGY 14 (3):203-7.

3901. RYDELL, J. and H. J. BAAGOE. 1996. GATLAMPOR OEKAR FLADDERMOESSENS PREDATION PAA FJAERILAR (STREET LAMPS INCREASE BAT PREDATION ON MOTHS). ENTOMOLOGISK TIDSKRIFT 117:129-135 (IN SWEDISH WITH ENGLISH SUMMARY). 
3902. RYDELL, J. and H. J. BAAGOE. 1996. STREET LAMPS INCREASE BAT PREDATION ON MOTHS. ENTOMOLOGISK TIDSKRIFT 117:129-135.

3903. RYSER, J. and K. GROSSENBACHER. 1989. A SURVEY OF AMPHIBIAN PRESERVATION AT ROADS IN SWITZERLAND. PAGES 7-13 IN LANGTON,T.E.S., EDITOR. AMPHIBIANS AND ROADS. PROCEEDINGS OF THE TOAD TUNNEL CONFERENCE; 1989 JANUARY 7-8; RENDSBURG, FEDERAL REPUBLIC OF GERMANY. ACO POLYMER PRODUCTS LTD., SHEFFORD, ENGLAND.

3904. RZEHAK, K., A. NADACHOWSKA-MARYANSKA and M. JORDAN. 1977. THE EFFECT OF KARBATOX 75, A CARBARYL INSECTICIDE, UPON THE DEVELOPMENT OF TADPOLES OF RANA TEMPORARIA AND XENOPUS LAEVIS. FOLIA BIOL. 25:391-399.

3905. SACHET, G. A. 1990. INTEGRATED TRAIL PLANNING GUIDELINES FOR WILDLIFE, RECREATION, AND FISH RESOURCES ON MOUNT HOOD NATIONAL FOREST. CLEMSON UNIVERSITY, PROFESSIONAL DEVELOPMENT FOR OUTDOOR RECREATION MANAGEMENT PROGRAM.

3906. SAGE, B. L. 1972. TITLE UNKNOWN. ANIMALS 14 (2):56-7.

3907. SAGE, R. W. JR., W. C. TIERSON, G. F. MATTFELD and D. F. BEHREND. 1983. WHITE-TAILED DEER VISIBILITY AND BEHAVIOR ALONG FOREST ROADS. J. WLDL. MANAGE. 47 (4):940-53.

3908. SAINSBURY, A. W., P. M. BENNETT and J. K. KIRKWOOD. 1995. THE WELFARE OF FREE-LIVING WILD ANIMALS IN EUROPE: HARM CAUSED BY HUMAN ACTIVITIES. ANIMAL WELFARE 4:183-206.

SALONEN, J. J. 1969. EXPERIMENTAL INDUCTION OF TERRITORIAL BEHAVIOR IN THE DEER MOUSE, PEROMYSCUS MANICLATUS. M.S. THESIS, MONTANA STATE UNIVERSITY, BOZEMAN, MT. 27 PP.

3910. SALWASSER, H., J. T. DOUGLAS and D. L. YOUNG. 1980. THE USE OF ROAD-KILLED DEER FOR ASSESSING REPRODUCTIVE POTENTIAL AND WINTER CONDITION OF THE DEVIL'S GARDEN INTERSTATE MULE DEER HERD. CALIFORNIA FISH AND GAME 66(2):105-111.

3911. SAMIS, S. C. 1991. GUIDELINES FOR THE PROTECTION OF FISH AND FISH HABITAT DURING BRIDGE MAINTENANCE OPERATIONS IN BRITISH COLUMBIA. CANADIAN TECHNICAL REPORT OF FISHERIES AND AQUATIC SCIENCES: CANADIAN TECHNICAL REPORT OF FISHERIES AND AQUATIC SCIENCES NO. 1692. SUPPLY AND SERVICES, OTTAWA, ONTARIO.

3912. SAMIS, S. C., M. D. NASSICHUK and B. J. REID. 1991. GUIDELINES FOR THE PROTECTION OF FISH AND FISH HABITAT DURING BRIDGE MAINTENANCE OPERATIONS IN BRITISH COLUMBIA. CANADIAN TECHNICAL REPORT OF FISHERIES AND AQUATIC SCIENCES.

3913. SAMUEL, N. 1970. INTRASPECIFIC DIFFERENCES BETWEEN COTTONTAIL AND WOODCHUCK ISOLATES OF THE TRICHOSTRONGYLID NEMATODE OBELISCOIDES CUNICULI (GRAYBILL) . M.S. THESIS, MONTANA STATE UNIVERSITY, BOZEMAN, MT. 34 PP.

3914. SAMUEL, W. M., G. A. CHALMERS, J. G. STELFOX, A. LOEWEN and J. J. THOMSEN. 1975. CONTAGIOUS ECTHYMA IN BIGHORN SHEEP AND MOUNTAIN GOATS IN WESTERN CANADA. J WILDL DIS:26-31.

3915. SANBORN, B. W. 1990. THE ECOLOGY OF RAINBOW TROUT IN THE BIGHORN RIVER, MONTANA. M.S. THESIS, MONTANA STATE UNIVERSITY, BOZEMAN, MT. 63 PP.

3916. SANCHEZ-CLEMOT, J. F. 1992. PROVISIONAL REPORT OF THE MORTALITY OF VERTEBRATES ON THE ROADS OF THE NORTH WESTERN PARTS OF GRANADA PROVINCE, SEPTEMBER 1991. PAGES 79-87 IN LOPEZ,REDONDO, EDITOR. I JORNADAS PARA EL ESTUDIO Y PREVENCION DE LA MORTALIDAD DE VERTEBRADOS EN CARRETERAS, MADRID, 5 Y 6 DE OCTUBRE DE 1991. TOMO 2. [SESSIONS IN THE STUDY OF PREVENTION OF ROAD MORTALITIES OF VERTEBRATES, MADRID, 5 AND 6 OCTOBER, 1991. VOLUME 2.]. COORDINADORA DE ORGANIZACCIONES DE DEFENSA, AMBIENTAL, MADRID.

3917. SANDERSON, D. W. 1980. IMPROVING THE MANAGEMENT OF TWO-WHEELED VEHICLES: EDUCATION. R. N. L. ANDREWS AND P. F. NOWAK, EDITORS. OFF-ROAD VEHICLE USE: A MANAGEMENT CHALLENGE. OFFICE OF ENVIRONMENTAL QUALITY, U.S. DEPARTMENT OF AGRICULTURE, SCHOOL OF NATURAL RESOURCES, UNIVERSITY OF MICHIGAN, UNIVERSITY OF MICHIGAN EXTENSION SERVICE. 
3918. SANDERSON, K. 1983. WLDLIFE ROADKILLS AND POTENTIAL MITIGATION IN ALBERTA. ECA83-ST/1. ENVIRONMENTAL COUNCIL OF ALBERTA, EDMONTON, ALBERTA.

3919. SANDERSON, K. 1983. WILDLIFE ROADKILLS AND POTENTIAL MITIGATION IN ALBERTA. ENVIRONMENT COUNCIL OF ALBERTA, EDMONTON, ALBERTA. 9PP.

3920. SANDILANDS, A. 1994. RESEARCH PROGRAM ON WETLAND ASSESSMENT AND THE EFFECTS OF HIGHWAYS ON WILDLIFE. RESEARCH AND DEVELOPMENT BRANCH, ONTARIO MINISTRY OF TRANSPORTATION, OTTAWA, ONTARIO.

3921. SANDO, S. K. 1981. THE SPAWNING AND REARING HABITATS OF RAINBOW TROUT AND BROWN TROUT IN TWO RIVERS MONTANA. M.S. THESIS, MONTANA STATE UNIVERSITY, BOZEMAN, MT. 67 PP.

3922. SANDSTROM, P. L. 1996. IDENTIFICATION OF POTENTIAL LINKAGE ZONES FOR GRIZZLY BEARS IN THE SWAN-CLEARWATER VALLEY USING GIS. M.S. THESIS, UNIVERSITY OF MONTANA, MISSOULA, MT. 73 PP.

3923. SANDSTROM, U. 1991. ENHANCED PREDATION RATES ON CAVITY BIRD NESTS AT DECIDUOUS FOREST EDGES: AN EXPERIMENTAL STUDY. ORNIS FENNICA 68 (3):93-8.

3924. SANKOH, O. A., D. BONNER, T. DETERMANN, J. GERSTEN, A. GROPP, I. HOELTERS, N. KRUEGER, U. LEHMANN and C. MARTY. 1993. FINDING AND ASSESSING ROUTE ALTERNATIVES. JOURNAL OF ENVIRONMENTAL MANAGEMENT 38 (4):323-34.

3925. SANTOS, T. and J. L. TELLERIA. 1992. EDGE EFFECTS ON NEST PREDATION IN MEDITERRANEAN FRAGMENTED FORESTS. BIOLOGICAL CONSERVATION 60 (1):1-5.

3926. SARBELLO, W. and L. W. JACKSON. 1985. DEER MORTALITY IN THE TOWN OF MALONE. N.Y. FISH GAME J. 32 (2 ):141-57.

3927. SARGEANT, A. B. 1981. ROAD CASUALTIES OF PRAIRIE NESTING DUCKS. WILDLIFE SOCIETY BULLETIN 9:65-69.

3928. SARGENT, R. R. and M. B. SARGENT. 1996. GREAT CRESTED FLYCATCHER (MYIARCHUS CRINITUS) FEEDING AT ROAD KILLS. ALABAMA BIRDLIFE 42(2):10-12.

3929. SASAKI, $\mathrm{H}$. and Y. ONO. 1994. HABITAT USE AND SELECTION OF THE SIBERIAN WEASEL MUSTELA SIBIRICA COREANA DURING THE NON-MATING SEASON. JOURNAL OF THE MAMMALOGICAL SOCIETY OF JAPAN 19 (1):21-32.

3930. SASKATCHEWAN, FISHERIES AND WLDLIFE BRANCH and M. CHEN. 1980. WALLEYE SPAWNING AND ROAD CONSTRUCTION HIGHWAY CREEK, LA RONGE. SASKATCHEWAN. DEPT. OF TOURISM AND RENEWABLE RESOURCES. FISHERIES AND WILDLIFE BRANCH. FISHERIES TECHNICAL REPORT: FISHERIES TECHNICAL REPORT (SASKATOON, SASK.) NO. 80-5.

3931. SATCHELL, J. E. 1976. THE EFFECTS OF RECREATION ON THE ECOLOGY OF NATURAL LANDSCAPES. COUNCIL OF EUROPE, EUROPEAN COMMITTEE FOR THE CONSERVATION OF NATURE AND NATURAL RESOURCES. STRASBOURG, FRANCE. NATURAL ENVIRONMENTAL SERIES 11.

3932. SATTERLUND, D. R. and P. W. ADAMS. 1992. WLDLAND WATERSHED MANAGEMENT, 2ND EDITION. JOHN WILEY AND SONS, NEW YORK, NEW YORK.

3933. SAUDER, D. W., R. L. LINDER, R. B. DAHLGREN and W. L. TUCKER. 1971. AN EVALUATION OF THE ROADSIDE TECHNIQUE FOR CENSUSING BREEDING WATERFOWL. J. WLDL. MANAGE. 35(3):538-43.

3934. SAUNDERS, D. A., R. J. HOBBS and C. R. MARGULES. 1991. BIOLOGICAL CONSEQUENCES OF ECOSYSTEM FRAGMENTATION: A REVIEW. CONSERVATION BIOLOGY 5:18-32.

3935. SAUNDERS, J. K. 1954. A TWO YEAR INVESTIGATION OF THE FOOD HABITS AND RANGE USE OF THE ROCKY MOUNTAIN GOAT IN THE CRAZY MOUNTAINS, MONTANA. M.S. THESIS, MONTANA STATE COLLEGE, BOZEMAN, MT. 22 PP. 
3936. SAUNDERS, S. C. 1993. RELATIONSHIPS BETWEEN WILDLIFE RICHNESS AND CHARACTERISTICS OF PROTECTED AREAS IN BRITISH COLUMBIA. MRM THESIS, SIMON FRASER UNIVERSITY (CANADA). 105 PP.

3937. SAVIDGE, T. 1998. MANAGEMENT OF PROTECTED FRESHWATER MUSSELS WITH REGARD TO NORTH CAROLINA DEPARTMENT OF TRANSPORTATION HIGHWAY PROJECTS. PAGES 143-150 IN EVINK,G., ZIEGLER,D., GARRETT,P., AND BERRY,J., EDITORS. PROCEEDINGS OF THE INTERNATIONAL CONFERENCE ON WILDLIFE ECOLOGY AND TRANSPORTATION; 1998 FEBRUARY 10-12; FT. MYERS, FL FLORIDA DEPARTMENT OF TRANSPORTATION, TALLAHASSEE, FL.

3938. SAVIDGE, T. and H. BAIN. 1996. PROTECTED SPECIES IMPACTS AND HABITAT MANAGEMENT ASSOCIATED WITH TRANSPORTATION PROJECTS IN NORTH CAROLINA. PAGES 141-152 IN EVINK,G., ZIEGLER,D., GARRETT,P., AND BERRY,J., EDITORS. TRANSPORTATION AND WILDLIFE: REDUCING WILDLIFE MORTALITY AND IMPROVING WILDLIFE PASSAGEWAYS ACROSS TRANSPORTATION CORRIDORS: PROCEEDINGS OF THE FLORIDA DEPARTMENT OF TRANSPORTATION/FEDERAL HIGHWAY ADMINISTRATION TRANSPORTATION-RELATED WILDLIFE MORTALITY SEMINAR; 1996 APRIL 30-MAY 2; ORLANDO, FL. FHWA-PD-96-041. U.S. DEPARTMENT OF TRANSPORTATION, FEDERAL HIGHWAY ADMINISTRATION, WASHINGTON, DC.

3939. SAWYER, P. T. 1967. BIOSYSTEMATIC STUDIES OF SPECIES OF DELPHINIUM OCCURRING IN MONTANA. M.S. THESIS, MONTANA STATE UNIVERSITY, BOZEMAN, MT. 60 PP.

3940. SAWYER, P. T. 1970. SYSTEMATIC STUDIES OF NON-FISTULOSE DELPHINIUM TAXA COMMON TO MONTANA. PH.D. DISSERTATION, MONTANA STATE UNIVERSITY, BOZEMAN, MT. 84 PP.

3941. SAXENA, R. 1992. MORTALITY RATE IN COMMON INDIAN NIGHTJAR IN ROAD ACCIDENTS. NEWSLETTER FOR BIRDWATCHERS 2(9-10):17-22.

3942. SCAGGS, G. B. 1979. VEGETATION DESCRIPTION OF POTENTIAL GRIZZLY BEAR HABITAT IN THE SELWAY-BITTERROOT WILDERNESS AREA, MONTANA AND ID. M.S. THESIS, UNIVERSITY OF MONTANA, MISSOULA, MT. 148 PP.

3943. SCANLON, P. F. and M. M. SUSAN. 1980. APPROACHES BY STATES TO EDUCATING DRIVERS ABOUT WLDLIFE HAZARDS ON ROADS. PROCEEDINGS OF THE ANNUAL CONFERENCE OF THE SOUTHEAST ASSOCIATION OF FISH AND WILDLIFE AGENCIES 33:765-766.

3944. SCHAEFER, J. A. and W. O. JR. PRUITT. 1991. FIRE AND WOODLAND CARIBOU IN SOUTHEASTERN MANITOBA. WILDL. MONOGR. 116:1-39

3945. SCHAFER, J. A., S. PENLAND and W. P. CARR. 1984. EFFECTIVENESS OF WLDLIFE WARNING REFLECTORS IN REDUCING DEER-VEHICLE ACCIDENTS IN WASHINGTON STATE. TRANSPORTATION RESEARCH RECORD [VOL. UNKNOWN]:85-88.

3946. SCHAFER, J. A. and S. T. PENLAND. 1985. EFFECTIVENESS OF SWAREFLEX REFLECTORS IN REDUCING DEER-VEHICLE ACCIDENTS. JOURNAL OF WLDLIFE MANAGEMENT 46:774-776.

3947. SCHALLAU, C. H. 1971. WHO SAYS ACCELERATED ROADBUILDING PAYS?. J. FOR. 69:279-280.

3948. SCHALLENBERGER, A. 1980. REVIEW OF OIL AND GAS EXPLOITATION IMPACTS ON GRIZZLY BEARS. INT. CONF. BEAR RES. AND MANAGE. 4:271-6.

3949. SCHALLENBERGER, A. 1980. REVIEW OF OIL AND GAS EXPLORATION IMPACTS ON GRIZZLY BEARS. INT. CONF. BEAR RES. AND MANAGE. 4: 271-276.

3950. SCHALLENBERGER, A. and C. J. JONKEL. ROCKY MOUNTAIN EAST FRONT GRIZZLY STUDIES,1979 ANNUAL REPORT BORDER GRIZZLY BEAR PROJECT SPECIAL REPORT 39. SCHOOL OF FORESTRY, UNIVERSITY OF MONTANA, MISSOULA. 207PP.

3951. SCHALLENBERGER, A. D. 1966. FOOD HABITS, RANGE USE AND INTER-SPECIFIC RELATIONSHIPS OF BIG HORN SHEEP IN SUN RIVER AREA, WEST-CENTRAL MONTANA. M.S. THESIS, MONTANA STATE UNIVERSITY, BOZEMAN, MT. 44 PP.

3952. SCHAPLOW, B. M. 1976. THE EFFECTS OF CHANNELIZATION AND MITIGATION ON THE MORPHOLOGY AND TROUT POPULATIONS OF THE ST. REGIS RIVER, MONTANA. M.S. THESIS, MONTANA STATE UNIVERSITY, BOZEMAN, 
MT. 46 PP.

3953. SCHIECK, J., K. LERTZMAN, B. NYBERG and R. PAGE. 1995. EFFECTS OF PATCH SIZE ON BIRDS IN OLD-GROWTH MONTANE FORESTS. CONSERVATION BIOLOGY 9 (5):1072-84.

3954. SCHIEFFELIN, J. B. 1973. THE POLITICAL ASPECTS OF WILDLIFE MANAGEMENT. PAGES 78-81 IN E. DECKER AND G. A. SWANSON, EDITORS. WILDLIFE AND THE ENVIRONMENT: PROCEEDINGS OF THE GOVERNOR'S CONFERENCE . COLORADO STATE UNIVERSITY. INFORMATION SERIES 7,

3955. SCHILDWACHTER, G. T. M. 1997. VOLUNTARY AGREEMENTS TO CONSERVE ENDANGERED SPECIES ON PRIVATE LAND ACCOMODATING LOCAL INTERESTS WITH TRUSTING RELATIONSHIPS. PH.D. DISSERTATION, UNIVERSITY OF MONTANA, MISSOULA, MT. 89 PP.

3956. SCHIPPERS, P., J. VERBOOM, J. P. KNAAPEN and R. C. VANAPELDOORN. 1996. DISPERSAL AND HABITAT CONNECTIVITY IN COMPLEX HETEROGENEOUS LANDSCAPES - AN ANALYSIS WITH A GIS-BASED RANDOM WALK MODEL. ECOGRAPHY 19(2):97-106.

3957. SCHIROKAUER, D. W. 1996. THE EFFECTS OF 55 YEARS OF VEGETATIVE CHANGE ON BIGHORN SHEEP HABITAT IN THE SUN RIVER AREA OF MONTANA. M.S. THESIS, UNIVERSITY OF MONTANA, MISSOULA, MT. 95 PP.

3958. SCHLADWEILER, P. 1974. MOOSE ECOLOGY IN SOUTHWESTERN MONTANA. MONTANA DEPARTMENT OF FISH AND GAME. W-98-R-5,6,7,8,9 AND W-120-R-1,2,3,4,5

3959. SCHLEYER, B. O. 1983. ACTIVITY PATTERNS OF GRIZZLY BEARS IN THE YELLOWSTONE ECOSYSTEM AND THEIR REPRODUCTIVE BEHAVIOR, PREDATION AND THE USE OF CARRION. M.S. THESIS, MONTANA STATE UNIVERSITY, BOZEMAN, MT. 130 PP.

3960. SCHLICHTER, L. 1981. LOW PH AFFECTS THE FERTILIZATION AND DEVELOPMENT OF RANA PIPIENS EGGS . CANADIAN JOURNAL OF ZOOLOGY 59:1693-1699.

3961. SCHLUPP, I., M. KIETZ, R. PODLOUCKY and F. M. STOLZ. 1989. PILOT PROJECT BRAKEN: PRELIMINARY RESULTS FROM THE RESETTLEMENT OF ADULT TOADS TO A SUBSTITUTE BREEDING SITE. PAGES 127-135 IN LANGTON,T.E.S., EDITOR. AMPHIBIANS AND ROADS. PROCEEDINGS OF THE TOAD TUNNEL CONFERENCE; 1989 JANUARY 7-8; RENDSBURG, FEDERAL REPUBLIC OF GERMANY. ACO POLYMER PRODUCTS LTD., SHEFFORD, ENGLAND.

3962. SCHLUPP, I. and R. PODLOUCKY. 1994. CHANGES IN BREEDING SITE FIDELITY: A COMBINED STUDY OF CONSERVATION AND BEHAVIOUR IN THE COMMON TOAD BUFO BUFO. BIOLOGICAL CONSERVATION 69 (3):285-91.

3963. SCHMIDLY, D. J. and K. T. WILKINS. 1977. COMPOSITION OF SMALL MAMMAL POPULATIONS ON HIGHWAY RIGHT-OF-WAYS IN EAST TEXAS. NATIONAL TECHNICAL INFORMATION SERVICE. SPRINGFIELD, VIRGINIA. FHWA TX 77197-IF .

3964. SCHMIDLY, D. J. and K. T. WILKINS. 1977. COMPOSITION OF SMALL MAMMAL POPULATIONS ON HIGHWAY RIGHT-OF-WAYS IN EAST TEXAS. FHWA/TX-77197-IF. U.S. DEPARTMENT OF TRANSPORTATION, FEDERAL HIGHWAY ADMINISTRATION, WASHINGTON, DC.

3965. SCHMUTZ, J. K. 1982. AN ESTIMATE OF FERRUGINOUS HAWKS IN ALBERTA AND THE RELATIONSHIP BETWEEN THEIR DENSITY AND LAND USE. UNPUBLISHED MS, UNIVERSITY OF CALGARY. 36PP.

3966. SCHNICK, R. A., J. M. MORTON, J. C. MOCHALSKI and J. T. BEALL. 1982. MITIGATION AND ENHANCEMENT TECHNIQUES FOR THE UPPER MISSISSIPPI RIVER SYSTEM AND OTHER LARGE RIVER SYSTEMS. U.S. FISH AND WILDLIFE SERVICE RESOURCE PUBLICATION 149. 714PP.

3967. SCHNICK, R. A. 1982. MITIGATION AND ENHANCEMENT TECHNIQUES FOR THE UPPER MISSISSIPPI RIVER SYSTEM AND OTHER LARGE RIVER SYSTEMS. RESOURCE PUBLICATION / UNITED STATES DEPARTMENT OF THE INTERIOR, FISH AND WILDLIFE SERVICE: RESOURCE PUBLICATION (U.S. FISH AND WILLIFE SERVICE) NO. 149. U.S. DEPT. OF THE INTERIOR, FISH AND WILDLIFE SERVICE, WASHINGTON, D.C.

3968. SCHNICK, R. A. and UPPER MISSISSIPPI RIVER BASIN COMMISSION. 1981. MITIGATION/ENHANCEMENT HANDBOOK FOR THE UPPER MISSISSIPPI RIVER SYSTEM (UMRS) AND OTHER LARGE RIVER SYSTEMS. PREPUBLICATION 
ED. COMPREHENSIVE MASTER PLAN FOR THE MANAGEMENT OF THE UPPER MISSISSIPPI RIVER SYSTEM TECHNICAL REPORT E. UPPER MISSISSIPPI RIVER BASIN COMMISSION, MINNEAPOLIS, MINNESOTA.

3969. SCHOEN, J. and L. BEIER. 1990. TITLE UNKNOWN. ALASKA DEPT. OF FISH AND GAME UNPUBLISHED WILDLIFE REPORT . 96 PP.

3970. SCHOEN, J. W. 1990. BEAR HABITAT MANAGEMENT: A REVIEW AND FUTURE PERSPECTIVE. INT. CONF. BEAR RES. AND MANAGE. 8:143-54.

3971. SCHOEN, J. W. and L. BEIER. BROWN BEAR HABITAT PREFERENCES AND BROWN BEAR LOGGING AND MINING RELATIONSHIPS IN SOUTHEAST ALASKA. ALASKA DEPT. OF FISH AND GAME. WLDL. RES. AND MANAGE. PROJ. NO. W-23-1, STUDY NO. 4.17, PERIOD COVERED 1 JULY 1987 - 30 JUNE 1988. 32PP.

3972. SCHOEN, J. W. and L. R. BEIER. 1989. TITLE UNKNOWN. ALASKA DEPT. FISH AND GAME UNPUBLISHED WILDLIFE REPORT 38 PP.

3973. SCHOEN, J. W., R. W. FLYNN, L. H. SURING, K. TITUS and L. R. BEIER. 1994. HABITAT-CAPABILITY MODEL FOR BROWN BEAR IN SOUTHEAST ALASKA. INT. CONF. BEAR RES. AND MANAGE. 9:327-37.

3974. SCHOEN, J. W. 1989. BEAR HABITAT MANAGEMENT: A REVIEW AND FUTURE.PERSPECTIVE. 35 PP.

3975. SCHOEN, W., R. W. FLYNN, L. H. SURING, L. R. BEIER and M. L. ORME. 1989. HABITAT CAPABILITY MODEL FOR BROWN BEAR IN SOUTHEAST ALASKA. ALASKA DEPT. FISH AND GAME UNPUBLISHED WILDLIFE REPORT.

3976. SCHOENTHAL, N. D. 1963. SOME EFFECTS OF DDT ON COLD WATER FISH AND FISH-FOOD ORGANISMS. PH.D. DISSERTATION, MONTANA STATE COLLEGE, BOZEMAN, MT. 47 PP.

3977. SCHOFIELD, R. D. 1960. DETERMINING HUNTING SEASON WASTE OF DEER BY FOLLOWING FOX TRAILS. J. WILDL. MANAGE. $24(3): 342-4$.

3978. SCHOFIELD, R. D. 1960. A THOUSAND MILES OF FOX TRAILS IN MICHIGAN'S RUFFED GROUSE RANGE. J. WLDL. MANAGE. 24 (4):432-4.

3979. SCHONEWALD-COX, C. and M. BUECHNER. 1992. PARK PROTECTION AND PUBLIC ROADS. PAGES $373-395$ IN P. L. FIEDLER AND S. K. JAIN, EDITORS. CONSERVATION BIOLOGY: THE THEORY AND PRACTICE OF NATURE CONSERVATION, PRESERVATION, AND MANAGEMENT. CHAPMAN AND HALL. NEWYORK.

3980. SCHORGER, A. W. 1984. A STUDY OF ROADKILLS. PASSENGER PIGEON 16:53-55.

3981. SCHRADER, W. C. 1989. TROUT MORTALITY, MOVEMETNS, AND HABITAT SELECTION DURING WINTER IN SOUTH WILLOW CREEK, MONTANA. M.S. THESIS, MONTANA STATE UNIVERSITY, BOZEMAN, MT. 89 PP.

3982. SCHRANCK, B. W. 1972. WATERFOWL NEST COVER AND SOME PREDATION RELATIONSHIPS. J. WLDL. MANAGE. 36 (1):182-6.

3983. SCHREIBER, K. F. and U. KIAS. 1983. A CONCEPT FOR ENVIRONMENTAL IMPACT ASSESSMENT OF NEW ROADS. APPLIED GEOGRAPHY AND DEVELOPMENT 21:95-107.

3984. SCHREIBER, R. K. and J. H. GRAVES. 1977. POWERLINE CORRIDORS AS POSSIBLE BARRIERS TO THE MOVEMENT OF SMALL MAMMALS. AMERICAN MIDLAND NATURALIST 97(2):504-508.

3985. SCHREINER, E. G. 1982. THE ROLE OF EXOTIC SPECIES IN PLANT SUCCESSION FOLLOWING HUMAN DISTURBANCE IN AN ALPINE AREA OF OLYMPIC NATIONAL PARK, WASHINGTON. DISSERTATION, UNIVERSITY OF WASHINGTON, SEATTLE, WASHINGTON.

3986. SCHUBLOOM, L. A. 1995. LICHENS AS AIR QUALITY INDICATORS IN THREE AREAS OF SOUTHWESTERN MONTANA: LICHEN FLORISTICS AND ELEMENTAL ANALYSIS. M.S. THESIS, MONTANA STATE UNIVERSITY, BOZEMAN, MT. $130 \mathrm{PP}$. 
3987. SCHULTZ, B. 1988. CONSTRUCTION AND MAINTENANCE OF POWER FENCES FOR INDIAN WILDLIFE. INDIA, ESTABLISHMENT OF THE WILDLIFE INSTITUTE OF INDIA; FAO, DEHRA DUN, INDIA.

3988. SCHULTZ, R. D. and J. A. BAILEY. 1978. RESPONSES OF NATIONAL PARK ELK TO HUMAN ACTIVITY. JOURNAL OF WILDLIFE MANAGEMENT 42:91-100.

3989. SCHULZ, T. T. and L. A. JOYCE. 1992. A SPATIAL APPLICATION OF A MARTEN HABITAT MODEL. WILDLIFE SOCIETY BULLETIN 20:74-83.

3990. SCHUMAKER, N. H. 1995. HABITAT CONNECTIVITY AND SPOTTED OWL POPULATION DYNAMICS. PHD. THESIS, UNIVERSITY OF WASHINGTON. 126 PP.

3991. SCHUMAKER, N. H. 1996. USING LANDSCAPE INDICES TO PREDICT HABITAT CONNECTIVITY. ECOLOGY 77 (4):1210-25.

3992. SCHWARTZ, C. C. 1974. ANALYSIS OF SURVEY DATA COLLECTED ON BOBWHITE IN IOWA. J. WILDL. MANAGE. 38 (4):676-8.

3993. SCHWARTZ, C. C. and B. BARTLEY. 1991. REDUCING INCIDENTAL MOOSE MORTALITY: CONSIDERATIONS FOR MANAGEMENT. P 227-31. IN: MOOSE CONFERENCE WORKSHOP; MAY17, 1991 ; ANCHORAGE.

3994. SCHWARTZ, C. C. and A. W. FRANZMANN. 1992. DISPERSAL AND SURVIVAL OF SUBADULT BLACK BEARS FROM THE KENAI PENINSULA, ALASKA. J. WILDL. MANAGE. 56 (3):426-31.

3995. SCHWARTZ, O. A., A. M. VIVAS, A. ORRIS and C. J. MILLER. 1994. SMALL MAMMAL SPECIES ASSOCIATIONS IN THREE TYPES OF ROADSIDE HABITATS IN IOWA. PRAIRIE NATURALIST $26: 45-52$.

3996. SCHWARZKOPH, W. F. 1973. RANGE USE AND RELATIONSHIPS OF MULE DEER (ODOCOILUS TREMIONUS) ON THE WEST SLOPE OF THE BRIDGER MOUNTAINS, MONTANA. M.S. THESIS, MONTANA STATE UNIVERSITY, BOZEMAN, MT. 65 PP.

3997. SCHWEHR, D. J. 1976. DISTRIBUTION AND DIVERSITY OF AQUATIC MACROINVERTEBRATES OF THE MIDDLE YELLOWSTONE RIVER. M.S. THESIS, UNIVERSITY OF MONTANA, MISSOULA, MT. 136 PP.

3998. SCOTT-BROWN, J. M. 1984. UNGULATE MONITORING ALONG THE TRANS-CANADA HIGHWAY, BANFF NATIONAL PARK. M.E. DES. THESIS, UNIVERSITY OF CALGARY, CALGARY.166 PP.

3999. SCOTT, M. D. 1992. BUCK-AND-POLE FENCE CROSSINGS BY 4 UNGULATE SPECIES. WILDLIFE SOCIETY BULLETIN 20 (2):204-10.

4000. SCOTT, M. D. 1978. ELK HABITAT SELECTION AND USE ON AN UNDISTURBED SUMMER RANGE IN WESTERN MONTANA. M.S. THESIS, UNIVERSITY OF MONTANA, MISSOULA, MT. 98 PP.

4001. SCOTT, T. G. 1938. WILDLIFE MORTALITY ON IOWA HIGHWAYS. AMERICAN MIDLAND NATURALIST 20:527-539.

4002. SCOTT, V. E. and E. L. BOEKER. 1972. AN EVALUATION OF WLD TURKEY CALL COUNTS IN ARIZONA. J. WILDL. MANAGE. 36 (2):628-30.

4003. SCOTTON, B. D. 1998. TIMING AND CAUSES OF NEONATAL DALL SHEEP MORTALITY IN THE CENTRAL ALASKA RANGE. M.S. THESIS, UNIVERSITY OF MONTANA, MISSOULA, MT. 44 PP.

4004. SCOW, K. L. 1981. ECOLOGICAL DISTRIBUTION OF SMALL MAMMALS AT SARPY CREEK, MONTANA, WITH SPECIAL CONSIDERATION OF THE DEER MOUSE, PEROMYSCUS MANICULATUS . M.S. THESIS, MONTANA STATE UNIVERSITY, BOZEMAN, MT. 73 PP.

4005. SCRIBNER, K. T., M. H. SMITH and R. K. CHESSER. 1997. SPATIAL AND TEMPORAL VARIABILITY OF MICROGEOGRAPHIC GENETIC STRUCTURE IN WHITE-TAILED DEER. JOURNAL OF MAMMALOGY 78(3):744-755.

4006. SEABROOK, W. A. and E. B. DETTMANN. 1996. ROADS AS ACTIVITY CORRIDORS FOR CANE TOADS IN AUSTRALIA. JOURNAL OF WLDLIFE MANAGEMENT 60(2):363-368. 
4007. SEARING, G. F. 1981. EFFECTS OF ELEVATED LINEAR DEVELOPMENTS ON WILDLIFE: A REVIEW AND ANNOTATED BIBLIOGRAPHY. LGL LTD. ENVIRONMENTAL RESEARCH ASSOC. PREPARED FOR FOOTHILLS PIPELINES -(SOUTH YUKON) LTD., CALGARY. 87PP.

4008. SEARING, G. F. and W. G. ALLISTON. 1979. ASSESSMENT OF IMPACTS OF A ROAD TO IZOK LAKE A REVIEW OF EXISTING INFORMATION AND RECOMMENDATIONS FOR SEARCH ON SELECTED SPECIES OF WLDLIFE. LGL LTD, EDMONTON, ALBERTA.

4009. SEARS, H. S. 1955. CERTAIN ASPECTS OF THE REPRODUCTIVE PHYSIOLOGY OF THE FEMALE MULE DEER. M.S. THESIS, MONTANA STATE UNIVERSITY, MISSOULA, MT. 82 PP.

4010. SECORD, M. L. 1994. WINTER HABITAT USE, MIGRATION, AND SPRING AND SUMMER USE OF CLEARCUTS BY WHITE-TAILED DEER IN THE PRIEST LAKE WATERSHED OF NORTHERN IDAHO. M.S. THESIS, UNIVERSITY OF MONTANA, MISSOULA, MT. 143 PP.

4011. SEGELQUIST, C. A. and R. E. PENNINGTON. 1968. DEER BROWSE IN THE OUACHITA FOREST IN OKLAHOMA. J. WILDL. MANAGE. 32 (3):623-6.

4012. SEGERSTROM, T. 1982. EFFECTS OF AN OPERATIONAL COAL STRIP MINE ON PRONGHORN ANTELOPE. PAGES 174-208 IN J. V. MCKENZIE, CHAIR. PROCEEDINGS OF THE TENTH PRONGHORN ANTELOPE WORKSHOP.

4013. SEGERSTROM, T. B. 1982. EFFECTS OF AN OPERATIONAL COAL MINE ON PRONGHORN ANTELOPE. M.S. THESIS, MONTANA STATE UNIVERSITY, BOZEMAN, MT. 68 PP.

4014. SEIBERT, H. C. and J. H. CONOVER. 1991. MORTALITY OF VERTEBRATES AND INVERTEBRATES ON AN ATHENS COUNTY, OHIO (USA), HIGHWAY. OHIO JOURNAL OF SCIENCE 91 (4):163-6.

4015. SEIBERT, S. G. 1989. BLACK BEAR HABITAT USE AND RESPONSE TO ROADS ON PISGAH NATIONAL FOREST, NORTH CAROLINA. M.S. THESIS, UNIV. TENNESSEE, KNOXVILLE, TN.

4016. SEIDENSTICKER, J. C. 1968. RESPONSE OF JUVENILE RAPTORS TO DDT IN THE DIET. PH.D. DISSERTATION, UNIVERSITY OF MONTANA, MISSOULA, MT. 74 PP.

4017. SEIP, D. 1991. LIMITING FACTORS OF CARIBOU IN SOUTHEASTERN BRITISH COLUMBIA. P 278-80. IN: BUTLER CE, MAHONEY SP, EDS. 4TH NORTH AMERICAN CARIBOU WORKSHOP PROC.; OCT 31-NOV 31989 ; ST. JOHN'S, NEWFOUNDLAND. NEWFOUNDLAND AND LABRADOR WILDLIFE DIV. NEWFOUNDLAND AND LABRADOR WILDLIFE DIV.

4018. SEIP, D. R. 1990. ECOLOGY OF WOODLAND CARIBOU IN WELLS-GRAY PROVINCIAL PARK. WILDL. BULL. B-68:43PP.

4019. SEIP, D. R. 1992. HABITAT USE AND POPULATION STATUS OF WOODLAND CARIBOU IN THE QUESNEL HIGHLANDS, BRITISH COLUMBIA. WILDL. BULL. B-71:50PP.

4020. SEIP, D. R. and F. L. BUNNELL. 1985. NUTRITION OF STONE'S SHEEP ON BURNED AND UNBURNED RANGES. J. WILDL. MANAGE. 49 (2):397-405.

4021. SEIP, D. R. and D. B. CICHOWSKI. 1996. POPULATION ECOLOGY OF CARIBOU IN BRITISH COLUMBIA. RANGIFER SPECIAL ISSUE NO.9:73-80.

4022. SELANDER, R. K. and D. W. KAUFFMAN. 1975. GENETIC STRUCTURE OF POPULATIONS OF THE BROWN SNAIL (HELIX ASPERSA I.): MICROGEOGRAPHIC VARIATION. EVOLUTION 29:385-401.

4023. SELSER, W. I. 1977. ASSIMILATION AND ACCUMULATION OF LEAD THROUGH THE AQUATIC FOOD CHAIN OF MIGRATORY WATERFOWL. M.S. THESIS, UNIVERSITY OF MONTANA, MISSOULA, MT. 65 PP.

4024. SELTING, J. P. 1994. SEASONAL USE OF AGRICULTURAL LANDS BY MULE DEER, WHITE-TAILED DEER AND PRONGHORN ANTELOPE IN CARTER COUNTY, MONTANA. M.S. THESIS, MONTANA STATE UNIVERSITY, BOZEMAN, MT. 66 PP. 
SERE, D. 1990. BARN OWL - EASTERN FORM - CADAVERS FOUND ON ROADS. ACROCEPHALUS (LJUBLJANA) 1(46):111-118.

4027. SERIE, J. R. and L. M. COWARDIN. 1990. USE OF SOCIAL INDICES TO PREDICT REPRODUCTIVE SUCCESS IN CANVASBACKS. J. WLDL. MANAGE. 54 (1):66-72.

4028. SERRE, D. and M. BIRKAN. 1985. IMPACT OF INSECTICIDES ON THE FOOD OF GREY PARTRIDGE CHICKS (PERDIX PERDIX L.) ON ARABLE FARMLAND IN THE BEAUCE REGION. GIBIER FAUNE SAUVAGE 985(4):21-61.

4029. SERROUYA, R. 1997. BLACK BEAR MOVEMENTS AND SURVIVAL IN THE BOW VALLEY, BNP. ROADS, RAILS AND ENVIRONMENT WORKSHOP II; 9-10 APR 1997 ; REVELSTOKE, B.C. COLUMBIA MOUNTAINS INSTITUTE, REVELSTOKE.

4030. SERVHEEN, C. 1993. GRIZZLY BEAR RECOVERY PLAN. U.S. FISH AND WLDLIFE SERVICE, WASHINGTON, DC.

4031. SERVHEEN, C. 1983. THE STATUS OF THE GRIZZLY BEAR IN THE LOWER 48 STATES: PROGRESS TOWARD RECOVERY. (PRES) 6TH INT. CONF. BEAR RES. AND MGT., GRAND CANYON, AZ. 31 PP.

4032. SERVHEEN, C. and P. SANDSTROM. 1993. ECOSYSTEM MANAGEMENT AND LINKAGE ZONES FOR GRIZZLY BEARS AND OTHER LARGE CARNIVORES IN THE NORTHERN ROCKY MOUNTAINS IN MONTANA AND IDAHO. ENDANGERED SPECIES BULLETIN 18:1-23.

4033. SERVHEEN, C. and P. SANDSTROM. 1993. HUMAN ACTIVITIES AND LINKAGE ZONES FOR GRIZZLY BEARS IN THE SWAN-CLEARWATER VALLEYS, MONTANA. U.S. FISH AND WLDLIFE SERVICE, MISSOULA, MT. 28 PP.

4034. SERVHEEN, C., J. WALLER, W. KASWORM, D. CARNEY, D. MOODY, J. VARLEY, H. NYBERG and R. MACE. 1997. DETERMINING EFFECTS OF HIGH-SPEED HIGHWAYS ON GRIZZLY BEAR MOVEMENT, MORTALITY, HABITAT-USE, AND HABITAT FRAGMENTATION-DRAFT PROPOSAL. U.S. FISH AND WLDLIFE SERVICE, MISSOULA, MT.

4035. SERVHEEN, C., J. WALLER, W. KASWORM, D. CARNEY, D. MOODY, J. VARLEY, H. NYBERG and R. MACE. 1997. DETERMINING EFFECTS OF HIGH-SPEED HIGHWAYS ON GRIZZLY BEAR MOVEMENT, MORTALITY, HABITAT-USE, AND HABITAT FRAGMENTATION. DRAFT PROPOSAL.

4036. SERVHEEN, C. W. 1975. ECOLOGY OF THE WINTERING BALD EAGLES ON THE SKAGIT RIVER, WASHINGTON. THESIS, UNIVERSITY OF WASHINGTON, SEATTLE, WASHINGTON. 96PP.

4037. SERVHEEN, C., J. WALLER and W. KASWORM. 1998. FRAGMENTATION EFFECTS OF HIGH-SPEED HIGHWAYS ON GRIZZLY BEAR POPULATIONS SHARED BETWEEN THE UNITED STATES AND CANADA. PAGES 97-103 IN G. L. EVINK, P. GARRETT, D. ZEIGLER, AND J. BERRY, EDITORS. PROCEEDINGS OF THE INTERNATIONAL CONFERENCE ON WILDLIFE ECOLOGY AND TRANSPORTATION. FLORIDA DEPARTMENT OF TRANSPORTATION, TALLAHASSEE, FLORIDA.

4038. SERVHEEN, C. W. 1981. GRIZZLY BEAR ECOLOGY AND MANAGEMENT IN THE MISSION MOUNTAINS, MONTANA. PH.D. DISSERTATION, UNIVERSITY OF MONTANA, MISSOULA, MT. 139 PP.

4039. SERVHEEN, G. and L. J. LYON. 1989. HABITAT USE BY WOODLAND CARIBOU IN THE SELKIRK MOUNTAINS. J. WILDL. MANAGE. 53 (1):230-7.

4040. SEVERINGHAUS, W. D. and W. D. GORAN. 1981. EFFECTS OF TACTICAL VEHICLE ACTIVITY ON THE MAMMALS, BIRDS, AND VEGETATION AT FORT LEWIS, WASHINGTON. U.S. DEPT. DEFENSE, ARMY CORPS ENG., CONSTRUCT. ENG. RES. LAB. CHAMPAIGN, ILLINOIS. CERL-TR-N-116. 50PP.

4041. SEVERINGHAUS, W. D., W. D. GORAN, G. D. SCHNELL and F. L. JOHNSON. 1981. EFFECTS OF TACTICAL VEHICLE ACTIVITY ON THE MAMMALS, BIRDS, AND VEGETATION AT FORT HOOD, TEXAS. FINAL REPORT. U.S. DEPT. DEFENSE, ARMY CORPS ENG., CONSTRUCT. ENG. RES. LAB. CHAMPAIGN, ILLINOIS. CERL-TR-N-113. 27PP. 
4042. SEVERINGHAUS, W. D., R. E. RIGGINS and W. D. GORAN. 1980. EFFECTS OF TRACKED VEHICLE ACTIVITY ON TERRESTRIAL MAMMALS AND BIRDS AT FORT KNOX, KENTUCKY. TRANS. KY. ACAD. SCI. 41:15-26.

4043. SEVERINGHAUS, W. D. and M. C. SEVERINGHAUS. 1982. EFFECTS OF TRACKED VEHICLE ACTIVITY ON BIRD POPULATIONS. ENVIRON. MANAGE. 6:163-169.

4044. SHANK, C. C. 1979. HUMAN-RELATED BEHAVIORAL DISTURBANCE TO NORTHERN LARGE MAMMALS: A BIBLIOGRAPHY AND REVIEW. REPORT PREPARED FOR FOOTHILLS PIPE LINES (SOUTH YUKON) LTD., CALGARY, ALBERTA. 254PP.

4045. SHANK, C. C. 1979. HUMAN-RELATED BEHAVIORAL DISTURBANCE TO NORTHERN LARGE MAMMALS: A REVIEW AND BIBLIOGRAPHY. PREPARED FOR FOOTHILLS PIPELINES(SOUTH YUKON) LTD., CALGARY. $246 P P$.

4046. SHANKMAN, D. 1993. CHANNEL MIGRATION AND VEGETATION PATTERNS IN THE SOUTHEASTERN COASTAL PLAIN. CONSERVATION BIOLOGY 7 (1):176-83.

4047. SHARMA, S. K. 1988. BIRD CASUALTIES IN ROAD ACCIDENTS. JOURNAL OF THE BOMBAY NATURAL HISTORY SOCIETY 85(1):195-197.

4048. SHARP, H. S. 1930. RED-HEADED WOODPECKERS AND AUTOMOBILES. BIRDLORE 32:352-356.

4049. SHAW, E. A. 1996. NOISE ENVIRONMENTS OUTDOORS AND THE EFFECTS OF COMMUNITY NOISE EXPOSURE. NOISE CONTROL ENGINEERING JOURNAL 44(3):109-119.

4050. SHAW, R. B. and V. E. DIERSING. 1990. TRACKED VEHICLE IMPACTS ON VEGETATION AT THE PINON CANYON MANEUVER SITE, COLORADO. J. ENVIRON. QUAL. 19:234-243.

4051. SHEA, R. E. 1979. THE ECOLOGY OF TRUMPETER SWAN IN YELLOWSTONE NATIONAL PARK AND VICINITY . M.S. THESIS, UNIVERSITY OF MONTANA, MISSOULA, MT. 132 PP.

4052. SHEATE, W. R. and R. M. TAYLOR. 1990. THE EFFECT OF MOTORWAY DEVELOPMENT ON ADJACENT WOODLAND. JOURNAL OF ENVIRONMENTAL MANAGEMENT 31:261-267.

4053. SHEELEY, D. G. and L. M. SMITH. 1989. TESTS OF DIET AND CONDITION BIAS IN HUNTER-KILLED NORTHERN PINTAILS. J. WILDL. MANAGE. $53(3): 765-9$.

4054. SHELDON, A. L. 1988. CONSERVATION OF STREAM FISHES: PATTERNS OF DIVERSITY, RARITY, AND RISK. CONSERVATION BIOLOGY 2 (2):149-56.

4055. SHELDON, J. SOCIAL BEHAVIOR AND POPULATION DYNAMICS OF COYOTES IN YELLOWSTONE NATIONAL PARK. MONTANA STATE UNIVERSITY, BOZEMAN, MT.

4056. SHELTON, P. A. 1982. THE IMPACTS OF TENNESSEE STATE ROUTE 29 UPON THE AVIAN POPULATIONS OF AN ADJACENT FLOODPLAIN [ABSTRACT]. TENNESSEE TECHNICAL JOURNAL 17:81.

4057. SHENK, T. M. and J. K. RINGELMAN. 1992. HABITAT USE BY CROSS-FOSTERED WHOOPING CRANES IN COLORADO. JOURNAL OF WLDLIFE MANAGEMENT 56(4):769-76.

4058. SHEPERD, B. F. and R. K. SWIHART. 1995. SPATIAL DYNAMICS OF FOX SQUIRRELS (SCIURUS NIGER) IN FRAGMENTED LANDSCAPES. CANADIAN JOURNAL OF ZOOLOGY 73 (11):2098-105.

4059. SHEPHERD, J. F. 1994. INITIAL RESPONSE OF SMALL MAMMALS TO NEW FORESTRY AND OVERSTORY REMOVAL TIMBER HARVESTS. M.S. THESIS, UNIVERSITY OF MONTANA, MISSOULA, MT. 84 PP.

4060. SHERBURNE, J. H. 1983. WILDLIFE POPULATIONS UTILIZING RIGHT-OF-WAY HABITAT ALONG INTERSTATE 95 IN NORTHERN MAINE. FHWA-ME-TP-83-5. U.S. DEPARTMENT OF TRANSPORTATION, FEDERAL HIGHWAY ADMINISTRATION, WASHINGTON, D.C. 
4061. SHERBURNE, S. S. and J. A. BISSONETTE. 1994. MARTEN SUBNIVEAN ACCESS POINT USE: RESPONSE TO SUBNIVEAN PREY LEVELS. J. WILDL. MANAGE. 58 (3):400-5.

4062. SHERIDAN, D. 1979. OFF-ROAD VEHICLES ON PUBLIC LAND. COUNCIL ON ENVIRONMENTAL QUALITY, WASHINGTON, D.C.

4063. SHERWOOD, H. W. 1981. MORPHOLOGICAL VARIATION OF GRIZZLY BEAR SKULLS FROM YELLOWSTONE NATIONAL PARK. M.S. THESIS, UNIVERSITY OF MONTANA, MISSOULA, MT. 96 PP.

4064. SHIDELER, R. T. 1986. IMPACTS OF HUMAN DEVELOPMENT AND LAND USE ON CARIBOU: A LITERATURE REVIEW. VOL. 2. IMPACTS OF OIL AND GAS DEVELOPMENT ON THE CENTRAL ARCTIC HERD. ALASKA DEPT. OF FISH AND GAME TECHNICAL REPORT 86-3128PP.

4065. SHIDELER, R. T. 1986. IMPACTS OF HUMAN DEVELOPMENTS AND LAND USE ON CARIBOU: A LITERATURE REVIEW. VOLUME I. A WORLDWIDE PERSPECTIVE. ALASKA DEPT. FISH GAME. JUNEAU, ALASKA. TECH. REPT. NO. 86-2. 234PP.

4066. SHIDELER, R. T., M. H. ROBUS, J. F. WINTERS and M. KUWADA. 1986. IMPACTS OF HUMAN DEVELOPMENTS AND LAND USE ON CARIBOU: A LITERATURE REVIEW. VOLUME I: A WORLDWIDE PERSPECTIVE. 86-2. ALASKA DEPARTMENT OF FISH AND GAME, ANCHORAGE, AK.

4067. SHIDELER, R. T., M. H. ROBUS, J. F. WINTERS and M. KUWALA. 1986. IMPACTS OF HUMAN DEVELOPMENTS AND LAND USE ON CARIBOU: A LITERATURE REVIEW. VOL 1. A WORLDWIDE PERSPECTIVE . ALASKA DEPT. OF FISH AND GAME TECHNICAL REPORT 86-2.

4068. SHINN, J. H., R. R. IRELAND, J. R. KERCHER, J. J. KORANDA and G. A. TOMPKINS. 1979. INVESTIGATIONS OF ECOSYSTEM IMPACTS FROM GEOTHERMAL DEVELOPMENT IN IMPERIAL VALLEY, CALIFORNIA. P 651-4. IN: GEOTHERM RESOUR COUNC 3RD ANNU MEET; 1979SEP 24-1979 SEP 27; RENO, NV

4069. SHOESMITH, M. W. and W. H. KOONZ. 1977. THE MAINTENANCE OF AN URBAN DEER HERD IN WINNIPEG, MANITOBA. TRANSACTIONS OF THE NORTH AMERICAN WILDLIFE AND NATURAL RESOURCES CONFERENCE 42:278-285.

4070. SHURY, T. K. 1996. A SUMMARY OF WILDLIFE MORTALITY IN BANFF NATIONAL PARK 1981-1995, FINAL REPORT. PARKS CANADA, BANFF NATIONAL PARK WARDEN SERVICE, BANFF, ALBERTA.

4071. SIBLEY, F. C. 1969. U.S. BUREAU OF SPORT FISHERIES AND WLDLIFE, ENDANGERED WLDLIFE RESEARCH STATION ADMINISTRATIVE REPORT. PATUXENT WILLIFE RESEARCH CENTER, LAUREL, MARYLAND. $19 P P$.

4072. SIDHU, S. S. and A. B. CASE. 1977. A BIBLIOGRAPHY ON THE ENVIRONMENTAL IMPACT OF FOREST RESOURCE ROADS: A LIST. NEWFOUNDLAND FOREST RESEARCH CENTRE. ST. JOHNS. INFO. REP. N-X-149. 28PP.

4073. SIDLE, J. G. and D. B. BOWMAN. 1988. HABITAT PROTECTION UNDER THE ENDANGERED SPECIES ACT. CONSERVATION BIOLOGY 2 (1):116-8.

4074. SIDLE, J. G. and E. M. KIRSCH. 1993. LEAST TERN AND PIPING PLOVER NESTING AT SAND PITS IN NEBRASKA. COLONIAL WATERBIRDS 16 (2):139-48.

4075. SIEBART, H. C. and J. H. CONOVER. 1991. MORTALITY OF VERTEBRATES AND INVERTEBRATES ON A ATHENS COUNTY, OHIO HIGHWAY. OHIO JOURNAL OF SCIENCE 91:163-166.

4076. SIEGLER, H. R. and C. C. NEWMAN. 1944. THE VALUE AND PRACTICABILITY OF WILDLIFE CENSUSES ALONG HIGHWAYS. J. WILDL. MANAGE. 8 (2):93-9.

4077. SIEGNER, J. 1994. BREEDING BIOLOGY AND DISMIGRATION OF BARN OWLS IN UPPER BAVARIA. ORNITHOLOGISCHER ANZEIGER 33 (1-3):55-62.

4078. SIEMER, W. F., G. R. BATCHELLER, R. J. GLASS and T. L. BROWN. 1994. CHARACTERISTICS OF TRAPPERS AND TRAPPING PARTICIPATION IN NEW YORK. WILDL. SOC. BULL. 22 (1):100-11. 
4079. SIEVERT, P. R. and L. B. KEITH. 1985. SURVIVAL OF SNOWSHOE HARES AT A GEOGRAPHIC RANGE BOUNDARY. J. WILDL. MANAGE. 49 (4):854-66.

4080. SIKOROWSKI, L. and D. W. CRUMPACKER. 1984. MITIGATION OF IMPACTS TO MULE DEER AND ELK FROM ENERGY DVELOPMENT IN NORTHWEST COLORADO. HABITAT RESOURCES SECTION, COLORADO DIVISION OF WILDLIFE, DENVER, COLORADO.

4081. SILVA, J. M. 1991. TURNING UP THE HEAT ON FIRE ANTS. NEWSLETTER OF THE MICHIGAN ENTOMOLOGICAL SOCIETY 6(1):8-10.

4082. SILVESTER, D. 1993. TRANSIT NEW ZEALAND AND THE ENVIRONMENT. ROAD AND TRANSPORT RESEARCH 2(4):4-15.

4083. SILVIA, T. D. 1995. RIPARIAN HABITATS OF THE CENTRAL PLATTE AS A CORRIDOR FOR DISPERSAL OF SMALL MAMMALS IN NEBRASKA.

4084. SIMBERLOFF, D. and J. COX. 1987. CONSEQUENCES AND COSTS OF CONSERVATION CORRIDORS. CONSERVATION BIOLOGY 1 (1):63-71.

4085. SIMBERLOFF, D., J. A. FARR, J. COX and D. W. MEHLMAN. 1992. MOVEMENT CORRIDORS: CONSERVATION BARGAINS OR POOR INVESTMENTS?. CONSERVATION BIOLOGY 6(4):493-504.

4086. SIME, C. A. 1991. SAGE GROUSE USE OF BURNED, NON-BURNED AND SEEDED VEGETATION COMMUNITIES ON THE IDAHO NATIONAL ENGINEERING LABORATORY, IDAHO. M.S. THESIS, MONTANA STATE UNIVERSITY, BOZEMAN, MT. 72 PP.

4087. SIMKIN, D. W. 1965. REPRODUCTION AND PRODUCTIVITY OF MOOSE IN NORTHWESTERN ONTARIO. J. WILDL. MANAGE. 29 (4):740-50.

4088. SIMMONS, C. A. 1974. SEASONAL MOVEMENTS AND MIGRATIONS OF THE SPOTTED BEAR ELK HERD. M.S. THESIS, UNIVERSITY OF MONTANA, MISSOULA, MT. 99 PP.

4089. SIMMONS, J. R. 1938. FEATHERS AND FUR ON THE TURNPIKE. CHRISTOPHER PUBLISHING HOUSE, BOSTON, MASSACHUSETTS.

4090. SIMPSON, K. 1987. THE EFFECTS OF SNOWMOBILING ON WINTER RANGE USE BY MOUNTAIN CARIBOU. B.C. MINIST. ENVIRON. PARKS WILDL. WORKING REP. NO. WR-25.13PP.

4091. SIMPSON, K. and L. GYUG. 1991. EFFECTS OF THE OKANAGAN CONNECTOR FREEWAY ON WLDLIFE AND EFFECTIVENESS OF MITIGATION TECHNIQUES. KEYSTONE WLDLIFE RESEARCH FOR THE BRITISH COLUMBIA MINISTRY OF TRANSPORT AND HIGHWAYS, [LOCATION OF PUBLISHER UNKNOWN].

4092. SIMPSON, K., J. P. KELSALL and M. LEUNG. 1996. INTEGRATED MANAGEMENT OF MOUNTAIN CARIBOU AND FORESTRY IN SOUTHERN BRITISH COLUMBIA. RANGIFER SPECIAL ISSUE NO.9:153-8.

4093. SIMPSON, K., G. P. WOODS and K. B. HEBERT. 1985. CRITICAL HABITATS OF CARIBOU IN THE MOUNTAINS OF SOUTHERN BRITISH COLUMBIA. MCGILL SUBARCT. RES. PAP. 40:177-91.

4094. SINGER, F. J. and J. B. BEATTIE. 1986. THE CONTROLLED TRAFFIC SYSTEM AND ASSOCIATED WILDLIFE RESPONSES IN DENALI NATIONAL PARK. ARCTIC 39 (3):195-203.

4095. SINGER, F. J. and J. B. BEATTIE. 1986. THE CONTROLLED TRAFFIC SYSTEM AND ASSOCIATED WILDLIFE RESPONSES IN DENALI NATIONAL PARK, ALASKA. ARCTIC 39:195-203.

4096. SINGER, F. J., J. B. BEATTIE and R. C. CUNNINGHAM. 1986. LARGE MAMMALS AND ROADS IN NATIONAL PARKS--A REVIEW. CONFERENCE ON SCIENCE IN NATIONAL PARKS 4:134-139.

4097. SINGER, F. J. and S. P. BRATTON. 1980. BLACK BEAR/HUMAN CONFLICTS IN THE GREAT SMOKY MOUNTAINS NATIONAL PARK. INT. CONF. BEAR RES. AND MANAGE. 4:137-9. 
4098. SINGER, F. J. and J. L. DOHERTY. 1985. MANAGING MOUNTAIN GOATS AT A HIGHWAY CROSSING. WILDLIFE SOCIETY BULLETIN 13:469-477.

4099. SINGER, F. J. and J. L. DOHERTY. 1985. MOVEMENTS AND HABITAT USE IN AN UNHUNTED POPULATION OF MOUNTAIN GOATS (OREAMNOS AMERICANUS). CANADIAN FIELD NATURALIST 99:205-217.

4100. SINGER, F. J., W. L. LANGLITZ and E. C. SAMUELSON. 1985. DESIGN AND CONSTRUCTION OF HIGHWAY UNDERPASSES USED BY MOUNTAIN GOATS. TRANSPORTATION RESEARCH RECORD 1016:6-10.

4101. SINGER, F. J., W. T. SWANK and E. E. C. CLEBSCH. 1984. EFFECTS OF WID PIG ROOTING IN A DECIDUOUS FOREST. J. WILDL. MANAGE. 48 (2):464-73.

4102. SINGER, F. J. 1975. BEHAVIOR OF MOUNTAIN GOATS, ELK, AND OTHER WLDLIFE IN RELATION TO U.S. HIGHWAY 2, GLACIER NATIONAL PARK. GLACIER NATIONAL PARK, WEST GLACIER, MT. 96 PP

4103. SINGER, F. J. 1978. BEHAVIOR OF MOUNTAIN GOATS IN RELATION TO U.S. HIGHWAY 2, GLACIER NATIONAL PARK, MONTANA. JOURNAL OF WLDLIFE MANAGEMENT 42:591-597.

4104. SINGH, N., M. YUNUS, K. SRIVASTAVA, S. N. SINGH, V. PANDEY, J. MISRA and K. J. AHMAD. 1995. MONITORING OF AUTO EXHAUST POLLUTION BY ROADSIDE PLANTS. ENVIRONMENTAL MONITORING AND ASSESSMENT 34 (1):13-25.

4105. SINGLETON, P. H. 1995. WINTER HABITAT SELECTION BY WOLVES IN THE NORTH FORK OF THE FLATHEAD RIVER BASIN, MONTANA AND BRITISH COLUMBIA. THESIS, UNIVERSITY OF MONTANA, MISSOULA, MONTANA. $116 P P$.

4106. SINHA, K. C., H. KANG and D. N. JOHN. 1984. CURRENT PRACTICES OF HARVESTING HAY ON HIGHWAY RIGHTS-OF-WAY. TRANSPORTATION RESEARCH RECORD 969:40-45.

4107. SIPILA, T. 1990. LAIR STRUCTURE AND BREEDING HABITAT OF THE SAIMAA RINGED SEAL (PHOCA HISPIDA SAIMENSIS NORDQ.) IN FINLAND. FINNISH GAME RESEARCH 0 (47):11-20.

4108. SIZEMORE, D. L. 1980. FORAGING STRATEGIES OF THE GRIZZLY BEAR ASRELATED TO ITS ECOLOGICAL ENERGETICS. M.S. THESIS, UNIVERSITY OF MONTANA, MISSOULA, MT. 67 PP.

4109. SJOGREN, P. and P. I. WYONI. 1994. CONSERVATION GENETICS AND DETECTION OF RARE ALLELES IN FINITE POPULATIONS. CONSERVATION BIOLOGY 8 (1):267-70.

4110. SKAGEN, S. K. 1980. BEHAVIORAL RESPONSES OF WINTERING BALD EAGLES TO HUMAN ACTIVITY ON THE SKAGIT RIVER, WASHINGTON. R. L. KNIGHT, G. T. ALLEN, M. V. STALMASTER, AND C. W. SERVHEEN, EDITORS. PROCEEDINGS OF THE WASHINGTON BALD EAGLE SYMPOSIUM. THE NATURE CONSERVANCY, SEATTLE, WASHINGTON.

4111. SKINNER, K. F. 1995. PLANT AND GRASSHOPPER COMMUNITY COMPOSITION: INDICATORS AND INTERACTIONS ACROSS THREE SPATIAL SCALES. M.S. THESIS, MONTANA STATE UNIVERSITY, BOZEMAN, MT. 144 PP.

4112. SKJONSBERG, T. 1988. STATUS OF BIGHORN SHEEP OF BANFF NATIONAL PARK. P1-4. IN: SAMUEL WM, ED. BIENNIAL SYMPOSIUM OF THE NORTHERN WILD SHEEP AND GOAT COUNCIL; 11-15 APR. 1988; BANFF, ALBERTA. NORTHERN WLD SHEEP AND GOAT COUNCIL.

4113. SKOGLAND, T., A. GUNN, F. L. MILLER and S. SKJENNEBERG. 1986. PROCEEDINGS OF THE FOURTH INTERNATIONAL REINDEER/CARIBOU SYMPOSIUM; $22-25$ AUG 1985;WHITEHORSE, YUKON, CANADA. HARSTAD, NORWAY: RANGIFER. SPECIAL ISSUE 1. NORDIC COUNCIL FOR REINDEER RESEARCH. 272 PP.

4114. SKOGLUND, R. R. 1983. ESTIMATED IMPACT OF A STATE HIGHWAY ON MAMMAL POPULATIONS, DISTRIBUTIONS, AND HOME RANGES. TENNESSEE TECHNICAL JOURNAL 18:68-72.

4115. SKOLVING, H. 1987. TRAFFIC ACCIDENTS WITH MOOSE AND ROE DEER IN SWEDEN. REPORT OF RESEARCH, DEVELOPMENT AND MEASURES. PAGES 317-325 IN BERNARD,J.M, DANSIRAT,M., KEMPF,C., AND TILLE,M., EDITORS. ROUTES ET FAUNE SAUVAGE: ACTES DU COLLOQUE. CONSEIL DE L'EUROPE, STRASBOURG. 
4116. SKOOG, P. J. 1982. HIGHWAYS AND ENDANGERED WILDLIFE IN FLORIDA: IMPACTS AND RECOMMENDATIONS. FHWA FLBMR/84272; FLE/R2784. FLORIDA GAME AND FRESH WATER FISH COMMISSION. SPONSORED BY THE - FEDERAL HIGHWAY ADMINISTRATION AND FLORIDA STATE DEPARTMENT OF TRANSPORTATION, BUREAU OF ENVIRONMENT, TALLAHASSEE, FL.

4117. SKOVLIN, J. M., L. D. BRYANT and P. J. EDGERTON. 1989. TIMBER HARVEST AFFECTS ELK DISTRIBUTIONS IN THE BLUE MOUNTAINS OF OREGON. PACIFIC NORTHWEST RESEARCH STATION RESEARCH PAPER NO. PNW-RP-415USDA-FOREST-SERVICE. 10PP.

4118. SLAMECKA, J., P. HELL and R. JURCIK. 1997. BROWN HARE IN THE WESTSLOVAK LOWLAND. PRIRODOVENDNE PRACE USTAVU AKADEMIE VED CESKE REPUBLIKY V BRNE $31: 1-115$.

4119. SLATTER, R. J. 1978. ECOLOGICAL EFFECTS OF TRAMPLING ON SAND DUNE VEGETATION. JOURNAL OF BIOLOGICAL EDUCATION $12: 89-96$.

4120. SLEDD, C. A. 1977. FISH POPULATION RESPONSE TO SILTATION RESULTING FROM ROAD CONSTRUCTION ACTIVITIES. VIRGINIA COMMONWEALTH UNIVERSITY, DEPT. OF BIOLOGY, RICHMOND, VIRGINIA.

4121. SLOTT, B. J. 1980. WHITE-TAILED DEER MOVEMENTS, SURVIVAL, AND POPULATION CHARACTERISTICS IN THE CLEARWATER RIVER DRAINAGE, MONTANA. M.S. THESIS, UNIVERSITY OF MONTANA, MISSOULA, MT. 62 PP.

4122. SMALL, J. F. and M. L. HUNTER. 1988. FOREST FRAGMENTATION AND AVIAN NEST PREDATION IN FORESTED LANDSCAPES. OECOLOGIA 76:62-64.

4123. SMALL, R. J., J. C. HOLZWART and D. H. RUSCH. 1991. PREDATION AND HUNTING MORTALITY OF RUFFED GROUSE IN CENTRAL WISCONSIN. J. WLDL. MANAGE. 55 (3):512-20.

4124. SMALLWOOD, K. S. and E. L. FITZHUGH. 1995. A TRACK COUNT FOR ESTIMATING MOUNTAIN LION FELIS-CONCOLOR-CALIFORNICA POPULATION TREND . BIOLOGICAL CONSERVATION 71:251-259.

4125. SMARDON, R. C., F. J. SINGER, W. L. LANGLITZ, E. C. SAMUELSON and G. L. ROACH. 1985. ROADSIDE ENVIRONMENT. TRB/TRR-1016. TRANSPORTATION RESEARCH BOARD, WASHINGTON, DC.

4126. SMISLOVS, V. 1990. METHODS OF COUNTING BIRDS PERISHED ON MOTOR-ROADS. PUTNI DABA 1990:169-170.

4127. SMITH, A. T. and M. M. PEACOCK. 1990. CONSPECIFIC ATTRACTION AND THE DETERMINATION OF METAPOPULATION COLONIZATION RATES. CONSERVATION BIOLOGY 4(3):320-3.

4128. SMITH, A. D. and D. SCHUBERT. 1988. DISCRIMINATING DEGREE OF WHITE-TAILED DEER TRAVEL ROUTE USE. PROCEEDINGS OF THE WEST VIRGINIA ACADEMY OF SCIENCE 60(1):19-20.

4129. SMITH, B. L. 1978. INVESTIGATIONS INTO BLACK AND GRIZZLY BEAR RESPONSES TO COASTAL LOGGING - 1977. B.S. THESIS, SIMON FRASER UNIV., BURNABY, BC. 85PP.

4130. SMITH, B. L. 1976. ECOLOGY OF ROCKY MOUNTAIN GOATS IN THE BITTERROOT MOUNTAINS, MONTANA. M.S. THESIS, UNIVERSITY OF MONTANA, MISSOULA, MT. 203 PP.

4131. SMITH, C. A. 1986. RATES AND CAUSES OF MORTALITY IN MOUNTAIN GOATS IN SOUTHEAST ALASKA. J. WLDL. MANAGE. $50(4): 743-6$

4132. SMITH, C. S. 1978. SUMMER-FALL MOVEMENTS, MIGRATIONS, SEASONAL RANGES, AND HABITAT SELECTION OF THE MIDDLE FORK ELK HERD. M.S. THESIS, UNIVERSITY OF MONTANA, MISSOULA, MT. 91 PP.

4133. SMITH, D. G. 1974. GREAT HORNED OWL FEEDING ON A ROAD KILL. CANADIAN FIELD-NATURALIST. 88(1)

4134. SMITH, D. J. 1995. THE DIRECT AND INDIRECT IMPACTS OF HIGHWAYS ON THE VERTEBRATES OF PAYNE'S PRAIRIE STATE PRESERVE. THESISDEPARTMENT OF WLDLIFE ECOLOGY AND CONSERVATION, UNIVERSITY OF FLORIDA, GAINSVILLE, FL. 
4135. SMITH, D. J., L. D. HARRIS and F. J. MAZZOTTI. 1996. A LANDSCAPE APPROACH TO EXAMINING THE IMPACTS OF ROADS ON THE ECOLOGICAL FUNCTION ASSOCIATED WTH WLDLIFE MOVEMENT AND MOVEMENT CORRIDORS: PROBLEMS AND SOLUTIONS. PAGES 260-272 IN EVINK,G., ZIEGLER,D., GARRETT,P., AND BERRY,J., EDITORS. TRANSPORTATION AND WILDLIFE: REDUCING WILDLIFE MORTALITY AND IMPROVING WILDLIFE PASSAGEWAYS ACROSS TRANSPORTATION CORRIDORS: PROCEEDINGS OF THE FLORIDA DEPARTMENT OF TRANSPORTATION/FEDERAL HIGHWAY ADMINISTRATION TRANSPORTATION-RELATED WILDLIFE MORTALITY SEMINAR; 1996 APRIL 30-MAY 2; ORLANDO, FL. FHWA-PD-96-041. U.S. DEPARTMENT OF TRANSPORTATION, FEDERAL HIGHWAY ADMINISTRATION, WASHINGTON, DC.

4136. SMITH, D. L. O. and J. W. DICKSON. 1990. CONTRIBUTIONS OF VEHICLE WEIGHT AND GROUND PRESSURE TO SOIL COMPACTION. JOURNAL OF AGRICULTURAL ENGINEERING RESEARCH 46:13-29.

4137. SMITH, D. S. and P. C. HELLMUND. 1993. ECOLOGY OF GREENWAYS DESIGN AND FUNCTION OF LINEAR CONSERVATION AREAS. UNIVERSITY OF MINNESOTA PRESS, MINNEAPOLIS, MINNESOTA.

4138. SMITH, D. L. 1978. WILDLIFE CONSIDERATIONS IN RIGHTS-OF-WAY MANAGEMENT. RURAL URBAN ROADS 16(2):26-28.

4139. SMITH, D. S. 1984. HABITAT USE, HOME RANGE, AND MOVEMENTS OF BOBCATS IN WESTERN MONTANA. M.S. THESIS, UNIVERSITY OF MONTANA, MISSOULA, MT. 58 PP.

4140. SMITH, J. L. D. 1993. THE ROLE OF DISPERSAL IN STRUCTURING THE CHITWAN TIGER POPULATION. BEHAVIOUR 124 $(3-4): 165-95$.

4141. SMITH, K. 1982. AN EVALUATION OF THE IMPACT OF PETROLEUM ACTIVITY ON UNGULATE DISTRIBUTION IN TWP. 52 RGE. 14 - W5M. ALBERTA FISH AND WILDLIFE DIVISION, EDMONTON. UNPUBLISHED REPORT.

4142. SMITH, K. 1988. FACTORS AFFECTING MOUNTAIN GOAT PRODUCTION AND SURVIVAL IN WEST CENTRAL ALBERTA. BIENNIAL SYMPOSIUM NORTHERN WILD SHEEP AND GOAT COUNCIL6: 308-329

4143. SMITH, K. 1988. FACTORS AFFECTING THE POPULATION DYNAMICS OF MOUNTAIN GOATS IN WEST CENTRAL ALBERTA. ALBERTA FISH AND WILDLIFE DIVISION, EDMONTON. UNPUBLISHED REPORT.

4144. SMITH, K. M. 1973. SOME EFFECTS OF CLARK CANYON RESERVOIR ON THE LIMNOLOGY OF THE BEAVERHEAD RIVER, MONTANA. M.S. THESIS, MONTANA STATE UNIVERSITY, BOZEMAN, MT. 62 PP.

4145. SMITH, K. and M. BLOOMFIELD. 1980. STRATEGY FOR ELK MANAGEMENT DURING A PERIOD OF INTENSE OIL AND GAS ACTIVITY. PAGES 34-56 IN W. MACGREGOR, EDITOR. PROCEEDINGS OF THE WESTERN STATES ELK WORKSHOP. WESTERN ASSOC. FISH \& WILDL. AGENCIES AND BRITISH COLUMBIA FISH \& WILDL. BRANCH,

4146. SMITH, K. and J. EDMONDS. 1988. WILDLIFE CONCERNS RELATIVE TO THE BERLAND RESOURCES ROAD PROPOSAL. ALBERTA FORESTRY, LANDS AND WILDLIFE, FISH AN WILDLIFE DIVISION, EDSON, ALBERTA.

4147. SMITH, L. M., J. W. HUPP and J. T. RATTI. 1982. HABITAT USE AND HOME RANGE OF GRAY PARTRIDGE IN EASTERN SOUTH DAKOTA. J. WILDL. MANAGE. 46 (3):580-7.

4148. SMITH, N. S. and P. R. KRAUSMAN. 1988. DESERT BIGHORN SHEEP: A GUIDE TO SELECTED MANAGEMENT PRACTICES. U.S. FISH AND WILDLIFE SERVICE. WASHINGTON, D.C. BIOLOGICAL REPORT 88(35). VII + 27 PP.

4149. SMITH, N. S. 1962. THE FALL AND WINTER ECOLOGY OF THE SHIRAS MOOSE (ALCES ALCES SHIRASI) IN THE ROCK CREEK DRAINAGE, GRANITE COUNTY, MONTANA. PH.D. DISSERTATION, MONTANA STATE UNIVERSITY, MISSOULA, MT. 52 PP.

4150. SMITH, R. B. and L. J. VAN DAELE. 1990. IMPACTS OF HYDROELECTRIC DEVELOPMENT ON BROWN BEARS, KODIAK ISLAND, ALASKA. INT. CONF. BEAR RES. AND MANAGE. 8:93-103.

4151. SMITH, R. L. and J. L. COGGIN. 1984. BASIS AND ROLE OF MANAGEMENT (CHAPTER 35). P571-600. IN: HALLS, L.K.,(EDITOR). WHITE-TAILED DEER: ECOLOGY AND MANAGEMENT HARRISBURG/ PA: STACKPOLE BOOKS

4152. SMITH, R. H. 1952. A STUDY OF WATERFOWL PRODUCTION ON ARTIFICIAL RESERVOIRS IN EASTERN MONTANA. M.S. THESIS, MONTANA STATE COLLEGE, BOZEMAN, MT. 43 PP. 
4153. SMITH, T. R. 1985. ECOLOGY OF BLACK BEARS IN A BOTTOMLAND HARDWOOD FOREST IN ARKANSAS. PHD. THESIS, UNIVERSITY OF TENNESSEE, KNOXVILLE. 209PP.

4154. SMITH, T. L. 1959. A STUDY OF CONSERVATION INFORMATION FLOW IN WESTERN MONTANA. M.S. THESIS, UNIVERSITY OF MONTANA, MISSOULA, MT. 67 PP.

4155. SMITH, W. and R. D. CAMERON. 1991. COMPARATIVE MOVEMENTS OF SATELLITE COLLARED CARIBOU NEAR AND DISTANT FROM OIL DEVELOPMENT IN ARCTIC ALASKA. P 382-91. IN: BUTLER CE, MAHONEY SP, EDS. 4TH NORTH AMERICAN CARIBOU WORKSHOP PROC.; OCT31-NOV 31989 ; ST. JOHN'S, NEWFOUNDLAND. NEWFOUNDLAND AND LABRADOR WLDLIFE DIV.

4156. SMITH, W. D. and R. D. CAMERON. 1985. REACTIONS OF LARGE GROUPS OF CARIBOU TO A PIPELINE CORRIDOR ON THE ARCTIC COASTAL PLAIN OF ALASKA. ARCTIC 38:53-7.

4157. SMITH, W. G. 1981. OBSERVATIONS OF A LARGE HIGHWAY KILL OF EVENING GROSBEARKS IN BRITISH COLUMBIA. SYESIS 14:163-164.

4158. SMITH, W. T. and R. D. CAMERON. 1983. RESPONSES OF CARIBOU TO INDUSTRIAL DEVELOPMENT ON ALASKA'S ARCTIC COAST. ACTA ZOOL. FENN. (175): 43-5.

4159. SMITH, W. T. and R. D. CAMERON. 1983. RESPONSES OF CARIBOU TO INDUSTRIAL DEVELOPMENT ON ALASKA'S ARCTIC SLOPE. ACTA ZOOL. FENN. 175:43-45.

4160. SMITH, W. T., R. D. CAMERON and E. PULLIAINEN. 1983. PROCEEDINGS OF THE THIRD INTERNATIONAL THERIOLOGICAL CONGRESS AND THIRD INTERNATIONAL REINDEER/CARIBOU SYMPOSIUM.; AUG 15,1982; HELSINKI, SAARISELKA. ACTA ZOOLOGICA FENNICA.

4161. SMITH, W. T., R. D. CAMERON and D. J. REED. 1994. DISTRIBUTION AND MOVEMENTS OF CARIBOU IN RELATION TO ROADS AND PIPELINES, KUPARUK DEVELOPMENT AREA, 1978-90. ALASKA DEPARTMENT OF FISH AND GAME, DIVISION OF WILDLIFE CONSERVATION WILLIFE TECHNICAL BULLETIN 2:1-54.

4162. SMITH, W. T., R. D. CAMERON and D. J. REED. 1994. DISTRIBUTION AND MOVEMENTS OF CARIBOU IN RELATION TO ROADS AND PIPELINES, KUPARUK DEVELOPMENT AREA, 1978-90. STATE OF ALASKA, DEPT. OF FISH AND GAME, DIVISION OF WILDLIFE CONSERVATION, JUNEAU, ALASKA. WLDLIFE TECHNICAL BULLETIN NO. 12.

4163. SMITHWMCK, J. W. P.I. 2000. DEVELOPMENT OF NUCLEAR DNA MARKERS TO DETECT HYBRIDIZATION AND ASSESS PHYLOGENETIC RELATIONSHIPS AMONG SUBSPECIES OF RAINBOW TROUT (ONCORHYNCHUS MYKISS) AND CUTTHROAT TROUT (ONCORHYNCHUS CLARKI). M.S. THESIS, UNIVERSITY OF MONTANA, MISSOULA, MT. 77 PP.

4164. SNELSON, S. I. 1996. RESPONSES OF RAINBOW (ONCORHYNCHUS MYKISS) AND BROWN TROUT (SALMO TRUTTA) TO CREATION OF ACCESS INTO A SPAWNING TRIBUTARY. M.S. THESIS, MONTANA STATE UNIVERSITY, BOZEMAN, MT. 82 PP.

4165. SNOW, C. 1973. HABITAT MANAGEMENT SERIES FOR ENDANGERED SPECIES, REPORT NO. 6: SAN JOAQUIN KIT FOX VULPES MACROTIS MUTICA, RELATED SUBSPECIES AND THE SWFT FOX, VULPES VELOX. U.S. BUREAU OF LAND MANAGEMENT. TECH. NOTE 238. 24PP

4166. SNOW, C. and C. SNOW. 1974. HABITAT MANAGEMENT SERIES FOR UNIQUE OR ENDANGERED SPECIES, REPORT NO. 13: FERRUGINOUS HAWK BUTEO REGALIS . USDI BUREAU OF LAND MANAGEMENT . TECHNICAL NOTE 225 (255?). 23PP

4167. SNYDER, R. O. 1969. FORAGE COMPETITION BETWEEN CATTLE AND ELK IN THE GIRD CREEK DRAINAGE OF WESTERN MONTANA. M.S. THESIS, UNIVERSITY OF MONTANA, MISSOULA, MT. 76 PP.

4168. SNYDER, W. D. 1974. PHEASANT USE OF ROADSIDES FOR NESTING IN NORTHEAST COLORADO. SPECIAL REPORT COLORADO DIVISION OF WLDLIFE ; NO. 36: SPECIAL REPORT (COLORADO. DIVISION OF WILDLIFE) NO. 36. COLORADO DIVISION OF WILDLIFE, DENVER, COLORADO.

4169. SOKALE, J. and L. TRULIO. 1996. SAN FRANCISCO BAY TRAIL PROJECT: WILDLIFE AND PUBLIC ACCESS STUDY PROPOSED RESEARCH PLAN. SAN FRANCISCO BAY TRAIL PROJECT. 34PP. 
4170. SOLHEIM, R., J. H. ENGAN and H. J. ENGAN. 1995. A CORRIDOR INTO THE FUTURE FOR WILD REINDEER (RANGIFER TARANDUS) IN NORWAY. FAUNA 48:90-95.

4171. SOLOMON, K. 1982. INVESTIGAION OF ANITCIPATED EFFECTS IF OAHE IRRIGATION UNIT DEVELOPMENT OF WLDLIFE HABITAT AND ASSOCIATED WLDLIFE POPULATIONS. SOUTH DAKOTA DEPARTMENT OF GAME, FISH AND PARKS.

4172. SOLOMON, K. 1978. INVESTIGATION OF ANTICIPATED EFFECTS OF OAHE IRRIGATION UNIT DEVELOPMENT ON WILDLIFE HABITAT AND ASSOCIATED WLDLIFE POPULATIONS. SO. DAKOTA DEPT. OF GAME, FISH \& PARKS.

4173. SOLTERO, R. A. 1968. CHEMICAL AND PHYSICAL FINDINGS FROM POLLUTION STUDIES ON THE EAST GALLATIN RIVER AND ITS TRIBUTARIES. M.S. THESIS, MONTANA STATE UNIVERSITY, BOZEMAN, MT. 111 PP.

4174. SOLTERO, R. A. 1971. LIMNOLOGICAL STUDIES ON BIGHORN LAKE (YELLOWTAIL DAM) AND ITS TRIBUTARIES. PH.D. DISSERTATION, MONTANA STATE UNIVERSITY, BOZEMAN, MT. 271 PP.

4175. SOMERMA, P. 1991. DEAD ANIMALS ON THE MOTORWAY IN HELSINKI. LUONNON TUTKIJA 95 (5):217-9.

4176. SOMERVILLE, R. J. 1965. AN EVALUATION OF THE 1961-63 ALASKAN BROWN AND GRIZZLY BEAR MANAGEMENT PROGRAM. M.S. THESIS, UNIVERSITY OF MONTANA, MISSOULA, MT. 117 PP.

4177. SOMSOOK, S. and H. M. STEINER. 1991. HOME-RANGE SIZE OF MICROTUS ARVALIS (PALLAS, 1779). ZEITSCHRIFT FUER SAEUGETIERKUNDE $56(4): 200-6$.

4178. SOPUCK, L. G. and R. D. JAKIMCHUK. 1988. A REVIEW OF WILDLIFE MITIGATION OPTIONS FOR PHASE III OF THE BANFF HIGHWAY TWINNING PROJECT. RENEWABLE RESOURCES CONSULTING SERVICES LTD. PREPARED FOR PUBLIC WORKS CANADA. 72PP.

4179. SOPUCK, L. G., C. E. TULL, J. E. GREEN and R. E. SALTER. 1979. IMPACTS OF DEVELOPMENT ON WILDLIFE: A REVIEW FROM THE PERSPECTIVE OF THE COLD LAKE PROJECT. LGL LTD., CALGARY, ALBERTA. PREPARED FOR ESSO RESOURCES CANADA LTD. 4OPP.

4180. SOPUCK, L. G. and D. J. VERNAM. 1986. DISTRIBUTION AND MOVEMENTS OF MOOSE (ALCES ALCES) IN RELATION TO THE TRANS-ALASKA OIL PIPELINE. ARCTIC 39 (2):138-44

4181. SORLEY, C. S. and D. E. ANDERSEN. 1994. RAPTOR ABUNDANCE IN SOUTH-CENTRAL KENYA'IN RELATION TO LAND-USE PATTERNS. AFRICAN JOURNAL OF ECOLOGY 32 (1):30-8.

4182. SOULE, M. E. 1987. VIABLE POPULATIONS FOR CONSERVATION. NEWYORK, N.Y.: CAMBRIDGE UNIVERSITY PRESS.

4183. SOULE, M. E., D. T. BOLGER, A. C. ALBERTS, J. WRIGHT, M. SORICE and S. HILL. 1988. RECONSTRUCTED DYNAMICS OF RAPID EXTINCTIONS OF CHAPARRAL-REQUIRING BIRDS IN URBAN HABITAT ISLANDS. CONSERVATION BIOLOGY 2 (1):75-92.

4184. SOUTH, P. R. 1957. FOOD HABITS AND RANGE USE OF THE MULE DEER IN THE SCUDDER CREEK AREA, BEAVERHEAD COUNTY, MONTANA. M.S. THESIS, MONTANA STATE COLLEGE, BOZEMAN, MT. 34 PP.

4185. SOUTHALL, P. D. 1991. THE RELATIONSHIP BETWEEN WLDLIFE AND HIGHWAYS IN THE PAYNES PRAIRIE BASIN. FLORIDA DEPARTMENT OF TRANSPORTATION, DISTRICT 2,PROJECT DEVELOPMENT \& ENVIRONMENT, ENVIRONMENTAL SECTION, LAKE CITY, FLORIDA.29PP.

4186. SOUTHERLAND, M. T. 1995. CONSERVING BIODIVERSITY IN HIGHWAY DEVELOPMENT PROJECTS. ENVIRONMENTAL PROFESSIONAL 17 (3):226-42.

4187. SOUTIERE, E. C. 1979. EFFECT OF TIMBER HARVESTING ON MARTEN IN MAINE. J. WLDL. MANAGE. 43 (4):850-60.

4188. SOVEY, S. J. 1988. BREEDING ECOLOGY OF CANADA GEESE ON AN IRRIGATION RESERVOIR IN NORTHWESTERN MONTANA. M.S. THESIS, UNIVERSITY OF MONTANA, MISSOULA, MT. 44 PP. 
4189. SOWL, L. W. and J. C. BARTONEK. 1974. SEABIRDS-ALASKA'S MOST NEGLECTED RESOURCE. TRANSACTIONS OF THE NORTH AMERICAN WLDLIFE AND NATURAL RESOURCES CONFERENCE 39:117-126.

4190. SPARKS, J. R. 1997. BREEDING BIRD COMMUNITIES IN MATURE AND OLD-GROWTH DOUGLAS FIR FOREST IN SOUTHWEST MONTANA. M.S. THESIS, MONTANA STATE UNIVERSITY, BOZEMAN, MT. 68 PP.

4191. SPARROWE, R. D. and P. F. SPRINGER. 1970. SEASONAL ACTIVITY PATTERNS OF WHITE-TAILED DEER IN EASTERN SOUTH DAKOTA. J. WILDL. MANAGE. 34 (2):420-31.

4192. SPENCER, H. J. and G. R. PORT. 1988. EFFECTS OF ROADSIDE CONDITIONS ON PLANTS AND INSECTS. II. SOIL CONDITIONS. JOURNAL OF APPLIED ECOLOGY 25:709-715.

4193. SPENCER, W. D., R. H. BARRETT and W. J. ZIELINSKI. 1983. MARTEN HABITAT PREFERENCES IN THE NORTHERN SIERRA NEVADA. J. WILDL. MANAGE. 47 (4):1181-6.

4194. SPERRY, C. C. 1933. HIGHWAY MORTALITY OF RABBITS IN IDAHO. JOURNAL OF MAMMALOGY 14:260-266.

4195. SPILLETT, J. J. and R. S. ZOBELL. 1967. INNOVATIONS IN TRAPPING AND HANDLING PRONGHORN ANTELOPES. J. WILDL. MANAGE. 31 (2):347-51.

4196. SPINDLER, J. C. 1954. GAME FISH LOSS IN CERTAIN IRRIGATION DIVERSIONS OF THE WEST GALLATIN RIVER, MONTANA, IN RELATION TO THE PHYSICAL CHARACTERISTICS OF CANAL INTAKES. M.S. THESIS, MONTANA STATE COLLEGE, BOZEMAN, MT. 33 PP.

4197. SPOON, R. L. 1985. REPRODUCTIVE BIOLOGY OF BROWN AND RAINBOW TROUT BELOW HAUSER DAM, MISSOURI RIVER, WITH REFERENCE TO PROPOSED HYDROELECTRIC PEAKING. M.S. THESIS, MONTANA STATE UNIVERSITY, BOZEMAN, MT. 144 PP.

4198. SPREADBURY, B., K. MUSIL, J. MUSIL, C. KAISNER and J. KOVAK. 1996. COUGAR POPULATION CHARACTERISTICS IN SOUTHEASTERN BRITISH COLUMBIA. J. WILDL. MANAGE.60(4):962-9.

4199. SPRINGER, J. T. 1982. MOVEMENT PATTERNS OF COYOTES IN SOUTH CENTRAL WASHINGTON. J. WILDL. MANAGE. 46 $(1): 191-200$

4200. STACEY, P. B. and M. TAPER. 1992. ENVIRONMENTAL VARIATION AND THE PERSISTENCE OF SMALL POPULATIONS. ECOLOGICAL APPLICATIONS 2:18-29.

4201. STADNYK, L. 1971. FACTORS AFFECTING THE DISTRIBUTION OF STONEFLIES IN THE YELLOWSTONE RIVER, MONTANA. PH.D. DISSERTATION, MONTANA STATE UNIVERSITY, BOZEMAN, MT. 36 PP.

4202. STALMASTER, M. V. 1983. AN ENERGETICS SIMULATION MODEL FOR MANAGING WINTERING BALD EAGLES. J. WILDL. MANAGE. 47 (2):349-59.

4203. STALMASTER, M. V. 1976. WINTER ECOLOGY AND EFFECTS OF HUMAN ACTIVITY ON BALD EAGLES IN THE NOOKSAC RIVER VALLEY, WASHINGTON. THESIS, WEST WASHINGTON UNIVERSITY, BELLINGHAM, WASHINGTON. 100PP.

4204. STALMASTER, M. V. and J. R. NEWMAN. 1978. BEHAVIORAL RESPONSES OF WINTERING BALD EAGLES TO HUMAN ACTIVITY. J. WILDL. MANAGE. 42 (3):506-13.

4205. STANGEL, P. W., M. R. LENNARTZ and M. H. SMITH. 1992. GENETIC VARIATION AND POPULATION STRUCTURE OF RED-COCKADED WOODPECKERS. CONSERV. BIOL. 6 (2):283-92.

4206. STANGL, J. M. 1994. EFFECTS OF MONITORING EFFORT AND RECREATION PATTERSN ON TEMPORAL AND SPATIAL ACTIVITIES OF BREEDING BALD EAGLES. M.S. THESIS, MONTANA STATE UNIVERSITY, BOZEMAN, MT. 74 PP.

4207. STANLEY, T. R. J. and J. BART. 1991. EFFECTS OF ROADSIDE HABITAT AND FOX DENSITY ON A SNOW TRACK SURVEY FOR FOXES IN OHIO. OHIO J. SCI. 91 :186-190. 
4208. STANSBERRY, B. 1996. EVALUATION OF BIGHORN SHEEP AND MULE DEER HABITAT ENHANCEMENTS ALONG KOOCANUSA RESERVOIR. MT FWP.

4209. STANSBERRY, B. J. 1991. DISTRIBUTION, MOVEMENTS, AND HABITAT USE DURING SPRING, SUMMER AND FALL BY MULE DEER IN THE NORTH SALISH MOUNTAINS, MONTANA. M.S. THESIS, MONTANA STATE UNIVERSITY, BOZEMAN, MT. 64 PP.

4210. STARRETT, W. C. 1938. HIGHWAY CASUALTIES IN CENTRAL ILLINOIS DURING 1937. WILSON BULLETIN 50:193-196.

4211. STATHAM, M. and H. L. STATHAM. 1997. MOVEMENTS AND HABITS OF BRUSHTAIL POSSUMS (TRICHOSURUS VULPECULA KERR) IN AN URBAN AREA. WILDLIFE RESEARCH 24(6):715-726.

4212. STEBBINS, R. C. 1974. OFF-ROAD VEHICLES AND THE FRAGILE DESERT. AM. BIOL. TEACH. 36:294-304.

4213. STEENHOF, K. and M. N. KOCHERT. 1982. AN EVALUATION OF METHODS USED TO ESTIMATE RAPTOR NESTING SUCCESS. J. WLDL. MANAGE. 46 (4):885-93.

4214. STEENHOF, K., M. N. KOCHERT and J. A. ROPPE. 1993. NESTING BY RAPTORS AND COMMON RAVENS ON ELECTRICAL TRANSMISSION LINE TOWERS. J. WLDL. MANAGE. 57(2):271-81.

4215. STEEREY, W. F. 1979. DISTRIBUTION, RANGE USE AND POPULATION CHARACTERISTICS OF MULE DEER ASSOCIATED WITH THE SCHAFER CREEK WINTER RANGE, BRIDGER MOUNTAINS, MONTANA. M.S. THESIS, MONTANA STATE UNIVERSITY, BOZEMAN, MT. 119 PP.

4216. STEFANICH, F. A. 1951. THE POPULATION AND MOVEMENT OF FISH IN PRICKLEY PEAR CREEK, MONTANA. M.S. THESIS, MONTANA STATE COLLEGE, BOZEMAN, MT. 42 PP.

4217. STEHN, T. V. 1973. DAILY MOVEMENTS AND ACTIVITIES OF COW ELK IN THE SAPPHIRE MOUNTAINS OF WESTERN MONTANA DURING SUMMER AND FALL. M.S. THESIS, UNIVERSITY OF MONTANA, MISSOULA, MT. 66 PP.

4218. STEIDL, R. J. 1994. HUMAN IMPACTS ON THE ECOLOGY OF BALD EAGLES IN INTERIOR ALASKA. PHD THESIS, OREGON STATE UNIVERSITY. 168PP

4219. STEINER, A. J. and S. P. LEATHERMAN. 1979. AN ANNOTATED BIBLIOGRAPHY OF OFF-ROAD VEHICLE AND PEDESTRIAN TRAFFIC ON COASTAL ECOSYSTEMS. NATIONAL PARK SERVICE COOPERATIVE RESEARCH UNIT. UNIVERSITY OF MASSACHUSETTS, AMHERST MASSACHUSETTS. REPORT 45. 87PP.

4220. STEINER, A. J. and S. P. LEATHERMAN. 1981. RECREATIONAL IMPACTS ON THE DISTRIBUTION OF GHOST CRABS OCYPODE QUADRATA FAB. BIOL. CONSERV. 20:11-122.

4221. STEINITZ, C. 1990. TOWARD A SUSTAINABLE LANDSCAPE WITH HIGH VISUAL PREFERENCE AND HIGH ECOLOGICAL INTEGRITY: THE LOOP ROAD IN ACADIA NATIONAL PARK, U.S.A. LANDSCAPE URBAN PLANN. 19:213-250.

4222. STELFOX, J. 1972. EFFECTS OF ROADS AND RAILWAYS ON NATIVE UNGULATES. CANADIAN WLDLIFE SERVICE, EDMONTON, ALBERTA.

4223. STELFOX, J. G. 1972. TITLE UNKNOWN. CAN. WILDL. SERV. UNPUBLISHED WILDLIFE REPORT. 67PP.

4224. STELFOX, J. G. and J. A. BINDERNAGEL. 1978. CARIBOU BEHAVIOR IN RELATION TO HUMAN-ELK-WOLF INFLUENCES; JASPER NATIONAL PARK, 1971-1974. CANADIAN WILDLIFE SERVICE, EDMONTON. UNPUBLISHED REPORT

4225. STELFOX, J. G. 1976. RANGE ECOLOGY OF ROCKY MOUNTAIN BIGHORN SHEEP IN CANADIAN NATIONAL PARKS. PH.D. DISSERTATION, UNIVERSITY OF MONTANA, MISSOULA, MT. 50 PP.

4226. STEMP, R. E. 1983. HEART RATE RESPONSES OF BIGHORN SHEEP TO ENVIRONMENTAL FACTORS AND HARASSMENT. THESIS, UNIVERSITY OF CALGARY, ALBERTA, CANADA. 314PP. + APPENDICES (371PP.)

4227. STEPHEN, W. J. D. 1963. SOME RESPONSES OF FEMALE MALLARDS TO DISTURBANCE BY MAN. J. WILDL. MANAGE. 27 (2):280-4. 
4228. STEPHENSON, R. O. 1974. CHARACTERISTICS OF WOLF DEN SITES. ALASKA DEPT. OF FISH AND GAME, JUNEAU. PROJ. NOS. W-17-2 THRU W-17-6, JOB NO. 14.6R

4229. STEVENS, D. R. 1965. RANGE RELATIONSHIPS OF ELK AND LIVESTOCK IN THE CROW CREEK DRAINAGE OF ELKHORN MOUNTAINS, MONTANA. M.S. THESIS, MONTANA STATE UNIVERSITY, BOZEMAN, MT. 68 PP.

4230. STEVENS, S., C. CALLAGHAN and R. OWCHAR. 1996. A SURVEY OF WLLLIFE CORRIDORS IN THE BOW VALLEY OF BANFF NATIONAL PARK, WINTER 1994/95. 41PP

4231. STEVENSON, H. R. 1975. THE TROUT FISHERY OF THE BIGHORN RIVER BELOW YELLOWTAIL DAM, MONTANA. M.S. THESIS, MONTANA STATE UNIVERSITY, BOZEMAN, MT. 67 PP.

4232. STEVENSON, J. A. 1996. FLORIDA'S ECOSYSTEM MANAGEMENT AND WLDLIFE. PAGES $273-277$ IN EVINK,G., ZIEGLER,D., GARRETT,P., AND BERRY,J., EDITORS. TRANSPORTATION AND WILDLIFE: REDUCING WILDLIFE MORTALITY AND IMPROVING WILDLIFE PASSAGEWAYS ACROSS TRANSPORTATION CORRIDORS: PROCEEDINGS OF THE FLORIDA DEPARTMENT OF TRANSPORTATION/FEDERAL HIGHWAY ADMINISTRATION TRANSPORTATION-RELATED WILDLIFE MORTALITY SEMINAR; 1996 APRIL 30-MAY 2; ORLANDO, FL. FHWA-PD-96-041. U.S. DEPARTMENT OF TRANSPORTATION, FEDERAL HIGHWAY ADMINISTRATION, WASHINGTON, DC.

4233. STEVENSON, R. E. 1971. TEMPERATURE ACCLIMATION IN THE BLACK-BILLED MAGPIE (PICA PICA HUDSONIIA SABINE). PH.D. DISSERTATION, MONTANA STATE UNIVERSITY, BOZEMAN, MT. 33 PP.

4234. STEVENSON, S. K. 1979. EFFECTS OF SELECTIVE LOGGING ON ARBOREAL LICHENS USED BY SELKIRK CARIBOU. FISH AND WILDLIFE REPORT NO. R-2, BRITISH COLUMBIA MINISTRY OF THE ENVIRONMENT.

4235. STEVENSON, S. K. and D. F. HATLER. N.D. WOODLAND CARIBOU AND THEIR HABITAT IN SOUTHERN AND CENTRAL BRITISH COLUMBIA VOL. 1. BRITISH COLUMBIA MINISTRY OF FORESTS, VICTORIA.

4236. STEWART, D. L. 1981. A PLAN FOR MANAGING DALL'S SHEEP ALONG THE DEMPSTER HIGHWAY, YUKON TERRITORY. CANADIAN THESES ON MICROFICHE 57191. UNIVERSITY OF CALGARY, FACULTY OF ENVIRONMENTAL DESIGN, CALGARY, ALBERTA.

4237. STEWART, S. T. 1975. ECOLOGY OF THE WEST ROSEBUD AND STILLWATER BIGHORN SHEEP HERDS, BEARTOOTH MOUNTAINS, MONTANA. M.S. THESIS, MONTANA STATE UNIVERSITY, BOZEMAN, MT. 130 PP.

4238. STIFF, R. K. 1998. FACTORS AFFECTING GROWTH OF YELLOWSTONE CUTTHROAT TROUT (ONCORHYNCHUS CLARKI BOUVIERI) IN ALPINE LAKES, OF THE ABSAROKA-BEARTOOTH WILDERNESS, MONTANA. M.S. THESIS, MONTANA STATE UNIVERSITY, BOZEMAN, MT. 108 PP.

4239. STILES, B. F. and G. O. HENDRICKSON. 1946. TEN YEARS OF ROADSIDE PHEASANT CENSUSES IN IOWA. J. WILDL. MANAGE. $10(3): 277-80$

4240. STIRLING, I. and W. CALVERT. 1983. ENVIRONMENTAL THREATS TO MARINE MAMMALS IN THE CANADIAN ARCTIC. POLAR REC. 21:433-449.

4241. STIVEN, A. E. and R. C. BRUCE. 1988. ECOLOGICAL GENETICS OF THE SALAMANDER DESMOGNATHUS QUADRAMACULATUS FROM DISTURBED WATERSHEDS IN THE SOUTHERN APPALACHIAN BIOSPHERE RESERVE CLUSTER. CONSERVATION BIOLOGY 2 (2):194-205.

4242. STIVERS, T. S. 1988. EFFECTS OF LIVESTOCK GRAZING ON GRIZZLY BEAR HABITAT ALONG THE EAST FRONT OF THE ROCKY MOUNTAINS, MONTANA. M.S. THESIS, MONTANA STATE UNIVERSITY, BOZEMAN, MT. 80 PP.

4243. STOBER, Q. J. 1962. SOME LIMNOLOGICAL EFFECTS OF TIBER RESERVOIR ON THE MARIAS RIVER. M.S. THESIS, MONTANA STATE COLLEGE, BOZEMAN, MT. 37 PP.

4244. STOBER, Q. J. 1968. ANALYSIS OF SOUND SPECTRA IN YELLOWSTONE LAKE IN RELATION TO ORIENTATION AND HOMING MOVEMENTS OF CUTTHROAT TROUT (SALMO CLARKI). PH.D. DISSERTATION, MONTANA STATE UNIVERSITY, BOZEMAN, MT. 40 PP. 
4245. STOCKSTAD, D. S. 1953. THE CHEMICAL CHARACTERISTICS OF NATURAL LICKS USED BY BIG GAME ANIMALS IN WESTERN MONTANA. M.S. THESIS, MONTANA STATE UNIVERSITY, MISSOULA, MT. 44 PP.

4246. STOCKWELL, C. A., G. C. BATEMAN and J. BERGER. 1991. CONFLICTS IN NATIONAL PARKS: A CASE STUDY OF HELICOPTERS IN BIGHORN SHEEP TIME BUDGETS AT THE GRAND CANYON. BIOL. CONSERV. 56:317-28

4247. STOCKWELL, S. S. and J. JACOBS. 1992. EFFECTS OF LAKESHORE DEVELOPMENT AND RECREATIONAL ACTIVITY ON THE REPRODUCTIVE SUCCESS OF COMMON LOONS IN SOUTHERN MAINE. PAGES 222-234 IN PROCEEDINGS FROM THE 1992 CONFERENCE ON THE LOON AND ITS ECOSYSTEMS: STATUS, MANAGEMENT, AND ENVIRONMENTAL CONCERNS. AUGUST 22-24, 1992, COLLEGE OF THE ATLANTIC, BAR HARBOR, MAINE. MAINE AUDOBON SOCIETY. FALMOUTH, MAINE.

4248. STOECKER, R. E. 1967. A POPULATION STUDY OF FIVE SPECIES OF SMALL RODENTS IN THE BRIDGER MOUNTAINS OF MONTANA. M.S. THESIS, MONTANA STATE UNIVERSITY, BOZEMAN, MT. 32 PP.

4249. STOHLGREN, T. J. and D. J. PARSONS. 1992. EVALUATING WLDERNESS RECREATIONAL OPPORTUNITIES: APPLICATION OF AN IMPACT MATRIX. ENVIRONMENTAL MANAGEMENT 16:397-403.

4250. STOLL, R. J. JR. 1980. INDICES TO RUFFED GROUSE HUNTING SUCCESS IN OHIO. WILDL. SOC. BULL. 8 (1):24-8.

4251. STONE, G. 1992. ROADSIDE MANAGEMENT WITHIN VIC ROADS - AN OVERVIEW. VICTORIAN NATURALIST 109(4):111-115.

4252. STONE, J. L. 1971. WINTER MOVEMENTS AND DISTRIBUTION OF MOOSE (ALCES ALCES SHIRASI) IN UPPER ROCK CREEK DRAINAGE, GRANITE COUNTY, MONTANA. M.S. THESIS, UNIVERSITY OF MONTANA, MISSOULA, MT. $80 \mathrm{PP}$.

4253. STONEBERG, R. P. 1967. A PRELIMINARY STUDY OF THE BREEDING BIOLOGY OF THE SPRUCE GROUSE IN NORTHWESTERN MONTANA. M.S. THESIS, UNIVERSITY OF MONTANA, MISSOULA, MT. 82 PP.

4254. STONER, D. 1925. THE TOLL OF THE AUTOMOBILE. SCIENCE 61:56-58.

4255. STORER, T. I. and G. H. TRUE, JR. 1931. DEER PROOF FENCES IN CALIFORNIA. CALIFORNIA FISH AND GAME 17:263-269.

4256. STORM, G. L. 1972. DAYTIME RETREATS AND MOVEMENTS OF SKUNKS ON FARMLANDS IN ILLINOIS. J. WILDL. MANAGE. $36(1): 31-45$.

4257. STORM, G. L. 1962. PORCUPINE DAMAGE IN PONDEROSA PINE STANDS OF WESTERN MONTANA. M.S. THESIS, MONTANA STATE UNIVERSITY; MISSOULA, MT. 149 PP.

4258. STOUFFER, P. C. and R. O. J. BIERREGAARD. 1995. EFFECTS OF FOREST FRAGMENTATION ON UNDERSTORY HUMMINGBIRDS IN AMAZONIAN BRAZIL. CONSERVATION BIOLOGY 9(5):1085-94.

4259. STOUFFER, P. C. and R. O. J. BIERREGAARD. 1993. SPATIAL AND TEMPORAL ABUNDANCE PATTERNS OF RUDDY QUAIL-DOVES (GEOTRYGON MONTANA) NEAR MANAUS, BRAZIL. CONDOR 95 (4):896-903.

4260. STOUFFER, P. C. and R. O. J. BIERREGAARD. 1995. USE OF AMAZONIAN FOREST FRAGMENTS BY UNDERSTORY INSECTIVOROUS BIRDS. ECOLOGY (WASHINGTON DC) 76 (8):2429-45.

4261. STOUT, B. M. I. 1992. IMPACTS OF OFF-ROAD VEHICLE USE ON VEGETATIVE COMMUNITIES OF NORTHERN CANAAN VALLEY, WEST VIRGINIA. PREPARED FOR THE CANAAN VALLEY TASK FORCE. FINAL REPORT. PP.12-13.

4262. STOUT, R. J., R. C. STEDMAN, D. J. DECKER and B. A. KNUTH. 1993. PERCEPTIONS OF RISK FROM DEER-RELATED VEHICLE ACCIDENTS: IMPLICATIONS FOR PUBLIC PREFERENCES FOR DEER HERD SIZE. WLDLIFE SOCIETY BULLETIN 21:237-249.

4263. STRAKA, U. 1995. CONTRIBUTION TO FREQUENCY AND SEASONAL DISTRIBUTION OF ROAD KILLS OF LONG-EARED OWL (ASIO OTUS) AND TAWNY OWL (STRIX ALUCO). EGRETTA 38(2):130-132. 
4264. STRAKER, A. 1998. MANAGEMENT OF ROADS AS BIOLINKS AND HABITAT ZONES IN AUSTRALIA. PAGES 181-188 IN EVINK, G., ZIEGLER,D., GARRETT,P., AND BERRY,J., EDITORS. PROCEEDINGS OF THE INTERNATIONAL CONFERENCE ON WILDLIFE ECOLOGY AND TRANSPORTATION; 1998 FEBRUARY 10-12; FT. MYERS, FL FLORIDA DEPARTMENT OF TRANSPORTATION, TALLAHASSEE, FL.

4265. STRAND, S. 1979. RECOVERY OF A SIERRAN MEADOW AFTER TRAMPLING BY PACK STOCK. PAGES 88-93 IN J. T. JR. STANLEY, H. T. HARVEY, AND R. J. HARTESVELT, EDITORS. A REPORT ON THE WLDERNESS IMPACT STUDY: THE EFFECTS OF HUMAN RECREATIONAL ACTIVITIES ON WLDERNESS ECOSYSTEMS WITH SPECIAL EMPHASIS ON SIERRA CLUB WILDERNESS OUTINGS IN THE SIERRA NEVADA. CONSOLIDATED PUBLICATIONS INC., PALO ALTO, CALIFORNIA.

4266. STRAUSS, E. G. 1990. REPRODUCTIVE SUCCESS, LIFE HISTORY PATTERNS, AND BEHAVIORAL VARIATION IN A POPULATION OF PIPING PLOVERS SUBJECTED TO HUMAN DISTURBANCE. PHD THESIS, TUFTS UNIVERSITY. 153 PP.

4267. STRAUSS, E. G. 1990. REPRODUCTIVE SUCCESS, LIFE HISTORY PATTERNS, AND BEHAVIORAL VARIATION IN A POPULATION OF PIPING PLOVERS SUBJECTED TO HUMAN DISTURBANCES. DISSERTATION, TUFTS UNIVERSITY, MEDFORD, MASSACHUSETTS. 153PP.

4268. STRELKE, W. K. and J. G. DICKSON. 1980. EFFECT OF FOREST CLEAR-CUT EDGE ON BREEDING BIRDS IN EAST TEXAS. J. WILDL. MANAGE. 44 (3):559-67.

4269. STREU, J. M. 1990. AN EVALUATION OF HABITAT IMPROVEMENT STRUCTURES IN THE BOULDER RIVER, MONTANA. M.S. THESIS, MONTANA STATE UNIVERSITY, BOZEMAN, MT. 54 PP.

4270. STRIBLING, H. L. and P. D. DOERR. 1985. NOCTURNAL USE OF FIELDS BY AMERICAN WOODCOCK. J. WILDL. MANAGE. 49 (2):485-91.

4271. STRONG, A. M. and G. T. BANCROFT. 1994. PATTERNS OF DEFORESTATION AND FRAGMENTATION OF MANGROVE AND DECIDUOUS SEASONAL FORESTS IN THE UPPER FLORIDA KEYS. BULLETIN OF MARINE SCIENCE 54 (3):795-804

4272. STRONG, A. M. and G. T. BANCROFT. 1994. POSTFLEDGING DISPERSAL OF WHITE-CROWNED PIGEONS: IMPLICATIONS FOR CONSERVATION OF DECIDUOUS SEASONAL FORESTS IN THE FLORIDA KEYS. CONSERVATION BIOLOGY $8(3): 770-9$.

4273. STUART, A. N. 1991. HOW CAN THE EDGE EFFECT BE MINIMIZED. PAGES 417-418 IN SAUNDERS,D.A. AND HOBBS,R.J., EDITORS. NATURE CONSERVATION 2: THE ROLE OF CORRIDORS. SURREY BEATTY AND SONS, CHIPPING NORTON, AUSTRALIA.

4274. STUART-SMITH, K., K. BRINK, C. EDEY, H. KLAASSEN, A. B. RIPPIN, D. SLAGHT and S. STUCKLESS. 1996. ACCESS MANAGEMENT IN CARIBOU AREAS - THE NERSC APPROACH. PAPER PRESENTED AT ASPB ACCESS MANAGEMENT CONFERENCE; 1996 APR10; CALGARY, ALBERTA.

4275. STUART-SMITH, K. and A. R. C. JAMES. 1996. DO LINEAR CORRIDORS AFFECT THE DISTRIBUTION AND MOVEMENTS OF CARIBOU AND WOLVES? 7TH NORTH AMERICAN CARIBOU CONFERENCE; 19-21 AUG 1996; LAKEHEAD UNIV., THUNDER BAY, ONTARIO.

4276. STUART, T. W. 1978. MANAGEMENT MODELS FOR HUMAN USE OF GRIZZLY BEAR HABITAT. DISSERTATION, UNIVERSITY OF CALIFORNIA, BERKELEY, CALIFORNIA. 252PP.

4277. STUART, T. W. 1977. MULTIOBJECTIVE ANALYSIS OF WILDERNESS TRAVEL IN GRIZZLY BEAR HABITAT USING PARAMETRIC LINEAR PROGRAMMING. TRANS. N. AMER. WIDL. NAT. RESOUR. CONF. 43:434-441.

4278. STUSSY, R. J., W. D. EDGE and T. A. O'NEIL. 1994. SURVIVAL OF RESIDENT AND TRANSLOCATED FEMALE ELK IN THE CASCADE MOUNTAINS OF OREGON. WILDL. SOC. BULL.22 (2):242-7.

4279. SUGDEN, L. G. and G. W. BEYERSBERGEN. 1987. EFFECT OF NESTING COVER DENSITY ON AMERICAN CROW PREDATION OF SIMULATED DUCK NESTS. J. WILDL. MANAGE. 51 (2):481-485.

4280. SULLIVAN, M. G. 1988. DISTRIBUTION, HABITAT USE, AND FOOD HABITS OF REINTRODUCED ELK IN THEODORE ROOSEVELT NATIONAL PARK, NORTH DAKOTA. M.S. THESIS, MONTANA STATE UNIVERSITY, BOZEMAN, MT. 
$94 \mathrm{PP}$.

4281. SUN, D. and M. J. LIDDLE. 1993. A SURVEY OF TRAMPLING EFFECTS ON VEGETATION AND SOIL IN EIGHT TROPICAL AND SUBTROPICAL SITES. ENVIRONMENTAL MANAGEMENT 17:497-510.

4282. SUNDEEN, D. R. 1968. ABUNDANCE AND MOVEMENTS OF YOUNG TROUT IN A PORTION OF THE MADISON RIVER, MONTANA. M.S. THESIS, MONTANA STATE UNIVERSITY, BOZEMAN, MT. 19 PP.

4283. SURING, L. H. and P. A. JR. VOHS. 1979. HABITAT USE BY COLUMBIAN WHITE-TAILED DEER. J. WILDL. MANAGE. 43 (3):610-9

4284. SURRENDI, C. 1984. MONITORING OF ANIMAL KILLS ON THE C.N. TWIN TRACK, JASPER NATIONAL PARK, REPORT \#2. PREPARED FOR CANADIAN NATIONAL, EDMONTON; PREPARED BY CARSAL ENTERPRISES LTD., EDMONTON. UNPUBLISHED REPORT.

4285. SURRENDI, C. 1983. PRELIMINARY REPORT ON WILDLIFE MORTALITY ALONG C.N. RIGHT OF WAY AND OBSERVATIONS ON HABITAT QUALITY IN JASPER NATIONAL PARK. PREPARED FOR CANADIAN NATIONAL, EDMONTON; PREPARED BY CARSAL ENTERPRISES LTD., EDMONTON. UNPUBLISHED REPORT.

4286. SURRENDI, C. R. 1972. EFFECTS OF ROAD CONSTRUCTION ON WETLANDS IN A DEAD-ICE MORAINE. M.S. THESIS, MONTANA STATE UNIVERSITY, BOZEMAN, MT. 25 PP.

4287. SURRENDI, D. C. and E. A. DEBOCK. SEASONAL DISTRIBUTION, POPULATION STATUS, AND BEHAVIOR OF THE PORCUPINE CARIBOU HERD. CANADIAN WILDLIFE SERVICE REPORT TO THE MACKENZIE VALLEY PIPELINE INVESTIGATION. 145PP.

4288. SURRENDI, D. C. 1969. THE MORTALITY, BEHAVIOR AND HOMING OF TRANSPLANTED JUVENILE CANADIAN GEESE. M.S. THESIS, MONTANA STATE UNIVERSITY, BOZEMAN, MT. 34 PP.

4289. SUTER, G. W. I. and J. L. JONESS. 1981. CRITERIA FOR GOLDEN EAGLE, FERRUGINOUS HAWK, AND PRAIRIE FALCON NEST SITE PROTECTION. RAPTOR RESEARCH 15:12-18.

4290. SUTTON, P. 1996. ROAD MORTALITY OF N. SAW-WHET OWLS IN SOUTHERN NEW JERSEY, WINTER 1995-96. NEW JERSEY AUDUBON RECORD OF NEW JERSEY BIRDS 22(2):31-32.

4291. SWANEY, W. R. 1993. EFFECTS OF NEST PREDATORS ON GROUND-NESTING BIRD COMMUNITIES IN NORTHWESTERN MONTANA. M.S. THESIS, UNIVERSITY OF MONTANA, MISSOULA, MT. 53 PP.

4292. SWANGER, J. L. 1977. ASPECTS OF DOE PRONGHORN SOCIAL STRUCTURE ON THE NATIONAL BISON RANGE. M.S. THESIS, UNIVERSITY OF MONTANA, MISSOULA, MT. 95 PP.

4293. SWANSON, C. S. and J. LOOMIS. 1998. ECONOMIC VALUES ASSOCIATED WITH ROADED AND NON-ROADED RECREATION AREAS IN THE PACIFIC NORTHWEST. PAGES 53-65 IN EVINK, G., ZIEGLER,D., GARRETT,P., AND BERRY,J., EDITORS. PROCEEDINGS OF THE INTERNATIONAL CONFERENCE ON WLDLIFE ECOLOGY AND TRANSPORTATION; 1998 FEBRUARY 10-12; FT. MYERS, FL FLORIDA DEPARTMENT OF TRANSPORTATION, TALLAHASSEE, FL.

4294. SWANSON, F. J. and C. T. DYRNESS. 1975. IMPACT OF CLEAR-CUTTING AND ROAD CONSTRUCTION ON SOIL EROSION BY LANDSLIDES IN THE WESTERN CASCADE RANGE, OREGON. GEOLOGY 3:393-396.

4295. SWANSON, G. A., V. A. ADOMAITIS, F. B. LEE, J. R. SERIE and J. A. SHOESMITH. 1984. LIMNOLOGICAL CONDITIONS INFLUENCING DUCKLING USE OF SALINE LAKES IN SOUTH-CENTRAL NORTH DAKOTA. J. WILDL. MANAGE. 48 (2):340-9.

4296. SWANSON, G. A. 1979. MITIGATION SYMPOSIUM: THE MITIGATION SYMPOSIUM A NATIONAL WORKSHOP ON MITIGATING LOSSES OF FISH AND WLDLIFE HABITATS, JULY 16-20, 1979, COLORADO STATE UNIVERSITY, FORT COLLINS, COLORADO. USDA FOREST SERVICE GENERAL TECHNICAL REPORT RM: GENERAL TECHNICAL REPORT RM 65. ROCKY MOUNTAIN FOREST AND RANGE EXPERIMENT STATION, FOREST SERVICE, U.S. DEPT. OF AGRICULTURE, FORT COLLINS, COLORADO. 
4297. SWANSTON, D. N. 1974. THE FOREST ECOSYSTEM OF SOUTHEAST ALASKA 5. SOIL MASS MOVEMENT. USDA.

4298. SWANSTON, D. N. 1971. JUDGING IMPACT AND DAMAGE OF TIMBER HARVESTING TO FOREST SOILS IN MOUNTAINOUS REGIONS OF WESTERN NORTH AMERICA. WESTERN REFORESTATION COORDINATING COMM., WESTERN FOR. AND CONS. ASSOC., 7 PP.

4299. SWANSTON, D. N. 1970. PRINCIPAL MASS MOVEMENT PROCESSES INFLUENCED BY LOGGING, ROAD BUILDING, AND FIRE. PAGES 29-40 IN PROC. SYMP. FOR. LAND USES AND STREAM ENVIRONMENT, OCT 19-21.

4300. SWEANOR, L., K. LOGAN and M. G. HORNOCKER. 1996. CHAPTER 4. COUGAR SOCIAL ORGANIZATION. P 114-92. IN: LOGAN KA, SWEANOR LL, RUTH TK, HORNOCKER MG. COUGARS OF THE SAN ANDRES MOUNTAINS, NEW MEXICO. HORNOCKER WILDLIFE INSTITUTE., P.O. BOX 3246, UNIVERSITY OF IDAHO, MOSCOW IDAHO 83843.

4301. SWENSON, J. E. 1979. FACTORS AFFECTING STATUS AND REPRODUCTION OF OSPREYS IN YELLOWSTONE NATIONAL PARK. J. WILDL. MANAGE. 43 (3):595-601.

4302. SWENSON, J. E. 1975. ECOLOGY OF THE BALD EAGLE AND OSPREY IN YELLOWSTONE NATIONAL PARK. M.S. THESIS, MONTANA STATE UNIVERSITY, BOZEMAN, MT. 146 PP.

4303. SWHART, R. K. and N. A. SLADE. 1984. ROAD CROSSING IN SIGMIDON HISPIDUS AND MICROTUS OCHROGASTER. JOURNAL OF MAMMALOGY 65(2):357-360.

4304. SWINGLE, K. W. 1986. EFFECT OF SUPPLEMENTAL WATER ON MORPHOLOGY, DENSITY, SURVIVAL AND POPULATION DYNAMICS OF AGROPYRON SMITHII AND BOUTELOUA GRACILIS. M.S. THESIS, MONTANA STATE UNIVERSITY, BOZEMAN, MT. 103 PP.

4305. SYMONS, R. D. 1967. TITLE UNKNOWN. BLUE JAY 25 (1):38.

4306. SZACKI, J. 1987. ECOLOGICAL CORRIDOR AS A FACTOR DETERMINING THE STRUCTURE AND ORGANIZATION OF A BANK VOLE POPULATION. ACTA THERIOLOGICA 32: 31-44

4307. SZEMKUS, B., P. INGOLD and U. PFISTER. 1998. BEHAVIOUR OF ALPINE IBEX (CAPRA IBEX IBEX) UNDER THE INFLUENCE OF PARAGLIDERS AND OTHER AIR TRAFFIC. ZEITSCHRIFT FUER SAEUGETIERKUNDE 63:84-89.

4308. SZYMCZAK, M. R. and W. J. ADRIAN. 1978. LEAD POISONING IN CANADA GEESE IN SOUTHEAST COLORADO. J. WILDL. MANAGE. $42(2): 299-306$.

4309. TABLER, R. D. 1973. NEW SNOW FENCE DESIGN CONTROLS DRIFTS, IMPROVES VISIBILITY, REDUCES ROAD ICE.

4310. TABLER, R. D. 1973. SNOW FENCES IMPROVE HIGHWAY SAFETY. PUBLIC WORKS MAGAZINE.

4311. TABOR, R. K. 1978. MOTORWAYS AND THE BIOLOGIST. NORTH EAST LONDON POLYTECHNIC, MOTORWAY RESEARCH PROJECT, LONDON, ENGLAND.

4312. TAILLE, J. Y. 1993. TGV NETWORK AND THE ENVIRONMENT. PAGES 136-145 IN HIGH SPEED GROUND TRANSPORTATION SYSTEMS I: PROCEEDINGS OF THE FIRST INTERNATIONAL CONFERENCE ON HIGH SPEED GROUND TRANSPORTATION SYSTEMS; 1992 OCTOBER 25-28; ORLANDO, FL DEPARTMENT OF TRANSPORTATION, ORLANDO, FL.

4313. TAKACS, C. D. 1999. THE FACTORS AFFECTING THE DISTRIBUTION AND DYNAMICS OF BACTERIOPLANKTON BIOMASS AND PRODUCTIVITY IN TAYLOR VALLEY LAKES, ANTARCTICA. PH.D. DISSERTATION, MONTANA STATE UNIVERSITY, BOZEMAN, MT. 149 PP.

4314. TAKATSUKI, S. 1992. A CASE STUDY ON THE EFFECTS OF A TRANSMISSION-LINE CORRIDOR ON SIKA DEER HABITAT USE AT THE FOOTHILLS OF MT. GOYO, NORTHERN HONSHU, JAPAN. ECOLOGICAL RESEARCH 7 (2):141-6.

4315. TAKEUCHI, M. and M. KOGANEZAWA. 1994. AGE DISTRIBUTION, SEX RATIO AND MORTALITY OF THE RED FOX VULPES VULPES IN TOCHIGI, CENTRAL JAPAN: AN ESTIMATION USING A MUSEUM COLLECTION. RESEARCHES ON POPULATION ECOLOGY (KYOTO) 36(1):37-43. 
4316. TAMADA, K. and Y. FUJIMAKI. 1993. BREEDING BIOLOGY OF CORVUS CORONE AND C. MACRORHYNCHOS IN CENTRAL HOKKAIDO. JAPANESE JOURNAL OF ORNITHOLOGY 42 (1):9-20.

4317. TARBURTON, M. K. 1972. DEATH ON THE ROADS. WILDLIFE IN AUSTRALIA 9(1):8-10.

4318. TARSHIS, I. B. 1971. AN UNUSUAL FATALITY OF A YEARLING CANADA GOOSE. JACK PINE WARBLER 49:128.

4319. TASKULA, K. and S. OY. 1997. THE MOOSE AHEAD. TRAFFIC TECHNOLOGY INTERNATIONAL [VOL. UNKNOWN]:170-173.

4320. TATE, J. and M. R. PELTON. 1983. HUMAN-BEAR INTERACTIONS IN GREAT SMOKY MOUNTAINS NATIONAL PARK. INT. CONF. BEAR RES. AND MANAGE. 5:312-21.

4321. TAYLOR, B. 1991. DESIGNING BRIDGES AND CULVERTS ON FOREST ROADS TO FACILITATE ANADROMOUS FISH PASSAGE. UBC. FACULTY OF FORESTRY. BSF THESIS. 1991.

4322. TAYLOR, G. S. 1978. DISTRIBUTION, BIOLOGY AND HARVEST OF COMMON SNIPE (CAPELLA GALLINAGO DELICATA) IN MONTANA. M.S. THESIS, MONTANA STATE UNIVERSITY, BOZEMAN, MT. 62 PP.

4323. TAYLOR, J. E. 1983. EFFECTS OF MASSIVE DISTURBANCES SUCH AS STRIP MINING ON THE CONTINUING EXIXTENCE OF NATIVE PLANT COMMUNITIES. BULL. ECOL. SOC. AM. 64:88 (ABSTRACT ONLY).

4324. TAYLOR, M. E. 1971. BONE DISEASE AND FRACTURES IN EAST AFRICAN VIVERRIDS. CANADIAN JOURNAL OF ZOOLOGY 49:1035-1042.

4325. TAYLOR, R. A. 1962. CHARACTERISTICS OF HORN GROWTH IN BIGHORN SHEEP RAMS. M.S. THESIS, MONTANA STATE UNIVERSITY, MISSOULA, MT. 129 PP.

4326. TAYLOR, T. M., M. RESHKIN and K. J. BROCK. 1982. RECREATION LAND USE ADJACENT TO AN ACTIVE HERON ROOKERY: A MANAGEMENT STUDY. PROC. INDIANA ACAD. SCI. 91:226-236.

4327. TAYLOR, T. T. 1989. WHITE-TAILED DEER RESPONSE TO HABITAT ATTRIBUTES IN THE RIO GRANDE PLAINS OF SOUTH TEXAS. PHD THESIS, TEXAS A\&M UNIVERSITY . 172 PP.

4328. TELFER, E. S. 1978. CERVID DISTRIBUTION, BROWSE AND SNOW COVER IN ALBERTA. J. WILDL. MANAGE. 42 (2):352-61.

4329. TELFER, E. S. 1976. FOREST PRACTICES AND WLDLIFE ON EXPERIMENTAL WATERSHEDS AT HINTON, ALBERTA. CANADIAN WLDLIFE SERVICE UNPUBLISHED WILDLIFE REPORT.

4330. TELLERIA, J. L. and T. SANTOS. 1995. EFFECTS OF FOREST FRAGMENTATION ON A GUILD OF WINTERING PASSERINES: THE ROLE OF HABITAT SELECTION. BIOLOGICAL CONSERVATION 71(1):61-7.

4331. TELLERIA, J. L. and T. SANTOS. 1992. SPATIOTEMPORAL PATTERNS OF EGG PREDATION IN FOREST ISLANDS: AN EXPERIMENTAL APPROACH. BIOLOGICAL CONSERVATION 62 (1):29-33.

4332. TEMPLE, S. A. and J. R. CARY. 1988. MODELING DYNAMICS OF HABITAT-INTERIOR BIRD POPULATIONS IN FRAGMENTED LANDSCAPES. CONSERVATION BIOLOGY 2 (4):340-7.

4333. TERBORGH, J. 1988. THE BIG THINGS THAT RUN THE WORLD--A SEQUEL TO E.O. WILSON. CONSERVATION BIOLOGY 2 (4):402-3.

4334. TEVIS, L. JR. 1959. MAN'S EFFECT ON BIGHORN IN THE SAN JACINTO-SANTA ROSA MOUNTAINS. TRANSACTIONS OF THE DESERT BIGHORN COUNCIL 3:69-76.

4335. TEWES, M. E. and D. R. BLANTON. 1998. POTENTIAL IMPACTS OF INTERNATIONAL BRIDGES ON OCELOTS AND JAGUARUNDIS ALONG THE RIO GRANDE WILDLIFE CORRIDOR. PAGES 135-139 IN EVINK, G., ZIEGLER,D., GARRETT,P., AND BERRY,J., EDITORS. PROCEEDINGS OF THE INTERNATIONAL CONFERENCE ON WILDLIFE ECOLOGY AND TRANSPORTATION; 1998 FEBRUARY 10-12; FT. MYERS, FL FLORIDA DEPARTMENT OF TRANSPORTATION, TALLAHASSEE, FL. 
4336. TEWS, A. E. 1986. THE WATER QUALITY AND FISHERY RESOURCE IN A SURFACE COAL MINE SEDIMENT POND IN EASTERN MONTANA. M.S. THESIS, MONTANA STATE UNIVERSITY, BOZEMAN, MT. 81 PP.

4337. THACH, E. E., L. M. DOYLE, J. L. MECHLER and R. L. LOWE. 1986. WILDLIFE MANAGEMENT, AN INTEGRAL PART OF INTENSIVE MULTIPLE USE: LAND BETWEEN THE LAKES, A CASE HISTORY. TRANSACTIONS OF THE NORTH AMERICAN WLDLIFE AND NATURAL RESOURCES CONFERENCE 51:141-150.

4338. THELANDER, C. G. 1973. SPECIAL WILDLIFE INVESTIGATIONS: BALD EAGLE REPRODUCTION IN CALIFORNIA, 1972-1973 . CALIFORNIA DEPARTMENT OF FISH AND GAME . PROJECT W-054-R-06/WP02/J05/8A [WILDLIFE MANAGEMENT BRANCH ADMINISTRATIVE REPORT NO. 73-5 (NOVEMBER 1973). PROJECT W-54R, SPECIAL WILDLIFE INVESTIGATIONS]. 18PP.

4339. THEOBALD, D. M., J. R. MILLER and N. T. HOBBS. 1997. ESTIMATING THE CUMULATIVE EFFECTS OF DEVELOPMENT ON WILDLIFE HABITAT. LANDSCAPE URBAN PLANN. 39:25-36.

4340. THERRES, G. D., M. A. BYRD and D. S. BRADSHAW. 1993. EFFECTS OF DEVELOPMENT ON NESTING BALD EAGLES: CASE STUDIES FROM CHESAPEAKE BAY. TRANS. N.A. WILDL. AND NATUR. RESOUR. CONF. 58:62-9.

4341. THIEL, R. P. 1980. THE RELATIONSHIP BETWEEN ROAD DENSITIES AND WOLF HABITAT SUITABILITY IN WISCONSIN. WISCONSIN DEPT. OF NAT. RESOURCES, BUREAU OF ENDANGERED RESOURCES, MADISON., 13 PP.

4342. THIEL, R. P. 1985. RELATIONSHIP BETWEEN ROAD DENSITIES AND WOLF HABITAT SUITABILITY IN WISCONSIN. AMERICAN MIDLAND NATURALIST 113:404-407.

4343. THIEL, R. P. and T. VALEN. 1995. DEVELOPING A STATE TIMBER WOLF RECOVERY PLAN WITH PUBLIC INPUT: THE WISCONSIN EXPERIENCE. P 169-75. IN: CARBYN LN, FRITTS SH, SEIP DR (EDS.). ECOLOGY AND MANAGEMENT OF WOLVES IN A CHANGING WORLD. OCCAS. PUBL. NO. 35. , CANADIAN CIRCUMPOLAR INST., EDMONTON.

4344. THIEL, R. P., S. MERRILL and L. D. MECH. 1998. TOLERANCE BY DENNING WOLVES, CANIS LUPUS, TO HUMAN DISTURBANCE. CANADIAN FIELD-NATURALIST 112:340-342.

4345. THIESSEN, J. L. 1976. SOME RELATIONS OF ELK TO LOGGING, ROADING, AND HUNTING IN IDAHO'S GAME MANAGEMENT UNIT 39. PAGES 3-5 IN S. R. HIEB, EDITOR. PROCEEDINGS OF THE ELK-LOGGING-ROADS SYMPOSIUM. FORESTRY WILDLIFE AND RANGE EXPERIMENT STATION, UNIVERSITY OF IDAHO, MOSCOW, IDAHO, USA.

4346. THIESZEN, A. W. 1992. AN EXAMINATION OF THE DECISION-MAKING PROCESS OF THE WOLF MANAGEMENT COMMITTEE NEGOTIATIONS : A CASE STUDY. M.S. THESIS, UNIVERSITY OF MONTANA, MISSOULA, MT. 198 PP.

4347. THIOLLAY, J. M. 1991. FORAGING, HOME RANGE USE AND SOCIAL BEHAVIOUR OF A GROUP-LIVING RAINFOREST RAPTOR, THE RED-THROATED CARACARA DAPTRIUS AMERICANUS. IBIS 133 (4):382-93.

4348. THIOLLAY, J. M. 1992. INFLUENCE OF SELECTIVE LOGGING ON BIRD SPECIES DIVERSITY IN A GUIANAN RAIN FOREST. CONSERVATION BIOLOGY 6 (1):47-63.

4349. THIOLLAY, J. M. 1993. RESPONSE OF A RAPTOR COMMUNITY TO SHRINKING AREA AND DEGRADATION OF TROPICAL RAIN FOREST IN THE SOUTH WESTERN GHATS (INDIA). ECOGRAPHY 16 (2):97-110.

4350. THOMAS, A. E. 1998. THE EFFECTS OF HIGHWAYS ON WESTERN COLD WATER FISHERIES. PAGES $249-252$ IN EVINK,G., ZIEGLER,D., GARRETT,P., AND BERRY,J., EDITORS. PROCEEDINGS OF THE INTERNATIONAL CONFERENCE ON WILDLIFE ECOLOGY AND TRANSPORTATION; 1998 FEBRUARY 10-12; FT. MYERS, FL FLORIDA DEPARTMENT OF TRANSPORTATION, TALLAHASSEE, FL.

4351. THOMAS, J. K. and C. E. ADAMS. 1985. SOCIOECONOMIC FACTORS AFFECTING LAND ACCESS TO HUNT WHITE-TAILED DEER. WLDL. SOC. BULL. 13 (4):388-94.

4352. THOMAS, J. W., H. BLACK, R. J. SCHERZINGER and PEDERSEN. R.J. 1979. DEER AND ELK. P 104-27.IN: THOMAS JW, ED. WILDLIFE HABITATS IN MANAGED FORESTS: THE BLUE MOUNTAINS OF OREGON AND WASHINGTON. WASHINGTON, DC.: USDA FOR. SERV. CHAPTER AGR. HDBK. NO. 553. 
4353. THOMAS, J. W., D. A. LECKENBY, M. HENJUM and R. J. B. L. D. PEDERSEN. 1988. HABITAT EFFECTIVENESS INDEX FOR ELK ON BLUE MOUNTAIN WINTER RANGES. USDA FOREST SERVICE GEN. TECH. REP. PNW-GTR-218. $28 P P$.

4354. THOMAS, J. W., D. A. LECKENBY, L. J. LYON, L. L. HICKS and C. L. MARCUM. 1988. INTEGRATED MANAGEMENT OF TIMBER-ELK-CATTLE: INTERIOR FORESTS OF WESTERN NORTH AMERICA. PACIFIC NORTHWEST RESEARCH STATION GENERAL TECHNICAL REPORT NO.PNW-GTR-225USDA FOREST SERVICE. 12 PP.

4355. THOMAS, J. W., C. MASER and J. E. RODIEK. 1978. RIPARIAN ZONES IN MANAGED RANGELANDS-THEIR IMPORTANCE TO WILDLIFE. P.21-3. IN: GRAZING \&RIPARIAN/STREAM ECOSYST SYMP.; 1978 NOV 3-1978 NOV 4; DENVER, CO.

4356. THOMAS, J. W. ED. 1979. WLDLIFE HABITATS IN MANAGED FORESTS: THE BLUE MOUNTAINS OF OREGON AND WASHINGTON. U.S. DEPARTMENT OF AGRICULTURE, FOREST SERVICE, AGRIC. HANDB. 533. WASHINGTON, DC.

4357. THOMAS, J. W., J. D. GILL, J. C. PACK, W. M. HEALY and H. R. SANDERSON. 1976. INFLUENCE OF FORESTLAND CHARACTERISTICS ON SPATIAL DISTRIBUTION OF HUNTERS. JOURNAL OF WILDLIFE MANAGEMENT 40:500-506.

4358. THOMAS, T. R. and L. R. IRBY. 1991. WINTER HABITAT USE BY MULE DEER WITH ACCESS TO WHEAT FIELDS AND PLANTED FORB-GRASSLAND. WILDL. SOC. BULL. 19 (2):155-62.

4359. THOMAS, T. R. 1987. YEARLONG MOVEMENTS AND HABITAT USE OF MULE DEER ASSOCIATED WITH THE WILLOW CREEK WINTER RANGE IN SOUTHEASTERN IDAHO. M.S. THESIS, MONTANA STATE UNIVERSITY, BOZEMAN, MT. 109 PP.

4360. THOMAS, V. G. 1983. EXPERIMENTALLY DETERMINED IMPACTS OF A SMALL SUCTION DREDGE ON A MONTANA STREAM. M.S. THESIS, UNIVERSITY OF MONTANA, MISSOULA, MT. 101 PP.

4361. THOMPSON, D. 1973. FEEDING ECOLOGY OF DIVING DUCKS ON KEOKUK POOL, MISSISSIPPI RIVER. J. WILDL. MANAGE. 37 (3):367-81

4362. THOMPSON, D. Q. 1952. TRAVEL, RANGE, AND FOOD HABITS OF TIMBER WOLVES IN WISCONSIN. J. MAMMAL. $33: 429-42$.

4363. THOMPSON, F. A. 1967. DEER ON HIGHWAYS 1966 SUPPLEMENT. DEPT. OF GAME AND FISH, SANTA FE, NM., 7 PP.

4364. THOMPSON, F. R., W. D. DIJAK, T. G. KULOWIEC and D. A. HAMILTON. 1992. BREEDING BIRD POPULATIONS IN MISSOURI OZARK FORESTS WITH AND WITHOUT CLEARCUTTING. JOURNAL OF WILDLIFE MANAGEMENT 56 (1):23-30.

4365. THOMPSON, I. D. 1994. MARTEN POPULATIONS IN UNCUT AND LOGGED BOREAL FORESTS IN ONTARIO. JOURNAL OF WILDLIFE MANAGEMENT 58 (2):272-80.

4366. THOMPSON, I. D. and P. W. COLGAN. 1994. MARTEN ACTIVITY IN UNCUT AND LOGGED BOREAL FORESTS IN ONTARIO. J. WILDL. MANAGE. 58 (2):280-8.

4367. THOMPSON, I. D. and W. J. CURRAN. 1995. HABITAT SUITABILITY FOR MARTEN OF SECOND-GROWTH BALSAM FIR FOREST IN NEWFOUNDLAND. CANADIAN JOURNAL OF ZOOLOGY 73(11):2059-64.

4368. THOMPSON, J. R. and A. J. RUTTER. 1986. THE SALINITY OF MOTORWAY SOILS: IV. EFFECTS OF SODIUM CHLORIDE ON SOME NATIVE BRITISH SHRUBS SPECIES, AND THE POSSIBILITY OF ESTABLISHING SHRUBS ON THE CENTRAL RESERVES OF MOTORWAYS. JOURNAL OF APPLIED ECOLOGY 23:299-315.

4369. THOMPSON, J. R., A. J. RUTTER and P. S. RIDOUT. 1986. THE SALINITY OF MOTORWAY SOILS. I. VARIATION IN TIME AND BETWEEN REGIONS IN THE SALINITY OF SOILS ON CENTRAL RESERVES. JOURNAL OF APPLIED ECOLOGY 23:251-267.

4370. THOMPSON, J. R., A. J. RUTTER and P. S. RIDOUT. 1986. THE SALINITY OF MOTORWAY SOILS. II. DISTANCE FROM THE CARRIAGEWAY AND OTHER SOURCES OF LOCAL VARIATION IN SALINITY. JOURNAL OF APPLIED ECOLOGY 23:269-280. 
4371. THOMPSON, M. and D. DICKSON. 1986. ELK MONITORING AND MITIGATION PROJECT. ANNUAL PROGRESS REPORT. BONNEVILLE POWER ADMINISTRATION.

4372. THOMPSON, M. and B. STERLING. 1986. IMPACT MITIGATION AND MONITORING OF THE BPA 500 KV GARRISON-TAFT TRANSMISSION LINE- EFFECTS ON ELK SECURITY AND HUNTER OPPORTUNITY--ANNUAL PROGRESS REPORT FOR 1985. BONNEVILLE POWER ADMINISTRATION., 70 PP.

4373. THOMPSON, M. J., R. E. HENDERSON and R. ORTEGON. 1991. DO HUNTERS SUPPORT ROAD CLOSURES TO ADDRESS ELK SECURITY PROBLEMS? PAGES 75-279 IN A. G. CHRISTENSEN, L. J. LYON, AND T. N. LONNER, COMPS. PROC. ELK VULNERABILITY SYMP.

4374. THOMPSON, M. J. 1981. MOUNTAIN GOAT DISTRIBUTION, POPULATION CHARACTERISTICS AND HABITAT USE IN THE SAWTOOTH RANGE, MONTANA. M.S. THESIS, MONTANA STATE UNIVERSITY, BOZEMAN, MT. 80 PP.

4375. THOMPSON, R. W. 1980. POPULATION DYNAMICS, HABITAT UTILIZATION, RECREATIONAL IMPACTS, AND TRAPPING INTRODUCED ROCKY MOUNTAIN GOATS IN THE EAGLES NEST WILDERNESS AREA, COLORADO. PROC. BIENN. SYMP. NORTHERN WLD SHEEP AND GOAT COUNCIL; 23-25 APR 1980 ; NORTHERN WLD SHEEP AND GOAT COUNCIL.

4376. THOMPSON, R. W. EFFECTS OF FOREST FRAGMENTATION AT SKI AREAS ON BREEDING NEOTROPICAL BIRD GUILDS. WESTERN ECOSYSTEMS, INC.

4377. THOMPSON, W. L. 1993. ECOLOGY OF MERRIAM'S TURKEYS IN RELATION TO BURNED AND LOGGED AREAS IN SOUTHEASTERN MONTANA. PH.D. DISSERTATION, MONTANA STATE UNIVERSITY, BOZEMAN, MT. 195 PP.

4378. THORBJARNARSON, J. B. 1993. DIET OF THE SPECTACLED CAIMAN (CAIMAN CROCODILUS) IN THE CENTRAL VENEZUELAN LLANOS. HERPETOLOGICA 49 (1):108-17.

4379. THORNBURG, D. D. 1973. DIVING DUCK MOVEMENTS ON KEOKUK POOL, MISSISSIPPI RIVER. J. WILDL. MANAGE. 37 (3):382-9.

4380. THORNTON, P. C. 1997. ON THE RELATIONSHIP BETWEEN AVIAN SPECIES RICHNESS AND NET PRIMARY PRODUCTIVITY IN WESTERN MONTANA. M.S. THESIS, UNIVERSITY OF MONTANA, MISSOULA, MT. 36 PP.

4381. THORPE, P. P. JR. 1997. TEMPORAL AND SPATIAL VARIATION IN HABITAT SELECTION AND MOVEMENTS OF FEMALE MALLARDS IN THE PARKLANDS OF CANADA. M.S. THESIS, MONTANA STATE UNIVERSITY, BOZEMAN, MT. 52 PP.

4382. THORSON, R. M. and S. L. HARRIS. 1991. HOW NATURAL ARE INLAND WETLANDS? AN EXAMPLE FROM THE TRAIL WOOD AUDUBON SANCTUARY IN CONNECTICUT, USA. ENVIRONMENTAL MANAGEMENT 15 (5):675-88.

4383. THORVILSON, R. C. 1969. AN APPRAISAL OF ENDOCRINE ACTIVITY IN STRUTTING SAGE GROUSE. M.S. THESIS MONTANA STATE UNIVERSITY, BOZEMAN, MT. 14 PP.

4384. THURBER CONSULTANTS LTD. 1975. INTERIM ENVIRONMENTAL IMPACT STUDY : CN MEZIADIN PROJECT, MILE 0-75. DEPARTMENT OF FISH AND WILDLIFE SERVICE, VICTORIA, B.C..

4385. THURBER; J. M., R. O. PETERSON, T. D. DRUMMER and S. A. THOMASMA. 1994. GRAY WOLF RESPONSE TO REFUGE BOUNDARIES AND ROADS IN ALASKA. WILDLIFE SOCIETY BULLETIN 22:61-68.

4386. THURBER, J. M., R. O. PETERSON, J. D. WOOLINGTON and J. A. VUCTICH. 1992. COYOTE COEXISTENCE WITH WOLVES ON THE KENAI PENINSULA, ALASKA. CANADIAN JOURNAL OF ZOOLOGY 70(12):2492-2498.

4387. THURSTON, R. V. 1966. ELECTROPHORETIC PATTERNS OF BLOOD SERUM PROTEINS FROM RAINBOW TROUT (SALMO GAIRDNERI). M.S. THESIS, MONTANA STATE UNIVERSITY, BOZEMAN, MT. 28 PP.

4388. TIERSON, W. C. 1969. CONTROLLING DEER USE OF FOREST VEGETATION WITH ELECTRIC FENCES. JOURNAL OF WILDLIFE MANAGEMENT 33:922-926. 
4389. TIETJE, W. D. and R. L. RUFF. 1983. RESPONSES OF BLACK BEARS TO OIL DEVELOPMENT IN ALBERTA. WILDL. SOC. BULL. $11(2): 99-112$.

4390. TIETJE, W. D. and R. L. RUFF. 1980. DENNING BEHAVIOR OF BLACK BEARS IN BOREAL FOREST OF ALBERTA. JOURNAL OF WILDLIFE MANAGEMENT 44:858-870.

4391. TILTON, M. E. 1977. HABITAT SELECTION AND USE BY BIGHORN SHEEP (OVIS CANADENSIS) ON A NORTHWESTERN MONTANA WINTER RANGE. M.S. THESIS, UNIVERSITY OF MONTANA, MISSOULA, MT. 121 PP.

4392. TISCH, E. L. 1961. SEASONAL FOOD HABITS OF THE BLACK BEAR IN THE WHITEFISH RANGE OF NORTHWESTERN MONTANA. M.S. THESIS, MONTANA STATE UNIVERSITY, MISSOULA, MT. 108 PP.

4393. TISCHNER, K. 1977. ROAD KILLS OF SOUTH JERSEY. CASSINIA 57:22-24.

4394. TITUS, K. and L. BEIER. 1992. POPULATION AND HABITAT ECOLOGY OF BROWN BEARS ON ADMIRALTY AND CHICHAGOF ISLANDS. FEDERAL AID IN RESTORATION RESEARCH PROJECT REPORT W-23-4, ALASKA DEPT. OF FISH AND GAME, DIV. WILDL. CONSERVATION, JUNEAU.

4395. TITUS, T. A. 1991. USE OF ROAD-KILLED AMPHIBIANS IN ALLOZYME ELECTROPHORESIS. HERPETOLOGICAL REVIEW 22(1):14-16.

4396. TJERNBERG, M., K. JOHNSSON and S. G. NILSSON. 1993. DENSITY VARIATION AND BREEDING SUCCESS OF THE BLACK WOODPECKER DRYOCOPUS MARTIUS IN RELATION TO FOREST FRAGMENTATION. ORNIS FENNICA 70 (3):155-62.

4397. TOBALSKE, C. 1998. MODELING THE DISTRIBUTION OF WOODPECKER SPECIES IN THE JURA, FRANCE, AND IN SWITERLAND, USING ATLAS DATA. PH.D. DISSERTATION, UNIVERSITY OF MONTANA, MISSOULA, MT. 137 PP.

4398. TODD, E. H. 1967. PRIMARY PRODUCTIVITY OF THE MADISON RIVER IN YELLOWSTONE NATIONAL PARK, WYOMING. PH.D. DISSERTATION, MONTANA STATE UNIVERSITY, BOZEMAN, MT. 120 PP.

4399. TODD, J. W. and R. M. HANSEN. 1973. PLANT FRAGMENTS IN THE FECES OF BIGHORNS AS INDICATORS OF FOOD HABITS. J. WILDL. MANAGE. 37 (3):363-6

4400. TODD, K. S. JR. 1964. HELMINTH PARASITES OF THE BLACK-BILLED MAGPIE (PICA PICA HUDSONIA SABINE) IN GALLATIN COUNTY, MONTANA. M.S. THESIS, MONTANA STATE COLLEGE, BOZEMAN, MT. 31 PP.

4401. TODD, P. A. 1990. THE DISTRIBUTION, POPULATION ABUNDANCE AND HABITAT REQUIREMENTS OF SIERRA MOUNTAIN BEAVER IN YOSEMITE NATIONAL PARK. M.S. THESIS, UNIVERSITY OF MONTANA, MISSOULA, MT. 56 PP.

4402. TOEPFER, J. E. 1988. THE ECOLOGY OF THE GREATER PRAIRIE CHICKEN AS RELATED TO REINTRODUCTIONS. PH.D. DISSERTATION, MONTANA STATE UNIVERSITY, BOZEMAN, MT. 536 PP.

4403. TOHTZ, J. 1990. DIET AND GROWTH OF LAKE WHITEFISH (COREGONUS CLUPEAFORMIS MITCHILL) AFTER THE INTRODUCTION OF MYSIS RELICTA TO FLATHEAD LAKE, MONTANA. M.S. THESIS, UNIVERSITY OF MONTANA, MISSOULA, MT. 63 PP.

4404. TOLAND, B. 1992. USE OF FORESTED SPOIL ISLANDS BY NESTING AMERICAN OYSTERCATCHERS IN SOUTHEAST FLORIDA. JOURNAL OF FIELD ORNITHOLOGY 63(2):155-8.

4405. TOMICH, P. Q. 1969. MOVEMENT PATTERNS OF THE MONGOOSE IN HAWAII. J. WILDL. MANAGE. 33 (3):576-84.

4406. TOMMERAAS, P. J. 1993. THE GOSHAWK ACCIPITER GENTILIS IN LEKSVIK- A SACRIFICE TO MODERN FORESTRY. FAUNA (OSLO) 46 (4):180-95.

4407. TOMMERAAS, P. J. 1993. THE STATUS OF GYRFALCON FALCO RUSTICOLUS RESEARCH IN NORTHERN FENNOSCANDIA 1992. FAUNA NORVEGICA SERIES C CINCLUS 16 (2):75-82. 
4408. TOMSON, S. D. 1999. ECOLOGY AND SUMMER/FALL HABITAT SELECTION OF AMERICAN MARTEN IN NORTHERN IDAHO. M.S. THESIS, UNIVERSITY OF MONTANA, MISSOULA, MT. 73 PP.

4409. TORGERSON, O. and W. R. PORATH. 1984. MIDWEST OAK/HICKORY FOREST (CHAPTER 21). P 411-26. IN: HALLS, L.K.,(EDITOR). WHITE-TAILED DEER: ECOLOGY AND MANAGEMENT. HARRISBURG, PA: STACKPOLE BOOKS.

4410. TORRES, S. G., T. M. MANSFIELD, J. E. FOLEY, T. LUPO and A. BRINKHAUS. 1996. MOUNTAIN LION AND HUMAN ACTIVITY IN CALIFORNIA: TESTING SPECULATIONS. WILDL. SOC. BULL. 24:451-460.

4411. TOWNSEND, J. E. 1952. A STUDY IN BEAVER ECOLOGY IN WESTERN MONTANA WITH SPECIAL REFERENCE TO MOVEMENTS. M.S. THESIS, MONTANA STATE COLLEGE, BOZEMAN, MT. 44 PP.

4412. TRACY, D. M. 1977. REACTION OF WILDLIFE TO HUMAN ACTIVITY ALONG MOUNT MCKINLEY NATIONAL PARK ROAD. M.S. THESIS, UNIV. ALASKA-FAIRBANKS. 260PP.

4413. TRACY, D. M. 1977. REACTIONS OF WLDLIFE TO HUMAN ACTIVITY ALONG MOUNT MCKINLEY NATIONAL PARK ROAD . THESIS, UNIVERSITY OF ALASKA, FAIRBANKS, ALASKA. 260PP.

4414. TRACY, D. M. and F. C. DEAN. 1978. POSSIBLE WILDLIFE RESPONSES TO STIPULATED HIGHWAY DESIGN CRITERIA FOR MOUNT MCKINLEY NATIONAL PARK ROAD. FINAL REPORT. U. S. NATIONAL PARK SERVICE, MOUNT MCKINLEY NATIONAL PARK, [LOCATION OF PUBLISHER UNKNOWN].

4415. TRAIL, P. W. and L. F. BAPTISTA. 1993. THE IMPACT OF BROWN-HEADED COWBIRD PARASITISM ON POPULATIONS OF THE NUTTALL'S WHITE-CROWNED SPARROW. CONSERVATION BIOLOGY 7 (2):309-15.

4416. TRAPP, J. L. 1973. MUTE SWANS ENTANGLED IN FISHING LINE. JACK-PINE WARBLER 51:91-92.

4417. TRAVERSO-MARTINEZ, J. M. 1992. ANIMALS RUN OVER ON THE ROADS OF SOUTH EAST MADRID COMMUNITY. PAGES 160-167 IN LOPEZ,REDONDO, EDITOR. I JORNADAS PARA EL ESTUDIO Y PREVENCION DE LA MORTALIDAD DE VERTEBRADOS EN CARRETERAS, MADRID, 5 Y 6 DE OCTUBRE DE 1991. TOMO 2. [SESSIONS IN THE STUDY OF PREVENTION OF ROAD MORTALITIES OF VERTEBRATES, MADRID, 5 AND 6 OCTOBER, 1991. VOLUME 2.]. COORDINADORA DE ORGANIZACCIONES DE DEFENSA, AMBIENTAL, MADRID.

4418. TRENKA, R. J. 2000. COMMUNITY STRUCTURE AND HABITAT ASSOCIATIONS OF FISHES OF THE LOWER TONGUE AND POWDER RIVERS. M.S. THESIS, MONTANA STATE UNIVERSITY, BOZEMAN, MT. 85 PP

4419. TREWEEK, J. and N. VEITCH. 1996. THE POTENTIAL APPLICATION OF GIS AND REMOTELY SENSED DATA TO THE ECOLOGICAL ASSESSMENT OF PROPOSED NEW ROAD SCHEMES. GLOBAL ECOLOGY AND BIOGEOGRAPHY LETTERS 5(4-5):249-257.

4420. TROUT, L. E. 1962. SUBLETT-BLACK PINE DEER CROSSING INVESTIGATION, JULY 1, 1962 TO JUNE 30, 1963. IDAHO FISH AND GAME DEPT., BOISE, ID. W 85-R-14, JOB NO. 5, 7 PP.

4421. TROUT, R. G. 1978. SMALL MAMMAL ABUNDANCE AND DISTRIBUTION IN THE MISSOURI RIVER BREAKS, MONTANA . M.S. THESIS, MONTANA STATE UNIVERSITY, BOZEMAN, MT. 64 PP.

4422. TROY, D. 1990. BIRD USE OF DISTURBED HABITAT AT PRUDHOE BAY, ALASKA: THE ABANDONED PEAT ROADS. UNPUBLISHED REPORT, TROY ECOLOGICAL RESEARCH ASSOC., ANCHORAGE, AK

4423. TROYER, W. A. 1962. SIZE, DISTRIBUTION, STRUCTURE AND HARVEST OF A KODIAK BEAR POPULATION. M.S. THESIS, MONTANA STATE UNIVERSITY, MISSOULA, MT.

4424. TRUETT, J. C. and K. KERTELL. 1992. TUNDRA DISTURBANCE AND ECOSYSTEM PRODUCTION: IMPLICATIONS FOR IMPACT ASSESSMENT. ENVIRON. MANAGE. 16:485-494.

4425. TRUETT, J. C., R. G. B. SENNER, K. KERTELL, R. RODRIGUES and R. H. POLLARD. 1994. WILDLIFE RESPONSES TO SMALL-SCALE DISTURBANCES IN ARCTIC TUNDRA. WILDL. SOC. BULL. 22(2):317-24. 
4426. TSAI, K. 1989. NESTING OF RING-NECKED PHEASANTS IN THE NINEPIPE AREA OF WESTERN MONTANA. M.S. THESIS, UNIVERSITY OF MONTANA, MISSOULA, MT. 47 PP.

4427. TSCHACHE, O.P. 1970. EFFECTS OF ECOLOGICAL CHANGES INDUCED BY VARIOUS SAGEBRUSH CONTROL TECHNIQUES ON SMALL MAMMAL POPULATIONS. M.S. THESIS, MONTANA STATE UNIVERSITY, BOZEMAN, MT. $51 \mathrm{PP}$

4428. TSCHARNTKE, T. 1992. FRAGMENTATION OF PHRAGMITES HABITATS, MINIMUM VIABLE POPULATION SIZE, HABITAT SUITABILITY, AND LOCAL EXTINCTION OF MOTHS, MIDGES, FLIES, APHIDS, AND BIRDS. CONSERVATION BIOLOGY $6(4): 530-6$.

4429. TSUKAMOTO, G. K. 1983. PRONGHORN ANTELOPE SPECIES MANAGEMENT P.LAN. UNPUBLISHED REPORT. NEVADA DEPARTMENT OF WLDLIFE. VI + 6OPP.

4430. TUBBS, D. M. 1972. ECOLOGY AND BEHAVIOR OF WHITE-TAILED DEER (ODOCOILEUS VIRGINIANUS) ALONG A FENCED SECTION OF A PENNSYLVANIA INTERSTATE HIGHWAY. THESIS, PENNSYLVANIA STATE UNIV., COLLEGE STATION, PA.

4431. TUCKER, J. K. 1995. NOTES ON ROAD-KILLED SNAKES AND. THEIR IMPLICATIONS ON HABITAT MODIFICATION DUE TO SUMMER FLOODING ON THE MISSISSIPPI RIVER IN WEST CENTRAL ILLINOIS. TRANSACTIONS OF THE ILLINOIS STATE ACADEMY OF SCIENCE $88(1-2): 61-71$.

4432. TUCKER, J. K. 1995. SALVAGE OF EGGS FROM ROAD-KILLED RED-EARED SLIDERS, TRACHEMYS SCRIPTA ELEGANS. CHELONIAN CONSERVATION AND BIOLOGY 1 (4):317-8.

4433. TUCKER, P. A. 1991. EVALUATION OF TECHNIQUES TO MONITOR WHITE-TAILED DEER POPULATIONS IN THE NORTH FORK OF THE FLATHEAD RIVER VALLEY, MONTANA. M.S. THESIS, UNIVERSITY OF MONTANA, MISSOULA, MT. $90 \mathrm{PP}$.

4434. TUELLINGHOFF, R. and H. H. BERGMANN. 1993. CURLEW HABITATS (NUMENIUS ARQUATA) IN LOWER SAXONY: PREFERRED AND AVOIDED STRUCTURES OF AGRICULTURAL LANDSCAPES. VOGELWARTE 37 (1):1-11.

4435. TURL, C. W. 1982. POSSIBLE EFFECTS OF NOISE FROM OFFSHORE OIL AND GAS DRILLING ACTIVITIES ON MARINE MAMMALS: A SURVEY OF THE LITERATURE. NAVAL OCEAN SYST. CENT. SAN DIEGO, CALIFORNIA. REPT. NO. NOSC/TR-776. 25PP.

4436. TURNER, I. M. 1996. SPECIES LOSS IN FRAGMENTS OF TROPICAL RAIN FOREST: A REVIEW OF THE EVIDENCE. JOURNAL OF APPLIED ECOLOGY 33:200-9.

4437. TURNER, I. M., H. T. W. TAN, Y. C. WEE, A. B. IBRAHIM, P. T. CHEW and R. T. CORLETT. 1994. A STUDY OF PLANT SPECIES EXTINCTION IN SINGAPORE: LESSONS FOR THE CONSERVATION OF TROPICAL BIODIVERSITY. CONSERVATION BIOLOGY 8 (3):705-12.

4438. TUTTLE, M. D. 1979. STATUS, CAUSES OF DECLINE, AND MANAGEMENT OF ENDANGERED GRAY BATS. J. WILDL. MANAGE. $43(1): 1-17$.

4439. TWETEN, R. G. 1984. BASELINE SURVEY OF FURBEARING MAMMALS WITHIN THE SOUTH FORK DRAINAGE, SUN RIVER, MONTANA. M.S. THESIS, MONTANA STATE UNIVERSITY, BOZEMAN, MT. 63 PP.

4440. TY; M. 1979. EFFECT OF HIGHWAY TRAFFIC ON TETRAONID DENSITIES. ORNIS FENN. 56(4):169-170.

4441. TYLER, N. J. C. 1991. TITLE UNKNOWN. BIOLOGICAL CONSERVATION 56 (2):179-94.

4442. TYNING, T. F. 1989. AMHERSTS TUNNELING AMPHIBIANS. DEFENDERS SEPT./OCT.:20-23.

4443. TYSER, R. W. and C. A. WORLEY. 1992. ALIEN FLORA IN GRASSLANDS ADJACENT TO ROAD AND TRAIL CORRIDORS IN GLACIER NATIONAL PARK, MONTANA (U.S.A.). CONSERVATION BIOLOGY 6 (2):253-62.

4444. TYSON, R. M. 1980. ROAD KILLED PLATYPUS. THE TASMANIAN NATURALIST 60:8-10. 
4445. TZILKOWSKI, W. M. and F. F. KNOWLTON. 1979. MAN-CAUSED MORTALITY OF COYOTES IN GRAND TETON NATIONAL PARK. PAGES 164-168 IN R. ITTNER, D. R. POTTER, J. K. AGEE, AND S. ANSCHELL, EDITORS. RECREATIONAL -IMPACT ON WILDLANDS. CONFERENCE PROCEEDINGS. U.S.D.A. FOREST SERVICE AND U.S.D.I. NATIONAL PARK SERVICE,

4446. U.S. ARMY ENGINEER INSTITUTE FOR WATER RESOURCES and GREELEY-POLHEMUS GROUP. 1991. ECONOMIC AND ENVIRONMENTAL CONSIDERATIONS FOR INCREMENTAL COST ANALYSIS IN MITIGATION PLANNING. IWR REPORT 91-R-1. THE INSTITUTE, FORT BELVOIR, VIRGINIA.

4447. U.S. BUREAU OF LAND MANAGEMENT. 1998. MONTANA ACCESS GUIDE TO FEDERAL AND STATE LANDS. MONTANA STATE OFFICE, U.S. BUREAU OF LAND MANAGEMENT. 33PP.

4448. U.S. BUREAU OF LAND MANAGEMENT and U.S. DEPT. OF THE AIR FORCE. 1980. DRAFT ENVIRONMENTAL IMPACT STATEMENT: CONTINUED USE OF PUBLIC LANDS AT THE LUKE AIR FORCE RANGE, ARIZONA. U.S. DEPT. INTERIOR, BUR. LAND MANAGE. U.S. GOVT. DOC. NO. 80-60-0050. 99PP.

4449. U.S. BUREAU OF OUTDOOR RECREATION, MINNESOTA DEPT. OF NATURAL RESOURCE and MINNESOTA DEPT. OF ECONOMIC DEVELOPMENT. 1970. PROCEEDINGS OF THE 2ND INTERNATIONAL SNOWMOBILE CONFERENCE. DULUTH, MINN. 222PP.

4450. U.S.D.A. SOIL CONSERVATION SERVICE. 1979. NATIONAL SOILS HANDBOOK PART II, GUIDE FOR RATING SOIL LIMITATIONS FOR OFF-ROAD VEHICLE TRAILS. U.S.D.A. SOIL CONSERVATION SERVICE.

4451. U.S.D.I. NATIONAL PARK SERVICE. 1973. PUBLIC USE AND RECREATION; VEHICLES AND TRAFFIC SAFETY. FEDERAL REGISTER 38. FEB. 14, $1973: 4405-4407$.

4452. U.S. DEPARTMENT OF AGRICULTURE, FOREST SERVICE, EASTERN REGION. 1974. USDA FOREST SERVICE ENVIRONMENTAL STATEMENT: OFF-ROAD VEHICLE POLICY HOOSIER NATIONAL FOREST. USDA-FS-R9-FES-ADM-73-51. 181PP. + MAPS

4453. U.S. DEPARTMENT OF THE INTERIOR. 1972. ORRV: OFF-ROAD RECREATION VEHICLES. A DEPARTMENT OF THE INTERIOR TASK FORCE STUDY, NOVEMBER 1971. 123PP.

4454. U.S. DEPARTMENT OF TRANSPORTATION FEDERAL HIGHWAY ADMINISTRATION. 1992. NATIONAL BICYCLE AND WALKING STUDY. CURRENT PLANNING GUIDELINES AND DESIGN STANDARDS USED BY STATE AND LOCAL AGENCIES FOR BICYCLE AND PEDESTRIAN FACILITIES. WASHINGTON, D.C.

4455. U.S. DEPARTMENT OF TRANSPORTATION FEDERAL HIGHWAY ADMINISTRATION. 1993. NATIONAL RECREATIONAL TRAILS ADVISORY COMMITTEE ANNUAL REPORT FOR THE FISCAL YEAR 1993. WASHINGTON, D.C.

4456. U.S. FISH AND WILDLIFE SERVICE. 1997. DRAFT ENVIRONMENTAL ASSESSMENT/HABITAT CONSERVATION PLAN FOR ISSUANCE OF AN ENDANGERED SPECIES ACT SECTION 10(A)(1)(B) PERMIT FOR THE INCIDENTAL TAKE OF THE GOLDEN-CHEEKED WARBLER (DENDROICA CHRYSOPARIA) DURING THE CONSTRUCTION AND OPERATION OF LIGHT INDUSTRIAL DEVELOPMENT ON PORTIONS OF THE 440-ACRE SCHLUMBERGER PROPERTY, AUSTIN, TEXAS. U.S. FISH AND WILDLIFE SERVICE, AUSTIN, TEXAS.

4457. U.S. FISH AND WILDLIFE SERVICE. 1995. DRAFT FINDING OF NO SIGNIFICANT IMPACT ISSUANCE OF AN ENDANGERED SPECIES SECTION 10(A)(1)(B) PERMIT FOR THE INCIDENTAL TAKE OF THE GOLDEN-CHEEKED WARBLER (DENDROICA CHRYSOPARIA) DURING CONSTRUCTION OF 164 ACRES OF RESIDENTIAL AND COMMERCIAL DEVELOPMENT LOCATED IN HAYS COUNTY, TEXAS. U.S. FISH AND WILDLIFE SERVICE, AUSTIN, TEXAS.

4458. U.S. FISH AND WILDLIFE SERVICE. 1998. ENVIRONMENTAL ASSESSMENT/HABITAT CONSERVATION PLAN FOR ISSUANCE OF AN ENDANGERED SPECIES SECTION 10(A)(1)(B) PERMIT FOR THE INCIDENTAL TAKE OF THE GOLDEN-CHEEKED WARBLER (DENDROICA CHRYSOPARIA) FOR CONSTRUCTION OF A SINGLE FAMILY RESIDENCE ON 18.79 ACRES (TAX PARCEL ID \#01-5118-0120 AND 01-5108-0120) SPICEWOOD SPRINGS ROAD, AUSTIN, TRAVIS COUNTY, TEXAS. U.S. FISH AND WLDLIFE SERVICE, AUSTIN, TEXAS.

4459. U.S. FISH AND WILDLIFE SERVICE. 1996. ENVIRONMENTAL ASSESSMENT/HABITAT CONSERVATION PLAN FOR ISSUANCE OF AN ENDANGERED SPECIES SECTION 10(A)(1)(B) PERMIT FOR THE INCIDENTAL TAKE OF THE GOLDEN-CHEEKED WARBLER (DENDROICA CHRYSOPARIA) FOR CONSTRUCTION OF A SINGLE FAMILY RESIDENCE ON 8.0 ACRES (TAX PARCEL ID \#01-5947-0116 0000 7) ON BULLICK BLUFF, AUSTIN, TRAVIS COUNTY, TEXAS. U.S. FISH AND WLDLIFE SERVICE, AUSTIN, TEXAS. 
4460. U.S. FISH AND WILDLIFE SERVICE. 1982. EUREKA VALLEY DUNES RECOVERY PLAN. U.S. FISH AND WILLIFE SERVICE. 84PP.

4461. U.S. FISH AND WILDLIFE SERVICE. 1993. GRIZZLY BEAR RECOVERY PLAN. U.S. FISH AND WILDLIFE SERVICE FINAL REPORT. 181PP.

4462. U.S. FISH AND WILDLIFE SERVICE. 1975. TASK FORCE REPORT ON EFFECTS OF ROAD CONSTRUCTION ON WETLAND WILDLIFE HABITAT. THE SERVICE, TWIN CITIES, MINNESOTA.

4463. U.S. FISH AND WILDLIFE SERVICE and DIVISION OF ENDANGERED SPECIES. 1997? DRAFT ENVIRONMENTAL ASSESSMENT ISSUANCE OF AN INCIDENTAL TAKE PERMIT FOR THE BALD EAGLE TO NICHOLAS GROSS, JR., SNOW CONSTRUCTION, INC., FOR THE CONSTRUCTION AND OCCUPANCY OF ASHLEY RESERVE, A RESIDENTIAL DEVELOPMENT IN OSCEOLA COUNTY FLORIDA. THE DIVISION, ATLANTA, GEORGIA.

4464. U.S. FISH AND WILDLIFE SERVICE and DIVISION OF ENDANGERED SPECIES. 1995. ENVIRONMENTAL ASSESSMENT ISSUANCE OF AN INCIDENTAL TAKE PERMIT TO FORTE MACAULAY DEVELOPMENT CO., INC. FOR CONSTRUCTION OF WINDSOR ESTATES SUBDIVISION IN BREVARD COUNTY, FLORIDA. THE DIVISION, .

4465. U.S. FISH AND WILDLIFE SERVICE, E.L. YEAGER CONSTRUCTION COMPANY, INC, UNITED STATES and BUREAU OF LAND MANAGEMENT. 1997. IMPLEMENTING AGREEMENT BY AND BETWEEN E.L. YEAGER CONSTRUCTION COMPANY, INC., U.S. FISH AND WILDLIFE SERVICE AND U.S. BUREAU OF LAND MANAGEMENT TO ESTABLISH A MITIGATION PROGRAM FOR THE THREATENED DESERT TORTOISE AT THE PROPOSED WILDWASH SAND AND GRAVEL MINE SITE, SAN BERNARDINO, CALIFORNIA.

4466. U.S. FISH AND WILDLIFE SERVICE and ECOLOGICAL SERVICES. 1996. ENVIRONMENTAL ASSESSMENT AND HABITAT CONSERVATION ISSUANCE OF AN ENDANGERED SPECIES SECTION 10(A)(1)(B) PERMIT FOR THE INCIDENTAL TAKE OF THE GOLDEN-CHEEKED WARBLER (DENDROICA CHRYSOPARIA) AND BLACK-CAPPED VIREO (VIREO ATRICAPILLUS) DURING CONSTRUCTION AND OPERATION OF THE LAKEFRONT MIXED-USE DEVELOPMENT ON THE 2,572.8-ACRE, REED ESTATE PROPERTY, AUSTIN, TRAVIS COUNTY, TEXAS. U.S. FISH AND WILDLIFE SERVICE, ECOLOGICAL SERVICES, AUSTIN, TEXAS.

4467. U.S. FISH AND WILDLIFE SERVICE and ECOLOGICAL SERVICES. 1996. ENVIRONMENTAL ASSESSMENT AND HABITAT CONSERVATION PLAN AMENDMENT OF AN ENDANGERED SPECIES SECTION 10(A)(1)(B) PERMIT TO INCLUDE INCIDENTAL TAKE OF THE GOLDEN-CHEEKED WARBLER (DENDROICA CHRYSOPARIA) DURING CONSTRUCTION AND OPERATION OF A 209-ACRE RESIDENTIAL AND COMMERCIAL DEVELOPMENT ON A 272-ACRE PARCEL IN DAVENPORT RANCH, AUSTIN, TRAVIS COUNTY, TEXAS. U.S. FISH AND WILDIFE SERVICE, ECOLOGICAL SERVICES, AUSTIN, TEXAS.

4468. U.S. FISH AND WILDLIFE SERVICE and ECOLOGICAL SERVICES. 1998. ENVIRONMENTAL ASSESSMENT AND HABITAT CONSERVATION PLAN FOR ISSUANCE OF AN ENDANGERED SPECIES SECTION 1O(A)(1)(B) PERMIT FOR THE INCIDENTAL TAKE OF THE GOLDEN-CHEEKED WARBLER (DENDROICA CHRYSOPARIA) DURING CONSTRUCTION, OPERATION, AND OCCUPATION OF A RESIDENTIAL AND COMMERCIAL DEVELOPMENT ON THE 714ACRE BALFOUR TRACT, TRAVIS COUNTY, TEXAS. U.S. FISH AND WILDLIFE SERVICE, AUSTIN, TEXAS.

4469. U.S. FISH AND WILDLIFE SERVICE and ECOLOGICAL SERVICES. 1996. ENVIRONMENTAL ASSESSMENT AND HABITAT CONSERVATION PLAN ISSUANCE OF AN ENDANGERED SPECIES SECTION 10(A)(1)(B) PERMIT FOR THE INCIDENTAL TAKE OF THE GOLDEN-CHEEKED WARBLER (DENDROICA CHRYSOPARIA) DURING CONSTRUCTION AND OPERATION OF APPROXIMATELY 289 ACRES OF RESIDENTIAL DEVELOPMENT FOR THE APPROXIMATELY 347-ACRE SEVEN OAKS RANCH PROPERTY, AUSTIN, TRAVIS COUNTY, TEXAS. U.S. FISH AND WILDLIFE SERVICE, ECOLOGICAL SERVICES, AUSTIN, TEXAS.

4470. U.S. FISH AND WILDLIFE SERVICE and ECOLOGICAL SERVICES. 1998. ENVIRONMENTAL ASSESSMENT/HABITAT CONSERVATION PLAN FOR ISSUANCE OF AN ENDANGERED SPECIES SECTION 1O(A)(1)(B) PERMIT FOR THE INCIDENTAL TAKE OF THE GOLDEN-CHEEKED WARBLER (DENDROICA CHRYSOPARIA) DURING CONSTRUCTION OF A SINGLE FAMILY RESIDENCE ON 10.117 ACRES (TAX PARCEL ID 013427) ON CITY PARK ROAD, TRAVIS COUNTY, TEXAS. U.S. FISH AND WILDLIFE SERVICE, ECOLOGICAL SERVICES, AUSTIN, TEXAS.

4471. U.S. FISH AND WILDLIFE SERVICE and ECOLOGICAL SERVICES. 1996. ENVIRONMENTAL ASSESSMENT/HABITAT CONSERVATION PLAN FOR ISSUANCE OF AN ENDANGERED SPECIES SECTION 10(A)(1)(B) PERMIT FOR THE INCIDENTAL TAKE OF THE GOLDEN-CHEEKED WARBLER (DENDROICA CHRYSOPARIA) FOR CONSTRUCTION OF A SINGLE FAMILY RESIDENCE AT O YUCCA MOUNTAIN ROAD (ACROSS FROM 9206 YUCCA MOUNTAIN ROAD), AUSTIN, TRAVIS COUNTY, TEXAS. U.S. FISH AND WILDLIFE SERVICE, ECOLOGICAL SERVICES, AUSTIN, TEXAS. 
4472. U.S. FISH AND WILDLIFE SERVICE and ECOLOGICAL SERVICES. 1996. ENVIRONMENTAL ASSESSMENT/HABITAT CONSERVATION PLAN FOR ISSUANCE OF AN ENDANGERED SPECIES SECTION 10(A)(1)(B) PERMIT FOR THE INCIDENTAL TAKE OF THE GOLDEN-CHEEKED WARBLER (DENDROICA CHRYSOPARIA) FOR CONSTRUCTION OF A SINGLE FAMILY RESIDENCE ON 1.68 ACRES ON 6800-3 WHITECLIFF ROAD, AUSTIN, TRAVIS COUNTY, TEXAS. U.S. FISH AND WILDLIFE SERVICE, ECOLOGICAL SERVICES, AUSTIN, TEXAS.

4473. U.S. FISH AND WILDLIFE SERVICE and ECOLOGICAL SERVICES. 1996. ENVIRONMENTAL ASSESSMENT/HABITAT CONSERVATION PLAN FOR ISSUANCE OF AN ENDANGERED SPECIES SECTION 10(A)(1)(B) PERMIT FOR THE INCIDENTAL TAKE OF THE GOLDEN-CHEEKED WARBLER (DENDROICA CHRYSOPARIA) DURING CONSTRUCTION AND OPERATION OF THE 33-ACRE COMMERCIAL DEVELOPMENT - SCHLUETER 33, AUSTIN, TRAVIS COUNTY, TEXAS. U.S. FISH AND WIDLIFE SERVICE, ECOLOGICAL SERVICES, AUSTIN, TEXAS.

4474. U.S. FISH AND WILDLIFE SERVICE and ENDANGERED SPECIES DIVISION. 1996. FINAL ENVIRONMENTAL ASSESSMENT ISSUANCE OF AN INCIDENTAL TAKE PERMIT FOR THE ALABAMA BEACH MOUSE TO BRETT REAL ESTATE, ROBINSON DEVELOPMENT CO., INC. FOR THE CONSTRUCTION AND OCCUPANCY OF PHOENIX VI \& VII A CONDOMINIUM DEVELOPMENT IN ORANGE BEACH, BALDWIN COUNTY, ALABAMA. THE SERVICE, ATLANTA, GEORGIA.

4475. U.S. FISH AND WILDLIFE SERVICE and ENDANGERED SPECIES DIVISION. 1997. ISSUANCE OF AN INCIDENTAL TAKE PERMIT TO EMILE J. MOUHOT FOR CONSTRUCTION AND OCCUPANCY OF A SINGLE-FAMILY RESIDENCE IN SARASOTA COUNTY, FLORIDA. U.S. FISH AND WLDLIFE SERVICE, ENDANGERED SPECIES DIVISION, ATLANTA, GEORGIA.

4476. U.S. FISH AND WILDLIFE SERVICE, GEI CONSULTANTS, U.S. FISH AND WILDLIFE SERVICE, REGION 6, COLORADO and BRIDGE/DAM/SAFETY SECTION. 1992. SUMMARY OF DRAFT ENVIRONMENTAL IMPACT STATEMENT MODIFICATION OF LAKE ILO DAM NEAR DUNN CENTER, NORTH DAKOTA. MICROFORM. U.S. FISH AND WILDLIFE SERVICE, REGION 6, DIVISION OF REFUGES AND WILDLIFE, SERVICE ENGINEERING CENTER, BRIDGE/DAM/SAFETY SECTION, DENVER, COLORADO.

4477. U.S. FISH AND WILDLIFE SERVICE and K. F. HIGGINS. 1977. CONSTRUCTION AND OPERATION OF CABLE-CHAIN DRAG FOR NEST SEARCHES. WILDLIFE LEAFLET 512. DEPT. OF THE INTERIOR, FISH AND WILDLIFE SERVICE, WASHINGTON, D.C.

4478. U.S. FISH AND WILDLIFE SERVICE, REGION IV, U.S. FISH AND WILDLIFE SERVICE and DIVISION OF ECOLOGICAL SERVICES. 1984. A REPORT OF FOLLOW-UP EVALUATIONS FOR SELECTED FEDERAL FLOOD CONTROL PROJECTS AND PERMITTED PROJECTS INVOLVING HIGHWAYS AND BRIDGES WITH PLACEMENT OF FILL IN WETLANDS. U.S. FISH AND WILDLIFE SERVICE, REGION 4, HABITAT RESOURCES, DIVISION OF ECOLOGICAL SERVICES, ATLANTA, GEORGIA.

4479. U.S. FISH AND WILDLIFE SERVICE and SWCA, INC. 1996. HABITAT CONSERVATION PLAN FOR THE ISSUANCES OF AN INCIDENTAL TAKE PERMIT UNDER SECTION 10(A)(1)(B) OF THE ENDANGERED SPECIES ACT FOR THE UTAH PRAIRIE DOG (CYNOMYS PARVIDENS) BY CONNEL GOWER CONSTRUCTION. REV. SWCA, INC, SALT LAKE CITY, UTAH.

4480. U.S. FISH AND WILDLIFE SERVICE, UNITED STATES, BUREAU OF LAND MANAGEMENT and E.L. YEAGER CONSTRUCTION COMPANY, INC. 1997. IMPLEMENTING AGREEMENT BY AND BETWEEN E.L. YEAGER CONSTRUCTION COMPANY, INC., U.S. FISH AND WLDLIFE SERVICE, AND U.S. BUREAU OF LAND MANAGEMENT. U.S. BUREAU OF LAND MANAGEMENT. E.L. YEAGER CONSTRUCTION COMPANY, INC. ; PORTLAND, OR. U.S. FISH AND WILDLIFE SERVICE, RIVERSIDE, CALIFORNIA.

4481. U.S. FISH AND WILDLIFE SERVICE, UNITED STATES, BUREAU OF LAND MANAGEMENT, UTAH and DIVISION OF WILDLIFE RESOURCES. 1996. IMPLEMENTING AGREEMENT BY AND BETWEEN CONNEL GOWER CONSTRUCTION, INC., U.S., FISH AND WLDLIFE SERVICE, U.S.D.I. BUREAU OF LAND MANAGEMENT, AND THE UTAH DIVISION OF WILDLIFE RESOURCES.

4482. U.S. FISH AND WILDLIFE SERVICE, UNITED STATES, NATIONAL MARINE FISHERIES SERVICE and PLUM CREEK TIMBER COMPANY. 1997. RECORD OF DECISION PROPOSED ISSUANCE OF A PERMIT TO ALLOW INCIDENTAL TAKE OF THREATENED AND ENDANGERED SPECIES TO PLUM CREEK TIMBER COMPANY, L.P. FOR LANDS IN THE I-90 CORRIDOR OF KING AND KITTITAS COUNTIES, WASHINGTON.

4483. U.S. FISH AND WILDLIFE SERVICE, UNITED STATES, NATIONAL MARINE FISHERIES SERVICE, RAEDEKE ASSOCIATES and PLUM CREEK TIMBER COMPANY. 1995. DRAFT ENVIRONMENTAL IMPACT STATEMENT FOR THE PROPOSED ISSUANCE OF A PERMIT TO ALLOW INCIDENTAL TAKE OF THREATENED AND ENDANGERED SPECIES PLUM CREEK TIMBER COMPANY, L.P. LANDS IN THE I-90 CORRIDOR, KING AND KITTITAS COUNTIES, WASHINGTON. PLUM CREEK, SEATTLE, WASHINGTON. 
4484. U.S. FISH AND WILDLIFE SERVICE, UTAH FIELD OFFICE and SWCA, INC. 1996. ENVIRONMENTAL ASSESSMENT FOR THE ISSUANCE OF AN INCIDENTAL TAKE PERMIT UNDER SECTION 10 (A) (1) (B) OF THE ENDANGERED SPECIES ACT FOR THE UTAH PRAIRIE DOG (CYNOMYS PARIDENS) BY CONNEL GOWER CONSTRUCTION, INC. REV. SWCA, INC, SALT LAKE CITY, UTAH.

4485. U.S. FOREST SERVICE. 1974. OUTDOOR RECREATION RESEARCH: APPLYING THE RESULTS. U.S. FOREST SERVICE. GENERAL TECHNICAL REPORT NC-9. 113PP.

4486. U.S. FOREST SERVICE AND TREAD LIGHTLY INC. 1991. TREAD LIGHTLY! ON PUBLIC AND PRIVATE LAND: A LAND USE ETHICS PROGRAM. U.S. FOREST SERVICE, INTERMOUNTAIN RESEARCH STATION AND TREAD LIGHTLY, INC. OGDEN, UTAH. 34PP.

4487. U.S. FOREST SERVICE ROCKY MOUNTAIN FOREST AND RANGE EXPERIMENT STATION. 1979. MITIGATION SYMPOSIUM: A NATIONAL WORKSHOP ON MITIGATING LOSSES OF FISH AND WLDLIFE HABITATS. GENERAL TECHNICAL REPORT RM-65. U.S. FOREST SERVICE, ROCKY MOUNTAIN FOREST AND RANGE EXPERIMENT STATION, FORT COLLINS, CO, .

4488. U.S. GENERAL ACCOUNTING OFFICE. 1995. FEDERAL LANDS: INFORMATION ON THE USE AND IMPACT OF OFF-HIGHWAY VEHICLES. REPORT TO THE HONORABLE BRUCE F. VENTO, HOUSE OF REPRESENTATIVES GAO/RCED-95-209. WASHINGTON, D.C.

4489. UECKERMANN, E. 1984. UNTERSUCHUNG DER EIGNUNG VON WILDDURCHLASSES UNDER WIRKSAMKEIT VON WILDWARNREFLECTOREN. FORSCHUNG STRASSENBAU UND STRASSENVERKEHRSTECHNIK 426:1-58.

4490. UEKERMANN, E. 1984. AN INVESTIGATION INTO THE SUITABILITY OF WILDLIFE CORRIDORS AND THE EFFECTIVENESS OF REFLECTORS TO WARN OF DEER CROSSING. FORSCHUNG STRASSENBAU UND STRASSENVERKEHRSTECHNIK 426:1-58.

4491. UJVÁRI, M., H. J. BAAGøE and A. B. MADSEN. 1998. EFFECTIVENESS OF WILDLIFE WARNING REFLECTORS IN REDUCING DEER-VEHICLE COLLISIONS: A BEHAVIORAL STUDY. JOURNAL OF WILDLIFE MANAGEMENT 62(3):1094-1099.

4492. ULLMANN, I., P. BANNISTER and J. B. WILSON. 1995. THE VEGETATION OF ROADSIDE VERGES WITH RESPECT TO ENVIRONMENTAL GRADIENTS IN SOUTHERN NEW ZEALAND. JOURNAL OF VEGETATION SCIENCE 6(1):131-142.

4493. UNITED STATES, ARMY and CORPS OF ENGINEERS. 1978. SUMMARY REPORT OF FISH AND WILDLIFE HABITAT CHANGES RESULTING FROM THE CONSTRUCTION OF A NINE-FOOT CHANNEL IN THE UPPER MISSISSIPPI RIVER, MINNESOTA RIVER, ST. CROIX RIVER AND ILLINOIS WATERWAY. CHICAGO, ILLINOIS.

4494. UNITED STATES, ARMY, CORPS OF ENGINEERS, LOS ANGELES DISTRICT, U.S. FISH AND WILDLIFE SERVICE, CALIFORNIA, REGIONAL WATER QUALITY CONTROL BOARDS and CAMP PENDLETON (CALIF.). 1997. DRAFT ENVIRONMENTAL IMPACT STATEMENT SANTA MARGARITA RIVER FLOOD CONTROL PROJECT, MILCON PROJECT P-101: BASILONE ROAD BRIDGE REPLACEMENT, MILCON PROJECT P-030, MARINE CORPS BASE, CAMP PENDLETON, CALIFORNIA. U.S. ARMY CORPS OF ENGINEERS, LOS ANGELES DISTRICT, LOS ANGELES, CALIFORNIA.

4495. UNITED STATES, ARMY, CORPS OF ENGINEERS, LOS ANGELES DISTRICT, U.S. FISH AND WILDLIFE SERVICE, CALIFORNIA and REGIONAL WATER QUALITY CONTROL BOARDS. 1997. FINAL ENVIRONMENTAL IMPACT STATEMENT SANTA MARGARITA RIVER FLOOD CONTROL PROJECT, MILCON PROJECT P-101 : BASILONE ROAD BRIDGE REPLACEMENT, MILCON PROJECT P-030, MARINE CORPS BASE, CAMP PENDLETON, CALIFORNIA. U.S. ARMY CORPS OF ENGINEERS, LOS ANGELES DISTRICT, LOS ANGELES, CALIFORNIA.

4496. UNITED STATES, ARMY, CORPS OF ENGINEERS and MISSOURI RIVER DIVISION. 1980? MISSOURI RIVER BANK STABILIZATION AND NAVIGATION PROJECT DRAFT FEASIBILITY REPORT AND DRAFT EIS FOR THE FISH AND WILDLIFE MITIGATION PLAN. U.S. ARMY, CORPS OF ENGINEERS, MISSOURI RIVER DIVISION,

4497. UNITED STATES, ARMY, CORPS OF ENGINEERS, NORTHWEST POWER PLANNING COUNCIL (U.S.) and COLUMBIA RIVER BASIN FISH AND WILDLIFE PROGRAM (U.S.). 1994. COLUMBIA RIVER SALMON MITIGATION ANALYSIS SYSTEM CONFIGURATION STUDY, PHASE I DRAFT. US ARMY CORPS OF ENGINEERS, WALLA WALLA, WASHINGTON.

4498. UNITED STATES, ARMY, CORPS OF ENGINEERS and PORTLAND DISTRICT. 1999. INTEGRATED FEASIBILITY REPORT FOR CHANNEL IMPROVEMENTS AND ENVIRONMENTAL IMPACT STATEMENT COLUMBIA \& LOWER WILLAMETTE RIVER FEDERAL NAVIGATION Ç52ANNEL. US ARMY CORPS OF ENGINEERS, PORTLAND 
4499. UNITED STATES, ARMY, CORPS OF ENGINEERS and PORTLAND DISTRICT. 1998. INTEGRATED FEASILIBILTY REPORT FOR CHANNEL IMPROVEMENTS AND ENVIRONMENTAL IMPACT STATEMENT COLUMBIA \& LOWER WILLAMETTE RIVER FEDERAL NAVIGATION CHANNEL. US ARMY CORPS OF ENGINEERS, PORTLAND DISTRICT, PORTLAND, OREGON.

4500. UNITED STATES, ARMY, CORPS OF ENGINEERS and WALLA WALLA DISTRICT. 1999. LOWER SNAKE RIVER JUVENILE SALMON MIGRATION FEASIBILITY STUDY DRAFT FEASIBILITY REPORT/ENVIRONMENTAL IMPACT STATEMENT. ARMY CORP OF ENGINEERS, WALLA WALLA DISTRICT, WALLA WALLA, WASHINGTON.

4501. UNITED STATES and BONNEVILLE POWER ADMINISTRATION. 1985. IMPACTS OF WATER LEVELS ON BREEDING CANADA GEESE AND THE METHODOLOGY FOR MITIGATION AND ENHANCEMENT IN THE FLATHEAD DRAINAGE ANNUAL REPORT 1984. BONNEVILLE POWER ADMINISTRATION, PORTLAND, OREGON.

4502. UNITED STATES, BONNEVILLE POWER ADMINISTRATION, DIVISION OF FISH AND WILDLIFE and HUNGRY HORSE IMPLEMENTATION GROUP. HUNGRY HORSE DAM FISHERIES MITIGATION BIENNIAL REPORT, 1992-1993.

4503. UNITED STATES, BUREAU OF LAND MANAGEMENT and CALIFORNIA STATE OFFICE. 1980. THE CALIFORNIA DESERT CONSERVATION AREA FINAL ENVIRONMENTAL IMPACT STATEMENT AND PROPOSED PLAN. THE BUREAU, SACRAMENTO, CALIFORNIA.

4504. UNITED STATES, BUREAU OF LAND MANAGEMENT and DIVIDE RESOURCE AREA. 1990. RECORD OF DECISION AND APPROVED RESOURCE MANAGEMENT PLAN FOR THE GREAT DIVIDE RESOURCE AREA. THE RESOURCE AREA, RAWLINS, WYOMING.

4505. UNITED STATES and BUREAU OF RECLAMATION. 1940. REARING PONDS, CANALS, DIKES, ROAD SURFACING, AND DRAINAGE AND WATER SYSTEMS, WINTHROP STATION, MIGRATORY-FISH CONTROL SCHEDULE, SPECIFICATIONS, AND DRAWINGS. SPECIFICATIONS: SPECIFICATIONS (UNITED STATES. BUREAU OF RECLAMATION) NO. 927. BRADFORD-ROBINSON PTG. CO., DENVER, COLORADO.

4506. UNITED STATES, BUREAU OF SPORT FISHERIES AND WILDLIFE, UNITED STATES and BUREAU OF PUBLIC ROADS. 1969. AN EVALUATION OF COORDINATION BETWEEN STATE HIGHWAY AND STATE FISH AND GAME DEPARTMENTS. THE BUREAU, WASHINGTON, D.C.

4507. UNITED STATES, CONGRESS, HOUSE and COMMITTEE ON RESOURCES. 1999. LAND AND MONEY MITIGATION REQUIREMENTS IN ENDANGERED SPECIES ACT ENFORCEMENT OVERSIGHT HEARING BEFORE THE COMMITTEE ON RESOURCES, HOUSE OF REPRESENTATIVES, ONE HUNDRED SIXTH CONGRESS, FIRST SESSION, MAY 26, 1999, WASHINGTON, DC. U.S. G.P.O., WASHINGTON, D.C.

4508. UNITED STATES, CONGRESS, HOUSE, COMMITTEE ON RESOURCES and SUBCOMMITTEE ON FISHERIES CONSERVATION, WILDLIFE, AND OCEANS. 1998. HEARING ON H.R. 2401, CBRA TECHNICAL CORRECTIONS; AND H.R. 2556, TO REAUTHORIZE THE NORTH AMERICAN WETLANDS CONSERVATION ACT OF 1989 HEARING BEFORE THE SUBCOMMITTEE ON FISHERIES CONSERVATION, WLDLIFE, AND OCEANS OF THE COMMITTEE ON RESOURCES, HOUSE OF REPRESENTATIVES, ONE HUNDRED FIFTH CONGRESS, FIRST SESSION, OCTOBER 23, 1997, WASHINGTON, DC. U.S. G.P.O., WASHINGTON, D.C.

4509. UNITED STATES, CONGRESS, SENATE, COMMITTEE ON ENERGY AND NATURAL RESOURCES and SUBCOMMITTEE ON PARKS, HISTORIC PRESERVATION, AND RECREATION. 1997. YELLOWSTONE NATIONAL PARK HEARING BEFORE THE SUBCOMMITTEE ON PARKS, HISTORIC PRESERVATION, AND RECREATION OF THE COMMITTEE ON ENERGY AND NATURAL RESOURCES, UNITED STATES SENATE, ONE HUNDRED FIFTH CONGRESS, FIRST SESSION, ON THE PRELIMINARY FINDINGS OF THE GENERAL ACCOUNTING OFFICE CONCERNING A STUDY ON THE HEALTH, CONDITION, AND VIABILITY OF THE RANGE AND WLDLIFE POPULATIONS IN YELLOWSTONE NATIONAL PARK, JULY 10, 1997. S. HRG. U.S. G.P.O., WASHINGTON, D.C.

4510. UNITED STATES, CONGRESS, SENATE, COMMITTEE ON ENERGY AND NATURAL RESOURCES and SUBCOMMITTEE ON WATER AND POWER. 1998. BONNEVILLE POWER ADMINISTRATION'S ANNUAL FISH AND WILDLIFE BUDGET HEARING BEFORE THE SUBCOMMITTEE ON WATER AND POWER OF THE COMMITTEE ON ENERGY AND NATURAL RESOURCES, UNITED STATES SENATE, ONE HUNDRED FIFTH CONGRESS, SECOND SESSION, ON THE IMPLEMENTATION OF THE 1996 GORTON AMENDMENT TO THE NORTHWEST POWER ACT, VANCOUVER, WA, FEBRUARY 17, 1998. S. HRG. U.S. G.P.O., WASHINGTON, D.C.

4511. UNITED STATES, CONGRESS, SENATE and COMMITTEE ON ENVIRONMENT AND PUBLIC WORKS. 1998. MONTANA FISH AND WILDLIFE CONSERVATION ACT OF 1998 FIELD HEARING BEFORE THE COMMITTEE ON ENVIRONMENT AND PUBLIC WORKS, UNITED STATES SENAIE 53 ONE HUNDRED FIFTH CONGRESS, SECOND SESSION ON S. 
1913 ... FEBRUARY 17, 1998, HELENA, MONTANA. S. HRG. U.S. G.P.O., WASHINGTON, D.C.

4512. UNITED STATES, CONGRESS, SENATE and COMMITTEE ON ENVIRONMENT AND PUBLIC WORKS. 1999. WILDLIFE CONSERVATION LEGISLATION HEARING BEFORE THE COMMITTEE ON ENVIRONMENT AND PUBLIC WORKS, UNITED STATES SENATE, ONE HUNDRED FIFTH CONGRESS, SECOND SESSION, JULY 7, $1998:$ S. 263 , BEAR PROTECTION ACT, S. 361 ... H.R. 2807, RHINO AND TIGER PRODUCT LABELING ACT, H.R. 3113, RHINOCEROS AND TIGER ... S. 659, GREAT LAKES FISH AND WILDLIFE ... S. 1970, NEOTROPICAL MIGRATORY BIRD ... S. 2094, FISH AND WILDLIFE REVENUE ... S. 2244, NATIONAL WILDLIFE REFUGE SYSTEM. S. HRG. U.S. G.P.O., WASHINGTON, D.C.

4513. UNITED STATES and FEDERAL HIGHWAY ADMINISTRATION. 1979. RESTORATION OF FISH HABITAT IN RELOCATED STREAMS. IMPLEMENTATION PACKAGE 79-3. DEPT. OF TRANSPORTATION, FEDERAL HIGHWAY ADMINISTRATION, WASHINGTON, D.C.

4514. UNITED STATES, FEDERAL HIGHWAY ADMINISTRATION, ENVIRONMENTAL DIVISION, U.S. FISH AND WILDLIFE SERVICE and URBAN WLDLIFE RESEARCH CENTER. 1982. EFFECTS OF HIGHWAYS ON WILDLIFE. THE ADMINISTRATION. NATIONAL TECHNICAL INFORMATION SERVICE DISTRIBUTOR, WASHINGTON, D.C.

4515. UNITED STATES, FOREST SERVICE and CALIFORNIA REGION. 1973? PROTECTING FISH HABITAT DURING FOREST ROAD DEVELOPMENT. COORDINATION GUIDELINES FOR FISH AND WILDLIFE HABITATS: COORDINATION GUIDELINES FOR WLDLIFE HABITATS NO. 7. U.S. DEPT. OF AGRICULTURE, FOREST SERVICE, CALIFORNIA REGION, SAN FRANCISCO, CALIFORNIA.

4516. UNITED STATES, FOREST SERVICE and INTERMOUNTAIN REGION. 1990-. SOUTH FORK SALMON RIVER ROAD PROJECT FINAL ENVIRONMENTAL IMPACT STATEMENT. U.S. DEPT. OF AGRICULTURE, FOREST SERVICE, INTERMOUNTAIN REGION, OGDEN, UTAH.

4517. UNITED STATES and GENERAL ACCOUNTING OFFICE. 1998? WILDLIFE MANAGEMENT: ISSUES CONCERNING THE MANAGEMENT OF BISON AND ELK HERDS IN YELLOWSTONE NATIONAL PARK... 158959... U.S. GAO... JULY 10.

4518. UNITED STATES, NATIONAL MARINE FISHERIES SERVICE, U.S. FISH AND WLDLIFE SERVICE, UNITED STATES, ARMY, CORPS OF ENGINEERS, HONOLULU DISTRICT, UNITED STATES and ENVIRONMENTAL PROTECTION AGENCY. 2000. ENVIRONMENTAL ASSESSMENT FOR NAVIGATIONAL ACCESS AND MATERIALS ACQUISITION IN SUPPORT OF THE CONSTRUCTION OF THE PALAU COMPACT ROAD, BABELDAOB ISLAND, REPUBLIC OF PALAU. DEPT. OF THE ARMY, U.S. ARMY ENGINEER DISTRICT, HONOLULU, FORT SHAFTER, HAWAII.

4519. UNITED STATES, ROCKY MOUNTAIN FOREST AND RANGE EXPERIMENT STATION, FORT COLLINS, COLO, UNITED STATES and FOREST SERVICE. 1979. MITIGATION SYMPOSIUM: THE MITIGATION SYMPOSIUM A NATIONAL WORKSHOP ON MITIGATING LOSSES OF FISH AND WILLIFE HABITATS, JULY 16-20, 1979, COLORADO STATE UNIVERSITY, FORT COLLINS, COLORADO. USDA FOREST SERVICE GENERAL TECHNICAL REPORT RM ; 65. DEPT. OF AGRICULTURE, FOREST SERVICE, ROCKY MOUNTAIN FOREST AND RANGE EXPERIMENT STATION, FORT COLLINS, COLORADO.

4520. UNITED STATES INTERNATIONAL TRADE COMMISSION and GOVERNMENT INSTITUTES. 1994. INTERNATIONAL AGREEMENTS TO PROTECT THE ENVIRONMENT AND WLDLIFE. GOVERNMENT INSTITUTES, INC, ROCKVILLE, MARYLAND.

4521. UNIVERSITY OF MONTANA and U.S. FOREST SERVICE. 1975. PROCEEDINGS OF THE FIRST INTERNATIONAL CONFERENCE ON NOISE FROM RECREATIONAL OFF-ROAD VEHICLES. UNIVERSITY OF MONTANA AND U.S. FOREST SERVICE. MISSOULA, MONTANA.

4522. UNIVERSITY OF UTAH SURVEY RESEARCH CENTER. 1994. REPORT OF THE 1994 UTAH OFF HIGHWAY VEHICLE USERS SURVEY. PREPARED FOR UTAH DEPARTMENT OF NATURAL RESOURCES, SALT LAKE CITY, UTAH.

4523. UNSWORTH, J. W., L. KUCK, M. D. SCOTT and E. O. GARTON. 1993. ELK MORTALITY IN THE CLEARWATER DRAINAGE OF NORTHCENTRAL IDAHO. JOURNAL OF WILDLIFE MANAGEMENT 57 (3):495-502.

4524. UNSWORTH, J. W. 1984. BLACK BEAR HABITAT USE IN WESTCENTRAL IDAHO. M.S. THESIS, MONTANA STATE UNIVERSITY, BOZEMAN, MT. 96 PP.

4525. UNSWORTH, J. W. 1993. ELK MORTALITY, HABITAT USE, AND HOME RANGE IN THE CLEARWATER DRAINAGE OF NORTH-CENTRAL IDAHO (CERVUS ELAPHUS). DISSERTATION, UNIVERSITY OF IDAHO, MOSCOW, IDAHO, USA. 
4527. US DEPARTMENT OF TRANSPORTATION FEDERAL HIGHWAY ADMINISTRATION. 1994. NATIONAL RECREATIONAL TRAILS ADVISORY COMMITTEE ANNUAL REPORT FOR THE FISCAL YEAR 1994. WASHINGTON, D.C.

4528. US DEPARTMENT OF TRANSPORTATION FEDERAL HIGHWAY ADMINISTRATION. 1993. TRADING OFF AMONG THE NEEDS OF MOTOR VEHICLE USERS, PEDESTRIANS, AND BICYCLISTS. WASHINGTON, D.C.

4529. USDA. 1967. MAGRUDER CORRIDOR RESOURCE INVENTORY. NORTHERN REGION -- BITTERROOT NATIONAL FOREST., 30 PP.

4530. USDA FOREST SERVICE. 1980. TRAIL DETERIORATION AND MAINTENANCE. USDA, FOREST SERVICE EQUIPMENT DEVELOPMENT CENTER. MISSOULA, MONTANA.

4531. USDI, FISH AND WILDLIFE SERVICE. 1978. RESERVOIR ECOSYSTEMS AND WESTERN COAL DEVELOPMENT IN THE UPPER MISSOURI RIVER BASIN. SUMMARY REPT, FISH AND WLDLF SERV. BIOL. SERV. PROG., FWS/OBS-78 25. 13 PP.

4532. USDI, NATIONAL PARK SERVICE. 1968. PARK ROAD STANDARDS. USDI., 20 PP.

4533. USHER, R. G. 1978. THE RESPONSE OF MOOSE AND WOODY BROWSE TO CLEARING IN THE BOREAL MIXED-WOOD ZONE OF ALBERTA. M.S. THESIS, U. CALGARY. CALGARY, ALBERTA. 137PP.

4534. UTAH STATE UNIVERSITY, INSTITUTE FOR LAND REHABILITATION, U.S. FISH AND WLDLIFE SERVICE, OFFICE OF BIOLOGICAL SERVICES and WESTERN ENERGY AND LAND USE TEAM. 1978. REHABILITATION OF WESTERN WILDLIFE HABITAT A REVIEW. FWS/OBS 78/86. DEPT. OF THE INTERIOR, FISH AND WILDLIFE SERVICE, OFFICE OF BIOLOGICAL SERVICES, WESTERN ENERGY AND LAND USE TEAM, FORT COLLINS, COLORADO.

4535. VALENTINE, J. M. JR. and R. E. NOBLE. 1970. A COLONY OF SANDHILL CRANES IN MISSISSIPPI. J. WILDL. MANAGE. 34 (4):761-8.

4536. VALKENBURG, P., J. L. DAVIS, J. M. VER HOEF, R. D. BOERTJE, M. E. MCNAY, R. M. EAGAN, D. J. REED, C. L. GARDNER and R. W. TOBEY. 1996. POPULATION DECLINE IN THE DELTA CARIBOU HERD WITH REFERENCE TO OTHER ALASKAN HERDS. RANGIFER SPECIAL ISSUENO.9:53-62.

4537. VAN APELDOORN, R. C., W. T. OOSTENBRINK, W. A. VAN and F. F. VAN DER ZEE. 1992. EFFECTS OF HABITAT FRAGMENTATION ON THE BANK VOLE, CLETHRIONOMYS GLAREOLUS, IN AN AGRICULTURAL LANDSCAPE. OIKOS 65 (2):265-74.

4538. VAN BALLENBERGHE, V. 1978. FINAL REPORT ON THE EFFECTS OF THE TRANS-ALASKA PIPELINE ON MOOSE MOVEMENTS. JOINT STATE/FEDERAL FISH AND WLDLIFE ADVISORY TEAM SPEC. REP. \#20. 41PP.

4539. VAN BALLENBERGHE, V. 1978. MOOSE MOVEMENT. SPECIAL REPORT NO. 23.

4540. VAN BALLENBERGHE, V., A. W. ERICKSON and D. BYMAN. 1975. ECOLOGY OF THE TIMBER WOLF IN NORTHEASTERN MINNESOTA. WILDL. MONOGR. (43):43PP.

4541. VAN BOHEMAN, H. D. 1995. MITIGATION AND COMPENSATION OF HABITAT FRAGMENTATION CAUSED BY ROADS: STRATEGY, OBJECTIVES, AND PRACTICAL MEASURES. TRANSPORTATION RESEARCH RECORD 1475:133-137.

4542. VAN DER GRIFT, E. A. and R. KUIJSTERS. 1998. MITIGATION MEASURES TO REDUCE HABITAT FRAGMENTATION BY RAILWAY LINES IN THE NETHERLANDS. PAGES 166-170 IN EVINK,G., ZIEGLER,D., GARRETT,P., AND BERRY,J., EDITORS. PROCEEDINGS OF THE INTERNATIONAL CONFERENCE ON WILDLIFE ECOLOGY AND TRANSPORTATION; 1998 FEBRUARY 10-12; FT. MYERS, FL FLORIDA DEPARTMENT OF TRANSPORTATION, TALLAHASSEE, FL.

4543. VAN DER REEST, P. J. 1992. SMALL MAMMAL FAUNA OF ROAD VERGES IN THE NETHERLANDS: ECOLOGY AND MANAGEMENT. LUTRA 35:1-27 [IN DUTCH WITH ENGLISH SUMMARY]. 
4544. VAN DER ZANDE, A. N., J. C. BERKHUIZEN, H. C. VAN LATESTEIJN, W. J. TER KEURS and A. J. POPPELAARS. 1984. IMPACT OF OUTDOOR RECREATION ON THE DENSITY AND NUMBER OF BREEDING BIRD SPECIES IN WOODS -ADJACENT TO URBAN RESIDENTIAL AREAS. BIOLOGICAL CONSERVATION 30:1-39.

4545. VAN DER ZANDE, A. N., W. J. TER KEURS and W. J. VAN DER WEIJDEN. 1980. THE IMPACT OF ROADS ON THE DENSITIES OF FOUR BIRD SPECIES IN AN OPEN FIELD HABITAT--EVIDENCE OF A LONG DISTANCE EFFECT. BIOLOGICAL CONSERVATION 18:299-231.

4546. VAN DER ZANDE, A. N. and T. J. VERSTRAEL. 1985. IMPACTS OF OUTDOOR RECREATION UPON NEST-SITE CHOICE AND BREEDING SUCCESS OF THE KESTREL. ARDEA 73:90-99.

4547. VAN DER ZEE, F. F., J. WIERTZ, C. J. TER, R. C. VAN APELDOORN and J. VINK. 1992. LANDSCAPE CHANGE AS A POSSIBLE CAUSE OF THE BADGER (MELES MELES L.) DECLINE IN THE NETHERLANDS. BIOLOGICAL CONSERVATION 61(1):17-22.

4548. VAN DYKE, F. 1981. MORTALITY IN CRIPPLED MALLARDS. J. WILDL. MANAGE.45(2):444-53.

4549. VAN DYKE, F. and W. C. KLEIN. 1996. RESPONSE OF ELK TO INSTALLATION OF OIL WELLS. J. MAMMALOGY 7.7(4):1028-41.

4550. VAN DYKE, F. G. 1983. A WESTERN STUDY OF COUGAR TRACK SURVEYS AND ENVIRONMENTAL DISTURBANCES AFFECTING COUGARS RELATED TO THE STATUS OF THE EASTERN COUGAR (FELIS CONCOLOR COUGAR). PHD. DISSERTATION, STATE UNIV. OF NEWYORK, SYRACUSE.

4551. VAN DYKE, F. G., R. H. BROCKE and H. G. SHAW. 1986. USE OF ROAD TRACK COUNTS AS INDICES OF MOUNTAIN LION PRESENCE. J. WILDL. MANAGE. 50 (1):102-9

4552. VAN DYKE, F. G., R. H. BROCKE, H. G. SHAW, B. B. ACKERMAN, T. P. HEMKER and F. G. LINDZEY. 1986. REACTIONS OF MOUNTAIN LIONS TO LOGGING AND HUMAN ACTIVITY. JOURNAL OF WILDLIFE MANAGEMENT 50:95-102.

4553. VAN ESTERIK, N., G. J. MARTENS, A. N. ZONDERL and A. ZUIDERWIJK. 1989. TUNNELS FOR MIGRATING BUFO BUFO IN OVERVEEN. LACERTA 7(3):74-80.

4554. VAN GELDER, J. J. 1973. A QUANTITATIVE APPROACH TO THE MORTALITY RESULTING FROM TRAFFIC IN A POPULATION OF BUFO BUFO. L. OECOLOGIA 13:93-5.

4555. VAN GELDER, J. J. 1973. A QUANTITATIVE APPROACH TO THE MORTALITY RESULTING FROM TRAFFIC IN A POPULATION OF BUFO BUFO L. OECOLOGIA 13:93-95.

4556. VAN HORN, R. C. 1993. A SUMMARY OF REPRODUCTIVE SUCCESS AND MORTALITY IN A DISTURBED FERRUGINOUS HAWK (BUTEO REGALIS) POPULATION IN NORTHCENTRAL MONTANA, 1990-92. J. RAPTOR RES. $27: 94$ (ABSTRACT ONLY).

4557. VAN HORN, R. C. 1993. FERRUGINOUS HAWK AND PAIRIE FALCON REPRODUCTIVE AND BEHAVIORIAL RESPONSES TO HUMAN ACTIVITY NEAR THE KEVIN RIM, MONTANA. M.S. THESIS, MONTANA STATE UNIVERSITY, BOZEMAN, MT. 86 PP.

4558. VAN LEEUWEN, B. H. 1982. PROTECTION OF MIGRATING COMMON TOAD (BUFO BUFO) AGAINST CAR TRAFFIC IN THE NETHERLANDS. ENVIRONMENTAL CONSERVATION 9:34-41.

4559. VAN LIEROP, A. M. M. 1988. MEANS OF PREVENTING WLD ANIMALS FROM DROWNING AND BEING INVOLVED IN ROAD ACCIDENTS. CENTRE NATUROPA DOCUMENTATION SERIESNO. 22:1-65. 22 (1-65).

4560. VAN MANEN, F. T. and M. R. PELTON. 1997. A GIS MODEL TO PREDICT BLACK BEAR HABITAT USE. J. FORESTRY 95:6-12.

4561. VAN RIPER, C. III and R. OCKENFELS. 1998. THE INFLUENCE OF TRANSPORTATION CORRIDORS ON THE MOVEMENT OF PRONGHORN ANTELOPE OVER A FRAGMENTED LANDSCAPE IN NORTHERN ARIZONA. PAGES 241-248 IN G. L. EVINK, P. GARRETT, D. ZEIGLER, AND J. BERRY, EDITORS. PROCEEDINGS OF THE INTERNATIONAL CONFERENCE ON WILDLIFE ECOLOGY AND TRANSPORTATION. FLORIDA DEPARTMENT OF TRANSPORTATION, TALLAHASSEE, FLORIDA. 

SARDINIAN HERPETOFAUNA. CONSERVATION BIOLOGY 92:263-269.

4563. VAN SICKLE, W. D. and F. G. LINDZEY. 1992. EVALUATION OF ROAD TRACK SURVEYS FOR COUGARS (FELIS CONCOLOR). GREAT BASIN NATURALIST 52(3):232-236.

4564. VAN TIGHEM, K. 1981. MORTALITY OF BIGHORN SHEEP (OVIS CANADENSIS) ON A RAILROAD AND HIGHWAY IN JASPER NATIONAL PARK, CANADA. CANADIAN WILDLIFE SERVICE UNPUBLISHED REPORT, EDMONTON.

4565. VANCE, D. R. 1971. PHYSICAL AND CHEMICAL ALTERATIONS OF GRIT CONSUMED BY PHEASANTS. J. WLDL. MANAGE. $35(1): 136-40$.

4566. VANDEELEN, T. R. 1991. DISPERSAL PATTERNS OF JUVENILE BEAVERS IN WESTERN MONTANA. M.S. THESIS, UNIVERSITY OF MONTANA, MISSOULA, MT. 91 PP.

4567. VANDEHEY, A. M. 1991. VEGETATION PRODUCTIVITY OF SELECTED GRIZZLY BEAR HABITAT UNITS IN SOUTHEASTERN BRITISH COLUMBIA. M.S. THESIS, UNIVERSITY OF MONTANA, MISSOULA, MT. 105 PP.

4568. VANDENBERG, R. J. 1974. THE EFFECTS OF ACID MINE POLLUTION ON THE BENTHIC MACROINVERTEBRATES OF THE DRY FORK OF BELT CREEK DRAINAGE. M.S. THESIS, MONTANA STATE UNIVERSITY, BOZEMAN, MT. 64 PP.

4569. VANDER HAEGEN, W. M. and R. M. DEGRAAF. 1996. PREDATION ON ARTIFICIAL NESTS IN FORESTED RIPARIAN BUFFER STRIPS. JOURNAL OF WILDLIFE MANAGEMENT 60:542-550.

4570. VANDER ZOUWEN, W. J. 1983. WATERFOWL USE AND HABITAT CHANGES OF A REFUGE IN SOUTHERN WISCONSIN: 1947-1980 AND VEGETATIONAL CHANGE IN UNIVERSITY BAY FROM 1966 TO 1980. THESIS, UNIVERSITY OF WISCONSIN, MADISON, WISCONSIN.

4571. VANDERWERF, E. A. 1994. INTRASPECIFIC VARIATION IN ELEPAIO FORAGING BEHAVIOR IN HAWAIIAN FORESTS OF DIFFERENT STRUCTURE. AUK 111 (4):917-32.

4572. VARLAND, D. E., E. E. KLAAS and T. M. LOUGHIN. 1993. USE OF HABITAT AND PERCHES, CAUSES OF MORTALITY AND TIME UNTIL DISPERSAL IN POST-FLEDGING AMERICAN KESTRELS. JOURNAL OF FIELD ORNITHOLOGY 64(2):169-178.

4573. VARLAND, D. E. and T. M. LOUGHIN. 1993. REPRODUCTIVE SUCCESS OF AMERICAN KESTRELS NESTING ALONG AN INTERSTATE HIGHWAY IN CENTRAL IOWA. WLSON BULLETIN 105 (3):465-74.

4574. VARLAND, K. L. and P. J. SCHAEFER. 1998. ROADSIDE MANAGEMENT TRENDS IN MINNESOTA. PAGES 214-228 IN EVINK,G., ZIEGLER,D., GARRETT,P., AND BERRY,J., EDITORS. PROCEEDINGS OF THE INTERNATIONAL CONFERENCE ON WILDLIFE ECOLOGY AND TRANSPORTATION; 1998 FEBRUARY 10-12; FT. MYERS, FL FLORIDA DEPARTMENT OF TRANSPORTATION, TALLAHASSEE, FL.

4575. VARLAND, K. L. 1998. ROADSIDE MANAGEMENT TRENDS IN MINNESOTA - 1973 TO 1997. PAGES $214-235$ IN G. L. EVINK, P. GARRETT, D. ZEIGLER, AND J. BERRY, EDITORS. PROCEEDINGS OF THE INTERNATIONAL CONFERENCE ON WILDLIFE ECOLOGY AND TRANSPORTATION. FLORIDA DEPARTMENT OF TRANSPORTATION, TALLAHASSEE, FLORIDA

4576. VARLEY, N. C. L. 1996. ECOLOGY OF MOUNTAIN GOATS IN THE ABSAROKA RANGE, SOUTH-CENTRAL MONTANA. M:S. THESIS, MONTANA STATE UNIVERSITY, BOZEMAN, MT. 91 PP.

4577. VARMAN, K. S. and R. SUKUMAR. 1995. THE LINE TRANSECT METHOD FOR ESTIMATING DENSITIES OF LARGE MAMMALS IN A TROPICAL DECIDUOUS FOREST: AN EVALUATION OF MODELS AND FIELD EXPERIMENTS. JOURNAL OF BIOSCIENCES (BANGALORE) 20 (2):273-87.

4578. VASKE, J. J., M. P. DONNELLY and R. D. DEBLINGER. 1990. NORM ACTIVATION AND THE ACCEPTANCE OF BEHAVIORAL RESTRICTIONS AMONG OVER SAND VEHICLE USERS. PAGES 153-159 IN T. A. MORE, M. P. DONNELLY, A. R. GRAEFE, AND J. J. VASKE, EDITORS. PROCEEDINGS OF THE 1990 NORTHEASTERN RECREATION RESEARCH SYMPOSIUM. U.S. DEPT. AGRICULTURE, FOREST SERV., NORTHEAST. FOR. EXP. STA., BROOMALL, PENNSYLVANIA. 
4579. VASKE, J. J., A. R. GRAEFE and F. R. KUSS. 1983. RECREATION IMPACTS: A SYNTHESIS OF ECOLOGICAL AND SOCIAL RESEARCH. TRANSACTIONS OF THE NORTH AMERICAN WLDLIFE AND NATURAL RESOURCES CONFERENCE 48:96-107.

4580. VASSANT, J., S. BRANDT and J. M. JULLIEN. 1993. EFFECTS OF THE WILDLIFE PASSAGE OVER MOTORWAY A5 ON THE POPULATIONS OF RED DEER AND WIL BOAR IN THE MASSIF D'ARC-EN-BARROIS. PART 2: CASE OF THE POPULATION OF WID BOAR. BULL.MENS.OFFICE NATL.CHASSE 184:24-33.

4581. VAUGHAN, J. P. 1970. INFLUENCE OF ENVIRONMENT ON THE ACTIVITY AND BEHAVIOR OF WHITE-TAILED DEER (ODOCOILEUS VIRGINIANUS) ALONG AN INTERSTATE HIGHWAY IN A FOREST REGION OF PENNSYLVANIA. PH.D. THESIS, PENNSYLVANIA STATE UNIV., UNIVERSITY PARK, PENN.

4582. VELAZQUEZ, A. 1993. MAN-MADE AND ECOLOGICAL HABITAT FRAGMENTATION: STUDY CASE OF THE VOLCANO RABBIT (ROMEROLAGUS DIAZI). ZEITSCHRIFT FUER SAEUGETIERKUNDE 58:54-61.

4583. VENDITTI, D. A. 1994. DIET OVERLAP AND HABITAT UTILIZATION OF RAINBOW TROUT AND JUVENILE WALLEYE IN COONEY RESERVOIR, MONTANA. M.S. THESIS, MONTANA STATE UNIVERSITY, BOZEMAN, MT. 90 PP.

4584. VENNER, D. 1978. INFLUENCE OF DEER MIRRORS ON ROAD LINKED MORTALITY OF DEER. PAGES $31-36$ IN TABOR,R.K., EDITOR. MOTORWAYS AND THE BIOLOGIST. NORTH EAST LONDON POLYTECHNIC, MOTORWAY RESEARCH PROJECT, LONDON, ENGLAND.

4585. VENTRY, W. F. 1995. VALUE ENGINEERING SUMMARY OF THE WILDLIFE CROSSINGS WPI NO. 1114163, STATE PROJECT NO. 03080-3519, COLLIER COUNTY, FLORIDA, JUNE 5-9, 1995. FLORIDA DEPARTMENT OF TRANSPORTATION, ORLANDO, FL.

4586. VERBOOM, J., J. A. METZ and E. MEELIS. 1993. METAPOPULATION MODELS FOR IMPACT ASSESSMENT OF FRAGMENTATION. PAGES 172-189 IN VOS,C.C. AND OPDAM,P., EDITORS. LANDSCAPE ECOLOGY OF A STRESSED ENVIRONMENT. CHAPMAN AND HALL, LONDON.

4587. VERBOOM, J., A. SCHOTMAN, P. OPDAM and J. A. J. METZ. 1991. EUROPEAN NUTHATCH METAPOPULATIONS IN A FRAGMENTED AGRICULTURAL LANDSCAPE. OIKOS 61(2):149-56.

4588. VERMEIJ, G. J. 1989. INVASION AND EXTINCTION: THE LAST THREE MILLION YEARS OF NORTH SEA PELECYPOD HISTORY. CONSERVATION BIOLOGY 3 (3):274-81.

4589. VERMEULEN, H. J. W. 1993. THE COMPOSITION OF THE CARABID FAUNA ON POOR SANDY ROAD-SIDE VERGES IN RELATION TO COMPARABLE OPEN AREAS. BIODIVERSITY AND CONSERVATION 4:331-350.

4590. VERMEULEN, H. J. W. 1994. CORRIDOR FUNCTION OF A ROAD VERGE FOR DISPERSAL OF STENOTOPIC HEATHLAND GROUND BEETLES (CARABIDAE). BIOLOGICAL CONSERVATION 69:339-349.

4591. VERMEULEN, H. J. W. and P. F. M. OPDAM. 1995. EFFECTIVENESS OF ROADSIDE VERGES AS DISPERSAL CORRIDORS FOR SMALL GROUND-DWELLING ANIMALS: A SIMULATION STUDY. LANDSCAPE AND URBAN PLANNING 31 $(1-3): 233-48$

4592. VESTJENS, W. J. 1973. WILDLIFE MORTALITY ON A ROAD IN NEW SOUTH WALES. EMU 73(3):107-112.

4593. VILLAFUERTE, R., J. A. LIVAITIS and D. F. SMITH. 1997. PHYSIOLOGICAL RESPONSES OF LAGOMORPHS TO RESOURCE LIMITATIONS IMPOSED BY HABITAT FRAGMENTATION: IMPLICATIONS FOR CONDITION-SENSITIVE PREDATION. CAN. J. ZOOL. 75 (148-151).

4594. VILLARD, M. A., P. R. MARTIN and C. G. DRUMMOND. 1993. HABITAT FRAGMENTATION AND PAIRING SUCCESS IN THE OVENBIRD (SEIURUS AUROCAPILLUS). AUK 110 (4):759-68.

4595. VILLARD, M. A., G. MERRIAM and B. A. MAURER. 1995. DYNAMICS IN SUBDIVIDED POPULATIONS OF NEOTROPICAL MIGRATORY BIRDS IN A FRAGMENTED TEMPERATE FOREST. ECOLOGY (WASHINGTON D C) 76 (1):27-40.

4596. VILLARD, M. A. and P. D. TAYLOR. 1994. TOLERANCE TO HABITAT FRAGMENTATION INFLUENCES THE COLONIZATION OF NEW HABITAT BY FOREST BIRDS. OECOLOGIA (BERLIN) 98(3-4):393-401. 
4597. VILLARRUBIA, C. R. 1982. MOVEMENT ECOLOGY AND HABITAT UTILIZATION OF BLACK BEARS IN CHEROKEE NATIONAL FOREST, TENNESSEE. M.S. THESIS, UNIVERSITY OF TENNESSEE, KNOXVILLE. 159 PP.

4598. VILLEY-DESMESERETS, F. 1988. ROAD AND ENVIRONMENT: ASSESSMENT AND OUTLOOK. TRAVAUX (638):2-4.

4599. VINCENT, E. R. 1966. A COMPARISON OF RIFFLE INSECT POPULATIONS IN THE GIBBON RIVER ABOVE AND BELOW GEYSER BASIN, YELLOWSTONE NATIONAL PARK. M.S. THESIS, MONTANA STATE UNIVERSITY, BOZEMAN, MT. 19 PP.

4600. VINSON, M. 1998. EFFECTS OF RECREATIONAL ACTIVITIES ON DECLINING ANURAN SPECIES IN THE JOHN MUIR WILDERNESS, CALIFORNIA. M.S. THESIS, UNIVERSITY OF MONTANA, MISSOULA, MT. 83 PP.

4601. VIOLA, A. E. 1986. EFFECTS OF BOZEMAN'S INCREASED SEWAGE TREATMENT ON WATER QUALITY AND AQUATIC INSECTS OF THE EAST GALLATIN RIVER, MONTANA. M.S. THESIS, MONTANA STATE UNIVERSITY, BOZEMAN, MT. 98 PP.

4602. VIRGINIA TRANSPORTATION RESEARCH COUNCIL. NONANADROMOUS FISH PASSAGE IN HIGHWAY CULVERTS.

4603. VIRGOS, C. E. 1992. MAMMAL MORTALITY ON ROADS. UP TO THE MOMENT INFORMATION COMPILATION BY PMVC. PAGES 49-64 IN LOPEZ,REDONDO, EDITOR. I JORNADAS PARA EL ESTUDIO Y PREVENCION DE LA MORTALIDAD DE VERTEBRADOS EN CARRETERAS, MADRID, 5 Y 6 DE OCTUBRE DE 1991. TOMO 2. [SESSIONS IN THE STUDY OF PREVENTION OF ROAD MORTALITIES OF VERTEBRATES, MADRID, 5 AND 6 OCTOBER, 1991. VOLUME 2.]. COORDINADORA DE ORGANIZACCIONES DE DEFENSA, AMBIENTAL, MADRID.

4604. VIRK, A. T. 1999. INTEGRATING WILDLIFE CONSERVATION WITH COMMUNITY-BASED DEVELOPMENT IN NORTHERN AREAS, PAKISTAN. PH.D. DISSERTATION, UNIVERSITY OF MONTANA, MISSOULA, MT. 168 PP.

4605. VIRK, A. T. 1991. MANAGEMENT PLAN FOR WID UNGULATES IN BALOCHISTAN, PAKISTAN. M.S. THESIS, UNIVERSITY OF MONTANA, MISSOULA, MT. 158 PP.

4606. VIRKKALA, R., T. ALANKO, T. LAINE and J. TIAINEN. 1993. POPULATION CONTRACTION OF THE WHITE-BACKED WOODPECKER DENDROCOPOS LEUCOTOS IN FINLAND AS A CONSEQUENCE OF HABITAT ALTERATION. BIOLOGICAL CONSERVATION 66(1):47-53.

4607. VLASIN, R. D. and P. DAVIS. 1978. ECOLOGICAL EFFECTS OF HIGHWAY CONSTRUCTION UPON MICHIGAN WOODLOTS AND WETLANDS. PHASE II REPORT. FHWA/MI78/3153. MICHIGAN STATE UNIVERSITY, AGRICULTURAL EXPERIMENT STATION, EAST LANSING, MI.

4608. VOGEL, W. O. 1983. THE EFFECTS OF HOUSING DEVELOPMENTS AND AGRICULTURE ON THE ECOLOGY OF WHITE-TAILED DEER AND MULE DEER IN THE GALLATIN VALLEY, MONTANA. M.S. THESIS, MONTANA STATE UNIVERSITY, BOZEMAN, MT. 86 PP.

4609. VOHMAN, E. C. 1997. EFECTS OF ROADS AND TRAILS ON WILDLIFE, PLANTS AND ECOSYSTEMS. SURVEY OF RELEVANT RESEARCH--PREPARED FOR HIGH COUNTY CITIZENS' ALLIANCE. 11PP.

4610. VOIGT, D. R. and J. D. BROADFOOT. 1995. EFFECTS OF COTTAGE DEVELOPMENT ON WHITE-TAILED DEER, ODOCOILEUS VIRGINIANUS, WINTER HABITAT ON LAKE MUSKOKA, ONTARIO. THE CANADIAN FIELD-NATURALIST. 109(2)

4611. VOIGT, J. A. 1979. WILDLIFE MITIGATION AT BUREAU OF RECLAMATION PROJECTS A CASE STUDY. THESIS COLORADO STATE UNIVERSITY.

4612. VOL'PERT, YA. L. and G. V. SAPOZHNIKOV. 1998. RESPONSES OF SMALL MAMMALIAN FAUNA TO DIFFERENT FORMS OF TECHNOGENIC INFLUENCES ON ARCTIC LANDSCAPES. RUSS. J. ECOL. 29:115-119.

4613. VOLF, B. 1986. THE GAME ANIMALS AND THE TRANSPORT COMMUNICATIONS. PR.VYZK.USTAVU LESN.HOSPOD.MYSLIVOSTI (STRNADY) 68(2):337-355.

4614. VOLLMER, A. T., B. G. MAZA, P. A. MEDICA, F. B. TURNER and S. A. BAMBERG. 1976. THE IMPACT OF OFF-ROAD VEHICLES ON A DESERT ECOSYSTEM. ENVIRONMENTAL MANAGEMENT 1:115-129. 
4615. VON DER OHE, C. G. 2000. NONINVASIVE FECAL MONITORING OF BLUCOCORTICOIDS IN ALASKAN BROWN BEARS. M.S. THESIS, UNIVERSITY OF MONTANA, MISSOULA, MT. 67 PP.

4616. VON GUNTEN, B. L. 1978. PRONGHORN FAWN MORTALITY ON THE NATIONAL BISON RANGE. M.S. THESIS, UNIVERSITY OF MONTANA, MISSOULA, MT. 82 PP.

4617. VOORHEES, L. D. 1976. WATERFOWL NESTING: HIGHWAY RIGHT-OF-WAY MOWING VERSUS SUCCESSION. PH.D. DISSERTATION, NORTH DAKOTA STATE UNIVERSITY, BISMARCK.

4618. VOORHEES, L. D. and J. F. CASSEL. 1980. HIGHWAY RIGHT-OF-WAY: MOWING VERSUS SUCCESSION AS RELATED TO DUCK NESTING. J. WLDL. MANAGE. 44 (1):155-63.

4619. VORE, D. W. 1993. SIZE, ABUNDANCE, AND SEASONAL HABITAT UTILIZATION OF AN UNFISHED TROUT POPULATION AND THEIR RESPONSE TO CATCH AND RELEASE FISHING. M.S. THESIS, MONTANA STATE UNIVERSITY, BOZEMAN, MT. 99 PP.

4620. VORE, J. and P. R. MALTA. 1994. HUNGRY HORSE ELK MITIGATION-NORTHWEST MONTANA WILDLIFE HABITAT ENHANCEMENT. MONTANA DEPT. OF FISH, WILDLIFE, AND PARKS. PROJECT NO. 5142

4621. VORE, J., P. R. MALTA and E. SCHMIDT. 1995. HUNGRY HORSE ELK MITIGATION-NORTHWEST MONTANA WILDLIFE HABITAT ENHANCEMENT. MONTANA DEPT. OF FISH, WILDLIFE, AND PARKS. PROJECT NO. 51421

4622. VORE, J. M. 1990. MOVEMENTS AND DISTRIBUTION OF SOME NORTHERN YELLOWSTONE ELK. M.S. THESIS, MONTANA STATE UNIVERSITY, BOZEMAN, MT. 80 PP.

4623. VOS, C. C. and J. P. CHARDON. 1998. EFFECTS OF HABITAT FRAGMENTATION AND ROAD DENSITY ON THE DISTRIBUTION PATTERN OF THE MOOR FROG RANA ARVALIS. JOURNAL OF APPLIED ECOLOGY 35:44-56.

4624. VOS, D. K., R. A. RYDER and W. D. GRAUL. 1985. RESPONSE OF BREEDING GREAT BLUE HERONS TO HUMAN DISTURBANCE IN NORTHCENTRAL COLORADO. COLONIAL WATERBIRDS 8:13-22.

4625. VOSBURGH, T. C. 1996. IMPACTS OF RECREATIONAL SHOOTING ON PRAIRIE DOG COLONIES. M.S. THESIS, MONTANA STATE UNIVERSITY, BOZEMAN, MT. 50 PP.

4626. VOTH, E. H. and H. C. BLACK. 1973. A HISTOLOGIC TECHNIQUE FOR DETERMINING FEEDING HABITS OF SMALL HERBIVORES. J. WLDL. MANAGE. 37 (2):223-31

4627. WADE, K. J., J. T. FLANAGAN, A. CURRIE and D. J. CURTIS. 1980. ROADSIDE GRADIENTS OF LEAD AND ZINC CONCENTRATIONS IN SURFACE-DWELLING INVERTEBRATES. ENVIRONMENTAL POLLUTION (SERIES B) $1: 87-93$.

4628. WADE, P. R. 1987. DISTRIBUTION AND ABUNDANCE OF PHYTOPLANKTON TAXA IN THE EASTERN SCOTIA SEA. M.S. THESIS, MONTANA STATE UNIVERSITY, BOZEMAN, MT. 72 PP.

4629. WAECHTER, A. 1979. ANIMAL MORTALITY ON A HIGH TRAFFIC ROAD. MAMMALIA 43(4):577-579.

4630. WAGAR, J. V. K. 1954. RECREATION AND WLDLIFE PROBLEMS OF THE CENTRAL ROCKY MOUNTAINS. JOURNAL OF FORESTRY 52:186-190.

4631. WAGNER, P., M. CAREY and J. LEHMKUHL. 1998. ASSESSING HABITAT CONNECTIVITY THROUGH TRANSPORTATION CORRIDORS ON A BROAD SCALE: AN INTERAGENCY APPROACH. PAGES 66-67 IN EVINK,G., ZIEGLER,D., GARRETT,P., AND BERRY,J., EDITORS. PROCEEDINGS OF THE INTERNATIONAL CONFERENCE ON WILDLIFE ECOLOGY AND TRANSPORTATION; 1998 FEBRUARY 10-12; FT. MYERS, FL FLORIDA DEPARTMENT OF TRANSPORTATION, TALLAHASSEE, FL.

4632. WAKELYN, L. A. 1987. CHANGING HABITAT CONDITIONS ON BIGHORN SHEEP RANGES IN COLORADO. J. WLDL. MANAGE. 51 (4):904-12.

4633. WALDER, B. 1998. ABOUT WLDLANDS CPR. PAGES 234-235 IN EVINK,G., ZIEGLER,D., GARRETT,P., AND BERRY,J., EDITORS. PROCEEDINGS OF THE INTERNATIONAL CONFERENCE ON WILDLIFE ECOLOGY AND 
TRANSPORTATION; 1998 FEBRUARY 10-12; FT. MYERS, FL FLORIDA DEPARTMENT OF TRANSPORTATION, TALLAHASSEE, FL.

4634. WALKER, D. A. and M. D. WALKER. 1991. HISTORY AND PATTERN OF DISTURBANCE IN ALASKAN ARCTIC TERRESTRIAL ECOSYSTEMS: A HIERARCHICAL APPROACH TO ANALYZING LANDSCAPE CHANGE. J. APPL. ECOL. 28:24476.

4635. WALKER, D. A., P. J. WEBBER, E. F. BINIAN, K. R. EVERETT, D. LEDERER, E. A. NORDSTRAND and WALKER. M.D. 1987. CUMULATIVE IMPACTS OF OILFIELDS ON NORTHERN ALASKA LANDSCAPES. SCIENCE 238:757-61.

4636. WALKER-SMITH, K. 1995. ENVIRONMENTAL AND BIOLOGICAL FACTORS LIMITING REPRODUCTION, RECRUITMENT AND GROWTH OF LARGEMOUTH BASS IN SEELEY AND ECHO LAKES, MONTANA. M.S. THESIS, UNIVERSITY OF MONTANA, MISSOULA, MT. 103 PP.

4637. WALKOWA, W., K. ADAMCZYK and H. CHELKOWSKA. 1991. ANTHROPOGENIC MDIFICATION OF DYNAMICS OF NUMBERS AND INTRAPOPULATION IN THE BANK VOLE. PAGES 649-652 IN B. BOBEK, K. PERZANOWSKI, AND W. REGELIN, EDITORS. GLOBAL TRENDS IN WILDLIFE MANAGEMENT. TRANS. 18TH INT. UNION GAME BIOL. CONGRESS. VOLUME 18(1). SWIAT PRESS, KRAKOW-WARSZAWA.

4638. WALLEN, R. L. 1987. HABITAT UTILIZATION BY HARLEQUIN DUCKS IN GRAND TETON NATIONAL PARK. M.S. THESIS, MONTANA STATE UNIVERSITY, BOZEMAN, MT. 67 PP.

4639. WALLER, A. J. 1992. SEASONAL HABITAT USE OF RIVER OTTERS IN NORTHWESTERN MONTANA. M.S. THESIS, UNIVERSITY OF MONTANA, MISSOULA, MT. 75 PP.

4640. WALLER, J. S. and R. D. MACE. 1995. GRIZZLY BEAR HABITAT SELECTION IN THE SWAN MOUNTAINS, MONTANA. (DRAFT). JOURNAL OF WLDLIFE MANAGEMENT ( IN PRESS )

4641. WALLER, J. S. 1992. GRIZZLY BEAR USE OF HABITATS MODIFIED BY TIMBER MANAEGMENT. M.S. THESIS, MONTANA STATE UNIVERSITY, BOZEMAN, MT. 64 PP.

4642. WALLESTAD, R. O. 1970. SUMMER MOVEMENTS AND HABITAT USE BY SAGE GROUSE BROODS IN CENTRAL MONTANA. M.S. THESIS, MONTANA STATE UNIVERSITY, BOZEMAN, MT. 51 PP.

4643. WALLIN, D. O. 1997. EFFECTS OF FOREST ROADS ON POPULATIONS AND MOVEMENT PATTERNS OF SMALL MAMMALS IN THE NORTHERN CASCADES: A GRANT PROPOSAL. WESTERN WASHINGTON UNIVERSITY, BELLINGHAM, WA.

4644. WALLMO, O. C., W. L. REGELIN and D. W. REICHERT. 1972. FORAGE USE BY MULE DEER RELATIVE TO LOGGING IN COLORADO. J. WLDL. MANAGE. 36 (4):1025-33.

4645. WALRO, J. M. 1976. ANALYSIS OF DEER-VEHICLE ACCIDENTS IN SOUTHEASTERN OHIO. M.S. THESIS, OHIO UNIVERSITY, ATHENS.

4646. WALSH, A. L. and S. HARRIS. 1996. FACTORS DETERMINING THE ABUNDANCE OF VESPERTILIONID BATS IN BRITAIN: GEOGRAPHICAL, LAND CLASS AND LOCAL HABITAT RELATIONSHIPS. JOURNAL OF APPLIED ECOLOGY 33:519-29.

4647. WALSH, A. L. and S. HARRIS. 1996. FORAGING HABITAT PREFERENCES OF VESPERTILIONID BATS IN BRITAIN. JOURNAL OF APPLIED ECOLOGY 33:508-18.

4648. WALSH, N. E., S. G. FANCY, T. R. MCCABE and L. F. PANK. 1992. HABITAT USE BY THE PORCUPINE CARIBOU HERD DURING PREDICTED INSECT HARASSMENT. J. WILDL. MANAGE.56 (3):465-73.

4649. WALTER, H. S. 1990. SMALL VIABLE POPULATION: THE RED-TAILED HAWK OF SOCORRO ISLAND. CONSERVATION BIOLOGY 4 (4):441-3.

4650. WAN, M. T. 1994. UTILITY RIGHT-OF-WAY CONTAMINANTS: POLYCYCLIC AROMATIC HYDROCARBONS. JOURNAL OF ENVIRONMENTAL QUALITY 23 (6):1297-304. 
4651. WANEK, W. J. 1973. ECOLOGICAL IMPACT ON VEGETATION AND SOIL MICROBES. SNOWMOBILE AND OFF THE ROAD VEHICLE RESEARCH SYMPOSIUM PROCEEDINGS. RECREATION RESOUR., MICHIGAN STATE UNIVERSITY. EAST LANSING, MICHIGAN.

4652. WANEK, W. J. 1972. A CONTINUING STUDY OF THE ECOLOGICAL IMPACT OF SNOWMOBILING IN NORTHERN MINNESOTA (FINAL RESEARCH REPORT FOR 1971-72). THE CENTER FOR ENVIRONMENTAL STUDIES, BEMIDJI STATE COLLEGE. BEMIDJI, MINNESOTA. 21PP.

4653. WANEK, W. J. 1971. SNOWMOBILING IMPACT ON VEGETATION, TEMPERATURES AND SOIL MICROBES. PAGES 117-130 IN M. CHUBB, EDITOR. PROCEEDINGS OF THE SNOWMOBILE AND OFF THE ROAD VEHICLE RESEARCH SYMPOSIUM.

4654. WANG, L. 1989. BEHAVIOR AND MICROHABITAT COMPETITION OF BROWN TROUT AND GREENBACK CUTTHROAT TROUT IN AN ARTIFICIAL STREAM. M.S. THESIS, MONTANA STATE UNIVERSITY, BOZEMAN, MT. 96 PP.

4655. WANG, L. 1992. CONTROL OF BACTERIOPLANKTON ACTIVITY IN A EUTROPHIC LAKE EMPHASIZING RELATIONSHIPS AMONG BACTERIA, CYANOBACTERIA AND NUTRIENTS . PH.D. DISSERTATION, MONTANA STATE UNIVERSITY, BOZEMAN, MT. 187 PP.

4656. WARBURTON, G. S., R. C. MADDREY and D. W. ROWE. 1993. CHARACTERISTICS OF BLACK BEAR MORTALITY ON THE COASTAL PLAIN OF NORTH CAROLINA. PROCEEDINGS OF THE ANNUAL CONFERENCE OF THE SOUTHEASTERN ASSOCIATION OF FISH AND WILDLIFE AGENCIES 47:276-286.

4657. WARD, A. L. 1982. MULE DEER BEHAVIOR IN RELATION TO FENCING AND UNDERPASSES ON I-80 IN WYOMING. TRANSPORTATION RESEARCH RECORD 859:8-13.

4658. WARD, A. L. 1982. MULE DEER BEHAVIOR IN RELATION TO FENCING AND UNDERPASSES ON INTERSTATE 80 IN WYOMING. TRANSPORTATION RESEARCH RECORD 859:8-13.

4659. WARD, A. L., G. A. CUPAL, G. A. GOODWIN and H. D. MORRIS. 1976. EFFECTS OF HIGHWAY CONSTRUCTION AND USE ON BIG GAME POPULATIONS. FHWA-RD-76-174. U.S. DEPARTMENT OF TRANSPORTATION, FEDERAL HIGHWAY ADMINISTRATION, WASHINGTON, DC.

4660. WARD, A. L. and J. J. CUPAL. 1979. TELEMETERED HEART RATE OF THREE ELK AS AFFECTED BY ACTIVITY AND HUMAN DISTURBANCE. IN: SHAW J, ED. DISPERSED RECREATION AND NATURAL RESOURCE MANAGEMENT, A SYMPOSIUM. UTAH STATE UNIV., LOGAN, UT.

4661. WARD, A. L., J. J. CUPAL, G. A. GOODWIN and H. D. MORRIS. 1976. EFFECTS OF HIGHWAY CONSTRUCTION AND USE ON BIG GAME POPULATIONS. FEDERAL HIGHWAY ADMINISTRATION. WASHINGTON, D.C. REPT. NO. FHWA-RD-76-174. 92PP.

4662. WARD, A. L., N. E. FORNWALT, S. E. HENRY and R. A. HODORFF. 1980. EFFECTS OF HIGHWAY OPERATION PRACTICES AND FACILITIES ON ELK, MULE DEER, AND PRONGHORN ANTELOPE. U.S. DEPT. TRANSPORTATION, FEDERAL HIGHWAY ADMINISTRATION. REPORT NO. FHWA-RD-79-143. 48PP.

4663. WARD, A. L., S. E. FORNWALT, S. E. HENRY and R. A. HODORFF. 1980. EFFECTS OF HIGHWAY OPERATION PRACTICES AND FACILITIES ON ELK, MULE DEER, AND PRONGHORN ANTELOPE. FHWA-RD-79-143. U.S. DEPARTMENT OF TRANSPORTATION, FEDERAL HIGHWAY ADMINISTRATION, WASHINGTON, DC.

4664. WARD, A. L. 1973. ELK BEHAVIOR IN RELATION TO MULTIPLE USES ON MEDICINE BOW NATIONAL FOREST . PROC. WESTERN ASSOCIATION OF STATE GAME FISH COMMISSIONS $53: 125-141$.

4665. WARD, A. L. 1976. ELK BEHAVIOR IN RELATION TO TIMBER HARVEST OPERATIONS AND TRAFFIC ON THE MEDICINE BOW RANGE IN SOUTH-CENTRAL WYOMING. PAGES 32-43 IN S. R. HIEB, EDITOR. PROCEEDINGS OF THE ELK-LOGGING-ROADS SYMPOSIUM. FORESTRY WILDLIFE AND RANGE EXPERIMENT STATION, UNIVERSITY OF IDAHO, MOSCOW, IDAHO, USA.

4666. WARD, A. L., J. J. CUPAL, A. L. LEA, C. A. OAKLEY and R. W. WEEKS. 1973. ELK BEHAVIOR IN RELATION TO CATTLE GRAZING, FOREST RECREATION, AND TRAFFIC. TRANSACTIONS OF THE NORTH AMERICAN WILDLIFE AND NATURAL RESOURCES CONFERENCE 38:327-337. 
4667. WARD, C. and B. S. LOW. 1997. PREDICTORS OF VIGILANCE FOR AMERICAN CROWS FORAGING IN AN URBAN ENVIRONMENT. WILSON BULLETIN 109:481-489.

4668. WARD, D. H., R. A. STEHN and D. V. DERKSEN. 1994. RESPONSE OF STAGING BRANT TO DISTURBANCE AT THE IZEMBEK LAGOON, ALASKA. WILDL. SOC. BULL. 22 (2):220-8.

4669. WARD, D. H. and R. A. STEHN. 1989. RESPONSE OF BRANT AND OTHER GEESE TO AIRCRAFT DISTURBANCE AT IZAMBEK LAGOON, ALASKA. FINAL REPORT. U.S. FISH AND WLDLIFE SERVICE, ALASKA FISH AND WLDLIFE RESEARCH CENTER FOR U.S. MINERALS MANAGEMENT SERVICE, OUTER CONTINENTAL SHELF REGION. ANCHORAGE, ALASKA. 241PP.

4670. WARD, L. A. 1986. DISPLACEMENT OF ELK RELATED TO SEISMOGRAPH ACTIVITY IN SOUTH-CENTRAL WYOMING. PAGES 246-254 IN R. D. COMER, T. G. BAUMANN, P. DAVIS, J. W. MONARCH, J. TODD, S. VANGYTENBEEK, D. WILLS, AND J. WOODLING, EDITORS. PROCEEDINGS II. ISSUES AND TECHNOLOGY IN THE MANAGEMENT OF IMPACTED WESTERN WILDLIFE: PROCEEDINGS OF A NATIONAL SYMPOSIUM. THORNE ECOL. INST., BOULDER, COLORADO.

4671. WARD, N. I. and J. M. SAVAGE. 1994. ELEMENTAL STATUS OF GRAZING ANIMALS LOCATED ADJACENT TO THE LONDON ORBITAL (M25) MOTORWAY. SCI TOTAL ENVIRON 146-147(0):185-9.

4672. WARD, N. M., R. R. BROOKS and E. ROBERTS. 1978. BLOOD LEAD LEVELS IN SHEEP EXPOSED TO AUTOMOBILE EMISSIONS. BULLETIN OF ENVIRONMENTAL CONTAMINATION AND TOXICOLOGY 20:44-51.

4673. WARD, R. L. 1999. THE OCCURRENCE OF TWO GENERA OF ARBOREAL LICHEN AND THEIR UTILIZATION BY DEER AND ELK ON SELECTED WINTER RANGES IN WEST-CENTRAL MONTANA. M.S. THESIS, UNIVERSITY OF MONTANA, MISSOULA, MT. 88 PP.

4674. WARING, G. H., J. L. GRIFFIS and M. E. VAUGHN. 1991. WHITE-TAILED DEER ROADSIDE BEHAVIOR, WILDLIFE WARNING REFLECTORS, AND HIGHWAY MORTALITY. APPLIED ANIMAL BEHAVIOUR SCIENCE 29:215-223.

4675. WARNER, R. E. 1994. AGRICULTURAL LAND USE AND GRASSLAND HABITAT IN ILLINOIS: FUTURE SHOCK FOR MIDWESTERN BIRDS? CONSERVATION BIOLOGY 8 (1):147-56.

4676. WARNER, R. E. 1985. DEMOGRAPHY AND MOVEMENTS OF FREE-RANGING DOMESTIC CATS IN RURAL ILLINOIS. J. WILDL. MANAGE. 49 (2):340-6.

4677. WARNER, R. E. 1992. NEST ECOLOGY OF GRASSLAND PASSERINES ON ROAD RIGHTS-OF-WAY IN CENTRAL ILLINOIS. BIOLOGICAL CONSERVATION 59:1-7.

4678. WARNER, R. E., L. M. DAVID, S. L. ETTER and G. B. JOSELYN. 1992. COSTS AND BENEFITS OF ROADSIDE MANAGEMENT FOR RING-NECKED PHEASANTS IN ILLINOIS. WILDL. SOC. BULL. 20(3):279-85.

4679. WARNER, R. E., S. P. HAVERA, L. M. DAVID and R. J. SIEMERS. 1989. SEASONAL ABUNDANCE OF WASTE CORN AND SOYBEANS IN ILLINOIS. J. WILDL. MANAGE. 53 (1):142-8.

4680. WARNER, R. E. and G. B. JOSELYN. 1986. RESPONSE OF ILLINOIS RING-NECKED PHEASANT POPULATIONS TO BLOCK ROADSIDE MANAGEMENT. J. WLDL. MANAGE. 50 (4):525-32.

4681. WARNER, R. E. and G. B. JOSELYN. 1978. ROADSIDE MANAGEMENT FOR PHEASANTS IN ILLINOIS: ACCEPTANCE BY FARM COOPERATORS. WLDL. SOC. BULL. 6 (3):128-34.

4682. WARNER, R. E., G. B. JOSELYN and S. L. ETTER. 1987. FACTORS AFFECTING ROADSIDE NESTING BY PHEASANTS IN ILLINOIS. WLDL. SOC. BULL. 15 (2):221-8.

4683. WARNER, R. A. 1970. SOME ASPECTS OF BROWSE PRODUCTION IN RELATION TO TIMBER HARVEST METHODS AND SUCCESSION IN WESTERN MONTANA. M.S. THESIS, UNIVERSITY OF MONTANA, MISSOULA, MT. 74 PP.

4684. WARNER, R. E. 1983. AN ADOPTION MODEL FOR ROADSIDE HABITAT MANAGEMENT BY ILLINOIS FARMERS. WILDLIFE SOCIETY BULLETIN 11(3):238-249. 
4685. WARNER, S. H. 1987. VISITOR IMPACT ON BROWN BEARS, ADMIRALTY ISLAND, ALASKA. INT. CONF. BEAR RES. AND MANAGE. 7:377-82.

4686. WARREN, E. R. 1936. CASUALTIES AMONG ANIMALS ON MOUNTAIN ROADS. SCIENCE 83:14-17.

4687. WARREN, E. R. 1936. MOUNTAIN ROAD CASUALTIES AMONG ANIMALS IN COLORADO. SCIENCE 84:485-489.

4688. WARREN, H. V., R. E. DELAVAULT and CITED IN H.L. CANNON AND J.M. BOWELS. 1962. CONTAMINATION OF VEGETATION BY TETRAETHYL LEAD. SCIENCE 137:765-766.

4689. WASHBURN, E. W. 1925. THE TOLL OF THE AUTOMOBILE. SCIENCE 61:56-57.

4690. WATERS, D. MONITORING PROGRAM, MITIGATIVE MEASURES, TRANS CANADA HIGHWAY TWINNING, KM 0-11.4. FINAL REPORT, ENVIRONMENT CANADA, BANFF NATIONAL PARK. 57PP.

4691. WATERS, D. 1988. MONITORING PROGRAM, MITIGATIVE MEASURES, TRANS-CANADA HIGHWAY TWINNING, KM 0-11.4. FINAL REPORT. ENVIRONMENT CANADA - PARKS, OTTAWA, ONTARIO.

4692. WATKINS, R. O. 1982. HIGHWAY IMPACTS ON THE DESERT. ENVIRONMENTAL SCIENCE APPLICATIONS 4:1339-1348.

4693. WATKINS, T. H. 1969. INFERNAL MACHINES ON THE PUBLIC LANDS. CRY CALIFORNIA 4:6-19.

4694. WATSON, A., N. BAYFIELD and S. M. MOYES. 1970. RESEARCH ON HUMAN PRESSURES ON SCOTTISH MOUNTAIN TUNDRA, SOILS, AND ANIMALS . PAGES 256-66 IN W. A. FULLER AND P. G. KEVAN, EDITORS . PRODUCTIVITY AND CONSERVATION IN NORTHERN CIRCUMPOLAR LANDS . VOLUME . IUCN , MORGES, SWIZERLAND .

4695. WATSON, J. 1991. ESSENTIAL CRITERIA FOR DESIGNATION OF WILDLIFE CORRIDORS. PAGES $403-404$ IN SAUNDERS,D.A. AND HOBBS,R.J., EDITORS. NATURE CONSERVATION 2: THE ROLE OF CORRIDORS. SURREY BEATTY AND SONS, CHIPPING NORTON, AUSTRALIA.

4696. WATSON, J. and R. H. DENNIS. 1992. NEST-SITE SELECTION BY GOLDEN EAGLES IN SCOTLAND. BRITISH BIRDS 85 (9):469-81.

4697. WATSON, J. W. 1993. RESPONSES OF NESTING BALD EAGLES TO HELICOPTER SURVEYS. WILDL. SOC. BULL. 21 (2):171-8.

4698. WATSON, J. W. 1984. ROUGH-LEGGED HAWK WINTER ECOLOGY IN SOUTHEASTERN IDAHO. M.S. THESIS, MONTANA STATE UNIVERSITY, BOZEMAN, MT. 101 PP.

4699. WATSON, J. 1992. DUNE BREEDING BIRDS AND OFF-ROAD VEHICLES. NATURALIST (SOUTH AFRICA) $36(3): 8-12$.

4700. WATTS, B. D. and D. S. BRADSHAW. 1994. THE INFLUENCE OF HUMAN DISTURBANCE ON THE LOCATION OF GREAT BLUE HERON COLONIES IN THE LOWER CHESAPEAKE BAY. COLONIAL WATERBIRDS 7(2):184-186.

4701. WAUTERS, L. A., L. SOMERS and A. A. DHONDT. 1997. SETTLEMENT BEHAVIOUR AND POPULATION DYNAMICS OF REINTRODUCED RED SQUIRRELS SCIURUS VULGARIS IN A PARK IN ANTWERP, BELGIUM. BIOLOGICAL CONSERVATION 82:101-107.

4702. WAY, J. M. 1970. ROADS AND THE CONSERVATION OF WILDLIFE. JOURNAL OF THE INSTITUTE OF HIGHWAY ENGINEERS JULY:5-11.

4703. WAY, J. M. 1977. ROADSIDE VERGES AND CONSERVATION IN BRITAIN: A REVIEW. BIOLOGICAL CONSERVATION 12:65-74.

4704. WAYNE, R. K., N. LEHMAN, M. W. ALLARD and R. L. HONEYCUTT. 1992. MITOCHONDRIAL DNA VARIABILITY OF THE GRAY WOLF: GENETIC CONSEQUENCES OF POPULATION DECLINE AND HABITAT FRAGMENTATION. CONSERVATION BIOLOGY 6 (4):559-69. 
4705. WEATHERHEAD, P. J. and K. A. PRIOR. 1992. PRELIMINARY OBSERVATIONS OF HABITAT USE AND MOVEMENTS OF THE EASTERN MASSASAUGA RATTLESNAKE (SISTRURUS CATENATUS CATENATUS). JOURNAL OF HERPETOLOGY $26(4): 447-52$.

4706. WEAVER, J., R. ESCANO, D. MATTSON, T. PUCHLERZ and D. DESPAIN. 1986. A CUMULATIVE EFFECTS MODEL FOR GRIZZLY BEAR MANAGEMENT IN THE YELLOWSTONE ECOSYSTEM. P. 234-46. IN: GLEN P. CONTRERAS AND KEITH E. EVANS (COMPILERS). PROC. GRIZZLY BEAR HABITAT SYMPOSIUM. USDA FOR. SERV. GEN. TECH. REP. INT-207.

4707. WEAVER, J. L., P. C. PAQUET and L. F. RUGGIERO. 1996. RESILIENCE AND CONSERVATION OF LARGE CARNIVORES IN THE ROCKY MOUNTAINS. CONS. BIOL. 10 (4):964-76.

4708. WEAVER, J. L. 1994. ECOLOGY OF WOLF PREDATION AMIDST HIGH UNGULATE DIVERSITY IN JASPER NATIONAL PARK, ALBERTA. PH.D. DISSERTATION, UNIVERSITY OF MONTANA, MISSOULA, MT. 166 PP.

4709. WEAVER, J. L., R. E. F. ESCANO and D. S. WINN. 1987. A FRAMEWORK FOR ASSESSING CUMULATIVE EFFECTS ON GRIZZLY BEARS. TRANS. N. AMER. WILDL. NAT. RESOUR. CONF. 52:364-376.

4710. WEAVER, R. A. and J. HALL. 1971. BIG GAME INVESTIGATIONS: BIGHORN SHEEP IN JOSHUA TREE NATIONAL MONUMENT AND ADJACENT AREAS. CALIFORNIA DEPTARTMENT OF FISH AND GAME. W-051-R-16/SP. 56PP.

4711. WEAVER, T. and D. DALE. 1978. TRAMPLING EFFECTS OF HIKERS, MOTORCYCLES, AND HORSES IN MEADOWS AND FORESTS. JOURNAL OF APPLIED ECOLOGY 15:451-457.

4712. WEBB, G. A. and W. S. CHAPMAN. 1983. NOCTURNAL ROAD BASKING BY GRAVID FEMALE CACOPHIS SQUAMULOSUS AND CRYPTOPHIS NIGRESCENS (SERPENTES: ELAPIDAE). HERPETOFAUNA 15(1):24-29.

4713. WEBB, N. R. 1989. STUDIES ON THE INVERTEBRATE FAUNA OF FRAGMENTED HEATHLAND IN DORSET, U.K., AND THE IMPLICATIONS FOR CONSERVATION. BIOLOGICAL CONSERVATION 47:153-165.

4714. WEBB, R. H. 1983. COMPACTION OF DESERT SOILS BY OFF-ROAD VEHICLES. PAGES 51-79 IN WEBB,R.H. AND WILSHIRE,H.G., EDITORS. ENVIRONMENTAL EFFECTS OF OFF-ROAD VEHICLES: IMPACTS AND MANAGEMENT IN ARID REGIONS. SPRINGER-VERLAG, NEWYORK.

4715. WEBB, R. H. and H. G. WILSHIRE. 1978. AN ANNOTATED BIBLIOGRAPHY OF THE EFFECTS OF OFF-ROAD VEHICLES ON THE ENVIRONMENT. U.S. GEOL. SURV. OPEN FILE REP. 78-149. 15 PP

4716. WEBB, R. H. and H. G. WILSHIRE. 1983. ENVIRONMENTAL IMPACTS OF OFF-ROAD VEHICLES: IMPACTS AND MANAGEMENT IN ARID REGIONS. SPRINGER-VERLAG, INC. NEWYORK. XXI + 534PP.

4717. WEBB, R. H., H. C. RAGLAND, W. H. GODWN and D. JENKINS. 1978. ENVIRONMENTAL EFFECTS OF SOIL PROPERTY CHANGES WITH OFF-ROAD VEHICLE USE. ENVIRONMENTAL MANAGEMENT 2:219-233.

4718. WEBER, K. T. 1996. IDENTIFYING LANDSCAPE ELEMENTS IN RELATION TO ELK KILL SITES IN WESTERN MONTANA. M.S. THESIS, UNIVERSITY OF MONTANA, MISSOULA, MT. 74 PP.

4719. WEBER, P. 1987. OBSERVATIONS OF BROWN BEAR MOVEMENTS IN THE HARGITA MOUNTAINS, ROMANIA. INT. CONF. BEAR RES. AND MANAGE. 7:19-21

4720. WECKWERTH, R. P. 1957. THE RELATIONSHIP BETWEEN THE MARTEN POPULATION AND THE ABUNDANCE OF SMALL MAMMALS IN GLACIER NATIONAL PARK. M.S. THESIS, MONTANA STATE UNIVERSITY, MISSOULA, MT. 76 PP.

4721. WEEDEN, R. B. 1963. MANAGEMENT OF PTARMIGAN IN NORTH AMERICA. J. WILDL. MANAGE. 27 (4):672-83.

4722. WEEKS, R. W., J. J. CUPAL and A. L. WARD. 1972. TELEMETRY TRACKING OF SUMMER TRANSPLANTED ELKIN SOUTHCENTRAL WYOMING. P 238-44. IN: INTERNAT. TELEM. CONF. PROC. OCT., 1972 ; LOS ANGELES, CALIF.

4723. WEGMANN, S. 1991. CONSERVATION OF WILLIFE IN INTEGRAL PLANNING OF ROAD CONSTRUCTION. SCHWEIZ.Z.FORSTWES 142(8):627-645. 
4724. WEGNER, J. F. and G. MERRIAM. 1979. MOVEMENTS BY BIRDS AND SMALL MAMMALS BETWEEN A WOOD AND ADJOINING FARMLAND HABITAT. J. APPLIED ECOLOGY 16:349-57.

4725. WEIDEMANN, G., M. REICH and H. PLACHTER. 1996. INFLUENCE OF ROADS ON A POPULATION OF PSOPHUS STRIDULATUS L. 1758 (SALTATORIA, ACRIDIDAE). VERHANDLUNGEN DER GESELLSCHAFT FUER OEKOLOGIE 6:259-267.

4726. WEIGAND, J. P. 1977. THE BIOLOGY AND ECOLOGY OF HUNGARIAN (EUROPEAN GRAY) PARTRIDGE (PERDIX PERDIX L.)IN NORTHCENTRAL MONTANA. PH.D. DISSERTATION, MONTANA STATE UNIVERSITY, BOZEMAN, MT. 388 PP.

4727. WEIGAND, J. P. 1994. RANGE USE AND INTERSPECIFIC COMPETITION OF ROCKY MOUNTAIN BIGHORN SHEEP IN THE HIGHLAND MOUNTAINS, MONTANA. M.S. THESIS, MONTANA STATE UNIVERSITY, BOZEMAN, MT. 75 PP.

4728. WEISE, T. F., W. L. ROBINSON, R. A. HOOK and L. D. MECH. 1975. AN EXPERIMENTAL TRANSLOCATION OF THE EASTERN TIMBER WOLF. AUDUBON CONSERV. REP. NO. 5, NAT. AUDUBON SOC. AND U.S. FISH AND WILDL. SERV., TWIN CITIES, MINN.

4729. WEISENBERGER, M. E., P. R. KRAUSMAN, M. C. WALLACE, D. W. DE YOUNG and O. E. MAUGHAN. 1996. EFFECTS OF SIMULATED JET AIRCRAFT NOISE ON HEART RATE AND BEHAVIOR OF DESERT UNGULATES. J. WILDL. MANAGE. 60 (1):52-61

4730. WEISS, E. F. JR. 1962. THE AGE, GROWTH AND FOOD HABITS OF THE MARINE COTTID LEPTOCOTTUS ARMATUS. M.S. THESIS, MONTANA STATE COLLEGE, BOZEMAN, MT. 18 PP.

4731. WELKER, T. L. and J. R. CHOATE. 1994. ECOGEOGRAPHY OF SOUTHERN BOG LEMMING AND MEADOW VOLE IN NORTH CENTRAL KANSAS. PRAIRIE NATURALIST 26 (4):283-6.

4732. WELLS, E. A. 1986. ALPINE LIMNOLOGY OF SELECTED WATER BODIES ON THE BEARTOOTH PLATEAU, MONTANA, WITH EMPHASIS ON BENTHOS . PH.D. DISSERTATION, MONTANA STATE UNIVERSITY, BOZEMAN, MT. 401 PP.

4733. WELLS, J. D. 1976. THE FISHERY OF HYALITE RESERVOIR DURING 1974 AND 1975. M.S. THESIS, MONTANA STATE UNIVERSITY, BOZEMAN, MT. 47 PP.

4734. WELLS, P. 1997. WILDLIFE MORTALITY ON THE CANADIAN PACIFIC RAILWAY BETWEEN FIELD AND REVELSTOKE, B.C. ROADS, RAILS AND ENVIRONMENT WORKSHOP II;9-10 APR 1997 ; REVELSTOKE, B.C. COLUMBIA MOUNTAINS INSTITUTE, REVELSTOKE.

4735. WELSH, C. J. E. and W. M. HEALY. 1993. EFFECT OF EVEN-AGED TIMBER MANAGEMENT ON BIRD SPECIES DIVERSITY AND COMPOSITION IN NORTHERN HARDWOODS OF NEW HAMPSHIRE. WILDLIFE SOCIETY BULLETIN 21 (2):143-54.

4736. WELSH, C. J. I. 1985. SPECIES-TYPICAL LIPIDS FROM THE BODY SURFACE AND PREPUTIAL GLANDS OF THE SYMPATRIC VOLES MICROTUS MONTANUS AND M. PENNSYLVANICUS : CHARACTERIZATION AND IDENTIFICATION. PH.D. DISSERTATION, MONTANA STATE UNIVERSITY, BOZEMAN, MT. 83 PP.

4737. WEMPLE, B. C. 1994. HYDROLOGIC INTEGRATION OF FOREST ROADS WITH STREAM NETWORKS IN TWO BASINS WESTERN CASCADES, OREGON. THESIS, OREGON STATE UNIVERSITY, CORVALLIS, OREGON.

4738. WENDLING, F. L. FINAL REPORT ON GRAVEL POROSITY STUDIES ALONG THE TRANS-ALASKA PIPELINE.

4739. WENDLING, F. L. PRELIMINARY REPORT ON GRAVEL POROSITY STUDIES ALONG THE TRANS-ALASKA PIPELINE.

4740. WENTLAND, H. J. 1968. SUMMER RANGE HABITS OF THE PRONGHORN ANTELOPE IN CENTRAL MONTANA WITH SPECIAL REFERENCE TO PROPOSED SAGEBRUSH CONTROL STUDY PLOTS. M.S. THESIS, MONTANA STATE UNIVERSITY, BOZEMAN, MT. 65 PP.

4741. WENUM, E. A. 1998. ACTIVITY PATTERNS AND TIME BUDGETS OF GRIZZLY BEARS IN THE SWAN MOUNTAINS OF MONTANA. M.S. THESIS, MONTANA STATE UNIVERSITY, BOZEMAN, MT. 116 PP. 
4742. WERNLI, B. A. 1939. THE DEGREE OF OSSIFICATION IN A CHRONOLOGICAL SERIES OF GROUND SQUIRREL EMBRYOS. M.S. THESIS, MONTANA STATE COLLEGE, BOZEMAN, MT. 27 PP.

4743. WEST, P. 1980. SUMMARY AND CONCLUSION. SNOWMOBILES. PAGES 282-283 IN R. N. L. ANDREWS AND P. F. NOWAK, EDITOR. OFF-ROAD VEHICLE USE: A MANAGEMENT CHALLENGE. UNIVERSITY OF MICHIGAN.

4744. WESTFALL, J. A. JR. 1989. THE ECOLOGY OF REINTRODUCED ELK IN THEODORE ROOSEVELT NATONAL PARK, NORTH DAKOTA. M.S. THESIS, MONTANA STATE UNIVERSITY, BOZEMAN, MT. 126 PP.

4745. WESTWORTH, D. A. 1981. THE EFFECTS OF OIL EXPLORATION ON MUSKRAT POPULATIONS IN THE MACKENZIE DELTA. PAGES 1698-1727 IN J. A. CHAPMAN AND D. PURSLEY, WORLDWIDE FURBEARER CONF. PROC.

4746. WEYBRIGHT, D. L. 1983. IMPACTS OF CATTLE GRAZING AND SUBDIVISIONS ON GRANT CREEK UNGULATES. M.S. THESIS, UNIVERSITY OF MONTANA, MISSOULA, MT. 100 PP.

4747. WHALEN, S. C. 1979. THE CHEMICAL LIMNOLOGY AND LIMNETIC PRIMARY PRODUCTION OF THE TONGUE RIVER RESERVOIR, MONTANA. M.S. THESIS, MONTANA STATE UNIVERSITY, BOZEMAN, MT. 205 PP.

4748. WHITE, B. P. 1977. HUNTER AND HIKER EDUCATION PROGRAMS IN CANADA: RECENT BRITISH COLUMBIAN INNOVATIONS. TRANS. N. AMER. WILDL. NAT. RESOUR. CONF. 42:493-501.

4749. WHITE, C. M., T. THUROW and J. F. SULLIVAN. 1979. EFFECTS OF CONTROLLED DISTURBANCE ON FERRUGINOUS HAWKS AS MAY OCCUR DURING GEOTHERMAL ENERGY DEVELOPMENT. P.777-781 IN: GEOTHERM RESOUR COUNC 3RD ANNU MEETING; 1979SEP 24-1979 SEP 27; RENO, NV.

4750. WHITE, C. M., T. L. THUROW and J. F. SULLIVAN. 1978. SITING CRITERIA AS A FUNCTION OF SENSITIVITY OF NESTING FERRUGINOUS HAWKS TO GEOTHERMAL DEVELOPMENT. NTIS REPORT CONF-781109-30, 1978(11)

4751. WHITE, C. M. and T. L. THUROW. 1985. REPRODUCTION OF FERRUGINOUS HAWKS EXPOSED TO CONTROLLED DISTURBANCE. CONDOR 87:14-22.

4752. WHITE, D. H., C. B. KEPLER, J. S. HATFIELD, P. W. J. SYKES and J. T. SEGINAK. 1996. HABITAT ASSOCIATIONS OF BIRDS IN THE GEORGIA PIEDMONT DURING WINTER. JOURNAL OF FIELD ORNITHOLOGY 67 (1):159-66.

4753. WHITE, D. D. 1996. TWO GRIZZLY BEAR STUDIES: MOTH FEEDING ECOLOGY AND MALE REPRODUCTIVE BIOLOGY. PH.D. DISSERTATION, MONTANA STATE UNIVERSITY, BOZEMAN, MT. 79 PP.

4754. WHITE, J. J., J. N. CARROLL, J. G. LOURENCO and A. D. IAALI. 1993. BASELINE AND CONTROLLED EXHAUST EMISSIONS FROM OFF-HIGHWAY VEHICLE ENGINES. SOCIETY OF AUTOMOTIVE ENGINEERS INTERNATIONAL. SOUTHWEST RESEARCH INSTITUTE AND THE CALIFORNIA AIR RESOURCE BOARD. PISA, ITALY. SAE 931541.

4755. WHITE, K. L. 1958. SUMMER RANGE ECOLOGY OF RATTLESNAKE CREEK MULE DEER IN THE SPRUCE-FIR ZONE. PH.D. DISSERTATION, MONTANA STATE UNIVERSITY, MISSOULA, MT. 95 PP.

4756. WHITE, R. G. and M. K. YOUSEF. 1978. ENERGY EXPENDITURE IN REINDEER WALKING ON ROADS AND ON TUNDRA. CANADIAN JOURNAL OF ZOOLOGY 56(2):215-223.

4757. WHITE, R. G. and M. K. YOUSEF. 1978. TITLE UNKNOWN. CANADIAN JOURNAL OF ZOOLOGY 56 (2): $215-23$.

4758. WHITFORD, P. C. 1985. BIRD BEHAVIOUR IN RESPONSE TO THE WARMTH OF BLACKTOP ROADS. TRANSACTIONS OF THE WISCONSIN ACADEMY OF SCIENCES ARTS AND LETTERS 3:135-143.

4759. WHITFORD, P. C. 1976. MICROCLIMATE FACTORS OF BLACKTOP ROADS AS THEY AFFECT BIRD BEHAVIOR, DIURNAL DISTRIBUTION AND RANGE. M.S. THESIS, UNIVERSITY OF WISCONSIN, STEVENS POINT.

4760. WHITFORD, T. C. 1991. DEFINING OLD-GROWTH DOUGLAS-FIR FORESTS OF CENTRAL MONTANA AND USE OF THE NORTHERN GOSHAWK (ACCIPITER GENTILIS) AS A MANAGEMENT INDICATOR SPECIES. M.S. THESIS, UNIVERSITY OF MONTANA, MISSOULA, MT. 62 PP. 
4761. WHITTAKER, D. 1991. NENANA RIVER CORRIDOR RECREATION STUDY. ALASKA DEPT. OF NATURAL RESOURCES. NATIONAL PARK SERVICE, ANCHORAGE, ALASKA.

4762. WHITTAKER, J. 1971. SNOWMOBILING OVER FORAGE GRASSES. CONFERENCE ON SNOWMOBILES AND ALL-TERRAIN VEHICLES. UNIVERSITY OF WESTERN ONTARIO. CANADA.

4763. WHITTEN, K. R. 1990. MOVEMENT PATTERNS OF THE PORCUPINE CARIBOU HERD IN RELATION TO OIL DEVELOPMENT. ALASKA DEPT. OF FISH AND GAME, DEVISION OF WILDLIFE CONSERVATION. PROJECT W-23-2, STUDY 3.34

4764. WHITTEN, K. R. 1992. MOVEMENT PATTERNS OF THE PORCUPINE CARIBOU HERD IN RELATION TO OIL DEVELOPMENT. ALASKA DEPT. OF FISH AND GAME, DIVISION OF WILDLIFE CONSERVATION. PROJECT W-23-5, STUDY 3.34

4765. WHITTEN, K. R. 1993. MOVEMENTS PATTERNS OF THE PORCUPINE CARIBOU HERD IN RELATION TO OIL DEVELOPMENT. ALASKA DEPT. OF FISH AND GAME, DIVISION OF WILDLIFE CONSERVATION. PROJECTS W-22-5, 6, W-23-2, 2, 3, 4, 5, \& W-24-1, STUDY 3.34

4766. WHITTEN, K. R. and R. D. CAMERON. 1983. MOVEMENTS OF COLLARED CARIBOU, RANGIFER TARANDUS, IN RELATION TO PETROLEUM DEVELOPMENT ON THE ARCTIC SLOPE OF ALASKA. CANADIAN FIELD NATURALIST 97:143-146.

4767. WHITTEN, K. R., G. W. GARNER, F. J. MAUER and R. B. HARRIS. 1992. PRODUCTIVITY AND EARLY CALF SURVIVAL IN THE PORCUPINE CARIBOU HERD. J. WILDL. MANAGE. 56 (2):201-12.

4768. WHITTEN, K. R. and W. L. REGELIN. 1988. MOVEMENT PATTERNS OF THE PORCUPINE CARIBOU HERD IN RELATION TO OIL DEVELOPMENT. ALASKA DEPT. OF FISH AND GAME, DIVISION OF GAME. PROJECT W-23-1, STUDY 3.34

4769. WHITTON, K. S. 1999. HABITAT USE OF JUVENILE SALMONIDS IN OPHIR AND EAST OPHIR CREEKS, YAKUTAT, ALASKA. M.S. THESIS, MONTANA STATE UNIVERSITY, BOZEMAN, MT. 181 PP.

4770. WICKHAM, J. D., J. G. WU and D. F. BRADFORD. 1997. A CONCEPTUAL FRAMEWORK FOR SELECTING AND ANALYZING STRESSOR DATA TO STUDY SPECIES RICHNESS AT LARGE SPATIAL SCALES. ENVIRONMENTAL MANAGEMENT 21(2):247-257.

4771. WIEGAND, P. and R. SCHROPFER. 1997. DNA FINGERPRINTING ANALYSIS OF SUBPOPULATIONS OF THE RED SQUIRREL (SCIURUS VULGARIS, L 1758). JOURNAL OF ZOOLOGICAL SYSTEMATICS AND EVOLUTIONARY RESEARCH 35(2):71-74.

4772. WIEMEYER, S. N., J. M. SCOTT, M. P. ANDERSON, P. H. BLOOM and C. J. STAFFORD. 1988. ENVIRONMENTAL CONTAMINANTS IN CALIFORNIA CONDORS. J. WILDL. MANAGE. 52(2):238-47.

4773. WIENEKE, F. and W. SCHRODER. 1995. PLANNING OF GREEN BRIDGES AT THE HIGHWAY, WITH SPECIAL CONSIDERATION OF THE BROWN BEAR. M.S. THESIS, INSTITUTE OF GEOGRAPHY AT LUDWIG-MAXIMILIANS UNIVERSITY, MUNICH, GERMANY.

4774. WILBUR, S. R. 1974. THE LITERATURE OF THE CALIFORNIA LEAST TERN . US FISH AND WILDIFE SERVICE. SPEC. SCI. REPORT - WLDL. 175. 18PP.

4775. WILCOVE, D. S. 1985. NEST PREDATION IN FOREST TRACTS AND THE DECLINE OF MIGRATORY SONGBIRDS. ECOLOGY 66:1211-1214.

4776. WILCOX, B. A. and D. D. MURPHY. 1985. CONSERVATION STRATEGY: THE EFFECTS OF FRAGMENTATION ON EXTINCTION. AMERICAN NATURALIST 125:879-87.

4777. WILCOX, D. A. 1989. MIGRATION AND CONTROL OF PURPLE LOOSESTRIFE (LYTHRUM SALICARIA L.) ALONG HIGHWAY CORRIDORS. ENVIRONMENTAL MANAGEMENT 13:365-370.

4778. WILDER, E. H. 1969. WALKING-TRAIL DEVELOPMENTS FOR HUNTERS ON THE NICOLET NATIONAL FOREST. JOURNAL OF WILDLIFE MANAGEMENT 33:762-768. 
4780. WILES, G. J. and H. P. JR. WEEKS. 1986. MOVEMENTS AND USE PATTERNS OF WHITE-TAILED DEER VISITING NATURAL LICKS. J. WLDL. MANAGE. 50 (3):487-96.

4781. WILKIN, J. G., W. C. EDWARDS, M. A. RAWLINGS, I. ROBERTSON and T. J. BEKHUYS. 1995. COMPARATIVE ENVIRONMENTAL ASSESSMENT OF LIONS GATE CROSSING OPTIONS RELATED TO STANLEY PARK AND FIRST NARROWS.. PROVINCE OF BRITISH COLUMBIA, MINISTRY OF TRANSPORTATION AND HIGHWAYS, HIGHWAY ENVIRONMENT BRANCH, VICTORIA, B.C..

4782. WILKINS, B. T. and G. A. HILL. 1971. A STUDY OF SNOWMOBILING IN CENTRAL NEW YORK. M. CHUBB, EDITOR. PROCEEDINGS OF THE 1971 SNOWMOBILE AND OFF-THE-ROAD VEHICLE RESEARCH SYMPOSIUM. DEP. PARKS AND RECREATION RESOUR., MICHIGAN STATE UNIV.,

4783. WILKINS, B. T. 1956. RANGE, USE, FOOD HABITS AND AGRICULTURAL RELATIONSHIPS OF THE MULE DEER, BRIDGER MOUNTAINS, MONTANA. M.S. THESIS, MONTANA STATE COLLEGE, BOZEMAN, MT. 34 PP.

4784. WILKINS, K. T. and D. J. SCHMIDLY. 1981. THE EFFECTS OF MOWING OF HIGHWAY RIGHTS-OF-WAYS ON SMALL MAMMALS. PAGES 55-56 IN TILLMAN,R.E., EDITOR. PROCEEDINGS OF SECOND SYMPOSIUM ON ENVIRONMENTAL CONCERNS IN RIGHTS-OF-WAY MANAGEMENT; 1979 OCTOBER 16-18; ANN ARBOR, MI UNIVERSITY OF MICHIGAN, ANN ARBOR.

4785. WILKINS, K. T. and D. J. SCHMIDLY. 1980. HIGHWAY MORTALITY OF VERTEBRATES IN SOUTHEASTERN TEXAS. TEXAS JOURNAL OF SCIENCE 4:343-350.

4786. WILKINS, K. T. 1982. HIGHWAYS AS BARRIERS TO RODENT DISPERSAL. SOUTHWESTERN NATURALIST 27(4):459-460.

4787. WILLIAMS, C. S. and J. E. FORBES. 1980. THE HABITAT AND DIETARY PREFERENCES OF DARK-BELLIED BRANT GEESE AND WIGEON IN RELATION TO AGRICULTURAL MANAGEMENT. WLDFOWL 31:151-157.

4788. WILLIAMS, J. S. 1992. ECOLOGY OF MOUNTAIN LIONS IN THE SUN RIVER AREAS OF NORTHERN MONTANA. M.S. THESIS, MONTANA STATE UNIVERSITY, BOZEMAN, MT. 110 PP.

4789. WILLIAMS JR., L. E., D. H. AUSTIN, T. E. PEOPLES and R. W. PHILLIPS. 1972. OBSERVATIONS ON MOVEMENT, BEHAVIOR, AND DEVELOPMENT OF TURKEY BROODS. PAGES 79-99+ IN G. C. SANDERSON AND H. C. SCHULTZ, EDITORS. PROCEEDINGS OF THE NATIONAL WILD TURKEY SYMPOSIUM 2.

4790. WILLIAMS JR., L. E., T. AUSTIN, E. PEOPLES and R. W. PHILLIPS. 1971. LAYING DATA AND NESTING BEHAVIOR OF WLD TURKEYS. PROCEEDINGS OF THE ANNUAL CONFERENCE OF THE SOUTHEAST ASSOCIATION OF GAME AND FISH COMMISSIONS 25:90-106.

4791. WILLIAMS, M. and A. LESTER. 1996. ANNOTATED BIBLIOGRAPHY OF OHV AND OTHER RECREATIONAL IMPACTS TO WILDLIFE. U.S. FOREST SERVICE PACIFIC SOUTHWEST REGION. ELDORADO NATIONAL FOREST, GEORGETOWN RANGER DISTRICT. 1OPP.

4792. WILLIAMS, T. H. I. 1990. HABITAT USE BY ADULT BROWN TROUT AND RAINBOW TROUT IN RESPONSE TO GAS SUPERSATURATION DOWNSTREAM OF THE YELLOWTAIL AFTERBAY DAM, BIGHORN RIVER, MONTANA. M.S. THESIS, MONTANA STATE UNIVERSITY, BOZEMAN, MT. 123 PP.

4793. WILLIAMS, W. D. 1971. TITLE UNKNOWN. THESIS UNIV BC; VANCOUVER, BC. 184PP.

4794. WILLOCK, T. A. and H. G. VRIEND. 1975. CROWSNEST PASS HIGHWAY IMPACT STUDY ASSESSMENT OF WILDLIFE HIGHWAY INTERACTIONS AND RELATED GAME MANAGEMENT POLICIES. FISH AND WILDLIFE DIVISION, ALBERTA RECREATION, PARKS AND WILDLIFE, EDMONTON, ALBERTA.

4795. WILMER, H. B. 2000. EFFECTS OF FIRE AND LOGGING ON LANDSCAPE STRUCTURE IN THE GREATER YELLOWSTONE ECOSYSTEM. M.S. THESIS, MONTANA STATE UNIVERSITY, BOZEMAN, MT. 78 PP. 
4796. WILSHIRE, H. G. 1983. OFF-ROAD VEHICLE RECREATION MANAGEMENT POLICY FOR PUBLIC LANDS IN THE UNITED STATES: A CASE HISTORY. ENVIRONMENTAL MANAGEMENT 7:489-500.

4797. WILSHIRE, H. G. STUDY RESULTS OF 9 SITES USED BY OFF-ROAD VEHICLES THAT ILLUSTRATE LAND MODIFICATION. U.S. GEOLOGICAL SURVEY. OPEN-FILE REPORT 77-601. V + 16PP.

4798. WILSHIRE, H. G., J. K. NAKATA, S. SHIPLEY and K. PRESTEGAARD. 1978. IMPACTS OF VEHICLES ON NATURAL TERRAIN AT SEVEN SITES IN THE SAN FRANCISCO BAY AREA. ENVIRONMENTAL GEOLOGY 2:295-319.

4799. WILSHIRE, H. G., S. SHIPLEY and J. K. NAKATA. 1978. IMPACTS OF OFF-ROAD VEHICLES ON VEGETATION. TRANS. N. AMER. WILDL. NAT. RESOUR. CONF. 43:131-139.

4800. WILSON, J. P. and J. P. SENEY. 1994. EROSIONAL IMPACT OF HIKERS, HORSES, MOTORCYCLES AND OFF-ROAD BICYCLES ON MOUNTAIN TRAILS IN MONTANA. MOUNTAIN RESEARCH AND DEVELOPMENT 14:77-88.

4801. WILSON, M. F., T. L. DE SANTO, C. SABAG and J. J. ARMESTO. 1994. AVIAN COMMUNITIES OF FRAGMENTED SOUTH-TEMPERATE RAINFORESTS IN CHILE. CONSERVATION BIOLOGY 8(2):508-20.

4802. WINCE, W. 1987. BADGERS ON ROADS. FLYCATCHER 8:18-22.

4803. WINCHELL, C. S. 1994. NATURAL HISTORY AND PROTECTION OF BURROWING OWLS. PAGES 83-86 IN W. S. HALVERSON AND A. C. CRABB, EDITORS. PROCEEDINGS, SIXTEENTH VERTEBRATE PEST CONFERENCE. UNIVERSITY OF CALIFORNIA, DAVIS, CALIFORNIA.

4804. WINCHELL, J. R. 1963. AGE CRITERIA FOR AMERICAN BISON. M.S. THESIS, MONTANA STATE UNIVERSITY, MISSOULA, MT. 70 PP

4805. WINDBERG, L. A., H. L. ANDERSON and R. M. ENGEMAN. 1985. SURVIVAL OF COYOTES IN SOUTHERN TEXAS. J. WLDL. MANAGE. 49 (2):301-7.

4806. WINDINGSTAD, R. M. 1988. NONHUNTING MORTALITY IN SANDHILL CRANES. J. WILDL. MANAGE. 52 (2):260-3

4807. WINTERS, J. B. 1969. DISTRIBUTION AND SEASONAL PREVALENCE OF THE BOVINE LUNGWORM (DICTYOCAULUS VIVIPARUS) IN SELECTED AREAS IN WESTERN MONTANA. M.S. THESIS, MONTANA STATE UNIVERSITY, BOZEMAN, MT. 41 PP.

4808. WIPPERMAN, A. H. 1963. CHANGES IN THE TROUT POPULATION OF A SMALL MONTANA STREAM. M.S. THESIS, MONTANA STATE COLLEGE, BOZEMAN, MT. 25 PP.

4809. WISCONSIN, DEPT. OF NATURAL RESOURCES, WISCONSIN, DIVISION OF HIGHWAYS, COLUMBIA COUNTY (WIS.) and HIGHWAY DEPT. 1974. ENVIRONMENTAL IMPACT STATEMENT FOR PROPOSED PROGAM AND FACILITY EXPANSION AT MACKENZIE ENVIRONMENTAL CENTER AND PROPOSED MODIFICATION OF COUNTY TRUNK HIGHWAYS CS AND Q, COLUMBIA COUNTY, WISCONSIN. STATE OF WISCONSIN DEPT. OF NATURAL RESOURCES, MADISON, WISCONSIN.

4810. WISCONSIN, DEPT. OF TRANSPORTATION, UNITED STATES and FEDERAL HIGHWAY ADMINISTRATION. 1983. DRAFT ENVIRONMENTAL IMPACT STATEMENT, ADMINISTRATIVE ACTION FOR ... SOUTH MADISON BELTLINE, FISH HATCHERY ROAD - I.H. 90, U.S.H. 12/18, DANE COUNTY. FHWA-WISC-EIS-83-01-D: ENVIRONMENTAL IMPACT STATEMENT : WISCONSIN HIGHWAYS AND BRIDGES 83-01-D. WISCONSIN DEPT. OF TRANSPORTATION, MADISON, WISCONSIN.

4811. WISCONSIN, DEPT. OF TRANSPORTATION, UNITED STATES and FEDERAL HIGHWAY ADMINISTRATION. 1984. FINAL ENVIRONMENTAL IMPACT STATEMENT, ADMINISTRATIVE ACTION AND U.S. ARMY CORPS OF ENGINEERS PERMIT ACTION ON SECTION 404 OF THE CLEAN WATER ACT FOR ... SOUTH MADISON BELTLINE, FISH HATCHERY ROAD - I.H. 90, U.S.H. 12/18, DANE COUNTY. FHWA-WISC-EIS-83-01-F: ENVIRONMENTAL IMPACT STATEMENT : WISCONSIN HIGHWAYS AND BRIDGES 83-01-F. WISCONSIN DEPT. OF TRANSPORTATION, MADISON, WISCONSIN.

4812. WISCONSIN, DIVISION OF TRANSPORTATION DISTRICTS and DISTRICT ONE. 1983. LAND \& WATER RESOURCES TECHNICAL REPORT, DRAFT. WISCONSIN DEPT. OF TRANSPORTATION, DIVISION OF TRANSPORTATION DISTRICTS, DISTRICT ONE, MADISON, WISCONSIN. 
4813. WISCONSIN, DIVISION OF TRANSPORTATION DISTRICTS and DISTRICT ONE. 1983. NOISE ANALYSIS TECHNICAL REPORT, DRAFT. WISCONSIN DEPT. OF TRANSPORTATION, DIVISION OF TRANSPORTATION DISTRICTS, -DISTRICT ONE, MADISON, WISCONSIN.

4814. WISDOM, M. J., L. R. BRIGHT, C. G. CAREY, W. W. HINES, R. J. PEDERSEN, D. A. SMITHEY, J. W. THOMAS and G. W. WITMER. 1986. A MODEL TO EVALUATE ELK HABITAT IN WESTERN OREGON. PUBL. NO. R6-F\&WL-216-1896. U.S.D.A., FOREST SERVICE, PACIFIC NORTHWEST REGION, LA GRANDE, OREGON. 36PP.

4815. WISHART, W. 1975. REPORT AND RECOMMENDATIONS OF THE ROCKY MOUNTAIN BIGHORN WORKSHOP GROUP. PAGES 165-207 IN.J. B. TREFETHEN, EDITOR . THE WILD SHEEP IN MODERN NORTH AMERICA. BOONE AND CROCKET CLUB AND THE WINCHESTER PRESS, NEWYORK, NEWYORK.

4816. WITHAM, J. J. and J. M. JONES. 1987. TITLE UNKNOWN. ILL. NAT. HIST. SURV. REP. NO.65. 4PP.

4817. WITMER, G. W. and D. S. DE CALESTA. 1985. EFFECT OF FOREST ROADS ON HABITAT USE BY ROOSEVELT ELK. NORTHWEST SCIENCE 9(2):122-125.

4818. WITTENHAGEN, K. W. 1996. RESPONSE OF WHITE-TAILED DEER FOLLOWING A FOREST FIRE IN THE LONG PINES, SOUTHEASTERN MONTANA. PH.D. DISSERTATION, MONTANA STATE UNIVERSITY, BOZEMAN, MT. 52 PP.

4819. WOELFEL, H. and H. H. KRUEGER. 1995. ON THE DESIGN OF GAME PASSAGES ACROSS HIGHWAYS. ZEITSCHRIFT FUER JAGDWISSENSCHAFT 41:209-216.

4820. WOLCOTT, T. G. and D. L. WOLCOTT. 1984. IMPACT OF OFF-ROAD VEHICLES ON MACRO-INVERTEBRATES OF A MID-ATLANTIC BEACH. BIOL. CONSERV. 29:217-240.

4821. WOLFF, J. O., E. M. SCHAUBER and W. D. EDGE. 1996. CAN DISPERSAL BARRIERS REALLY BE USED TO DEPICT EMIGRATING SMALL MAMMALS?. CANADIAN JOURNAL OF ZOOLOGY 74:1826-1830.

4822. WOLLITZ, R. E. 1958. THE EFFECTS OF CERTAIN COMMERCIAL TOXICANTS ON THE LIMNOLOGY OF THREE COLD WATER PONDS NEAR THREE FORKS, MONTANA. M.S. THESIS, MONTANA STATE COLLEGE, BOZEMAN, MT. 63 PP.

4823. WOLLUM, A. G. II. 1962. GRASS SEEDING AS A CONTROL FOR ROADBANK EROSION. USDA FOR. SERV. PACIFIC NW FOR. AND RANGE EXP. STA., (\#218), 5 PP.

4824. WOOD, A., D. CASEY, B. STANSBERRY, J. VORE, B. KUROPAT, R. KOMAC and J. HOLIFIELD. 1995. MONTANA WLDLIFE MITIGATION PROGRAM ANNUAL REPORT FY94. MONTANA DEPT. OF FISH, WLLLIFE, AND PARKS., 33 PP.

4825. WOOD, A. K. 1987. ECOLOGY OF A PRAIRIE MULE DEER POPULATION. PH.D. DISSERTATION, MONTANA STATE UNIVERSITY, BOZEMAN, MT. 205 PP.

4826. WOOD, M. and A. OLSEN. 1984. CLARK FORK PROJECTS: THOMPSON FALLS DAM OPERATOR: MONTANA POWER COMPANY. MONTANA DEPARTMENT OF FISH, WILDLIFE AND PARKS. PROJECT NO. 83-464

4827. WOOD, M. A. 1992. NORTHWEST MONTANA WILDLIFE MITIGATION PROGRAM HABITAT PROTECTION ANNUAL REPORT FY91. MONTANA DEPT. OF FISH, WILDLIFE, AND PARKS., 25 PP.

4828. WOOD, M. A. 1992. NORTHWEST MONTANA WILDLIFE MITIGATION PROGRAM HABITAT PROTECTION PROJECT-ANNUAL REPORT-FY 1992. MONTANA DEPT. OF FISH, WLDLIFE, AND PARKS., 32 PP.

4829. WOOD, P. and M. L. WOLFE. 1988. INTERCEPT FEEDING AS A MEANS OF REDUCING DEER-VEHICLE COLLISIONS. WILDLIFE SOCIETY BULLETIN 16:376-380.

4830. WOOD, P. B., T. C. JR. EDWARDS and M. W. COLLOPY. 1989. CHARACTERISTICS OF BALD EAGLE NESTING HABITAT IN FLORIDA. J. WILDL. MANAGE. 53 (2):441-9.

4831. WOODARD, T. N. 1976. DEER-AUTO ACCIDENT INVESTIGATIONS: EFFECTS OF HIGHWAY LIGHTING ON NUMBER OF DEER KILLED BY VEHICLES. STATE OF COLORADO, DIVISION OF WILDLIFE, DENVER, CO. 
4832. WOODARD, T. N., D. F. REED, L. GREEN, W. B. ZIMMERMAN, T. M. POJAR, J. K. MOSER and R. MASON. 1972. AN EVALUATION OF DEER-PROOF FENCE LENGTH REQUIRED TO PREVENT DEER MOVEMENT ON OR ACROSS -HIGH SPEED HIGHWAYS. STATE OF COLORADO, DIVISION OF WILDLIFE , DENVER, CO.

4833. WOODARD, T. N., D. F. REED and T. M. POJAR. 1973. EFFECTIVENESS OF SWAREFLEX WILDLIFE WARNING REFLECTORS IN REDUCING DEER-VEHICLE ACCIDENTS. UNPUBL.REPT. STATE OF COLORADO, DIVISION OF WILDLIFE , DENVER, CO.

4834. WOODGERD, W. R. 1952. A STUDY OF PLANT DEVELOPMENT COINCIDENT WITH SOME PHASES OF RING-NECKED PHEASANT BREEDING BEHAVIOR. M.S. THESIS, MONTANA STATE UNIVERSITY, MISSOULA, MT. 64 PP.

4835. WOODING, F. J. and S. D. SPARROW. 1979. AN ASSESSMENT OF DAMAGE CAUSED BY OFF-ROAD VEHICLE TRAFFIC ON SUBARCTIC TUNDRA IN THE DENALI HIGHWAY AREA OF ALASKA. R. ITTNER, D. R. POTTER, J. K. AGEE, AND S. ANSCHELL, EDITORS. RECREATIONAL IMPACT ON WLDLANDS. USDA FOREST SERVICE, USDI NATIONAL PARK SERVICE,

4836. WOODING, J. B. and J. R. BRADY. 1987. BLACK BEAR ROADKILLS IN FLORIDA. PROCEEDINGS OF THE ANNUAL CONFERENCE OF THE SOUTHEAST ASSOCIATION OF FISH AND WLDLIFE AGENCIES 41:438-442.

4837. WOODING, J. B. and T. S. HARDISKY. 1994. HOME RANGE, HABITAT USE, AND MORTALITY OF BLACK BEARS IN NORTH-CENTRAL FLORIDA. INT. CONF. BEAR RES. AND MANAGE. 9:349-56.

4838. WOODS, G., K. SIMPSON, J. KELSALL and C. CLEMENS. 1991. MOUNTAIN CARIBOU HABITAT MANAGEMENT PLANNING. P 501-5. IN: BUTLER CE, MAHONEY SP, EDS. 4THNORTH AMERICAN CARIBOU WORKSHOP PROC.; OCT 31-NOV 31989 ; ST. JOHN'S, NEWFOUNDLAND. NEWFOUNDLAND AND LABRADOR WLDLIFE DIV.

4839. WOODS, J. 1991. ECOLOGY OF A PARTIALLY MIGRATORY ELK POPULATION. PH.D. THESIS, UNIVERSITY OF BRITISH COLUMBIA , VANCOUVER.

4840. WOODS, J. 1989. SECOND PROGRESS REPORT: EFFECTIVENESS OF FENCES AND UNDERPASSES ON THE TRANS-CANADA HIGHWAY AND THEIR IMPACT ON UNGULATE POPULATIONS PROJECT. SEPT. 1985 TO MAY 1988. ENVIRONMENT CANADA-PARKS, OTTAWA, ONTARIO.

4841. WOODS, J. and R. H. MUNRO. 1996. ROADS, RAILS AND THE ENVIRONMENT: WILDLIFE AT THE INTERSECTION IN CANADA'S WESTERN MOUNTAINS. PAGES 39-45 IN EVINK,G., ZIEGLER,D., GARRETT,P., AND BERRY,J., EDITORS. TRANSPORTATION AND WLDLIFE: REDUCING WILDLIFE MORTALITY AND IMPROVING WILDLIFE PASSAGEWAYS ACROSS TRANSPORTATION CORRIDORS: PROCEEDINGS OF THE FLORIDA DEPARTMENT OF TRANSPORTATION/FEDERAL HIGHWAY ADMINISTRATION TRANSPORTATION-RELATED WLDLIFE MORTALITY SEMINAR; 1996 APRIL 30-MAY 2; ORLANDO, FL. FHWA-PD-96-041. U.S. DEPARTMENT OF TRANSPORTATION, FEDERAL HIGHWAY ADMINISTRATION, WASHINGTON, DC.

4842. WOODS, J. G. 1987. BOW VALLEY ELK POPULATION CHARACTERISTICS 1985-1987: A DISCUSSION PAPER AND EXAMPLE COMPUTER SIMULATION OF THE IMPACT OF THE BANFF HIGHWAY PROJECT. PARKS CANADA UNPUBLISHED WLDLIFE REPORT.

4843. WOODS, J. G. 1990. EFFECTIVENESS OF FENCES AND UNDERPASSES ON THE TRANS-CANADA HIGHWAY, AND THEIR IMPACT ON UNGULATE POPULATIONS. CANADIAN PARKS SERVICE UNPUBLISHED WILDLIFE REPORT ..

4844. WOODS, J. G. 1990. EFFECTIVENESS OF FENCES AND UNDERPASSES ON THE TRANS-CANADA HIGHWAY AND THEIR IMPACT ON UNGULATE POPULATIONS PROJECT. PARKS CANADA, BANFF NATIONAL PARK WARDEN SERVICE, BANFF, ALBERTA.

4845. WOODS, J. G. 1986. METHODOLOGIES: EFFECTIVENESS OF FENCES AND UNDERPASSES ON THE TRANS CANADA HIGHWAY AND THEIR IMPACT ON UNGULATE POPULATIONS. PARKS CANADA, CALGARY. UNPUBLISHED REPORT.

4846. WOODS, J. G. 1988. SECOND PROGRESS REPORT, EFFECTIVENESS OF FENCES AND UNDERPASSES ON THE TRANS CANADA HIGHWAY AND THEIR IMPACT ON UNGULATE POPULATION. NATURAL HISTORY RESEARCH DIVISION, PARKS CANADA UNPUBLISHED WLDLIFE REPORT.

4847. WOODS, J. G., B. BROWNE and D. WATERS. 1988. INITIAL EFFECTS OF HIGHWAY EXPANSION AND FENCING ON ELK MORTALITIES AND MOVEMENTS IN BANFF NATIONAL PARK, ALBERTA. P 181-7. IN: PROCEEDINGS OF THE 4TH WESTERN.STATES AND PROVINCES ELK WORKSHOP WENATCHEE, WASHINGTON. OLYMPIA, WASH.: 
WASHINGTON. DEPT. OF WILDLIFE.

4848. WOODWARD CLYDE CONSULTANTS--SAN FRANCISCO CA. 1976. PRELIMINARY REPORT: GRAVEL REMOVAL STUDIES IN SELECTED ARCTIC AND SUB-ARCTIC STREAMS IN ALASKA. FWS/OBS 76-21. U.S. FISH AND WILDLIFE SERVICE, OFFICE OF BIOLOGICAL SERVICES, WASHINGTON, D.C, .

4849. WOODWARD, S. M. 1990. POPULATION DENSITY AND HOME RANGE CHARACTERISTICS OF WOODCHUCKS MARMOTA MONAX AT EXPRESSWAY INTERCHANGES. CANADIAN FIELD-NATURALIST $104: 421-428$.

4850. WOOLDRIDGE, D. R. 1983. POLAR BEAR ELECTRONIC DETERRENT AND DETECTION SYSTEMS. INT. CONF. BEAR RES. AND MANAGE. 5:264-9.

4851. WOOLDRIDGE, D. R. and P. BELTON. 1980. NATURAL AND SYNTHESIZED AGGRESSIVE SOUNDS AS POLAR BEAR REPELLENTS. INT. CONF. BEAR RES. AND MANAGE. 4:85-91.

4852. WOOLF, A., D. R. SHOEMAKER and M. COOPER. 1993. EVIDENCE OF TULAREMIA REGULATING A SEMI-ISOLATED COTTONTAIL RABBIT POPULATION. J. WILDL. MANAGE. 57(1):144-57.

4853. WOOLSTON, C. D. 1994. NITROGEN TRANSFORMATIONS IN LAKE BONNEY, ANTARTICA: DYNAMICS IN A NON-TURBULENT ENVIRONMENT. M.S. THESIS, MONTANA STATE UNIVERSITY, BOZEMAN, MT. 159 PP.

4854. WORKMAN, D. L. 1971. A COMPARISON OF FISH POPULATION ESTIMATES FOR TWO POTHOLE LAKES IN MONTANA. M.S. THESIS, MONTANA STATE UNIVERSITY, BOZEMAN, MT. 26 PP.

4855. WRIGHT, B. A. and R. A. KAISER. 1986. WLDLIFE ADMINISTRATORS' PERCEPTIONS OF HUNTER ACCESS PROBLEMS: A NATIONAL OVERVIEW. WILDL. SOC. BULL. 14 (1):30-5.

4856. WRIGHT, B. A., R. A. KAISER and J. E. FLETCHER. 1988. HUNTER ACCESS DECISIONS BY RURAL LANDOWNERS: AN EAST TEXAS EXAMPLE. WILDL. SOC. BULL. 16 (2):152-8.

4857. WRIGHT, K. L. 1983. ELK MOVEMENTS, HABITAT USE, AND THE EFFECTS OF HUNTING ACTIVITY ON ELK BEHAVIOR NEAR GUNNISON, COLORADO. M.S. THESIS. COLORADO STATE UNIV., FORT COLLINS, CO. $206 P P$.

4858. WRIGHT, R. G., K. JENKIN, B. BUTTERFIELD, C. KEY and P. HAPPE. WILDLIFE HABITATS IN RIPARIAN ZONES OF THE NORTH FORK AND MAINSTEM FLATHEAD RIVER, MONTANA. NATIONAL PARK SERVICE.

4859. WU, E. 1998. ECONOMIC ANALYSIS OF DEER - VEHICLE COLLISIONS IN OHIO. PAGES 43-52 IN G. L. EVINK, P. GARRETT, D. ZEIGLER, AND J. BERRY, EDITORS. PROCEEDINGS OF THE INTERNATIONAL CONFERENCE ON WILDLIFE ECOLOGY AND TRANSPORTATION. FLORIDA DEPARTMENT OF TRANSPORTATION, TALLAHASSEE, FLORIDA.

4860. WU, J. and J. L. VANKAT. 1991. AN AREA-BASED MODEL OF SPECIES RICHNESS DYNAMICS OF FOREST ISLANDS. ECOLOGICAL MODELING 58 (1-4):249-72.

4861. WUNDER, M. 1980. ELK-CATTLE RANGE RELATIONSHIPS IN THE CRAZY MOUNTAINS, MONTANA. M.S. THESIS, UNIVERSITY OF MONTANA, MISSOULA, MT. 128 PP.

4862. WUNDERLICH, M. P. 1985. FEEDING ECOLOGY OF LARVAL FISHES IN LAKE ROOSEVELT, WASHINGTON. M.S. THESIS, MONTANA STATE UNIVERSITY, BOZEMAN, MT. 61 PP.

4863. WYATT, R. L. IMPLICATIONS OF ILLEGAL OFF-ROAD VEHICLE ACTIVITY ON THE CHEROKEE WILDLIFE MANAGEMENT AREA, UNICOI COUNTY, TENNESSEE. PROC. ANNU. CONF. SOUTHEAST. ASSOC. FISH AND WILDL. AGENCIES 42:533-539.

4864. YAHNER, R. H. 1988. CHANGES IN WLDLIFE COMMUNITIES NEAR EDGES. CONSERVATION BIOLOGY 2 (4):333-9.

4865. YAHNER, R. H. 1992. DYNAMICS OF A SMALL MAMMAL COMMUNITY IN A FRAGMENTED FOREST. AMERICAN MIDLAND NATURALIST 127 (2):381-91. 
4866. YAHNER, R. H. 1993. EFFECTS OF LONG-TERM FOREST CLEAR-CUTTING ON WINTERING AND BREEDING BIRDS. WILSON BULLETIN 105 (2):239-55.

4867. YAHNER, R. H. 1995. FOREST-DIVIDING CORRIDORS AND NEOTROPICAL MIGRANT BIRDS. CONSERVATION BIOLOGY 9 (3):476-7.

4868. YAHNER, R. H. 1996. FOREST FRAGMENTATION, ARTIFICIAL NEST STUDIES, AND PREDATOR ABUNDANCE. CONSERVATION BIOLOGY 10 (2):673.

4869. YAHNER, R. H. and B. L. CYPHER. 1987. EFFECTS OF NEST LOCATION ON DEPREDATION OF ARTIFICIAL ARBOREAL NESTS. J. WLLL. MANAGE. 51 (1):178-81.

4870. YAHNER, R. H., T. E. MORRELL and J. S. RACHAEL. 1989. EFFECTS OF EDGE CONTRAST ON DEPREDATION OF ARTIFICIAL AVIAN NESTS. J. WILDL. MANAGE. 53 (4):1135-8.

4871. YAHNER, R. H. and D. P. SCOTT. 1988. EFFECTS OF FOREST FRAGMENTATION ON DEPREDATION OF ARTIFICIAL NESTS. J. WLDL. MANAGE. 52 (1):158-61.

4872. YAHNER, R. H. and R. A. VOYTKO. 1989. EFFECTS OF NEST-SITE SELECTION ON DEPREDATION OF ARTIFICIAL NESTS. J. WILDL. MANAGE. 53 (1):21-5.

4873. YAHNER, R. H. and A. L. WRIGHT. 1985. DEPREDATION ON ARTIFICIAL GROUND NESTS: EFFECTS OF EDGE AND PLOT AGE. J. WLDL. MANAGE. 49 (2):508-13.

4874. YAMAGIWA, J., N. MWANZA, A. SPANGENBERG, T. MARUHASHI, T. YUMOTO, A. FISCHER and B. B. STEINHAUER. 1993. A CENSUS OF THE EASTERN LOWLAND GORILLAS GORILLA GORILLA GRAUERI IN KAHUZI-BIEGA NATIONAL PARK WITH REFERENCE TO MOUNTAIN GORILLAS GORILLA GORILLA BERINGEI IN THE VIRUNGA REGION, ZAIRE. BIOLOGICAL CONSERVATION 64 (1):83-9.

4875. YANAGAWA, H. and T. SHIBUYA. 1996. CAUSES OF WILD BIRD MORTALITY IN EASTERN HOKKAIDO II. RES.BULL.OBIHIRO UNIV.NAT.SCI. 19(4):251-258.

4876. YANES, M. and F. SUAREZ. 1995. VERTEBRATE CROSSING THROUGH CULVERTS AND UNDER ROADS AND RAILWAYS. QUERCUS 12:31-33.

4877. YANES, M., J. M. VELASCO and F. SUAREZ. 1995. PERMEABILITY OF ROADS AND RAILWAYS TO VERTEBRATES - THE IMPORTANCE OF CULVERTS. BIOLOGICAL CONSERVATION 71(3):217-222.

4878. YARMOLOY, C., M. BAYER and V. GEIST. 1988. BEHAVIOR RESPONSES AND REPRODUCTION OF MULE DEER, ODOCOILEUS HEMIONUS, DOES FOLLOWING EXPERIMENTAL HARASSMENT WITH AN ALL-TERRAIN VEHICLE. THE CANADIAN FIELD-NATURALIST. 102(3)

4879. YARMOLOY, C. P. 1984. THE IMPACT OF OFF-HIGHWAY VEHICLES ON BIG GAME MANAGEMENT IMPLICATIONS FOR ALBERTA'S EASTERN SLOPES. M.E.DES. THESIS, UNIVERSITY OF CALGARY

4880. YARMOLOY, C., M. BAYER and V. GEIST. 1988. BEHAVIOR RESPONSES AND REPRODUCTION OF MULE DEER DOES FOLLOWING EXPERIMENTAL HARASSMENT WITH AN ALL-TERRAIN VEHICLE. CANADIAN FIELD-NATURALIST $102: 425-429$

4881. YARMOLOY, C. P. 1983. THE IMPACT OF OFF-HIGHWAY RECREATION VEHICLES ON BIG GAME MANAGEMENT IMPLICATIONS FOR ALBERTA'S EASTERN SLOPES. FACULTY OF ENVIRONMENTAL DESIGN, UNIVERSITY OF CALGARY, CALGARY, ALBERTA.

4882. YATES, R. E. 1989. BALD EAGLE NESTING ECOLOGY AND HABITAT USE : LAKE MCDONALD, GLACIER NATIONAL PARK MONTANA. M.S. THESIS, UNIVERSITY OF MONTANA, MISSOULA, MT. 102 PP.

4883. YDE, C. A. 1977. THE DISTRIBUTION AND MOVEMENTS OF SHARP-TAILED GROUSE DURING SPRING AND SUMMER IN RELATION TO REST-ROTATION GRAZING. M.S. THESIS, MONTANA STATE UNIVERSITY, BOZEMAN, MT. 70 PP. 
4884. YEAGER, R. T. 1984. USE OF COVER BY MULE DEER ON A WESTERN MONTANA WINTER RANGE. M.S. THESIS, UNIVERSITY OF MONTANA, MISSOULA, MT. 36 PP.

4885. YEE, C. S. and T. D. ROELOFS. 1980. INFLUENCE OF FOREST AND RANGELAND MANAGEMENT ON ANADROMOUS FISH HABITAT IN WESTERN NORTH AMERICA. U. S. DEPT. OF AGRICULTURE, FOREST SERVICE, PACIFIC NORTHWEST FOREST AND RANGE EXPERIMENT STATION, PORTLAND, OREGON. GENERAL TECHNICAL REPORT / U.S. DEPT. OF AGRICULTURE, FOREST SERVICE: GENERAL TECHNICAL REPORT PNW 109.

4886. YERK, D. B. 2000. POPULATION CHARACTERISTICS AND HABITAT USE OF A DEVELOPING WALLEYE POPULATION IN CANYON FERRY RESERVOIR, MONTANA. M.S. THESIS, MONTANA STATE UNIVERSITY, BOZEMAN, MT. 195 PP.

4887. YLARANTA, T. 1995. EFFECT OF ROAD TRAFFIC ON HEAVY METAL CONCENTRATIONS OF PLANTS. AGRICULTURAL SCIENCE IN FINLAND 4(1):35-48.

4888. YOSEF, R. 1994. THE EFFECTS OF FENCELINES ON THE REPRODUCTIVE SUCCESS OF LOGGERHEAD SHRIKES. CONSERVATION BIOLOGY 8 (1):281-5.

4889. YOSHIDA, M., S. SHIGETADA and O. TAMAO. 1994. MORPHOLOGICAL AND GENETICAL DIFFERENCES IN THE WILD POPULATIONS OF APODEMUS SPECIOSUS SEPARATED BY THE EXPRESS WAY. J.FAC.AGRIC.SHINSHU UNIV. 31(2):109-124.

4890. YOUMANS, C. C. 1991. ANALYSIS OF LONG-TERM TRENDS IN ELK VULNERABILITY ON THE BITTERROOT NATIONAL FOREST IN RELATION TO SELECTED PREDICTOR VARIABLES. PAGES 159-167 IN A. G. CHRISTENSEN, L. J. LYON, AND T. N. LONNER, COMPILERS. PROCEEDINGS OF THE ELK VULNERABILITY SYMPOSIUM. MONTANA STATE UNIVERSITY, BOZEMAN, MONTANA, USA.

4891. YOUMANS, C. C. 1992. ASSESSMENT OF HABITAT FRAGMENTATION, ROADS, AND WEATHER ON ELK HARVEST AND ELK VULNERABILITY IN THE UPPER BITTERROOT VALLEY, MONTANA (CERVUS ELAPHUS). DISSERTATION, MONTANA STATE UNIVERSITY, BOZEMAN, MONTANA. 181PP.

4892. YOUMANS, C. C. 1979. CHARACTERISTICS OF POCKET GOPHER POPULATIONS IN RELATION TO SELECTED ENVIRONMENTAL FACTORS IN PELLICAN VALLEY, YELLOWSTONE NATIONAL PARK. M.S. THESIS, MONTANA STATE UNIVERSITY, BOZEMAN, MT. 79 PP.

4893. YOUMANS, H. B. 1979. HABITAT USE BY MULE DEER OF THE ARMSTRONG WINTER RANGE, BRIDGER MOUNTAINS, MONTANA. M.S. THESIS, MONTANA STATE UNIVERSITY, BOZEMAN, MT. 66 PP.

4894. YOUNG, D. A. 1986. OLDMAN RIVER DAM WLDLIFE INVESTIGATIONS SPRING AND SUMMER 1985. ALBERTA ENVIRONMENT, PLANNING DIVISION, EDMONTON, ALBERTA.

4895. YOUNG, D. D. 1984. BLACK BEAR HABITAT USE AT PRIEST LAKE, IDAHO. THESIS, UNIVERSITY OF MONTANA, MISSOULA, MONTANA. 66PP.

4896. YOUNG, D. D. and J. J. BEECHAM. 1986. BLACK BEAR HABITAT USE AT PRIEST LAKE, IDAHO. INT. CONF. BEAR RES. AND MANAGE. 6:73-80.

4897. YOUNG, D. L. 1986. CUMULATIVE EFFECTS ANALYSIS OF GRIZZLY BEAR HABITAT ON THE LEWS AND CLARK NATIONAL FOREST. P. 217-21. IN: GLEN P. CONTRERAS AND KEITH E. EVANS (COMPILERS). PROC. GRIZZLY BEAR HABITAT SYMPOSIUM. USDA FOR. SERV. GEN. TECH. REP. INT-207.

4898. YOUNG, K. R. 1994. ROADS AND THE ENVIRONMENTAL DEGRADATION OF TROPICAL MONTANE FORESTS CONSERVATION BIOLOGY 8(4):972-976.

4899. YOUNG, L. S. 1983. MOVEMENTS OF BALD EAGLES ASSOCIATED WITH AUTUMN CONCENTRATIONS IN GLACIER NATIONAL PARK. M.S. THESIS, UNIVERSITY OF MONTANA, MISSOULA, MT. 102 PP.

4900. YOUNG, L. and C. YDE. 1990. URAL-TWEED BIGHORN SHEEP WLDLIFE MITIGATION PROJECT FINAL COMPLETION REPORT. BONNEVILLE POWER ADMININSTRATION, DIVISION OF FISH AND WILDLIFE, PORTLAND, OREGON. 
4901. YOUNG, M. K. 1986. ECOLOGY AND STATUS OF A WILDERNESS FISHERY: WESTSLOPE CUTTHROAT TROUT IN THE SOUTH FORK FLATHEAD RIVER. M.S. THESIS, UNIVERSITY OF MONTANA, MISSOULA, MT. 87 PP.

4902. YOUNG, R. J. and G. L. MACKIE. 1991. EFFECT OF OIL PIPELINE CONSTRUCTION ON THE BENTHIC INVERTEBRATE COMMUNITY STRUCTURE OF HODGSON CREEK, NORTHWEST TERRITORIES. CANADIAN JOURNAL OF ZOOLOGY 69 (8):2154-60.

4903. YOUNG, T.P. 1994. NATURAL DIE-OFFS OF LARGE MAMMALS: IMPLICATIONS FOR CONSERVATION. CONSERVATION BIOLOGY 8 (2):410-8.

4904. YOUSEF, Y. A. and L. L. YU. 1992. POTENTIAL CONTAMINATION OF GROUNDWATER FROM COPPER, LEAD, AND ZINC IN WET DETENTION PONDS RECEIVING HIGHWAY RUNOFF. JOURNAL OF ENVIRONMENTAL SCIENCE AND HEALTH PART A ENVIRONMENTAL SCIENCE AND ENGINEERING 27 (4): 1033-44

4905. YUKON TERRITORY and DEPT. OF RENEWABLE RESOURCES. 1983. DEMPSTER HIGHWAY SUMMARY OF BACKGROUND ANALYSIS AND REVISED HIGHWAY CORRIDOR MANAGEMENT SUGGESTIONS. DEMPSTER HIGHWAY PLANNING PROJECT. DEPT. OF RENEWABLE RESOURCES, WHITEHORSE, YUKON.

4906. YUKON TERRITORY and WLDLIFE BRANCH. 1977. ALASKA HIGHWAY GAS PIPELINE PROJECT ENVIRONMENTAL CONCERNS AND RECOMMENDATIONS OF THE YUKON WILDLIFE BRANCH. --. THE BRANCH, WHITEHORSE, YUKON.

4907. ZACKHEIM, H. S. 1982. ECOLOGY AND POPULATION STATUS OF THE RIVER OTTER IN SOUTHWESTERN MONTANA . M.S. THESIS, UNIVERSITY OF MONTANA, MISSOULA, MT. 100 PP.

4908. ZACKS, J. L. DO WHITE-TAILED DEER AVOID RED? AN EVALUATION OF THE PREMISE UNDERLYING THE DESIGN OF SWAREFLEX WILDLIFE REFLECTORS. TRANSPORTATION RESEARCH RECORD 1075:35-43.

4909. ZACKS, J. L. 1986. DO WHITE-TAILED DEER AVOID RED? AN EVALUATION OF THE PREMISE UNDERLYING THE DESIGN OF SWAREFLEX WLDLIFE REFLECTORS. TRANSPORTATION RESEARCH RECORD 1075. TRANSPORTATION RESEARCH BOARD, NATIONAL RESEARCH COUNCIL, WASHINGTON, DC.

4910. ZACKS, J. L. 1985. AN INVESTIGATION OF SWAREFLEX WILDLIFE WARNING REFLECTORS, FINAL REPORT. FHWA-MI-RD-85-04. U.S. DEPARTMENT OF TRANSPORTATION, FEDERAL HIGHWAY ADMINISTRATION, WASHINGTON, DC.

4911. ZAGATA, M. D. and A. O. HAUGEN. 1974. INFLUENCE OF LIGHT AND WEATHER ON OBSERVABILITY OF IOWA DEER. JOURNAL OF WLDLIFE MANAGEMENT 38:220-228.

4912. ZAGER P., JONKEL C. and HABECK J. 1983. LOGGING AND WILDFIRE INFLUENCE ON GRIZZLY BEAR HABITAT IN NORTHWESTERN MONTANA. INT. CONF. BEAR RES. AND MANAGE. 5:124-32.

4913. ZAGER, P. E. 1980. GRIZZLY BEAR HABITAT UTILIZATION. P 99-132. IN: JONKEL C, ED. ANNUAL REPORT NO. 5, BORDER GRIZZLY PROJECT. MISSOULA, MT.: UNIV. MONTANA.

4914. ZAGER, P. E. and C. J. JONKEL. 1983. MANAGING GRIZZLY BEAR HABITAT IN THE NORTHERN ROCKY MOUNTAINS. J. FORESTRY 81 (8):524-6, 536

4915. ZAHN, H. M. 1974. SEASONAL MOVEMENTS OF THE BURDETTE CREEK ELK HERD. M.S. THESIS, UNIVERSITY OF MONTANA, MISSOULA, MT. 71 PP.

4916. ZANGGER, A. 1995. WILDLIFE OVERPASSES OVER A MOTORWAY AS CONNECTING MEANS FOR FOREST ARTHROPOD COMMUNITIES. M.S. THESIS, UNIVERSITAT BERN, SWITERLAND.

4917. ZAPATKA, T. P. 1963. SOME RESULTS OF TWO LIMITED HUNTING SEASONS ON HEN PHEASANTS IN NORTHCENTRAL MONTANA. M.S. THESIS, MONTANA STATE COLLEGE, BOZEMAN, MT. 26 PP.

4918. ZELENAK, J. R. and J. J. ROTELLA. 1997. NEST SUCCESS AND PRODUCTIVITY OF FERRUGINOUS HAWKS IN NORTHERN MONTANA. CANADIAN JOURNAL OF ZOOLOGY 75(7):1035-1041. 
4919. ZELENAK, J. R. 1996. BREEDING ECOLOGY OF FERRUGINOUS HAWKS AT THE KEVIN RIM IN NORTHERN MONTANA. M.S. THESIS, MONTANA STATE UNIVERSITY, BOZEMAN, MT. 74 PP.

4920. ZENG, Z. 1996. STOCHASTIC MODELING OF ECOLOGICAL TIME SERIES: ANIMAL POPULATION DYNAMICS COMPLEX REGULATION AND STRUCTURAL CHANGES. PH.D. DISSERTATION, MONTANA STATE UNIVERSITY, BOZEMAN, MT. 177 PP.

4921. ZEVELOFF, S. I. 1983. ISLAND BIOGEOGRAPHIC CONSIDERATIONS FOR POCOS IN WILDLIFE CONSERVATION. JOURNAL OF THE ELISHA MITCHELL SCIENTIFIC SOCIETY 99 (3):69-77.

4922. ZHIGAREV, I. A. 1993. ON THE INFLUENCE OF RECREATIONAL PRESSURE ON THE POPULATION DENSITY OF RODENTS AT THE SOUTH OF MOSCOW DISTRICT. ZOOLOGICHESKII ZHURNAL 72 (12):117-37.

4923. ZILLGES, G. F. JR. 1971. THE AQUATIC INSECTS OF BLUEWATER CREEK, MONTANA ABOVE AND BELOW AN AREA OF INTENSIVE AGRICULTURE. M.S. THESIS, MONTANA STATE UNIVERSITY, BOZEMAN, MT. 29 PP.

4924. ZIMMER, G. E. 1979. THE STATUS AND DISTRIBUTION OF THE COMMON LOON IN WISCONSIN. M.S. THESIS, STEVENS POINT: UNIV. WIS. 63PP.

4925. ZIMMERMAN, A. L. 1998. REESTABLISHMENT OF SWFT FOX IN NORTH CENTRAL MONTANA. M.S. THESIS, MONTANA STATE UNIVERSITY, BOZEMAN, MT. 44 PP.

4926. ZINK, T. A., M. F. ALLEN, T. B. HEINDL and E. B. ALLEN. 1995. THE EFFECT OF A DISTURBANCE CORRIDOR ON AN ECOLOGICAL RESERVE. RESTORATION ECOLOGY 3 (4):304-10.

4927. ZOLLWEG, E. C. 1998. PISCINE PREDATION ON BULL TROUT IN THE FLATHEAD RIVER, MONTANA. M.S. THESIS, MONTANA STATE UNIVERSITY, BOZEMAN, MT. 97 PP.

4928. ZUBAID, A. 1993. A COMPARISON OF THE BAT FAUNA BETWEEN A PRIMARY AND FRAGMENTED SECONDARY FOREST IN PENINSULAR MALAYSIA. MAMMALIA 57 (2):201-6.

4929. ZUBIK, R. J. 1983. THE FISHERY OF HYALITE RESERVOIR, MONTANA, WITH AN EVALUATION OF CUTTHROAT TROUT REPRODUCTION IN ITS TRIBUTARIES. M.S. THESIS, MONTANA STATE UNIVERSITY, BOZEMAN, MT. 70 PP.

4930. ZUIDERWIJK, A. 1989. AMPHIBIAN AND REPTILE TUNNELS IN THE NETHERLANDS. PAGES 67-74 IN LANGTON,T.E.S., EDITOR. AMPHIBIANS AND ROADS. PROCEEDINGS OF THE TOAD TUNNEL CONFERENCE; 1989 JANUARY 7-8; RENDSBURG, FEDERAL REPUBLIC OF GERMANY ACO POLYMER PRODUCTS LTD., SHEFFORD, ENGLAND. 